\title{
MARKETING ESTRATÉGICO E ESTRATÉGIA COMPETITIVA DE EMPRESAS TURÍSTICAS \\ UM ESTUDO DE CASO DA CADEIA HOTELEIRA SOL MELIÁ
}

\author{
Jesús Álvarez Valdés
}

Orientador: Prof. Dr. Geraldo Luciano Toledo

Tese apresentada à Faculdade de Economia, Administração e Contabilidade da Universidade de São Paulo, como requisito parcial à obtenção do título de Doutor em Administração.

\section{São Paulo}

2003 
Asessores:

Prof. Dr. Guillermo Cardoza Bulla,

Diretor de Centro Eurolatinoamericano do Instituto de Empresa de Madri.

Prof. Dr. Ramón Díaz Bernardo,

ViceDiretor do Centro de Turismo do Instituto de Empresa de Madri.

Prof. Dr. Miguel Seguí Llinás,

Titular da Facultad de Filosofía y Letras. Departamento de Ciencias de la Tierra. Universidad de las Islas Baleares.

Profa. Dra. Ana Ramón Rodríguez, ViceDiretora da Escola de Turismo da Unversidade de Alicante, España 
REITOR DA UNIVERSIDADE DE SÃO PAULO

PROF. DR. ADOLPHO JOSÉ MERLFI

DIRETOR DA FACULDADE DE ECONOMIA, ADMINISTRAÇÃO E CONTABILIDADE PROFA. DRA. MARIA TEREZA LEME FLEURY

CHEFE DO DEPARTAMENTO DE ADMINISTRAÇÃO

PROF. DR. EDUARDO PINHEIRO GONDIM DE VASCONCELLOS 


\section{FICHA CATALOGRÁFICA}

\section{Valdés, Jesús Álvarez}

Marketing estratégico e estratégia competitiva de empresas turísticas: um estudo de caso da cadeia hoteleira Sol Meliá / Jesús Álvarez Valdés -- São Paulo : FEA/USP, 2003.

$313 \mathrm{p}$.

Tese - Doutorado

Bibliografia.

1. Marketing 2. Estratégia 3. Indústria turística 4. Marketing turístico 5. Hotéis I. Faculdade de Economia, Administração e Contabilidade da USP II.Título.

$$
\mathrm{CDD}-658.8
$$




\section{AGRADECIMENTOS}

Circunstâncias especiais acompanharam a redação e a edição desta tese. É nesses casos que o calor humano das pessoas mais se aprecia.

Minha esposa e filhas foram o arrimo principal para seguir e vencer.

Agradecimento especial para meus pais e sogros, irmãos e cunhados, e para Héctor, Dania, Enrique e Andrés, amigos à prova de balas.

No Brasil, um reconhecimento às seguintes instituições: Universidade de São Paulo, Faculdade de Economia, Administração e Contabilidade, Departamento de Administração, Secretaria e UPD; CAPES e FAPESP. Mas, em especial, às pessoas, esses incríveis companheiros e professores brasileiros, de quem muito aprendi e recebi tanto calor humano. Entre eles, e com muito carinho, a Robinson Magalhães, Humberto Petrelli e Eliana, por serem amigos incondicionais. À Adriana, Germán, Nati Díaz e outros amigos da Espanha.

Ao Álvaro Castromán, por sua amizade, e por compartilhar intelectualmente muito dos trabalhos e resultados desta tese.

Ao Professor Mário Beni, Jefe do Departamento de Turismo da Universidade de São Paulo, por seu apoio desprendido e ensinamentos sobre turismo.

Aos meus queridos professores da Universidade de Havana, Ileana e Barreiro, sempre ao meu lado.

Ao Guillermo Cardoza Bulla, Diretor do Centro Euro-latinoamericano del Instituto de Empresas de Madri, e o professor Ramón Díaz Bernardo, por suas seguras orientações e sus conselhos na elaboração dos casos sobre Sol Meliá.

À Marité López, Miguel Rivas, Adriana, Jesús Felipe Gallego, Presidente da Asociación Española de Directores de Hoteles, a Miguel Seguí, da Universidad de Islas Baleares, e a outros tantos que me deram apoio, na Espanha.

À Fundação Carolina, à Universidade de Alicante, pela possibilidade de cursar o Master en Gestião e Administração Turística que me permitiu aprofundar nos conhecimentos sobre turismo numa das potencias mais importantes do turismo mundial: Espanha. A seus professores e companheiros de aulas, e em especial ao professor Dr. Fernando Vera Rebollo, Diretor da Escola de Turismo, à Prfa. Dra. Ana Ramón Rodríguez, codiretora desta tese por esta Universidade. Ao Joseph Vivars e a Elisa por seu inestimável apoio.

Aos dirigentes da Sol Meliá, desde seu Presidente, D. Gabriel Escarrer, seu Vice Presidente Sebastián Escarrer, ao D. Jaime Puig de la Bellacasa, assesor, e aos diretores da Casa Matriz, que ministraram-me valiosas informaçãoes em Palmas de Mallorca. Aos diretores das suas filiais no 
Brasil e em Cuba, D. Canavés e D. Oliveira por suas decissivas contribuições. Aos diretores dos hotéis visitados.

Um último agradecimento que inicio com letras maiúsculas: quero fazer uma homenagem ao PROFESSOR GERALDO LUCIANO TOLEDO, meu orientador, homem excepcional, que, além de ser o melhor professor que tive, com sua afabilidade, entusiasmo, amor à vida e apoio incondicional para que esta tese terminasse, demonstrou que há pessoas neste mundo que nasceram para construir, e ele é uma delas. Obrigado por sua amizade à prova de tudo.

A todos, meu agradecimento infinito!

\section{RESUMO}

O objeto da tese está voltado para o processo do marketing estratégico e do desenvolvimento de vantagens competitivas em organizações empresariais do setor de turismo, visando à obtenção de uma posição competitiva superior, mediante a satisfação de seus clientes, dos seus diversos públicos (stakeholders) e da sociedade em que estão inseridas.

O estudo incorpora, como parte de seu projeto conceitual, a análise de um modelo teórico recente sobre estratégia empresarial -Modelo Delta - e as relações que se desenvolvem entre as empresas na era da globalização. Nesse contexto de globalização, é discutido o fenômeno de internacionalização das empresas e o impacto da crescente concentração, decorrente de fusões e aquisições, que se observa atualmente no setor de turismo.

O problema em estudo está mais vinculado com os países receptivos que, por suas condições naturais, especializam-se em desenvolver ofertas para receber turistas de todas partes do mundo. A metodologia da pesquisa empírica que integra esta tese é de natureza qualitativa e modalidade exploratório - descritiva, tendo por método o estudo de caso.

O estudo responde aos objetivos da pesquisa acadêmica e expõe o processo de expansão da Sol Meliá na América Latina, com ênfase no Brasil e em Cuba, particularmente nas cidades de São Paulo e Havana, respectivamente.

Dentre as evidências encontradas destaca-se que, no setor de turismo, aparece de forma evidente a grande evolução econômica e sócio-cultural que se está operando no mundo contemporâneo. Observou-se, ainda, que, nos próximos anos, os destinos turísticos deverão se adaptar a uma situação de competitividade extrema, em que a obtenção de lucros e a sustentabilidade dos negócios turísticos serão muito mais complexos. As empresas terão que projetar suas ofertas de forma cada vez mais diferenciada e integrada ao planejamento dos destinos turísticos, em correspondência com o desenvolvimento sustentável do setor. Deverão, ainda, ser capazes de atrair a atenção de novos turistas e reter os atuais clientes, pela inovação de suas propostas. 


\begin{abstract}
This thesis is focused on the strategic marketing process and on the search of competitive advantages in the tourist sector business organizations for the purpose of achieving an advantageous competitive position through the satisfaction of their customers as well as that of their stakeholders and of the society to which they belong.

As part of its conceptual project the study includes analysis of a recent theoretical model about business strategy - Delta Model - and the relationships among companies in the era of globalization. In this context of globalization, the phenomenon of the companies' internationalization is discussed, as well as the impact of increasing concentration that has resulted from mergers and acquisitions, currently perceived in the tourist sector.

The issue under study is related to host countries that, because of their natural attributes have specialized in promoting offers for clients from all over the world. The methodology of empiric research applied in this thesis is of a qualitative and exploratory-descriptive nature and and makes use of the case study method.

The study meets the objectives of academic research and presents the process of expansion of the Sol Meliá in Latin America, with emphasis on Brazil and on Cuba, particularly in the cities of São Paulo and Havana.

Among the evidences detected, it maybe noted that in the tourist sector the great economic and socio-cultural evolution taking place in today's world is quite apparent. It was further observed that, in the coming years, tourist destinations will have to adjust to situations of fierce competition, where achievement of profits and sustainability of tourist businesses will be much more complex. The companies will have to design their offers in an increasingly differentiated and comprehensive manner of planning tourist destinations in accordance with the sustainable development of the sector. Further, by means of the innovativeness of their proposals, they will have to be capable of keeping the current customers and of attracting the attention of new tourists.
\end{abstract}




\section{SUMÁRIO}

\section{CAPÍTULO I - CARACTERIZAÇÃO DO ESTUDO}

I - Caracterização do estudo. A situação-problema, objeto de investigação, marco conceitual com o qual foram desenvolvidas as análises e análise de contexto.

II - Análise do contexto.

1. O turismo como fator de desenvolvimento econômico internacional

2. Evolução do turismo na globalização. Turismo pós-fordista ou de terceira geração. Novas megatendências.

3. O turismo na Espanha e América Ibérica como contexto do estudo. Casos particulares do desenvolvimento turístico no Brasil e Cuba.

III - Descrição dos capítulos.

\section{CAPÍTULO II - MARKETING ESTRATÉGICO E ESTRATÉGIAS COMPETITIVAS 51}

1. Desenvolvimento histórico da teoria e prática da administração 51

2. Estratégia Empresarial. Principais Conceitos.

3. O marketing estratégico como base para entender o mercado e elaborar a estratégia da empresa. 56

4. Estratégias corporativas de crescimento empresarial. 76

$\begin{array}{ll}\text { 5. Estratégias competitivas. } & 78\end{array}$

$\begin{array}{ll}\text { 6. Estratégias de internacionalização. } & 78\end{array}$

7. Os clusters de empresas. $\quad 94$

CAPÍTULO III - A COMPETITIVIDADE NO SISTEMA DE TURISMO 98

$\begin{array}{ll}\text { 1. Sistema de turismo } & 98\end{array}$

Principais conceitos.

Uma visão sistêmica do turismo.

Subsistema operativo do turismo.

Organização turística: agentes e facilitadores.

A empresa hoteleira. Sua situação na atual fase da globalização.

O papel dos tour operators: canais de distribuição ou empresas produtoras?

2. O marketing turístico

Particularidades do produto turístico.

A oferta turística. 
Segmentação do mercado turístico.

3.

rocesso de planejamento estratégico no setor de turismo

segundo os critérios de sustentabilidade.

Variáveis que determinam a sustentabilidade do setor de turismo.

Planejamento estratégico das empresas de turismo.

4. A competitividade e o posicionamento no sistema de turismo. Clusters turísticos

Competitividade das empresas turísticas na atual fase da globalização.

Marketing de relacionamento como dinamizador da estratégia competitiva

do cluster turístico.

5. A internacionalização das empresas de hotelaria. Análise das Top Ten cadeias internacionais.

CAPÍTULO IV - MODELO DELTA DE PENSAMENTO ESTRATÉGICO E SEU IMPACTO NO SETOR DO TURISMO

1. Principais Modelos de formulação estratégica na empresa 157

2. O Modelo Delta. 161

3. Empresas com enfoque estratégico de melhor produto. 177

4. Empresas com enfoque estratégico centrado no cliente. 178

5. Empresas com enfoque estratégico centrado no sistema. 178

6. Modelo de pensamento estratégico no setor de turismo. 179

7. Impacto do Modelo Delta no setor de turismo. 184

CAPÍTULO V -METODOLOGIA DA PESQUISA EMPÍRICA 190

1. Determinação do tipo de pesquisa $\quad 190$

2. O projeto de pesquisa. $\quad 194$

3. Definição das questões de estudo 197

4. Objetivos da pesquisa 198

5. Modelo operacional 199

6. Desenho da pesquisa 201

7. Tipos e fontes de informação 201

8. Métodos de acesso aos dados 202

9. Desenho das entrevistas 203

10. Coleta, análise e processamento da informação 211

11. Critérios seguidos para julgar a qualidade da pesquisa desenvolvida 212

12. Limitações da pesquisa de campo. 214 
13. Utilidade prática. 214

14. Modelo de pesquisa 215

CAPÍTULO VI - ESTUDO DE CASO: SOL MELIÁ 218

I - Introdução: Sol Meliá - décima empresa hoteleira no ranking internacional $\begin{array}{ll}\text { de cadeias hoteleiras } & 218\end{array}$

1. Breve história da empresa: a expansão nacional e a internacionalização 218

2. A saída para a bolsa 222

3. Estratégia de marketing. Orientação para o cliente 226

4. Estratégia de marcas. 230

5. Cultura organizacional. Gestão de recursos humanos 241

6. A gestão da qualidade 252

7. A introdução e o desenvolvimento de novas tecnologias da informação: a e-transformação da empresa 255

8. Análise econômico-financeira 259

9. Alianças, fusões e aquisições. Problemas estratégicos 261

II. Sol Meliá Cuba: o desafio $\quad 266$

1. Particularidades do crescimento em Cuba 266

$\begin{array}{ll}\text { III. Sol Meliá na América do Sul. } & 271\end{array}$

IV. Análise da concorrência $\quad 276$

CAPÍTULO VII - CONCLUSÕES LIMITAÇÕES E RECOMENDAÇÕES 289

$\begin{array}{ll}\text { BIBLIOGRAFIA } & 299\end{array}$ 
Capítulo I

\section{CARACTERIZAÇÃO DO ESTUDO}




\section{CAPÍTULO I \\ CARACTERIZAÇÃO DO ESTUDO}

I - Caracterização do estudo. A situação-problema, objeto de investigação, marco conceitual com o qual foram desenvolvidas as análises e análise de contexto.

II - Análise do contexto.

4. O turismo como fator de desenvolvimento econômico internacional

5. Evolução do turismo na globalização. Turismo postfordista ou de terceira geração. Novas megatendências.

6. O turismo na Espanha e América Ibérica como contexto do estudo. Casos particulares do desenvolvimento turístico no Brasil e Cuba.

\section{III - Descrição dos capítulos.}

I - Caracterização do estudo. A situação-problema, objeto de investigação, marco conceitual com o qual foram desenvolvidas as análises e análise de contexto.

A tese, objeto desse estudo, procura estudar o papel que o marketing estratégico e o desenvolvimento de vantagens competitivas têm nas organizações empresariais do setor de turismo, para a obtenção de uma posição competitiva vantajosa, como forma de satisfazer aos seus clientes, aos seus diversos públicos e à sociedade de forma geral.

O estudo começa por uma revisão da literatura, desde a Escola da Administração Científica de Taylor, nas primeiras décadas do século passado, até a evolução do marketing estratégico na atualidade, com enfoque direcionado ao cliente, ao mercado e ao posicionamento da empresa. Inclui também a avaliação prática, na empresa Sol Meliá, de um recente modelo teórico sobre estratégia empresarial, seguindo a metodologia do estudo de casos, bem como as relações que se desenvolveram entre as empresas na era da globalização. O Modelo Delta de Hax (2001) caracteriza a evolução da estratégia das empresas, de um enfoque mais centrado no produto, passando por uma etapa mais recente de orientação para o cliente e para o mercado, até chegar à orientação atual, em que a empresa se envolve integralmente no sistema em que atua, como um elemento próprio de seu negócio. Busca-se a competitividade e o posicionamento em novas formas de relações com clientes, competidores, empresas complementares, de forma a garantir, assim, um posicionamento competitivo sistêmico. São expostos também os critérios que sustentam o surgimento dos clusters de empresas, como nova configuração empresarial, no ambiente de globalização. 
A tese apresenta, ainda, um modelo de organização para atingir esses objetivos, de tal forma que uma estratégia corporativa eficaz seja sustentável pelo desenvolvimento de relações sólidas no interior da empresa e um contínuo aperfeiçoamento empresarial. É exposto o modelo EFQM, de excelência da gestão empresarial, adotado pelas principais empresas européias. O modelo coloca a qualidade em termos de satisfação de seus clientes como seu mais importante processo. Dessa forma, o estudo proporciona, não só as ferramentas para posicionar a empresa de uma forma competitiva no mercado, como acrescenta, também, os elementos para contínuos aperfeiçoamentos internos, para consolidar os objetivos estratégicos.

Quais são as condições de atuação das empresas turísticas no mercado, em ambiente globalizado? Como evoluiu o Marketing Estratégico nas empresas neste contexto? Como atuar local e pensar global? Como desenvolver as capacidades internas da empresa no âmbito de uma atuação global?

Para abordar essas questões, o estudo trata do fenômeno da internacionalização da empresa na era da globalização, e o impacto da crescente concentração por fusões e aquisições entre empresas, atualmente presente no cenário contemporâneo.

Esses conceitos são analisados em um setor com impacto cada vez maior na economia mundial: o setor do turismo, um setor que apresenta ainda pouco tratamento por parte dos estudiosos da Administração. O estudo contribui, deste modo, para introduzir as recentes teorias sobre a prática da administração estratégica e competitiva nas empresas de turismo.

O setor do turismo resume em si mesmo a grande evolução econômica e sócio-cultural que se está presenciando no mundo. Seu impacto no desenvolvimento da humanidade vai além de seu papel dinamizador das economias, pois representa um componente catalizador da globalização, no âmbito da cultura e do intercâmbio entre os povos de qualquer latitude. Por sua vez, as transformações tecnológicas dinâmicas que vêm ocorrendo e que se têm aplicado no setor, desde avanços nas telecomunicações até transporte intercontinental, em economia de tempo e conforto nunca antes visto, têm uma repercussão significativa no comportamento do mercado turístico, obrigando todos os integrantes do Sistema de Turismo a mudar seu modo de atuar, se tiverem a pretensão de ser competitivos.

O homem pratica turismo desde o começo da humanidade, mas, somente nas últimas décadas é que os avanços da tecnologia têm-lhe permitido, de um lado, maior tempo para desfrutar de suas horas livres e, de outro, a possibilidade cada vez maior de viagens rápidas, atingindo os lugares mais longínquos e diversificados do planeta. Com o desenvolvimento das comunicações é 
possível conhecer, por intermédio de imagens, qualquer ponto do planeta, o que provoca o desejo de apreciar esses lugares pessoalmente, incitando milhões de pessoas ao viajar.

Esses fatores têm convertido o turismo em uma atividade de extrema atualidade e importância, não somente por sua repercussão no contexto econômico, como também pelo impacto sobre os fatores político-legal, cultural, social e demográfico do meio ambiente.

Acredita-se que nos próximos anos os destinos turísticos deverão se adaptar a uma situação de máxima competitividade, em que a obtenção de lucros e a sustentabilidade dos negócios turísticos serão mais difíceis. Os destinos turísticos terão de enfrentar oferta crescente de leitos, atrativos diversos e serviços turísticos diversificados, em diferentes núcleos receptores. As prestadoras de serviço, nesse cenário, deverão trabalhar para atender a uma demanda cada vez mais exigente e sofisticada. Esse fato faz com que o poder de negociação sobre a demanda se reduza e, como conseqüência, os preços sofram grandes pressões para serem reduzidos, com a possível diminuição nas taxas de retorno sobre os investimentos.

As empresas turísticas terão de projetar suas ofertas de forma cada vez mais diferenciada e integrada ao planejamento dos destinos em que estão inseridas, em correspondência com a consecução de desenvolvimento sustentável do setor. Deverão ser capazes de captar a atenção de novos turistas e reter os atuais clientes, investindo na inovação de suas propostas. Em determinados pólos turísticos, é possível verificar como as empresas que exploraram os recursos turísticos da região de forma intensiva - sem ter uma estratégia adequada para garantir uma oferta diferenciada - têm perdido seu posicionamento competitivo no mercado - além de provocar danosas conseqüências ao ecossistema.

É possível verificar que as empresas do setor turístico apresentam diferentes estágios de desenvolvimento, os quais estão em correspondência direta com o grau de aplicação das técnicas do marketing estratégico ${ }^{1}$ :

Empresas no primeiro estágio: dedicam-se apenas a produzir bens facilitadores, alcançando uma participação mínima no valor de transação da viagem turística, o qual é majoritariamente captado pela operadora turística, tendo uma limitada influência na satisfação total do turista e na agregação de valor pela transação.

Empresas no segundo estágio: incorporam os incentivadores à produção de bens facilitadores e complementam a oferta básica - acolhida - com outras, voltadas para a satisfação de necessidades relativas a viagens de interesse científico, de negócios ou lazer ou relacionadas com

\footnotetext{
${ }^{1}$ Classificação própria
} 
saúde e bem estar. Essas empresas conseguem entregar maior valor aos seus clientes, mas têm ainda uma forte dependência da intermediação, ou seja, das operadoras turísticas, como atacadistas e agências de viagem no varejo.

Empresas no terceiro estágio: voltadas para viagens turísticas integrais, com uma oferta combinada de bens facilitadores e incentivadores. Estando em contato direto com os turistas potenciais, oferecem-lhes um pacote turístico único e diferenciado, capaz de satisfazer às mais diversas expectativas. São as empresas com maior capacidade de entregar o valor.

Empresas no quarto estágio de desenvolvimento: são as empresas configuradas em rede, tanto vertical como horizontalmente. A rede integra essas empresas com as que integram sua cadeia, ou seja, complementadoras, distribuidores, fornecedores, organizações públicas e privadas do destino turístico que, em conjunto, buscam satisfaz a seus clientes e fidelizá-los. São os chamados clusters turísticos, onde as estratégias competitivas predadoras cedem lugar às estratégias de cooperação entre si e de aproximação com os clientes, com o recurso da marketing de relacionamento.

Atualmente, como conseqüência da globalização, e sendo parte desse fenômeno, os processos de internacionalização de umas poucas grandes empresas turísticas que controlam praticamente todo o mercado se ampliam e generalizam. O processo está resultando em uma forte concentração de empresas, de forma tal que, praticamente, só cinco grandes operadoras e dez cadeias hoteleiras dominam atualmente o mercado mundial, com forte tendência de que o fenômeno da concentração continue. Sendo assim, o setor se caracteriza internacionalmente, por uma rede empresarial concentrada e internacionalizada. Essa rede normalmente abrange os principais países emissores de turismo e os novos destinos turísticos, esse em geral de países subdesenvolvidos, sem recursos para explorar por si mesmos suas potencialidades.

O problema em estudo está vinculado aos países receptivos que, por suas condições naturais, especializam-se em desenvolver ofertas para receber turistas de todas partes do mundo. Nesses países, as empresas turísticas têm muita dificuldade de alcançar seus objetivos. Por um lado, dependem fortemente da infra-estrutura do país ou região em que se encontram; por outro lado, não recebem a devida atenção das instituições públicas. Elas se sentem submissas, ainda, aos agentes intermediários que controlam o mercado, já que seus clientes encontram-se normalmente em outros países, muitas vezes distantes. Isso acarreta uma dependência quase completa das linhas aéreas e das operadoras turísticas internacionais que, por meio das agências de viagens, negociam diretamente com os clientes potenciais. 
As organizações turísticas dos países receptivos, normalmente identificados como os novos destinos, se especializam quase exclusivamente na produção de bens facilitadores para garantir a acessibilidade, acolhida e estada dos turistas. Existe carência de conhecimento gerencial, "knowhow", pelo que seus resultados se vêem muito limitados. A falta de infra-estrutura necessária requer vultosos recursos materiais e humanos e, em geral, muitos destes países são subdesenvolvidos. Sendo assim, a captação de recursos financeiros para fomentar a indústria é uma necessidade presente.

Portanto, analisa-se, no contexto desta pesquisa, um duplo fenômeno:

a. Os novos destinos turísticos, em geral, carecem de recursos financeiros e humanos para se desenvolverem, existindo insuficiente conhecimento para a gestão das empresas locais;

b. Com a globalização, as grandes empresas turísticas dos países emissores estão se internacionalizando, levando o necessário know-how, o capital para investimento em infraestrutura e promovendo o acesso ao mercado.

O estudo pretende contribuir para difundir, a partir do estudo de uma das empresas internacionais, com atuação na América Latina, quais são suas práticas de gestão estratégica e como ela está contribuindo para que o turismo seja verdadeiramente uma via de desenvolvimento para os destinos que explora.

A pesquisa empírica que integra a tese é de natureza qualitativa e de caráter exploratóriodescritivo, tendo como método o estudo de caso (Ein, 2001). O caso estudado foi a empresa Sol Meliá, tendo como foco principal sua atuação estratégica na América Latina. Foram desenvolvidas entrevistas em profundidade e coletados dados secundários e junto à sede da matriz da empresa, na Espanha, e em suas filiais no Brasil (correspondente a toda América de Sul) e Cuba. Como resultado, obteve-se um estudo multicaso, a partir da análise de uma única empresa (matriz européia, Brasil, incluindo América do Sul, e Cuba).

Como base teórico-conceitual de análise dos resultados, adotou-se o Modelo Delta de Hax (2001), anteriormente mencionado, e como estrutura expositiva dos resultados o modelo EFQM de excelência empresarial da União Européia.

Nesse sentido, o interesse central motivador do trabalho foi a verificação de como estão sendo adotadas, pelas empresas turísticas, as estratégias de marketing, em função da crescente competitividade decorrente da saturação dos mercados, em um contexto de ambiente globalizado. Em síntese, o problema de pesquisa pode ser expresso por meio das seguintes perguntasproblema: 
1. Quais são os instrumentos do marketing estratégico utilizados pelas empresas turísticas, para gerar vantagens competitivas?

2. Como as empresas turísticas estão utilizando os elementos de análise e decisão de Marketing Estratégico, para competir no mercado internacional de turismo?

3. Que influência têm as técnicas do marketing estratégico aplicadas pelas empresas turísticas pesquisadas, no seu posicionamento estratégico de mercado?

Para isso, pretende-se responder às seguintes questões de estudo:

1. Quais são as tendências do mercado turístico global em que operam as empresas?

2. Qual é a estrutura competitiva do setor em que operam?

3. Qual o impacto sobre as empresas turísticas dos ambientes econômico, tecnológico, ecológico, demográfico, físico, político e social presentes onde elas operam?

4. Como administram sua carteira de produtos?

5. Que políticas de preços empregam?

6. Quais são as estruturas e motivações dos canais de distribuição que utilizam?

7. Que força e qualidade têm os meios de comunicação que empregam?

8. Que tipos de capacidades internas, estruturas e cultura organizacional adotam?

9. Qual é o grau de criatividade e inovação de suas ofertas?

10. Quais são os desempenhos de sucesso?

11. Que tipo de estratégias competitivas têm adotado?

12. Estão as organizações em condições de obter vantagens competitivas sustentáveis?

Uma vez formuladas as perguntas-problema, o objetivo geral perseguido foi: "estudar a utilização dos elementos de análise e decisão de Marketing Estratégico pelas empresas turísticas nos países receptivos, particularmente no Brasil e em Cuba, para alcançar um posicionamento de mercado compatível com o desenvolvimento do Turismo em suas regiões".

A partir deste objetivo geral derivaram-se os seguintes objetivos específicos:

1. Identificar a utilização dos conceitos, modelos e técnicas de análise, associados ao marketing estratégico e avaliar sua contribuição para alcançar a competitividade das empresas pesquisadas no Brasil e Cuba; 
2. Avaliar, do ponto de vista do marketing estratégico, como as empresas que operam o turismo nos países receptivos, como Brasil e Cuba, desenvolvem suas potencialidades para serem competitivas;

3. Contribuir com o desenvolvimento de metodologias para o delineamento de estratégias competitivas no setor turístico em países como Brasil e Cuba;

4. Sugerir recomendações sobre as direções principais de mudança no enfoque gerencial das organizações turísticas que operam o turismo no Brasil e Cuba.

O estudo de caso, como já mencionado, foi desenvolvido junto à empresa Sol Meliá que tem uma importante presença na América Latina. O estudo descreve o crescimento e a expansão internacional de uma das empresas espanholas de maior sucesso do setor turístico. O Grupo Sol Meliá, maior empresa hoteleira de temporadas de férias do mundo, é:

- Líder absoluto do mercado espanhol tanto no segmento urbano (no trabalho também chamado de turismo de negócios) como no de temporadas (turismo de férias).

- Primeira empresa hoteleira da América Latina e Caribe;

- Terceira cadeia hoteleira da Europa;

- Sétima empresa por capitalização em Bolsa

- Décima no mundo em número de aposentos (quartos);

- Presente em 30 países;

- Efetivo superior a 33.000 empregados.

O estudo de caso Sol Meliá também se aprofunda no papel da cultura organizacional e sua influência no processo de tomada de decisões frente às condições mutáveis do ambiente. Nesse sentido, o caso analisado cobre a evolução histórica do Grupo Sol Meliá, uma das empresas espanholas que mais se destacaram no processo de internacionalização, agregando-lhe um valor de excelência empresarial, com base no modelo EFQM. Finalmente, o Caso traz particularidades do setor turístico, na Espanha e na América Latina, o que lhe dá uma relevância maior, pela importância cada vez maior do turismo no cenário mundial.

\section{II - Análise do contexto.}

\section{O turismo como fator de desenvolvimento econômico internacional}

O ser humano parece ter nascido com o desejo de viajar. Segundo MUÑOZ (1993), em 1841, na Inglaterra, quando o senhor Thomas Cook organizou uma viagem de ida e volta LeicesterOughrough-Leicester, reunido 540 clientes, com a finalidade de irem a uma convenção de exalcoólatras, inaugurou a primeira viagem turística de que se tem registro na história. O senhor Cook não obteve nenhum lucro com a organização e venda do seu primeiro produto turístico, 
mas percebeu o potencial do negócio. Tanto assim, que, em 1845, decidiu dedicar-se exclusivamente a organizar excursões. Surgiu a primeira operadora turística da história.

Sempre existiram motivações para se fazerem viagens turísticas. Entretanto, a maioria das pessoas não tinha condições de realizá-las. Esas condições, no século XX, foram gradualmente alcançadas e as viagens se tornaram um produto de grande consumo. Os fatores que permitiram o desenvolvimento do turismo são, entre outros, o aumento da renda familiar, o progresso tecnológico, a melhoria do nível de instrução, a concentração urbana, o aumento do tempo livre e a pacificação geopolítica do mundo.

O setor turístico converte-se, neste final de século, num dos setores de fundamental importância para o desenvolvimento social e econômico de muitos países, influindo de forma ativa nas mudanças sociais, econômicas, culturais e tecnológicas, que estão ocorrendo $\mathrm{n}$ a sociedade.

Como informa a OMT, em “Turismo: Panorama 2020, Previsões Mundiais e perfis dos segmentos de mercado": desde 1950, quando o turismo internacional começou a ser acessível ao público, a atividade turística cresceu a uma taxa média anual de 7,1\%, passando de 25 milhões (1950) a 565 milhões de pessoas, em 1995, e a uma taxa de 12,4\%, em termos da receita turística internacional (a preços correntes e excluindo o gasto de transporte internacional), passando de 2.100 milhões a 406.000 milhões de dólares, conforme mostra a seguinte Tabela.

Tabela 1 - Evolucão do turismo internacional de 1996 a 2001.

\begin{tabular}{|c|c|c|c|}
\hline \multicolumn{5}{|c|}{ Evolución do turismo internacional } \\
\hline Ano & $\begin{array}{c}\text { Chegadas } \\
\text { (milhões) }\end{array}$ & $\begin{array}{c}\text { Aumento en valores } \\
\text { absolutos (milhões) }\end{array}$ & $\begin{array}{c}\text { \% Variación } \\
\text { Anual }\end{array}$ \\
\hline 1996 & 586 & 34 & 6.2 \\
\hline 1997 & 610 & 24 & 4.1 \\
\hline 1998 & 629 & 19 & 3.1 \\
\hline 1999 & 652 & 23 & 3,7 \\
\hline 2000 & 696,6 & 45 & 6.8 \\
\hline 2001 & 692,5 & -5 & -0.6 \\
\hline
\end{tabular}

Fonte. Elaboração própria a partir de dados da OMT

O continuado e vigoroso crescimento das chegadas de turistas internacionais, na primeira metade dos anos noventa, - de 4,3\% anuais -, só meio-ponto porcentual abaixo da taxa de crescimento alcançada na década de oitenta - indica o fortalecimento do turismo frente à desaceleração econômica experimentada em princípios dos anos noventa. As regiões com mais flutuação, entre 1990 e 1995, foram as seguintes: Oriente Médio (6,6\% de crescimento anual por chegadas), Ásia Oriental e o Pacífico (8,3\% anual), Ásia Meridional (5,9\% anual) e África (6,1\% anual), com resultado abaixo da média, só no caso da Europa (3,7\% anual) e das Américas (3,3\% anual). 
As cotas de mercado de chegadas de turistas internacionais de longa distância ou intra-regionais permaneceram constantes, entre 1990 e 1995, a 82:12. Existem marcadas diferenças entre as regiões com as chegadas intra-regionais dominando, em 1995, na Europa (88\%), Ásia Oriental e o Pacífico (79\%), as Américas (77\%) e África (58\%), enquanto que as chegadas de longa distância constituem a categoria principal para Ásia Meridional (76\%) e Oriente Médio (58\%).

Entre 1995 e 1998, a crise financeira na Ásia produziu efeitos sobre o crescimento do turismo, em particular na Ásia Oriental e no Pacífico. Em 1996 os resultados na Ásia Oriental e no Pacífico, todavia, eram bons com um incremento de 9,4\% nas chegadas. Contudo, a crise financeira que surgiu em 1997 deteve o crescimento de chegadas na região e produziu uma queda de perto de $1 \%$ durante dois anos seguidos. Esta queda abrupta foi também visível nos resultados do turismo em todo o mundo. Embora o aumento de 5,7\% nas chegadas de turistas internacionais em todo o mundo em 1996 foi superior à média lograda durante os cinco anos anteriores, o crescimento diminuiu 3,4\% em 1997 e uns 3\% em 1998. Globalmente, não obstante, o turismo prosperasse em finais dos anos noventa. Salvo para Ásia Oriental e para o Pacífico, as demais regiões melhoraram ou igualaram as taxas de crescimento do período 19901995. Ásia Meridional, África e Oriente Médio mostraram um crescimento contínuo e sustentável superior ao 7\% anual em média entre 1995 e 1998. A Europa aumentou em 4,3\% anual e as Américas em 3,3\%.

Os anos 2000 e 2001 foram excepcionais para o turismo. Durante o primeiro, o turismo internacional cresceu em quarenta e cinco milhões de chegadas e fez com que alcançasse cotas raramente vistas antes.

No ano 2001 se contratou - 0,6\%. Há que se retroceder até 1982 para encontrar um ano com sinal negativo na evolução do turismo internacional. Não obstante, os resultados do ano 2001 estão em linha com o que havia sido a tendência da última década, se o incremento de chegadas turísticas do ano 2000 não tivesse se situado tão nitidamente acima das cifras registradas nos últimos anos.

Foi igualmente excepcional a natureza de alguma das causas, os acontecimentos de 11 de setembro, que determinaram os resultados do turismo internacional no ano 2001, assim como a forma em que afetou certos destinos e setores.

Uma crise de confiança como a vivida no ano 2001 não é fácil de encontrar nas décadas anteriores. 
A situação econômica começou a deteriorar-se nos países ocidentais em finais do ano 2000 e a de alguns países emissores asiáticos até mesmo antes desse período. Seus efeitos no turismo receptor, em regiões como as Américas, Ásia do Sul e / ou Oriente Médio, se fizeram sentir nos primeiros oito meses do ano 2001.

A saturação de imagens dos fatos lutuosos do mês de setembro nos meios de comunicação, a reiteração das mensagens associadas e o aumento das reações diplomáticas e militares decorrentes, a princípio por não contar com informações precisas e depois pelo risco de ocorrência de situações que ultrapassassem os limites, originaram uma contração dos fluxos turísticos internacionais.

O que se viu nos meses posteriores a setembro de 2001 foi que não se renunciava às viagens mas que se reestruturavam, dando prioridade aos destinos de raio mais curto, conhecidos e acessíveis, com meios de transporte percebidos como seguros, talvez por ser individualmente controláveis. A situação em que se encontrava o setor aéreo não fez mais que agravar-se, e suas conseqüências ainda se alargam, com um final que não é fácil de perfilar neste momento.

As seguintes tabelas mostram as estatísticas de comportamento do turismo em 2001, relativo ao ano 2000, reflexo da situação de 11 de setembro, e os resultados globais da última década, segundo a OMT: 
Tabela 2 Chegadas de turistas internacionais por (sub)regiões

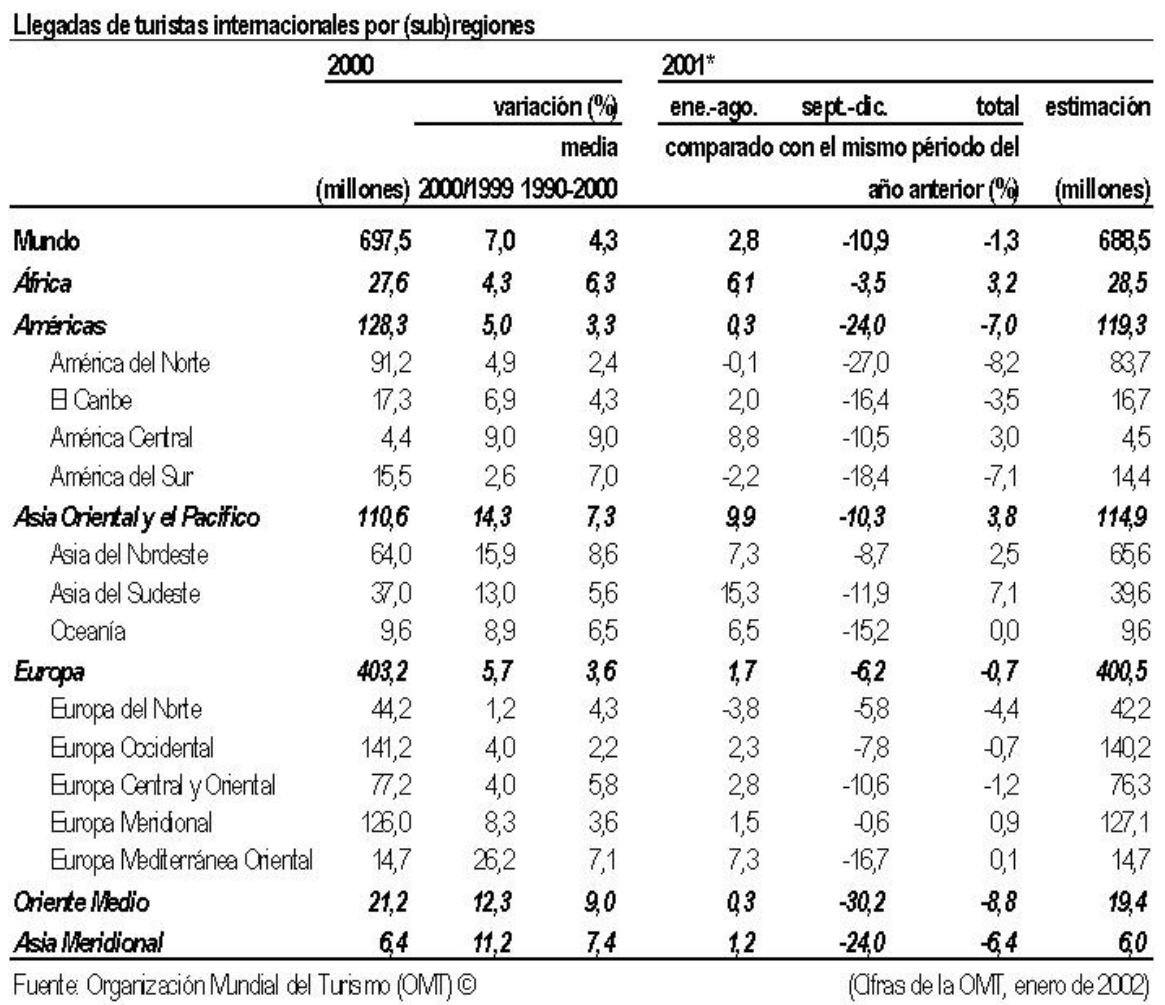

Tabela 3 - Chegadas de turistas internacionais por sub(regiões)

No ano 2001, gerou-se uma receita turística no mundo de 462 mil de milhões de dólares dos Estados Unidos, o que supôs um decrescimento de - 3\% sobre o ano anterior. Isso significa que foi gerada, uma receita média diária da ordem de 1.300 milhões de dólares.

No ano 2000, estima-se que se geraram 97.000 milhões de dólares em termos de receita por transporte internacional (computam-se como tais as receitas de empresas de transporte ocorridos como fora de seu país de origem), conforme mostram as figuras seguintes. 
Llegadas de turistas intemacionales por (sub)regiones

\begin{tabular}{|c|c|c|c|c|c|c|c|c|c|c|}
\hline & \multicolumn{5}{|c|}{ Uegadas de turistas intemacionales } & \multicolumn{2}{|c|}{$\begin{array}{l}\text { Guota de } \\
\text { mercado }\end{array}$} & \multicolumn{2}{|c|}{ Variación } & \multirow{2}{*}{$\begin{array}{r}\text { Crecimiento } \\
\text { medio } \\
\text { anual }(\%) \\
95-01^{*}\end{array}$} \\
\hline & 1990 & 1995 & 1999 & 2000 & 2001 & 1995 & 2001 & 00 irg & $01^{*}=0$ & \\
\hline Klundo & 457,3 & 551,7 & 652,3 & 696,6 & 692,5 & 100 & 100 & 6,8 & $-0,6$ & 3,9 \\
\hline Áfixa & 15,0 & 20,0 & $\mathbf{6 , 2}$ & 27,2 & 284 & 3,6 & 4,1 & 3,6 & 4,6 & 6,0 \\
\hline Árica del Norte & 8,4 & 7,3 & 9,4 & 10,1 & 106 & 1,3 & 1,5 & 6,8 & 4,8 & 6,3 \\
\hline África Occidental & 1,4 & 19 & 2,5 & 2,7 & 30 & 0,3 & 0,4 & 6,4 & 12,8 & 7,8 \\
\hline Árica Central & 0,4 & 0,3 & 0,4 & 0,4 & 0,5 & 0,1 & 0,1 & 3,1 & 16,2 & 7,8 \\
\hline África Orental & 2,9 & 4,5 & 5,8 & 5,8 & .. & 0,8 & & $-1,1$ & & \\
\hline f́rica Austral & 2,0 & 60 & 8,0 & 8,2 & 8,4 & 1,1 & 1,2 & 2,3 & 2,4 & 5,8 \\
\hline Américas & 929 & 1089 & 122,4 & 1285 & 120,8 & 19,7 & 17,4 & 5,0 & $-6,0$ & 1,7 \\
\hline América del Norte & 71,7 & 80,5 & 87,0 & 91,2 & 850 & 14,6 & 12,3 & 4,9 & 6,8 & 0,9 \\
\hline 日 Caribe & 11,4 & 140 & 16,3 & 17,4 & 169 & 2,5 & 2,4 & 6,9 & $-2,9$ & 3,2 \\
\hline Aménica Central & 1,8 & 26 & 4,0 & 4,3 & 4,4 & 0,5 & 0,6 & 8,9 & 1,7 & 9,2 \\
\hline América del Sur & 7,9 & 11,8 & 15,1 & 15,5 & 14,5 & 2,1 & 2,1 & 2,4 & 6,3 & 3,5 \\
\hline Asja Orientaly el Pacifico & 54,6 & $\$ 1,3$ & 96,8 & 109,1 & 1151 & 14,7 & 16,6 & 127 & 5,5 & 6,0 \\
\hline Asia del Nordeste & 28,0 & 44,1 & 55,2 & 62,5 & 656 & 80 & 9,5 & 13,2 & 5,0 & 6,8 \\
\hline Asia del Sude ste & 21,5 & 292 & 32,7 & 36,9 & 400 & 5,3 & 5,8 & 13,0 & 8,3 & 5,4 \\
\hline Oceanía & 5,2 & 8,1 & 8,9 & 9,7 & 9,5 & 1,5 & 1,4 & 8,9 & $-2,1$ & 2,7 \\
\hline Europa & 2827 & 324,2 & 300,6 & 4025 & 390,8 & 58,8 & 57,7 & 5,8 & $-0,7$ & 3,6 \\
\hline Europa del Norte & 29,1 & 376 & 43,6 & 44,2 & 416 & 6,8 & 6,0 & 1,2 & $-5,7$ & 1,7 \\
\hline Europa Occidental & 113,8 & 116,7 & 135,8 & 141,2 & 1402 & 212 & 20,2 & 4,0 & $-0,7$ & 3,1 \\
\hline Eur. Central/Oriental & 43,8 & 67,1 & 73,8 & 76,5 & 76,3 & 122 & 11,0 & 3,7 & $-0,3$ & 2,2 \\
\hline Europa Meridional & 88,6 & 91,3 & 115,8 & 126,0 & 1270 & 16,5 & 18,3 & 8,8 & 0,8 & 5,7 \\
\hline Eur. Medit. Oriental & 7,4 & 11,4 & 11,6 & 14,7 & 14,7 & 2,1 & 2,1 & 26,2 & $-0,1$ & 4,3 \\
\hline Oriente Niedio & 9,0 & 131 & 20,5 & 232 & 227 & 2,4 & 33 & 132 & $-2,5$ & 9,6 \\
\hline Asia Neridional & 32 & 4,2 & 5,8 & 6.1 & 5,7 & 0,8 & 0,8 & 54 & $-6,3$ & 5,2 \\
\hline
\end{tabular}

Figuras 1 e 2: Participação de mercado mundial, receita por turismo internacional e receita média por chegadas no ano 2000, segundo a OMT:
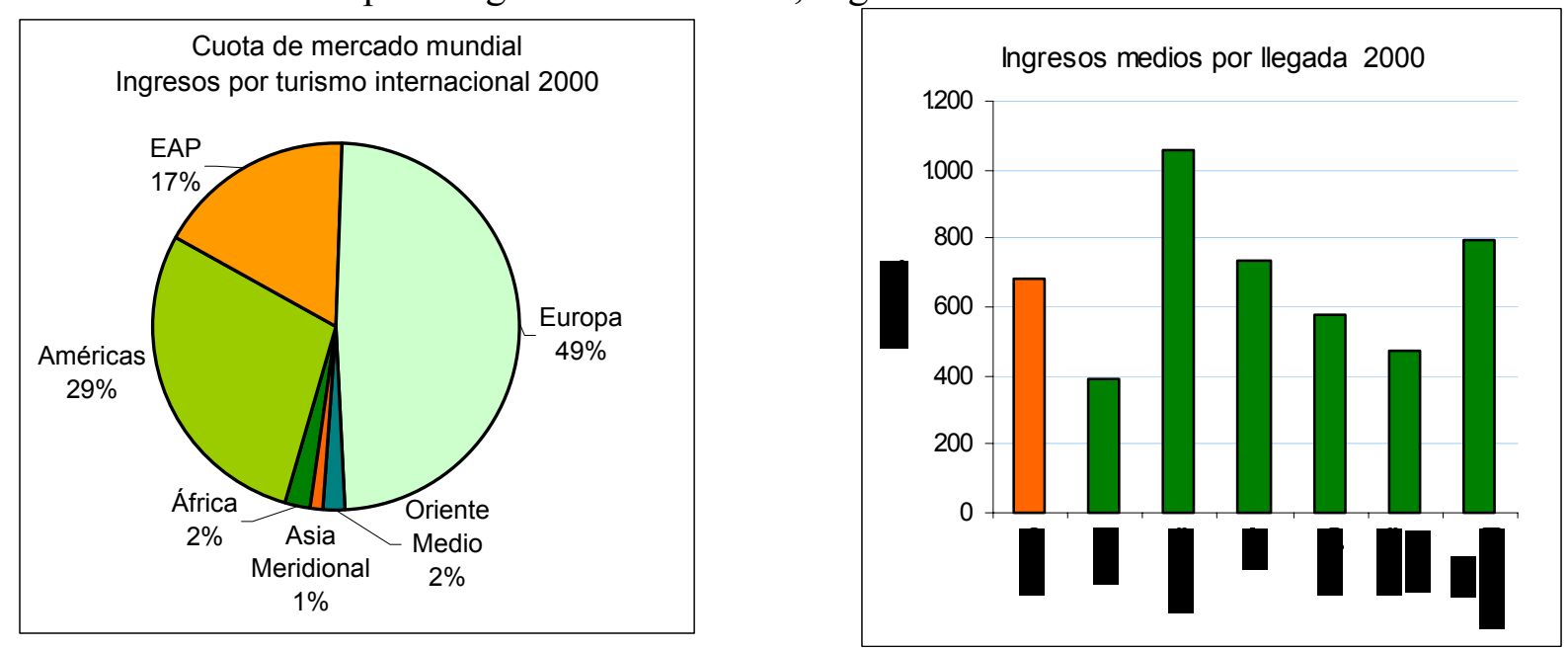

Fonte: Organización Mundial do Turismo (OMT)

Figura 1 - Participação no mercado mundial $\quad$ Figura 2 - Receitas médias por chegada 2000 
A Tabela 4 reflete, segundo a OMT, os resultados do turismo em nível mundial na última década:

\begin{tabular}{|c|c|c|c|c|c|c|c|c|c|c|}
\hline & \multicolumn{5}{|c|}{$\begin{array}{l}\text { Ingre sos por turismo interna cional } \\
\text { (tEE.UW., miles de millones) }\end{array}$} & \multicolumn{2}{|c|}{$\begin{array}{r}\text { Cuota de } \\
\text { mercado } \\
\text { (fio) }\end{array}$} & \multicolumn{2}{|c|}{$\begin{array}{r}\text { Variación } \\
\text { (pio) } \\
\end{array}$} & \multirow{2}{*}{$\begin{array}{r}\begin{array}{r}\text { Crecimiento } \\
\text { medio } \\
\text { anual (fin) }\end{array} \\
\mathbf{9 - 0 0}\end{array}$} \\
\hline & 1990 & 1995 & 1999 & 2000 & 2001 & 1999 & 2001 & 00099 & $01^{*} \mathrm{D0}$ & \\
\hline Mundo & 263,4 & 405,3 & 456,7 & 476,7 & 462,3 & 100 & 100 & 4,4 & $-3,0$ & 3,3 \\
\hline Ánica & 5,3 & $\$ 1$ & 10,5 & 10,8 & $n, 7$ & 2,0 & 25 & 25 & 8,1 & 5,8 \\
\hline áfrica del Norte & 2,3 & 2,7 & 3,5 & 3,7 & 4,2 & 0,7 & 0,9 & 36 & 15,6 & 5,9 \\
\hline áfrica Occidental & $0, B$ & 0,7 & 1,0 & 10 & 1,2 & 02 & 0,3 & 18 & 12,7 & 8,4 \\
\hline áfica Central & 0,1 & 0,1 & 0,1 & 0,1 & .. & 0,0 & & 0,0 & & 6,6 \\
\hline áfrica Oriental & 1,1 & 1,9 & 2,6 & 26 & 2,6 & 0,5 & 0,6 & $-1,1$ & 3,1 & 5,8 \\
\hline áfrica Austral & 12 & 2,6 & 3,2 & 3,4 & .. & 0,7 & & 46 & & 5,0 \\
\hline Américas & 69,2 & 99,6 & 122,1 & 132,8 & 1225 & 24,6 & 26,5 & 88 & $-7,7$ & 5,9 \\
\hline América del Norte & 548 & 77,5 & 92,1 & 1010 & 91,5 & 19,1 & 19,8 & 9,7 & $-9,5$ & 5,5 \\
\hline El Caribe & 8,7 & 12,2 & 15,8 & 168 & 16,9 & 30 & 3,7 & 66 & 0,4 & 6,7 \\
\hline A.mérica Central & 0,7 & 1,6 & 2,6 & 3,1 & 3,1 & 0,4 & 0,7 & 189 & 1,9 & 14,4 \\
\hline América del Sur & 4,9 & 8,4 & 11,6 & 118 & 11,0 & 2,1 & 2,4 & 22 & $-6,9$ & 7,0 \\
\hline Asia Osiental y elPac zico & 39,2 & 73,8 & 74,4 & $\$ 1,6$ & $\$ 2,1$ & 18,2 & 17,8 & 9,6 & 0,6 & 20 \\
\hline Asia del Norde ste & 176 & 33,7 & 37,7 & 41,3 & 43,2 & 8,3 & 9,3 & 9,4 & 4,7 & 4,1 \\
\hline Asia del Sudeste & 14,5 & 27,9 & 23,8 & 26,5 & 25,6 & 69,9 & 5,5 & 11,3 & $-3,3$ & $-1,0$ \\
\hline Oceanía & 7,1 & 12,2 & 12,9 & 138 & 13,3 & 30 & 2,9 & 7,3 & $-3,9$ & 2,5 \\
\hline Europa & 143,2 & 211,3 & 233,9 & 234,5 & 229,5 & 52,1 & 49,7 & 0,2 & $-2,1$ & 2,1 \\
\hline Europa del Norte & 24,7 & 32,6 & 34,8 & 346 & 30,9 & 80 & 6,7 & $-0,6$ & $-10,6$ & 1,2 \\
\hline Europa Occidental & 632 & 80,5 & 83,6 & 822 & 80,4 & 19,9 & 17,4 & $-1,7$ & $-2,2$ & 0,4 \\
\hline Eur. CentralOriental & 48 & 22,7 & 26,2 & 262 & 26,0 & 5,6 & 5,6 & $-0,1$ & $-0,6$ & 2,9 \\
\hline Europa Meridional & 44,6 & 65,8 & 79,3 & 782 & 79,2 & 162 & 17,1 & $-1,4$ & 1,2 & 3,5 \\
\hline Eur. Medit. Oriental & 5,9 & 9,7 & 10,1 & 13,3 & 13,1 & 2,4 & 2,8 & 32,8 & $-2,0$ & 6,6 \\
\hline Oriente Me do & 4,4 & $\$ 9$ & $n, 2$ & 12,2 & $n, s$ & 2,2 & 26 & 9,1 & $-3,5$ & 6,5 \\
\hline Asa Meridional & 2,0 & 3,5 & 4,6 & 4,9 & 4,7 & 0,9 & 1,0 & 7,5 & $-4,8$ & 7,2 \\
\hline
\end{tabular}

Tabela 4 - Receitas por turismo internacional por (sub)regiões

A média mundial da receita por chegada foi, no ano 2000, de 680 dólares, e de 668 em 2001. Neste último ano a receita média por chegada mais alta se registrou nas Américas, 1.014 dólares, seguidos pela Ásia Meridional, 825 dólares e Ásia Oriental e Pacífico, 713 dólares. A Europa registrou uma receita por chegada da ordem de 574 dólares, considerando que, em destinos da Europa do Norte, Ocidental e do Sul a receita se situa acima desta cifra.

Além destes resultados, o turismo tem outras dimensões e impactos não menos importantes que os específicos do campo econômico. Segundo destaca BENI (1996), o turismo é um eficiente meio para:

1. Promover a divulgação da informação sobre uma determinada região ou localidade, seus valores naturais, culturais e sociais; 
2. Abrir novas perspectivas sociais como resultado do desenvolvimento econômico e cultural da região;

3. Gerar empregos diretos e indiretos especialmente importante em regiões que não possuam recursos para desenvolver outras indústrias mas têm atrativos naturais ${ }^{2}$.

4. Integrar socialmente, incrementar (em determinados casos) a consciência nacional;

5. Desenvolver a criatividade em vários campos;

6. Promover o sentimento de liberdade mediante a abertura ao mundo, estabelecendo e/ou estendendo os contatos culturais.

O turismo também pode provocar, no meio visitado, os seguintes prejuízos:

1. Degradação e destruição dos recursos naturais;

2. Perda da autenticidade da cultura e identidade local;

3. Criação estereotipada e falsa do turista e do país ou região de que procede, por falta de informação adequada;

4. Ausência de perspectivas para aqueles grupos da população local das áreas de destino turístico, que não obtêm benefícios diretos das visitas dos turistas ou do próprio sistema de turismo da localidade;

5. Aparecimento de fenômeno de disfunção social na família, patologia no processo de socialização, desintegração da comunidade;

6. Dependência do capital estrangeiro, quando o país ou a região não possui os recursos próprios para desenvolver o turismo.

Pode-se constatar que a maioria destes prejuízos, não é intrínseca ao fenômeno do turismo como tal, senão que surgem por uma incorreta exploração do mesmo como negócio sustentável, tanto pelas organizações públicas como pelas privadas. Neste caso as empresas devem estabelecer estratégias que, além de gerar os resultados esperados economicamente, contribuam para desenvolver o turismo na região de forma sustentável. O problema surge quando não se tem correspondência entre os desempenhos de ambos subsistemas: se as instituições privadas e o Estado não aplicam políticas tendentes a fortalecer o Sistema de Turismo da região como um todo, as empresas operadoras finalmente não poderão garantir satisfação esperada pelos visitantes e em longo prazo provocará perdas.

\footnotetext{
${ }^{2}$ Segundo dados da OMT o turismo gera atualmente emprego para 280 milhões de pessoas, uma entre dez pessoas da população mundial economicamente ativa, contribuindo com US\$ 770 bilhões em impostos e taxas, diretos e indiretos, em todo o mundo, e um faturamento de US\$ 8 trilhões de novos investimentos em equipamentos e serviços.
} 
A consideração da conservação do meio ambiente é estratégica no setor. Se as empresas não respeitam as leis ambientais de conservação do meio ambiente e exploram os recursos naturais da região sem as considerar, esgotaram seus recursos em médio prazo.

Este estudo se insere em meio de profundas transformações em toda a sociedade, como a globalização e a regionalização, que apresentam uma notável repercussão no turismo. Vive-se em tempos de transição, onde o que hoje é válido e consumido, amanhã já se tornará obsoleto, não respondendo, portanto, às necessidades que originalmente tinham que satisfazer. $\mathrm{O}$ setor deve buscar reagir rapidamente a esta situação, adequando-se aos desejos e motivações dos consumidores e suas decisões de compra mediante as ferramentas do marketing estratégico.

Como destaca BENI (1999), na nova era do turismo, os destinos devem ser transformados em produtos inseridos nos sistemas globais de distribuição. Os GDSs (Global Distribuition Sestem) integrando-se à Internet vão oferecer cada vez mais serviços completos aos clientes durante todo o ano, 24 horas, levando o cliente a reservar sua preferência via Web, e, às agências, de executar a tramitação da documentação necessária. Mais de 150 mil agências operadoras conectadas aos GDSs, com mais de 500 mil terminais e um milhão de operadores, estão fazendo negócios nos novos mercados, permitindo que cada hotel possa inserir toda a sua oferta nos mínimos detalhes, as vantagens desse sistema são exponenciais com a abertura à demanda global e à recepção de reservas de qualquer continente.

No século XXI as viagens serão mais rápidas, confortáveis e agradáveis, com aviões supersônicos e trens de alta velocidade, a bordo de imensos navios, já são realidades tecnológicas que movimentam os novos contingentes de turistas, possuidores de uma imaginação criativa, sonhadora e especulativa, alimentada pelos desafios e pela comunicação global da Internet, da TV a cabo e das abundantes publicações de excelente qualidade gráfica e conteúdos ilustrativos.

O turismo de massas do século XXI provocará grandes mudanças no setor das viagens.Os efeitos já começaram a ser experimentados. A partir de 1994, nasceram as mega-agências como a American Express e Thomas Cook, Carlson e Wagonlit.

O tempo das viagens será mais curto, com alta incidência de grupos e famílias, motivados por escapar da rotina do trabalho e pelo acesso melhorado aos destinos turísticos. As operadoras de turismo estarão atuando de forma mais qualificada, estruturada e integrada, em razão de fatores de qualidade do produto, da introdução de novas técnicas de mercado e do poder do cliente atual. Para o ano 2020, recentes estudos da OMT, prevêem que haverá 1,6 bilhões de turistas internacionais em todo o mundo. Esses turistas gastarão em torno de quatro trilhões de dólares, 
que, somados ao turismo interno de cada país, deverá chegar à cifra extraordinária de US\$ 9 trilhões. Estes dados representam taxa média de crescimento anual de caráter sustentável de $4,3 \%$ a $6,7 \%$, maior que a expansão máxima da riqueza mundial que será na ordem de 3\%. Surge neste contexto a necessidade de adequar o gerenciamento das empresas turísticas às novas condições do mercado turístico no século XXI com a utilização de técnicas, como as aportadas pelo marketing estratégico, que lhes permitem alcançar um adequado posicionamento de mercado, problema que será estudado nesta pesquisa. As empresas que não conseguirem atingir estes objetivos, não somente perderão seus mercados como degradarão o meio em que estão inseridas.

\section{Evolução do turismo na globalização. Turismo pós-fordista ou de terceira geração. Novas megatendências}

Segundo Donaire (2001), a eclosão do turismo de massas (aqui também chamado de turismo massivo ou turismo massificado), nas décadas de 50 e 60, esteve amparada em um modelo de crescimento claramente fordista. Neste período se iniciou a produção em massa de destinos turísticos estandardizados a baixo preço e com uma notável rigidez da oferta. Em princípios dos anos 80 , o modelo de crescimento fordista oferece os primeiros sintomas de esgotamento. Neste período, se fazem eloqüentes as principais tensões que derivam do turismo tradicional e as debilidades estruturais do sistema. Vera (1994) identificou cinco desequilíbrios básicos deste modelo turístico: (ao) desequilíbrios setoriais, (b) desequilíbrios tecnológicos, (c) desequilíbrios ambientais, (d) desequilíbrios espaciais e (e) desequilíbrios socioculturais.

(a) O turismo fordista baseou-se de forma quase unânime na especialização setorial em torno de uns poucos recursos naturais (a praia ou a montanha), em uma oferta caracterizada pela homogeneização. Esta alta especialização sofre, por um lado, da ausência de critérios de segmentação ou de singularidade da demanda, que é concebida como uma massa uniforme. Por outro lado, este processo implica em uma elevada vulnerabilidade dos destinos turísticos, que baseiam sua capacidade de desenvolvimento em uma só oferta turística.

(b) A rápida consolidação do turismo fordista esteve baseada no avanço tecnológico dos transportes e das comunicações. A generalização do uso do automóvel, a formação de uma densa rede de estradas na Europa e na América do Norte e a melhora substancial do tráfico aéreo facilitarão o acesso à oferta turística das classes médias européias. Contudo, a oferta turística fordista não foi capaz de incorporar avanços tecnológicos que permitam uma inovação nos processos de produção e uma maior capacidade de adaptação às necessidades da demanda. O baixo nível de profíssionalização do setor turístico, a escassa intervenção da 
investigação e o desenvolvimento no campo do turismo e a própria debilidade, inclusive, dos estudos turísticos contrastavam com o crescimento e dinamismo do setor turístico.

(c) O principal objetivo do turismo fordista foi a maximização do número de visitantes. Este culto ao número imperou em cima de qualquer outra lógica e é o principal responsável pelos processos de degradação ambiental, próprios da maior parte de destinos turísticos maduros. A crescente sensibilidade para os problemas ambientais e a progressiva implantação de uma ética ecológica entram em contradição com as formas turísticas fordistas, que geram fortes impactos ambientais no meio que as acolhe.

(d) Em termos geográficos, o modelo fordista se caracteriza pela extrema concentração da oferta turística em um âmbito muito reduzido, em torno do elemento de atração (a linha costeira, a estação de esqui etc.)

(e) Enfim, o modelo turístico fordista se caracterizou por uma tensão cultural e social entre anfitriões e hóspedes. Uma das abordagens mais sugestivas neste campo é a obra de McCannol (1976). O sociólogo americano constata que o conflito entre a intromissão do turista e a vontade de preservar um espaço de relações por parte da população local, dá lugar a uma autenticidade teatral (staged), isto é, uma banalização da cultura e da identidade locais. Esta versão estereotipada dos destinos turísticos, alheia à realidade local, parece haver entrado em crise. Tal e como constatam alguns autores (Feifer: 1985, Urre: 1990, Pretes: 1995), o turista contemporâneo assumiu a singularidade da experiência turística. Como destaca Feifer (1985:271), “o pós-turista sabe que não é um viajante do tempo quando visita um lugar histórico, nem um selvagem quando está em uma praia tropical, nem um observador invisível quando visita um campo nativo. Resolutamente "realista" não se evade de sua condição de forasteiro".

O modelo turístico fordista que havia prevalecido de forma hegemônica desde a década de 50 mostra, definitivamente, em meados dos anos 80, claros sintomas de esgotamento. Os desequilíbrios inerentes nesta estrutura sofrem de uma forte crise de identidade e favorecem uma mudança de modelo.

Neste contexto de mudança, reestruturação e instabilidade, o modelo turístico tradicional fordista é lentamente substituído, em uma difícil transição, por um novo modelo pós-fordista. Não existe um consenso, na hora de pesquisar as características do turismo pós-fordista, apreentadas por, entre outros, Urre (1990), Hitchock (1993), Warren (1993), Marchena (1994), Pretes (1996), Donaire (1996), o Llurdés (1998). Contudo, podemos identificar uma série de conceitos-chave: (a) a crise da estandardização, (b) a ampliação das fronteiras do turismo, (c) a redefinição da autenticidade, (d) a renovação tecnológica e (e) a universalização da visão turística. 
a. A crise da estandardização. Sem dúvida alguma, o traço mais significativo do turismo pósfordista é a singularidade. De fato, o termo pós-fordista alude à crise da produção seriada, à estandardização e à homogeneização, características que são substituídas por critérios de singularidade e de especificidade. A leitura turística desse processo é a substituição dos produtos turísticos massivos, dirigidos aos grupos não diferenciados, por produtos específicos, que tentam satisfazer às necessidades individuais de segmentos concretos da população. Os espaços turísticos não são concebidos como produtos de consumo, aptos para o conjunto da demanda, senão como bens posicionais (Llurdés:1996), que competem por um determinado nicho desta demanda.

Contudo, a resposta à estandardização é plural: o turismo pós-fordista pode-se considerar como uma reivindicação da imagem romântica da viagem (antes do fordismo), uma celebração das experiências não autênticas (depois do fordismo) ou como um rechaço frente à homogeneização do turismo massivo (contra o fordismo).

b. A ampliação das fronteiras do turismo. Pode ser que um dos traços que melhor caracterizam a sociedade pós-industrial seja a não-diferenciação (Harvee: 1989), isto é, as difíceis fronteiras entre as diversas esferas da organização social e econômica. No turismo, isso implica um deterioramento das diferenças entre o turismo e a compra (os grandes centros comerciais são, por sua vez, áreas comerciais, centros lúdicos e espaços turísticos), o turismo e a cultura (a revalorização do patrimônio ou a criação de espaços de ócio em torno de um elemento cultural); o turismo e o espetáculo (os mega-eventos - leia-se Exposição Universal, Jogos Olímpicos, grandes certames desportivos - adquiriram um peso capital no turismo contemporâneo) ou o turismo e o esporte (a aparição de complexos turísticos em torno do golfe ou do mergulho). De fato, o turismo não consegue sequer dissociar-se de seu antônimo, o trabalho. É o caso da aposta no trabalho ou no negócio, da administração turística das Baleares, a crescente importância do turismo de congressos ou a função turística dos complexos fabris em desuso.

c. A redefinição da autenticidade. O turismo contemporâneo parece haver transcendido o modelo de autenticidade teatral que propôs McCannol e que caracteriza as relações entre a população local e o turista, no modelo fordista. De qualquer forma, a interação entre hóspedes e anfitriões toma, na atualidade, dois caminhos contrapostos: a celebração da falta de autenticidade, a hiperrealidade e a reivindicação da identidade local.

Foi Umberto Eco quem advertiu, já em princípios dos anos 70, sobre a importância dos novos cenários hiper-reais. Eco (1985) se mostra interessado pelos espaços que abertamente transcenderam sua própria veracidade (o castelo de Randolph, os hotéis de Madonna Inn, Las 
Vegas...). Uma vez assumida a essência não autêntica destes ambientes, então, é possível recriar espaços hiper-reais, simulações na escala 1:1 de outros espaços, de períodos históricos ou da própria imaginação coletiva. Estas simulações são oferecidas como uma verdadeira superação da realidade:

"O prazer da imitação, os antigos o sabiam, é um dos mais inerentes à natureza humana; mas aqui, ao invés de se desfrutar de uma natureza perfeita, desfruta-se da persuasão de que a imitação alcançou seu apogeu e que a realidade será sempre inferior a ela" (Eco: 1985, 48).

Em última instância, portanto, estes espaços hiper-reais são concebidos como uma versão aperfeiçoada dos espaços que imitam, uma verdadeira alternativa à geografia “autêntica”. Assim, a Disneylândia é uma sombra perpétua, que empurra seus frequentadores para um passado não "visitável", ou para o futuro ou para alguma lugar inacessível. O sistema inteiro é validado, então, pelo fato de que se viajou literalmente, que a Disneylândia foi escolhida em lugar de qualquer das alternativas representadas. Preferiu-se a simulação à realidade"'(Sorkin: 1992, 216) A outra face do pós-modernismo é o interesse pela identidade local, a importância do passado na definição do sentido de coletividade, a relevância dos espaços liguísticos ou o auge do nacionalismo. O turismo contemporâneo também se mostra atraído pela especificidade dos destinos turísticos e pela identidade do espaço de acolhida, o que explica a consolidação do turismo de patrimônio.

c. A renovação tecnológica. A transição de um modelo a outro se fundamenta na irrupção no campo do turismo de novas tecnologias, especialmente no campo das tecnologias da informação $(\mathrm{TI})^{3}$.

As empresas, turisticamente, mostram, nitidamente, os processos produtivos, organizativos ou espaciais características da acumulação flexível, pós-fordista: a incorporação de novas tecnologias, os avanços na gestão da informação (sistemas de decisão global, sistemas de reserva computadorizados, gestão via Internet), a segmentação do mercado com a criação de produtos específicos, os processos de concentração horizontal e vertical ou os processos de difusão espacial são alguns exemplos eloqüentes. As novas tecnologias têm sido uma peça essencial no processo de substituição de pacotes turísticos - criados sob os critérios da montagem em série - pelos

$03^{3}$.- De fato, uma das interpretações mais freqüentes sobre a consolidação do pós-fordismo na sociedade contemporânea é, precisamente, o aporte de inovação tecnológica. Esta interpretação neo-Schumpeteriana aduz que os saltos no capitalismo são possíveis quando uma acumulação de avanços tecnológicos (neste caso, tecnologias da informação e da distribuição) permite superar o ciclo de crescimento precedente cria, por conseqüência, um novo contexto. 
novos produtos modulares, muito sensíveis às necessidades específicas dos diferentes segmentos de demanda (Bote Gómez e Sinclair: 1991, Aguiló: 1996, Falkenstein: 1997).

d. A universalização da visão turística. Embora a principal característica do turismo fordista seja a concentração da oferta turística em um ambiente muito reduzido (a "periferia do prazer"), com o turismo contemporâneo, temos assistido a um processo de globalização do consumo de espaços turísticos. Desta forma, a geografia do turismo deve incorporar novos cenários emergentes, que tentam fazer frente à hegemonia dos espaços tradicionais ${ }^{4}$. Contudo, o processo mais notável não é tanto a aparição de novos ambientes mais ou menos ativos, mas a globalização do turismo: a crescente demanda de espaços singulares propicia a que qualquer espaço possa ser potencialmente um espaço turístico (Urre: 1990).

Levado ao seu extremo, este jogo de discriminação entre práticas turísticas fordistas (homogeneização, produção em série, autenticidade teatral, concentração espacial, delimitação das fronteiras do turismo...) e o turismo pós-fordista (singularidade, produção modular, falta de autenticidade, difusão espacial, fronteiras imprecisas do turismo) conduz a uma clara imagem de ruptura. Segundo este critério, em meados dos anos 80, assistiríamos a uma espécie de big bang, uma violenta mudança de cenário que supunha a desaparição do modelo precedente e a aparição de uma nova concepção turística.

Sem embargo, a fratura entre um modelo e outro não é tão evidente. Mas bem ao contrário, tudo parece indicar que na lenta transição do modelo, há mais elementos de continuidade que de ruptura. E isso é assim, ao menos, por três motivos:

1. Em primeiro lugar, porque algumas das características do modelo turístico pós-fordista estavam presentes na organização turística tradicional. A incorporação de novas tecnologias, a flexibilidade local, a difusão espacial ou a celebração da autenticidade estão já presentes no turismo dos anos 60. De certa maneira, o turismo é pós-fordista antes do pós-fordismo.

2. Em segundo lugar, porque o progressivo incremento dos espaços emissores (a ampliação da demanda) configurou um comportamento muito heterogêneo da demanda, em que também cabe uma necessidade meramente fordista. Este é o caso, seguramente, da demanda turística dos países orientais do continente europeu. De fato, o turismo não só aceita como também precisa de redutos de fordismo.

3. Finalmente, porque as respostas locais ao marco geral da transição do modelo turístico são

14 .- De fato, um dos primeiros sintomas da reorganização do modelo fordista foi a aparição de uma série de espaços industriais e de serviços, que competiam de forma eficaz com os grandes complexos produtivos do pós-guerra; são os NIC como Hong Kong, Singapura, Coréia o Taiwan. É possível estabelecer um paralelismo com a consolidação de novos destinos como Tailândia, Tunísia ou Cuba, que mereceriam ser denominados NTC (New Touristic Countries) 
muito plurais e admitem drásticas rupturas e organizações resolutamente novas ou tímidas mudanças em um contexto de clara continuidade do modelo tradicional. Por conseguinte, a leitura espacial do turismo contemporâneo é caleidoscópica, formada por cenários turísticos diversos, amiúde contrapostos.

\section{O turismo na Espanha e América Ibérica como contexto do estudo. Casos particulares do desenvolvimento turístico no Brasil e Cuba.}

\section{Espanha}

Pelas características de identidade cultural com a América Latina, pela forma como desenvolveu seu turismo e influiu em sua economia, e por ser uma cadeia hoteleira espanhola - objeto de estudo nesta tese - inclui-se uma visão do desenvolvimento turístico da Espanha, como parte da análise do contexto.

Segundo Figuerola Paomo (2002), a atividade turística jogou um importante papel como partida fundamental para equilibrar o déficit comercial e superar os estrangulamentos exteriores das distintas fases do desenvolvimento econômico espanhol, durante o período 1974-98: como cobertura das importações derivadas da primeira e segunda crise energética dos anos sessenta e do processo de reconversão industrial de princípios dos anos oitenta e, indiretamente, contribuiu, por conseqüência, à consolidação da democracia durante o período 1973 - 82 de crise econômica e transição política. A partir de 1986 está contribuindo também para enxugar importante deficit comercial que implica a integração na UE. Ao turismo espanhol the correspondeu o papel, que, em outros tempos, jogaram alguns poucos produtos com possibilidades de fácil colocação no mercado externo.

Apesar desse salto qualitativo da economia espanhola, durante estas últimas décadas, o problema estrutural do déficit comercial não se resolveu. Pelo contrário, a integração da UE acentuou fortemente o déficit comercial, sublinhando de novo a debilidade da Balança de Pagamentos espanhola embora em um contexto diferente do dos anos sessenta.

O turismo espanhol cresceu de maneira constante desde os primeiros anos da década de 60 , e progride em termos comparativos com relação aos destinos que concorrem na mesma linha de produto. Por conseqüência, projetou um horizonte sempre positivo, no qual não esperam ameaças por parte de outras fontes competidoras, que lhes absorva parcela de mercado. Além disso, a combinação qualidade /preço torna o país um lugar dificilmente superável.

Mesmo assim, o Balanço do turismo espanhol para o ano 2000, apresenta dados demonstrativos de que a economia segue apoiando-se de maneira decisiva nos excelentes comportamentos da 
atividade turística, pilar significativo na formação do P.I.B.

A Espanha em 2000 ocupou o terceiro lugar, depois da França e os Estados Unidos, com relação ao número de turistas recebidos procedentes do exterior. Mesmo assim, isso corresponde à primeira posição, quanto ao total de ocupações realizadas em seu território pela demanda externa.

Com respeito à receita de divisas medida em dólares comerciais, a Espanha mantém o segundo posto na classificação mundial, com valores muito próximos aos da França, que ocupa o terceiro lugar.

Segundo as últimas cifras da capacidade receptiva, a Espanha possui 3,9\% do total mundial do número de quartos em hotéis e estabelecimentos assemelhados; correspondendo sua participação na oferta hoteleira quase a $10,2 \%$ do conjunto europeu. Não obstante, há que destacar número de camas não hoteleiras, que põe à disposição da demanda turística, e que se estima atualmente acima de doze milhões, o qual a situa nos primeiros lugares do turismo residencial.

Os primeiros dados calculados da produção turística para o ano 2000 mostram comportamentos desiguais com referência aos dois segmentos da demanda:

O turismo internacional teve um excelente comportamento, com um crescimento real perto de $7 \%$ e um crescimento corrente algo superior ao $11 \%$. Paralelamente, a demanda interna ou turismo doméstico manteve a mesma cifra em termos constantes com relação a 1999 (4\%), e um crescimento nominal de $8 \%$, o qual permite apontar, que, de maneira ponderada, o consumo turístico conjunto terá ultrapassado um aumento real acima de 5,3\%.

Um valor importante a considerar é a relação existente entre o total do consumo turístico e o valor da demanda privada, a qual, para o ano 2000, é igual a 17\%, o que demonstra a forte dependência do consumo turístico por parte do sistema econômico.

Há que destacar que desde 1990 o Turismo na Espanha cresceu em termos constantes de 61\%, aumento que se considera muito influente no desenvolvimento de nossa economia.

Agora, é muito importante que se considere ao influência indireta que o consumo turístico tem sobre outros setores da economia. Neste sentido, aplicando os resultados da última análise origem-destino que se realizou, para o ano 1992, podem extrair-se conclusões interessantes, ao valorar os multiplicadores da produção ligados à atividade turística.

De novo o turismo no ano 2000 na Espanha, favoreceu os resultados da economia externa. O aporte de recursos para cobrir os déficits estruturais - ou desajustes da balança comercial - voltou a resolver problemas na Balança de Pagamentos espanhola, injetando na sua balança de serviços aqueles fluxos de divisas necessárias para facilitar o equilíbrio geral e para contribuir para 
conseguir os fundos adequados para aumentar as reservas internacionais.

Destaca-se na análise, que a baixa cotização média do dólar no ano 1992 motiva a irregularidade no crescimento da cifra de recursos correntes, em dólares comerciais. É importante assinalar que o aumento da receita no período ascendeu a $44 \%$.

Por sua vez a receita medida em pesetas nominais cresceram na mesma fase $154 \%$. Tal grandeza cresceu em termos reais só cerca de $84 \%$.

O aumento do gasto por turismo dos residentes no exterior, no mesmo período, foi de 91,7\%, muito inferior ao experimentado pela receita, a qual é outro elemento demonstrativo de que a demanda interna nos últimos cinco anos manteve um comportamento muito cauteloso quanto ao consumo turístico.

Em relação à estrutura da oferta hoteleira, a acolhida de um número tão elevado de turismo, tanto de residentes como de não-residentes, logicamente exige a existência de uma capacidade de receber muito elevada, que equivale, no total da oferta mundial de quartos em hotéis e assemelhados, a quase $4 \%$.

\section{A América.}

Considera-se de interesse avaliar o comportamento do turismo no continente americano. As Américas apresentam uma séria dificuldade de análise como região, devido a que é o único continente que vai de pólo a pólo. A enorme distância que separa o Canadá ou Alasca do Sul do Brasil ou Argentina para qualquer classe de intercâmbio, é maior e muito mais cara que deslocamentos transcontinentais no Atlântico Norte, para citar só este exemplo. Outra dificuldade não exclusiva das Américas, mas aqui com um caráter muito agudo, consiste na desigualdade extrema que há entre as diversas sub-regiões e entre os países mesmos, os quais vão desde o primeiro até o terceiro mundo em seu nível de desenvolvimento, mas ainda reúnem toda a heterogeneidade imaginável quanto à condição de tamanho, vocação, conectividade e diversificação de sua oferta turística.

No decênio de 1990, a taxa de crescimento de chegadas turísticas internacionais registradas e nas Américas foi mais baixa do que em qualquer outra região do mundo, 3,3\% em média. Isto pode resultar surpreendente, considerando que esta região contém o mercado emissor mais importante do mundo, Estados Unidos, e que oferece uma extraordinária diversidade de atrações. América do Sul registrou igualmente um forte crescimento médio de 7\%, no decênio de 1990, mas este se reduziu a 2,3\%, entre 1999 e 2000 , e a $2,2 \%$ nos oito primeiros meses de 2001 . No Caribe, o crescimento médio foi mais pausado (4.3\%), representando $2 \%$ nos oito meses anteriores a 11 de setembro. Sem embargo, nestas duas regiões estão localizados alguns destinos mundiais onde se 
registra um crescimento mais rápido (Cuba, República Dominicana, Ilhas Turcas e Caicos, Brasil e Peru), atingindo um nível igual a dos países, cujo turismo internacional se reduziu notavelmente na segunda metade do decênio de 1990, a saber, Colômbia e Venezuela.

A América recebe principalmente três correntes turísticas diferentes. A primeira, e mais importante, está representada pelas viagens de residentes dos países da América aos demais países do próprio continente. Esta forma é denominada turismo intra-regional. A segunda corrente turística se refere às chegadas procedentes da Europa, principalmente dos países da

\section{Europa Ocidental. A terceira é procedente dos países da Ásia}

Os fluxos intra-regionais são os predominantes na América. Pelo número de chegadas registradas, quase 121 milhões, a região das Américas manteve, em 2001, seu posto como segundo destino regional. A complexa relação de fatores que se deram em 2001 fez com que a região registrasse um decrescimento relativo ao ano anterior de -6 per cento.

Os fluxos turísticos da Ásia e do Pacífico progrediram em média mais de 10\% ao ano durante a última década. Estes fluxos provêm fundamentalmente do Japão e da Austrália. Apontam igualmente um forte crescimento, se bem que com cifras mais baixas, os turistas procedentes dos novos mercados emergentes como Taiwan, Coréia, Hong Kong e Singapura.

A classificação dos países em função das chegadas reflete uma alta concentração geográfica dos movimentos turísticos na região da América. Três países recebem quase $72 \%$ das chegadas turísticas: Estados Unidos, México e Canadá. Dos vinte destinos mais visitados na América sete correspondem ao Caribe. Os Estados Unidos situam-se na cabeça da lista, com 48 milhões de chegadas (segundo destino mundial depois da França em 1997). México tira o segundo lugar do Canadá, se bem que o número de turistas recebidos nesse país é menor que a metade da dos Estados Unidos; o que se pode apreciar na Tabela 5. A seguir, Argentina sobe para a quarta posição, atrás do Canadá, enquanto Porto Rico conseguiu manter-se entre os cinco primeiros destinos turísticos da América. 
Tabela 5: Principais destinos turísticos na América 1985-2001.

Americas

Chegadas de turistas internacionais e ingresos por turismo international por

(sub)regiões

\begin{tabular}{|c|c|c|c|c|c|c|c|c|c|c|c|}
\hline & & & & & & & Cuota de 1 & nercado & & riaci6n & Cresciment \\
\hline & 1985 & 1990 & 1995 & 1999 & 2000 & 2001 & 1995 & 2000 & $00 / 99$ & $1 * / 00$ & $1995-2000$ \\
\hline & Chegad & s de tu & istas in & ternacic & nais $(m$ & ilhões) & & $\%$ & & $\%$ & $\%$ \\
\hline Americas & 64.3 & 92.9 & $\begin{array}{r}108 . \\
9\end{array}$ & 122.4 & 128.5 & 120.8 & 100 & 100 & 5.0 & .6 .0 & 3.4 \\
\hline America do Norte & 48.3 & 71.7 & 80.5 & 87.0 & 91.2 & 85.0 & 73.9 & 71.0 & 4.9 & -6.8 & 2.5 \\
\hline EI Caribe & 8.0 & 11.4 & 14.0 & 16.3 & 17.4 & 16.9 & 12.9 & 13.6 & 6.9 & -2.9 & 4.4 \\
\hline America Central & 1.3 & 1.8 & 2.6 & 4.0 & 4.3 & 4.4 & 2.4 & 3.4 & 8.9 & 1.7 & 10.7 \\
\hline America do Sul & 6.8 & 7.9 & 11.8 & 15.1 & 15.5 & 14.5 & 10.8 & 12.0 & 2.4 & -6.3 & 5.6 \\
\hline Ingresos par & smo inte & nationa & (miles & de mill & hões \$E & E.UU.) & & $\%$ & & $\%$ & $\%$ \\
\hline Americas & 33.3 & 69.2 & 99.6 & 122.1 & 132.8 & 122.5 & 100 & 100 & 8.8 & .7 .7 & 5.9 \\
\hline America do Norte & 23.8 & 54.8 & 77.5 & 92.1 & 101.0 & 91.5 & 77.7 & 76.1 & 9.7 & -9.5 & 5.5 \\
\hline EI Caribe & 5.1 & 8.7 & 12.2 & 15.8 & 16.8 & 16.9 & 12.2 & 12.7 & 6.6 & 0.4 & 6.7 \\
\hline America Central & 0.5 & 0.7 & 1.6 & 2.6 & 3.1 & 3.1 & 1.6 & 2.3 & 18.9 & 1.9 & 14.4 \\
\hline America do Sul & 4.0 & 4.9 & 8.4 & 11.6 & 11.8 & 11.0 & 8.4 & 8.9 & 2.2 & -6.9 & 7.0 \\
\hline & & & $\begin{array}{l}\text { Ingr } \\
\text { (\$EE }\end{array}$ & $\begin{array}{l}\text { sos } \\
\text { UU.) }\end{array}$ & par 1 & legada & & & & $\%$ & $\%$ \\
\hline Americas & 517 & 745 & 915 & 998 & 1,033 & 1,014 & & & 3.6 & -1.9 & 2.5 \\
\hline America do Norte & 492 & 764 & 962 & 1,060 & 1,107 & 1,076 & & & 4.5 & -2.8 & 2.8 \\
\hline EI Caribe & 634 & 764 & 869 & 968 & 966 & 999 & & & -0.3 & 3.5 & 2.1 \\
\hline America Central & 369 & 404 & 605 & 651 & 711 & 712 & & & 9.2 & 0.2 & 3.3 \\
\hline America do Sul & 592 & 626 & 714 & 765 & 764 & 759 & & & -0.2 & -0.7 & 1.4 \\
\hline
\end{tabular}

Fonte: Organizacion Mundial do Turismo

(OMT)@

(Cifras procedentes da OMT, agoso de 2002)

Fonte: Organização Mundial do Turismo (OMT).

\section{Particularidades do crescimento turístico no Brasil.}

$\mathrm{O}$ crescimento do turismo no Brasil tem suas particularidades no que se refere à América. Este registra resultados rentáveis até 1986, ano em que alcança seu melhor desempenho, com mais de 5 milhões de turistas estrangeiros e uma renda de US\$ 3,6 bilhões, para chegar em 1990 ao seus índices mais baixos, com um receptivo de pouco mais de um milhão. A partir de 1993, volta a apresentar um discreto crescimento, passando de 1,5 milhão de chegadas em 1992 para 2,1 milhões em 1997 e 3,2 milhões em 1998, apresentando uma taxa de crescimento inferior a 2\% ao ano. Referente à receita, ocupou o quinto lugar entre os países da região, arrecadando US\$ 2,6 bilhões e apresentando um crescimento de 5,4\% em 1996. Segundo COBRA (2001), 5.100,000 turistas estrangeiros visitaram Brasil em 1999, perto de 30\% eram argentinos, $11 \%$ americanos e $6 \%$ alemães. A renda média anual destes turistas era, em 1999, de US\$ 37.505,00 e o gasto per capita do turista estrangeiro no país, não incidindo o transporte internacional é de US\$79,00. 
O Brasil situou-se em terceiro lugar, depois do Canadá e Estados Unidos, em gastos por viagem dos brasileiros ao estrangeiro entre 1995 e 1996. Seus gastos aumentaram em US\$ 2,4 milhões, a maior taxa de crescimento, da ordem de $71 \%$ com respeito a 1995.

Nos últimos anos vem ocorrendo no país uma política de fomento ao turismo sob a perspectiva de geração de divisas, empregos e atendimento às imensas potencialidades existentes.

Em 1998, mais de 4,5 milhões de turistas brasileiros foram para o exterior. Em 1999 a crise do Real reduziu a tendência de viagens ao estrangeiro e estimulou o turismo interno. A desvalorização do Real de 1999 tornou o Brasil mais atraente para os turistas estrangeiros. O país se apresentou mais barato com respeito ao dólar, o que permitiu aos turistas comprar mais produtos-serviços do que antes da modificação do câmbio.

No Brasil, o turismo atinge 52 segmentos diferentes da economia, empregando em sua cadeia, desde mão-de-obra mais qualificada em áreas de alta tecnologia, até as de menor qualificação, tanto em empregos formais como informais. Segundo BENI (1996), os 10 mil meios de hospedagem existentes no país são responsáveis pela geração de 720 mil empregos, sendo 180 mil diretos.

O setor no Brasil ocupa $1,5 \%$ da força de trabalho nacional e é responsável nos últimos 4 anos por 6,5 milhões de empregos. Os empregos nos segmentos de viagens e Turismo no Brasil são bem remunerados e representam $6,1 \%$ acima do salário médio do país.

O setor de eventos cresce em todo o mundo e no Brasil não está sendo diferente. Somente no Estado de São Paulo a instituição pública Convention and Visitors Bureau estima que o segmento movimenta mais de US\$ 900 milhões por ano e emprega 35 mil pessoas. Na cidade de São Paulo são arrecadados aproximadamente US\$ 100 milhões em ISS por ano.

Os mega-eventos se transformam em um instrumento poderoso para a promoção do desenvolvimento local, como exemplos, o Festival de Parintins, o Círio de Nazaré, a Oktoberfest, Fórmula 1, entre outros. A festa do Peão do Boiadeiro, na cidade de Barretos, de 1998 atraiu um público de 1,5 milhão de pessoas em dez dias, e o faturamento chegou a quase US\$ 10 milhões.

Para que o Brasil constitua-se em um destino turístico importante, segundo BENI (1998), é necessário que consolide primeiro um turismo interno forte, de qualidade e competitivo, depois um turismo intra-regional significativo, para então poder consagrar-se como um destino internacional.

Uma pesquisa da FIPE assinalou que, no período compreendido entre agosto de 1997 a agosto de 1998, em um cenário pessimista, 34 milhões de brasileiros viajaram por todo o país, ou 38 
milhões em um cenário otimista, gerando entradas respectivamente de US\$10,2 bilhões ou US\$ 12,7 bilhões.

Partindo de um universo estimado de propensão a viajar de 38 milhões, equivalentes a 24,3\% da população do país, 73,2\% (27,8 milhões) quando viajam se hospedam em casas de parentes e amigos, 15,3\% (5,8 milhões) utilizam uma segunda residência, própria ou alugada, 2,3\% pousadas e $4,7 \%$ outros. Somente $11,5 \%$ solicitam alojamentos, serviços e instalações turísticas, ou seja, 4,3 milhões. Referente aos meios de transportes utilizados, 49,6\% utiliza ônibus de linhas regulares, 6,1\% ônibus de excursão, 6,8\% avião e 37,5\% utilizam seus próprios meios de transporte. Por outro lado, 35\% do fluxo doméstico restringe-se ao 30 dos 6 mil municípios do país. São Paulo responde com 4,1\%, Rio de Janeiro 3,5\%, Fortaleza 2,5\%, Salvador 2,3\%.

Os fluxos emitidos e receptivos estão concentrados principalmente em cinco estados: São Paulo, Paraná, Minas Gerais, Rio de Janeiro e Rio Grande do Sul que acumulam 51,1\% do emissivo e recebem $44,5 \%$ dos turistas. As maiorias são viagens intra-regionais e 44,5\% destas são intraestaduais. Os estados que mais se destacam como receptores são Ceará $(7,2 \%)$ e Bahia $(6,9 \%)$.

Segundo dados da Empresa Brasileira de Turismo (EMBRATUR) os investimentos públicos em infra-estrutura básica em regiões turísticas são inéditos na história brasileira. Desde 1995 somam mais de US\$ 2,5 bilhões. Somente a região Nordeste supera mais de US\$ 670 milhões do programa Prodetur-NE. Aeroportos, novas estradas, urbanização da costa marítima, recuperação do patrimônio histórico, são exemplos de obras em fase de conclusão que estão mudando a aparência dos estados brasileiros, valorizando melhor o potencial turístico existente.

O programa Avança Brasil pretende consolidar as diretrizes estratégicas da Política Nacional de Turismo até 2002 e estabelecer novas metas e números, entre as quais criar condições para que 30 milhões de brasileiros possam ter acesso ao turismo interno e para que o ingresso anual de divisas com turistas cresça de 2,4 bilhões de dólares de hoje para cinco bilhões em dois anos. Esse quadro estima mais de US\$ cinco bilhões de investimentos em projetos turísticos privados que estão hoje em fase de implantação em todo o país, o que gerará uma expectativa de 120 mil novos empregos diretos. Durante muitos anos os objetivos oficiais do turismo brasileiro foram a fixação de espaços regionais turísticos e a implantação de equipamentos receptivos dirigidos à conquista do fluxo turístico internacional e, só recentemente, passou-se a priorizar o desenvolvimento do tráfego turístico interno e regional. Foi quando o governo estabeleceu como meta o Plano Nacional de Municipalização do Turismo (PNMT), com o conceito de que seja a célula irradiadora da planificação integrada do turismo. 
Outros aspectos a trabalhar no que se refere ao desenvolvimento turístico do Brasil são os problemas estruturais de sua rede hoteleira. Segundo pesquisas do setor feitas em 1998, a oferta hoteleira nacional teve alta concentração de equipamentos classificados entre 4 e 5 estrelas, aplicando diárias com uma média de US\$ 200. Isto requer um redimensionamento do equipamento instalado para evitar as altas taxas de ociosidade na estação de baixa temporada. A taxa média de ocupação no Brasil é de 47,7\%. Esses hotéis de luxo construídos com um alto custo por unidade habitacional devem oferecer tarifas mais reduzidas a preços de vôos charters como solução.

Como uma reação à diferença entre o alto custo das instalações e o baixo nível de seu rendimento e do prazo dilatado do retorno, nota-se hoje uma tendência em direção aos investimentos em hotéis mais econômicos, com unidades habitacionais ao preço aproximado de 40 mil dólares "chaves em mão", e aplicações de capital que não excedam US\$ 2,5 milhões, para poder aplicar médias diárias entre US\$ 40 e US\$ 70. Exemplo desta tendência está nos investimentos do grupo Accor e sua divisão Novoto em parceria com a PREVI do Banco do Brasil, que têm projetado 43 hotéis da rede Ibis em 5 anos; Caesar Tower/FUMCEF da Caixa Econômica Federal, com um projeto de 35 hotéis também em cinco anos; Choice Atlântica com um programa de 35 hotéis no Brasil.

As "ilhas da fantasia" como a da Transamérica na ilha de Comandatuba, o Clube Mediterranée de Itaparica e ao Praia do Forte-Eco Resort, todas na Bahia, além do Clube Med das Pedras em Mangaratiba no Rio de Janeiro, agora estão mudando seu perfil. Vários projetos para a construção de novos resorts estão sendo tratados com a perspectiva de atrair o turismo interno e externo simultaneamente, pretende-se conseguir taxas de ocupação mais equilibradas.

A cadeia Sol Meliá tem valorizado a importância de se investir em capacidade de alojamento no aeroporto internacional de Guarulhos em São Paulo. Tomando por referência a notícia publicada em O Estado de São Paulo ${ }^{5}$ o grupo tem valorizado a importância da cidade, uma entre as de maior crescimento populacional de todo o Estado de São Paulo. Guarulhos com uma população de aproximadamente um milhão de habitantes é a segunda maior cidade do Estado que tem uma infra-estrutura completa de comércio, serviços e lazer devido, em grande parte, ao Aeroporto Internacional. Ele é o maior e mais movimentado aeroporto da América do Sul e recebe, anualmente, mais de 500 mil estrangeiros, principalmente executivos, empresários, políticos e turistas em geral.

\footnotetext{
${ }^{5}$ O Estado de São Paulo, Sábado, 17 de julho de 1999.
} 
Outros produtos altamente diferenciados que constituem um componente importante da oferta turística e que precisam ser desenvolvidos são os espaços naturais protegidos, tais como, florestas, parques ecológicos, e áreas de preservação da fauna. Estas ofertas encontram-se com muita dificuldade nos roteiros turísticos, pela resistência da administração governamental, tornando-se necessário adotar uma política conciliatória entre a preservação e o desenvolvimento que permita a utilização turística sem comprometer a biodiversidade destes espaços, com respeito às recomendações técnicas do impacto ambiental, capacidade de carga e planos de operação.

É necessário priorizar o turismo interno e Sul-americano, em um país de proporções como as do Brasil. Deve-se priorizar a comercialização de roteiros turísticos por meio de fórmulas de integração empresarial que reduzam significativamente o custo das viagens aos destinos turísticos nacionais. Pois, em muitos casos, este custo é maior que o de viagens internacionais.

A EMBRATUR reflete as seguintes estatísticas sobre as chegadas de turistas em nível internacional, América do Sul e Brasil no período 1992/2001. 


\section{I - TURISMO NO MUNDO}

\section{FLUXO RECEPTIVO INTERNACIONAL}

Tabela 1

Chegada de Turistas no Mundo, América do Sul e Brasil $1992 / 2001$

\begin{tabular}{|c|c|c|c|c|c|c|}
\hline \multirow{2}{*}{ Ano } & \multicolumn{6}{|c|}{$\begin{array}{l}\text { Chegada de Turistas } \\
\text { (Em milhöes de turistas) }\end{array}$} \\
\hline & No Mundo & $\begin{array}{c}\text { Incremento } \\
(\%)\end{array}$ & $\begin{array}{c}\text { Na América } \\
\text { do Sul }\end{array}$ & $\begin{array}{c}\text { Incremento } \\
(\%)\end{array}$ & No Brasil & $\begin{array}{c}\text { Incremento } \\
(\%)\end{array}$ \\
\hline 1992 & 503,4 & - & 10,4 & - & 1,7 & - \\
\hline 1993 & 519,0 & 3,09 & 11,5 & 10,58 & 1,6 & 5,88 \\
\hline 1994 & 550,5 & 6,06 & 10,8 & 6,09 & 1,9 & 18,75 \\
\hline 1995 & 565,5 & 2,72 & 11,8 & 9,26 & 2,0 & 7,45 \\
\hline 1996 & 596,5 & 5,48 & 12,9 & 9,32 & 2,7 & 33,84 \\
\hline 1997 & 610,5 & 2,35 & 13,5 & 4,65 & 2,8 & 6,91 \\
\hline 1998 & 626,6 & 2,64 & 15,5 & 14,81 & 4,8 & 69,07 \\
\hline 1999 & 650,2 & 3,77 & 15,1 & $-2,58$ & 5,1 & 5,99 \\
\hline 2000 & 697,3 & 7,24 & 15,5 & 3,31 & 5,3 & 4,03 \\
\hline 2001 & 688,6 & $-1,25$ & 14,4 & $-7,70$ & 4,8 & $-10,18$ \\
\hline
\end{tabular}

Tabela 2

Participação das Chegadas de Turistas no Brasil na América do Sul, da América do Sul do Brasil no Total Mundial - 1992/2001

\begin{tabular}{|c|c|c|c|}
\hline Ano & $\begin{array}{c}\text { Brasil na América } \\
\text { do Sul (\%) }\end{array}$ & $\begin{array}{c}\text { América do Sul } \\
\text { no Mundo (\%) }\end{array}$ & $\begin{array}{c}\text { Brasil no } \\
\text { Mundo (\%) }\end{array}$ \\
\hline 1992 & 16,35 & 2,07 & 0,34 \\
\hline 1993 & 16,91 & 2,22 & 0,31 \\
\hline 1994 & 17,59 & 1,96 & 0,34 \\
\hline 1995 & 16,95 & 2,09 & 0,35 \\
\hline 1996 & 20,93 & 2,17 & 0,46 \\
\hline 1997 & 20,74 & 2,21 & 0,47 \\
\hline 1998 & 30,97 & 2,47 & 0,77 \\
\hline 1999 & 33,77 & 2,32 & 0,78 \\
\hline 2000 & 34,19 & 2,22 & 0,76 \\
\hline 2001 & 33,14 & 2,09 & 0,69 \\
\hline
\end{tabular}

Fonte: Oraanizacão Mundial do Turismo - OMT

Tabelas 6 e 7 (1 e 2) Chegada de turistas no mundo - Participação as chegadas (1992/2001)

Segundo o informe da OMT para as Américas, os resultados da atividade turística no Brasil até 2001 podem resumir-se na seguinte tabela: 
Tabela 8 - Resultados da atividade turística

\begin{tabular}{|c|c|c|c|c|c|}
\hline \multirow{2}{*}{$\begin{array}{l}\text { Resultados da atividade turística } \\
\text { Chegadas internacionais }\end{array}$} & \multirow[t]{2}{*}{1999} & \multirow[t]{2}{*}{2000} & \multicolumn{2}{|c|}{$\begin{array}{l}2001 * \\
2001 * / 2000 \\
\end{array}$} & \multirow[t]{2}{*}{$2000 / 1999$} \\
\hline & & & & & \\
\hline Turistas (visitantes que pernoitam) (1000) & 5.107 & 5.313 & 4.773 & 4,0 & $-10,2$ \\
\hline - por 100 habitantes & 3 & 3 & 3 & & \\
\hline \multicolumn{6}{|l|}{ Alojamento turístico } \\
\hline Pernoites em hotéis (1000) & 262.764 & 233.355 & 203.206 & $-11,2$ & $-12,9$ \\
\hline - por turistas no residentes (turismo receptivo) & 52.553 & 46.650 & 40.641 & $-11,2$ & $-12,9$ \\
\hline - por turistas residentes (turismo interno) & 210.211 & 186.705 & 162.565 & $-11,2$ & $-12,9$ \\
\hline \multicolumn{6}{|l|}{ Turismo emissor } \\
\hline Viagens ao exterior $(1000)$ & 2.863 & 2.888 & 2.269 & 0,9 & $-21,4$ \\
\hline - por 100 habitantes & 2 & 2 & 1 & & \\
\hline \multicolumn{6}{|l|}{ Receitas e gastos em turismo internacional } \\
\hline Receitas em turismo internacional (milhões \$EE.UU.) & 3.994 & 4.228 & 3.701 & 5,9 & $-12,5$ \\
\hline - por chegada de turista (\$EE.UU.) & 782 & 796 & 775 & 1,8 & $-2,6$ \\
\hline - per capita (\$EE.UU.) & 23 & 24 & 21 & & \\
\hline Receitas de transporte internacional (milhões \$EE.UU.) & 92 & 159 &.. & 72,8 & \\
\hline Gastos em turismo internacional (milhões \$EE.UU.) & 3.085 & 3.893 & 3.199 & 26,2 & $-17,8$ \\
\hline - por viagem (\$EE.UU.) & 1.078 & 1.348 & 1.410 . & 25,1 & 4,6 \\
\hline - per capita (\$EE.UU.) & 18 & 23 & 18 & & \\
\hline Gastos em transporte internacional (milhões \$EE.UU.) & 466 & 654 &.. & 40,3 & \\
\hline t:, Balança do turismo internacional (milhões \$EE.UU.) & 909 & 335 & 502 & & \\
\hline t:, Balança do transporte internacional (milhões \$EE.UU.) & -374 & -495 & & & \\
\hline
\end{tabular}

Um balanço sobre os resultados da atividade turística dos últimos anos, no Brasil, reflete:

\section{Fatores positivos:}

- Estabilidade política e econômica.

- Ampliação do número de estabelecimentos integrantes das grandes redes internacionais de alojamento, como Accor, Vila Gale e Choice, principalmente na região do noroeste do Brasil. Essa ampliação, além de provocar um aumento da oferta do número de quartos, propiciou o aporte de uma tecnologia de ponta para gerência hoteleira e permite uma competição saudável entre os estabelecimentos, realizando-se de forma favorável e imediata junto ao público consumidor.

- Ampliação da oferta de cruzeiros marítimos, representando uma opção adicional para que os turistas nacionais e internacionais possam conhecer os produtos turísticos da costa brasileira. No ano 2000, 35 embarcações transatlânticas realizaram 323 escalas em nosso litoral brasileiro. 
- Ampliação e modernização dos terminais aeroportuários, com destaque naqueles localizados nas regiões noroeste e sul de Brasil. Incremento do número de vôos charter domésticos e internos e aumento dos vôos charter desde a Europa até a região noroeste do Brasil.

- Crescimento da presença de empresas aéreas regulares de Portugal, com um substancial aumento da oferta dos destinos localizados na Região Nordeste de Brasil.

- Ampliação do número de pontos de fronteira integrados com os demais países do MERCOSUL.

- Continuação da Política Nacional de Turismo, abarcando um período de oito anos, o que permitiu o pleno desenvolvimento de projetos de longo prazo.

- Consolidação de importantes programas de desenvolvimento turístico regionais, a exemplo do Prodetur Nordeste 1.

- Avanço nas negociações de implementação de novos programas de desenvolvimento turístico regionais, a exemplo do Prodetur Nordeste 11. Formalização de novos programas de desenvolvimento turístico regionais, a exemplo do Prodetur Sul.

- Ausência de neve nas principais estações de esqui dos destinos especializados na América do Sul.

- Aumento do número de efetivos e a intensificação dos trabalhos da polícia especializada em assistência aos turistas da cidade do Rio de Janeiro, principal porta de entrada dos turistas estrangeiros do Brasil.

\section{Fatores negativos:}

- Há uma substancial desproporção entre a "sensibilidade" do setor público e do privado quanto à importância econômica do turismo. Da mesma forma, isso ainda se observa na determinação do grau de profissionalismo necessário na gerência dos negócios turísticos, o que implica, entre outros, que o setor privado faça um modesto investimento na qualificação profissional de seu pessoal.

- Ampliação da oferta de cruzeiros marítimos, representando uma opção adicional para que os turistas nacionais e internacionais possam conhecer os produtos turísticos da costa brasileira. No ano 2000, 35 embarcações transatlânticas realizaram 323 escalas em nosso litoral.

- Deficiência na manutenção de alguns trechos das estradas, ocasionando uma dificuldade na promoção e comercialização das viagens por via terrestre;

- Cancelamento de vôos charter a partir da Argentina, resultado da desvalorização cambial 
que sofreu a moeda argentina em finais do ano 2001.

- Redução dos aportes orçamentários destinados à promoção comercial do destino Brasil nos mercados internacionais, resultado da desvalorização da moeda brasileira frente ao dólar norte-americano.

- Ausência de um fundo orçamentário de investimento, que contemple as demandas específicas da pequena e média empresa turística nacional - grande maioria.

Segundo a ONT, as cifras estimadas da atividade turística no Brasil se refletem na Tabela: 9

Tabela 9 - Tendências dos mercados turísticos: as Américas 2002

\begin{tabular}{|c|c|c|c|c|c|c|c|c|c|}
\hline $\begin{array}{c}\text { Tendências dos m } \\
\text { Brasil }\end{array}$ & ados turísti & $\cos :$ as Am & iéricas - & 2002 & & & & & \\
\hline Chegadas de turist & nternaciona & is às front & eiras por & residência & & & & & \\
\hline & & & & & merc & do $(\%)$ & & $(\%)$ & \\
\hline & 1995 & 1999 & 2000 & 2001* & 1995 & 2001* & 2000/99 & $2001 * / 00$ & 1995-2001* \\
\hline Total & 1.991 .416 & 5.107 .169 & 5.313 .463 & 4.772 .575 & 100 & 100 & 4,0 & $-10,2$ & 15,7 \\
\hline Das Américas & 1.374 .111 & 3.643 .223 & 3.803 .069 & 3.377 .951 & 69,0 & 70,8 & 4,4 & $-11,2$ & 16,2 \\
\hline Argentina & 657.942 & 1.548 .571 & 1.744 .004 & 1.482 .403 & 33,0 & 31,1 & 12,6 & $-15,0$ & 14,5 \\
\hline Estados Unidos & 224.577 & 559.367 & 648.026 & 594.309 & 11,3 & 12,5 & 15,8 & $-8,3$ & 17,6 \\
\hline Uruguay & 200.423 & 383.741 & 403.896 & 372.467 & 10,1 & 7,8 & 5,3 & $-7,8$ & 10,9 \\
\hline Paraguai & 90.716 & 501.425 & 371.873 & 342.936 & 4,6 & 7,2 & $-25,8$ & $-7,8$ & 24,8 \\
\hline Chile & 63.900 & 170.564 & 172.807 & 159.360 & 3,2 & 3,3 & 1,3 & $-7,8$ & 16,5 \\
\hline Bolívia & 20.737 & 145.070 & 134.640 & 124.163 & 1,0 & 2,6 & $-7,2$ & $-7,8$ & 34,8 \\
\hline Canadá & 16.707 & 49.350 & 54.916 & 50.643 & 0,8 & 1,1 & 11,3 & $-7,8$ & 20,3 \\
\hline Venezuela & 29.490 & 58.980 & 52.929 & 48.810 & 1,5 & 1,0 & $-10,3$ & $-7,8$ & 8,8 \\
\hline Peru & 14.997 & 48.564 & 51.627 & 47.610 & 0,8 & 1,0 & 6,3 & $-7,8$ & 21,2 \\
\hline Colômbia & 13.484 & 48.531 & 50.065 & 46.169 & 0,7 & 1,0 & 3,2 & $-7,8$ & 22,8 \\
\hline México & 13.283 & 39.090 & 41.328 & 38.112 & 0,7 & 0,8 & 5,7 & $-7,8$ & 19,2 \\
\hline Guiana Francesa & 3.435 & 21.761 & 22.728 & 20.959 & 0,2 & 0,4 & 4,4 & $-7,8$ & 35,2 \\
\hline Equador & 4.685 & 18.239 & 14.573 & 13.439 & 0,2 & 0,3 & $-20,1$ & $-7,8$ & 19,2 \\
\hline Guiaana & 4.359 & 9.798 & 10.322 & 9.519 & 0,2 & 0,2 & 5,3 & $-7,8$ & 13,9 \\
\hline Suriname & 1.894 & 6.440 & 6.705 & 6.183 & 0,1 & 0,1 & 4,1 & $-7,8$ & 21,8 \\
\hline Costa Rica & 2.563 & 6.593 & 5.356 & 4.939 & 0,1 & 0,1 & $-18,8$ & $-7,8$ & 11,6 \\
\hline Panamá & 1.952 & 7.691 & 4.668 & 4.305 & 0,1 & 0,1 & $-39,3$ & $-7,8$ & 14,1 \\
\hline Puerto Rico & 897 & 2.079 & 2.104 & 1.940 & 0,0 & 0,0 & 1,2 & $-7,8$ & 13,7 \\
\hline Outros América Central & 8.070 & 17.369 & 10.502 & 9.685 & 0,4 & 0,2 & $-39,5$ & $-7,8$ & 3,1 \\
\hline De outras regiões & 607.099 & 1.432 .773 & 1.487 .793 & 1.374 .283 & 30,5 & 28,8 & 3,8 & $-7,6$ & 14,6 \\
\hline Alemanha & 102.106 & 282.846 & 290.335 & 267.743 & 5,1 & 5,6 & 2,6 & $-7,8$ & 17,4 \\
\hline Itália & 84.001 & 177.589 & 202.903 & 187.114 & 4,2 & 3,9 & 14,3 & $-7,8$ & 14,3 \\
\hline França & 55.257 & 131.978 & 165.117 & 152.269 & 2,8 & 3,2 & 25,1 & $-7,8$ & 18,4 \\
\hline Portugal & 52.183 & 115.088 & 147.143 & 137.955 & 2,6 & 2,9 & 27,9 & $-6,2$ & 17,6 \\
\hline Reino Unido & 38.520 & 125.607 & 127.903 & 117.950 & 1,9 & 2,5 & 1,8 & $-7,8$ & 20,5 \\
\hline Espanha & 59.502 & 99.677 & 110.765 & 102.146 & 3,0 & 2,1 & 11,1 & $-7,8$ & 9,4 \\
\hline Suíça & 33.505 & 71.667 & 67.947 & 62.660 & 1,7 & 1,3 & $-5,2$ & $-7,8$ & 11,0 \\
\hline Países Baixos & 20.851 & 56.725 & 42.428 & 39.126 & 1,0 & 0,8 & $-25,2$ & $-7,8$ & 11,1 \\
\hline
\end{tabular}




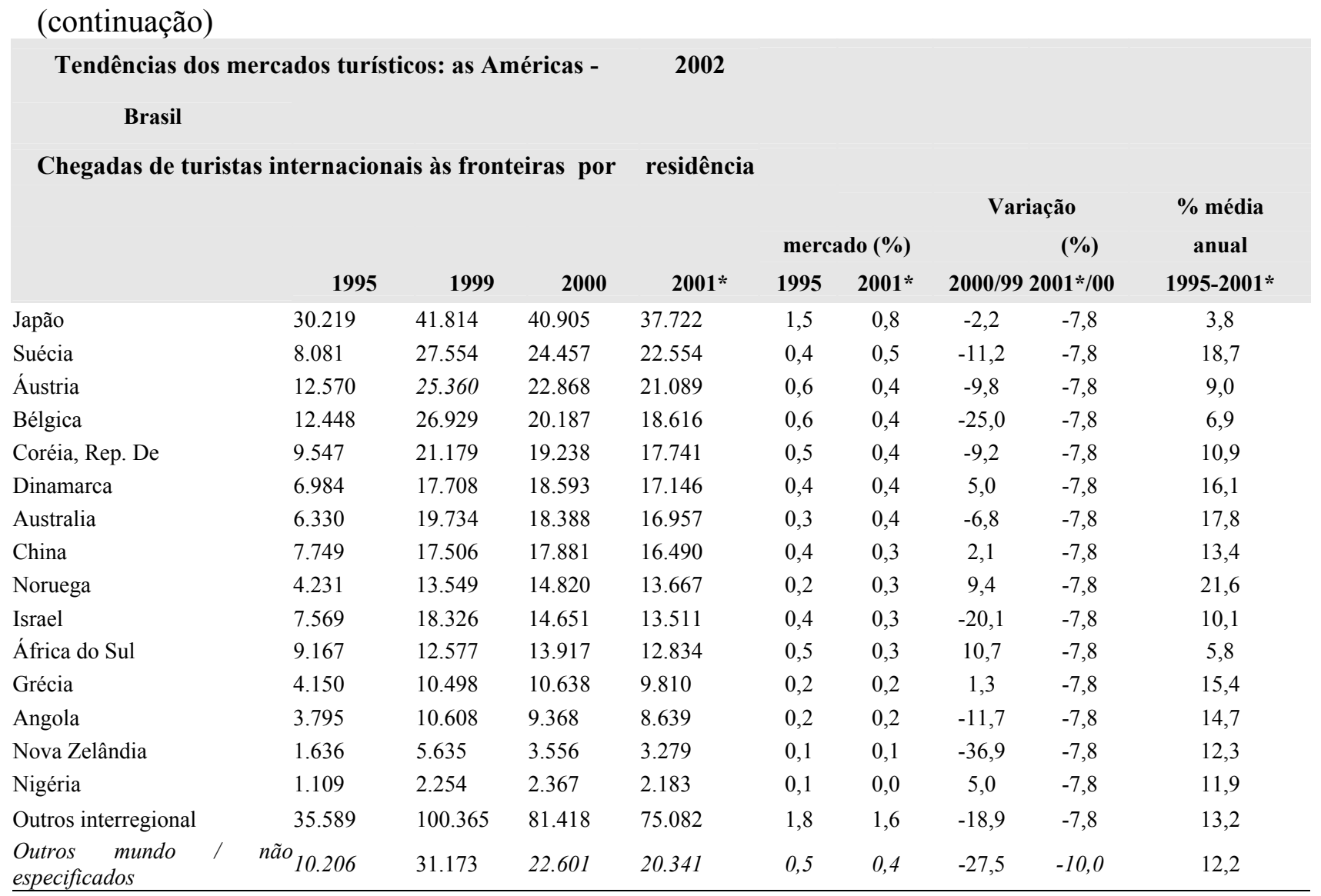

Fonte: Organização Mundial do Turismo (ONT) @

(Cifras procedentes da ONT, setembro de 2002)

O movimento turístico interno é também de muita importância no Brasil: Segundo a EMBRATUR, no ano 2001, se movimentaram internamente no Brasil 41 milhões de turistas nacionais, com uma duração média de permanência de 10,8 dias, e com um gasto médio por viagem de 253,5 reais, conforme resumido na tabela. 


\section{Tabela 7}

Principais aspectos das viagens domésticas 1998 e 2001

\begin{tabular}{|c|c|c|}
\hline Itens & 1998 & 2001 \\
\hline Nümero de Turistas & 38.208 .000 & 41.000 .000 \\
\hline \multicolumn{3}{|l|}{ Meio de transporte utilizado } \\
\hline - Onibus de linha & $49,6 \%$ & $36,6 \%$ \\
\hline - Onibus de excursáo & $6,1 \%$ & $6.5 \%$ \\
\hline - Carro próprio & $19,1 \%$ & $30,9 \%$ \\
\hline - Aviāo & & $9.0 \%$ \\
\hline \multicolumn{3}{|l|}{ Meio de hospedagem utilizado } \\
\hline - Hotel & $11,5 \%$ & $15,0 \%$ \\
\hline -Pousada & $2,9 \%$ & $5,0 \%$ \\
\hline - Casa alugada & $5.3 \%$ & $5,0 \%$ \\
\hline - Casa de amigos & $73.2 \%$ & $66.0 \%$ \\
\hline $\begin{array}{l}\text { Utilizam serviços agencia de } \\
\text { viagem }\end{array}$ & $5.4 \%$ & $7.7 \%$ \\
\hline Duração media da viagem (dias) & 11,7 & 10.8 \\
\hline Gasto medio por viagem (R\$) & 492.3 & 253.5 \\
\hline
\end{tabular}

Tabela 10 - Principais aspectos das viagens domésticas: 1998 e 2001

Finalmente deve-se destacar o crescente impacto que está tendo o turismo na geração de empregos. A tabela seguinte reflete os dados da EMBRATUR sobre o número de estabelecimentos e empregados diretos em atividades turísticas.

\section{V - MÃO-DE-OBRA EMPREGADA NO SETOR TURISTICO}

Tabela 19

\section{Número de estabelecimentos e empregados em} atividades turisticas - 1994/200

\begin{tabular}{|c|c|c|c|c|c|}
\hline Anos & $\begin{array}{c}\mathbf{N}^{\circ} \text { de } \\
\text { Estabelecimentos }\end{array}$ & $\begin{array}{l}\text { Incremento } \\
(\%)\end{array}$ & $\begin{array}{c}\mathrm{N}^{\circ} \text { de } \\
\text { Empregados }\end{array}$ & $\begin{array}{l}\text { Incremento } \\
(\%)\end{array}$ & $\begin{array}{c}\text { Participação do } n^{\circ} \\
\text { de empregados nas } \\
\text { Atividades } \\
\text { Turisticas na PEA }\end{array}$ \\
\hline 1994 & 83.436 & - & 703.429 & - & 2.619 .121 \\
\hline 1995 & 97.144 & 16,43 & 911.354 & 29,56 & 3.410 .368 \\
\hline 1996 & 105.197 & 8,26 & 882.215 & $-3,20$ & 3.261 .156 \\
\hline 1997 & 113.859 & 8,26 & 926.693 & 5,04 & 3.489 .893 \\
\hline 1998 & 117.907 & 3,56 & 936.825 & 1,09 & 3.659 .761 \\
\hline 1999 & 144.727 & 22,75 & 1.189 .040 & 26,92 & 4.758 .914 \\
\hline $2000^{*}$ & 150.227 & 3,80 & 1.241 .708 & 4,43 & 4.569 .512 \\
\hline
\end{tabular}

Tabela 11- Número de estabelecimentos e empregados em atividades turísticas: 1994/2000 


\section{Particularidades do crescimento turístico de Cuba.}

Cuba é o maior arquipélago do Caribe insular. Possui uma beleza caracterizada, pela exuberância de sua vegetação, pela harmoniosa combinação de clima, natureza, identidade cultural. Com 255 quilômetros de praias, entre elas a mais conhecida internacionalmente é Varadero, com mais de 20 quilômetros. Suas áreas montanhosas são pouco abundantes, mas existem três sistemas com especial atrativo turístico no Ocidente, Centro e Oriente do país.

Em Cuba localizam-se três cidades com regiões de forte arquitetura colonial como Trinidad, Santiago de Cuba e a Cidade de Havana, declarada, há alguns anos, pela UNESCO, como "Patrimônio da Humanidade".

$\mathrm{Na}$ atualidade, Cuba é um destino novo, o qual estimula a entrada de turistas com o interesse em conhecer suas cidades, sua natureza e sua identidade, especialmente o povo, cuja hospitalidade, capacidade de comunicação e forma de ser, que o converte num dos maiores motivos de visita e de retorno dos turistas ${ }^{6}$.

Tais atributos outorgam à ilha condições privilegiadas para o desenvolvimento do turismo que, como menciona OPUP (1995), inicia-se a partir do ano de 1884. E, a partir dos anos 30 do século XX é que começa, de uma forma regular e dirigida, a atividade turística no país.

Ao analisar as estatísticas da época, observa-se um crescimento do setor entre 1934 e 1949, onde a quantidade de turistas que visita o país passou de 91.297 para 180.014. Entretanto, os gastos investidos pelos mesmos aumentaram, de seis milhões de dólares até mais de 39 milhões ${ }^{7}$. Precisamente na década de quarenta, Cuba encabeçou o grupo com maior desenvolvimento turístico no Caribe, integrou pela Jamaica, Porto Rico e Bermudas e, segundo dados fornecidos pela ONT, em 1950 ocupou o décimo lugar mundial por receita, e o décimo oitavo por recepção turística, de um seleto grupo de 25 países (PÉREZ et al.. 1994).

Nesta época, desenvolveram-se grandes investimentos, com forte participação do capital norteamericano, sobretudo em termos de infra-estrutura hoteleira (mais de 3 mil quartos) na capital e em Varadero, o que permite ao país ser, em 1957, o maior receptor de turismo do Caribe, com 23\% de participação. Em apenas oito anos (entre 1949 e 1957) a ilha conseguiu o que não tinha alcançado nos 15 anos anteriores: duplicar a cifra de turistas recebidos até um total de 423.407, GARCOL (1994). A indústria turística converteu-se na segunda fonte de receita do país, acima da tradicional e experimentada indústria do tabaco.

\footnotetext{
${ }^{6}$ PUBLICITUR (agosto-setembro de 1995) apresentou que 59,7\% da amostra de turistas entrevistados destacaram que "conhecer o povo cubano" foi o principal motivo para a viagem.

${ }^{7}$ Report on Cuba. Findings and Recommendations of an Economic and Technical Mission. Organized by the International Bank for reconstruction and Development in collaboration with the Goverment of Cuba in 1950 .
} 
Com o triunfo da Revolução em 1959, decidiu-se privilegiar o desenvolvimento do turismo doméstico em detrimento do turismo internacional que, somado ao bloqueio norte-americano (mercado emissor natural do turismo ao Cuba), deprimiu o volume tanto de entrada de turistas quanto de receita.

Em 32 anos (entre 1957 e 1989) construíram-se mais de 4 mil habitações. É na década de 80 que se começou a observar um impulso na atividade turística internacional no país, aumentando anualmente a entrada de turistas entre 1985 e 1990 de 240.000 para 340.000, respectivamente. Observou-se que a quantidade de turistas que entraram no país, em relação aos totais absorvidos pelo Caribe, de 11,4 milhões, a participação de Cuba foi mínima.

A partir da década de 90 que o desenvolvimento do setor turístico alcançou um renovado estímulo ao converter-se em uma das indústrias priorizadas pela política estratégica do governo. Em seis anos, de 1991 a 1997, o setor de turismo cresceu de modo vertiginoso, como mostra a

\section{Tabela 12.}

Tabela 12: Indicadores sobre o turismo em Cuba.

\begin{tabular}{|cccccccc|}
\hline $\begin{array}{c}\text { Indicador } \\
\text { Chegadas (Milhares) }\end{array}$ & 1991 & 1992 & 1993 & 1994 & 1995 & 1996 & 1997 \\
& 418 & 455 & 544 & 617 & 740 & 1.004 & 1.171 \\
Crescimento anual (\%) & - & 8,9 & 19,5 & 13,5 & 19,9 & 35,6 & 16,6 \\
Receita brutos (Milhões US\$) & 549,5 & 699,2 & 720,0 & 850,0 & 1100,0 & 1300,0 & 1500,0 \\
Crescimento anual (\%) & & 27,2 & 3,0 & 18,1 & 29,4 & 18,1 & 15,3 \\
Habitações (Milhares) & 15,9 & 17 & 18,5 & 23,0 & 26,0 & 27,0 & 28,0 \\
Crescimento anual (\%) & - & 11,9 & 3,9 & 24,3 & 13,0 & 3,8 & 3,7 \\
\hline
\end{tabular}

Fonte: Cuba's Economic Reforms: Results and Future Prospects The Financial Research Institute. IRAIDA CALZADILLA: "Turismo en el camino do liderazgo" in: Jornal Granma, 6 de Janeiro de 1997.

Os recursos humanos do setor de turismo em Cuba possuem uma adequada qualificação, devido à obrigatoriedade do ensino até a nona série ${ }^{8}$. Um em cada oito trabalhadores cubanos tem nível técnico médio ${ }^{9}$ e um em cada 15 trabalhadores do setor é universitário, o que proporciona um mercado de trabalho com níveis de instrução adequada.

Sobre a infra-estrutura, Cuba possui uma rede de estradas de mais de 45 mil quilômetros (mais de 17.000 pavimentadas), uma rede ferroviária de mais de $5.000 \mathrm{~km}$ destinado ao serviço

\footnotetext{
${ }^{8}$ Correspondente à última série do Ensino Fundamental do Brasil.

${ }^{9}$ Correspondente ao Ensino Técnico de Segundo Grau do Brasil.
} 
público. Possui 16 aeroportos (7 dos internacionais), e 31 portos, que permitem acessar por mar praticamente todas as províncias do país. Entretanto, no que se refere às telecomunicações, o país ainda está abaixo dos níveis de exigência do turismo internacional, embora venha realizando investimentos significativos com participação do capital estrangeiro.

A hotelaria, no final de 1997, possuía aproximadamente 28 mil habitações, agrupadas em cadeias hoteleiras: Gran Caribe, Cubanacán, Gaviota, Horizontes e Isla Azul, correspondendo ao 14\%, $42 \%$ e $30 \%$ aos hotéis de cinco, quatro e três estrelas respectivamente, concentrando-se $63 \%$ do total em Havana e Varadero.

Cuba atualmente não possui recursos financeiros suficientes, principalmente devido à contração que tem vivido sua economia nos últimos anos. Como parte da estratégia do Governo para a saída da crise, priorizou-se o crescimento do setor turístico, pois atraía recursos vultosos. A isto se uniu o estímulo aos investimentos estrangeiros que com a construção de 21 empresas mistas, com um capital de mais de US\$ 667 milhões, e com a exploração de 2500 habitações, que representavam 9,3\% das existentes, segundo CALZADILLA (1997).

Cuba sustenta um crescimento do setor devido às condições naturais que possui e que lhe permitem deter uma vantagem comparativa. Isto é importante para o desenvolvimento do Turismo, mas não único fator para competir com êxito na globalização, já que essas condições não são únicas ou privativas da Ilha. Estas condições devem ser combinadas com outros fatores especializados (criados ou vantagens competitivas), que lhe permitam aproveitar alternativas menos tradicionais de venda do "produto turístico" e oferecer algo diferente de outros competidores da região do Caribe, que possuem as mesmas condições naturais.

O turismo não é uma atividade nova em Cuba. Da igual forma que no mundo, teve seu auge a partir dos anos 50, quando esteve muito ligado à máfia. Nessa época os Estados Unidos era o mercado principal, e o jogo e a prostituição eram as principais ofertas da Ilha. Este turismo de cidade condicionou o pouco desenvolvimento de nosso produto natural nessa etapa.

Com o triunfo da Revolução começou a política norte-americana de bloqueio e se eliminou o turismo proveniente de Estados Unidos.

A partir de 1959, o desenvolvimento da economia esteve dirigido a outros programas importantes do país, pelo qual o turismo era então fundamentalmente nacional, fato que condicionou uma estrutura habitacional pouco competitiva como produto internacional.

Nos anos 80 começa a reabertura ao turismo internacional, mas é em 1990 que se produz um novo enfoque do desenvolvimento deste setor, se criam as primeiras empresas mistas e há um crescimento acelerado nas chegadas de visitantes e na receita. 
Desde 1996, quando se logrou pela primeira vez ultrapassar o milhão de visitantes, Cuba se propôs consolidar-se como destino mundial e do Caribe. Para os primeiros anos da entrante centúria, se espera que cheguemos ao sete milhões de turistas e tenhamos 125 mil quartos hoteleiros.

Para comercializar seu produto turístico, a maior das Antilhas conta, principalmente, com a hospitalidade popular e qualidade de seu povo, além de excepcionais atrativos naturais, um patrimônio histórico autóctone, prolífica vida artística e cultural, um desenvolvimento sanitário único, a estabilidade política e a segurança para os turistas.

Mediante o Decreto-Lei 147 sobre a modificação dos organismos da Administração Central do Estado, o dia 21 de abril de 1994 foi criado o Ministério de Turismo para exercer as funções diretoras de direção política, regulação e controle do setor e da atividade empresarial nele.

O MINTUR é o organismo estatal diretor do Sistema de Turismo, no qual participam outras entidades do país. Neste sentido, o MINTUR elabora a política e controla sua aplicação nas entidades que administram diretamente as propriedades do setor. Seus objetivos estratégicos atuais são os seguintes:

- Desenhar e concretizar uma comercialização mais eficiente do produto turístico.

- Incrementar e diversificar uma oferta turística mais competitiva.

- Recuperar e fazer crescer a planta (sic) hoteleira.

- Elevar o nível de eficiência econômica do Sistema de Turismo.

- Desenvolver até os níveis mais avançados a informática e os sistemas de comunicação.

- Incorporar mais capital estrangeiro ao desenvolvimento do turismo.

- Ampliar a projeção do horizonte temporal do desenvolvimento do turismo ao ano 2010, assim como adequar as estruturas organizativas aos ritmos de desenvolvimento.

Para cumprir com as responsabilidades que lhe foram atribuídas, o Ministério de Turismo adotou uma estrutura veloz, horizontal e flexível. O organismo tem dois níveis de direção: o primeiro está composto pelo Ministro e os vice-ministros; enquanto que o segundo é integrado pelos funcionários a cargo das distintas áreas de trabalho: Secretaria, Qualidade do Produto, Investimentos, Negociações, Relações Internacionais, Jurídico, Desenvolvimento, Promoção e Publicidade, Análise Econômica, e Administração, Pessoal e Quadros. Para a formação e superação do pessoal do setor, com vistas a garantir o profissionalismo, qualidade e eficiência no serviço, o país conta com o Sistema Nacional de Formação Profissional do Turismo 
(FORMATUR), que integram 19 escolas em todo o território nacional. Mesmo assim, o MINTUR tem outras entidades de apoio, entre as que se sobressaem Publicitur (agência de comunicação e publicidade) e Fintur (casa financeira do setor).

Com o propósito de que toda Cuba seja um destino turístico de primeira ordem, dar ao desenvolvimento do setor no país integralidade e oferecer ao visitante opções diferenciais que incrementem a competitividade e a possibilidade de conhecer todo o arquipélago, existem várias regiões, todas com sua imagem própria, em função dos mercados e segmentos que se querem captar.

As regiões de desenvolvimento turístico priorizadas são:

- La Habana: Centro da vida política, econômica, cultural e social do país. Aqui está o Centro Histórico da Havana Velha, declarado Patrimônio da Humanidade pela UNESCO.

- Varadero: Principal balneário do país e considerado sua capital turística. Perto se encontra o Gran Parque Natural Montemar, localizado na Península de Zapata.

- Jardines do Ree: O mais prometedor dos destinos turísticos cubanos se estende ao norte desde Caibarién (Villa Clara) até Camagüey. Nele se incluem as restingas de Santa Maria, Coco e Guillermo

- Norte de Camagüee: Aqui se encontra a praia Santa Lucía.

- Litoral norte holguinero: Conta com belas praias: Guardalavaca, Esmeralda e Pesquero.

- Santiago de Cuba: Histórica e hospitaleira cidade, cheia de tradições, onde está o Parque Baconao.

- Costa Sur central: Define-se pelos destinos Cienfuegos e Trinidad, cidade fundada em 1515, declarada Patrimônio da Humanidade.

- Os Canarreos: Aqui figura Cayo Largo del Sul, a única ilha de Tudo Incluído* do mundo.

Cuba se consolida como destino turístico a partir de um crescimento acelerado do número de chegadas e de receitas. Assim, se incrementa desde o ano 90, com 340.300 viajantes, até alcançar, em 1999, cerca de 1,6 millhão, com uma taxa média de crescimento anual de 19\% nessa década.

Desde 94 até esta data, Canadá, Itália, Espanha, Alemanha e França, embora variando na ordem dos lugares líderes, mantiveram-se como os cinco principais países emissores. Em 1999, os cinco países continuaram açambarcando as maiores chegadas, agrupando $56 \%$ do total de chegadas ao país. 
Ao término de 1999, haviam chegado ao país um 1.602.781 visitantes, para um crescimento de 13,2\% em relação ao igual lapso de 1998. Os principais mercados emissores foram Canadá (276.346), Alemanha (182.159), Itália (160.843), Espanha (146.978). França (123.607), seguidos de Reino Unido (85.829), México (70.983) e Argentina (42.612).

O projeto hoteleiro de Cuba se desenvolveu a um ritmo anual de $11 \%$, passando de 12.900 quartos, em 1990, para 32.260, ao final de 1999. Agora é um produto de alta qualidade internacional, e a maior quantidade de suas instalações se concentra em hotéis de quatro e cinco estrelas, 64\%. No ano 2000 a cifra ascendeu a 36.000. Varadero é o destino que concentra a maior capacidade de hospedagem, com 11.245, seguida de Havana, onde há 9.850. No começo do ano 2000, havia 189 hotéis, a maioria nos destinos de praia e cidade. O número de quartos que oferecem serviços de alojamento ao turismo internacional cresceu, de 1990 a 2000, a uma taxa média anual de 11\%, passando de 12,9 mil de quartos, em 1990, a 35,3 mil de quartos, o que quase triplica a cifra de partida.

A maior parte da construção de instalações hoteleiras é resultado de investimento do próprio país. Não obstante, os investimentos estrangeiros exercem um importante papel no desenvolvimento turístico de Cuba.

A dinâmica do desenvolvimento do turismo internacional constituiu um estímulo para o investimento estrangeiro; ao final de 2000 existiam 29 empresas mistas, com um capital de 1,1 milhão de dólares, que incluem 26 empresas hoteleiras com 15.600 quartos, das quais 3.700 estão em operação, e os restantes em projeto ou em construção.

Por outra parte em 2000 havia 17 gerências estrangeiras, de oito países, administrando 52 hotéis, com 16.120 quartos, o que representa $46 \%$ dos quartos para o turismo internacional.

Cuba é membro da Organização Mundial de Turismo (ONT) e da Organização de Turismo do Caribe (CTO). Além disso, trabalha em conjunto com seus vizinhos do Caribe para fazer da área um só destino, estratégia na qual se inscreve a criação da Zona Sustentável de Turismo, a primeira do mundo e aprovada pela Cúpula de Chefes de Estado e Governo da Associação de Estados do Caribe. Em matéria de formação de pessoal, Cuba é, ainda, membro da Confederação Panamericana de Escolas de Hotelaria e Turismo (COMPEHT)

O Turismo desenvolve sua missão como captador direto de divisas frescas e contribui para a reanimação de outros setores da economia nacional. Ocupa-se em alojar, alimentar, distrair e transportar aqueles que viajam para fora de seu lugar de residência. Em Cuba, as atividades anteriormente citadas destinam-se a satisfazer os interesses de visitantes estrangeiros e de 
segmentos prioritários da população, para o qual o sistema do turismo encarregado de garantir as mesmas, está integrado por organizações empresariais que se agrupam nas instituições seguintes: As principais premissas a partir das quais as organizações empresariais do sistema desenvolvem sua gestão, são as seguintes:

- Constituir o turismo como uma atividade de todo o país.

- Desenvolver as atividades empresariais com autonomia, independência e especialização, com a eficiência econômica como princípio diretor.

- Aproveitar o potencial territorial.

- Aproveitar os potenciais culturais, intelectuais e humanos do povo cubano.

Estas premissas se expressam nos propósitos que se desejam alcançar pelo conjunto de organizações que integra o sistema, constituindo sua razão de ser e que consistem em:

- Comercializar um produto turístico autóctone, sustentável e competitivo internacionalmente.

- Fundamentar o produto na realidade social e identidade histórico-cultural da nação, os extraordinários valores do povo cubano, a beleza de nossa natureza, a segurança, a sanidade e o profissionalismo nos serviços de qualidade que brindam seus trabalhadores.

Os grupos e empresas que integram o sistema do turismo, assim como as atividades principais nas quais desenvolvem seus objetos sociais e empresariais são os seguintes:

- O desenvolvimento do turismo constituiu um dos elementos fundamentais para a reanimação da indústria nacional, permitiu, segurança de emprego; fonte de financiamento; a modernização das tecnologias; a abertura de novas linhas de produção e produtos; a modificação na cultura empresarial mediante a aplicação de novos conceitos sobre o valor da qualidade, a atenção ao cliente e o cumprimento de prazos de entrega.

Ao final do ano 2000, o turismo dava emprego a cerca de 100.000 trabalhadores, que comparados com os 52.000 que trabalhavam em 1990, representaram um crescimento de $6,4 \%$ médio anual. Do total de trabalhadores ou 80,0\% trabalham em período integral. Os elementos fundamentais de composição desta força de trabalho são:

- $78,4 \%$ dos trabalhadores têm menos de 45 anos,

- $36,1 \%$ são mulheres,

- 30,0\% são negros e mestiços,

- Um em cada cinco trabalhadores é graduado universitário,

- $70 \%$ dos trabalhadores tem mais de 12 anos de estudo

O sistema de formação de trabalhadores e quadros do turismo, Formatur, é composto por 19 
escolas, localizadas nas regiões turísticas do país, no total 1.020 pessoas dão aula, devididos em: 277 especialistas principais, 220 professores ajudantes e 523 instrutores. Esse sistema de formação nasce com o desenvolvimento do turismo internacional e tem solucionado as necessidades apresentadas pelo sistema, em todos os aspectos vinculados à superação dos trabalhadores e quadros. Em 2000 se alcançaram mais de 127 mil ações de capacitação em todo o sistema do turismo.

Participam do turismo nacional, ou doméstico, todas as entidades turísticas com um peso fundamental de Islazul e o Campismo Popular. Os esforços realizados se concentraram no melhoramento paulatino das instalações, na elevação da qualidade do serviço, na preparação profissional dos trabalhadores e em um discreto aumento dos níveis de turistas/dia, que alcançaram, em 2000, a cifra de 2,6 milhões. Esses serviços se prestam, essencialmente, aos trabalhadores e jovens destacados.

A sazonalidade, identificada como parasitária da eficiência, conseguiu-se; ainda assim, e em que pesem as medidas adotadas, os período de maio-junho e setembro-outubro continuaram se comportando de forma muito modesta.

\begin{tabular}{|c|c|}
\hline \multicolumn{2}{|c|}{ Flutuação de visitantes } \\
\hline ANO & Mes Máx/Mes Mín. \\
\hline 97 & $157,8 \%$ \\
\hline 98 & 165,0 \\
\hline 99 & 176,2 \\
\hline 00 & 162,6 \\
\hline
\end{tabular}

Tabela 13 - Flutuação de visitantes

Custo e gasto (US\$) versus (US\$) de receitas

\begin{tabular}{|c|c|c|c|c|c|}
\hline \multirow{2}{*}{ ANOS } & \multicolumn{4}{|c|}{ MESES } & TOTAL \\
ANO \\
\hline 1999 & $\begin{array}{c}\text { MAIO } \\
0,794\end{array}$ & $\begin{array}{c}\text { JUNHO } \\
0864\end{array}$ & $\begin{array}{c}\text { SETEMBRO } \\
0,826\end{array}$ & $\begin{array}{c}\text { OUTUBRO } \\
0,844\end{array}$ & $.0,766$ \\
\hline 2000 & 0,793 & 0,872 & 0,890 & 0,895 & 0,769 \\
\hline
\end{tabular}

Tabela 14 - Custo e gasto (US\$) versus (US\$) de receitas

Embora a referida sazonalidade ocorra em diferentes mercados, o Canadá, que concentra 7,3\% das chegadas, é decisivo. Dos 307.725 visitantes que chegam, a média dos quatro meses de extrema baixa foi de 12.500, enquanto que a dos quatro meses de alta chega a 43.400, aproximadamente 3,5 vezes. 


\begin{tabular}{|c|c|c|c|c|}
\hline \multirow[b]{2}{*}{ MERCADOS } & \multirow{2}{*}{$\begin{array}{c}\% \\
\text { Participalõ }\end{array}$} & \multicolumn{2}{|c|}{ MÉDIO DE VISITANTES } & \multirow{2}{*}{$\begin{array}{c}\text { índiece } \\
\text { Máximo/mínimo }\end{array}$} \\
\hline & & $\begin{array}{l}\text { Janeiro-fevereiro } \\
\text { março-dezembro }\end{array}$ & $\begin{array}{c}\text { maio -junho } \\
\text { setembro- outubro }\end{array}$ & \\
\hline CANADÁ & 17,3 & 43400 & 12500 & 3,5 \\
\hline $\begin{array}{l}\text { ALEMANIA, ITALIA, ESPANHA. } \\
\text { FRANCIA, R. UNIDO, MÉXICO, } \\
\text { ARGENTINA }\end{array}$ & $50,5^{\prime}$ & 80640 & 64960 & 1,2 \\
\hline RESTO & 32,2 & 50580 & 40560 & 1,2 \\
\hline TOTAL & 100,0 & 174620 & 118020 & 1,5 \\
\hline
\end{tabular}

Tabela 14: Ano de 2000: Visitantes (máximo e mínimo)

Quanto à rede gastronômica, têm sido construídos novos restaurantes e cafés, assim como remodelados outros, cuja oferta, em geral, é adequada. Mas o serviço, na maioria dos casos, não é comparável com os padrões internacionais. Também têm sido recuperadas, para os turistas estrangeiros, áreas de recreação, como cabarés, centros noturnos e desportivos entre outros.

Os meios de transporte são outro ponto fraco. A linha aérea nacional tem melhorado em pontualidade e cumprimento dos vôos internacionais e é reconhecida pela confiabilidade de seus pilotos e comandantes, mas suas aeronaves são, em sua maioria, de tecnologia obsoleta. Há poucas linhas internacionais que chegam ao país, o que dificulta um acesso fácil. Existe também um amplo programa de ampliação e modernização dos aeroportos e das suas aeronaves. O transporte urbano é muito deficiente e o intermunicipal não é de qualidade, pois é limitado, pela dificuldade de se conseguir as reservas e pela impontualidade das viagens.

Se o panorama das indústrias de apoio não é alentador, tampouco o é o das indústrias provedoras, já que ainda não se consegue totalmente que o turismo converta-se no motor impulsor de toda a economia. Uma melhoria tem-se alcançado na participação da indústria de materiais de construção e da indústria de móveis entre outras. Entretanto, ainda persiste, sobretudo nas indústrias relacionadas com o turismo, a necessidade de importantes importações, pelo fato de a produção nacional não cumprir os quesitos de qualidade e de prazos de entrega.

Durante estes últimos anos, a estratégia foi centrada, fundamentalmente, na criação de infraestrutura que facilitasse o acesso e permanência do turista, todas as vezes que Cuba carecia das condições necessárias para assimilar o crescimento do fluxo de turistas.

Os turistas procuram Cuba por diversos motivos. Por exemplo, na pesquisa realizada pela Publicitur, empresa cubana de publicidade, em agosto / setembro de 1995, os motivos que 
influenciaram a viagem, declarados pelos turistas, foram: conhecer o povo: 59,7\%; condições naturais: 51,9\%; curiosidade: $37,4 \%$ e interesse cultural: $15,9 \%$.

Uma valorização do Sistema de Turismo cubano permite identificar, como ponto que mais atua contra a competitividade do setor ao enfoque de curto prazo do seu planejamento, o qual também se manifesta na pouca orientação ao cliente e suas necessidades. A esses fatores soma-se uma cultura insuficiente na qualidade total atual na área dos serviços. Isto corresponde à valoração, feita pelos próprios turistas, do "produto turístico" cubano, apresentado na Tabela 15, na qual se destaca-se como o ambiente físico e sócio-cultural de Cuba se posiciona em relação à média dos países do Caribe (Tabela 15). A infra-estrutura (especialmente acesso aéreo, marítimo e telecomunicações) e a hospitalidade encontram-se situadas abaixo das de outros países da região, salvo em algumas atividades como o esporte e centro de convenções.

Cabe destacar que o setor de turismo em Cuba tem um conjunto de potencialidades ao se desenvolver, e que devidamente aproveitadas poderão se converter em fontes de vantagens competitivas. Refere-se à existência de condições naturais atrativas, às características de identidade da população cubana, o alto nível cultural de seus recursos humanos e uma infraestrutura adequada de estradas, aeroportos, entre outros. 
Tabela 15: Estimativas do produto turístico cubano (1 é o pior e 10 o melhor).

\begin{tabular}{lccccccc}
\hline $\begin{array}{c}\text { COMPONENTE } \\
\text { DO PRODUTO }\end{array}$ & Cuba & $\begin{array}{c}\text { República } \\
\text { Dominicana }\end{array}$ & Jamaica & $\begin{array}{c}\text { México/ } \\
\text { Cancún }\end{array}$ & $\begin{array}{c}\text { Porto } \\
\text { Rico }\end{array}$ & $\begin{array}{c}\text { Aruba } \\
\text { Margarita } \\
\text { (Ve) }\end{array}$ \\
\hline Ambiente Físico: & 9 & 8 & 9 & 9 & 7 & 9 & 8 \\
Praias & 9 & 8 & 8 & 6 & 6 & 3 & 3 \\
Ecologia & & & & & & &
\end{tabular}

Infra-estrutura:

$\begin{array}{lccccccc}\text { Acesso Aéreo } & 5 & 8 & 8 & 10 & 10 & 8 & 3 \\ \text { Rodovias } & 7 & 6 & 6 & 7 & 8 & 8 & 7 \\ \text { Marinhas } & 5 & 8 & 9 & 10 & 10 & 8 & 7 \\ \text { Telecoumicação } & 5 & 7 & 8 & 8 & 9 & 8 & 6\end{array}$

Hospitalidade:

$\begin{array}{llllllll}\text { Hotéis Habitações } & 6 & 7 & 8 & 9 & 8 & 8 & 7 \\ \text { Treinamento/staff } & 6 & 7 & 7 & 8 & 8 & 8 & 6 \\ \text { Alimentos } & 6 & 7 & 8 & 8 & 8 & 8 & 8 \\ \text { Bebidas } & 7 & 7 & 7 & 10 & 9 & 7 & 8 \\ \text { Centro Convenções } & 8 & 7 & 8 & 9 & 9 & 7 & 6 \\ \text { Esporte } & 5 & 7 & 8 & 10 & 8 & 5 & 7 \\ \text { Excursões } & 2 & 7 & 8 & 8 & 8 & 8 & 6\end{array}$

Ambiente Sócio-

Cultural:

Arte

7

Sítios hist./ museus

Lazer/ Vida noturna

$9 \quad 8$

8

8

10

4

4

3

Amizade do povo

Segurança

6
8
7

7
7
7

8
5
5

$\begin{array}{llll}8 & 6 & 6 & 6 \\ 6 & 9 & 9 & 6 \\ 7 & 9 & 9 & 7\end{array}$

Fonte: Tourism Deveopment in Transition Econonic. The Cuba Case. Francoise L. Simon: The Columbia Journal of World Business, 1995. 


\section{Descrição dos capítulos.}

Capítulo I. Caracterização do estudo. Neste capítulo é descrita a situação-problema, objeto de investigação, sob que marco conceitual foi desenvolvida a análise, e em que contexto. A análise de contexto resume a evolução internacional do turismo como atividade econômica internacional, e as particularidades do impacto do turismo na Espanha, América, Brasil e Cuba, por ser as áreas geográficas em que se desenvolveu a investigação. De igual forma faz uma análise da evolução do mercado turístico, e as novas formas de comportamento do consumidor turístico na globalização. Destaca, por sua vez, as tendências que manifestam as empresas prestadoras dos serviços turísticos. A metodologia de investigação desenvolvida é resumida e os objetivos do estudo. Destaca a importância do caso Sol Meliá.

Capítulo II. Marketing estratégico e estratégias competitivas. Este capítulo desenvolve o marco conceitual mais geral que sustenta a investigação e a tese. São abordados os principais conceitos de estratégia empresarial, o marketing estratégico como base para entender o mercado e elaborar a estratégia da empresa, as principais tipologias de estratégias corporativas de crescimento empresarial, os enfoques de estratégias competitivas, as principais estratégias de internacionalização, e os fundamentos da mais recente configuração das empresas na globalização: os clusters de empresas.

Capítulo III. O Modelo Delta de pensamento estratégico. O capítulo descreve os postulados básicos da formulação estratégica da empresa, segundo o Modelo Delta e estabelece os três enfoques básicos: empresas com enfoque estratégico de melhor produto, empresas com enfoque estratégico centrado no cliente e empresas com enfoque estratégico centrado no sistema. Destacam-se as políticas de produto, preço, distribuição e comunicação nas empresas segundo esses estágios, assim como a orientação para o cliente e formas adotadas pela concorrência nos setores onde predominem empresas, segundo cada tipo de estratégia. São destacados: as fontes de vantagem competitiva; o papel da tecnologia de informação e da inovação; os processos de implantação e mensuração de resultados.

Capítulo IV. Esse capítulo dedica-se a analisar o Sistema de Turismo e as particularidades do setor. São abordados o sistema de turismo e seus principais conceitos. A organização turística: agentes e facilitadores, empresa hoteleira. Sua situação, na atual fase a globalização, e o papel dos tour-operators como canais de distribuição ou empresas produtoras. Uma segunda parte do capítulo aprofunda-se no marketing turístico e suas particularidades, para em continuidade abordar o processo de planificação estratégica no setor de turismo, segundo os critérios de 
sustentabilidade, para concluir abordando o tema da competitividade e o posicionamento no sistema de turismo.

Capítulo V. Este capítulo descreve a metodologia de pesquisa adotada, como foi definido o ciclo de construção e avaliação do modelo teórico referencial, a definição da situação-problema, os objetivos da investigação, o modelo operacional, o desenho da pesquisa, os tipos e fontes de informação, os métodos de coleta de dados, o projeto das entrevistas, assim como a coleta, análise e processamento da informação.

Capítulo VI. O capítulo está dedicado ao estudo de caso de Sol Meliá. É abordada a história da empresa, sua expansão inicial na Espanha, seu processo de internacionalização, a saída para a bolsa, sua estratégia de marketing e orientação ao cliente, a gestão de seus recursos humanos. A estratégia de gestão de qualidade, a introdução e desenvolvimento das novas tecnologias da informação: a e-transformação da empresa, a análise econômico-financeira, assim como as alianças, fusões e aquisições seguidas e seus atuais problemas estratégicos. O capítulo também resume as particularidades do crescimento da empresa em Cuba e no Brasil.

Capítulo VII. Capítulo dedicado às conclusões, limitações e recomendações para estudos futuros. Caracterizar-se-á, ainda, a estratégia desenvolvida pela cadeia Sol Meliá, segundo o modelo Delta, classificando-a segundo seu estágio de desenvolvimento (melhor produto centrada no cliente - centrada no sistema) e segundo os diferentes modelos teóricos sobre estratégia (Mintzberg e outros). Será também analisada a estratégia da cadeia na América Latina, como forma de vincular o desenho estratégico à sua implementação, e avaliado o grau de sustentabilidade de sua estratégia, aplicando o teste de sustentabilidade da estratégia:

Primeiro: Estratégia de criação de valor econômico. Atingir um desempenho financeiro superior e sustentável, medido em termos de rentabilidade a longo prazo.

Segundo: Estratégia relacional com os clientes: apoiada em uma proposta exclusiva de valor para o cliente. Atrair, satisfazer e reter os clientes.

Terceiro: Estratégia para a criação do "espírito de sucesso" na empresa. Fluxo líquido de talento. Atrair, satisfazer e reter os empregados que se destacarem. 


\title{
CAPÍTULO II
}

\author{
MARKETING ESTRATÉGICO E \\ ESTRATÉGIAS COMPETITIVAS
}




\section{CAPÍtULO II}

\section{MARKETING ESTRATÉGICO E ESTRATÉGIAS COMPETITIVAS}

1. Desenvolvimento histórico da teoria e prática da administração

2. Estratégia Empresarial. Principais Conceitos.

3. O marketing estratégico como base para entender o mercado e elaborar a estratégia da empresa.

4. Estratégias corporativas de crescimento empresarial.

5. Estratégias competitivas.

6. Estratégias de internacionalização.

7. Os clusters de empresas.

\section{Desenvolvimento histórico da teoria e prática da administração}

Dificilmente se pode determinar e alcançar objetivos numa empresa, sem uma estrutura de organização que gerencie os esforços individuais de cada trabalhador e os converta em uma cooperação real e efetiva.

Desde o início do século, a busca das melhores formas de organizar e dirigir uma empresa, de modo a viabilizar seu desenvolvimento e gerar bons resultados vem sendo o tema central de estudiosos de administração em todo o mundo. Uma primeira aproximação foram os modelos clássicos de Administração (administração científica, relações humanas, comportamental e burocrática), que se concentraram na forma de otimizar a utilização dos recursos disponíveis, considerando somente o que ocorria no interior das empresas. TAYLOR, MAYO, FAYOL, GELINIER, URWICK, entre outros, são alguns dos pioneiros destas escolas mais importantes de organização, cujas contribuições determinaram a realidade atual.

TAYLOR desenvolveu a teoria da racionalização no trabalho com o objetivo de encontrar o modelo mais produtivo para o trabalho. Para isto, primeiramente, realizou uma análise das tarefas, depois as estudou num laboratório, onde desenhou a forma mais eficaz de realizá-las, a fim de incrementar a produtividade. Posteriormente, e em função de como houvesse desenhado o posto de trabalho, selecionava os trabalhadores mais capazes, e, em seguida, dava capacitação aos mesmos. Por último, desenvolveu um sistema de incentivos que estimulasse a produtividade do empregado.

Nesta teoria encontram-se conceitos importantes como ergonometria, capacitação, seleção e motivação, utilizadas por muitas empresas hoje e, especialmente no setor de hotelaria, 
continuam-se aplicando muitos deles, apenas com ligeiras modificações e adaptações aos novos tempos.

Estes conceitos, centrados na produtividade, conforme GALLEGO (1996), dão lugar a um trabalho muito reiterativo, monótono, padronizado, sujeito a controle e pressão, carente, na maioria das vezes, do significado humano do trabalho.

Assim, surgiu a escola de relações humanas, cujo expoente foi MAYO. Seu objetivo não foi só incrementar a produtividade, mas também melhorar o bem-estar moral dos empregados, considerando que o homem, por natureza, é um ser social, e a organização deve permitir-lhe satisfazer suas necessidades sociais de interação.

FAYOL representou, igualmente, um importante papel no desenvolvimento da Teoria da Administração, enquanto que TAYLOR se orientou nas tarefas, e MAYO desenvolveu as origens do trabalho em equipe. FAYOL, por sua vez, criou as bases de uma organização integrada, delimitando a função administrativa.

Desde a escola da Organização Científica do Trabalho de TAYLOR, na qual se pretendeu uma maior racionalização do trabalho, passando pela organização formal de FAYOL, cujo objetivo era a função administrativa, até os teóricos das relações humanas, como MAYO e MASLOW, havia uma preocupação por todos os aspectos que influem na empresa como organização. Atualmente, isto continua sendo motivo de estudos de sociólogos, técnicos, dirigentes e psicólogos, com o objetivo de conseguir uma maior consciência dos problemas humanos que surgem na empresa e sua melhor adaptação ao meio competitivo em que devem se desenvolver.

Foi somente a partir dos anos 60, com o surgimento da Teoria Geral dos Sistemas de BERTALANFFY, que as empresas passaram a serem vistas como sistemas abertos em interação com o ambiente. Uma série de importantes pesquisas conduzidas, entre outros, por CHANDLER (1962), demonstrou que a estrutura de uma organização e seu funcionamento era influenciada pelo meio ambiente externo, concluindo que não existia uma única forma de organizar. Estes descobrimentos deram origem à Escola Contingencial, primeiro Modelo Contemporâneo de Administração.

Desta forma, o bom desempenho empresarial passou a ser considerado uma função do ajuste da empresa ao seu ambiente, alcançado a partir do uso de estratégias adequadas. A busca das melhores formas para definir esta estratégia deu origem ao Modelo de Administração por Objetivos, depois ao Planejamento Estratégico e ao Modelo de Administração Estratégica, cujo pioneiro foi ANSOFF (1965). PORTER (1980 e 1985) e LAMBIN (1989) tiveram grande relevância neste processo, afirmando que a sobrevivência de qualquer empresa dependia da 
obtenção de alguma vantagem sustentável em relação a seus concorrentes e segundo a óptica dos clientes.

Paralelamente, o marketing deixou de ser interpretado puramente do ponto de vista econômico e consolidou-se como uma disciplina independente. DRUCKER (1974) afirmou que a criação de consumidores satisfeitos era o único objetivo válido para qualquer empresa, promovendo o Marketing ao posto de função vital na organização. Autores como LEVITT (1960 e 1975) e KOTLER (1975) consolidaram a idéia de que as empresas somente podem ter êxito se puderem compreender as reais necessidades dos clientes e os atender bem.

A ênfase dada à adequação da empresa ao ambiente/cliente, como forma de garantir um desempenho superior, começou a ser questionada por PETERS e WATERMAN (1982), tendo por base uma extensa pesquisa em empresas bem-sucedidas nos Estados Unidos. Estes autores concluíram que estas tinham sete características, "7S": estrutura (structure), estratégia (strategy), sistemas (systems), equipes dirigentes (staff), estilo (style), habilidades (skills) e valores compartilhados (shared values). Não obstante, houve o fato de que depois da pesquisa, algumas das empresas estudadas não conseguiram manter seu nível de desempenho.

A partir destes estudos surgiram os Modelos de Administração Participativa (LERNER, 1986) e Administração Empreendedora (PINCHOT, 1989) e, em paralelo, o Modelo de Administração Japonês (WOOD, 1991) que conduziu às empresas desse país a importantes resultados.

Foram PRAHALAD e HAMEL (1990) que deram uma forma mais concreta às análises dos fatores internos relacionados ao bom desempenho empresarial, estabelecendo que qualquer empresa bem sucedida devia ter competências essenciais (core competences), que constituíam o foco da estratégia empresarial corporativa. A empresa, para eles, era uma hierarquia de competências essenciais, produtos essenciais e negócios focalizados em mercados específicos. STALK, EVANS e SHULMAN (1992) completaram as análises, definindo capacidades (capabilities) como as características da empresa visíveis aos consumidores, reflexo de suas competências essenciais.

DAY (1990 e 1994) estabeleceu, dentro desta nova visão que, para se ter um desempenho superior, não basta à empresa estar próxima ao cliente e orientada para o mercado. Esta teria que ser guiada pelo mercado (market-driven), o que significa ter, além dos recursos e competências para produzir, habilidades superiores (ou capacidades) no entendimento da satisfação dos clientes, misturando crenças, informações e aplicação coordenada de recursos interfuncionais. Atualmente estão em desenvolvimento os modelos emergentes de Administração Holística (RIBEIRO, 1989), Administração Virtual (DAVIDOW e MALONE, 1992) e o surgimento do 
meta-conceito de empresa de classe mundial administrada globalmente (KANTER, 1989, 1992, 1996).

\section{Estratégia Empresarial. Principais conceitos}

As incertezas geradas pelas turbulências do ambiente externo e a necessidade de preparar a organização para o futuro, garantindo a criação e a multiplicação de seu valor, nessas condições, determinam a necessidade da previsão e projeção do rumo a ser seguido para alcançar uma vantagem competitiva defensável e sustentável no tempo. Tem, assim, a maior importância e dimensão a estratégia empresarial, elemento que aglutina a cultura da empresa, suas políticas com clientes e outros atores, em seu processo de criação de valor. Na atual fase da globalização, caracterizada pela terceira revolução tecnológica, provocada pelas tecnologias da informação e das comunicações, o desenvolvimento de uma economia de redes, obriga os empresários a revisar seus enfoques de pensamento estratégico. Em todo caso, a essência dos conceitos sobre estratégia empresarial segue vigente, já que conseguir um desempenho financeiro superior e sustentável, medido em termos de rentabilidade a longo prazo, segue sendo a motivação fundamental para elaborar a estratégia de uma empresa. Os principais estudiosos da ciência da administração, os consultores de empresas e os próprios dirigentes, com diferentes enfoques, reforçam o valor destas idéias.

Para MINTZBER e QUINN (1998), a estratégia empresarial destaca questões fundamentais sobre as intenções, comportamentos e atividades no contexto da organização. Ao definir a empresa como o resultado de uma ação coletiva, em busca de uma missão comum, a estratégia se aprofunda nas intenções da mesma, para ser difundida por meio do conjunto de colaboradores, de modo que sejam intrinsecamente integradas e convertidas em normas e valores compartidos. Desse modo, a estratégia não é apenas uma idéia de como lidar com um inimigo comum, em um ambiente de concorrência, mas também a forma de conduzir as questões mais essenciais e fundamentais no interior da empresa, forjando sua cultura.

A literatura sobre o tema apresenta numerosas definições de estratégia no campo empresarial. A estratégia, segundo PORTER (1998), se manifesta em atividades específicas que se realizam em todas as partes do negócio. A estratégia e sua implementação devem estar intrinsecamente vinculadas, e esta união deve manifestar-se em toda a atividade que a empresa realiza, desde o treinamento e a formação, no processo de gestão da informação, até a forma de relacionar-se com sues clientes, de onde se deverá observar de forma inter-relacionada e integralmente, todo o seu desempenho. Basicamente, a estratégia é um grupo de atividades internamente consistentes, 
alinhadas com um determinado posicionamento no mercado. $\mathrm{O}$ autor destaca, também, a importância de cada indivíduo com suas funções e como parte da estratégia da organização.

A estratégia, segundo ANSOFF (1977), é uma regra direcionada à tomada de decisões, sob condições de incerteza ou o desconhecimento parcial das variáveis ambientais. Segundo este autor, são quatro os elementos, complementares entre si, que compõem a estratégia:

* conjuntos de produtos e mercados: são os elementos básicos para o estabelecimento do domínio competitivo e do alcance da ação da empresa;

* vetor de crescimento: estabelece a direção a ser seguida;

* vantagem competitiva: é o componente que descreve as características de cada setor de atividade e define o papel com respeito à concorrência no estabelecimento de estratégias empresariais;

* sinergia: está relacionada à capacidade da empresa de tirar proveito de seu ingresso em uma nova área definida pela conjugação de produtos-mercados.

MINTZBERG e QUINN (1998), adotaram cinco definições formais de estratégia:

Estratégia como plano: a estratégia adotada como plano significa que existe um caminho a seguir conscientemente, o seja, há uma linha ou guia que conduz a determinada situação. Esses planos podem ser estabelecidos de forma explícita em documentos formais ou não, e também podem ser gerais ou específicos, sendo em todo caso estratégias deliberadas. A estratégia como plano, introduz a noção de intenção e enfatiza o papel de liderança consciente.

Estratégia como manipulação: este tipo de estratégia significa uma manobra intencional para confundir um oponente ou competidor. Na estratégia como manipulação, se destaca o estudo da concorrência e do meio ambiente, assim como, o de uma meta, ou de resultados que podem ser perdidos pela não execução da linha de ação traçada.

Estratégia como padrão do realizado: este tipo de estratégia é a ocorrida, encontrada ou realizada independentemente de haver sido pretendida ou não. É aquela estratégia que emerge da ação. A estratégia como padrão do realizado enfoca a ação realizada (comportamento adotado) e introduz a noção de que a estratégia pode ser emergente.

Estratégia como posição: este tipo de estratégia é aquela que interage ou faz uma mediação entre a empresa e seu ambiente. Dada uma empresa e seu meio ambiente é a estratégia natural da interação e comunicação entre eles, sem mudanças e ações drásticas. Na estratégia como posição se introduz o contexto ambiental, buscando considerar questões como concorrência, cooperação, ou podendo reforçar a importância da manipulação. 
Estratégia como perspectiva: este tipo de estratégia é concebida conjuntamente pelos integrantes da empresa, por meio de sua maneira de ver as coisas, Os acontecimentos, seus modelos mentais, sua visão de grupo e de sua aprendizagem, são a maneira pela qual empresa forma seu conceito do mundo. É a partir de como o mundo funciona para os integrantes da empresa, englobando seus aspectos éticos, culturais, ideológicos, paradigmáticos, que se conformará a estratégia que escolheram. Este enfoque se direciona mais para o interior da organização.

De igual maneira, MINTZBERG e QUINN (1998), em sua revisão sobre o conceito de estratégia, consideraram que a estratégia emergente pode ser de tanto sucesso como a estratégia deliberada, esta última, como resultado do planejamento formal. De fato, os autores afirmam, na elaboração de estratégias de sucesso, avança-se sobre dois eixos, um deliberado e outro emergente

Todas as definições anteriormente apresentadas destacam, de uma forma ou de outra, três postulados básicos, os quais, segundo HAX e WILDE (1999), devem considerar toda estratégia empresarial:

Primeiro: Criação de valor econômico. Conseguir um desempenho financeiro superior e sustentável, medido em termos de rentabilidade a longo prazo.

Segundo: Vinculação com clientes. Apoiada por uma proposta exclusiva de valor para o cliente. Atrair, satisfazer e reter o cliente.

Terceiro: Criação do "espírito de sucesso" na empresa. Fluxo líquido de talento: Atrair, satisfazer e reter os empregados destacados.

Desta forma, os conceitos anteriormente destacados refletem uma forte relação entre o conceito de estratégia, sua formulação e implementação e o marketing estratégico, como o conjunto de instrumentos para entender as necessidades dos consumidores e avaliar as capacidades e recursos da empresa, em relação aos da concorrência, para satisfazê-los melhor e conquistar vantagem competitiva sustentável.

\section{O marketing estratégico como base para entender o mercado e elaborar a estratégia da empresa.}

Do marketing de vendas ao marketing estratégico. Segundo CASTELLI (1984), ao se analisar o marketing historicamente podem ser identificadas as seguintes etapas:

Primeira Etapa: A oferta de bens e serviços é inferior à demanda. Nesta fase, a empresa está com um mercado garantido, porque tudo o que é produzido é consumido. Nesta etapa, a função 
do marketing é garantir a produção. O turismo viveu esta etapa na década de 50, quando começou a ser um fenômeno de massa. A oferta não suportava o grande crescimento da demanda, e levou os núcleos receptores a improvisar suas ofertas, para logo melhorá-las gradualmente;

Segunda Etapa: A oferta de bens e serviços é igual à demanda. Vários fatores contribuíram para aumentar a oferta de bens e serviços. Entre estes, o destaque maior cabe ao progresso do transporte, comunicações e distribuição dos produtos fabricados. O elemento diferenciador nesta etapa é a fabricação padronizada de produtos, buscando diminuir os custos de produção. A função do marketing nessa etapa está centrada na racionalização dos processos de produção. No que se refere ao turismo, verificou-se que no início da década de 70, houve uma extraordinária expansão da oferta turística, até o ponto em que alguns países chegaram ao limite entre a oferta e a demanda;

Terceira Etapa: A oferta de bens e serviços é superior à demanda. Entra-se assim na era da super-oferta e do consumo de massa. Muitos lugares turísticos chegaram a esta terceira etapa, entrando em declínio sem que a demanda chegasse à saturação. Sabe-se que um produto turístico pode ser consumido várias vezes por um mesmo consumidor, mas não infinitamente. O turista deseja ver outras localidades turísticas. Uma localidade turística só terá uma vida maior em função da estratégia de marketing adotada.

O marketing, segundo ROMÁN (1996), surgiu no início do século como área econômica e social, analisando a produção, distribuição e processos de fixação de preços de produtos agrícolas, teve o início de seu desenvolvimento como disciplina administrativa independente em 1948, quando a Associação de Marketing Americana definiu “marketing é o desempenho de atividades de negócios, dirigidas para incidentes sobre o fluxo de bens e serviços do produtor para o consumidor ou usuário".

Como área empresarial, o marketing teve uma consolidação rápida, contribuindo para o melhor desempenho do fluxo produtor-consumidor. A partir da Administração das Vendas, iniciam-se progressivamente o planejamento e desenvolvimento de produtos, promoção, distribuição e a pesquisa de mercado. Por sua vez, ao buscar um maior rigor em suas análises, incorporou técnicas comportamentais e quantitativas (estatística e matemática).

DRUCKER (1954) considerou o marketing como a principal função empresarial, já que a criação de consumidores satisfeitos é o único objetivo válido para qualquer negócio. LEVITT (1960) afirmou que "a organização precisa aprender a considerar sua função na produção de bens e serviços, mais sua aquisição pelos clientes". 
O marketing desempenha o papel fundamental de orientar a empresa para a geração de satisfação no maior número possível de consumidores. O marketing também extrapola o campo específico dos negócios, quando KOTLER (1967) o definiu como "o conjunto das atividades humanas que têm por objetivo facilitar e consumar as relações de troca".

Segundo esta definição, o marketing é aplicável a todos tipos de trocas, entendida como a troca de valor entre, pelo menos, duas partes. Desta forma, o marketing passa a ser objeto de interesse não somente da empresa ou organizações com fins lucrativos, como também daquelas não lucrativas, para alcançar as relações com todos os públicos.

No campo empresarial, o marketing consolida-se principalmente nas grandes empresas hierárquicas e burocratizadas, no desempenho de dois papéis fundamentais. Por um lado, o desenvolvimento de uma maior compreensão do mercado, de forma a garantir a produção de bens e serviços realmente demandados pelos consumidores e, por outro, ajustando o "mix" (vendas, promoção, preço e distribuição) para que os negócios ocorram segundo o planejado. Isto pressupõe duas dimensões distintas para o campo de atuação do Marketing: a análise e a ação.

Segundo LAMBIN (1989), a função essencial do Marketing Operacional é gerar vendas, utilizando os meios mais eficazes com o menor custo possível. Respondendo pelas ações necessárias para que o produto seja atrativo, tendo um preço aceitável, estando disponível nos pontos de distribuição adequados, ou seja, apoiados por ações promocionais que o façam conhecido e destaquem suas qualidades. Constituiu-se, assim, o braço comercial da empresa, sem o qual nenhum plano estratégico teria bons resultados.

O papel do Marketing Estratégico é orientar a empresa para as oportunidades de mercado mais bem adaptadas aos seus recursos e às suas habilidades, e que tenham um potencial adequado de crescimento e rentabilidade, buscando os seguintes objetivos básicos:

- Identificar opções estratégicas sólidas e claramente definidas;

—Desenvolver sistemas para o acompanhamento do meio ambiente e da competência;

- Reforçar a capacidade de adaptação da empresa às mudanças ambientais;

- Prever a renovação da carteira de produtos da empresa.

A eficácia do Marketing Estratégico ficou evidenciada por diferentes autores, dentre os quais se destacou COOPER (1978). Analisando as condições de êxito de 200 produtos industriais novos, o autor identificou três fatores-chaves, dos quais dois estavam relacionados com marketing estratégico: a presença de características diferenciais no produto e a compreensão do mercado. 
Nos anos 80, a dinâmica da globalização dos mercados estimulou o surgimento de novas formas de organização, enfatizando a parceria entre as empresas, formação de equipes, delegação e novas formas de controle mais flexíveis. Segundo MILES e SNOW (1986), as organizações necessárias para responder rapidamente às constantes mudanças em tecnologia, competência e preferências dos consumidores são as redes (networks) flexíveis de especialistas, formadas por múltiplas alianças, com ênfase na administração de relacionamentos e não de intercâmbios individuais.

Em organizações deste tipo, o marketing assumiu maior importância, passando a ser responsável por manter os parceiros interessados no mesmo consumidor, informados sobre os movimentos dos concorrentes, e, as mudanças nas necessidades e expectativas do mercado. O foco de sua atuação situa-se no estabelecimento de relações de longo prazo com os consumidores, a formação e administração de alianças estratégicas com todos os públicos envolvidos na operação da empresa. Em vez de analisar produtos e clientes, passou-se a se estudar pessoas, organizações e processos sociais que mantinham juntos os atores da organização.

Segundo WEBSTER (1992), o marketing na nova realidade das organizações contribui para as decisões, tanto no nível corporativo quanto nos de unidades de negócios e operacionais. Envolvendo tanto a dimensão cultural quanto a estratégica e a tática. No nível corporativo, a principal questão é: em que negócio deve-se estar? O marketing contribui para responder à pergunta, definindo a atratividade dos mercados, promovendo na organização a orientação para o consumidor, e desenvolvendo propostas de valor para a empresa. No nível de unidades de negócios, a questão principal é: como devemos competir nos negócios escolhidos? Neste caso, o marketing tem a responsabilidade de decidir quais funções e atividades devem ser compradas no mercado, quais serão desempenhadas pelos parceiros e quais serão desempenhadas internamente. No nível operacional, o marketing procura os recursos humanos, financeiros e produtivos necessários para viabilizar a implantação das estratégias corporativas e das unidades de negócios. 
Empresas dirigidas pelo mercado. DAY (1990) introduziu o conceito de empresa "dirigida pelo mercado" (market-driven) ampliando aos tradicionais enfoques de empresa orientada para o mercado (market oriented). As empresas dirigidas pelo mercado se equipam melhor para responder às suas exigências e antecipar suas mudanças, enquanto as empresas orientadas para o mercado procuram estar próximas ao mercado e consideram seu principal objetivo criar e reter consumidores satisfeitos.

As empresas dirigidas pelo mercado apresentam habilidades essenciais para entender e satisfazer os consumidores. Suas principais características são:

- Um conjunto de crenças que colocam o interesse do consumidor em primeiro lugar (DESHPANDÉ, FARLEY e WEBSTER, 1993);

- Habilidades para gerar, disseminar e utilizar informações privilegiadas sobre os consumidores e concorrentes (KOHLI e JAWORSKI, 1990);

- Aplicação coordenada de recursos interfuncionais para a criação de um valor superior para o consumidor (NARVER; SLATER, 1990 e SHAPIRO, 1988).

Além disso, segundo DAY (1994), as empresas dirigidas pelo mercado têm orientação tanto para os clientes quanto para os concorrentes. Elas competem com um serviço superior e com características inovadoras e mantêm os custos sob controle. Pesquisam também todos os tipos de informações para determinar suas fontes de vantagens competitivas, e adotam estratégias gerais para o mercado, fixando medidas para segmentos específicos.

Segundo DAY (1990), a abordagem das capacidades, combinada com a Qualidade Total (TQM Total Quality Management) oferece um rico conjunto de formas para projetar programas destinados a aumentar a característica "market-driven" das empresas. A empresa guiada pelo mercado terá capacidades superiores de sensibilidade do mercado, ligação com os clientes, estruturação de canais e monitoramento tecnológico. Os processos subjacentes a estas capacidades, de fora para dentro, são bem entendidos, efetivamente administrados e geram informações precisas para guiar as capacidades, de dentro para fora, e integradoras. Todos os processos assim terão orientação externa.

A sensibilidade do mercado é a habilidade da empresa de estar informada sobre seus consumidores, seus concorrentes e os elementos do canal de distribuição, de forma a atuar continuamente em relação com os eventos e tendências dos mercados atuais e potenciais. Segundo KOHLI e JAWORSKI (1990), os processos que o sustentam são a geração de inteligência de marketing para toda a organização, a disseminação desta inteligência entre os departamentos e a responsabilidade da direção por esta. As empresas dirigidas pelo mercado 
distinguem-se pela habilidade em identificar eventos e tendências de seus mercados antes dos concorrentes, porque são superiores na forma como buscam informações, na ampla distribuição e valorização que dão às mesmas, no uso de cenários e modelos baseados nestas, e na forma como as informações são guardadas e acessadas por todos os integrantes da organização.

A ligação com os consumidores consiste na criação e administração de relações de proximidade com estes. As empresas dirigidas pelo mercado devem estar preparadas para desenvolver equipes conjuntas com seus clientes, por meio das quais se produzam trocas de informações sobre suas necessidades e problemas, e que seja possível a participação destes nos processos de desenvolvimento de novos produtos ou serviços. Neste contexto, o pessoal de vendas será responsável pela coordenação das demais funções, antecipação de necessidades, demonstração de responsabilidade e construção de credibilidade e confiança.

Marketing estratégico e vantagem competitiva. Observou-se nas últimas décadas um esforço acadêmico crescente para desenvolver novos instrumentos de análises estratégicas, buscando contribuir para os processos de tomada de decisão da empresa. Neste contexto, o processo estratégico de marketing repousou sobre vários conceitos inter-relacionados, cuja base era o desenvolvimento de instrumentos que permitiam à empresa a configuração e a manutenção de vantagem competitiva.

A identificação de vantagens competitivas pode realizar-se dentro da empresa e em seu meio ambiente.

Para PORTER (1989), a base fundamental do desempenho empresarial em longo prazo é a vantagem competitiva sustentável. Segundo ele: "a vantagem competitiva surge fundamentalmente do valor que uma empresa consegue criar para seus compradores e que ultrapassa o custo de fabricação da empresa. O valor é aquele que os compradores estão dispostos a pagar, e o valor superior origina-se da oferta de preços mais baixos que dos da competência por beneficios equivalentes ou por prover beneficios singulares que compensem um preço alto. Existem dois tipos básicos de vantagens competitivas: liderança em custos e diferenciação”.

O conceito de cadeia de valor como um instrumento básico de análise para a competitividade, introduzido por PORTER (1989), baseava-se na análise de todas as atividades da empresa, no modo como elas interagiam e na determinação das que podiam gerar valor para o cliente. Esta análise é vital para o estudo das fontes de vantagens competitivas. PORTER (1989) definiu que "as atividades de valor são as atividades fisicas e tecnologicamente distintas, por meio das 
quais a empresa cria um produto valioso para seus compradores. A margem é a diferença entre o valor total e o custo coletivo da execução das atividades de valor".

Segundo OHMAE (1985), estratégia é o modo pelo qual a empresa procura distinguir-se de maneira positiva da concorrência, usando seus pontos fortes para atender melhor as necessidades dos clientes. Será vitoriosa a estratégia que conseguir posicionar os pontos fortes da empresa e as necessidades dos clientes, num equilíbrio superior ao que a concorrência tem conseguido.

DAY (1990) destacou que as duas características mais importantes de um mercado competitivo são os clientes e os concorrentes, pois constituem as duas dimensões ao longo das quais se podem obter vantagens competitivas. As empresas centradas em seus concorrentes tendem a adotar estratégias de custos, e as empresas centradas em seus clientes tendem a adotar estratégias de diferenciação.

PORTER (1989) deu maior peso à obtenção de vantagens competitivas a partir da avaliação do ambiente e do ajuste da cadeia de valor da empresa a este.

Com referência ao ambiente externo, a empresa deve se empenhar em procurar formas de diferençar sua oferta da de seus concorrentes, em termos de linhas de produtos, serviços, recursos humanos e imagem.

A diferenciação refere-se à ação de delinear um conjunto de qualidades significativas de modo a distinguir inequivocamente a oferta da empresa da de seus concorrentes, enquanto o posicionamento é o ato de projetar a oferta da empresa de forma que ela ocupe um lugar distinto nas mentes dos compradores do segmento-alvo.

WIND (1982) considerou a diferenciação do produto um conceito significativo na medida em que se baseava nas diferenças e similitudes de percepção dos consumidores, entre produtos e marcas concorrentes. O posicionamento não deve ser concebido tomando por base somente a similitude percebida e as percepções genéricas dos consumidores, mas deve considerar o conjunto de suas preferências gerais e específicas, que são o resultado de suas necessidade e atitudes. O comportamento do consumidor é, portanto, uma função tanto da percepção quanto da preferência, podendo ser diferençado com base em ambas dimensões.

LAMBIN (1989) apresentou uma visão diferente, destacando a importância dos aspectos internos da empresa. Segundo estas idéias, a superioridade conferida pela vantagem competitiva é relativa, estabelecida em relação ao competidor melhor posicionado no produto-mercado no segmento, e pode ser derivada de fatores internos ou externos à empresa.

A vantagem competitiva será externa se estiver baseada em qualidades diferençais do produto ampliado, que reapresentam valor para o consumidor, seja pela diminuição dos custos, seja pelo 
aumento de seu desempenho na atenção às necessidades do segmento-alvo. Uma vantagem competitiva externa da empresa proporciona um poder de mercado efetivo, permitindo impor um preço superior ao do principal competidor. Uma estratégia baseada neste tipo de vantagem será uma estratégia de diferenciação, utilizando a capacidade da empresa de fazer marketing para atender às necessidades dos clientes não cobertas pelos produtos existentes.

A vantagem competitiva será interna se repousar em uma superioridade da empresa baseada nos custos de fabricação, administração ou gestão do produto, proporcionando um custo inferior ao do principal competidor. Esta vantagem resulta em uma melhor produtividade, e facilita uma melhor rentabilidade à empresa, ou uma maior capacidade de resistência a uma baixa de preços imposta pelo mercado ou pela competência. Uma estratégia competitiva baseada neste tipo de vantagem será uma estratégia de custos, e utiliza principalmente a capacidade organizacional e tecnológica da empresa.

LAMBIN (1989) diferenciou dois tipos de vantagens competitivas, que são de origem e natureza distintas e incompatíveis, já que implicam capacidades e culturas organizacionais diferentes.

Explorando com maior profundidade a contribuição dos fatores internos à empresa para a obtenção de um desempenho superior, vários autores apresentaram um novo modelo, mais adequado aos ambientes competitivos, e cada vez mais dinâmicos. Desta forma, HAMEL e PRAHALAD (1990) introduziram o conceito de competências essenciais (core competences), definindo: "são o conhecimento coletivo de uma organização, especialmente das formas de coordenar diversas habilidades produtivas e integrar múltiplas correntes e tecnologias".

STALK, EVAN e SHULMAN (1992) ampliaram este enfoque, introduzindo o conceito de competência em capacidades (capabilities), dizendo que: "competências e capacidades reapresentam duas dimensões diferentes, mas complementares ao paradigma emergente para uma estratégia corporativa. Ambos os conceitos enfatizam os aspectos comportamentais da estratégia em contraste com o tradicional modelo estrutural. Mas quando as competências essenciais enfatizam o conhecimento tecnológico e de produção em pontos específicos da cadeia de valor, as capacidades têm uma base mais ampla, envolvendo toda a cadeia de valor. As capacidades são visíveis para o consumidor de uma forma que as competências essenciais raramente são".

Segmentação de mercado e posicionamento. TOLEDO e HEMZO (1992) notaram que o posicionamento estratégico era descrito como um instrumento de apoio aos processos de decisões estratégicas vinculadas à concepção de produtos e empresas, assim como à 
comunicação de suas características e atributos a segmentos de mercados específicos. O conceito de posicionamento evoluiu, durante o tempo, de forma que, partindo da busca de uma definição para os produtos, teve-se voltado para a adoção de uma postura de segmentação por parte da empresa no desenvolvimento de seu processo estratégico.

RIES e TROUT (1981) apresentaram a idéia do posicionamento como uma ferramenta de apoio ao composto de comunicação. Este conceito foi modificando-se com as contribuições de outros autores como WIND (1982), KOTLER (1995), que o ampliaram, identificando-o como Marketing Estratégico. DIMINGO (1988) propôs uma estrutura mais clara para a compreensão do processo de posicionamento estratégico, suprimindo sua divisão em duas partes: posicionamento de mercado e posicionamento psicológico. Para DIMINGO (1988), o posicionamento estratégico de mercado fundamentava-se no empenho da empresa em oferecer ao mercado um produto ou serviço, de forma mais eficiente e eficaz que a da concorrência. Vence o mais competitivo.

DIMINGO (1988) afirmou que “o verdadeiro posicionamento é o processo de distinguir uma empresa ou um produto de seus competidores com base em dimensões reais -produtos ou valores corporativos significativos para seus consumidores, para tornar à empresa ou ao produto preferido pelo mercado". Segundo esta óptica, o posicionamento não parte somente da concepção que os consumidores fazem do produto ou da empresa, mas deve ajudá-las a distinguir as diferenças entre produtos concorrentes.

Para WIND (1982), “o termo posicionamento de um produto ou marca refere-se à posição que um produto ocupa num mercado dado. Neste contexto, a palavra posicionamento abarca os significados de posição como lugar, um posto dentro de uma hierarquia e uma atitude mental em relação a determinado produto".

O processo de posicionamento é uma seqüência natural do processo de segmentação de mercado. Uma análise com enfoque de segmentação permite verificar como o mercado é definido, e direcionar os esforços de marketing para uma ou mais oportunidades de mercado. O posicionamento se dirige a um segmento de mercado-alvo e possibilita avaliar como competir mais efetivamente naquele segmento.

$\mathrm{O}$ processo decisório que irá definir o posicionamento supõe o conhecimento de alguns elementos. É preciso identificar, inicialmente, as dimensões ou atributos utilizados pelos consumidores na avaliação dos programas de marketing das empresas concorrentes no mercado. 
Toma-se por base esses atributos, identifica-se na avaliação dos consumidores o grau de importância, a posição relativa da empresa frente a seus concorrentes e o processo decisório de compras.

É necessário destacar que se está posicionando é o produto completo, ou seja, toda a oferta, e não somente a propaganda e sua avaliação psicológica, como sugeriram RIES e TROUT (1981), ou somente as características físicas do produto. Deve-se estimular o interesse sobre o conjunto completo de utilidades oferecidas: atributos físicos, imagem, serviços, distribuição e preço do produto. Antes que se formulem estratégias de posicionamento, têm que se entender como os consumidores avaliam as ofertas, desde o ponto de vista da multiplicidade de seus atributos, até como eles escolhem entre os produtos competitivos.

Do ponto de vista da evolução do pensamento estratégico em marketing, nota-se que o conceito de posicionamento reflete claramente o estágio do que KOTLER (1995) chamou de marketing direcionado (Targeting Marketing). A evolução do marketing competitivo leva à empresa a descobrir que as estratégias de marketing de massa e de variedade de produtos são inadequadas na atualidade. Os mercados de massa estão em processo de fragmentação em centenas de minimercados caracterizados por uma grande diversidade de perfis e de interesses em termos de produtos e canais de distribuição. As empresas estão sendo obrigadas a adotar o marketing direcionado, como forma de identificar melhor as oportunidades de mercado e desenvolver os compostos de marketing mais ajustados a cada segmento. Concentrando seus esforços nos compradores que elas estão em melhores condições de atender.

O marketing direcionado pressupõe, segundo TOLEDO e HEMZO (1992), como etapa inicial, o processo de segmentação, (posicionamento de mercado, segundo DIMINGO apud os autores), culminando com a estratégia de posicionamento e posicionamento psicológico. A última fase da estratégia global do marketing direcionado é, portanto, o posicionamento psicológico. $\mathrm{Na}$ primeira etapa, a empresa estabelece a posição desejável, na segunda, define a forma de comunicação dessa posição no mercado. Contrariamente ao que se propõe no marketing massivo e o de variedades de produtos, o marketing direcionado contempla a seleção das bases de segmentação, a identificação dos segmentos de mercado e a seleção dos segmentos-alvo como centro da ação estratégica.

Um caso extremo do marketing direcionado é o marketing individualizado, onde cada comprador é visto como um mercado potencial refletindo os desejos e necessidades únicas.

A etapa de posicionamento de mercado tem por pressuposto a determinação de critérios para o êxito competitivo e o conhecimento do mercado. Parte de uma etapa zero em que a empresa 
empreende o estabelecimento de sua missão, seus objetivos, suas metas e sua estratégia de crescimento, conduzindo a um conjunto de oportunidades relevantes e atrativas do mercado.

Uma oportunidade do mercado pode ser identificada mediante uma série de indicadores: potencial de vendas, taxa de crescimento, características dos compradores e seu grau de influência, localização do mercado, hábitos de compras, características dos fornecedores e seu grau de influência, custos de produção, custos de vendas, preços, margem de lucro, intensidade da concorrência, dinâmica do mercado e canais de distribuição. Estes indicadores dão uma visão da posição competitiva da empresa e da concorrência.

Vencida a etapa zero, o processo de posicionamento de mercado requer desenvolver três etapas:

- Segmentação de mercado;

— Avaliação e seleção dos segmentos de mercado;

—Estabelecimento de estratégias competitivas.

A definição de uma oferta diferençada diz respeito ao estabelecimento de um pacote de benefícios ou valores, expressos por produto, preço, distribuição e por todo o composto de capacidades e serviços de suporte da empresa.

A diferenciação sempre é possível, estando limitada somente à capacidade da empresa em usar suas competências como ferramentas para a solução dos problemas do consumidor.

Não sendo possível a diferenciação por meio de produtos novos e inovadores, existem muitas outras possibilidades: resposta rápida às dúvidas e problemas, políticas de entregas, políticas de garantia e devolução, condições de preço e pagamento, serviços de manutenção, habilidades do pessoal de vendas, tecnologia do processo e forte rede de distribuição.

Uma vez definidas as vantagens competitivas, a empresa deve empreender uma ação concreta para anunciá-las de forma persuasiva, tomando cuidado para evitar erros de posicionamento. $\mathrm{O}$ desenvolvimento de uma estratégia de posicionamento deve considerar dois fatores: as diferenças existentes entre os diversos segmentos de mercado e a interação entre linhas e itens do composto de produtos da empresa.

No desenho de uma estratégia de posicionamento podem ser usadas diversas bases alternativas, destacadas por WIND (1982):

- Posicionamento baseado em atributos especificos do produto;

- Posicionamento com base nos benefícios, nas necessidades e na solução aos problemas dos clientes;

— Posicionamento com base em ocasiões específicas de uso;

— Posicionamento por categorias de usuários; 
- Posicionamento contra outro produto;

— Posicionamento por dissociação tipo de produto.

$\mathrm{O}$ estabelecimento de um posicionamento psicológico adequado supõe o conhecimento dos processos cognitivos e preceptivos dos consumidores sobre o produto em questão, como por exemplo, os conceitos da teoria da Gestalt sobre percepção, organização e armazenamento de estímulos, que oferece indicações sobre o modo como a mensagem será recebida e a imagem desejada será aceita.

LEVY (apud WIND, 1982) definiu imagem como "uma interpretação, um conjunto de inferências e reações, um símbolo do objeto ao que se refere e que complementa sua existência fisica com significados: crenças, atitudes e opiniões".

O conhecimento da teoria do comportamento do consumidor permite entender o processo de assimilação da mensagem e oferecer alternativas para a comunicação.

SCHRAMM (apud WIND, 1982) sugeriu algumas condições para aumentar a eficiência da comunicação:

- A mensagem (posicionamento) deve ser desenvolvida e encaminhada de modo que se possa ganhar a atenção do destinatário;

— A mensagem (posicionamento) deve empregar sinais que se refiram às experiências comuns ao emissor e ao destinatário;

- A mensagem (posicionamento) deverá despertar no receptor necessidades psicológicas e sugerir algumas formas para satisfazê-las;

- A mensagem (posicionamento) deve sugerir um modo de o receptor atender essas necessidades de uma forma apropriada à situação em que ele se encontra no momento.

Considera-se que, do ponto de vista estratégico, interessa definir o posicionamento em longo prazo, pois é importante o conhecimento do processo de aprendizagem e sua influência, nas mudanças de seleção de marcas e produtos.

O posicionamento de uma empresa, de uma linha de produtos e de uma marca, dentro do contexto do Marketing Estratégico, deve ser desenvolvido a partir de uma avaliação das características e restrições da empresa e seu ambiente, culminando com uma comunicação com credibilidade junto a seus consumidores.

O posicionamento de mercado identifica os atributos a serem comunicados pelo posicionamento psicológico, garantindo a efetividade do processo. Deve-se buscar sempre a compatibilidade entre os desejos e necessidades do consumidor e as vantagens diferenciais que a empresa possui, 
buscando-se a oferta de um conjunto de produtos ou serviços mais valorizados pelos consumidores que a dos concorrentes.

O posicionamento psicológico consiste no desenvolvimento de uma identidade corporativa ou identidade de produto distintas, baseadas fortemente nos fatores de posicionamento de mercado e direcionadas para o uso dos instrumentos de comunicação, buscando predispor favoravelmente ao consumidor a decisão de compras desejada pela empresa.

O papel do posicionamento psicológico é modificar as atitudes e o comportamento do consumidor, procurando criar o interesse suficiente para produzir a compra, a experimentação do produto e a comprovação das vantagens anunciadas.

Por meio do posicionamento psicológico, procura-se traduzir os valores identificados no mercado com o auxílio de uma linguagem clara e específica, e transmiti-los mediante imagens simbólicas, de modo a inserir o produto num nicho próprio na mente do consumidor. Cada segmento requer da empresa o desenvolvimento de uma estratégia específica de posicionamento psicológico. Para KOTLER (1995), o posicionamento psicológico desenvolve-se em três etapas:

—Identificação de vantagens competitivas potenciais;

— Seleção das mais apropriadas;

- Comunicação ao mercado.

Como expressaram SAUNDERS e HOOLEY (1996), a essência do desenvolvimento de uma estratégia de marketing para uma empresa é assegurar que suas capacidades sejam compativeis com o ambiente competitivo, no mercado em que opera, não apenas hoje como também no futuro previsivel”.

Desta forma, o estabelecimento de uma estratégia de marketing efetiva começa com uma avaliação detalhada das capacidades da empresa em relação à concorrência, assim como as oportunidades e ameaças apresentadas pelo ambiente, identificadas no mercado de referência, identificando a vantagem diferencial ou vantagem competitiva da empresa, as metas com respeito à concorrência e as bases do posicionamento competitivo da organização.

Desta forma, o marketing estratégico, como observa TOLEDO (1997), “(...) está focado principalmente no desenvolvimento de uma resposta efetiva, não da área funcional de marketing e sim da empresa como um todo, uma vez determinadas as oportunidades ambientais e de mercado, em uma situação em que a empresa possua uma vantagem competitiva em relação à concorrência”. Acrescenta, ainda, TOLEDO (1997), que “o marketing estratégico é o conjunto de decisões que combinam harmoniosamente as dimensões funcionais administrativas $e$ 
filosóficas do marketing. Trata-se de uma postura de ação gerencial e de um processo que, a partir da missão e do campo de ação da empresa, busca identificar os públicos que serão o foco central do esforço de marketing, desenvolver um composto de marketing que garanta a adequação da oferta aos beneficios buscados por esse público, de modo a promover a rentabilidade do negócio a longo prazo e explorar as oportunidades de mercado pelo aproveitamento das vantagens competitivas".

O marketing estratégico é, essencialmente, um processo de análise sistemática e permanente das necessidades do mercado, direcionada ao desenvolvimento de conceitos de produtos e serviços rentáveis, destinados a grupos de compradores específicos, que representem qualidades distintivas que os diferençam dos competidores imediatos, assegurando, assim, ao produtor uma vantagem competitiva defensável.

O marketing estratégico se apóia, inicialmente, na análise das necessidades dos indivíduos e das organizações. Do ponto de vista do marketing, o que o comprador busca é a solução de um problema, a satisfação de uma necessidade ou desejo, que o produto ou serviço é susceptível de oferecer-lhe; esse serviço pode ser obtido por diferentes tecnologias, as quais estão, por sua vez, em continua mudança. A função do marketing estratégico é seguir a evolução do mercado de referência e identificar os diferentes produtos-mercados e segmentos atuais e potenciais, tendo por base a diversidade das necessidades a satisfazer.

Os produtos-mercados identificados reapresentam uma oportunidade econômica cuja atratividade é preciso avaliar. A atratividade dos produtos-mercados se mede, em termos quantitativos, pela noção de mercado potencial e, em termos dinâmicos, pela duração de sua vida econômica, reapresentada por seu ciclo de vida. Para uma empresa determinada, a atratividade de seus produtos-mercados depende de sua competitividade, ou seja, de sua capacidade para atrair, melhor que seus competidores, a demanda dos compradores. Essa competitividade existirá na medida em que a empresa detenha uma vantagem competitiva, seja pela presença de qualidades distintivas que a diferenciem dos rivais, seja por uma produtividade superior, que lhe dê uma vantagem de custo.

A função do marketing estratégico é orientar a empresa em busca de oportunidades econômicas atrativas para ela, ou seja, completamente adaptadas a seus recursos e a seu "saber fazer", e que oferece um potencial de crescimento e rentabilidade. A gestão do marketing estratégico se situa no médio-longo prazo, sua função é precisar a missão da empresa, definir seus objetivos e oferecer a informação inicial necessária para a elaboração de sua estratégia de desenvolvimento. A consolidação do marketing estratégico na empresa permite: 
1. fundamentar sua atividade em opções estratégicas sólidas e claramente definidas

2. desenvolver sistemas de vigilância do ambiente e de análise da concorrência

3. reforçar a capacidade de adaptação às mudanças do ambiente

4. prever regularmente a renovação do portfolio de produtos-mercados.

A gestão de marketing estratégico deve permitir à empresa criar um produto ou serviço que represente, para o comprador, um valor superior ao da ofertas da concorrência. Como mostram NARVER e SLASTER (1990), realizar uma gestão cujo resultado seja superior à média do mercado implica a existência de uma vantagem competitiva defensável que resulte da criação de um valor superior para o comprador. Os fatores chaves que caracterizam uma orientação para o mercado são: sua orientação para o cliente, para a concorrência, a coordenação interfuncional e o monitoramento dos ambientes tecnológico, social, político, para detectar rapidamente as ameaças e oportunidades para a mesma.

A função do marketing na empresa implica a adoção das prioridades seguintes:

- Reestruturação do portfolio de atividades. As empresas devem reorientar-se para atividades de maior valor agregado para seus clientes, baseada tanto nos avanços tecnológicos como no know how organizacional.

- Elaboração de uma estratégia de marketing ajustada ou adaptada. Os consumidores buscam soluções adaptadas a seus problemas específicos e não soluções padronizadas. Corresponde à empresa encontrar estas expectativas por um esquema de segmentação ajustado e por uma comunicação interativa.

- Orientação para a concorrência. Esta capacidade implica a existência de um sistema de análise e seguimento da concorrência, que permita a antecipação de suas ações.

- Desenvolvimento de sistemas de previsão. Em um ambiente turbulento, os métodos clássicos de previsão se convertem em inoperantes. A empresa deve estar "disposta a tudo" e, para eles, deve reforçar sua capacidade de adaptação e de desenvolver cenários alternativos.

- Incorporação de uma ótica de marketing global. Com a globalização, aparecem segmentos supranacionais, que constituem oportunidades importantes para a empresa.

- Adoção do marketing responsável. Surgem novas necessidades na sociedade, que deseja proteger seu ambiente, e que espera que as empresas se preocupem com o bem-estar dos indivíduos e da sociedade, e não somente com o curto prazo, e de forma sustentável.

Metodologicamente, para aplicar estas prioridades, a empresa deve identificar o mercado no qual deseja competir e definir uma estratégia de presença. Esta escolha do mercado de referência implica a partição do mercado total em subconjuntos homogêneos em termos de necessidades e 
de motivações de compra, suscetíveis de constituir mercados potenciais distintos. Uma empresa pode escolher entre dirigir-se à totalidade de seu mercado, ou concentrar-se em um ou vários segmentos que formam parte do mercado de referência. Esta partição se realiza normalmente em duas etapas distintas: uma etapa de macrosegmentação que identifica os produtos-mercados; uma etapa de microsegmentação que leva a identificar os segmentos no interior de cada um dos produtos-mercados selecionados. Se se tomar por base a partição do mercado total, a empresa poderá, de imediato, avaliar a atratividade dos produtos-mercados e segmentos selecionados, medir sua própria competitividade e definir uma estratégia de cobertura do mercado de referência.

Para desenvolver esta estratégia de segmentação ${ }^{10}$ do mercado de referência, a empresa deve dirigir seu enfoque para o consumidor. Em sua busca pelo bem-estar, o consumidor se comporta como um indivíduo confrontado com um problema de decisão que intervém ativamente para resolvê-lo. A teoria econômica do comportamento do consumidor, devida principalmente a ABBOTT (1955), BECKER (1965) e LANCASTER (1966), constitui o marco conceitual sobre o qual se apóia o marketing estratégico. Esta teoria descreve o consumo como uma atividade em que os bens selecionados pelo indivíduo, são utilizados, sozinhos ou em combinação, com a finalidade de "produzir" serviços a partir dos quais deriva a utilidade. A partir dessa perspectiva, os bens são considerados como conjuntos de atributos ${ }^{11}$, e o consumidor como um produtor de satisfação final. Esta noção de produto, considerado como um conjunto de atributos, é completamente básica no delineamento do marketing estratégico.

As estratégias de segmentação funcional - benefit segmentation (HALEY, 1968)- consistem então em buscar sistematicamente conjuntos de novos produtos, para os quais não existe oferta competitiva no mercado, mas que satisfazem as expectativas de um grupo específico de compradores, suficientemente importantes para justificar o lançamento de um produto ou marca

\footnotetext{
${ }^{10}$ É necessário não confundir as noções de segmentação e de diferenciação. A diferenciação é um conceito alicerçado na diversidade da oferta em dois níveis: entre competidores, para um mesmo tipo de produto, e entre os produtos de uma empresa, propostos para diferentes segmentos. A diferenciação se dirige à diversidade dos produtos, a segmentação se orienta para a diversidade dos compradores potenciais que constituem o mercado (SMITH, 1965).

${ }^{11}$ Por noção de atributo, segundo LAMBIN (1996), se entende a vantagem procurada pelo comprador. É o atributo que "gera" o serviço, a satisfação e que, como tal, é utilizado como um critério de escolha. Denominam-se atributos determinantes os que permitem discriminar entre as marcas. Fala-se, então, do nível de um atributo, e cada marca constitui um conjunto específico de atributos, cuja especificidade se baseia no fato de que os atributos estão presentes em níveis determinados. A importância de um atributo para um indivíduo reflete os valores ou as prioridades que ele reserva a cada uma das vantagens trazidas pela marca, considerando que ele se procura necessariamente fazer avaliações comparativas entre as vantagens procuradas. As medidas de importância dos atributos permitem às empresas praticar estratégias de segmentação, cujo objetivo é refletir o melhor possível a diversidade de necessidades dos compradores. Um atributo pode ser considerado como muito importante por um comprador, mas não ser percebido como muito bem reapresentado em uma marca determinada. As medidas de importância devem ser completadas por medidas do grau de presença percebida dos atributos.
} 
adaptado a suas necessidades. Uma estratégia de segmentação se apóia, inicialmente, na identificação das vantagens buscadas pelos diferentes grupos de compradores, continuando, após, com a elaboração e o desenvolvimento de conceitos de produtos destinados a solucionar as expectativas específicas do grupo de compradores eleito como objetivo. O objetivo é definir o mercado de referência do ponto de vista do comprador, e não em termos de produto.

Para alcançar este objetivo, três dimensões são consideradas na divisão do mercado de referência em macrosegmentos:

1. as necessidades, funções ou combinações de funções a satisfazer

2. os diferentes grupos de compradores potencialmente interessados no produto

3. as tecnologias existentes suscetíveis de produzir estas funções

O mercado de referência pode ser, então, definido segundo três enfoques:

- Como produtos-mercados, definidos como a intersecção grupos de compradores e de uma mescla de funções baseadas em uma tecnologia concreta. Este conceito é o mais adequado ao enfoque de marketing estratégico. Ao definir o mercado de referência em relação à função realizada para um grupo determinado de compradores, a empresa se ajusta à realidade da demanda e das necessidades. Esta definição permite determinar automaticamente quatro elementos chaves da estratégia da empresa: Os compradores a satisfazer, o conjunto de vantagens procuradas pelos compradores, os competidores a serem superados e as capacidades a serem adquiridas.

- Como mercado, que cobre o conjunto das tecnologias para uma função e um grupo de compradores. A noção de mercado está muito próxima do conceito de necessidade genérica, pelos compradores a serem atendidos e no caráter substituível das diferentes tecnologias para uma mesma função.

- Como indústria, que é definida por uma tecnologia, quaisquer que sejam as funções e os grupos de compradores afetados. A noção de indústria é a mais clássica, seu enfoque em direção às características da oferta não favorece uma orientação de mercado da empresa.

A escolha de uma estratégia de cobertura do mercado de referência se baseará na análise de atratividade e competitividade, levada a cabo em cada segmento. Segundo ABELL, (1980) diferentes estratégias de cobertura podem ser consideradas pela empresa:

- Estratégia de concentração, pela qual a empresa define seu campo de atividade de maneira restritiva em um produto-mercado, uma função e um grupo de compradores. Procura uma participação de mercado elevada, em um nicho bem diferençado. 
- Estratégia de especialista em produto. A empresa prefere especializar-se em uma função, mas cobrindo todos os grupos de compradores afetados por esta função.

- Estratégia de especialista em cliente. A empresa se especializa em uma categoria de clientes.

- Estratégia de especialização seletiva. Esta estratégia consiste em introduzir vários produtos sem vínculo entre eles.

- Estratégia de cobertura completa. Consiste em propor uma linha completa para satisfazer as necessidades de todos os grupos de compradores.

A microsegmentação consiste em analisar a diversidade de necessidades e dividir o produtomercado em subconjuntos de compradores que buscam no produto o mesmo conjunto de atributos. O processo de microsegmentação se realiza em quatro etapas:

1. Análise de segmentação. Dividir o produto-mercado em segmentos homogêneos do ponto de vista das vantagens procuradas e diferentes dos outros segmentos;

2. Escolha dos segmentos objetivos. Selecionar um ou vários segmentos-alvo, tendo em conta os objetivos da empresa e suas qualidades distintivas;

3. Escolha do posicionamento. Em cada um dos segmentos considerados, posicionar-se sobre as bases das expectativas dos compradores, tendo em conta as posições mantidas pela concorrência;

4. Programa de marketing objetivado. Desenvolvimento de um programa de marketing adaptado às características dos segmentos-alvo.

A divisão do binômio produto-mercado em segmentos homogêneos pode fazer-se de várias maneiras:

- Pelas características sociodemográficas dos consumidores (segmentação sociodemográfica ou descritiva). Sua hipótese é que as diferenças nos perfis sociodemográficos são as que estão na origem das diferenças nas vantagens procuradas e nas preferências. As variáveis mais utilizadas são a localização, o sexo, a idade, a renda e as classes profissionais.

- Pelas vantagens procuradas no produto, pelos consumidores potenciais (segmentação por vantagens). Na segmentação por vantagens procuradas, a ênfase é colocada, não tanto nas diferenças sociodemográficas dos compradores, mas nas diferenças nos sistemas de valores.

- Pelas características do comportamento de compra (segmentação comportamental). Os diferentes critérios utilizados são: status do usuário, a taxa de uso do produto, status de fidelidade, a sensibilidade a um fator de marketing. 
- Pelos estilos de vida, descritos em termos de atividades, interesses e opiniões (segmentação sociocultural). Parte da idéia de que indivíduos muito diferentes, em termos socioeconômicos, podem ter comportamentos muito diferentes: o objetivo consiste em desenhar um retrato mais humano dos compradores, que não se limite apenas ao perfil sociodemográfico, mas que compreenda igualmente informações sobre valores, atividades, interesses e opiniões ${ }^{12}$. A segmentação por estilo de vida, ou segmentação psicográfica, vai mais além e aborda o domínio das motivações e da pessoalidade em relação ao consumo.

Para ser eficaz, uma segmentação deve reunir três grupos de condições: respostas diferençadas, tamanho suficiente, mensurabilidade e acessibilidade.

Estratégias de posicionamento devem ser adotadas para cada um dos segmentos escolhidos. O posicionamento ${ }^{13}$ define a maneira como a marca ou a empresa deseja ser percebida pelos compradores - alvo. O posicionamento consiste na aplicação de uma estratégia de diferenciação. Segundo WIND (1982), podem ser identificados seis tipos possíveis de posicionamento de uma marca:

- Posicionamento baseado na qualidade distintiva do produto

- Posicionamento baseado nas vantagens ou na solução proposta

- Posicionamento baseado em uma oportunidade de utilização específica

- Posicionamento baseado em uma categoria de usuários

- Posicionamento com relação a uma marca competidora

- Posicionamento de ruptura com relação à categoria de produto

Para proceder validamente à escolha de um posicionamento devem ser reunidas as condições prévias seguintes:

- Ter um bom conhecimento do posicionamento atualmente ocupado pela marca na mente dos compradores

- Conhecer o posicionamento conseguido pelas marcas competidoras prioritárias

- Escolher o posicionamento e selecionar o argumento mais adequado e confiável para justificar o posicionamento adotado

\footnotetext{
${ }^{12}$ Como assinala VALETTE-FLORENCE (1988), o conceito de estilo de vida se articula em três níveis de análise, de distinta proximidade com o ato de compra. No nível mais estável e mais definido se encontram os valores individuais, quais sejam, as crenças firmes e duradouras, em que prevalece um modo específico de comportamento, ou em que um objetivo é melhor do que outro. No nível intermediário se encontra o conjunto de atividades, interesses e opiniões próprias de um indivíduo, reveladoras de seu sistema de valores. São menos estáveis do que os valores individuais e estão mais próximas do ato de compra. No nível periférico se situa o conjunto de produtos comprados e consumidos, que são reflexos efêmeros dos níveis precedentes. O estilo de vida é o resultado global do sistema de valores de um indivíduo, de suas atitudes e atividades, e de seu modo de consumo.

${ }^{13}$ RIES e TROUT (1981) definem posicionamento como "a concepção de um produto e de sua imagem, com o objetivo de imprimir, na mente do comprador, um lugar preferencial e diferente do que ocupa a concorrência".
} 
- Avaliar a rentabilidade do posicionamento selecionado

- Verificar se a marca possui a pessoalidade requerida para conseguir manter o posicionamento procurado

- Medir a vulnerabilidade do posicionamento adotado

- Assegurar que existe coerência entre o posicionamento escolhido e as outras variáveis de marketing: preço, comunicação e distribuição.

Uma análise de atratividade tem por objetivo a medida do nível de demanda e de prever o ciclo de vida ${ }^{14}$ de cada segmento identificado. A evolução da demanda pode ser provocada por dois grupos de fatores explicativos: Os fatores fora de controle da empresa e os fatores sob controle da empresa. Os fatores sob controle da empresa são essencialmente os instrumentos de marketing operacional que a empresa pode manipular para atuar sobre a demanda ${ }^{15}$. Entre os fatores fora de controle está o conjunto de restrições e circunstâncias às quais a empresa deve fazer frente em um mercado, e que não são controlados por ela. Entre os fatores incontroláveis mais importantes encontra-se a evolução da tecnologia, que favorece o desenvolvimento de novos produtos mais rentáveis; os produtos existentes e a evolução dos hábitos de consumo, que tornam alguns produtos inadequados ao mercado, demandando outros.

Após avaliar a atratividade própria dos binômios produto-mercado e segmentos que formam parte do mercado de referência, a etapa seguinte da gestão do marketing estratégico tem por objetivo analisar o clima ou situação competitiva de cada um dos binômios, e avaliar, em seguida, a natureza e a força da vantagem competitiva que os competidores existentes ostentam em cada um deles. Um binômio produto-mercado pode ser mu atrativo em si mesmo, não o sendo, entretanto, para uma empresa determinada, dadas suas forças e fraquezas, comparadas com as dos competidores prioritários. Uma análise da competitividade tem por objetivo identificar o tipo de vantagem competitiva que uma empresa ou uma marca pode manter, e avaliar em que medida esta vantagem é defensável, tendo em conta a situação competitiva, as relações das forças existentes e as posições ocupadas pelos competidores.

Por vantagem competitiva entendem-se as características ou atributos que um produto ou uma marca possui, que lhe confere uma certa superioridade sobre seus competidores imediatos. Esta superioridade é uma superioridade relativa, estabelecida em referência ao competidor melhor situado no mercado ou segmento. Uma vantagem competitiva se denomina externa, quando se

\footnotetext{
${ }^{14} \mathrm{O}$ mercado potencial mede a importância da oportunidade econômica que reapresenta um produto- mercado. Essa primeira dimensão da atratividade, essencialmente quantitativa, deve completar-se com uma avaliação dinâmica, descrevendo seu ciclo de vida, isto é, a evolução da demanda potencial no tempo.

${ }^{15}$ Segundo expressão de MCCARTHY (1960), trata-se dos quatro P's: produto, praça (distribuição), preço, promoção, que são as variáveis táticas do marketing operacional, e que são os instrumentos determinantes da demanda da empresa.
} 
apóia em qualidades distintivas do produto, as quais constituem um valor superior para o comprador, seja diminuindo seus custos de uso, seja aumentando seu rendimento de uso. Uma vantagem competitiva se denomina interna, quando se apóia em uma superioridade da empresa na área dos custos de fabricação, de administração ou de gestão do produto, que confere um valor ao produtor, dando-lhe um custo unitário inferior ao do competidor prioritário.

A noção de rivalidade ampliada, devida a PORTER (1982), se apóia na idéia de que a capacidade de uma empresa para explorar uma vantagem competitiva em seu mercado de referência depende não somente da concorrência direta que ali ela encontre, mas também do papel exercido pelas forças rivais, como os competidores potenciais, os produtos substitutos, os clientes e os fornecedores. As duas primeiras forças constituem uma ameaça direta; as outras duas, uma ameaça indireta, devido a seu poder de negociação. O jogo combinado destas cinco forças competitivas é o que determina, em última instância, o benefício potencial de um binômio produto-mercado. A situação competitiva descreve o grau de interdependência entre os competidores.

Com esses elementos, a empresa classifica os diferentes binômios produto-mercado cobertos por ela, em função da atratividade do mercado de referência (análise de atratividade) e em função das posições mantidas em cada segmento (análise de competitividade). As análises do portfolio ${ }^{16}$ de negócios ou produtos permitem caracterizar a posição estratégica de cada um, com base em duas dimensões independentes: a atratividade intrínseca dos segmentos mercado de referência, onde se exercem as atividades, e a força competitiva da empresa em cada célula produto-mercado considerada.

\section{Estratégias corporativas de crescimento empresarial.}

Para estabelecer a estratégia básica de desenvolvimento, é necessário conhecer a natureza da vantagem competitiva a ser defendida.

A vantagem competitiva pode definir-se segundo duas dimensões: uma dimensão produtividade, em termos de preços de custo e uma dimensão poder de mercado, em termos de preço de venda máximo aceitável, conforme mostra a figura:

\footnotetext{
${ }^{16}$ Os principais modelos possíveis de utilizar na análise de portfolio são:

- a matriz BCG (crescimento-participação de mercado relativa), construída em torno de dois critérios: a taxa de crescimento do mercado de referência, que serve de indicador de atratividade, e a participação de mercado, relativamente ao competidor mais importante, a qual é utilizada como indicador da competitividade dos produtos ou negócios da empresa.

- a matriz multiatributos, que considera que a atratividade de mercado e a competitividade de um produto-mercado podem depender de muitos fatores, como sua acessibilidade, seu tamanho, a existência de uma rede de distribuição organizada, a ausência de competidores poderosos, uma legislação favorável etc.; de igual modo, a vantagem competitiva pode derivar de uma imagem de marca, de uma boa estrutura comercial, de um avanço tecnológico etc..
} 


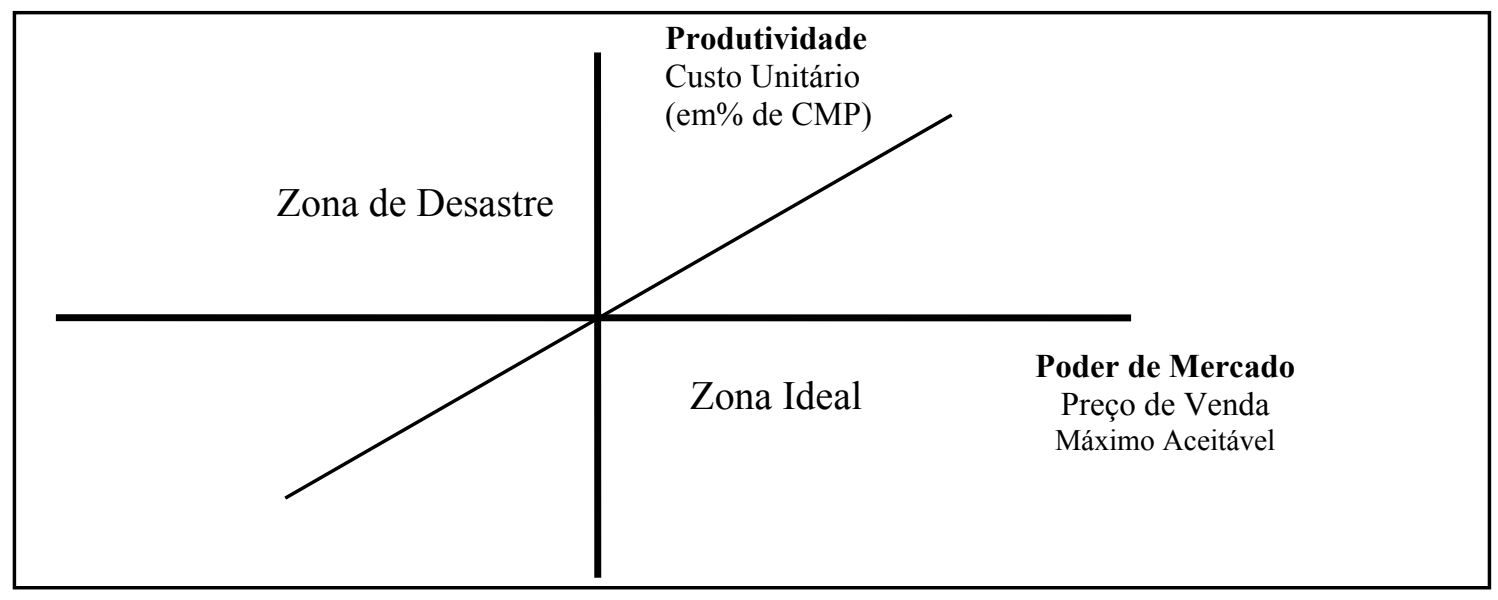

PORTER (1980) considera que existem três estratégias básicas de desenvolvimento frente à concorrência: estratégia de liderança em custos, estratégia de diferenciação e estratégia do especialista.

A estratégia básica de liderança em custos se apóia na dimensão produtividade, e está geralmente ligada à existência de um efeito experiência.

A estratégia básica de diferenciação tem por objetivo conferir ao produto qualidades distintivas importantes. A empresa tende a criar uma situação de concorrência monopolista, por deter um poder de mercado decorrente do elemento distintivo (CHAMBERLIN, 1950).

A estratégia básica do especialista se concentra nas necessidades de um segmento ou de um grupo particular de compradores, sem pretender dirigir-se ao mercado todo.

\section{Estratégias de crescimento.}

Definida a estratégia básica de desenvolvimento, em função da atratividade de mercado e da natureza da vantagem competitiva detida, a empresa está em condições de escolher uma estratégia de crescimento que pode ser selecionada segundo três níveis diferentes:

1. um objetivo de crescimento, no âmbito do mercado de referência em que opera, ou crescimento intensivo, o qual pode ocorrer por penetração de mercado -desenvolver a demanda primária, aumentar a participação de mercado, aquisição de mercados por meio de fusões e/ou aquisições de empresas, defesa de uma posição de mercado, reforçando o marketing operacional-; pelo desenvolvimento de mercados, introduzindo os produtos da empresa em novos segmentos de usuários, ou novos critérios de distribuição, ou por expansão geográfica, etc.; por desenvolvimento de produtos, adicionando características novas aos produtos existentes, ampliando a gama de produtos, rejuvenescendo a linha de produtos, adquirindo uma gama de produtos para completar ou ampliar a gama de produtos existentes 
etc.).

2. um objetivo de crescimento integrado, ou crescimento no setor, por meio de uma extensão vertical ou horizontal. Uma estratégia de integração vertical para cima, ou em direção à origem, tem por objetivo estabilizar ou proteger uma fonte fornecedora de importância estratégica para a empresa, integrando a fornecedores chaves. Uma estratégia de integração vertical para baixo tem por objetivo assegurar o controle da distribuição por sistemas de franquia, de contratos de exclusividade, ou o desenvolvimento de um sistema de distribuição próprio. Uma estratégia de crescimento por integração horizontal tem por objetivo reforçar a posição competitiva, absorvendo ou controlando alguns competidores, para neutralizá-los, alcançar o ponto crítico para obter efeitos de escala, beneficiar-se da complementaridade da gama de produtos, ter acesso a redes de distribuição ou a segmentos de compradores etc..

3. um objetivo de crescimento por diversificação, que se apóia nas oportunidades da empresa situadas fora de seu campo habitual. Uma estratégia de diversificação implica a entrada em produtos-mercados novos para a empresa. Em uma estratégia de diversificação concêntrica, a empresa sai de seu setor e busca acrescentar novos negócios, complementares aos existentes sob o aspecto tecnológico e/ou comercial, para beneficiar-se dos efeitos de sinergia devidos à complementaridade das atividades, e ampliar o mercado potencial da empresa.

\section{Estratégias competitivas.}

A consideração explícita da posição e do comportamento dos competidores é um dado importante de uma estratégia de desenvolvimento. As análises de competitividade permitem avaliar a importância da vantagem competitiva conquistada em relação aos competidores mais perigosos e identificar seus comportamentos competitivos. O desenvolvimento de uma estratégia competitiva se baseia nas avaliações realistas da relação de forças existentes e na definição dos meios para alcançar o objetivo fixado. KOTLER (1991) estabelece uma distinção entre quatro estratégias competitivas, baseada na importância da participação de mercado: estratégia de líder (por desenvolvimento da demanda primária, por uma estratégia defensiva, ou por uma estratégia ofensiva), de retalhador (por ataque frontal o por ataques laterais), de seguidor (por comportamento adaptativo, pautando suas decisões na decisões adotadas pela concorrência) e de especialista (de especialização em um nicho).

\section{Estratégias de internacionalização}


A globalização é uma das tendências mais significativas observadas nos últimos anos. A fronteira entre os âmbitos nacional e internacional se torna cada vez mais difusa, e algumas formas de concorrência internacional se tornaram obsoletas. A maior afinidade entre países, produzida pelo desaparecimento de barreiras alfandegárias, o desenvolvimento tecnológico e a globalização dos mercados tem significado modificações importantes na área internacional, uma vez que têm suscitado um crescente interesse pelos negócios fora do próprio país. Estes e outros acontecimentos da vida econômica supõem não só uma mudança na economia internacional, com está na raiz de um fenômeno de largo alcance, que se manifesta com uma intensidade maior do que nunca: trata-se da globalização dos mercados que, simultaneamente, é causa e conseqüência do fenômeno universal da internacionalização das empresas. Fato característico desta época é, precisamente, a rapidez e intensidade com que estes fenômenos estão se estendendo. A internacionalização da empresa e os problemas derivados da gestão do processo de internacionalização requerem cada dia maior atenção por parte dos dirigentes das empresas, homens de governo, acadêmicos e meios de informação.

A globalização da vida econômica internacional afeta as empresas de maneira direta. A globalização dos mercados abre, em primeiro lugar, novas oportunidades de expansão no exterior. As possibilidades de diversificação em outros mercados geográficos nunca haviam sido tão altas como na atualidade, em um mundo com barreiras comerciais decrescentes, com umas facilidades de comunicação extraordinárias e com custos de transportes inferiores. A globalização implica certos desafios para as empresas. O primeiro é a crescente presença de empresas estrangeiras nos mercados locais, tanto por via da exportação, como pela do investimento direto; isso significa uma rivalidade maior, mais concorrência de preços e pressão adicional para melhorar constantemente a qualidade dos produtos. Precisamente, a globalização tem provocado nos últimos anos uma crescente e intensa rivalidade internacional em muitos setores da economia.

Os objetivos perseguidos em uma estratégia de desenvolvimento internacional são fundamentalmente os seguintes:

- ampliar a demanda potencial

- diversificar o risco comercial

- ampliar o ciclo de vida

- proteger-se da concorrência

- reduzir custos de armazenamento e de produção 
As modalidades de desenvolvimento internacional são caracterizadas, segundo LEROY, RICHARD e SALLENAVE (1978), em seis etapas:

Etapa de Exportação. Como a necessidade de saída a um excedente de produtos.

Etapa de estado contratual. A empresa busca acordos a prazo mais longo, com objetivo de estabilizar sus saídas, particularmente quando sua capacidade de produção foi calibrada em função do potencial de exportação.

Estado participativo. Por razões de controle sobre o parceiro estrangeiro, ou para financiar sua expansão, a empresa pode ser induzida a comprometer-se diretamente com seu capital, mediante a feitura de sociedades comerciais ou em co-propriedade.

Etapa de investimento indireta. Quando o compromisso pode ser total, possuindo a empresa cem $\%$ do capital da filial estrangeira.

Etapa de filial autônoma. A filial estrangeira busca desenvolver-se de forma autônoma, utilizando financiamento local, uma atividade de P\&D própria, distinta da matriz.

Etapa de empresa global. Administra o mercado global como se se tratasse de um mercado único e igual. Este tipo de empresa se apóia na interdependência entre os mercados, os quais já não são administrados de forma autônoma. Essa evolução implica mudanças importantes no pensamento estratégico e coloca o dilema padronização-adaptação como enfoque.

A estas diferentes etapas de desenvolvimento internacional correspondem a modalidades específicas de organização, reveladoras de concepções distintas de marketing internacional. KEEGAN (1989) estabelece uma distinção entre quatro orientações diferentes:

Organização doméstica. A empresa está centrada em seu mercado interior, e a exportação é uma atividade esporádica, como resposta a oportunidades sem que se tenha uma visão de longo prazo. Este tipo de filosofia de gestão se encontra amiúde nas empresas que estão no estado de marketing passivo.

Organização Internacional. A internacionalização se faz de forma mais ativa, mas sempre centrada no mercado interno, que segue sendo a preocupação principal. A empresa apresenta uma orientação etnocêntrica e, consciente ou inconscientemente, considera que os métodos, os valores, as visões e as pessoas do país de origem são transferidos a outros países. Acentuam-se as semelhanças com os países de origem, e a estratégia básica é a estratégia de expansão; os produtos pensados para os países de origem são exportados, sem qualquer modificação, para os outros países.

Organização multidoméstica. Após um certo número de anos de prática nos mercados externos, a empresa se torna consciente da importância das diferenças entre os mercados, e se 
esforça para adaptar sua estratégia de marketing às particularidades locais. A empresa se converte em multinacional (em oposição a uma orientação doméstica) e a orientação é policêntrica. Esta orientação considera que os mercado são diferentes e únicos, e que, para ter sucesso, é necessário adaptar-se o melhor possível às particularidades nacionais. Cada país tem sua organização própria e é dirigido como uma identidade independente.

Organização global ou transnacional. Um mercado global é um mercado em que as necessidades podem aparecer por um produto básico e sustentado pelos mesmos argumentos de venda e de comunicação. A empresa tem uma visão geocêntrica, que se apóia na hipótese de que os mercados pelo mundo são tanto similares como diferentes, e que é possível desenvolver uma estratégia global que se apóie nas similitudes, que transcendem as particularidades nacionais, adaptando-se às diferenças locais, onde for necessário. Fala-se, então de organização transnacional, mais que global. É a fase que atualmente está se impondo na economia mundial.

\section{Razões para o investimento estrangeiro no exterior}

As razões do investimento estrangeiro podem classificar-se, em geral, em dois grandes grupos. O primeiro inclui investimentos que buscam uma expansão ou diversificação de mercado. $\mathrm{O}$ segundo corresponde a investimentos que perseguem vantagens do ponto de vista do custo do levantamento de recursos.

São vários os fatores que influem na tomada de decisão em direção à internacionalização da empresa. Na globalização das atividades econômicas, uma empresa deve analisar sua posição competitiva e decidir se a mesma se vê reforçada ante um processo de internacionalização, ou ao contrário, a dimensão internacional introduz uma ameaça adicional, sem que, simultaneamente, proporcione fontes adicionais de vantagens competitivas. O custo do transporte é uma das primeiras razões para o investimento direto orientado para o mercado. Nos modelos clássicos do comercio internacional não levavam em consideração o custo do transporte, do lugar de produção, até o de consumo. Sem embargo, com a internacionalização dos mercados há numerosos produtos de baixo custo, cujo alto custo de transporte faz com que seja impossível sua exportação direta, pelo que as empresas que decidam abastecer o mercado estrangeiro deverão instalar-se ns respectivos países. Um segundo tipo de investimentos motivados pelo mercado são as pautas de consumo do país de destino das exportações. Em um país pode haver uma forte propensão a consumir somente produtos nacionais, por razões puramente nacionalistas, por imagem do produto ou pela segurança de estar adquirindo um produto realmente valioso. Tal é o caso dos investimentos dos países do Sudeste asiático e Japão nos Estados Unidos e Europa. 
Outro motivo de investimento estrangeiro tem que a ver com a existência de taxas alfandegárias altas, ou de outras barreiras protecionistas que desestimulam os intercâmbios comerciais.

Uma razão adicional relacionada com o mercado são os investimentos motivados pela estratégia de seguir os clientes e competidores. Este tipo de decisão é muito importante em empresas fornecedoras de outras multinacionais e as de turismo.

A busca de fatores produtivos abundantes e baratos tem sido outro fator importante no investimento estrangeiro direto. As empresas que fabricam produtos com numerosos componentes distribuem sua fabricação de modo que cada um deles é produzido em diferentes países com o fim de aproveitar ao máximo as vantagens que, do ponto de vista da abundância de recursos, cada um oferece. Em certas ocasiões trata-se de aproveitar o baixo custo da força de trabalho, mas também tirar partido das oportunidades de certas matérias-primas.

A integração vertical é outro motivo do investimento estrangeiro que visa à oferta de recursos produtivos. A integração vertical supõe incrementar o controle das diferentes etapas da cadeia de valor da empresa, desde o levantamento de fatores até os serviços pós-vendas.

Para Ansoff (1984), uma empresa pode procurar ir aos mercados internacionais motivadas por dos tipos de fatores:

Necessidades operacionais, dentre as quais há que se destacar: assegurar o fornecimento e manutenção de bens de capital, assegurar o fornecimento de matérias-primas, assegurar a disponibilidade e uso de tecnologia, ou distribuir excessos de produção final (por excederem a demanda em seus mercados locais).

Necessidades estratégicas, distinguindo entre: assegurar a sobrevivência da empresa diante de futuras mudanças no ambiente; assegurar o crescimento contínuo, por meio de manutenção da tendência de crescimento histórica, ou evitar o estancamento causado pela saturação; aumentar o volume de negócio ou aumentar, a taxa de crescimento e assegurar e aumentar a rentabilidade.

- $\quad$ Em resumo, a empresa adotará o processo de internacionalização sempre que se lhe permita:

- Conquistar uma vantagem competitiva sustentável, impossível de alcançar de um modo alternativo;

- Conquistar uma vantagem competitiva sustentável, de uma forma mais eficiente, isto é, com um menor uso de recursos;

- Contribuir de uma forma mais eficiente para as vantagens competitivas de que já dispõe a empresa 
Seguramente, isso dependerá do grau de complementaridade que o processo de internacionalização produza sobre o conjunto de recursos ${ }^{17}$ e capacidades ${ }^{18}$ de que a empresa disponha; em suma, até que ponto a internacionalização aumenta suas competências distintivas ${ }^{19}$. Em síntese, a empresa se internacionalizará quando dispuser de recursos e capacidades excedentes ${ }^{20}$ suscetíveis de serem utilizados de forma eficiente.

Como em qualquer processo de investimento, a decisão de investir no exterior deverá vir avaliada pelos resultados de uma análise custo-benefício. Os benefícios em termos de excedente econômico e financeiro devem superar os custos, alem do que, em dita análise há de se considerar o nível de risco agregado associado ao investimento, derivado de fatos tais como as relações com o governo local na repatriação dos benefícios, controles de cambio, etc. Do ponto de vista dos custos, as vantagens derivadas do investimento no exterior devem superar o custo produzido pela aquisição de informação, ou familiaridade com o ambiente, como, por exemplo, conhecimento das preferências do consumidor, usos e costumes empresariais do país, adaptação ao ambiente industrial ou setor de atuação, aspectos legais e econômicos específicos, custos de comunicação etc..

\section{Dinâmica do processo de internacionalização da empresa}

O processo de internacionalização da empresa é condicionado, intrinsecamente pelos recursos e capacidades que ela possui, e extrinsecamente, pelas características específicas do país anfitrião. Ambos os condicionantes respondem às perguntas sobre que bens serão vendidos, que mercados serão escolhidos e como entrar em ditos mercados, que estariam integrados em um contexto de controle total ou parcial, que é, em última instância, a estratégia desenhada pela estrutura de propriedade da empresa. Do ponto de vista estratégico, as principais características do processo de internacionalização são: 1) a empresa transfere produtos, serviços ou recursos além das fronteiras nacionais, ou seja, tem que escolher os países nos quais se vão realizar as transações; 2) a empresa tem que escolher a modalidade de realização dessas transações, ou seja, tem que escolher um modo de entrada (Anderson, 1997). Esses dois aspectos - a escolha do mercado

\footnotetext{
$0^{17}$ Os recursos são definidos como o estoque de fatores disponíveis que a empresa possui ou controle. Os recursos são convertidos em produtos ou serviços finais, usando um amplo espectro de outros ativos e mecanismos de vinculação, tais como tecnologia de informação, sistemas de incentivos, clima de confiança entre a direção e os trabalhadores, entre outros (Amit e Schoemaker, 1993). Os recursos podem ser tangíveis ou intangíveis, sendo esses últimos os que mais contribuem para a conquista de vantagens competitivas sustentáveis.

$1^{18}$ As capacidades da empresa podem ser definidas como um conceito dinâmico, que expressa a conjunção entre recursos e processos administrativos, e determinam o que uma empresa é e pode chegar a ser (Ventura Victoria, 1994).

$2^{.0}$ As capacidades da empresa se convertem em concorrências distintivas, quando não são extensivas para o restante das empresas, e permitem obter produtos, a partir delas, os quais satisfazem as necessidades dos segmentos objetivos da empresa, de forma superior ao dos competidores (Ventura Victoria, 1994).

$3^{\circ}$ Ademais, os mercados onde os recursos e as capacidades são transacionados sofrem de importantes imperfeições, o que garante a não acessibilidade aos mesmos por parte das empresas competidoras.
} 
internacional e a escolha do modo de entrada - reapresentam as decisões estratégicas chaves em relação à internacionalização de uma empresa (Bradley, 1995) ${ }^{21}$.

$\mathrm{Na}$ primeira etapa, a empresa terá de delimitar aquilo que quer e pode vender. Esse processo se desenvolverá promovendo os produtos-serviços existentes, ou mediante uma nova linha de produtos-serviços, incluindo tecnologias e conhecimentos técnicos. Ao mesmo tempo em que a empresa determina os bens, serviços ou conhecimentos técnicos que irá vender, isto é, traça sua meta, estará justificando o processo de internacionalização, por três motivos:

- Devido ao crescimento externo da empresa;

- Por ter alcançado a fase de madureza nos mercados nacionais;

- Por diversificar riscos

A etapa seguinte do processo de internacionalização refere-se à determinação dos MERCADOS onde a empresa pode atuar. Ao tomar tal decisão, a direção deve contemplar as possíveis variações de um país para outro, e, ao longo do tempo, em razão dos diferentes ambientes e das inevitáveis mudanças que se produzirão nesse, a partir de seu estado inicial. A localização dos mercados permitirá à empresa perceber diferentes oportunidades de investimento. Nessa etapa, Faz-se necessário um estudo rigoroso sobre as características do mercado correspondente do país anfitrião. E preciso, também, fazer-se uma análise dos ambientes legal, político e cultural dos mercados potenciais de entrada. No mesmo sentido, aponta (Canals, 1994), é necessário analisar o grau atual e futuro da globalização no setor correspondente. Não é o mesmo que este se encontre em uma fase emergente ou madura, pois essa situação pode condicionar o sucesso da decisão.

O último estágio para culminar o processo de internacionalização se alcança com a escolha do modo de entrada. Dita escolha dependerá da natureza das vantagens específicas que a empresa tem ou espera ter no exterior. Quando uma empresa investe nos mercados exteriores, combina alguma das vantagens específicas desenvolvidas no próprio país, que podem ser exploradas no exterior a um custo marginal baixo, com outros ativos disponíveis no país anfitrião. O nível e a natureza das vantagens específicas da empresa investidora determinam se a entrada terá de ser feita por meio de aquisições ou mediante novos estabelecimentos (Hennart e Park, 1993). A escolha de um mercado externo para entrar, mediante a participação total ou parcial em outra empresa, pode ser resultado de uma escolha racional de um país determinado ou uma

\footnotetext{
$4^{21}$ Citado em Anderson O., 1997, Internationalization and the market entry mode: a review of theories and conceptual
} frameworks, Management International Review 
conseqüência inerente à disponibilidade, ou não, de uma empresa para ser adquirida. O processo de aquisição propicia o surgimento de oportunidades que favorecem o entendimento do processo de aculturação ${ }^{22}$ como uma dimensão importante da internacionalização.

As três etapas descritas configuram um esquema teórico a seguir pela empresa, no processo de internacionalização, e se integram em uma quarta fase, de CONTROLE, onde a empresa expressa a maneira de exercer os direitos de propriedade em sua projeção ao exterior. Tal processo se verá impulsionado, em seu comportamento dinâmico, pelo potencial de internacionalização específico de cada empresa, que seria determinado basicamente por dois fatores: o grau de especificidade do ativo (conhecimentos, matérias-primas, serviços, capital de distribuição, capital financeiro) e a cultura empresarial internacional de cada empresa. $\mathrm{O}$ primeiro dos citados fatores tem caráter dominante relativamente ao segundo, na determinação do potencial de internacionalização.

A entrada em mercados externos requer por parte da empresa efetuar uma análise acerca do controle das operações no futuro, e do volume de recursos a comprometer em tais operações (Anderson e Gatignon, 1986; Kogut e Singh, 1988; Hill et al. 1990). Os modos de entrada integrados supõem o comprometimento de importantes quantidades de recursos (subsidiárias possuídas integralmente), seja por meio de nova unidade, seja mediante a aquisição de outra empresa no exterior.

\section{Principais teorias de internacionalização}

A literatura que tem contribuído de forma mais expressiva para a elaboração de um corpo doutrinário em torno da empresa multinacional se caracteriza por centrar seus argumentos ao redor de um núcleo central, que poderia concentrar-se em uma vantagem comparativa, a qual, em um sentido mais amplo, poderíamos conceber como um conjunto de conhecimentos não disponíveis, nem facilmente exeqüíveis para as empresas competidoras locais. Essa superioridade sobre empresas locais permitirá à multinacional a obtenção de excedentes ou receitas diferenciais, que se traduzirão em um maior crescimento e expansão. Sendo assim, a empresa multinacional tentará preservar durante o maior tempo possível suas vantagens comparativas, sempre e quando as receitas geradas mediante sua exploração superarem os custos

$5^{22}$ Denomina-se aculturação o fenômeno derivado do contato direto entre pessoas com diferente cultura. 
e possíveis desvantagens de atuar em ambientes diferentes. Esse processo ocorre sob a ótica de um regime de concorrência imperfeita.

Assim, Stephen Hymer, em sua tese de doutorado, apresentada em 1960, realça as imperfeições dos mercados de patentes e outras formas de conhecimento, que reforçam as vantagens potenciais das empresas multinacionais sobre as empresas locais ou nativas. Estas vantagens comparativas podem resumir-se em: conhecimentos especiais de gestão em geral, e a distribuição e comercialização em particular; conhecimentos e controle de funções de produção mais eficientes; produtos diferenciados; economias de escala e de crescimento; acesso favorável ao mercado de capitais etc.. Hymer argumentou que as atividades de investimento estrangeiro direto não só contemplam a transferência de capital financeiro como também de recursos (tecnologia, conhecimento, habilidades gerenciais, etc.). Segundo esse autor, outra característica da P\&D é que não implica mudança de propriedade dos bens transferidos. Desta maneira, introduz um fator diferenciador entre o investimento direto e o investimento indireto e o conceito de imperfeição do mercado. Segundo o mesmo autor, as imperfeições do mercado são um resultado das vantagens de "propriedade" que possuem as empresas estrangeiras, e seu sucesso depende das vantagens de inovação, custos, finanças ou marketing. Kindleberger (1969), partindo do importante trabalho de Hymer, assinala, como condição necessária para a produção internacional, a existência de mercados imperfeitos (tanto de produtos como de fatores). Portanto, nesse contexto, toda a empresa que possua certas vantagens comparativas tentará apropriar-se da totalidade de rendas de que delas possam derivar, controlando ditas vantagens em diferentes países e eliminando, ao mesmo tempo, a concorrência potencial, o que implica, por sua vez, um aumento das barreiras de entrada. Isso conduz a que as empresas multinacionais controlem determinados setores industriais em vários países.

O custo de informação incorrido, ao se investir no exterior, que será dado pela aquisição de conhecimentos adequados sobre os ambientes legal, sócio-político e econômico do país em questão, pode ser considerado como um custo fixo para a empresa, já que, uma vez assumido por ela, não é necessário novamente incorrer nele. Por outro lado, o custo marginal de utilização no exterior das vantagens comparativas ("conhecimentos" no sentido mais amplo) pode chegar a ser praticamente nulo, ou consideravelmente inferior ao que teria que suportar uma empresa local para desenvolver conhecimentos similares comparáveis. Daí decorre, como observa Johnson (1970), que o núcleo central do investimento direto, é a transferência de conhecimentos, já que esses possuem as características de um bem público no interior do sistema de uma empresa 
multinacional. Assim é que as grandes empresas se encontram imersas em um processo contínuo de desenvolvimento de novos conhecimentos como fonte principal de renda.

A partir desses conceitos, diversas teorias relacionadas com o processo de internacionalização das empresas têm sido desenvolvidas na literatura.

Em seguida, são resumidas as principais delas: 1) teoria da internalização; 2) teoria dos custos de transação; 3) teoria da agência; 4) teoria de recursos e capacidades; 5) teoria eclética; 6) modelo Uppsala de internacionalização.

\section{Teoria da internalização.}

As causas que podem gerar resultados positivos para a empresa multinacional em seu processo de investimento direto, poderiam, em uma primeira aproximação, resumir-se nas seguintes: vantagens de operar perto do consumidor e manter um mercado, determinadas fontes de financiamento, participar dos oligopólios locais, acesso a fontes privilegiadas de financiamento em geral, o uso repetitivo de conhecimentos já adquiridos. Uma razão fundamental consiste na possibilidade de explorar uma vantagem tecnológica e de conhecimentos próprios da empresa, e assim realizar economias internas no sentido assinalado por Coase (1963). Conhecimentos tecnológicos, de distribuição e comercialização, de gestão em um sentido amplo, podem ser utilizados pela empresa multinacional, sem necessidade de incorrer pela segunda vez no mesmo tipo de custos originais de desenvolvimento dos mesmos (Coase, 1963). Por isso, conhecimentos especiais e próprios da empresa podem ser considerados como "bens públicos" da mesma, posto que podem ser utilizados por uma filial, sem praticamente nenhum custo adicional, e sem afetar a possibilidade de exploração por qualquer outra unidade do grupo que compreenda a empresa. Isso permite à empresa multinacional reduzir o custo de produção e venda abaixo do que conseguiria uma empresa local, e isso é fundamentalmente devido a seus conhecimentos tecnológicos e empresariais, o que dá base a que a vantagem comparativa se apóie na exploração interna desses conhecimentos, assumindo, assim, as funções que teoricamente corresponderiam ao mercado.

A explicação do investimento direto no exterior, em um sistema de mercados imperfeitos, pode estar no fato de que o custo de oportunidade da utilização do bem ou bens primitivos e peculiares da empresa em outro país seja nulo ou relativamente menor do que a rentabilidade que se pode obter pelo emprego desse bem em investimentos diretos, e que essa rentabilidade deve depender, de alguma maneira, da localização das atividades da empresa. 
Desta forma, a teoria da internalização identifica as situações nas quais as empresas decidem internalizar seus mercados, quer dizer, aquelas operações onde as empresas possuem e controlam atividades de valor agregado fora de sus fronteiras naturais. Para que esses ativos intangíveis tenham um valor agregado no âmbito internacional, as empresas têm que "internalizar" os mercados externos, mediante o investimento direto no fora do país de origem. O valor da empresa aumenta, se o benefício de utilizar seus ativos intangíveis em um mercado estrangeiro é maior do que o custo de abertura, coordenação e operação de uma sucursal ${ }^{23}$ (Mork, 1992). Portanto, as empresas decidem investir em P\&D cada vez que percebem que os benefícios líquidos de suas atividades domésticas, juntamente com suas atividades externas superarão os benefícios obtidos por meio de suas relações comerciais externas (Dunning, 1992).

\section{Teoria dos custos de transação}

A teoria dos custos de transação, cuja raiz se encontra em um artigo original de Coase (1937), ampliado posteriormente por Williamsom $(1975,1981)$, apresenta "as imperfeições do mercado" como atributos inerentes ao conhecimento, e o papel que se atribui às empresas é evitar tais imperfeições. Diversos autores que têm desenvolvido esta teoria, como Mcmanus (1972), Buckley e Casson (1976), Brown (1976) e Hennart (1977, 1982) têm coincidido na argumentação.

$\mathrm{Na}$ teoria econômica, a transação representa a unidade básica de análise de uma empresa (Milgrom, 1992). Por transação se entende a transferência de bens ou serviços de um indivíduo a outro. As transações se realizam de diferentes maneiras: 1) se a transação ocorre periodicamente e de um modo similar, a pessoas desenvolvem rotinas e procedimentos, e 2) no caso de transações não usuais, a partes envolvidas têm que negociar e definir as condições, o que determina um aumento do custo da transação.

Segundo Coase (1939), os custos de transação dependem tanto da natureza da transação como do modo empregado para sua realização. Assim mesmo, segundo o princípio de eficiência ${ }^{24}$, a tendência é adotar o modo de organização que reduza os custos de transação. Em conseqüência, as transações tendem a realizar-se em mercados onde as formas de organização são mais eficientes.

Os tipos de custos de transação que podem existir são: a) custos de coordenação; e b) custos de motivação (Milgrom, 1992).

\footnotetext{
$6^{23}$ Manejar uma sucursal estrangeira é mais custoso do que manejar uma sucursal doméstica, dados os custos que decorrem das diferenças culturais, políticas e legais (Mork, 1992).

$7^{24}$ Segundo (Milgrom, 1992), o Princípio de Eficiência estabelece que, se as pessoas podem negociar e implementar eficientemente os resultados das negociações, então a atividade econômica tende a ser também eficiente.
} 
a. Custos de coordenação. Os problemas de coordenação que podem ocorrer durante uma transação estão relacionados à necessidade de definir a localização de potenciais compradores e vendedores, reuni-los para realizar a transação, acordar os preços e completar outros aspectos da transação ${ }^{25}$.

b. Custos de motivação. Os custos de motivação têm principalmente duas origens: 1) a assimetria e a imperfeição da informação, e 2) o compromisso imperfeito entre a partes.

A teoria dos custos de transação introduz também o conceito de compromisso imperfeito, o qual se refere em grande medida ao comportamento oportunista ${ }^{26}$ das pessoas. De acordo com Williamson (1985), os indivíduos não respeitam os compromissos, não mantêm as promessas, ou apresentam informação incompleta ou destorcida, para confundir os demais. O oportunismo se evita por meio dos contratos que especificam papéis, e estabelecem responsabilidades e normas, ou por meio da internalização dos mercados criando hierarquias que protejam a organização do comportamento oportunista. Qualquer das duas medidas significa custos adicionais ${ }^{27}$ (Shane, 1992).

Una possibilidade de diminuir o comportamento oportunista das pessoas é por meio da criação da confiança (Ouchi, 1980). Ouchi afirma que, nas culturas onde existe maior confiança e menos oportunismo, existirão menos motivos para criar hierarquias a fim de conquistar objetivos econômicos comuns. $^{28}$

Nos estudos dos processos de internacionalização, a teoria dos custos de transação tem sido utilizada para investigar a escolha da modalidade de entrada em um novo mercado. Segundo a teoria, a decisão de entrar em um mercado estrangeiro desconhecido implica a avaliação, por parte da empresa, dos custos incorridos para diminuir a incerteza e obter a informação necessária

$8^{25}$ Também reapresentam custos de transação o gasto feito pelo vendedor em um certo mercado, para determinar as preferências do comprador, ou para tornar conhecido produto no novo mercado.

${ }^{26}$ Um caso típico é o que se apresenta na negociação entre um fabricante e seu fornecedor: por um lado, o fabricante tenta influir na decisão do fornecedor de adquirir uma nova tecnologia que lhe permitiria obter provisões mais adequadas às suas necessidades. Por outro lado, o fornecedor sabe que, após essa compra, que fará sua produção mais dependente da demanda do fabricante, e esse último poderia forçar a diminuição de preços. Dessa maneira, gera-se desconfiança e o resultado é que o investimento não se realiza, ou é necessário implantar medidas custosas para impedir o comportamento oportunista.

${ }^{27}$ Distinguem-se neste caso dois tipos de Custos: Os Custos de agência, no caso de optar por contratos para proteger-se da assimetria da informação, e Os Custos de transação no caso de optar pela hierarquia como forma de proteção contra o comportamento oportunista.

${ }^{28}$ A confiança (Chiles, 1996) diminui também os custos de governança da empresa. A explicação é simples e está em conformidade com as afirmações dos autores anteriormente mencionados (Hymer, 1968; Milgrom, 1992): se se consegue trabalhar com confiança, os custos nos quais a empresa incorrerá, para fechar seus contratos e definir sua estrutura, serão menores; em conseqüência, os custos de governança diminuirão. 
sobre as transações envolvidas: 1) a aquisição de ativos (físicos e humanos), 2) o manejo de ambientes incertos e imprevisíveis (mercado, fornecedores, compradores, competidores, etc.); e 3) o controle e avaliação de sus agentes internos.

Os aspectos mencionados na teoria dos custos de transação - o oportunismo, a falta de confiança a normas e a motivação - são elementos que fazem parte da cultura, tanto da empresa investidora como do mercado estrangeiro em que se vai operar. Por esse motivo, a cultura está incluída implicitamente nesta teoria, na decisão da modalidade de entrada.

Posteriormente e sob uma perspectiva de custos de transação, Rugman (1980) alude ao elevado número de imperfeições do mercado e aos altos custos de transação como a principais razões para que a empresas criem seus mercados internos.

\section{Teoria da agência}

A teoria da agência entende a organização como um conjunto de contratos. Uma das razões pelas quais se estabelece um contrato é o problema da confiança entre a partes. A falta da confiança, a incerteza e, em parte, a assimetria da informação fazem que se firmem contratos que implicam custos elevados.

As duas contrapartes de um contrato são o principal e o agente. Tanto o principal como o agente estão motivados por seus próprios interesses e atuam racionalmente (Bergen, Dutta, e Walker 1992). Os conflitos surgem porque o principal e o agente têm diferentes metas e estão dispostos a assumir riscos distintos. A meta de ambos é maximizar sua utilidade, e cada um atua em seu próprio interesse.

A teoria da agência propõe dois problemas para o principal. O primeiro, que ocorre antes que a relação se inicie, tem a ver com as dúvidas sobre as características (habilidades, capacidades, cultura corporativa) que o principal necessita que o agente tenha. O segundo ocorre após o inicio da relação, e contempla as ações que empreende o agente para assegurar a maximização das utilidades do principal (Spake e outros, 1999). Para assegurar estas ações, o principal tem que estabelecer um contrato e projetar um sistema de incentivos para comprometer o agente com seus objetivos.

A diferença dos custos de transação, associados à definição da modalidade de entrada em um mercado estrangeiro, e os custos da agência correspondem a governança. Jensen e Meckling (1976) definem os custos da agência como a soma de: 1) gastos de supervisão por parte do principal; 2) gastos de compromisso do agente e 3) perdas residuais. As diferenças culturais 
podem aumentar a desconfiança na governança corporativa e, portanto, podem aumentar os custos da agência.

\section{Teoria de recursos e capacidades}

A teoria de recursos e capacidades (Wernerfelt, 1984; Barney, 1991) estuda a relação que existe em uma empresa entre seus recursos tangíveis e intangíveis, sua estratégia e seus resultados. Os recursos incluem todos os ativos, capacidades, processos organizacionais, conhecimentos etc., que permitem à empresa conceber e implementar uma estratégia específica e, assim, melhorar sua eficiência (Penrose, 1959).

A teoria de recursos argumenta que, para alcançar resultados sustentáveis, as empresas devem dispor ou desenvolver recursos que se caracterizem por sua raridade, alto valor, impossibilidade de imitação, e que não tenham substitutos. Em outras palavras, a vantagem competitiva das empresas baseia-se em desenvolver recursos de alto valor agregado e difíceis de duplicar.

Quando as empresas não dispõem de certos tipos de recursos, podem adquiri-los ou desenvolvêlos. A aquisição desses recursos pode ser feita de maneira rápida, por meio das alianças internacionais, de aquisições e fusões, ou por meio de P\&D.

As teorias de internacionalização (Buckley e Casson, 1985, Dunning, 1988, 1993) afirmam que, para poder investir em um mercado estrangeiro, uma empresa tem que levar em conta certos tipos de recursos para a decisão estratégica de investimento (Elango, 2000):

1. Recursos intangíveis: são recursos como a marca, ou a capacidade de inovação. Geralmente são difíceis de serem copiados e, portanto, representam uma importante fonte de vantagem competitiva ou poder de mercado.

2. Recursos financeiros. Referem-se aos médios financeiros como a margem custo / preço, ou o disponível. Os dirigentes têm a opção de redistribuir os recursos financeiros disponíveis como dividendos ou reinvesti-los em novos mercados, incluindo os mercados estrangeiros, para aumentar seus benefícios.

3. Recursos físicos. Referem-se aos investimentos em plantas ou equipamentos. Esses recursos deveriam permitir à empresa produzir novos produtos mais eficientemente, e, por isso, é muito importante a existência de operações e atividades internacionais.

4. Recursos operacionais. Referem-se à habilidade dos dirigentes de coordenar e criar processos administrativos capazes de converter as matérias-primas em serviços e produtos finais. 
A presença ou ausência desses recursos pode motivar ou não a empresa a perseguir uma estratégia de internacionalização e, por esta via, aumentar seu tamanho e rentabilidade. Desta maneira, os recursos representam um fator significativo na definição da estratégia de internacionalização de uma empresa (Elango, 2000) e, por conseqüência, na escolha da modalidade de entrada em um mercado estrangeiro.

\section{Teoria eclética.}

Em 1979, Dunning propõe um paradigma eclético, baseado em um conjunto de fatores: vantagens de propriedade, vantagens de internacionalização e vantagens de localização. Os primeiros guardam relação com as capacidades da empresa que forem superiores às da empresas do país anfitrião. O segundo grupo de fatores faz referência às vantagens da empresa em explorar (internalizando) suas próprias capacidades, em lugar de cedê-las mediante licenças ou patentes; finalmente, o último conjunto de vantagens decorre da utilização dos fatores de produção localizados fora do país de origem, para levar a cabo o processo produtivo, em outro país.

A teoria eclética de Dunning $(1980,1988)$ reúne varias teorias focadas no estudo da escolha da modalidade de entrada em um novo mercado: a teoria de recursos, a teoria de "internalização" e a teoria dos custos de transação. Dunning (1980, 1988) afirma que o sucesso da internacionalização das empresas depende de sua capacidade de gerar e aproveitar as vantagens de: 1) propriedade; 2) localização; e 3 ) internalização.

As vantagens de propriedade se referem às capacidades e ativos específicos da empresa. Os ativos são tangíveis (como o capital ou os recursos naturais), enquanto que as capacidades são intangíveis (como a informação, habilidades de empreendedores, de direção ou de marketing) (Dunning, 1992) ${ }^{29}$. Para converter-se em uma vantagem competitiva para as empresas, as vantagens de propriedade têm que ser tanto únicas como sustentáveis (Brouthers et al., 1996).

As vantagens de localização se referem à atratividade que apresenta um país ou região, em função do potencial de mercado e o risco de investimento (Root, 1987). Adicionalmente, outros fatores incluem a similitude de culturas, ala qualidade dos ambientes políticos, legais, e institucionais, as políticas do governo, a estrutura do mercado e a possibilidade de reduzir os custos de produção (Dunning, 1992).

Finalmente, a vantagem de internalização se refere ao custo de operação com uma estrutura hierárquica interna, em lugar de uma externa. Tal como analisado na teoria de internalização,

$0^{29}$ Os ativos estão refletidos no tamanho e a experiência multinacional da empresa, enquanto que as capacidades se refletem na habilidade de desenvolver produtos diferençados (Andersen, 1997). 
muitas vezes é menos custoso adquirir uma empresa local do que abrir uma sucursal estrangeira (Dunning 1988, 1992).

\section{Modelo Uppsala de internacionalização.}

A teoria gradualista, ou modelo Uppsala, consiste em considerar que muitas empresas começam suas operações internacionais quando são ainda muito pequenas, e se expandem gradualmente. Assim, a empresa se desenvolve primeiro em seu mercado nacional e a internacionalização é a conseqüência de uma serie de decisões adicionais. O modelo Uppsala é o resultado de uma pesquisa realizada por um grupo de estudiosos da Universidade de Uppsala, na Suécia (Johanson/Wiedersen-Paul 1975, Johanson/Vahlme 1977, 1990) ${ }^{30}$. O modelo condiciona a internacionalização da empresa a um processo incremental, que depende do conhecimento e da experiência das empresas nos mercados estrangeiros. Assim, a imperfeição do mercado implica um alto grau de incerteza no processo de internacionalização, que faz com que os dirigentes se orientem, em uma primeira etapa, em direção aos mercados "psicologicamente" mais próximos, e que comprometam, durante essa etapa, uma quantidade restrita de recursos.

Com o aumento da experiência comercial em mercados estrangeiros, as empresas estarão dispostas a atribuir cada vez mais recursos às operações internacionais, e a investir em países distintos do país de origem.

O modelo descreve o processo de internacionalização das empresas em quatro etapas:

\section{Exportações sem regularidade}

\section{Exportações via agente independente}

\section{Filiais comerciais}

\section{Filiais de produção}

As sucessivas etapas requerem maiores compromissos de recursos, coincidindo, ademais, com um maior conhecimento do mercado, por meio da experiência adquirida previamente. Em definitivo, o processo é determinado por um progressivo aumento do conhecimento do mercado devido à experiência, e a um maior compromisso de recursos devido à necessidade de controlar o processo “internacionalizador”. Tal processo terá lugar, primeiro nos países que se consideram mais próximos psicológica e geograficamente, que são os que oferecem um maior grau de similitude com o nacional, para, posteriormente, estender-se aos mais distantes.

Uma limitação desse modelo é a falta de mecanismos para determinar a relação entre a experiência nos mercados estrangeiros e a alocação de recursos nesses mercados (Andersen,

\footnotetext{
$1^{30}$ Citado em Oviatt B., Phlillips P., Challenges for International Process theory: the case of international new ventures,
} 1997, Management International Review. 
1993). Por outro lado, Forsgren (1989) afirma que o modelo é válido somente nas primeiras fases dos processos de internacionalização, quando a falta de conhecimento do mercado e a atribuição de recursos podem ser consideradas uma restrição ${ }^{31}$. Segundo o autor, os fatores anteriormente mencionados não são importantes quando a empresa está já presente em vários mercados.

Na teoria de Uppsala, a cultura é o elemento central. A distância cultural determina a confiança dos investidores nos mercados estrangeiros. À medida que ganham experiência nos mercados similares culturalmente, as empresas estarão dispostas a arriscarem-se com investimentos em mercados diferentes.

Resumidamente, pode-se observar que no modelo da Universidade de Uppsala, o processo de internacionalização da empresa implica uma interação, de um lado, entre o desenvolvimento do conhecimento acerca do mercado e as operações externas, e, de outro, em um maior compromisso de recursos com tais mercados. Pode-se chegar a delimitar os aspectos estático e dinâmico da internacionalização. $\mathrm{O}$ aspecto estático faz referência ao conhecimento e ao compromisso do mercado (quantidade de recursos e grau de compromisso), e o aspecto dinâmico reflete as atividades de negócio correntes e as decisões sobre o comprometimento de recursos. Existem diversas tendências atuais que enfraquecem os argumentos do modelo de Uppsala: A globalização dos mercados e padronização dos produtos fazem com que o mundo dos negócios tenda à homogeneização. Nesse sentido, têm se pronunciado Vernon (1979), Porter (1980, 1984, 1986), Levitt (1983) e Ohmae (1985). O mais firme defensor dessa tese foi Levitt, ao destacar a tecnologia como a principal força que tem feito com que o mundo tenda à convergência, ao ter conseguido tornar mais acessíveis a comunicação. Também cabe apontar outros argumentos que têm contribuído para a homogeneização, como a formação de mercados comuns na Europa, Oriente Próximo, Ásia e América, e a eliminação das barreiras comerciais.

O espetacular desenvolvimento experimentado pelas tecnologias da informação tem propiciado o crescimento de fluxos de informação e, por sua vez, tem tornado possível um acesso mais fácil e rápido aos conhecimentos que exigem as operações, no contexto internacional.

A emergência de empresas, que administram suas atividades como se o mundo fosse um mercado único e homogêneo, tem-se configurado como uma força que aponta para uma comunidade global.

\section{Os clusters de empresas.}

\footnotetext{
$2^{31}$ Citado em Anderson S., The internationalization of the firm from an entrepeneurial perspective, Spring 2000,
} International Studies of Management \& Organizations 
Sabe-se que os países não podem ser competitivos em todos os setores da atividade econômica. Segundo Porter (1998), na atual fase da globalização, esta sendo eliminada a maioria das fontes de vantagens comparativas tradicionais. O autor destaca, que na atualidade, a busca de competitividade tem tido como resultado organizar o mapa econômico do mundo com uma nova estruturação espacial, que se denomina cluster, definido por ele como concentrações geográficas de empresas e instituições interconectadas além da concorrência entre elas. Suas características principais são:

1-ser um conglomerado multisetorial de empresas e organizações integradas sinergicamente (Cravens, Piercy, 1994; Slater, Narver, 1995; Hunt, Morgan, 1995);

2-produzir uma massa crítica para agregar maior valor a sua oferta, mediante a atividade conjunta no portfolio de produtos de todas as empresas organizadas segundo essa configuração (Dull, Mohn, Noren, 1995);

3-estar localizado em um local geográfico específico com uma fonte especial de competitividade (Porter, 1998);

4-estar acima dos interesses nacionais e regionais (Cravens, Piercy, 1994; Slater, Narver, 1995; Hunt, Morgan 1995);

5-ser típicos e diferenciados ainda que não únicos (Porter, 1998);

6-alcançar as vantagens competitivas por seus conhecimentos e relações, trabalhadas no âmbito local de forma melhor do que seus competidores globais (Cravens, Piercy, 1994; Slater, Narver, 1995; Hunt, Morgan 1995);

7-estarem integradas suas empresas vertical (incluindo canais de distribuição e clientes) e horizontalmente (integração com produtos complementares, indústria de tecnologias próximas e fornecimentos comuns) (Porter 1998; Dull, Mohn, Noren, 1995).

Um cluster apresenta características intrínsecas da atual fase da globalização, pois integra, com um objetivo comum, as diversas instituições intersetoriais que surgem da nova relação entre entidades públicas, privadas, mistas, governamentais, ONG's, universidades, associações comerciais, de classe, órgãos de pesquisa, entre outras.

Segundo Dull, Mohn, Noren (1995), o cluster constitui uma forma alternativa de organizar a cadeia de valor do sistema, por meio de redes, alianças e sociedades entre as empresas, de forma a aumentar e facilitar a flexibilidade para superar a rígida concorrência tradicional.

Como destacam Cravens e Piercy (1994), o fenômeno de formação de cluster atrai naturalmente a presença de empresas convergentes entre si, em um país ou região, para alcançar a vantagem competitiva de forma conjunta. A presença de indústrias internacionalmente competitivas tem 
um efeito multiplicador, o qual atrai clientes sofisticados, interna e externamente, e estimula os serviços relacionados. Para Porter, (1998) esse tipo de configuração alcança seu sucesso pela cooperação entre todos os seus integrantes, consolidando-se uma história de sucesso mundial, que passa a ter o efeito de atração competitiva seletiva. É favorecido pelo próprio interesse de coordenação das empresas atuantes, pela entrada de empresas mais competitivas, eliminando-se as barreiras tradicionais. Com o apoio desses novos competidores, de empresas complementares e de demais fatores, produz-se um efeito multiplicador eficiente e competitivo. 


\title{
Capítulo III
}

\author{
A COMPETITIVIDADE \\ NO SISTEMA DE TURISMO
}




\section{CAPÍTULO III}

\section{A COMPETITIVIDADE NO SISTEMA DE TURISMO}

\section{Sistema de turismo}

Principais conceitos.

Uma visão sistêmica do turismo.

Subsistema operativo do turismo.

Organização turística: agentes e facilitadores.

A empresa hoteleira. Sua situação na atual fase da globalização.

O papel dos tour operators: canais de distribuição ou empresas produtoras?

7. O marketing turístico.

Particularidades do produto turístico.

A oferta turística.

Segmentação do mercado turístico.

8. Processo de planejamento estratégico no setor de turismo segundo os critérios de sustentabilidade.

Variáveis que determinam a sustentabilidade do setor de turismo.

Planejamento estratégico das empresas de turismo.

9. A competitividade e o posicionamento no sistema de turismo. Clusters turísticos Competitividade das empresas turísticas na atual fase da globalização.

Marketing de relacionamento como dinamizador da estratégia competitiva do cluster turístico.

10. A internacionalização das empresas de hotelaria. Análise dos Top 10 de cadeias internacionais.

\section{Sistema de turismo.}

Principais conceitos

Para compreender adequadamente o papel da empresa de turismo, deve-se estudar seu desempenho e estabelecer as bases para o desenho de sua estratégia competitiva. É necessário, para isto, aplicar o enfoque sistêmico no setor turístico, para poder conhecer todas as interrelações existentes, e seus respectivos impactos sobre o planejamento estratégico. Como mencionou BENI (2001), "não será possível entender uma célula, a estrutura do cérebro, a família, uma cultura, ou o Turismo se forem isoladas de seus contextos”.

Distinguem-se três linhas de análises teóricas da atividade turística, segundo destacou BENI (2000): 
A primeira linha, coloca-se na perspectiva da produção, e envolve uma pluralidade de empresas que atuam no setor, algumas das quais operam a transformação de matéria-prima em produto acabado, enquanto outras oferecem bens e serviços já existentes.

A segunda linha, refere-se à distribuição, e onde são produzidos, preferencialmente, serviços. É também um setor de atividades, no qual o momento produtivo pode corresponder ao distributivo, com a passagem dos bens e serviços turísticos diretamente do produtor ao consumidor.

A terceira linha, consiste em identificar e estabelecer as condicionantes da viagem e os componentes comportamentais do viajante, isto é, a origem da viagem, os meios de transportes utilizados, a natureza da viagem, o tempo de permanência no local, os equipamentos receptivos solicitados, suas motivações, necessidades e preferências, o grau de participação nas atividades turísticas recreativas de sua destinação, a estrutura de gastos e a estratificação socioeconômica do consumidor.

Primeiramente, será analisado como tem evoluído o conceito de turismo, o qual proporcionará os elementos necessários para entendê-lo como fenômeno sistêmico.

A partir de 1929, até o início do turismo de massas, depois da Segunda Guerra Mundial, elaboraram-se várias definições, entre as quais destacam-se as coletadas por FUSTER (1978):

GLUCKMANN - "Uma conquista do espaço por pessoas que chegam a uma determinada localidade onde não possuem lugar fixo de residência. Turismo é uma soma de relações existentes entre as pessoas que se encontram passageiramente em uma localidade (núcleo receptor) e os habitantes desta".

SCHWINK - "Movimento de pessoas que abandonam temporariamente o lugar de sua residência permanente por qualquer motivo psíquico, fisico ou profissional".

MORGENROTH - "Tráfego de pessoas que se afastam temporalmente do lugar residencial fixo para outro, com o objetivo de satisfazer suas necessidades vitais (pessoais), culturais e os desejos mais diversos, aparecendo unicamente como consumidor de bens econômicos e culturais".

A Organização Mundial do Turismo (OMT), para unificar critérios com fins estatísticos, adotou as seguintes definições:

Turistas: visitantes que permanecem pelo menos 24 horas no país visitado movidos por: lazer, lazer, férias, saúde, estudos, religiões, esportes, neglazers, família, reuniões, missões, entre outros;

Excursionistas: visitantes temporários que permanecem por um período inferior a 24 horas no país visitado (incluídos os visitantes de cruzeiros). 
A definição DE HUNZIKER e KRAPT (1942) apontou que o "turismo é o conjunto de relações e fenômenos resultantes da viagem e da estada, independentemente do motivo que o tem determinado, sempre que a estada seja temporária".

Uma definição mais holística do turismo foi oferecida por JAFARI (1990), como sendo “o estudo do homem longe de seu local de residência habitual, da indústria que satisfaz suas necessidades e os impactos de ambos que ambos geram sobre os ambientes físicos, econômicos e sociocultural da área receptora".

Nas numerosas definições existentes de turismo e de turista têm-se alguns elementos comumente aceitos:

— Turismo implica necessariamente deslocamento. O deslocamento é um elemento essencial para que o turismo ocorra. A viagem ou o "tour" é um componente essencial do fato turístico;

— Permanência fora do domicílio. Turismo é movimento de um lugar para outro. É a saída da residência habitual na direção das localidades ou centros turísticos por algum tempo. A prática do turismo implica permanência fora do domicílio habitual de residência;

— Temporalidade. No caso do turismo, a viagem implica sempre um retorno, uma ida e volta;

— Turismo compõe-se sempre de dois elementos:

Sujeito: o homem, que é o centro de todo o fato turístico, já que por meio de seus desejos e necessidades origina às várias atividades provocadas pelo turismo;

Objeto: oferta turística, o homem viaja temporariamente em busca de uma gama de elementos, que formam a oferta turística.

Observa-se uma preocupação interrogativa em alguns meios acadêmicos no sentido de saber se o turismo é ciência, em que estágio de desenvolvimento se encontra e se poderia ser tratado em etapas científicas. Como disse BENI (2000), "a verdade é que muitos teóricos, desde KRAPF e HUNZIKER e todos os pesquisadores da Escola berlinense, passando por FUSTER da escola funcionalista, bem como os autores da atualidade como JAFARI, RITCHIE, KRIPPENDORF, KELLER, SWARBROOKE, FIGUEROLA, CÁRDENAS, WAHAB, GUTIÉRREZ, BORDAS, DEFERT, ACERENZA, BARETJE, pela Escola de Frankfurt, que faz a crítica teórica dos marxistas vendo o turismo circunscrito à relação de consumo, até os estruturalistas da corrente do sistemismo como SESSA, BENI, PIERRE LANÉ, MOLINA, BOULLÓN, fenomenologistas como CETENO, e estudiosos do cotidiano como MAFESOLI, vêm investigando e propondo as bases de categorização epistemológica do turismo, contribuindo todos eles para o estabelecimento de seus fundamentos cientificos".

\section{Uma visão sistêmica do turismo}


A Teoria Geral de Sistemas nasce do trabalho de LUDWIG VON BERTALANFFY, RAPPAPORT, GERARD, ASHBY, entre outros, no começo dos anos 40, conjuntamente com a fundação da Sociedade para a Pesquisa Geral de Sistemas em 1954. O problema principal que enfocaram estes cientistas é de complexidade organizada. Os conceitos que compartilham o ambiente intelectual, com um forte enfoque inter-disciplinar, e uma concepção integral de conteúdo multidisciplinar; fez romper, assim, com os planejamentos tradicionais de sistemas fechados. Entende-se os sistemas como abertos, aqueles que supõe a inter-relação dentro do sistema estudado e seu redor, de tal maneira que se produza entre eles uma série de relações e intercâmbios de elementos.

Neste estudo, a Teoria dos Sistemas aplica-se ao setor de turismo, que fica assim definido como um sistema aberto homeostático ${ }^{32}$. BENI (2000) definiu o Sistema de Turismo (SISTUR) como sendo "o conjunto de procedimentos e doutrinas, idéias ou princípios, ordenados logicamente e coesos com a intenção de descrever o funcionamento da atividade turística como um todo". $\mathrm{O}$ autor situa o turismo em toda sua amplitude, complexidade e multi-causalidade, num esquema sintetizador dinâmico que demonstra as combinações múltiplas de forças e energias.

O turismo não é uma atividade isolada, pois o turista é a peça central de todo o sistema. $\mathrm{O}$ turismo, também, está relacionado com as várias atividades humanas. A interpretação do turismo como sistema compreende uma análise multi-disciplinar, na medida das inter-relações entre os diferentes sistemas em que o ser humano participa, como o econômico, social, político, cultural, ecológico e tecnológico. Isto faz com que a abordagem do turismo implique o conhecimento integrado destas diferentes áreas e suas inter-relações.

O fenômeno turístico pode ser analisado dentro de um enfoque sistêmico, como mostra, de maneira simplificada, a Figura 1.

BENI (2000) procurou conceituar, descrever e definir o SISTUR, identificando os componentes desse sistema, suas relações de causa e efeito, e o surgimento de subsistemas controladores e dependentes. Procurou também identificar e analisar outros sistemas antecedentes, interferentes e condicionantes do SISTUR.

\footnotetext{
${ }^{32}$ Para a interpretação do sistema de turismo destaca-se algumas das principais características de um sistema aberto homeostático: a. O sistema se inter-relaciona em torno do seu meio: intercambia elementos com o seu meio, os transforma e os devolve ao mesmo, gerando uma corrente de entradas e saídas, que permite o comportamento do sistema ser como uma caixa preta, mas com um elemento regulador; b. Em função dos processos de transformação (relação entre os fluxos de entradas e saídas) consegue-se os objetivos preestabelecidos; c. O sistema dispõe de funções e mecanismos de controle e auto-regulação (feedback) que permitem conduzir e adaptar o processo de transformação para alcançar os fins desejados; d. A relação de entradas e saídas deve permitir que o sistema mantenha-se em equilíbrio homeostático.
} 
Ao analisar os elementos que constituem as relações do sistema com todos os componentes a ele ligados, em interdependência, estruturou-se, mediante tal análise, o Modelo Referêncial do SISTUR.

Estes elementos, em linhas descritivas gerais, são:

1. Estudo do espaço turístico, abrangendo o levantamento de:

- Delimitação e descrição física da área receptora;

- Recursos naturais e culturais e analise do diferencial turístico;

- Equipamentos receptivos: de alojamento hoteleiro, extra-hoteleiro e complementares de alimentação e recreação;

- Infra-estrutura de apoio à atividade turístico-recreativa.

2. Perfil lazer-econômico da área receptora, compreendendo o levantamento de:

- Ocupação do território e densidade demográfica;

- Composição étnica da população e organização social;

- Indicadores macroeconômicos, tais como: renda, investimentos de capital, consumo, importação e exportação;

- Indicadores dos setores da atividade econômica, com ênfase no setor terciário.

3. Estudo de ordenação geopolítica e administrativa da área receptora, compreendendo a necessidade do levantamento de:

- Organização institucional e legal;

- Grau de intervenção do estado;

- Políticas básicas.

4. Estudo e previsões do comportamento do mercado de turismo na área receptora, compreendendo a análise de clusters e o levantamento de:

- Oferta: indicadores de ocupação dos equipamentos receptivos e medidas de ocupação dos espaços de recreação;

- Demanda: qualificação e quantificação do tráfego turístico para caraterização e classificação dos fluxos em função de permanência, solicitações de equipamentos e outras variáveis de consumo. Mais as medidas de intensidade de participação nas várias atividades de recreação e entretenimento.

5. Diagnóstico do turismo na área receptora, analisando-se seu potencial de influência no processo de desenvolvimento econômico. Para tanto, conhecidos em profundidade os elementos constitutivos das relações do sistema, pode-se partir para a elaboração do prognóstico da situação da área receptora, que necessariamente exigirá eventuais ajustes para atingir o equilíbrio de 
mercado. Este será alcançado otimizando-se as áreas vocacionadas para o processo de ocupação turístico-recreativa, aumentando o volume de novos investimentos, o nível de emprego e quantidade de equipamentos, instalações e serviços oferecidos.

Figura 1: Sistema de Turismo (SISTUR).

\section{SISTUR - SISTEMA DE TURISMO}

Modelo Teórico Referencial - Diagrama de Contexto

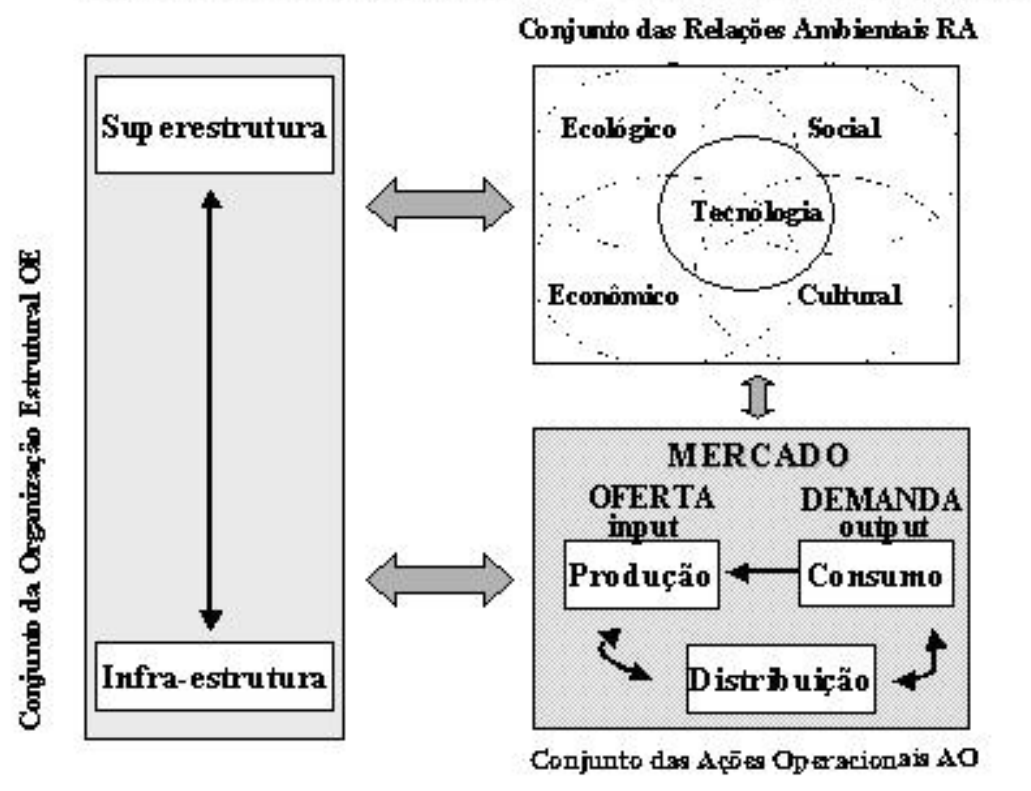

Fonte: BENI (1987)

O turismo, de acordo com a Teoria Geral dos Sistemas, pode ser considerado um sistema aberto, que permite a identificação das características básicas dos seus elementos. Da análise da Figura 1 é possível visualizar três grandes conjuntos: a) o das relações ambientais, b) o da organização estrutural e, c) o das ações operacionais. Cada um destes três conjuntos pode ser considerado como um subsistema, já que apresenta funções próprias e específicas.

O Subsistema das Relações Ambientais está composto pelo conjunto de condições do meio em que se desenvolve a atividade turística, onde existirá um determinado ambiente econômico, social, ecológico e cultural, em constante movimento e mudança, que interagem com o Sistema de Turismo, numa relação múltipla e complexa.

O Subsistema da Organização Estrutural é formado pelos elementos que compõem a superestrutura e da infra-estrutura, imprescindíveis para que o turismo aconteça. Neste subsistema participa o Estado, definindo a Política Nacional ou local do turismo, assim como, o restante das instituições públicas ou privadas que, direta ou indiretamente, participam da atividade turística ou a facilitam, criando condições indispensáveis na comunidade para seu desenvolvimento. São próprios deste subsistema a estruturação do Sistema Nacional de Turismo, sua ordenação 
jurídico-administrativa e a determinação de ações normativas e executivas necessárias para conseguir sua ordenação.

O Subsistema Operativo do Turismo, pela sua importância para esta pesquisa, será tratado pormenorizadamente, num item independente.

A partir do ponto de vista desta pesquisa, na conceitualização do Sistema de Turismo de BENI (2000), teria que se destacar o elemento cliente. Nos modelos de gestão estratégicos atuais é altamente hierarquizado o conceito de cliente, porque com seus inputs (necessidades, desejos, expectativa, satisfação entre outros) otimizam a configuração do sistema e o retro-alimentam com sua participação direta no processo simultâneo de produção-consumo-avaliação.

\section{Subsistema operativo do turismo}

O conjunto das ações operacionais desenvolve-se no mercado turístico, em que acontece a produção e o consumo, segundo as leis da oferta e da procura, garantidos pelo subsistema de distribuição. Por ser objeto deste estudo, é necessária uma visão mais detalhada dos elementos componentes deste subsistema. As características deste subsistema são influenciadas pelas peculiaridades que tem o produto turístico como tal.

Por formar parte do setor de serviços, as características mais relevantes destes produtos são: ser intangíveis, necessitar do contato direto produtor-cliente e a participação simultânea do usuário no processo de produção. Estas características condicionam as particularidades do setor de turismo e de seu produto:

- A empresa turística não trabalha com estoque pela imaterialidade de sua produção. Isto ocorre com o transporte, o alojamento, as operadoras de turismo, as agências de viagens e quase todas as empresas do sistema;

- Os serviços turísticos não consumidos são, como qualquer serviço, perecíveis com o tempo;

- O produto turístico final, no sentido macroeconômico, é um conjunto de prestações singulares, muito variado, de um lado, e nunca idêntico, de outro. É um produto composto concebido a partir de uma série de outros serviços;

- O produto final pode ser composto pelo próprio consumidor, que tem a possibilidade de organizar sua própria viagem turística;

- O consumidor deve dirigir-se para o próprio lugar da produção turística, para desfrutar do consumo e satisfazer seus desejos e necessidades;

- Geralmente o consumidor de turismo deve pagar seus gastos antes do consumo; 
- A qualidade do produto turístico estará sempre comprometida pela multiplicidade de contatos diretos entre a empresa e o cliente;

- A lei da utilidade marginal decrescente não é aplicável ao fenômeno turístico. As viagens de turismo formam parte daqueles produtos cujo consumo é estimulado pelo próprio consumo.

Estas características dão ao turismo uma alta complexidade. O turista desloca-se do lugar habitual de residência para desfrutar de outro lugar, que muitas vezes só conhece pelos meios de comunicação. Espera obter produtos e serviços que satisfaçam suas necessidades e desejos. Para consumir o produto turístico como tal, requer-se a participação de múltiplas empresas e pessoas, que nem sempre têm os mesmos padrões de qualidade. Desta forma, a estada num lugar pode ficar arruinada por um tratamento indevido no aeroporto, ou porque alguns dos elementos que compunham o "pacote" não foram bem coordenados. Estas características são as que aumentam a complexidade nas empresas turísticas para o desenho de suas estratégias competitivas, já que, para conseguir um adequado posicionamento no mercado, a empresa deve considerar que faz parte de um sistema, e adequar sua oferta a essa característica.

O produto turístico é constituído do trabalho de muitas empresas, que nem sempre se relacionam entre elas. Para identificar quais empresas podem ser consideradas como "empresas de turismo", segundo KRIPPENDORF (1971), basta selecionar aquelas que fornecem, não importa de que maneira, bens materiais ou serviços turísticos, que servem diretamente à satisfação das necessidades dos turistas, e, que durante a distribuição entram em contato com eles. Como as necessidades são heterogêneas e múltiplas, as empresas assumem maior ou menor grau de importância para o turista em função do grau de satisfação que a mesma lhe proporciona.

KRIPPENDORF (1971) elaborou umas relações, apresentado no Quadro 1, que reúne os principais grupos de necessidades turísticas, de um lado, e, de outro, as principais empresas capazes de satisfazê-las. 
Quadro 1: Necessidades/Empresas Turísticas.

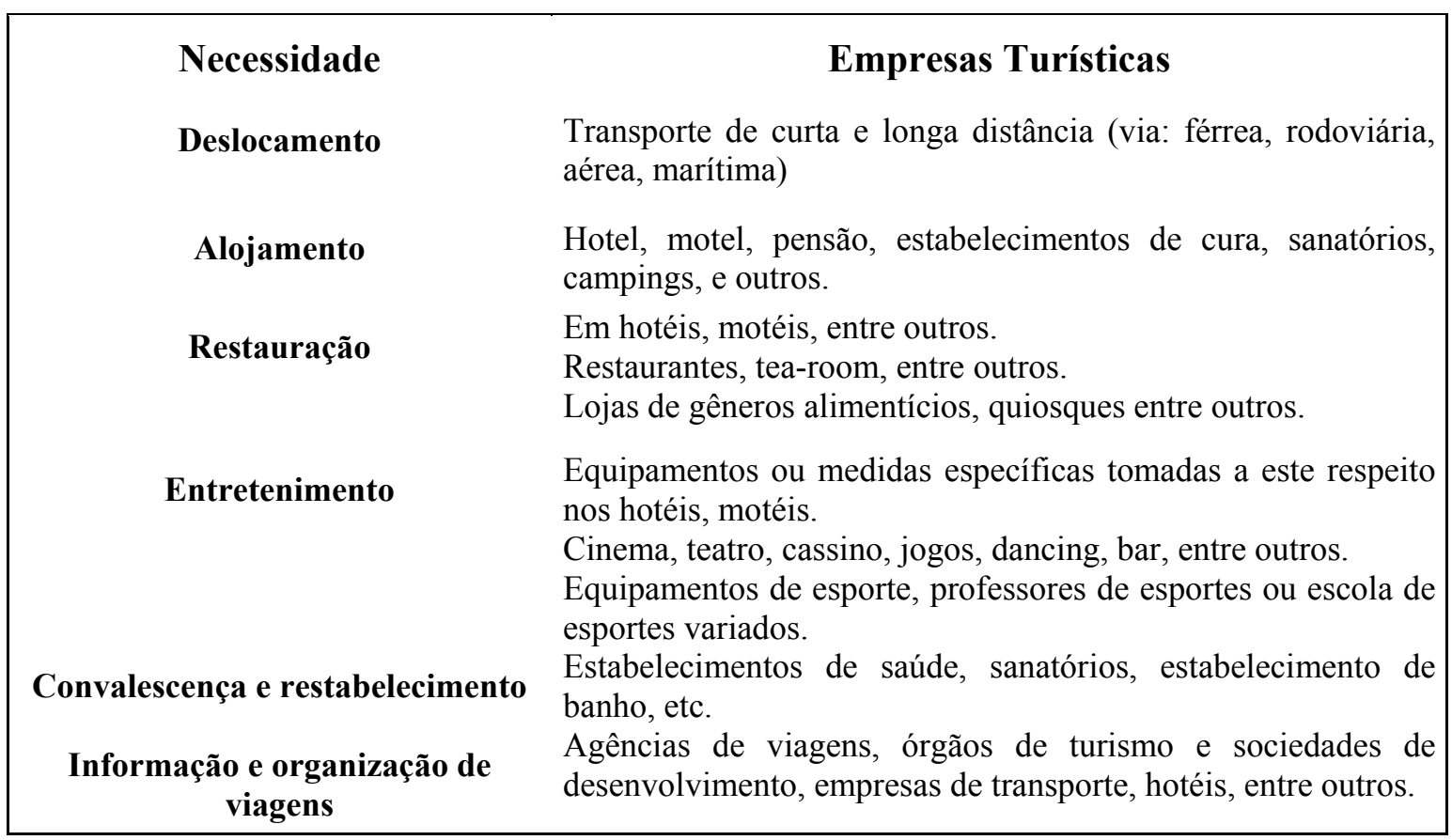

Fonte: KRIPPENDORF, J. Marketing et Tourisme, 1971.

Desta forma, as inter-relações dentro do Subsistema de Operacionalização podem ser refletidas segundo a Figura 2, onde se pode apreciar como são estabelecidas as conexões internas do sistema entre seus dois subsistemas, o sujeito e o objeto, assim como as influências recíprocas entre o Sistema Turismo com os demais sistemas, na forma de inputs (entradas), e as influências exercidas pelos demais sistemas no turismo e outputs (saídas), como também, as influências do turismo nos demais sistemas.

São as relações sujeito-objeto no turismo, que estabelecem a relação produtor-consumidor. $\mathrm{O}$ ponto de partida para um adequado posicionamento dos produtos da empresa é o cliente, o qual é válido para quase todo tipo de empresas. Raramente está eficientemente aplicado no setor turístico, devido à intangibilidade da oferta turística e seu consumo. Por isso, é decisivo o papel das empresas de intermediação no turismo, que em muitos casos são as verdadeiras produtoras da oferta propriamente dita, ao menos por criar a ilusão, ou, simplesmente, porque são capazes de comporem as distintas opções oferecidas pelas empresas receptivas, de forma de satisfazer os mais variados desejos e interesses. 
Figura 2: Estrutura do sistema turístico.

\section{ESTRUTURA DO SISTEMA TURÍSTICO}

Sistemas sup erior es

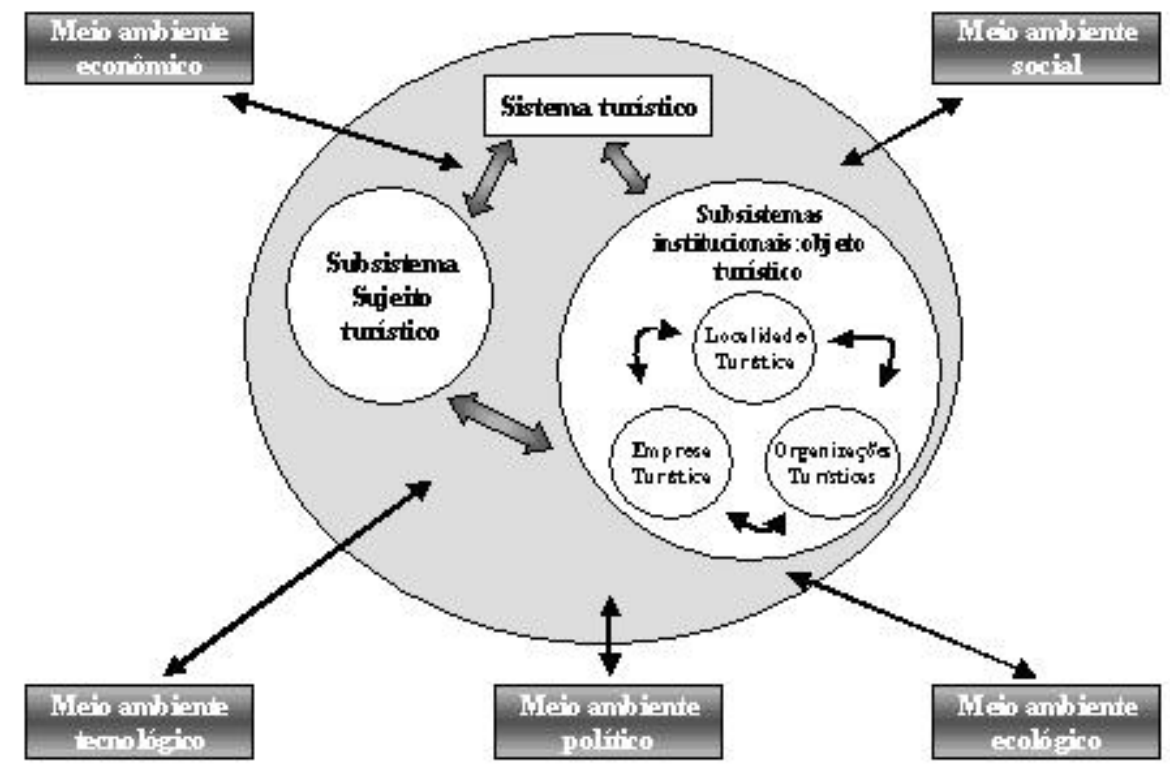

Fonte: Revue de Tourisme, n. 4/76, p. 3.

\section{Organização turística: agentes e facilitadores}

As principais empresas turísticas a destacar são:

Agências de Turismo: definidas assim, segundo a legislação brasileira de turismo. As agências de turismo classificam-se em duas categorias: 1. agências de viagens e turismo e 2. agências de viagens. São empresas comerciais que têm a finalidade de organizar viagens, oferecendo todas as prestações de serviços relativas aos transportes, hotelaria e manifestações turísticas de todos os tipos. Organizam viagens individuais e coletivas a um preço determinado, seja por programas estabelecidos por estas mesmas, seja pela seleção dos próprios clientes, como indica a Figura 3.

1. Agências de viagens e turismo: correspondem ao conceito de "operadoras turísticas", conhecidas internacionalmente como "tour operadores". As operadoras efetuam contratos com hotéis, cadeias de hotéis, transportadoras, empresas de serviços recreativos, de saúde, de eventos científicos, em dependência dos estudos das necessidades dos clientes previamente efetuados. Assumem o risco de lotar as vagas solicitadas, em vez do hotel ou da transportadora, que não se arriscam em vender suas ofertas. As operadoras turísticas para comprar grandes quantidades de serviços das empresas prestadoras básicas, e de assumir os riscos pela não ocupação, obtêm preços preferênciais, abaixo dos preços de lista; 
2. Agências de viagens: oferecem os serviços de assessoria, organização de viagens e promoção diretamente aos turistas potenciais, provocando a venda, segundo os desejos dos mesmos. A loja de venda direta situada no lugar de residência habitual dos potenciais consumidores é considerada como empresa varejista.

Empresas de Transporte: o transporte é essencial para a existência do turismo como fenômeno. Para que exista deslocamento existirão os distintos meios de transportes, segundo a distância da viagem e os desejos dos turistas. Cada uma das modalidades de transporte possíveis possui inúmeras empresas prestadoras de serviços. Cada uma delas com seus próprios canais de distribuição, semelhante ao setor hoteleiro. Ainda que todos os tipos de transporte tenham importância para o turismo, é o transporte aéreo que tem tornado possível o desenvolvimento internacional do turismo massivo na atualidade. O avanço científico presente na aviação é de vital importância para reduzir o tempo em que se alcançam as mais longínquas distâncias. Também o transporte terrestre, nas localidades turísticas, complementa em grande medida o empenho para satisfazer aos turistas. Formas de transportes confortáveis, seguros, eficientes e a preços acessíveis, possibilitam um pleno desfrute aos turistas, que visitam uma localidade dada.

Figura 3: Subsistema de distribuição do SISTUR.

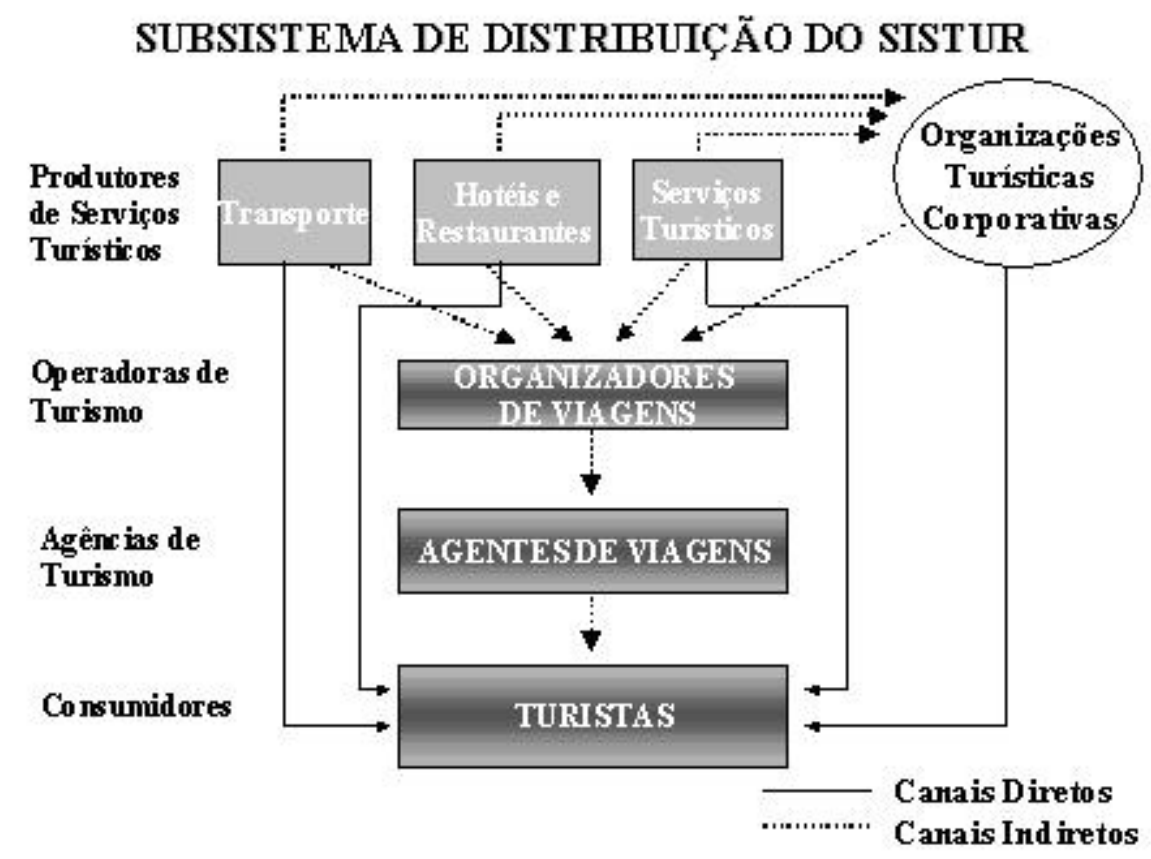

Fonte: J. Krippendorf, op. Cit

A empresa hoteleiras: sua situação na atual fase de globalização

Segundo CASTELLI (1984), "a hotelaria é uma empresa que oferece serviços que podem agrupar-se em: hospedagem, alimentação e lazer". Apesar do progresso tecnológico das últimas 
décadas, o serviço pessoalizado na empresa hoteleira continua sendo o mais apreciado pelo turista. Tomando-se como foco a empresa hotelaria, segundo uma visão sistêmica, cada um dos departamentos de um hotel forma um todo estruturado, que têm por objetivo principal satisfazer às necessidades e desejos de seus hóspedes. Além disso, a empresa hoteleira se inter-relaciona com outras empresas afins, como agências de viagens, transportadoras, empresas de congressos, serviços médicos, e outras que intervêm na atividade turística. O suporte básico deste todo denominado hotel é formado de pessoas, equipamentos, funções e instalações. O elemento humano tem predomínio sobre os demais. A Figura 4 mostra a inter-relação da empresa hoteleira com as outras empresas que compõem o Sistema de Turismo.

\section{Figura 4: Subsistema de produção do SISTUR.}

\section{SUBSISTEMA DE PRODUÇÃO DO SISTUR}

Relações de Interdependência

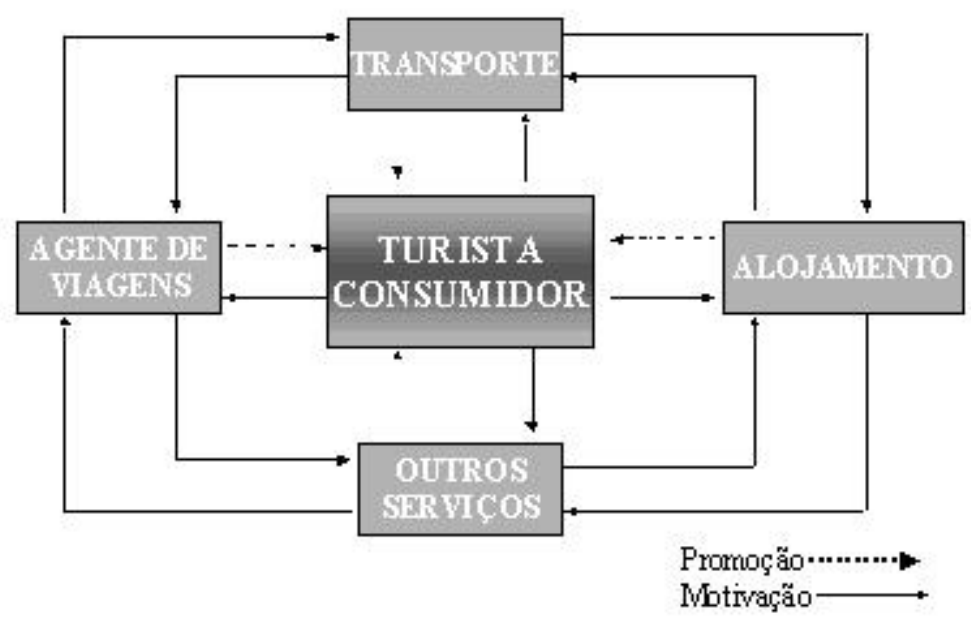

Fonte: Nestor Fermandez Vertti, CICATUR, México, 1977

Uma característica do Sistema de Turismo é que as empresas intermediárias ou distribuidoras, na maioria dos casos, são as que estabelecem os parâmetros de serviços que desejam para seus clientes, e os obtêm a preços muito abaixo dos preços de lista, ou seja, aqueles oferecidos ao cliente direto, baseados no risco assumido e na garantia de uma ocupação maior. As operadoras turísticas, além de intermediárias, são também produtoras de serviços turísticos, pois compõem pacotes segundo os desejos dos potenciais clientes; para isso, se requer um profundo conhecimento do mercado e seu funcionamento. Estas empresas normalmente estabelecem acordos de parceria com linhas aéreas, cadeias hoteleiras, transportadoras terrestres, criando, assim, toda a infra-estrutura necessária que lhes permite obter a melhor margem de lucro. Um país ou região que aspire obter seu desenvolvimento pela via do turismo terá que considerar a 
possibilidade de conseguir ter suas próprias operadoras turísticas e, assim, conseguir as melhores margens de lucro e melhoramento competitivo para o fomento da região.

\section{A empresa hoteleira. Sua situação na atual fase da globalização.}

GALLEGO (1996) destacou que, “encaminhamo-nos para um novo século, estamos deixando para trás o período pós-industrial dos anos setenta e cada vez nos encontramos mais perto da era dos serviços, das novas gerações da eletrônica, da biotecnologia, e de todo um mundo novo que se vai abrindo ante os olhos perplexos dos homens, que vivem as contradições das grandes maravilhas e das grandes misérias. Esta nova etapa, que se iniciou nos anos oitenta e que ainda está sem se definir, forma parte de um futuro incerto, mas que tem algumas características claramente determinadas que nos afetam da seguinte maneira: 1. os traslados cada vez mais freqüentes de milhões de pessoas de uns lugares a outros, por motivos muito diversos, através de meios de transportes cada vez mais rápidos e mais sofisticado; 2. a possibilidade de comunicação instantânea, vendo, ouvindo, falando, ordenando, informando-se etc., de um lugar a outro do planeta; 3. a necessidade básica de se alojar para o descanso daqueles que em seus deslocamentos vão permanecer fora de seu lugar de residência. Aqui começa o turismo. Estes três aspectos interessam, sem dúvida, ao que poderíamos denominar "indústria do alojamento". Em primeiro lugar, porque se nestes momentos têm-se mais de 500 milhões de pessoas formando parte do fluxo turístico, nos próximos anos aumentaria, pois o transporte será mais fácil e mais aberto. Na próxima década, chegar-se-á a dobrar esta cifra.

Em segundo lugar, a facilidade das comunicações servirá para fomentar um maior interesse por ver, descobrir, visitar novos espaços, paisagens e culturas.

E, por último, os alojamentos turísticos e os hotéis em geral seguirão representando essa segunda casa, que irá perfilando-se com as necessidades que irão tendo seus futuros clientes”.

Nota-se que a hotelaria moderna nasceu em finais do século XIX e início do século XX. Era a época dos complexos hoteleiros nos balneários, os grandes palacetes nas cidades mais importantes, posta em marcha as primeiras marcas geoturísticas. Eram alojamentos destinados a prestar serviços à grande burguesia, e, por isso, essas organizações caracterizavam-se pela verticalidade, a hierarquia, a organização em departamentos e o luxo com um serviço pessoalizado à semelhança de seus padrões de consumo, acessíveis somente a uma minoria rica. A partir do ano de 1971, quando se produziu a primeira crise do petróleo, que originou uma crise econômica de envergadura, é que os hotéis se ressentiram desta situação e se deu início à primeira conversão empresarial, dando lugar à reduções de pessoal, com o objetivo principal de 
baixar os custos. Este fato voltou a se repetir nas sucessivas circunstâncias de instabilidade econômica, e na década de 80 é que as mudanças nos hotéis responderam mais a uma mudança de enfoque em suas estratégias, com a simples redução de pessoal.

As contínuas inovações tecnológicas começaram a ser assimiladas atualmente pelo setor, ocorrendo transformações mais estruturais, porque mudaram também as expectativas e interesses dos clientes.

Dados da OMT mostraram que em 1996 existiam, no mundo, 26 milhões de camas de hotel. Entre 1980 e 1996, a capacidade mundial de alojamento, expressa em número de camas, aumentou quase um 58\%, passando por uma taxa anual média de 2,9\%, de 16 milhões para os 26 milhões atuais. A taxa mais alta de aumento da capacidade de alojamento expressa em número de camas, correspondeu à Ásia Oriental e ao Pacífico, com um aumento de 3,1 milhões de camas entre 1980 e 1996 para uma taxa anual média de 10,8\%.

Em termos comparativos, a Europa ofereceu a maior proporção de camas (44\% em 1996), seguida pela América (35\%) e Ásia Oriental/Pacífico (15,2\%), como se pode apreciar nos dados contidos na Tabela 7

Segundo a Associação Internacional de Hotéis e Restaurantes, esta indústria gerou, em 1995, um total mundial estimado de US\$ 253.000 milhões. A Europa ficou com a maior parte $(39,5 \%$ e 100.000 milhões), seguida pela América (32\% e 81.000 milhões).

$\mathrm{O}$ número de estabelecimentos hoteleiros também correspondeu à Europa a primeira posição ( 171.123 equivalentes ao 55\% dos hotéis registrados no mundo). A América ocupou o segundo lugar (87.969 hotéis, 28\%). A quota hoteleira da Ásia Oriental/Pacífico foi a mais modesta, embora de maior crescimento relativo.

Uma boa parte desses milhares de hotéis existentes conta com estruturas muito rígidas, condicionadas pela própria origem da empresa hotelaria. A hierarquia das profissões/ocupações são determinadas, de escalão em escalão, de forma rígida, até o vértice da pirâmide. Por outro lado, seguindo-se com esquemas fechados, o hotel organiza-se funcionalmente em departamentos que trabalham, diz GALLEGO (1996), “como estados independentes”, e assim estabelecem-se regras que freiam a participação e o trabalho sinérgico em equipe.

Ao mesmo tempo, as profissões/ocupações em hoteleira estão divididas por tarefas muito especializadas, baseadas em esquemas clássicos franceses e suíços. Somente nos finais da década de 80 que nos estabelecimentos hoteleiros apareceram novos conceitos e técnicas de sua aplicação; e, sem dúvida, influenciou nos organogramas e nas profissões/ocupações dos estabelecimentos hoteleiros. Assim, a qualidade em todas as suas dimensões, o tele-marketing, 
os sistemas de comercialização agressivos, os sistemas de reservas, a contratação de terceiros para a realização de tarefas antes desempenhadas pelo próprio hotel, o avanço nos produtos de alimentação cada vez mais aperfeiçoados, as centrais telefônicas digitais, a incorporação da informática à hotelaria até chegar aos chamados "hotéis inteligentes", são exemplos claros das mudanças e inovações que estão ocorrendo e devem generalizar-se nas empresas hoteleiras de hoje.

Na última década, as transformações nas empresas têm sido múltiplas, as mudanças produzem-se em grande velocidade e esta sensação de mudança contínua é percebida também pelos clientes, de forma tal que se pode afirmar que a empresa voltada unicamente a seu funcionamento está morta, já que a relação entre o cliente e a organização necessita de maior amplitude e abertura para satisfazer a ambos. Os clientes de hoje e de amanhã querem ter claro o valor diferenciado dos produtos/serviços que recebem ou vão receber. Tudo isso origina mudanças no interior da empresa hoteleira que deve incorporar como filosofia o tipo de "organização por processos orientados ao cliente", e não o de "funções", para ter um desempenho satisfatório. Os processos de trabalho desenvolvem-se criando produtos/serviços com valor para os clientes e, portanto, as atividades que os trabalhadores realizam têm que ter este objetivo.

É necessário destacar os impactos que a globalização tem na indústria de hotelaria. Em primeiro lugar, em termos de integração das empresas hoteleiras, tem favorecido um grande crescimento de cadeias internacionais, que operam nos diferentes destinos turísticos, conforme pode ser apreciado na Tabela 8, que reflete a concentração de hotéis nas maiores cadeias hoteleiras do mundo.

Em segundo lugar, em termos de transferência de tecnologia e de padronização dos processos, que consegue alcançar níveis de qualidade semelhantes em destinos, e com diferentes graus de desenvolvimento.

Em terceiro, porque para os países em desenvolvimento tem significado um financiamento necessário para o desenvolvimento mais acelerado do turismo e desenvolvimento econômico da região. Entretanto, existe o perigo de que o dinheiro investido por essas grandes cadeias hoteleiras nem sempre seja reaplicado no fomento da região em benefício direto da população. 
Tabela 8: As maiores cadeias hoteleiras no mundo em 2000.

\begin{tabular}{|c|c|c|c|}
\hline \multicolumn{2}{|c|}{ RAHIKING COLPAA1A } & N' HOTELES & $N^{\circ} \mathrm{HAB}$. \\
\hline 1 & CE HLAIIT CORP. & 6.315 & 542630 \\
\hline 2 & BASS HOTELS \& RESORTS & 2.886 & 471680 \\
\hline 3 & MARRIOTT INT ERNATIONAL & 1.888 & 355.900 \\
\hline 4 & ACCDR & 3.134 & 354652 \\
\hline 5 & CHOICE HOTELS INTERNATIONAL & 4.248 & 338254 \\
\hline 6 & BEST WESTERN INTERNATIONIAL & 4.037 & 313247 \\
\hline $\mathrm{T}$ & HILTON HOTELS CORP. & 1.700 & 290.000 \\
\hline 8 & STARWOOD HOTELS \& RESORSTS & 716 & 217651 \\
\hline 9 & CARLSON HOSPITALITY & 616 & 114.161 \\
\hline 10 & SOL MELIÁ & 420 & 103274 \\
\hline 11 & HYATT & 195 & 85.743 \\
\hline 12 & SOCIÉTÉ DU LQUVRE & 990 & 65.970 \\
\hline 13 & HILTON INTERNATIONAL & 217 & 61889 \\
\hline 14 & FORTE HOTEL G ROUP & 449 & 58636 \\
\hline 15 & FELCOR LODGIMG TRUST & $18 \mathrm{~B}$ & 50.000 \\
\hline
\end{tabular}

Fonte: Revista Fortune, 1999.

\section{O papel dos tour operators (agências): canais de distribuição ou empresas produtoras?}

O reconhecimento do papel das operadoras turísticas e agências de turismo, segundo a legislação brasileira, foi interpretado de maneira diferente por diversos autores. Têm-se desde os enfoques mais tradicionais, que as situam como empresas intermediárias, ou empresas varejistas no canal de distribuição, até os que a colocam na categoria de produtoras, pois são as que oferecem o único e verdadeiro produto turístico. É a operadora ou a agência de turismo responsável pela organização de uma viagem de ida e regresso do lugar de residência habitual até um destino determinado, para satisfazer os mais variados interesses e necessidades.

Turismo é basicamente deslocamento temporal de ida e volta, para visitar outras cidades e países, com fins bem determinados. Isto supõe que se poderão mudar os hábitos de consumo, os interesses e motivações para viajar, as vias para organizar os pacotes turísticos, os meios de transporte, que estão se tornando cada vez mais confortáveis, seguros e rápidos. No entanto, o hotel seguirá ainda como tendo um lugar imprescindível para o descanso e o prazer nas viagens. Precisará, então, adequar-se cada vez mais, de acordo com as necessidades de seus futuros hóspedes.

A literatura sobre turismo e marketing turístico, apresenta uma contradição ainda não resolvida sobre quem são os produtores e os distribuidores em turismo. Reflete sobre o papel outrogado às agências de viagens e às operadoras turísticas. Alguns autores colocam estas empresas na linha da distribuição e outros como os verdadeiros produtores. Entre estes últimos está MUÑOZ (1990) que seguiu como 
critério partir da definição de produto turístico, para concluir que as empresas que desenvolvem este produto para o mercado, como oferta turística integrada, são as que constituem o setor produtivo. Seguiu-se, assim, o critério de oferta empregado na teoria econômica clássica. Então, "empresas turísticas são, conseqüentemente, aquelas que se dedicam a produzir planos de deslocamentos de 'ida e volta' para serem oferecidos no mercado, com determinada especificação de qualidades, preços e formas de pagamento; segundo este enfoque alternativo, as empresas turísticas são as chamadas operadores turísticas ou agências atacadistas".

A operadora turística, do inglês tour operator, literalmente quer dizer 'organizador de roteiros turísticos', e constitui um sistema integrado de empresas sob um único centro de decisões, que abarca um conglomerado de atividades, agências de viagens, companhias de transportes, acolhida hoteleira, serviços dazer, entre outros.

As operadoras turísticas têm sido fundamentais para impulsionar o turismo de massa em escala internacional, ao mesmo tempo que sobre elas têm recaído numerosas críticas, pelo fato de que grande parte dos benefícios de sua atividade fica em seus países de origem.

O esquema de relações de troca no turismo, segundo MUÑOZ (1990), refletiu graficamente, conforme Figura 5, tanto as relações comerciais de empresas, como as que têm lugar entre estas e a demanda final, incluídos os auto-consumidores.

Neste esquema, a teoria convencional do turismo estudou basicamente a relação de tipo A, conforme Figura 5. Ao restante das relações possíveis concedeu-se uma atenção escassa, a qual varia de um autor para outro. Geralmente, as operadoras turísticas passam despercebidas para muitos especialistas, sobretudo para os que estudam o turismo do ponto de vista dos países de acolhida. Para os que o estudam do ponto de vista dos países de residência, os tour operadores se dedicam a organizar "pacotes" de produtos, com referência a um espaço econômico, que é, ao mesmo tempo, lugar de residência habitual e lugar de acolhida. 
Figura 5: Esquema das relações de intercâmbio do turismo.

\section{ESQUEMA DAS RELAÇÕES DE INTERCÂMRIO DO TURISMO}

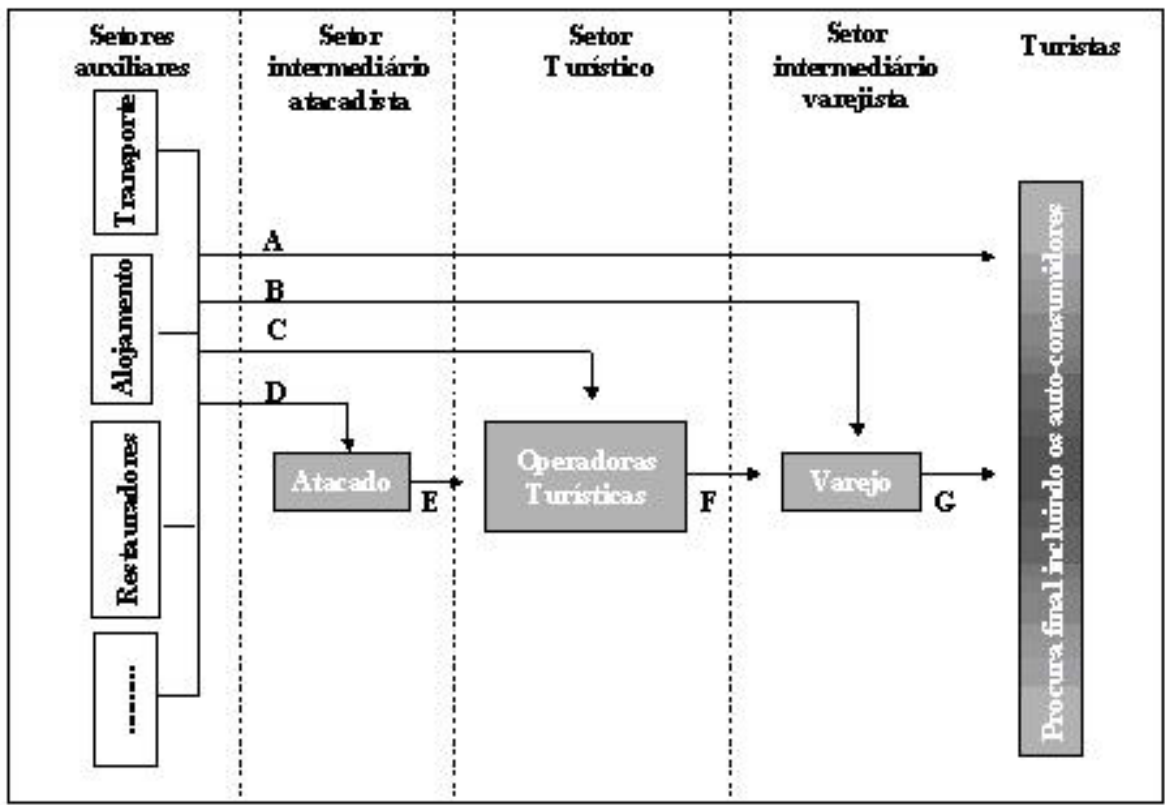

Fonte: Muñoz de Escalona, Tour-operadores e produção de turismo, Madrid, 1990

\section{Marketing turístico.}

O marketing, desde seu surgimento, foi aplicado aos produtos indústriais. Posteriormente, suas técnicas se estenderam aos serviços, principalmente bancários, e, ultimamente, aos serviços turísticos. Hoje, o produto turístico forma parte da produção massiva de bens e serviços, e, como afirma CASTELLI (1984), “um consumo em massa requer uma produção em massa; para ajustar permanentemente este consumo à produção é que surgiu o marketing turístico”. Neste sentido RUSCHMANN (1995) destaca que "a intangibilidade da experiência vivencial proporcionada pala viagem turística e as singularidades do produto fazem com que sua comercialização necessite de técnicas mercadológicas específicas -as do marketing turísticoamplamente estudado na Europa e nos EUA e, de forma incipiente, no Brasil."

$\mathrm{O}$ relativo atraso do marketing turístico deve-se, entre outras causas, aos fatores enumerados por SCHWARZ (1976):

O fator humano: os homens que asseguravam o êxito do turismo, no início, eram pessoalidades influentes, que conheciam bem a região sem possuir uma formação especializada. Na hotelaria foi onde primeiro se percebeu a necessidade da capacitação, criando-se instituições de ensino para preencher esta lacuna, tanto que existem instituições de ensino em hotelaria a cerca de cem anos. Embora em outras áreas relacionadas ao turismo não existissem qualquer tipo de 
preparação, pois era muito difícil a aplicação de técnicas atualizadas como o marketing, gestão estratégica, entre outras, que tivessem evitado a atuação totalmente empírica.

O meio: os centros turísticos eram conduzidos, nos primeiros tempos, basicamente pelas entidades turísticas (empresas, associações, poder público). Entre estas entidades nem sempre existiram interesses e visões comuns, o que dificultou a necessária integração para o surgimento do marketing turístico, em nível de cada localidade, ou clusters.

A estrutura: na maioria dos países o que existia no passado era um órgão de turismo encarregado de organizar o setor. Este organismo oficial, mediante instrumentos legais e de uma política turística, procurava ajudar os participantes do Sistema de Turismo, mas nem sempre se podia alcançar o necessário espírito de solidariedade para uma ação conjunta dos diferentes elementos do setor. Isto se deveu às diferenças de ordem jurídica entre os componentes do sistema (empresas privadas, mistas, estatais), que originavam diferenças na capacidade de resposta e rapidez de execução, o que repercutiu no desenvolvimento do marketing.

Os recursos financeiros: em quase todos os países receptores, os recursos financeiros de que se dispunham para aumentar o turismo eram limitados e muitas vezes mal administrados.

Hoje, como afirma COBRA (2001), em um ambiente globalizante, “as empresas de serviço precisam acompanhar a evolução tecnológica e o novo perfil dos clientes do século 21 , tendo um equipe de vendas profissionais capazes de identificar rápida e corretamente as necessidades e, principalmente propor soluções que atendam as necessidades, desejos e fantasias de seus clientes".

Tal como sucedeu com o marketing genérico, existem múltiplas definições de marketing turístico. Destacam-se as mais importantes:

KRIPPENDORF (1977) definiu o marketing turístico como " a adaptação sistemática e coordenada da política das empresas de turismo, assim como a política turística privada e do Estado, sobre o plano local, regional, nacional e internacional, buscando a plena satisfação das necessidades de grupos determinados de consumidores, obtendo com isto um lucro adequado";

ARAGAY e GRANDE (1978) consideraram que "é o conjunto dinâmico das atividades necessárias para o aprimoramento, criação, distribuição dos bens, produtos e serviços turísticos por qualquer ente com a finalidade de colocá-lo à disposição do consumidor ou do usuário para satisfazer suas necessidades, como, onde e quando o usuário turístico demanda”;

KOTLER (1995) definiu que "o marketing de lugares envolve as atividades empreendidas para criar, manter ou alterar atitudes ou comportamentos em relação aos lugares em particular. Como exemplos temos o marketing de lugares, de neglazers e o marketing de férias". 


\section{Particularidades do produto turístico}

Em geral, a literatura específica do turismo e em especial a de hotelaria busca adaptar as idéias e os conceitos gerais de marketing às peculiaridades do produto turístico, destacando essas diferenças de atributos do produto, como:

Produto/serviço é intangível: isto supõe que um cliente, de um hotel ou restaurante, uma vez que gasta seu dinheiro, não tem a possibilidade de mostrar fisicamente o que obteve em troca do mesmo, já que o que recebe é atenção, bem-estar, instalações, alimentos, entre outros. Tem um componente psicológico muito grande, por isso é decisiva a percepção que o cliente tem sobre o serviço recebido e o dinheiro gasto para obtê-lo;

Produto/serviço é perecível: isto supõe que, do ponto de vista empresarial, o fato de não vender uma habitação de um hotel hoje, significa que o lucro que ele poderia ter se perdeu para sempre;

Simultaneidade entre produção e consumo: o cliente não pode provar o produto/serviço antes de o consumir. Pela informação obtida é que são geradas as expectativas. Assim, o cliente é parte integrante do serviço, existindo uma interação entre ele e o provedor do mesmo. Isto em geral produz muita pressão sobre os hoteleiros e ansiedade nos clientes, que estão na expectativa sobre o que vai ocorrer, e o grau de satisfação que vão obter;

Produto/serviço é variável: isto significa que vai depender de quem o produz e quem o recebe. Por isto a necessidade de padronizar-se os procedimentos, sempre dando uma margem de liberdade necessária para atender cada cliente na medida de suas necessidades.

Estas idéias ficaram sintetizadas e refletidas na definição de VILAFRADERA (1969) sobre turismo, que "é um bem de consumo abstrato, imaterial, inapreensivel, invisivel que está integrado por elementos materiais, visíveis, apreensiveis entre outros."

São estas as características fundamentais do produto turístico que imprimem determinadas peculiaridades ao marketing turístico.

Em linhas gerais, além de considerar os atrativos naturais das regiões que motivam principalmente o desenvolvimento de fluxos turísticos, pode ser definida a oferta básica como o conjunto de equipamentos, bens e serviços de alojamento, de alimentação, de recreação e lazer, de caráter artístico, cultural, social ou de outros tipos, capaz de atrair e assentar em uma certa região, durante um certo período de tempo, um determinado público visitante. A oferta em turismo pode ser concebida como o conjunto de recursos naturais e culturais, que constituem a matéria-prima da atividade turística, porque, na realidade, esses são os produtos que provocam a afluência de turistas. A esse conjunto é necessário agregar os serviços produzidos, que integram a oferta num sentido amplo na estrutura de mercado. 


\section{A oferta turística}

Os diferentes enfoques do marketing turístico ocupam-se em caracterizar a oferta turística como tal. Além da heterogeneidade e da intangibilidade, como afirmou BENI (1998), alguns especialistas assinalaram que o produto turístico não pode ser normalizado pelo seu forte componente psicológico; outros falam do componente "sonho" do turismo. Vender turismo, dizem, é vender sonhos, e não é fácil que os sonhos possam ser padronizados.

Outros autores, como GRASSIELLI (1989) afirmaram que, "na produção de 'inclusive tours', alcançou-se já um grau bastante alto de normalização”. Referindo-se às viagens de turismo, este autor disse que o produto que o turista compra é, por exemplo, férias num alojamento confortável, num clima ensolarado da costa mediterrânea. Se estas características são respeitadas - assinalou - o nome da companhia aérea, o do proprietário do alojamento e o do país no qual se encontra a localidade, assumem um significado marginal e não representam, portanto, características do produto turístico que influíram substancialmente na decisão de compra. $\mathrm{O}$ autor apontou, assim, os critérios que o mercado estava utilizando para conseguir um nível adequado de normalização do produto. Encontrou-se o preço e, junto com ele, apareceram outros elementos, tais como, as técnicas incentivadoras (descanso, estudo, esportes, espetáculos, aventuras, congressos, saúde, museus, monumentos) e facilitadoras (transporte, alojamento, guias turísticos) utilizadas. Observando-se o tipo de destino intermediário que se propõe (cidade, campo, praia, montanha, mar), num país ou região determinados. Tratava-se de uma fórmula de normalização que, ao utilizar três critérios, além do preço, encontrava-se muito próxima da estimada pelo marketing para outros produtos.

Outros enfoques dentro do marketing turístico procuram trabalhar a noção de demanda no turismo. A satisfação que o turista procura pelo consumo de bens e serviços turísticos passa pela aquisição de experiências muito diversificadas, encontradas no consumo de diferentes componentes do produto, ou função de utilidade, segundo a linguagem da teoria econômica convencional. Como a viagem turística é um movimento entre dois pontos (emissor e receptor), a demanda turística é a demanda por esse movimento, e depende tanto das características relativas a esses dois pontos quanto do custo desse movimento.

A heterogeneidade é, portanto, a característica principal da demanda turística, pois as motivações para as viagens estão longe de serem idênticas. A estratificação estrutural da demanda não segue um modelo sistemático, baseado, por exemplo, em variáveis de ordem slazer-econômica, geográfica, de comportamento, entre outras. Não obstante, todas elas, são utilizadas para segmentá-la. Por isso, uma profunda análise das motivações faz necessária para se conhecer 
melhor o fenômeno do turismo e elaborar a oferta da melhor forma. É muito difícil segmentar um mercado segundo estes critérios que podem ser totalmente diferentes, tais como, ir ao encontro de uma cultura antiga (civilização, modo de vida, arte da época), a prática de esportes, recuperação da saúde, a busca de calma e repouso, ou turismo de neglazers entre outros.

Os autores mais centrados nos processos de decisão de compras do produto turístico, com ênfase no comportamento do consumidor, destacaram que as preferências dos consumidores, seus comportamentos de gastos, suas inclinações, em muitos casos, são definitivos na hora de programar suas férias e suas decisões de compras.

PLOG (1974) classificou em vários grupos os viajantes, em função de suas preferências, e estabeleceu uma escala que vai desde os consumidores, chamados "psicocêntricos", que são atraídos por certos destinos de ascendência familiar, até os consumidores "alocêntricos", que demandam lugares desconhecidos.

Todos esses critérios refletiam a complexidade dos enfoques e dos pontos de vista que estão na literatura sobre o marketing turístico. Portanto, é necessário ter conhecimento profundo disso como ponto de partida para alcançar um adequado posicionamento no mercado e competitividade pelas empresas deste setor. Assim, os enfoques diferem, segundo o ponto de referência dos autores, e uns casos consideram como critério de análise os países receptivos, em outros, os países onde residem habitualmente os turistas.

Este estudo centra sua atenção na competitividade das empresas turísticas dos países receptivos, como foi expresso anteriormente. $\mathrm{O}$ alto grau de massificação e padronização, que se aprecia hoje no mercado turístico vai em detrimento das empresas turísticas dos países receptivos. A produção de viagens turísticas integrais e sua oferta nos países de residência são, nesta perspectiva, a única forma de gerar desenvolvimento sustentável por meio do turismo.

\section{Segmentação do mercado turístico.}

São de total prioridade no marketing turístico os estudos de mercado e de segmentação. O motivo da viagem é a principal variável para segmentar o mercado. Assim, as principais motivações de viagens agrupam os seguintes fluxos turísticos, como turismo: de férias, de neglazers, de compras, desportivo, ecológico, rural, de aventura, religioso, cultural, científico, gastronômico, estudantil, de congressos, de convenções, de encontros e similares, familiar, de amigos, de saúde e médico-terapêutico dentre outros. Subdividem-se, então, cada um desses segmentos de mercado, dependendo dos fatores como renda, idade, sexo, ciclo de vida da família 
entre outros. Em geral, as particularidades de cada segmento têm em comum o consumir o mesmo tipo de elementos da oferta turística.

A oferta turística original é considerada como a matéria-prima, isto é, o elemento que a natureza oferece e que constitui os atrativos turísticos da região ou país. Assim, o clima, a montanha, a praia, a caverna, tornam-se bens com grande atrativos por meio de um processo de transformação, que os introduzem no circuito econômico.

O segundo componente é constituído pela oferta turística derivada, e tem como finalidade reagrupar, coordenar e facilitar o conjunto de prestações dos serviços oferecidos pelas empresas de turismo, a fim de satisfazer o turista. A oferta turística derivada é composta pelos transportes, pelas diversas formas de alojamentos, lazer e recreação, entre outras. Para satisfazer à demanda tem que haver uma combinação entre os diferentes fatores da oferta derivada e da oferta original. O consumo de todos esses elementos, tangíveis e intangíveis, realiza-se em momentos diferentes, uns interligados com os outros. E esse consumo temporal sucessivo só permite reconhecer antecipadamente o produto turístico no momento do consumo.

\section{Processo de planejamento estratégico no setor de turismo segundo os critérios de sustentabilidade.}

O planejamento estratégico é o processo que estabelece os grandes eixos do desenvolvimento turístico. ACERENZA (1986) o definiu como "o processo destinado a determinar os objetivos gerais do desenvolvimento, as políticas e as estratégias que guiarão os aspectos relativos aos investimentos, ao uso e ao ordenamento dos recursos utilizáveis com este fim". O autor, a partir dos estudos efetuados por especialistas como Gilmore e Brandenburg, propôs um esquema metodológico destinado a orientar o processo de planejamento estratégico em turismo, contemplando não apenas as decisões fundamentais, como também as condições particulares que devem ser levadas em consideração. Na prática, o planejamento estratégico implica tomar decisões quanto a três aspectos básicos:

a) definição dos objetivos e formulação da política;

b) determinação da estratégia de desenvolvimento;

c) especificação dos programas de ação.

De acordo com o esquema proposto por ACERENZA (1986), o desenvolvimento do processo de planejamento estratégico do turismo deve obedecer a uma determinada seqüência, compreendendo as fases descritas a seguir:

Fase A: análise da situação passada; 
Fase B: avaliação da posição do turismo: avaliação do turismo sob o aspecto de prioridades de desenvolvimento; avaliação da atitude da comunidade; avaliação das expectativas do setor turístico;

Fase C: formulação da política turística, levando em conta aspectos como satisfação do cliente, proteção ao ambiente natural, retorno para os investidores;

Fase D: determinação da estratégia indutora do desenvolvimento;

Fase E: especificação dos programas de ação;

Fase F: coleta de dados, avaliação e controle dos resultados operacionais.

O planejamento estratégico se completa com o planejamento operacional, que se refere a questões inerentes à execução dos diferentes programas destinados ao fomento e ao desenvolvimento do turismo, estando, pois, estreitamente ligado a aspectos orçamentários.

O turismo deve produzir desenvolvimento sustentável, como destacou MANNING (1993), para ter uma capacidade para ser líder, por ser multi-setorial, e dada a sua alta sensibilidade de distribuição de vários benefícios, em toda a comunidade anfitriã. Este desenvolvimento pode ser entendido como a conjugação de crescimento econômico com melhoria progressiva das condições econômicas, culturais e sociais do conjunto da população. Essa melhoria deve vir acompanhada de uma certa estabilidade e perspectiva de sustentabilidade desse processo considerando o meio ambiente. Trata-se de um conceito relacionado diretamente com inovação tecnológica (tangível e intangível).

O desenvolvimento, segundo BENI (1998), deve garantir e assegurar os componentes dos diferenciais turísticos, mediante o processo racional de exploração dos recursos ambientais naturais e de caráter histórico-cultural e temático-artificial. De acordo com esse conceito, no processo de ocupação espacial e de exploração dos recursos naturais deve-se assegurar a preservação máxima das características originais do meio ambiente. Na exploração dos recursos de caráter históricos-culturais requer-se que haja manutenção e restauração da integridade patrimonial e cultural, como permanente aproveitamento social. No desenvolvimento de recursos de caráter temático-artificial é necessário haver flexibilização do tratamento dos temas e aproveitamento do espaço com estrita observância da legislação ambiental. O mesmo autor ressaltou que a maioria dos conceitos desenvolvidos sobre turismo sustentável compreendia definições limitadas, porque só contemplavam recursos ambientais e econômicos, deixando de analisar a origem e a transformação do valor turístico intrínseco, e sua conversibilidade em renda por meio de produção, distribuição e consumo. Do mesmo modo, esses conceitos limitados não 
consideravam a participação da população residente no processo produtivo, razão pela qual, em geral, conduziam a modelos limitados de gestão do sistema.

\section{Variáveis que determinam a sustentabilidade do setor de turismo.}

RUSCHMANN (1994) ponderou que os impactos do turismo se referiam a uma gama de modificações ou seqüências de eventos provocados pelo processo de desenvolvimento turístico nas localidades receptoras. As variáveis que provocam impactos no meio ambiente têm natureza, intensidade, direção e magnitude diversas, apesar de os resultados interagirem e serem geralmente irreversíveis. Ressalta a autora que a complexidade das interações do fenômeno turístico quase sempre impossibilita medir o impacto total da atividade, devido a dificuldades metodológicas de seleção de indicadores, como da escolha das variáveis a serem levadas em consideração.

Segundo a OMT (1990), apud RUSCHMANN (1997), a evolução do turismo está condicionada às forças do mercado, constituídas pela demanda, pela oferta e pela distribuição dos produtos e serviços turísticos, e também pelas variáveis exógenas, fatores não relacionados diretamente com o turismo, mas que influenciam os seus fluxos. As variáveis consideradas na determinação das projeções para o desenvolvimento do setor são as seguintes:

— Variações demográficas e sociais;

—Evolução econômica e social;

- Oscilações políticas e de legislação;

- Progresso tecnológico;

- Evolução comercial;

- Infra-estrutura de transportes;

- Segurança nas viagens.

As dificuldades de obter estatísticas representativas desses fatores, fez com que a maioria dos estudos relacionados com a determinação de tendências selecionasse, basicamente, os fatores econômicos na composição de modelos, como apontou RABAHY (1990). Esse autor relacionou uma série de outros fatores quantitativos e qualitativos, que deverão ser considerados na elaboração de modelos econométricos de previsão turística.

\section{Planejamento estratégico das empresas de turismo.}

SECTUR, México (2000), elaborou um planejamento estratégico, sabendo que ele convergia para o pacote de diretrizes realizáveis, delineadas para manter ou tornar competitivo um produto 
ou destino determinado. Este, pois, tornar-se-á um marco de referência para todos os agentes públicos e privados, que atuam no setor de turismo dessa região.

INSKEEP (1994) assinalou que, como sistema interrelacionado, é importante que o planejamento turístico tenha por objeto o desenvolvimento integral de todas as partes do sistema, tanto os fatores da demanda e da oferta quanto os elementos físicos e institucionais.

O sistema funcionará com maior eficácia e os objetivos desejados serão alcançados se houver atuação de forma integral, de modo a desenvolver todos os seus componentes.

MILL, MORRISON (1985) e PLOG (1973) relacionaram estreitamente o conceito de planejamento estratégico com o de ciclo de vida do destino. O planejamento estratégico tratará o destino como um todo em seu ciclo de vida. Se não se praticar um planejamento estratégico adequado surgirão impactos físicos, como a alteração do meio natural e o problema de capacidade de carga. Os impactos humanos, como a falta de identidade cultural ou despreparo dos empregados para atender aos requisitos de hospitalidade; os impactos de marketing, como impossibilidade de explorar novas oportunidades ou inadequada imagem do destino; os impactos organizacionais, como a pouca cooperação entre os diferentes agentes econômicos individuais; e outros impactos, como a falta de atrações suficientes em carteira ou a baixa ou deteriorada qualidade da infra-estrutura, de equipamentos e de serviços.

Segundo SECTUR, México (2000), o setor de turismo impactou de modo relevante o processo de desenvolvimento sustentável da região, pelo que sempre se deve-avaliar seu custo-benefício, principalmente por consumir recursos naturais, produzir desperdícios de vários tipos, importar materiais e tecnologias estrangeiras à região, trazer cargas numerosas de turistas com identidade culturais diferentes da anfitriã, edificar em áreas vulneráveis e gerar assentamentos humanos de suporte para a atividade turística.

VALLS (1996) afirmou que são dois os requisitos essenciais de todo o planejamento estratégico em turismo: deve-se ser sustentável e consensual. A competição turística se estabelece atualmente entre clusters no mesmo ambiente dos neglazers. Para enfrentar a competição entre destinos, requer-se que os agentes econômicos, públicos e privados, de um determinado destino cheguem a um consenso quanto ao modelo de planejamento que proporcionam, melhor do que a concorrência pela satisfação dos clientes quanto ao uso do tempo livre.

VÁZQUEZ e TRESPALACIOS (1994) estabeleceram o processo de planejamento estratégico em turismo em três níveis ou fases:

1. O nível corporativo, "supra-empresarial", que abrange o âmbito global de um pólo ou país, destinado a manter o turismo de uma região a longo prazo, preservando e atualizando os fatores 
especiais que a tornam diferente de outros destinos. Este nível tem que levar em conta a redução dos impactos negativos e a potencialização dos impactos positivos;

2. O nível da unidade de neg-lazer, que se circunscreve à empresa turística e compreende as atividades relativas ao gerenciamento estratégico: delinear o mercado, identificar segmentos de consumidores, dimensionar a demanda, avaliar a rentabilidade, escolher uma estratégia de posicionamento e especificar as vantagens competitivas;

3. O nível operacional, que estabelece as ações necessárias para alcançar os objetivos propostos no planejamento estratégico, por meio das decisões que integram o composto de marketing: ajustamento do produto, fixação de preço, comunicação informativa e persuasiva, distribuição e logística, comercialização e pós-transação.

O planejamento de marketing, no setor de turismo, deve levar em conta as particularidades e as características dos serviços como, intangibilidade, perecibilidade e demanda flutuante, inseparabilidade e heterogeneidade. Essas características influenciam significativamente o processo decisório no campo dos serviços, conforme esclareceu TOLEDO (1978).

BENI (2000) acrescentou que, especificamente no setor de serviços de turismo, o produto final é sempre diferente e pode ser configurado com o auxílio do próprio usuário. Este deve, ainda, estar presente no local em que o serviço é proporcionado. Além disso, o serviço turístico apresenta outras peculiaridades como, segundo GALLEGO (1996), o pagamento antecipado, múltiplo e complexo, em razão das pessoas que intervêm no processo, oferecendo também uma utilidade marginal crescente.

O estudo do setor turístico, sob o enfoque sistêmico, e o exame detalhado do processo de PE dos agentes turísticos, permitem asseverar que, na era da globalização, para uma atuação estratégica bem sucedida, é indispensável que se incorporem novos elementos ao estudo e à prática do turismo, como: desenvolvimento sustentável, análise do comportamento dos turistas (atuais e potenciais), métodos de distribuição dos benefícios, cultura e identidade da sociedade anfitriã.

Compartilha-se a idéia de Sachs (1986) que o planejamento do desenvolvimento envolve a elaboração de políticas no intuito de moldar ou, pelo menos, influenciar a ação do homem em relação à "natureza" e a si mesmo, no processo de utilização do meio natural. O planejamento turístico deve ser para cada "ecorregião" e insistir nas soluções específicas de seus problemas particulares. Deve levar em conta os dados ecológicos da mesma forma que os culturais, as necessidades imediatas como também aquelas a longo prazo. Valls (1996) afirma que são dois os requisitos essenciais de todo o PE em turismo deve ser sustentável e deve ser consensual. 
Toledo, Alvarez e Castroman (2001) dividem em 4 módulos as diretrizes e atividades críticas a serem desenvolvidas por uma região turística, no processo de apropriação e consumo de espaços pelo turismo, para o desenvolvimento sustentável:

\section{Módulo i- Roteiro metodológico:}

1- Identificar todos os participantes (atores) ativos e passivos no processo de desenvolvimento;

2- Determinar os critérios, explícitos ou implícitos que sustentam as posições dos atores;

3- Determinar os problemas de cada um dos atores em função de suas necessidades e aspirações (prioridades);

4- Determinar diretamente ou por inferência os problemas, metas e objetivos de cada um dos atores (hierarquia);

5- Inventário, avaliação e diagnóstico físico e socioeconômico dos âmbitos territoriais e funcionais onde se pretende alcançar os objetivos. Análise da sustentabilidade ambiental;

6- Identificar as restrições técnicas, políticas, legais, econômicas, financeiras, organizacionais, funcionais, culturais, educacionais, comerciais, e outras que obstaculizem ou impeçam os objetivos. Hierarquia;

7- Gerar as opções de solução para superar as restrições previamente identificadas e hierarquizadas as soluções, Selecionar;

8- Delinear as estratégias para por em prática as soluções e ações de caráter descontínuo (projetos de investimentos) e contínuo (serviços, sistema de produção e outros);

9- Programar as ações (programas, projetos, atividades e tarefas) sob a base das soluções e as estratégias selecionadas, execução das atividades de controle e seguimento dos resultados obtidos;

10- Materializar as ações programadas em cada âmbito. Controle sistemático dos objetivos e da sustentabilidade ambiental. Manejo ambiental;

11- Reiniciar o ciclo em níveis progressivamente mais detalhados e precisos.

\section{Módulo ii- Articulação da iniciativa pública, privada e a sociedade civil.}

1- O nível Intitucional setorial, deve ser quem guia as diretrizes e políticas para criar o marco institucional. É conduzido pelos ministérios, secretarias, organizações de classe e outras identidades centrais que têm a responsabilidade de criar o devido marco legal e institucional, para que esta atividade tenha um desenvolvimento econômico com uma distribuição mais eqüitativa. Deve respeitar o meio ambiente, cultura e identidade local e facilitar a articulação das 
redes regionais com as redes internacionais como são organismos mundiais (OMT, BID, PNUD, entre outros);

2- O nível de grandes empresas, destinado a manter o turismo de uma região em longo prazo, preservando e atualizando os investimentos e financiamentos, tecnologias, e melhores práticas de gestão. Ajudam a cadeia de valor das pequenas empresas;

3- O nível de redes pequena e médias empresas, que se circunscreve à empresa do ciclo turístico regional e compreende as atividades relativas ao gerenciamento estratégico e atendimento do turista, mão de obra, hospitalidade do espaço e desenvolvimento local;

4- O nível social de participação da sociedade civil, que estabelece mediante sua participação, capacitação e controle das ações necessárias para alcançar os objetivos propostos no PE. São decisões que integram a temas referentes ao desenvolvimento ambiental e econômico-cultural da própria sociedade.

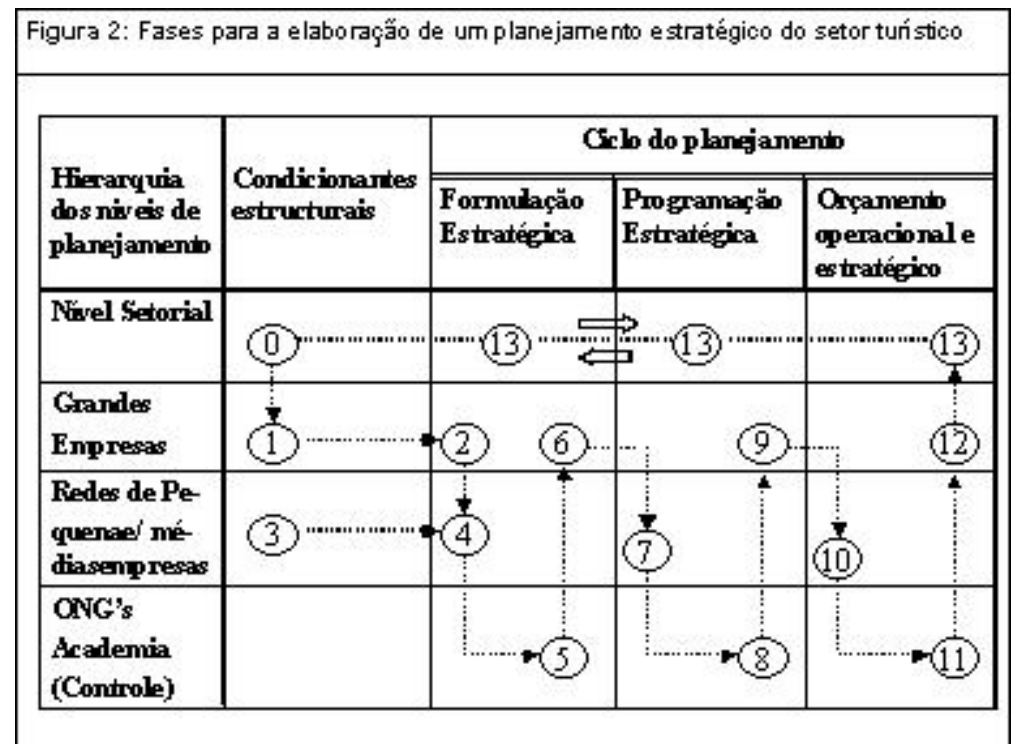

\section{Módulo iii- Perspectiva e análise da informação.}

Em vista do exposto, a estruturação e o funcionamento descrito para um PE deve ser integrado e incluir as seguintes premissas:

iii.1- Uma análise do turismo precisa ser tratada mediante enfoque sistêmico, pela forte interrelação de todos os elementos, agentes e forças que compõem o sistema. As iniciativas públicas, privadas e sociais são subsistemas a serem articulados.

iii.2- Estimular o desenvolvimento do pensamento sistêmico pelos administradores, de forma a integrar três níveis de pensamento no delineamento das estratégias de atuação, a saber:

- Primeiro nível: planejar, com base nos eventos ocorridos in loco. Geralmente, como explica Senge (1998), é com base nos eventos que as pessoas explicam situações, razão pela qual as 
ações são reativas, não obstante tais eventos serem evidências de padrões de comportamento dos elementos da realidade descrita.

- Segundo nível: analisar as tendências de longo prazo e avaliar suas implicações. Neste nível, é avaliado o comportamento passado das variáveis, buscando-se evidências que permitam prever seu comportamento futuro, o que pode ser feito com o recurso de indicadores. Neste caso, as ações figuram como resposta às tendências detectadas.

- Terceiro nível: procurar a compreensão estrutural da situação em questão, investigando as causas dos padrões de comportamento e buscando explicar a influência recíproca dos agentes do sistema. Este nível é o mais preciso e criativo já que permite as melhores intervenções para antecipar e delinear as estratégias.

iii.3- Variáveis a serem contempladas. Observa Acerenza (1986), que dada a grande quantidade de variáveis, freqüentemente se levantam muitos dados para concluir-se algo sem encadeamento lógico de valor estratégico para os agentes. $\mathrm{Na}$ análise sistêmica dos fenômenos complexos, como o setor de turismo, existem vários critérios para determinar as variáveis críticas aqui foi utilizado o método, propostos por Senge (1998), como:

1) Definir a situação complexa e suas inter-relações;

2) Apresentar a trajetória histórica do objeto estudado;

3) Identificar as variáveis críticas presentes no sistema;

4) Delinear o comportamento das variáveis críticas;

5) Identificar a influência das variáveis críticas e suas inter-relações;

6) Identificar modelos e padrões de comportamento;

7) Transformar os padrões em elementos do sistema modelado;

8) Desenvolver arquétipos que definam e tornem operacional o sistema;

9) Modelar por computador;

10) Reprojetar o sistema.

As variáveis críticas do Quadro I tiveram por base a revisão da literatura, e foram seguidas as linhas de análise dos estudos de Acerenza (1986), Manning (1992), Sachs (1986), Santos (2000), OMT (2000), SECTUR (2000), Yázigi (2001). 
Quadro 1: Variáveis de impacto e principais indicadores a levantar no planejamento participativo do turismo no processo espacial da globalização.

\begin{tabular}{|c|c|}
\hline Variáveis de impacto & Indicadores \\
\hline $\mathbf{X}_{1}$ - Macroeconomia: & $\begin{array}{l}\mathrm{X}_{11^{-}} \mathrm{PIB}, \mathrm{X}_{12^{-}} \text {Recursos disponíveis, } \mathrm{X}_{13^{-}} \text {Desenvolvimento da infra-estrutura, } \mathrm{X}_{14^{-}} \\
\text {Desenvolvimento de outras indústrias relacionadas, } \mathrm{X}_{15^{-}} \text {Estrutura de empregos, } \mathrm{X}_{16^{-}} \\
\text {Regulamentação estatal e incentivos para o fomento, } \mathrm{X}_{17^{-}} \text {Sistema tributário, } \mathrm{X}_{18^{-}} \\
\text {Desenvolvimento do setor de serviços, } \mathrm{X}_{19^{-}} \text {Desenvolvimento do setor turístico } \\
\text { existente, } \mathrm{X}_{110^{-}} \text {Balança turística, } \mathrm{X}_{18^{-}} \text {Organismos internacionais. }\end{array}$ \\
\hline $\begin{array}{l}\mathrm{X}_{2^{-}} \quad \text { Meio } \quad \text { ambiente } \\
\text { natural/artificial }\end{array}$ & $\begin{array}{l}X_{21-} \text { Recursos hídricos, } X_{22} \text { Recursos da flora e da fauna, } X_{23} \text { - Recursos históricos, } \\
X_{24} \text { - Recursos artificiais para atender o turista. }\end{array}$ \\
\hline $\begin{array}{l}\mathbf{X}_{3} \text { - Estrutura e } \\
\mathrm{PE}\end{array}$ & $\begin{array}{l}X_{31^{-}} \text {Processo, } X_{32^{-}} \text {Orientação e objetivos gerais, } X_{33^{-}} \text {Recursos, } X_{34^{-}} \text {Programa de } \\
\text { ação e prazos. }\end{array}$ \\
\hline $\begin{array}{l}X_{4}-\text { Supra-estrutura e infra- } \\
\text { estrutura }\end{array}$ & $\begin{array}{l}\mathrm{X}_{41^{-}} \text {Sistema nacional de turismo, } \mathrm{X}_{42^{-}} \text {Ordenação jurídico-administrativa, } \mathrm{X}_{43^{-}} \text {Serviço } \\
\text { de apoio à comunidade, } \mathrm{X}_{44^{-}} \text {Sistemas de acesso e transportes, } \mathrm{X}_{45^{-}} \text {Sistemas de } \\
\text { comunicações, } \mathrm{X}_{46^{-}} \text {Sistemas de segurança. }\end{array}$ \\
\hline $\mathbf{X}_{5}-$ Tecnologia & $\begin{array}{l}\mathrm{X}_{51^{-}} \text {Definição da estratégia, } \mathrm{X}_{52^{-}} \text {Orientação e objetivos gerais, } \mathrm{X}_{53^{-}} \text {Tecnologia de } \\
\text { Recursos Humanos, } \mathrm{X}_{54} \text { Prazos do planejamento de gestão tecnológica, } \mathrm{X}_{55} \\
\text { Posicionamento tecnológico pólo-cliente. }\end{array}$ \\
\hline $\mathbf{X}_{6}-$ RH e o sistema social & $\begin{array}{l}\mathrm{X}_{61^{-}} \text {Hospitalidade da população receptora, } \mathrm{X}_{62^{-}} \text {Nível de instrução da população } \\
\text { receptora, } \mathrm{X}_{63^{-}} \text {Índices de emprego da população, } \mathrm{X}_{64^{-}} \text {Renda per capita, } \mathrm{X}_{65^{-}} \\
\text {Capacitação da força de trabalho para desenvolver o setor. }\end{array}$ \\
\hline $\mathbf{X}_{7}$ - Mercado & $\begin{array}{l}\mathrm{X}_{71^{-}} \text {Oferta (produto turístico), } \mathrm{X}_{72^{-}} \text {Perfil da demanda do país emissor), } \mathrm{X}_{73^{-}} \\
\text {Empresas, } \mathrm{X}_{74^{-}} \text {Canais de distribuição. }\end{array}$ \\
\hline $\mathbf{X}_{8}$ - Turista & $\begin{array}{l}Z_{81^{-}} \text {Base de dados para relacionamento com o turista, } Z_{82^{-}} \text {Tipos de turistas, } Z_{83^{-}} \\
\text {Orientação da estrutura empresarial para o turista, } Z_{84^{-}} \text {Mensuração da satisfação do } \\
\text { turista, } Z_{85^{-}} \text {Valor agregado ao turista, } Z_{86^{-}} \text {Flexibilidade para o turista, } Z_{87^{-}} \text {Segurança, } \\
Z_{88^{-}} \text {Identidade cultural. }\end{array}$ \\
\hline Variáveis do $\mathbf{P E}$ & Indicadores \\
\hline $\mathbf{Z}_{1}$-Qualidade / hospitalidade & $\begin{array}{l}Z_{11^{-}} \text {Ambiente acolhedor, } Z_{12}-\text { Normas de Qualidade, } Z_{12^{-}} \text {Amizade, } Z_{13^{-}} \\
\text {Hospitalidade, } Z_{14^{-}} \text {Atenção individualizada, } Z_{15}-\text { Ajuda, } Z_{16^{-}} \text {Comodidade, } Z_{17} \\
\text { Identidade cultural do país emissor. }\end{array}$ \\
\hline $\begin{array}{l}\mathrm{Z}_{2^{-}} \text {Tecnologia } \\
\text { (tangível/intangível) }\end{array}$ & $\begin{array}{l}Z_{21^{-}} \text {Estratégia tecnológica, } Z_{22^{-}} \text {Tecnologia orientada para o cliente, } Z_{23^{-}} \text {Tecnologia } \\
\text { orientada para o processo, } Z_{24^{-}} \text {Tecnologia do país emissor. }\end{array}$ \\
\hline $\mathrm{Z}_{3-}$ Recursos Humanos & $Z_{31^{-}}$Capacitação, $Z_{32}$ - Motivação, $Z_{33-}$ Orientação para o cliente, \\
\hline $\begin{array}{l}\mathrm{Z}_{4^{-}} \quad \text { Posicionamento } \\
\text { mercado }\end{array}$ & $\begin{array}{l}Z_{41^{-}} \text {Segmentação, } Z_{42^{-}} \text {Posicionamento de mercado, } Z_{43^{-}} \text {Posicionamento psicológico, } \\
Z_{44^{-}} \text {Valor percebido pelo país emissor. }\end{array}$ \\
\hline $\mathrm{Z}_{5}$-Impacto Meio Ambiente & $\begin{array}{l}Z_{51^{-}} \text {Estudo de Impacto Ambiental (EIA), } Z_{52^{-}} \text {Relatório do Impacto Meio Ambiente } \\
\text { (RIMA), } Z_{53^{-}} \text {Capacidade e manejo de carga turística, } Z_{54^{-}} \text {Controle de flutuações da } \\
\text { demanda. }\end{array}$ \\
\hline $\mathrm{Z}_{6}-$ Recursos financeiros & $\begin{array}{l}Z_{61^{-}} \text {Orçamento, } Z_{62^{-}} \text {Análise de sensibilidade, } Z_{63^{-}} \text {Parcerias, } Z_{62^{-}} \text {Relação Custo- } \\
\text { benefício. }\end{array}$ \\
\hline
\end{tabular}


iii.4 Atividades que o marco institucional deve controlar no processo de apropriação e consumo de espaços pelo turismo. Além de propiciar o planejamento participativo da sociedade deve determinar para cada projeto:

1. Examinar cuidadosamente todos os efeitos significativos a montante e jusante das atividades do projeto;

2. Identificar para cada efeito os atores sociais envolvidos;

3. Saber seu posicionamento (ameaças, oportunidades). Hirarquizar-los;

4. A partir dos conflitos elaborar soluções comprometidas e consensuadas para as prioridades a curto e longo prazo da região;

Fazer conhecer as soluções. Recomeçar uma nova análise mais detalhada

\section{A competitividade e posicionamento no sistema de turismo.}

\section{Competitividade das empresas turísticas na atual fase da globalização. Clusters turísticos}

A globalização é uma referência constante nas discussões sobre as transformações econômicas que estão ocorrendo nos últimos anos. Envolve múltiplos e complexos aspectos, como a abertura das economias nacionais, a unificação dos mercados e a concorrência em escala planetária, possibilitada pelo avanço tecnológico nas comunicações e nos transportes.

Neste contexto mundial, a estratégia para uma inserção global estrutura-se a partir da competitividade, tornando-se assim, uma das preocupações centrais do governo e das empresas de todos os países. Sabe-se que os países não podem ser competitivos em todos os setores da atividade econômica. Suas distintas dotações de recursos, as características da população, suas culturas e instituições, assim como a história do desenvolvimento indústrial-social os fazem aptos para determinadas atividades. Nasce com a globalização, um binômio a ser cuidadosamente harmonizado nos países da América Latina: organização pública e iniciativa privada. Estes fatores devidamente trabalhados criam um ambiente favorável para o aproveitamento das vantagens comparativas regionais.

PORTER (1998) afirmou que na atualidade empresarial internacional manifesta-se o fenômeno que algumas fontes de vantagens competitivas tradicionais ficam anuladas, ou, ao menos, ficam com efeitos menores, pela facilidade de acesso que a globalização permite. Atividades como fornecimento de matéria prima, canais de comunicações, know-how para a gestão das empresas, informações para a toma de decisões, fluxo de capitais, facilidades alfandegárias e outras, ficam com maior facilidade e podem ser resolvidas por um simples click do mouse. O autor destacou que a busca de competitividade na globalização tem tido como resultado configurar o mapa 
econômico do mundo pelo tipo de arranjo empresarial que se denomina de clusters. Definiu-o como concentrações geográficas de empresas e instituições interconectadas além da competição entre elas. Suas características são: 1. ser um conglomerado multi-setorial, de empresas e organizações integradas sinergicamente; 2. produzir uma massa crítica que agrega maior valor mediante atividades conjuntas em seus portfólio de produtos; 3. estar localizado num lugar geográfico específico com uma original fonte para a competitividade; 4. estar por cima dos interesses regionais e nacionais; 5. ser típicos e diferenciados embora não únicos; 6. alcançar a vantagens competitivas por seus conhecimentos e inter-relações trabalhadas no âmbito local melhor que seus competidores globais; 7. estar integradas suas empresas verticalmente (incluindo aos canais de distribuição e clientes) e na horizontal (integração com manufaturadoras de produtos complementares, indústrias de tecnologia correlatas e fornecimentos comuns) obtendo como resultado uma configuração flexível e competitiva para o relacionamento duradouro com o cliente.

Um dos principais efeitos da globalização, no turismo, refere-se à alocação espacial dos investimentos em nível global com a criação de ambientes propícios para alcançar a competitividade. Na configuração atual das estratégias competitivas das empresas de turismo é necessário considerar as principais mudanças ocorridas:

1. Mudanças no setor: o desenvolvimento do setor constava de etapas bem diferenciadas até que, em 1841, Cook fez o primeiro tour registrado na história, sem fins lucrativos. Na atual fase, a concorrência desenvolve-se entre mega grupos altamente sofisticados e entre clusters turísticos. O setor inicialmente estrutura-se a partir da simples concentração aleatória de empresas em torno de algum atrativo turístico, com vantagem comparativa em nível da região (pólo turístico). Esta etapa, sem um planejamento racional de exploração dos recursos, como das necessidades da demanda, é baseada na concorrência predatória (principalmente em nível de preços e sustentabilidade dos recursos) entre as próprias empresas.

Hoje, existe a tendência crescente de que os elementos do destino integram-se, a fim de aprimorar a vantagem competitiva do pólo em seu conjunto, para promover a competitiva sustentabilidade dos recursos turísticos da região. Para isto desenvolve-se naturalmente a idéia de cooperação e integração entre os elementos da região aplicando-se o conceito de clusters desenvolvido em outros setores econômicos.

Neste sentido GUTIERREZ e BORDAS (1993) afirmaram que a concorrência nos mercados turísticos internacionais realizavam-se cada vez mais entre clusters turísticos, que são 
conglomerados de vários atrativos turísticos, infra-estruturas compatíveis, equipamentos, serviços receptivos, e a organização turística concentrada num âmbito geográfico.

Um cluster apresenta características intrínsecas na atual fase da globalização, pois integra com um objetivo comum a diversas instituições inter-setoriais que surgem da nova relação públicaprivada: entidades mistas, governamentais, não governamentais, universidades, de capacitação da força de trabalho, incubadoras de projetos, associações comerciais de classe, agências de informação, órgãos de pesquisa e de suporte técnico, entre outras. É formado por empresas independentes unidas, informalmente, para poder oferecer ao cliente vantagens diferenciadas. Constitui-se uma forma alternativa de organizar a cadeia de valor, através de redes de alianças e sociedades, entre as empresas, de forma tal a facilitar e aumentar a flexibilidade, para superar a rígida concorrência tradicional.

Este fenômeno de formação de clusters atrai naturalmente a presença de empresas competitivas relacionadas entre si, para um país ou região, tornando-se significativo para alcançar a vantagem competitiva do conjunto. A presença de indústrias internacionalmente competitivas tem um efeito de alavancagem que proporciona compradores sofisticados, interna e exteriormente, e estimula os serviços correlatos. Este tipo de arranjo obtém seu sucesso pela cooperação entre todos os seus integrantes, quando se consolida uma história bem sucedida de renome mundial, que passa a ter o efeito de atração competitiva seletiva.

Favorece-se pelo próprio interesse da coordenação entre as empresas atuantes, a entrada das realmente mais competitivas, eliminando as barreiras de entrada tradicionais. Com a entrada destes novos concorrentes, empresas complementares e demais fatores, produz-se um efeito multiplicador de melhoria contínua da eficiência e competitividade.

Como resultado têm-se: 1. melhores recursos humanos; 2. clientes mais qualificados e sofisticados; 3. indústrias principais e correlatas competitivas a nível mundial; 4. facilidades para financiamentos; 5. incentivos governamentais para o fomento da atividade; 6 . alianças ou coalizões estratégicas de nível global; 7. associações públicas-privadas pró-ativas; 8. incorporação de tecnologias de última geração.

HUNT e MORGAN (1995) definiram este ambiente cooperativo formado por grupos de empresas independentes que concordavam em ser parceiras, ao invés de adversárias, devido ao fato de que o sucesso individual de cada uma dependia do sucesso da cadeia de valor daquelas que perseguiam objetivos comuns integrados. Elas se engajavam em comportamentos cooperativos, com atividades coordenadas em cadeia de valores, como marketing, produção, finanças, compras, P\&D, logística entre outras. 
Segundo GUMMERSON (1999) estas forças levaram o conjunto de organizações a: 1. buscar soluções inovadoras e tecnológicas que possibilitam responder, a baixo custo, às preferências e hábitos de consumo fragmentados, com sistemas flexíveis de atenção e serviços complementares, que permitam a otimização em grande escala; 2. buscar um arranjo mais flexível para suas operações específicas que espelhe a diversidade; 3. otimizar a capacidade de captar e processar informação do mercado para responder com produtos e serviços inovadores.

Surge deste tipo de configuração organizacional uma nova perspectiva no planejamento estratégico das empresas, em que a concorrência tradicional agora necessita da cooperação entre empresas de diferentes setores, a fim de poder atender melhor ao cliente atual. O que é primordial é a formação de estratégias inter-setoriais, em que as ações passem a ser exercidas numa base coletiva consistente. A estratégia a ser escolhida pelas empresas devia estar em correspondência, segundo MINTZBERG e QUINN (1998), com a perspectiva de enxergar as coisas pelos integrantes que formam o destino, segundo seus modelos mentais e sua visão da concepção de como o mundo funciona na globalização. Uma estratégia de desenvolvimento de competitividade sustentável do destino turístico combinará os interesses empresariais, a curto e longo prazo, com os de crescimento sustentável da região, como um todo. Em face da globalização no setor de turismo, da mesma forma como ocorre em outros setores de atividade, torna-se aguda a tendência de a competitividade ocorrer no âmbito de clusters. GUTIÉRREZ e BORDAS (1993) ponderaram que a concorrência nos mercados turísticos internacionais se realizavam cada vez mais entre clusters. A existência do clusters justificava-se pelas alianças estratégicas entre organizações produtivas e oficiais, o que produzia efeito sinérgico, e a agregação de valor diferenciado ao produto turístico total. Pode haver vários tipos de configurações, dependendo das variáveis políticas, econômicas e tecnológicas, que, por sua concepção, permitam atingir resultados coletivos de difícil replicação ou imitação. Exemplos destas configurações são os clusters transnacionais no Caribe, Disney World, Polinésia, Costa Brava, museus da Europa Ocidental, ou a possibilidade, pouco explorada, do cone sul latinoamericano;

2. Qualidade e perfil do consumidor: o turista atual apresenta um comportamento como consumidor diferente do passado, pelo aumento de sua qualificação e experiência. Como destacou BENI (1998), busca-se a qualidade mais que a forma. Devido à sua qualificação e à grande oferta competitiva existente não se consumirá qualquer produto turístico. Ele possui maior poder de decisão, conhece da relação preço-qualidade dos produtos, a partir do valor que lhe agrega na satisfação de suas necessidades e desejos. A percepção da qualidade que o cliente 
possui conduz as empresas a elaborar estratégias de relacionamentos duradouros com ele, a fim de se conseguir sua fidelização. Este conceito, embora seja muito mencionado, ainda não é totalmente interiorizado nos objetivos estratégicos e táticos de gestão das empresas e, continuase utilizando, erradamente, a estratégia de crescimento da oferta como fator gerador de demanda, em muitas regiões com atrativos turísticos.

No turismo a estratégia de marketing de conquista dá lugar à estratégia de relacionamento com o cliente. Para obter a adequada orientação do cliente pelas empresas, desenvolveram-se as várias técnicas de análise de mercado, que têm como foco o comportamento do consumidor, procurando conhecer e antecipar suas necessidades, desejos, motivações, atitudes e expectativas, para assim poder cativá-lo com uma oferta, que o satisfaça integralmente. As diferentes empresas, a partir dos atrativos turísticos do destino, incorporaram diferentes tecnologias e serviços que fizeram possível o objetivo de desenvolver uma oferta diferenciada, concentrada na orientação à satisfação integral do cliente.

A partir destas mudanças constata-se que o consumidor turístico percebeu como melhor destino, aquele que lhe proporcionava uma oferta combinada dos produtos-serviços, e não a oferta por separado, como podem ser um hotel, praias, restaurantes, museus, e outros, que normalmente são oferecidos por prestadores diferentes e não inter-relacionados. O turista atual deseja que todos os serviços, e não só alguns, que ele consome, estejam em correspondência com os padrões de qualidade para sua satisfação. Estes estudos sobre o comportamento do consumidor turístico levam a considerar que, para assegurar sua satisfação, as empresas do destino, teriam que funcionar num arranjo de variados serviços e produtos inter-relacionados e integrados, num âmbito geográfico específico. Produzindo simultaneamente inúmeros produtos heterogêneos com os padrões de qualidade que lhe agreguem valor de forma superior aos concorrentes desta empresa.

3. Hospitalidade: na concepção de GALLEGO (1998), falar de planejamento estratégico ou, simplesmente, de gestão no setor de turismo, sem o conceito de hospitalidade, implicaria uma visão limitada. Para o autor, a consideração do cliente - o turista - como centro do processo é algo não incorporado e sedimentado junto aos agentes do sistema, embora seja muito mencionado. O princípio de atenção ao cliente e o conceito de valor percebido pelo cliente têm sua expressão concreta na forma como o destino turístico, em seu conjunto, e os participantes do processo de prestação de serviços, em particular, materializam o conceito de hospitalidade humana e ambiental. 
4. Novas legislações ambientalistas: MANNING (1993) considerou que a partir da Comissão Brundtland (Comissão Mundial sobre o Meio Ambiente e o Desenvolvimento, 1978), a Estratégia Mundial pela Conservação (1980), Agenda do Rio 92, entre outras, começaram a divulgação do "desenvolvimento sustentável" como um objetivo para a sociedade humana. Este conceito está sendo cada vez mais utilizado para nomear o uso dos recursos naturais, com a finalidade de criar uma atividade econômica sem comprometer a capacidade do meio ambiente humano, e, de produzir e conservar os recursos necessários para as gerações futuras. Atualmente, a etiqueta ecológica tem o poder de valorizar o produto turístico.

\section{A internacionalização das empresas de hotelaria. Análise das TOP TEN cadeias internacionais.}

\section{Estratégias de crescimento das cadeias hoteleiras - As alianças estratégicas como estratégia de crescimento}

Existem muitos tipos de alianças estratégicas, começando da mais simples, onde os diferentes hotéis se agrupam para utilizar o mesmo sistema de reservas e de marketing, até as mais complexas, onde não apenas os hotéis, como também outras empresas, como as agências de viagens, se unem em aliança, em uma tendência à integração vertical. A força de usar a aliança estratégica como meio de crescimento está em que rapidamente se pode aproveitar do reconhecimento da empresa por muitas multinacionais. Portanto, as alianças estratégicas estão se convertendo em uma prática importante de expansão, na maioria de indústrias, particularmente na turística, uma vez que as empresas estão cada vez mais globalizadas.

As alianças estratégicas se definem como «acordos a longo prazo entre empresas rivais, que vão além das transações normais de mercado, sem chegar a constituírem fusões» (Jarillo e Martínez, 1991); ou como «cooperação entre duas ou mais empresas, onde cada parte busca aumentar sua competitividade mediante a combinação de seus recursos com os de seus parceiros» (Dawson e Shaw, 1992).

Segundo Martorell (2002), as vantagens da utilização das alianças estratégicas na indústria hoteleira são:

- A habilidade que proporciona para responder às necessidades mutáveis dos consumidores.

- Os importantes lucros potenciais obtidos graças à ampliação do mercado, tanto em número de segmentos como geograficamente.

- Os custos de marketing podem repartir-se sobre uma base mais ampla, tornando mais eficazes e eficientes os esforços realizados para conseguir importantes economias de 
escala. Rápido reconhecimento de muitas marcas antes desconhecidas no mercado.

- Diminuição de muitos dos problemas de mão-de-obra e maior capacidade de gestão, assim como dos problemas associados com diferenças multiculturais, tão amiúde encontradas quando as empresas buscam sua expansão em novas áreas do mundo.

Em geral, pode afirmar-se que o setor hoteleiro está sofrendo um processo de crescimento relativamente à utilização de alianças estratégicas, tanto em nível operacional como estratégico. No primeiro nível produzem-se alianças, à medida que o setor avança em seu ciclo de vida; no nível estratégico estão aparecendo organizações com sistemas de reservas integrados e sistemas de comunicação comuns.

\section{Os consórcios como estratégia de crescimento}

Segundo Housden (1984), a natureza fortemente independente de muitos dos hoteleiros é a característica principal que diferencia o consórcio de qualquer outro tipo de aliança. Segundo o autor, o consórcio hoteleiro pode ser entendido como «proprietários de unidades independentes que se afiliam voluntariamente, buscando lucros ao ter acesso a recursos mais importantes do que conseguiriam por si mesmos». Litteljohn acrescenta que «seus objetivos se obterão mediante o estabelecimento de um escritório centralizado, cujas atividades se financiarão graças a um levantamento de recursos ou por subscrição dos hotéis membros do consórcio» (1982). Há quatro tipos básicos de consórcios (Slattery outros, 1985):

- Consórcios íntegros: estas organizações não apenas contam com especialistas em marketing e serviços, como também oferecem assistência no tocante a recursos humanos e financeiros.

- Consórcios de marketing: tais consórcios estão providos de expertos em marketing.

- Consórcios de reservas: esses consórcios proporcionam um sistema de reservas central baseado em um número de telefone gratuito.

- Consórcios de referência: eles baseiam-se em acordos de hotéis com empresas aéreas e seus sistemas de reservas.

O crescimento dos consórcios tende a provocar sua conversão em uma sociedade limitada ou corporação, mantendo os membros eleitos como um quadro de diretores.

Os consórcios internacionais compreendem estabelecimentos hoteleiros historicamente enfocados em uma clientela internacional; portanto, esses hotéis têm necessidade de pertencer a um consórcio que os ampare em assuntos relacionados à promoção e vendas, para melhorar a base de clientes internacionais já existente.

$\mathrm{O}$ auge do turismo, assim como o nascimento de novos "neglazer" turísticos, tem feito com que 
os hoteleiros independentes tendam a buscar novos mercados.

Pertencer a um consórcio internacional lhes tem aberto possibilidades de acesso a uma série de clientes, o que não seria possível caso os hoteleiros houvessem optado pelo esquema individual; proporciona, ainda, obter os conhecimentos de marketing necessários, além do que o processo proporciona redução de custo, graças às economias de escala que derivam do fato de pertencerem ao esquema. Dessa forma, os consórcios criam uma série de instrumentos essenciais de promoção, tais como escritórios de vendas internacionais e sistemas centrais de reservas.

Os hoteleiros independentes que fazem parte de um consórcio têm a possibilidade de utilizar algumas das estratégias levadas a cabo pelas grandes cadeias hoteleiras, especialmente no referente à criação de uma imagem de marca.

Os consórcios aspiram, tanto ou mais que os operadores das grandes cadeias, a um crescimento contínuo.

As atividades levadas a cabo pelos consórcios, são similares às conduzidas pelas grandes cadeias hoteleiras. Essas similaridades se concentram, essencialmente, na promoção e nos canais de distribuição.

Uma das principais funções da promoção, junto com o desenvolvimento e lançamento de campanhas publicitárias, é a criação de uma imagem de marca, o que se consegue estabelecendo o nome da marca e sua imagem, mediante logotipos e slogans na imprensa, rádio e outros meios de comunicação.

Os consórcios mais representativos da indústria turística são:

\section{Best Western lnternational}

Com sede em Phoenix, Arizona, a Best Western lnternational tem sido, em numerosas ocasiões, definida como uma cadeia hoteleira, mas, na realidade, não deixa de ser uma associação de hoteleiros independentes, de caráter não lucrativo, apesar de possuir sua própria central e sistema de reservas. A Best Western International tem em seu esquema um total aproximado de 4.052 hotéis e mais de 307.000 aposentos, distribuídos em cerca de 78 países, fato que a situa na sétima posição entre os TOP TEN mundiais. Esta associação, como já se mencionado, não se enquadra nos moldes convencionais de cadeia hoteleira, sendo suas metas algo diferentes das da uma cadeia convencional, a saber: não se centra unicamente no crescimento da empresa, anualmente rechaça uma grande quantidade de solicitações, mas a adequada expansão geográfica se considera muito importante. A força que possui em marketing e em vendas, cada vez mais importante, é o principal sucesso da organização. Cabe destacar que sua principal desvantagem é o fato de não ter informação completa sobre o perfil do mercado de seus hotéis membros. 


\section{Leading Hotels in the World}

A Leading Hotels in the World tem o programa de clientes freqüentes, reunindo aproximadamente 27.000 membros, e sua divisão destinada ao segmento alto do mercado, Prima Hotels, planeja acrescentar outra marca de hotéis de cinco estrelas, destinada ao segmento de luxo.

\section{Pegasus}

A Pegasus proporciona soluções tecnológicas de GDS a hotéis e outros segmentos relacionados com os neglazer de viagens, por meio de suas três divisões: TravelWeb, Disco e HCC. Além disso, a Pegasus processa reservas hoteleiras por meio da Internet, mediante seu próprio serviço de reserva informática "TravelWeb" e via "NetBooker". Durante o ano de 1997, acrescentou 5.000 hotéis a TravelWeb e NetBooker, somando um total de 8.700 estabelecimentos distribuídos por 140 países.

\section{Preferred Hotels Worldwide}

Trata-se de uma associação altruísta, que constitui um dos menores grupos, com um total de 120 estabelecimentos.

\section{Relais et Chateaux}

Organização de vendas e marketing, com sede em Paris, e com mais de 415 membros, a maior parte deles na França.

\section{Rezsolutions}

A Rezsolutions é o resultado da fusão, em 1997, entre a Utell e a Anasazi, empresas vinculadas ao neglazer de reservas e marketing. O objetivo de Rezsolutions é ser a primeira escolha da indústria hoteleira para sistemas tecnológicos, serviços de reservas e marketing. Possui um total de 25.000 hotéis, com 80 marcas e três milhões de aposentos. Atualmente a Rezsolutions gera quatro milhões de reservas ao ano.

\section{SRS-Worldhotels}

A SRS-Worldhotels foi conhecida como Steigenberger, ou SRS, até princípios de 1998. Em 1997, vendeu 815.000 estadias (diárias), e obteve um faturamento de 122 milhões de dólares, uma média de 153,37 dólares a diária. A empresa tem uma orientação altruísta e planeja crescer de 350 hotéis para 700 nos próximos cinco anos, em suas três categorias: confort, primeira classe e deluxe collection. Atualmente, conta com 400 hotéis.

\section{. Summi}

A Summi planeja expandir seus 140 hotéis de alta permanência até atingir cerca de 275 unidades no ano de 2005. 


\section{A franquia na indústria hoteleira como estratégia de crescimento}

\section{Conceito de franquia}

Mediante o contrato de franquia, um hotel, o franqueado, passa a operar com a mesma imagem de marca e o mesmo método de produção que o de uma cadeia, o franqueador. A empresa que concede a franquia deve ser uma cadeia hoteleira de grande prestígio, pela qualidade dos serviços que presta em seus estabelecimentos, e a boa imagem corporativa que possui como conseqüência desse fato.

O contrato de franquia costuma ser firmado por períodos de vinte a trinta anos, e por uma quantidade fixa anual, sendo prorrogável em seu vencimento, se ambas as partes se mostrem satisfeitas pela mútua colaboração. Não obstante, a empresa franqueadora efetuará periodicamente inspeções, a fim de observar o exato cumprimento das normas de unidade corporativa e do processo produtivo. A existência de irregularidades em um ou em ambos os aspectos, haverá motivo suficiente para a denúncia do contrato, pelo descrédito que o estabelecimento em questão pode acarretar à franqueadora.

Os contratos de franquia estão orientados indubitavelmente a favor do franqueador, com a intenção de manter a qualidade e conseguir o estrito controle global do produto hoteleiro. Em alguns casos, o franqueador insistirá para que o estabelecimento de uma nova edificação seja desenhado, segundo suas próprias especificações; em outros casos, franqueará propriedades já existentes, sempre e quando puderem ser modificadas para ajustar-se a seus requisitos específicos.

É vital que o neglazer tenha uma situação financeira satisfatória. O franqueador deverá ser selecionado com grande cuidado, já que a relação entre ambos será de longo prazo. Os franqueadores ideais terão uma larga experiência, um histórico e uma reputação financeira de primeira ordem, oferecendo ainda fortes programas de apoio.

A franquia consegue maior sucesso, quando os hotéis apresentam padrões, níveis de qualidade idênticos, e o projeto dos hotéis pode reproduzir-se de forma universal.

A franquia é percebida, essencialmente, como um método de baixo risco, que parte de uma estratégia de expansão global para conseguir a admissão e estabelecer sua presença em certos países onde a sociedade controladora é relativamente desconhecida. A Europa é considerada como a principal oportunidade por várias cadeias hoteleiras de primeira ordem; e, mais concretamente, pelos operadores baseados no saturado mercado norte-americano, que estão ansiosos para ingressar em novos mercados, sem grandes investimentos financeiros e sem os riscos implícitos na aquisição de estabelecimentos. As franquias anteriores a 1989, na Europa 
central e oriental, não tiveram sucesso, devido à incapacidade da direção e do pessoal locais de cumprir com as normas estabelecidas de funcionamento e de atenção ao cliente. A estratégia de franquia pode resultar tão simples como a de uma pequena empresa, com uma única unidade de licenciada por um franqueado, ou pode resultar tão complexa como unifranquia máster, onde uma empresa tem o direito de expandir uma marca em uma determinada região do mundo. $\mathrm{O}$ franqueador anseia ter um grande número de franqueados para assim poder alcançar importantes economias de escala que lhe permitirão reduzir os custos e aumentar as receitas.

A indústria hoteleira foi uma das pioneiras em incorporar a franquia a seu neglazer convertendo, mediante este sistema, hotéis novos e outros já existentes a suas próprias marcas. Os franqueadores de hotéis de serviço completo, além da assistência inicial aos franqueados, oferecem um plano de financiamento do neglazer, assim como um assessoramento no projeto e na construção dos estabelecimentos.

As empresas franqueadoras oferecem serviços de reservas, suporte de relações públicas, planos de qualidade, campanhas publicitárias, programas de marketing e outros serviços de ajuda a sus franqueados.

Uma das primeiras cadeias hoteleiras a introduzir as cotas como contraprestação dos serviços prestados pelo franqueador foi a cadeia Holliday Inn, atualmente pertencente ao grupo Six Continents PLC. Esta cadeia, pioneira na construção de hotéis nos Estados Unidos, durante os anos 50, foi crescendo mediante hotéis de estrada localizados em pontos chaves e centros comerciais. Apesar disso, a filosofia da cadeia era tratar de crescer rapidamente pelo que se incorporaram os contratos de franquia; em troca exigiu dos franqueados os pagamentos de umas cotas, a fim de financiar os serviços oferecidos pela empresa e aumentar suas receitas.

\section{Vantagens e inconvenientes da franquia}

O contrato de franquia oferece uma série de vantagens e inconvenientes tanto para franqueador como para o franqueado.

a) Para o franqueador

Vantagens

- O franqueador recebe uma quantidade fixa pelo pagamento de royalties.

- Ocorre um crescimento e internacionalização do produto hoteleiro, assim como um conhecimento mais generalizado da marca, evidenciando os grandes compromissos financeiros que acarretam as aquisições.

- Surge a oportunidade de fortalecer as vendas e as atividades de marketing nos maiores mercados alvo, tanto nacional como internacionalmente, sem gastos proibitivos. 
- O franqueador constitui parte do neglazer, pelo que estará profundamente motivado para aumentar a faturamento.

- Por último, permitirá ratear os principais custos operacionais de um sistema de reservas informatizado, entre um grande número de propriedades.

Inconvenientes

- Perigo de que o franqueado não apresente controle de qualidade satisfatório descuidando de seu estabelecimento, permitindo uma diminuição dos níveis de serviço e danificando, assim, a reputação da cadeia. Por isso, os franqueadores deverão efetuar dois tipos de inspeções; a primeira, para comprovar a qualidade do serviço, e a segunda para comprovar a qualidade do produto.

- O possível sentimento de rivalidade entre franqueador e franqueado.

- O alto cussto da instalação inicial do sistema de franquia.

- A seleção ótima dos franqueados.

- A possível falta de certeza na transparência dos resultados transmitidos pelo franqueado.

b) Vantagens e inconvenientes para o franqueado

\section{Vantagens}

- A segurança de um sistema operacional aprovado e de confiança, o know how que implantará em seu estabelecimento, com o que passará a ser proprietário de um neglazer experimentado, reduzindo-se o risco que acarreta o início de qualquer atividade.

- Uma identidade de marca reconhecida internacionalmente, que posiciona o estabelecimento no mercado como membro de uma reputada cadeia hoteleira.

- A conexão a um sistema de reservas regional/global, vinculado aos enormes sistemas de distribuição globais (GDS) desenvolvidos pelas empresas aéreas.

- Suporte e apoio em vendas, marketing e relações públicas por parte do franqueador, já que, se o cliente percebe uma falha em um estabelecimento franqueado, a extrapolará a toda a cadeia hoteleira.

- A adoção do know how é um elemento indispensável ao sistema, já que se vai além do conhecimento absoluto que o franqueador possui de seu neglazer. Este conhecimento, que deve atualizar-se continuamente, ficará registrado nos manuais de franquia ou Bíblia, que é como familiarmente se denominam esses documentos. Tudo isso permitirá um maior crescimento em vendas e uma melhora nos processos, com o que o franqueado poderá aumentar as tarifas.

- Apoio à formação profissional do pessoal por parte do franqueador. 
- Consultoria experimentada para a introdução e aplicação de novas tecnologias.

- Economias de escala provenientes das compras centralizadas.

- Participação nos programas de fidelização de clientes e outros programas de marketing.

- Atenção ao cliente pelas referências recebidas de outros estabelecimentos da cadeia.

- Normas de qualidade garantidas e procedimentos supervisados.

- Existência de um número de telefone gratuito em vários países do mundo, para a realização de reservas. Assessoramento na gestão financeira.

- Aconselhamento sobre a localização da propriedade.

\section{Inconvenientes}

- O alto custo das cotas e o fato de que a taxa de ocupação hoteleira e as tarifas por habitação devem aumentar para compensar tais cotas.

- Um investimento inicial considerável para converter ou construir o estabelecimento seguindo as normas e requisitos do franqueador, assim como a formação do pessoal.

- A dificuldade e o custo de readaptar o edifício a uma nova franquia alternativa em caso de ruptura do acordo de franquia com a cadeia anterior.

- O risco de que o franqueador possa quebrar e a conseqüente extinção do neglazer.

- A perda de identidade individual.

- As cotas da franquia

- Em razão da grande quantidade de vantagens que tem o franqueado, ao fazer um contrato de franquia, o franqueador exige o pagamento de elevados royalties ou cotas de franquia, que, em muitos casos, são o segundo custo mais importante para a maioria dos franqueados, já que os custos de pessoal são os que encabeçam a lista.

Todos os franqueados hoteleiros têm estruturas de cotas similares. Estas comportam basicamente o seguinte:

Uma cota inicial: costuma ser uma quantidade ou cota fixa por apartamento; cobre o custo de uma revisão inicial da propriedade existente ou potencial, e os gastos incorridos antes da abertura do estabelecimento.

Um royalty anual: costuma ser uma porcentagem sobre as receitas brutas de hospedagem, devida pelo uso da marca, logotipo e grafismo.

Uma cota anual por publicidade e marketing: está baseada em uma porcentagem das receitas brutas do alojamento e proporciona o financiamento das atividades promocionais, ao nível de cadeia. 
Uma cota por reserva: costuma ser uma quantidade fixa por cada reserva efetuada; ademais, deve-se ter em conta as comissões pagas aos agentes de venda e as cotas satisfeitas por utilizar os GDS que são, geralmente, consideradas como custos operacionais do sistema central de reservas. Por último, pode haver outras cotas variáveis, com o fim de cobrir diversas atividades de apoio relacionadas com a formação do pessoal, etc.

\section{CASOS REAIS DE FRANQUIAS NA INDÚSTRIA HOTELEIRA MUNDIAL}

A franquia é a única estratégia de crescimento utilizada por todas as cadeias do TOP TEN. As maiores cadeias hoteleiras do mundo, como Cendant Corporation, Choice Hotels lnternational e Six Continents PLC, junto com Carlson Hospitality Worldwide e Hilton Hotels Corporation, são as que têm uma porcentagem de franquia maior dentro de suas carteiras. Assim, ocorre que a Cendant Corporation, a número um do mundo em termos de carteira de aposentos, com um total de 553.771 alojamentos, e a Choice Hotels International, a número cinco, com um total de 362.549 aposentos, unicamente utilizam esse tipo de contrato como estratégia de crescimento. Por isso, são chamadas cadeias franqueadoras «puras», quer dizer, $100 \%$ de suas unidades de alojamento operam sob o contrato de franquia.

A Carlson Hospitality Worldwide, com 96\% de sua carteira de aposentos sob o contrato de franquia, ocupa o segundo lugar em termos percentuais de unidades de alojamento franqueadas.

A Six Continents $P L C$, a segunda maior cadeia do mundo, também utiliza de forma majoritária esse tipo de contrato, já que $76 \%$ de seus aposentos, quer dizer, 372.029 unidades, estão franqueadas.

A cadeia Hilton Hotels Corporation, com $63 \%$ de aposentos franqueados, tem esse tipo de estratégia de crescimento como a principal; concretamente, a Hilton Hotels Corporation franqueia um total de 200.717 aposentos.

O restante das cadeias que fazem parte das TOP TEN mundiais por número de aposentos, como é o caso das americanas Marriott lnternational e Starwood Hotels \& Resorts Worldwide, da francesa Accor e da espanhola Sol Meliá, também utiliza a franquia como estratégia de crescimento, ainda que com porcentagens inferiores às do restante das cadeias citadas. Dessas, nenhuma utiliza o contrato de franquia como principal estratégia de crescimento.

\section{O Management contract (contrato de gestão) como estratégia de crescimento}

O management contract surge devido à falta de formação empresarial em muitos setores de atividade, sendo o setor hoteleiro o de maior aplicação de dessa modalidade de contrato.

Segundo Sharma (1984), o contrato de gestão empresarial é «aquele contrato, por meio do qual, uma empresa se compromete a administrar outra, por conta e risco dessa última, em troca de 
uma contraprestação de natureza econômica. A aplicação do esquema contratual próprio do contrato de gestão empresarial, ou de gestão empresarial no âmbito hoteleiro, tem produzido como resultado o surgimento do conhecido como «contrato de gestão hoteleira» (Pérez Moriones, 1998).

Definição similar é dada por outros autores, já com um maior enfoque no contexto do setor hoteleiro: «Um contrato de gestão é essencialmente um acordo entre uma empresa de gestão de hotéis e a empresa proprietária, pelo qual a empresa de gestão explora o hotel. O proprietário não toma decisões operacionais, mas assume responsabilidades relativas ao capital necessário, os gastos e as dividas. Aa empresa de gestão recebe uma cota por seus serviços e o proprietário normalmente recebe o lucro residual, depois de deduzidas as despesas».

Recentemente, o management contract entrou de cheio nas operações hoteleiras, invadindo o terreno abandonado do arrendamento. A lnter-Continental Hotels, estabelecida em 1946 como uma subsidiária de propriedade da Pan American World Airways, começou a operar alguns de seus hotéis na América Latina nos anos 50, mediante contratos de gestão. A maioria das propriedades iniciais do Hilton International era operada com um acordo de arrendamento modificado, comparável, em alguns aspectos, ao management contract atual.

Nos Estados Unidos o management contract iniciou sua grande entrada nos anos 70, tendo o Hyatt à frente, porque os custos crescentes dos terrenos, a construção e os encargos hipotecários tornaram proibitivo o investimento em grandes propriedades para as empresas hoteleiras, ao mesmo tempo em que aumentava o risco empresarial. Graças aos management contract, o risco do investimento se transferiu do operador ao dono da propriedade. Esse tipo de contrato também permite às cadeias hoteleiras aumentar seu crescimento, aumentando o número de aposentos geridos, melhorando, assim, os lucros por ação. Por outra parte, também existiam promotores sem experiência em gestão hoteleira, os quais estavam construindo grandes hotéis, de 200, 300 ou mais aposentos, e que não tinham qualquer desejo de explorá-los com proveito, ou não podiam fazê-lo, pelo que foram absorvidos por organizações hoteleiras que haviam demonstrado sua capacidade de gestão. Algumas cadeias hoteleiras proprietárias de seus estabelecimentos decidiram que, devido ao custo crescente, era mais conveniente desfazer-se de seus bens imóveis e concentrar-se na operação.

Atualmente, os investidores internacionais têm aceitado o fato de que a habilidade ou capacidade de gestão são os ingredientes principais para poder realizar operações hoteleiras com sucesso, e estão dispostos a investir milhões de dólares em propriedades hoteleiras, sem que a empresa operadora tenha que comprometer-se do ponto de vista financeiro. $\mathrm{O}$ management contract exige 
do operador que invista apenas pouco capital financeiro no projeto.

$\mathrm{Na}$ construção de hotéis de planta nova, e anteriormente a ela, é comum, em muitos casos, combinarem-se management contracts. Isto permite à empresa operadora dar aconselhamento e assessorar em vários aspectos importantes, como a localização, o financiamento, o projeto do hotel, para aumentar a eficiência operativa e a produtividade dos empregados, a negociação das concessões para as lojas situadas no edifício, a organização das atividades de pré-abertura, assim como a seleção, contratação e formação do pessoal.

Geralmente, os contratos são feitos para grandes projetos, dado que, é nesta área onde as empresas possuem os conhecimentos mais especializados de gestão. Assim mesmo, não seria rentável gerir hotéis de 200 aposentos ou menos. Para ocupar esse vazio têm sido organizadas muitas novas empresas independentes, sem os grandes custos gerais provenientes de escritórios centrais, e com maior flexibilidade de operação.

As empresas menores freqüentemente operam com um contrato de gestão a curto prazo, de um a dez anos, e em certas ocasiões, inclusive, tomando o controle de propriedades embargadas por um investidor institucional, um banco, por exemplo, até que se recupere e volte a ser uma operação economicamente viável. Sem embargo, para a maioria dos estabelecimentos, os management contract são feitos a longo prazo, supondo períodos de até vinte e cinco ou trinta anos, períodos suficientemente extensos para cobrir a o período coberto pelo crédito assumido pelo promotor.

Algumas empresas hoteleiras, que operam mediante o contrato de franquia oferecem seus serviços de gestão a concessionários de franquias que já não desejam seguir operando os estabelecimentos por si mesmos. Em tais casos, o concessionário deve ter cuidado para não ficar bloqueado com um contrato de gestão a longo prazo que o impeça de vender sua propriedade, se assim o desejar, devendo exigir uma opção de cancelamento do contrato para proteger-se de tal possibilidade.

Sob um contrato de gestão, a empresa tem a responsabilidade operacional completa sobre as receitas e os gastos, mas a carga financeira, incluindo a responsabilidade de arcar com os custos de operação, é do proprietário. Sem embargo, e devido ao fato de que cada vez mais as grandes cadeias hoteleiras oferecem seus serviços por meio de um contrato de gestão, a competitividade entre elas implica que os proprietários/promotores possam ser mais seletivos e possam exigir uma melhor repartição das responsabilidades operacionais e financeiras, podendo, até mesmo, exigir da empresa operadora um aporte de capital. $\mathrm{O}$ aporte pode tomar várias formas: que a empresa de management pague os gastos de pré-abertura e/ou proporcione o capital de giro 
inicial requerido; isso poderia até ampliar-se a ter que comprar o mobiliário e/ou adornos e/ou equipo. Alguns tipos de ingresso de capital podem tomar a forma de uma aliança estratégica entre o proprietário e a empresa de gestão, onde ambos fazem o aporte de um capital em espécie e fazem a hipoteca sobre a propriedade, de forma conjunta.

As cotas do management contract. Há três tipos gerais de cotas: uma cota básica única, uma cota básica mais uma cota por incentivos e uma cota básica ou um incentivo, dependendo de qual for maior.

\section{Cota básica}

Com esse tipo de acordo, a empresa hoteleira apenas recebe uma cota básica, que pode ser de até $5 \%$ da receita bruta do estabelecimento. De forma alternativa, a cota pode estar baseada em duas porcentagens em separado: uma sobre as receitas brutas por alojamento e outra sobre as receitas brutas por food \& beverage. As cotas básicas não oferecem qualquer incentivo para manter os custos reduzidos, o que estimula a maximização do esforço de vendas, mas à custa de algumas despesas algo descontroladas. O proprietário poderia acabar sem lucro, pelo que se acrescenta uma cota de incentivo para estimular a empresa a manter os custos sob controle.

\section{Cota básica mais incentivo}

Sob este acordo, a cota básica poderia ser uma porcentagem da receita bruta (normalmente até 5\%) mais um incentivo até 10\% do Gross Operating Profit (G.O.P.), o lucro operacional bruto. O G.O.P. é igual à receita bruta menos todos os gastos de exploração habituais, excetuando os impostos sobre a propriedade, seguros, aluguel, juros e amortização e imposto sobre lucros. Uma segunda alternativa seria ter a cota básica dividida em uma porcentagem das receitas por alojamento e outra porcentagem sobre as receitas por food \& beverage, mais um incentivo igual a uma porcentagem do lucro bruto operacional. Uma terceira alternativa pode ser uma cota básica baseada em uma quantidade fixa por unidade habitacional disponível, mais uma porcentagem do lucro bruto operacional como incentivo. Outra variação consiste em basear o incentivo no cash-flow.

Cota básica o incentivo

Esse terceiro tipo de acordo consiste em ter uma cota básica ou um incentivo, dependendo de qual seja o maior. Obviamente, há uma ampla variedade de alternativas disponíveis no que refere a esse aspecto.

\section{Vantagens e inconvenientes do management contract}

a) Vantagens para a empresa operadora ou gestora

- Financiamento da propriedade. Uma vantagem óbvia e imediata é o financiamento de 
100\%. A menos que o proprietário exija investimentos de capital, a empresa de management requer pouco ou nenhum capital inicial, já que a expansão é limitada pela disponibilidade de pessoal especializado na gestão de novas propriedades a operar.

- Risco reduzido. Os riscos para a empresa operadora, provenientes de excesso de custos de construção, de construção em si, de recessão do mercado e de mudanças fortes são consideravelmente reduzidos.

- R.O.I. e R.O.E. elevados. Com efeito, devido ao investimento baixo ou quase nulo, a empresa de management pode obter uma rentabilidade, tanto econômica como financeira, muito alta.

Para o proprietário:

Diminuição do risco de desenvolvimento de uma atividade.

- Garantia de um lucro mínimo e de uma rápida recuperação do capital investido.

- Mediante o reconhecimento e fixação de uma determinada marca, o valor de sua unidade de neglazer será aumentado.

b) Inconvenientes do management contract

Para a empresa operadora ou gestora:

- Obtenção de apenas uma parte do lucro. Naturalmente, a outra parte do lucro fica com o proprietário, ainda que, como já assinalado anteriormente, a rentabilidade da empresa gestora é muito alta e seu risco muito reduzido.

- Ainda que a empresa operadora não possa conseguir tanto lucro, nos bons tempos, como o proprietário (dado que os ganhos são compartilhados), perderá menos nos maus tempos, uma vez que proprietário absorverá as perdas.

- Perda da potencial avaliação da propriedade. Se uma operação, sob contrato de gestão, tiver sucesso, o valor da propriedade aumentará. Essa valorização repercute sobre o proprietário e não sobre a empresa de management.

- Obstrução do proprietário. O proprietário pode desejar interferir nas tarefas de direção do hotel, limitando o potencial operativo da cadeia gestora.

- Perda do contrato. Se a empresa de gestão não mantiver ou não conseguir a rentabilidade desejada por o proprietário, ainda que não haja cometido qualquer falha, sempre corre o risco de cancelamento do contrato ou de entrar em litígio.

Para o proprietário:

- Perda do controle operacional do estabelecimento.

- Risco de que a empresa gestora não possua inicialmente os recursos necessários e a 
experiência requerida para adaptar-se à cultura local de onde se encontra o estabelecimento.

Exemplos de management contract na indústria hoteleira mundial

\section{Hilton Hotels Corporation}

Empresa emergente durante os anos 50. Mediante aquisição e posterior restauração de antigos hotéis, tais como o Stevens em Chicago e o Plaza, em Nova York, incorreu em algumas dívidas e, portanto, nos riscos de ser empresa proprietária; por isso, a Hilton Hotels Corporation desenvolveu o primeiro desses hotéis no Caribe, com o nome de Caribe Hilton, em San Juan, Porto Rico, mediante um contrato de leasing com o Governo, equivalente a 2/3 do lucro bruto. Assim, o Hilton Hotels Corporation se converteu em empresa pioneira no desenvolvimento de estratégias de expansão, mediante essa modalidade de contrato. A única coisa que a empresa deveria dar em troca era o total dos gastos de abertura e início das atividades. Isso serviu de antecedente para tomar, posteriormente, hotéis localizados em lugares como Istambul, México e Cuba. Foi precisamente em Cuba, e em conseqüência da instabilidade política, que a empresa sofreu perdas (ocupação do 14\%), o que provocou a entrega do hotel ao Governo do país (Bell, 1993).

Provavelmente essa foi a principal razão que conduziu a empresa a converter todos os contratos de leasing que possuía em contratos de gestão, sob os quais os proprietários têm o total controle e assumem o risco de perdas operacionais de desenvolvimento da atividade, assim como o total das dívidas. Em ambos contratos, leasing e gestão, a empresa teria o domínio sobre a exploração do estabelecimento. A Hilton Hotels Corporation, pioneira em contratos desse tipo, introduziu a estrutura de tarifas, mediante a implantação de uma tarifa básica de 5\%, e uma tarifa incentivada de $10 \%$ sobre o lucro bruto. Também recebeu outras quantias de dinheiro por parte de seus franqueados, $2 \%$ da receita bruta, graças ao uso de seu sistema de reservas e de outros o grupo serviços que possuía (Strand, 1996).

As dez cadeias hoteleiras do mundo com o maior número de estabelecimentos em regime de management contract são:

Marriott Interantional Inc, de um total de 2.400 hotéis, possui 931 administrados sob a modalidade de management contract; Société du Louvre, de seus 990 estabelecimentos, 565 são administrados em management contract; Accor, que possui 3.650 hotéis, 456 deles administrados sob a modalidade de management contract; as empresas Tharaldson Enterprises, com 314 hotéis, Westmont Hospitality Group Inc., com 296 hotéis, que administram 100\% de seus estabelecimentos, sob a modalidade de management contract; Starwood Hotels \& Resorts 
Worldwide, que, com 750 hotéis administra em management contract um total de 263; Hyatt Hotels/Hyatt International administra em management contract quase $100 \%$ de seus estabelecimentos, 191 de 195 hotéis; Marcus Hotels \& Resorts, com 185 hotéis, também administra $100 \%$ de seus estabelecimentos sob a modalidade de management contract; Six Continents Hotels, com um total de 3.244 estabelecimentos, dedica ao management contract 334; em último lugar aparece Milton Hotels Corporation que, de seus 1.986 hotéis, administra 191 sob a modalidade de management contract.

\section{As Joint Ventures como estratégia de crescimento}

Outro veículo de crescimento para as empresas hoteleiras com consideráveis recursos financeiros são as joint ventures, estratégia normalmente utilizada por um grande investidor imobiliário e uma empresa relacionada com hotelaria e viagens. As Joint Ventures, empregadas de forma habitual unicamente pelos grandes grupos investidores com interesse na mais-valia do capital, constitui a estratégia de crescimento mais complicada e com o maior nível de risco.

Uma joint venture pode ser definida como «um acordo mediante o qual duas ou mais empresas legalmente independentes decidem criar uma empresa com entidade jurídica própria.

\section{Exemplos de joint ventures na indústria hoteleira}

Duas cadeias hoteleiras espanholas, Barceló e Sol Meliá, têm se inclinado, nos últimos anos, a adotar essa estratégia de crescimento. A primeira, Barceló, constituiu, em agosto de 1998, uma joint venture com as empresas FCC (Fomento de Construcciones y Contratas) e Argentaria, visando a revolucionar o setor hoteleiro espanhol. A idéia original consistiu em criar uma nova empresa hoteleira, Grubarges, que abarcasse todo o processo produtivo da indústria, o que se conseguiu graças ao fato de que as atividades das três empresas integrandetes do projeto eram plenamente complementares às do setor hoteleiro. Os três sócios constituíram, por sua vez, duas divisões dentro de Grubarges: a) Grubarges Investimento, sociedade patrimonial canalizadora dos investimentos e proprietária dos estabelecimentos; b) Grubarges Gestão, encarregada da gestão dos hotéis.

O projeto supôs o aporte de onze hotéis à Grubarges Investimento, nove da Argentaria e dois de Barceló, com o objetivo de criar no prazo de um ano e meio, uma cadeia com mais de 40 hotéis, situados na Europa e América; o investimento realizado foi cerca de 600 milhões de euros.

O projeto, que não descartava a inclusão de outros sócios, todos eles procedentes do setor hoteleiro, contemplava, a longo prazo, a possibilidade de uma futura ida à bolsa da sociedade, com o objetivo de financiar a expansão internacional da empresa.

O segundo exemplo foi levado a cabo por Iberia e Sol Meliá. A realização da joint venture foi 
um marco na história do setor turístico espanhol, já que integrava empresas líderes em cada um de sus segmentos de atividade.

Com a realização da estratégia anterior nasceu Viva Tours, operador turístico causador de grandes sinergias entre as empresas.

\section{Os contratos de arrendamento na indústria hoteleira como estratégia de crescimento}

O contrato de arrendamento consiste no aluguel de um estabelecimento hoteleiro por um período longo, normalmente nunca inferior a três anos, e suscetível de prorrogações automáticas. O objeto do contrato, no caso da indústria hoteleira, é o arrendamento do neglazer e não do estabelecimento, com todos os seus pertences, instalações, decoração e empregados. O habitual é que o arrendatário seja um grupo hoteleiro, uma vez que o arrendamento costuma incorporar a adoção da imagem corporativa e do processo produtivo da cadeia hoteleira arrendatária. Assim, o hotel arrendado faz parte quase totalmente (a propriedade não está em suas manos) da estrutura fixa da cadeia hoteleira.

Devido ao fato de que o objeto do contrato é o arrendamento do neglazer, e não o estabelecimento em si, as cotas anuais de amortização costumam ficar a cargo do arrendador, que deverá encarrregar-se da manutenção e conservação do edifício.

Quanto à contraprestação econômica levada a cabo pelo arrendatário, a favor do arrendador, cabe dizer que existem diversas modalidades, ainda que as mais costumeiras sejam as seguintes:

Cobrança de uma quantidade anual fixa, revista anualmente, de acordo com uma determinada condição, normalmente o índice de preços.

Cobrança de uma porcentagem, ao redor do $5 \%$, sobre a produção hoteleira.

Cobrança de uma porcentagem, ao redor do $15 \%$, sobre o «cash-flow» gerado.

Qualquer das duas últimas modalidades é combinada com uma quantidade fixa.

É habitual pactuar, por imposição do arrendador, o aporte de uma determinada quantidade anual por parte do arrendatário para financiar as diversas reposições que afetam os diferentes serviços. É por isso que se costuma realizar um inventário de todos os pertences e instalações que se arrendam, com o fim de solucionar futuros conflitos.

O proprietário do hotel tem o direito de inspecionar o estabelecimento, com o objetivo de verificar o estado de conservação em que se encontram as instalações. Uma vez finalizado o contrato, a cadeia hoteleira é obrigada a devolver os móveis e as instalações a seu proprietário, no mesmo estado em que se encontravam no inicio do mesmo.

Uma cadeia hoteleira que empreende um contrato de arrendamento poderá realizar um management contract com outra empresa, sem necessidade de obter o consentimento do 
proprietário do hotel, se estiver estipulado no contrato de arrendamento.

Os arrendamentos têm se convertido na estratégia de crescimento menos utilizada pelas empresas que fazem parte das TOP TEN.

A francesa Accor é a cadeia que mais aplica esse tipo de contrato como estratégia de crescimento, com $38 \%$ de sua carteira de aposentos. Não é por acaso que isto ocorre, devido a que são as cadeias européias as mais inclinadas a essa modalidade contratual. O Hilton lnternational, com $28 \%$ de sua carteira de aposentos sob contrato de arrendamento, é outro exemplo a mencionar.

A Starwood Hotels \& Resorts Worldwide, com um 5,3\% de sua carteira de aposentos, é a única cadeia norte-americana integrante dos TOP TEN que emprega o arrendamento como estratégia de crescimento; o restante de cadeias das TOP TEN não a aplica.

\section{A propriedade como estratégia de crescimento}

A propriedade é a estratégia de crescimento mais lenta, menos rentável e mais arriscada, tanto operativa como financeiramente de todas as estratégias de crescimento. Ademais, o grande volume de recursos financeiros necessários a torna praticamente inviável quando se fala do tamanho de cadeias hoteleiras, como, por exemplo, as americanas, entre as quais somente a Cendant Corporation tem mais praças hoteleiras do que todo um grande país turístico como a Espanha.

Dentro das TOP TEN mundiais, unicamente a cadeia Accor, juntamente com a Sol Meliá, utiliza o contrato de propriedade como segunda principal estratégia de crescimento, representando $32 \%$ de sua carteira de aposentos.

A Starwood Hotels \& Resorts Worldwide e a Hilton Hotels Corporation são as únicas cadeias americanas das TOP TEN mundiais que apresentam percentuais significativos de propriedade, com $19 \%$ e $11 \%$ de sua carteira de aposentos, respectivamente, ainda que em nenhum dos casos essa estratégia seja a mais utilizada.

A Six Continents Hotels, ainda que utilize também a propriedade como estratégia de crescimento, o faz de maneira minoritária, já que 5\% dos aposentos estão sob a modalidade conjunta de propriedade e aluguel. O restante de cadeias hoteleiras que figuram entre as TOP TEN mundiais, com exceção da espanhola Sol Meliá, que utiliza esse contrato em $36 \%$ de sua carteira de aposentos, não utilizam, em absoluto, a propriedade como estratégia de crescimento.

\section{Aquisições, fusões e absorções na indústria hoteleira}

Esses tipos de estratégias refletem a postura de crescimento desejada por muitas empresas. O crescimento se concentra no desenvolvimento de uma imagem/marca ou grupo de marcas 
mundialmente conhecidas com a intenção de obter uma margem competitiva na luta pela participação de mercado, aproveitando as economias de escala e de alcance.

A maioria de empresas parece estar tentando cortar os riscos para evitar o investimento em ativos em nível multinacional; somente aquelas envolvidas em joint ventures e em aquisições têm querido correr esse tipo de risco.

Uma forma alternativa de desenvolver a propriedade é mediante fusões e absorções de cadeias hoteleiras. São muitas as razões que podem aconselhar a fusão ou a absorção, ainda que as mais importantes sejam do tipo econômico, a saber:

- Economias operacionais ou de gestão. Graças às fusões e absorções podem ser obtidas notáveis economias operacionais, sobretudo quando a integração é do tipo horizontal, já que, ao tratar-se de empresas que produzem o mesmo produto, muitos dos gastos comuns das diferentes sociedades implicadas podem ser eliminados.

- Razões financeiras. Algumas empresas, em setores de rápido crescimento, podem encontrar-se com sérias dificuldades financeiras para desenvolver-se, já que o financiamento interno não é suficiente, e o externo é inviável. As empresas, face ao dilema «crescer ou desaparecer do mercado», vão apelar para a fusão ou absorção como última solução; por outra parte, uma maior dimensão do tamanho conduz, geralmente, a uma maior facilidade de acesso aos mercados de crédito e de capital; se a fusão ou absorção resulta vantajosa do ponto de vista econômico, isso se traduzirá em um lucro por ação maior.

- Razões comerciais. Para poder vender com maior facilidade e assegurar-se da obtenção de certos inputs, mediante a eliminação das barreiras alfandegárias de outros países, as grandes empresas dos países industrializados têm absorvido, se têm fundido o têm conseguido participação acionária em empresas desses outros países. Com esse propósito nasceram muitas das empresas multinacionais atuais, que não são senão uma prolongação histórica das grandes corporações nacionais.

- Razões fiscais. As fusões, em determinadas ocasiões, respondem ao simples desejo de economizarem-se impostos ou obter lucros fiscais; algumas normas fiscais beneficiam as empresas que realizaram fusões ou aquisições.

- Diversificação e redução de riscos. Mediante a diversificação o lucro da empresa é mais estável, quer dizer, o risco é menor. Muitas empresas têm realizado integrações verticais e horizontais com empresas fornecedoras de matéria-prima ou distribuidoras do produto final, com o fim de não ficar à mercê de fornecedores e agentes de vendas não 
controláveis, que, em qualquer momento, poderiam por em perigo a continuidade do processo produtivo de suas fábricas.

- Razões técnicas e de pessoal. As fusões e absorções costumam levar-se a cabo com o objetivo de aproveitar o pessoal altamente qualificado, hoje em dia um dos principais ativos de qualquer empresa, de alguma das organizações envolvidas na operação.

- Sinergias. As fusões e absorções de empresas podem produzir efeitos sinérgicos muito importantes, que fazem com que o lucro por ação, das empresas que se fundiram, seja superior ao que se obteria se se somasse o lucro por ação das empresas antes da fusão. Todas as razões citadas anteriormente podem ser consideradas, também, efeitos sinérgicos.

São numerosas as cadeias hoteleiras que adquiram, se fundiram ou absorveram outra cadeia hoteleira; destacar-se-ão os casos mais recentes:

Em 1996, a HFS adquiriu a Travelodge North America, pela qual pagou quase 170 milhões de libras. Um ano depois, fruto da fusão da HFS com a CUC International, surgiu a cadeia hoteleira mais importante do mundo, a Cendant Corporation.

Ainda em 1996, a Grandeada adquiriu a metade da cadeia Forte, por 3.900 milhões de dólares.

A Starwood Hotels \& Resorts Worldwide, graças às aquisições da Westin Hotels \& Resorts, em 1996, e IIT Corporation, em 1997, por um valor de 1.800 e 10.200 milhões de dólares, respectivamente, chegou a ser uma das cadeias hoteleiras mais importantes do mundo.

Em 1997, a Patriot American adquiriu a Wyndham por um total de 1.100 milhões de dólares. Um ano mais tarde, a Patriot iniciou sua expansão internacional com a compra da cadeia européia Arcadian por 239 milhões de dólares.

A rápida expansão de Marriott International, durante os anos de 1997 e 1998, foi devida às aquisições do grupo Ritz-Carlton e de Renaissance, essa última, realizada por um total de 1.000 milhões de dólares, acrescentou as marcas internacionais Renaissance, New World e Ramada, com as quais dobrou sua carteira internacional.

Em 1998, o grupo britânico Six Continents Hotels adquiriu a Inter-Continental, da Seibu Saison, por 2.900 milhões de dólares. Fruto de tal aquisição a Six Continents Hotels se converteu na segunda cadeia mais importante do mundo.

A cadeia Canadian Pacific realizou duas importantes aquisições em 1998: a primeira implicou a compra da Delta Hotels por quase 100 milhões de dólares; a segunda, a compra da Princess Hotels por 540 milhões de dólares.

Em 1998, Host Marriott adquiriu o 25\% de Swissotel. 
O grupo Blackstone adquiriu, conjuntamente com a Colony Capital, o grupo de hotéis Savoy de Grandeada, por 1.200 milhões de dólares.

Scandic, o maior grupo hoteleiro da região nórdica, adquiriu a finlandesa Arctia, por 95 milhões de dólares. Em 1998, fundiram-se a FelcorSuite Hotels e Bristol Hotels \& Resorts. Fruto dessa fusão, a capitalização da empresa ascendeu a 4.000 milhões de dólares.

Em 1999, a Hilton Hotels Corporation adquiriu a cadeia hoteleira Promus por um montante total de 4.000 milhões de dólares.

Em 1999, a Accor adquiriu a cadeia Red Roo! Inns por um montante de 1.100 milhões de dólares.

No ano 2000 Sol Meliá adquiriu a cadeia hoteleira Tryp Hotels por um montante de 360,6 milhões de euros.

\section{A internacionalização-globalização das cadeias hoteleiras}

Nos últimos cinqüenta, anos o turismo tem tido um efeito profundo sobre o desenvolvimento econômico e social em escala internacional. Mas, que determinantes específicos tornaram possível a atividade turística multinacional?

A expansão de empresas transnacionais turísticas deveu-se em particular aos seguintes fatores:

A aparição de novos centros comerciais em todo o mundo, em particular no Oriente Médio e no Extremo Oriente, e a competitividade entre os países recentemente industrializados, para converter-se em centros comerciais e financeiros líderes, produziu um «boom» de construção de hotéis e uma grande oportunidade de desenvolvimento para as Empresas Transnacionais na área turística.

O volume de viagens ao exterior depende do nível de ingressos, do nível de educação e de outros fatores, mas também é muito dependente do tamanho do país de origem e de sua situação geográfica.

Os governos tendem a jogar um papel importante, estimulando ou restringindo o crescimento do turismo internacional. Pode encontrar-se uma grande variedade de barreiras para viajar ao redor do mundo, como, por exemplo: freio ao fluxo de pessoas (vistos); atrasos administrativos para obter autorizações; por exemplo, para iniciar a construção ou a operação de hotéis; e discriminação com respeito às empresas nacionais. Por outro lado, os incentivos governamentais podem animar muitas corporações envolvidas com turismo a estender suas atividades a esses países recentemente industrializados. A maioria das transações comerciais internacionais turísticas, incluindo a transferência de capital, tecnologia, know-how, está relacionada com corporações multinacionais ou transnacionais (Ajami, 1988; McQueen, 1989: 287). 
Com o crescimento das viagens e do comércio internacional, uma tática empregada pelas cadeias hoteleiras é seguir seus clientes aos destinos internacionais. Nesse sentido, a cadeia tenta desenvolver e explorar a lealdade da empresa, mediante a familiaridade, serviço uniforme e sistemas de reservas internacionais. Muitos executivos crêem que as operações internacionais servem para melhorar a imagem, aumentando o reconhecimento do nome da empresa. Assim, a consciência criada pela presença global das empresas reforça sua posição no mercado para os viajantes internacionais. Por outra parte, existem, atualmente, empresas que estão competindo no mercado americano, que se vêem obrigadas a crescer internacionalmente e a criar, assim, marcas conhecidas, já que cada vez mais norte-americanas viajam ao exterior (Bell, 1989).

A aparição de corporações transnacionais no turismo tem contribuído significativamente para obtenção de operadores mais eficazes, utilização efetiva de recursos e globalização crescente da economia nos anos noventa. Mas, a atuação dessas Empresas Transnacionais no turismo também tem dado lugar, em nível nacional, à aparição de múltiplos desafios nos países anfitriões.

Vários são os fatores particulares que contribuem para a obtenção de vantagem competitiva ou de propriedade das Empresas Transnacionais, na indústria turística:

- A oferta de serviços de alta qualidade, incluindo atributos tais como o projeto, comodidade, rendimento, eficácia, grau de profissionalismo e atitude orientada para o cliente?

- A habilidade das cadeias hoteleiras internacionais para entrar em novos mercados, de forma fácil e rápida, graças a um conjunto de ativos intangíveis e habilidades logísticas que podem proporcionar a qualquer hotel, recentemente incorporado à cadeia, um custo mais baixo do que no caso de novas entradas potenciais de outros competidores no neglazer hoteleiro.

- A disponibilidade de um sistema global de reservas de viagem é percebida pelos viajantes internacionais, geralmente, como lucrativa e como um meio de facilitar o processo da reserva (UNCTC, 1988: 429).

Adicionalmente às economias de escala que se podem aplicar às corporações turísticas, as grandes empresas multinacionais têm outras vantagens, como, por exemplo:

A possibilidade de obter insumos mais baratos do que as empresas pequenas conseguiriam, devido a seu maior poder de negociação.

Como resultado de sua capacidade de negociação, há a faculdade de conseguir um custo de marketing mais baixo, ao levar a cabo as campanhas de propaganda internacionais.

Seu tamanho lhes permite beneficiar-se do custo diferencial de fatores, da especialização 
internacional em atividades de valor agregado e das economias de gestão que surgem de sua capacidade de deslocar pessoas entre as diferentes partes da mesma organização. 


\section{Capítulo IV}

\section{MODELO DELTA DE PENSAMENTO ESTRATÉGICO E SEU IMPACTO NO SETOR DO TURISMO}




\section{CAPÍTULO IV}

\section{MODELO DELTA DE PENSAMENTO ESTRATÉGICO E SEU IMPACTO NO}

\section{SETOR DO TURISMO}

\section{Principais Modelos de formulação estratégica na empresa}

\section{O Modelo Delta.}

3. Empresas com enfoque estratégico de melhor produto.

4. Empresas com enfoque estratégico centrado no cliente.

5. Empresas com enfoque estratégico centrado no sistema.

6. Modelo de pensamento estratégico no setor de turismo.

7. Impacto do Modelo Delta no setor de turismo.

\section{Principais Modelos de formulação estratégica na empresa}

Os modelos de pensamento estratégico são instrumentos para apoiar as análises estratégicas nas discussões dos grupos dirigentes nas empresas, ativando o conhecimento, enfocando a discussão dos grupos e questionando os modelos mentais anteriormente existentes dos participantes. Permitem entender a estratégia adotada pela empresa e transmiti-la a todos os colaboradores.

Um breve resumo dos principais modelos de pensamento estratégico mais comumente utilizados será apresentado a seguir:

- O modelo DAFO, como uma reflexão sobre a definição do negócio da empresa, e suas forças e fraquezas frente às ameaças e oportunidades que oferece o ambiente com o aumento da concorrência.

- As matrizes BCG e GE, que surgem como resultado da diversificação das grandes empresas, com o surgimento de conglomerados e amplas carteiras de produtos e a necessidade de avaliar os resultados da curva de experiência e do portfolio e da rentabilidade da empresa.

- O modelo das cinco forças de Porter, que destaca a estrutura do setor como determinante da rentabilidade da empresa, por meio das chamadas cinco forças que determinam a atratividade da indústria. A intensidade da rivalidade entre os competidores existentes, a ameaça de novos atores potenciais, a ameaça de possíveis substitutos, o poder de negociação dos compradores e o poder de negociação dos fornecedores é que determinam a rivalidade e a concorrência como as componentes chaves da estratégia da empresa.

- O modelo da vantagem competitiva, a cadeia de valor da empresa e os recursos e capacidades da mesma como fatores de sustentabilidade de sua vantagem competitiva, estabelece que as empresas desfrutam de alta utilidade, não pelas características intrínsecas da indústria na qual competem, mas graças às capacidades e recursos que possam conseguir. 
- O modelo dos recursos e capacidades da empresa, como fonte de vantagem competitiva. Ele estabelece que as empresas desfrutam altas utilidades não pelas características intrínsecas da indústria na qual competem, mas graças aos recursos e capacidades que podem conseguir.

- Mais recentemente, o Modelo Delta (Hax e Wilde, 2001), objeto principal de estudo nesse capítulo, é uma nova abordagem às estratégias de crescimento e de gestão, em uma economia hoje cada vez mais inter-relacionada e globalizada.

\section{Os três postulados básicos da formulação da estratégia}

Segundo Hax e Wilde (2001), toda formulação estratégica parte de duas perguntas:

a) Qual é o objetivo central da estratégia?

b) Quais são os mecanismos básicos para consegui-lo?

Pode-se responder brevemente a essas questões com os três postulados básicos da estratégia (ver Figura 1); o primeiro define o objetivo estratégico e os outros dois indicam as formas de consegui-lo.

- Primeiro: Criação de valor econômico, conseguir um desempenho financeiro superior e sustentável, medido em termos de rentabilidade de longo prazo.

- Segundo: Vinculação com os clientes, apoiada por uma proposta exclusiva de valor para o cliente. Atraiu, satisfazer e reter o cliente.

- Terceiro: Criação do "Espírito de Sucesso" Fluxo líquido de talento: Atrair, satisfazer e reter a os empregados que se destacam.

Figura 1. Os três postulados básicos da estratégia

Fonte: The Delta Project de Hax (2001)

Postulado $\mathrm{n}^{\mathrm{o}} 1$

Criação de Valor Econômico: Objetivo central da estratégia.

Segundo os autores, por muito tempo se aceitou que a empresa, em seu conjunto, e suas atividades comerciais individuais têm por objetivo fundamental conseguir um desempenho financeiro superior e sustentável, medido em termos de rentabilidade a longo prazo.

Existem três grandes desafios implícitos nessa frase. Em primeiro lugar, o desempenho financeiro deve ser de nível superior, vale dizer, deve-se controlar uma posição de liderança importante. Portanto, a empresa deve desenvolver um sentido de criatividade, de originalidade e exclusividade que a tornem digna de retornos especialmente atrativos. Jamais poderá consegui-lo simplesmente imitando o seguindo os passos de seus competidores. 
Em segundo lugar, esse desempenho financeiro superior deve ser sustentável, vale dizer que não só deve descansar sobre uma posição sólida de liderança, mas também que essa posição deve ser prolongada capaz de suportar as inevitáveis mudanças que se produzam no ambiente.

Faz-se necessário adaptar-se flexivelmente a circunstâncias novas e estar disposto e ser capaz de transformar continuamente a organização. A empresa deve experimentar e estar envolvida em um processo de aprendizagem permanente que, mais que evitar, assimile a mudança.

E, em terceiro lugar, esse desempenho financeiro superior e sustentável deve poder medir-se em termos de rentabilidade a longo prazo, o que implica uma solução de compromisso crítica entre

resultados de curto e longo prazo. É outro principio fundamental que custa menos enunciar do que praticar. O futuro oferece incertezas e riscos. Existe tanta pressão por obter resultados de curto prazo que é difícil manter-se solidamente comprometido com um futuro eivado de surpresas.

A Criação de Valor Econômico é o objetivo central da estratégia, mas é somente o resultado, o produto de um trabalho bem feito. Como pode ser bem sucedido? A resposta chave se encontra nos seguintes pontos:

\section{Postulado no 2:}

Criação de Proposta Exclusiva de Valor para o Cliente - Vinculação com o cliente, base para a criação de valor econômico.

Uma empresa só sobrevive e cresce em função de seus clientes. Eles são o depósito de todas as atividades da mesma. No cerne da gerência, e certamente no cerne da estratégia, está o cliente. A regra do jogo é atrair, satisfazer e reter o cliente, e estabelecer um laço irrompível e uma relação estreita, denominado vinculação com o cliente. Essa vinculação implica outro desafio fundamental, porque só se pode estabelecer, se conseguir adquirir um conhecimento e compreensão das necessidades e desejos de cada um dos clientes que se está atendendo (ou pelo menos os mais importantes), e se lhes pode oferecer uma proposta econômica de valor superior e exclusiva. Por vezes se observa que muitas empresas, incluindo aquelas pertencentes ao setor de serviço ao cliente, não têm esse conhecimento íntimo dos mesmos, o que lhes permitiria abordar adequadamente esse tema (valor), ou estão tão absortas em uma orientação centrada no produto que não conseguem envolver-se com esse tipo de pensamento estratégico.

Existe uma variedade de razões que contribuem para não se concentrar intensamente no cliente. Uma das mais importantes é a barreira que levantam os canais de distribuição e que costumam bloquear o caminho da empresa em direção aos clientes finais. Outra razão para a falta de 
concentração no cliente é a mentalidade de fechada que costuma permear muitas organizações. As empresas têm a tendência de tratar os clientes pelo tamanho, oferecendo-lhes produtos em série por meio de canais de distribuição em massa, e não fazem nenhum esforço para compreender e satisfazer as necessidades dos clientes, considerados individualmente.

O contato clássico com a organização do cliente torna a equipe de vendas familiarizada com o departamento de compras do cliente. Com isso, a relação se dá em condições de igualdade, as quis não permitem alimentar nem desenvolver um conhecimento adequado sobre o cliente.

Por último a proposta de valor exclusivo para o cliente deveria incluir a carteira (portfolio) de negócios e a capacidade funcional completa da empresa. Em outras palavras, essa proposta exige contar com uma estratégia corporativa integral que seja o contrário de uma estratégia comercial isolada, baseada em produtos individuais.

O cliente no centro do Modelo Delta e seu produto básico é uma proposta de valor diferenciado.

\section{Postulado no 3:}

Criação do "Espírito de Sucesso" - ou fluxo líquido de talento como indicador chave de desempenho estratégico.

O último postulado básico se relaciona com a capacidade de atrair, satisfazer e reter o talento. A nova economia oferece oportunidades valiosas para profissionais jovens e talentosos: um clima empresarial que impulsiona o uso das técnicas mais avançadas de gestão e as respectivas compensações financeiras. Todas as empresas se vêem confrontadas com o imenso desafio de superar a atração magnética das empresas "ponto.com", e oferecer um ambiente para seus empregados tão excitante como o que parecem ter as mesmas.

Por isso, um indicador importante da saúde estratégica de uma empresa é esse fluxo líquido de talento. Se for positivo, significa que não haverá problemas para atrair e reter sua pessoal chave; Se negativo, vale o contrário. É a evidência inegável de que sua organização, qualquer que seja a natureza de sua situação financeira atual, deverá enfrentar, em um prazo muito curto, fortes pressões. Chama-se "Espírito de Sucesso" a natureza desejada de um ambiente de trabalho cheio de vigor e de energia, que acredita em criar as capacidades coletivas para chegar a ser a organização líder em que todos esperem trabalhar. 


\section{O Modelo Delta}

O Modelo Delta traz quatro grandes contribuições. Considerado integralmente, o modelo constitui um novo enfoque e uma nova disciplina de gestão estratégica. As quatro contribuições são: o Triângulo, os Processos Adaptativos, a Medição, e a Experimentação e Feedback (ver Figura 2).

\begin{tabular}{|c|c|c|c|}
\hline $\mathrm{O}$ triângulo & $\begin{array}{l}\text { Abrir a mente a novas } \\
\text { posições estratégicas }\end{array}$ & $\begin{array}{l}\text { Nem sempre ganha o } \\
\text { melhor produto }\end{array}$ & $\begin{array}{l}\text { Três alternativas estratégicas } \\
\text { diferentes: } \\
\text { - melhor produto } \\
\text { - soluções totais ao cliente } \\
\text { - lock-in de sistema }\end{array}$ \\
\hline $\begin{array}{l}\text { O Processo } \\
\text { Adaptativo }\end{array}$ & $\begin{array}{l}\text { Comorincular } \\
\text { realmente a estratégia } \\
\text { com a execução }\end{array}$ & 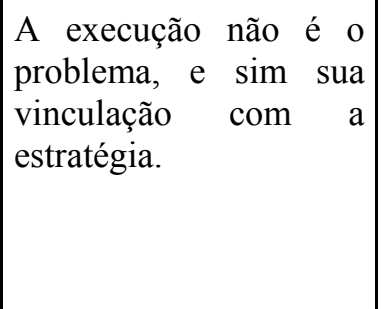 & $\begin{array}{l}\text { A execução se dá mediante três } \\
\text { processos adaptativos: } \\
\text { A eficiência operativa; a } \\
\text { orientação para o cliente e a } \\
\text { inovação. Seus papéis mudam à } \\
\text { medida que apóiem uma } \\
\text { alternativa estratégica diferente. }\end{array}$ \\
\hline A Medição & $\begin{array}{l}\text { Não basta contar com a } \\
\text { Medição Global. Deve- } \\
\text { se complementar com a } \\
\text { Medição detalhada. }\end{array}$ & $\begin{array}{l}\text { A gestão por médias } \\
\text { conduz à obtenção de } \\
\text { desempenhos } \\
\text { subordinados à média }\end{array}$ & $\begin{array}{l}\text { As medições de desempenho } \\
\text { estão também alinhadas com as } \\
\text { alternativas e os processos } \\
\text { estratégicos. A medição em } \\
\text { detalhe permite concentrar, } \\
\text { medir a variabilidade, detectar as } \\
\text { fontes de variabilidade, aprender, } \\
\text { melhorar, inovar. }\end{array}$ \\
\hline $\begin{array}{l}\text { A Experimentação } \\
\text { E Feedback }\end{array}$ & $\begin{array}{l}\text { A experimentação e } \\
\text { Feedback são } \\
\text { mecanismos } \\
\text { adaptativos } \\
\text { fundamentais }\end{array}$ & $\begin{array}{l}\text { Não se fazem planos } \\
\text { serem seguidos. }\end{array}$ & 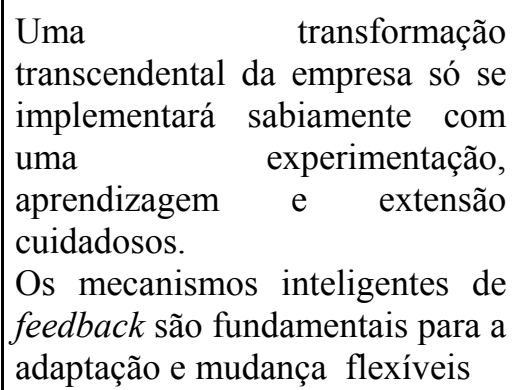 \\
\hline
\end{tabular}

Figura 2: Contribuições do Modelo Delta. 


\section{O Triângulo}

A primeira reflexão que surge normalmente no processo de definição da estratégia da empresa é decidir o posicionamento estratégico correspondente. Trata-se simplesmente de uma intenção de captar, em essência a forma como a empresa decide competir em seu próprio mercado ou, na metodologia do modelo, a forma como decide atrair, satisfazer e reter o cliente.

Há três alternativas estratégicas diferentes que apresentam critérios muito distintos para conseguir a retenção do cliente. São descritos graficamente como um triângulo, tal como se mostra na Figura 3.

O posicionamento do melhor produto se baseia na fórmula clássica da concorrência. O cliente é atraído pelas características inerentes do próprio produto, seja pelo baixo custo, que lhe conferem uma vantagem de preço, a qual pode transferir-se parcialmente para o cliente; ou pela diferenciação, que introduz características exclusivas que o cliente valoriza, pelas quais está disposto a pagar um preço superior. O produto tende a ser padrão e desagregado. O cliente é algo genérico, massivo e sem rosto. A atenção se centra principalmente na concorrência, que se pretende igualar o superar.

Suas forças impulsoras são a economia do produto e a cadeia interna de distribuição que move uma produção eficiente do produto. A inovação centra-se no processo interno de desenvolvimento de produtos. A maior limitação desse enfoque reside em que há um mínimo de relações com o cliente e, então, as empresas envolvidas se tornam sumamente vulneráveis a novos ingressantes.

\section{Concorrência baseada na Economia de Sistemas \\ Sistema Fechado (lock-in)}

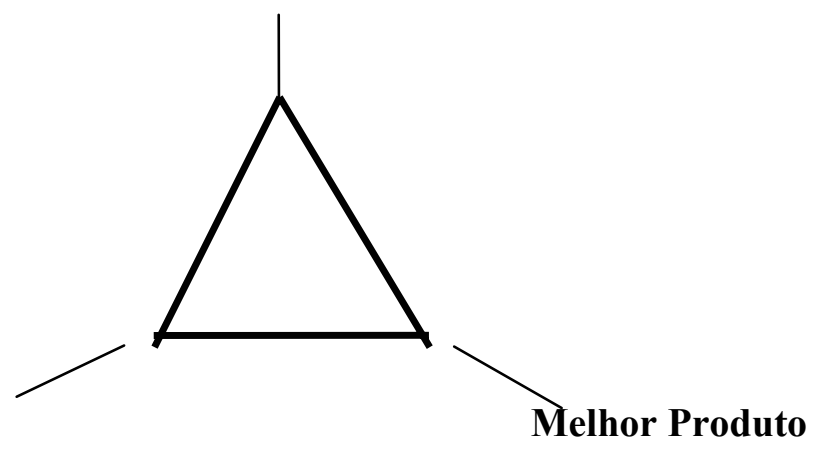

Soluções Totais ao cliente

Concorrência baseada em Economia ao Cliente:

Concorrência baseada na economia do produto:.

Figura 3: Modelo de estratégia empresarial: Três alternativas estratégicas distintas 
A preocupação obsessiva pela concorrência costuma levá-las à imitação e à guerra de preços, com a resultante rivalidade e concorrência, o pior de todos os negócios. Apesar das limitações intrínsecas dessa posição estratégica, é de longe a mais adotada e A posição por descarte de todas aquelas empresas que não tenham estudado deliberadamente alternativas estratégicas.

A Solução Total ao Cliente é a situação completamente inversa à do critério anterior, do Melhor Produto. Em lugar de tratar o cliente pelo tamanho, busca-se compreender e relacionar-se íntima e profundamente com ele. Com isso, podem-se criar propostas valiosas de relacionamento com cada cliente em particular. Em lugar de desenvolver e vender produtos uniformes e isolados busca-se entregar uma gama coerente de produtos e serviços que procuram melhorar a capacidade do cliente para criar seu próprio valor econômico. Em lugar de concentrar-se em uma postura "para dentro" na cadeia de suprimento, procura-se desenvolver uma cadeia integrada que vincule os fornecedores e os clientes chaves. Em lugar de centrar-se na concorrência e imitá-la, a empresa redefine as formas de captar e atender os clientes reunindo todas as capacidades corporativas, complementadas com serviços externos adequados que aperfeiçoam a oferta de produtos. A orientação direciona-se para fora, tendo em vista a economia para o cliente. A estratégia não consiste em uma guerra contra os competidores, mas em querer atender o cliente de forma superior.

O processo de inovação não está orientado ao projeto de produtos padronizados, mas aponta para iniciativas junto aos clientes mais importantes para desenvolver, em conjunto, produtos exclusivos.

A alternativa estratégica de Lock-In do Sistema (Sistema Fechado) é de alcance mais amplo, incluindo a empresa em toda sua extensão: a empresa, os clientes, os fornecedores e, mais importante, os complementadores chave. Um complementador é uma empresa cujos produtos e serviços reforçam a própria linha de produtos e serviços.

É fundamental nessa alternativa identificar, atrair e alimentar esses complementadores, que geralmente são empresas externas, mas que podem também pertencer à corporação, sobre tudo no caso de organizações grandes e diversificadas.

É raro detectar e explorar, com eficácia, esses complementadores, e é por isso que uma estratégia do sistema lock-in deve começar com um horizonte corporativo global, não só para um produto ou negócio, e continuar com a identificação e incorporação de todos os atores externos passíveis de transformar-se em complementadores. O cliente continua no centro, mas agora a empresa ampliou-se ao máximo. Levando em conta a cadeia completa de suprimentos, e não unicamente a cadeia de suprimentos, e aproveitar a inovação, infiltrando-se por todo o sistema. A riqueza e 
profundidade do produto ou serviço colocam-no no interior do sistema, fechando o espaço para a concorrência. Isso força o cliente a comprar sua oferta e construir relações com o cliente. Uma forma óbvia de tornar realidade o que foi dito é uma empresa desenvolver e apoderar-se das "normas" industriais. Assim o fizeram, no século passado, a Microsoft e a Intel, um grupo excepcional de complementadores. Outro elemento chave para esse posicionamento é a propriedade de canais de distribuição exclusivos que limitem o acesso aos competidores externos. Uma empresa que consiga criar um sistema fechado (lock-in) pode exercer um tremendo poder. Nem sempre é possível estar em condições de fechar (lock-in) um sistema, já que existe uma condição prévia. A adoção massiva do produto em si mesma deve ampliar consideravelmente o valor do produto percebido pelo cliente. É a natureza auto-reforçadora da proposta de valor ao cliente. Essa oportunidade pode tomar corpo, seja apropriando-se de um padrão proprietário, como é o caso do sistema operacional Windows, da Microsoft, seja controlando o canal de distribuição. Essa posição apresenta o duplo desafio de mantê-la e exercer esse poder de maneira ética, sem cair nos excessos de uma conduta monopolista.

\section{As diversas dimensões do Triângulo - Cuidado com a mentalidade centrada no produto}

$\mathrm{Na}$ Figura 4, é apresentado um resumo das diferenças entre os posicionamentos estratégicos do Triângulo, na linha de algumas dimensões importantes de gestão. Usa-se esse gráfico para mostrar claramente as conseqüências de adotar, sem demasiada reflexão, o posicionamento do Melhor Produto, que desencadeia uma mentalidade "centrada no produto". Sugere-se que a estratégia do Melhor Produto não seja a mais apropriada. De fato, existem empresas excelentes que revelam um desempenho extraordinário em todas as dimensões concebíveis, e que se localizam nesse vértice do Triângulo. Adverte-se sobre a adoção irrefletida e rejeição dessa estratégia, sem pensar em alternativas. No passado, pregava-se, por vezes, sobre os perigos dos "silos funcionais". O fato é que as funções não são silos e se supõe que exercem um alto grau de sinergia dentro de uma organização, por sua própria natureza. Se em uma empresa estruturada funcionalmente se está a cargo da divisão de Pesquisa e Desenvolvimento, assume -se que se está a cargo de todos os aspectos de inovação de todos os produtos na empresa. O mesmo vale se se é responsável por qualquer outra função importante, como finanças, recursos humanos, operações etc...

O que mais preocupa é a mentalidade "centrada no produto" que pode gerar "silos" por estreiteza de visão, impedindo que uma empresa utilize inteligentemente todas as suas capacidades, e atenda com a maior eficiência possível os clientes. 


\begin{tabular}{|c|c|c|c|}
\hline $\begin{array}{l}\text { POSICIONAMENTO } \\
\text { COMPETITIVO }\end{array}$ & MELHOR PRODUTO & $\begin{array}{l}\text { SOLUCÕES TOTAIS } \\
\text { PARA O CLIENTE }\end{array}$ & $\begin{array}{l}\text { LOCK-IN DO } \\
\text { SISTEMA }\end{array}$ \\
\hline Enfoque Estratégico & $\begin{array}{l}\text { Produto: o negócio, seu } \\
\text { setor e os competidores. }\end{array}$ & $\begin{array}{l}\text { Corporação: a empresa, } \\
\text { clientes e fornecedores. }\end{array}$ & 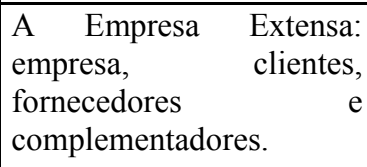 \\
\hline Benchmarking & Concorrência & Clientes & Complementadores \\
\hline $\begin{array}{l}\text { A proposta de valor para } \\
\text { o cliente }\end{array}$ & $\begin{array}{l}\text { Centrada no Produto: } \\
\text { economia em produto }\end{array}$ & $\begin{array}{l}\text { Centrada no Cliente: } \\
\text { Economia para o cliente }\end{array}$ & $\begin{array}{l}\text { Centrada em Sistemas } \\
\text { Economia do sistema }\end{array}$ \\
\hline Oferta de produtos & Produtos padronizados & $\begin{array}{l}\text { Composição } \\
\text { personalizada de produtos } \\
\text { e serviços }\end{array}$ & $\begin{array}{l}\text { Carteira de produtos e } \\
\text { serviços ampliada por } \\
\text { Complementadores }\end{array}$ \\
\hline $\begin{array}{l}\text { Cadeia de suprimento } \\
\text { correspondente }\end{array}$ & $\begin{array}{l}\text { Cadeia interna } \mathrm{de} \\
\text { fornecimento }\end{array}$ & $\begin{array}{lll}\text { Cadeia integrada } & \text { de } \\
\text { fornecimento: } & \\
\text { fornecedores, empresa } & \text { e } \\
\text { clientes. } & & \end{array}$ & $\begin{array}{l}\text { Cadeia de } \\
\text { sistema: forimento do } \\
\text { empresa, fornecedores, } \\
\text { Complementadores. }\end{array}$ \\
\hline Canais correspondentes & $\begin{array}{ll}\text { Canais } & \text { genéricos, } \\
\text { distribuição em massa. }\end{array}$ & $\begin{array}{l}\text { Canal direto a grupo } \\
\text { objetivo }\end{array}$ & Canal direto massivo \\
\hline Impacto sobre as marcas & $\begin{array}{l}\text { Orientação para o } \\
\text { produto: } \\
\text { Explosão de marcas }\end{array}$ & $\begin{array}{l}\text { Marcas harmonizadas em } \\
\text { torno do cliente: carteira } \\
\text { coerente de marcas. }\end{array}$ & $\begin{array}{l}\text { Marcas harmonizadas em } \\
\text { torno ao Sistema } \\
\text { Integração de marcas }\end{array}$ \\
\hline Enfoque na inovação & $\begin{array}{l}\text { Desenvolvimento interno } \\
\text { de } \\
\text { produtos }\end{array}$ & $\begin{array}{l}\text { Inovação de produtos em } \\
\text { conjunto com o cliente }\end{array}$ & $\begin{array}{lr}\text { Arquitetura } & \text { aberta, } \\
\text { complementadores } & \text { como } \\
\text { inovadores chaves. } & \end{array}$ \\
\hline $\begin{array}{l}\text { Papel da tecnologia da } \\
\text { informação }\end{array}$ & $\begin{array}{l}\text { Suporte interno: exemplo } \\
\text { SAP. }\end{array}$ & $\begin{array}{l}\text { Suporte a clientes e } \\
\text { fornecedores. }\end{array}$ & $\begin{array}{l}\text { Comércio eletrônico (e- } \\
\text { business e e-commerce } \\
\text { Suporte total de rede: } \\
\text { Exemplo, } e \text {-system. }\end{array}$ \\
\hline $\begin{array}{l}\text { Grau de vínculo com } \\
\text { clientes }\end{array}$ & $\begin{array}{lr}\text { Escasso, } & \text { depende } \\
\text { exclusivamente } & \text { das } \\
\text { características do produto. }\end{array}$ & $\begin{array}{|lr|}\text { Potencialmente } & \text { alto: } \\
\text { reforçado } & \text { pela } \\
\text { personalização } & \text { e } \\
\text { aprendizagem mútuas. } & \\
\end{array}$ & $\begin{array}{l}\text { Potencialmente o mais } \\
\text { alto: reforçado pelo } \\
\text { fechamento (lockout) ao } \\
\text { competidor e bloqueio } \\
\text { (lock-in) } \\
\text { complementador. }\end{array}$ \\
\hline
\end{tabular}

Figura 4: As diversas dimensões do Triângulo

Observa-se, na Figura 4, na coluna "Melhor Produto", o desdobramento das respostas associadas a essa opção. O foco estratégico é um produto único; os pontos de referência (benchmarks) são os competidores. A proposta de valor para o cliente é ditada pela economia interna do produto, isto é, uma oferta padrão de produtos. A cadeia de suprimentos correspondente é interna; os canais são genéricos e de orientação massiva; a orientação para o produto leva a uma explosão de marcas, sem conexão umas com as outras; o processo de inovação é autocentrado; o papel da Tecnologia da Informação, que é tão fundamental para a moderna gerência, é internalizado. Ao 
final das contas, tudo isso produz um nível muito fraco de vinculações com o consumidor, e uma visão bem convencional da empresa, o que pode ser limitante para a criatividade. E basicamente uma estratégia de orientação para dentro, com uma visão externa centrada na concorrência. Tendo essa perspectiva em mente, poderá dar-se conta de que é completamente incompatível com a economia da Internet, baseada em redes.

Comparando a opção do Melhor Produto com a posição de Soluções Integrais para o Cliente, e possível se ver como fica enriquecida enormemente seu alcance e conteúdo, os quais são maximizados quando se adota o posicionamento estratégico do Lock-In do Sistema. A Figura 5 mostra, de maneira explícita essas três alternativas.

Devem-se destacar duas dimensões, tanto por sua importância crítica como porque recebem tratamento distinto em cada opção. Essas dimensões são o papel dos canais de distribuição e o papel da tecnologia da informação.

Canais de distribuição. Em geral uma estratégia do Melhor Produto depende de canais massivos genéricos para sua distribuição, como supermercados, lojas de alimento etc... Ocorrem dois problemas associados a essa escolha de canais. A primeira e principal é que o canal fechará o caminho da empresa para o consumidor final, o que limita essa compreensão íntima, que é tão essencial para desenvolver uma estratégia de orientação para o cliente. Em segundo lugar, os canais massivos só são bons para consumidores massivos e excluem de um adequado tratamento os dois extremos, que são os muito pobres e os muito ricos.

\section{Canal Massivo Direto \\ (o caso do mercado D e E de Hindustan Lever) \\ Sistema Fechado (lock-in)}

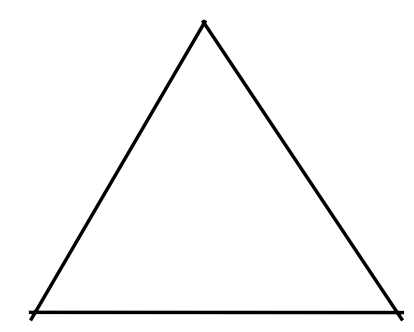

\section{Soluções Totais ao Cliente}

Objetivo - Direto

(caso do segmento alto da Unilever de México)
Melhor Produto

Canal genérico - distribuição em massa

Figura 5: Papel dos canais de distribuição nas três alternativas estratégicas

Por essa razão, os gigantes da produção de bens de consumo, como a Unilever, devem concentrar seus esforços para criar canais diretos que respondam a esses segmentos. 
A estratégia do Melhor Produto tem por objetivo básico desenvolver uma infra-estrutura e uma cadeia de suprimento internas muito rápidas que lhe dêem o suporte de baixo custo, que é fundamental para o êxito de seu posicionamento.

\section{Papel das TI}

Suporte Total da Rede (Exemplo: $e-$ system)

Sistema Fechado (lock-in)

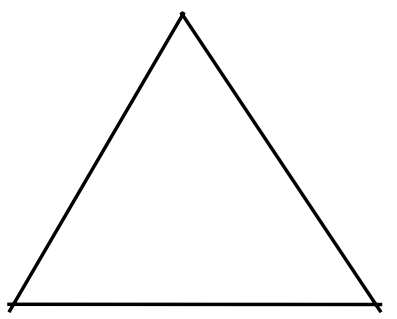

Soluções Totais ao Cliente

Suporte ao cliente: a empresa e os fornecedores (por exemplo, e-business, comércio eletrônico):
Melhor Produto

Suporte interno (Exemplo SAP)

Figura 6: o papel da TI nas três alternativas estratégicas

Os Processos Adaptativos - Como unir verdadeiramente a estratégia e a execução

O Triângulo oferece diretrizes sobre como iniciar a formação da estratégia. O Processo

Adaptativo diz como levar a posição estratégica a um alto nível de excelência na execução. Cada posicionamento estratégico do Triângulo gera um conjunto de tarefas e de atividades diferente. É necessário, todavia analisar tais diferenças a partir de um programa focado na ação. Para

alcançá-lo, devem ser identificados três processos da empresa, os quais captam muito concretamente a natureza do trabalho gerencial. Eles são:

1. Eficiência Operacional (EO) - A produção e entrega de bens e serviços.

2. "Targeting" no Cliente (TC) - A gestão das interfaces com o cliente

3. Inovação (I) - o processo de desenvolvimento de novos produtos.

São denominados processos adaptativos com o propósito de ressaltar a natureza mutável das tarefas.

A Figura 7 apresenta as interações existentes no Triângulo - as quais são fundamentais para definir o papel mutável de cada processo adaptativo - e entre os processos em si mesmos - já que cada um deles exerce grande influência sobre os demais. 


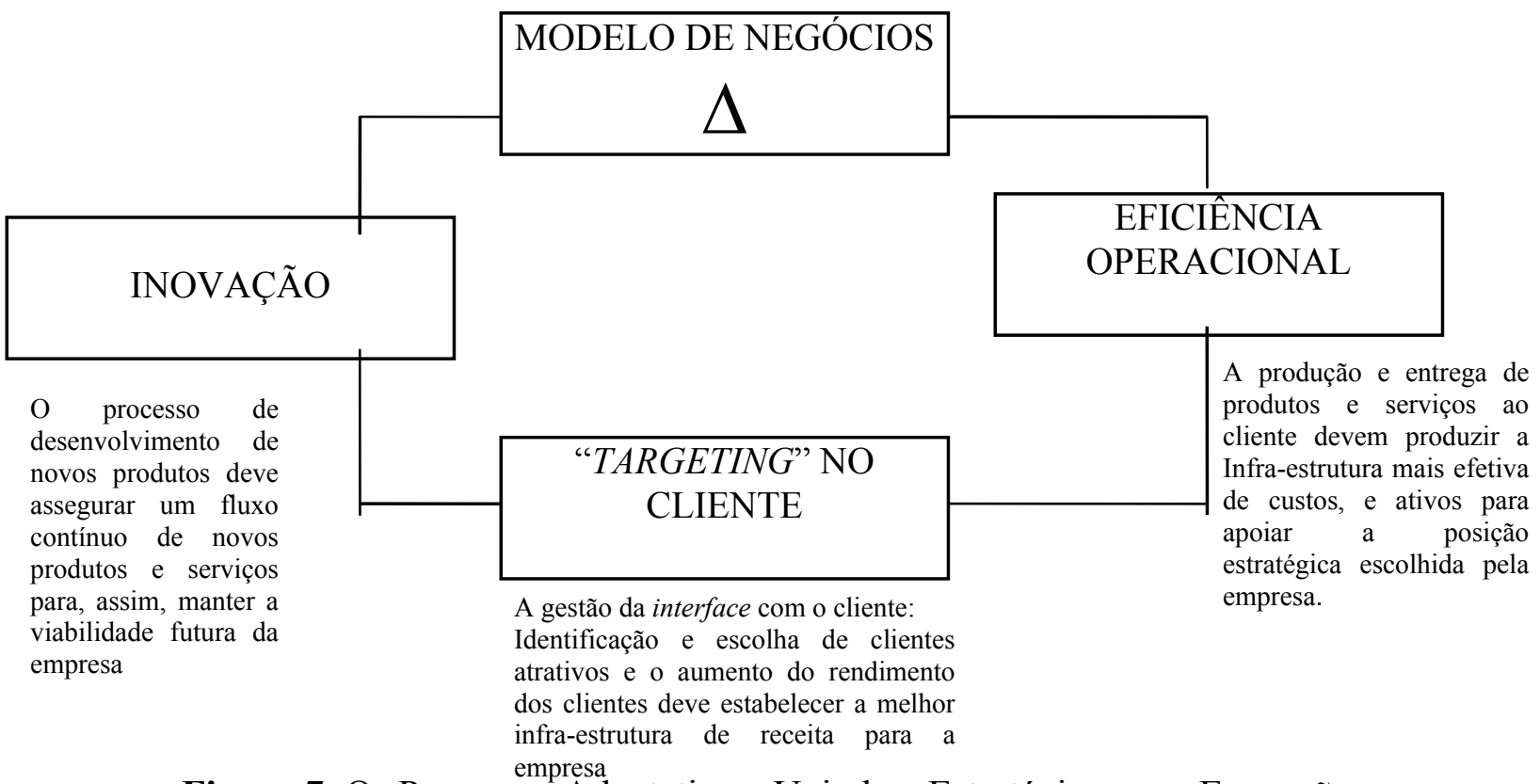

Figura 7: Os Processos Adaptativos: Unindo a Estratégia com a Execução

Além de se advogar que a estratégia e a execução devem ser congruentes entre si, e estar assentada de forma consistente, é necessário dar um passo ainda maior, ao discutir detalhadamente o papel do processo adaptativo em apoio a cada um dos três posicionamentos estratégicos do Triângulo. A Figura 8 apresenta uma visão resumida desses papéis.

Os gerentes tendem a definir cada processo de acordo com a uma estratégia de Melhor Produto. Nesse tipo de estratégia a Eficiência Operacional busca estabelecer uma infra-estrutura de custos internamente eficiente; o "Targeting" de Clientes busca a cobertura por meio de canais de distribuição; e a Inovação persegue um melhor desenvolvimento de produtos, com a ajuda de plataformas apropriadas e expectativas de "primeiros no mercado". A Figura 8 mostra que a situação é bem diferente quando o processo adaptativo apóia as opções estratégicas TCS e SLI.

Na estratégia TCS, a Eficiência Operacional tem por objetivo básico a maximização do valor para o cliente e tem por suporte a cadeia de valor da empresa e seus clientes. A finalidade do "Targeting" em Clientes é desenvolver laços com os clientes individuais, aumentando a inteligência de marketing e a interface com o cliente. A inovação é dirigida ao desenvolvimento, em conjunto com o cliente, de um mix de produtos personalizados.

$\mathrm{Na}$ posição estratégica SLI, o papel de cada processo continua variando. Aqui, a Efetividade Operacional busca aumentar o rendimento geral do sistema por meio da consolidação de alianças com complementadores. O "Targeting" em Clientes busca dos mesmos consolidar uma arquitetura harmônica do sistema, por meio de uma rede de complementadores e de interfaces de 
complementadores. A meta máxima quanto à inovação é o desenvolvimento de um padrão apropriado para a indústria, manipulando os processos de aplicação e suas interfaces.

Novamente, o objetivo primordial é evitar uma mentalidade centrada no produto, e expandir as alternativas abertas à empresa. A rivalidade e a concorrência podem não ser as estratégias ganhadoras.

\begin{tabular}{|c|c|c|c|}
\hline & MELHOR PRODUTO & $\begin{array}{c}\text { SOLUÇÕES TOTAIS } \\
\text { AO } \\
\text { CLIENTE } \\
\end{array}$ & LOCK-IN DO SISTEMA \\
\hline $\begin{array}{c}\text { Eficiência } \\
\text { Operacional }\end{array}$ & $\begin{array}{l}\text { Custo do Melhor produto } \\
\text { Identificar } \\
\text { influenciadores do custo } \\
\text { de produto } \\
\text { Melhorar custo "stand } \\
\text { along" do produto }\end{array}$ & $\begin{array}{l}\text { Lucros do Melhor Cliente } \\
\text { Melhorar a economia do } \\
\text { cliente } \\
\text { Melhorar os vínculos } \\
\text { horizontais nos componentes } \\
\text { de soluções totais }\end{array}$ & $\begin{array}{l}\text { Rendimento do Melhor Sistema } \\
\text { Melhorar os geradores de renda } \\
\text { do sistema . Integração de } \\
\text { complementadores para melhorar } \\
\text { o rendimento do sistema }\end{array}$ \\
\hline $\begin{array}{l}\text { Targeting nos } \\
\text { Clientes }\end{array}$ & $\begin{array}{l}\text { Identificar Canais de } \\
\text { Distribuição } \\
\text { Maximizar a cobertura } \\
\text { por meio de canais } \\
\text { múltiplos } \\
\text { Alcançar baixos custos } \\
\text { de distribuição } \\
\text { Identificar e aumentar A } \\
\text { rentabilidade de cada } \\
\text { produto por canal }\end{array}$ & $\begin{array}{l}\text { Identificar "pacotes" para os } \\
\text { Clientes } \\
\text { Identificar e explorar } \\
\text { oportunidades de agregar } \\
\text { valor a clientes chaves } \\
\text { reunindo soluções e } \\
\text { personalização } \\
\text { Aumentar o valor para o } \\
\text { cliente e possíveis alianças } \\
\text { para agrupar soluções } \\
\text { Selecionar mercados } \\
\text { verticais chaves } \\
\text { Examinar opções de } \\
\text { propriedade de canais }\end{array}$ & $\begin{array}{l}\text { Identificar a Arquitetura do } \\
\text { Sistema } \\
\text { Identificar complementadores } \\
\text { principais do sistema } \\
\text { Consolidar uma posição de lock- } \\
\text { in com os complementadores } \\
\text { Aumentar o número e variedade } \\
\text { de complementadores } \\
\text { Se possível, conseguir } \\
\text { propriedade de canais de } \\
\text { distribuição direta }\end{array}$ \\
\hline Inovação & $\begin{array}{l}\text { Inovação de produtos } \\
\text { Desenvolver uma família } \\
\text { de produtos sobre a base } \\
\text { de uma plataforma } \\
\text { comum } \\
\text { Fluxo de produtos } \\
\text { pioneiros no mercado }\end{array}$ & $\begin{array}{l}\text { Inovação no Serviço ao } \\
\text { Cliente } \\
\text { Identificar e explorar o } \\
\text { desenvolvimento conjunto } \\
\text { associado com a cadeia de } \\
\text { valor do cliente } \\
\text { Aumentar a oferta à cadeia } \\
\text { de valor do cliente para } \\
\text { melhorar a economia do } \\
\text { cliente } \\
\text { Integrar e inovar funções de } \\
\text { atenção ao cliente } \\
\text { Aumentar o confiança do } \\
\text { cliente por meio da } \\
\text { personalização } \\
\text { aprendizagem }\end{array}$ & $\begin{array}{l}\text { Inovação do Sistema } \\
\text { Criar lock-in do cliente e sistema } \\
\text { e um lock-out competitivo } \\
\text { Projetar um padrão proprietário } \\
\text { com arquitetura aberta: } \\
\text { Interfaces complexOs } \\
\text { Evolução rápida } \\
\text { Compatibilidade para trás }\end{array}$ \\
\hline
\end{tabular}

Figura 8: Papel do Processo Adaptativo ao Apoiar as Opções Estratégicas do Triângulo

\section{A Métrica}

São necessárias tanto a métrica agregada como a pontual, e, ademais, em concordância com a estratégia. 
As medidas de receita e os indicadores quantificáveis são fundamentais para o desenvolvimento, execução, e monitoramento da estratégia desejada. O Modelo Delta alinha a métrica da rentabilidade com as opções estratégicas escolhidas e reconhece que essa métrica será fundamentalmente diferente, dependendo da posição estratégica que pretende privilegiar.

Há dois tipos de métrica. Primeiro, a métrica agregada para obter uma visão geral e integrada do negócio e do rendimento da empresa. Segundo, a métrica pontual, com parâmetros específicos para conseguir um entendimento profundo de seu comportamento.

A métrica agregada proposta está associada ao processo adaptativo antes mencionado. Esses processos são os instrumentos para executar cada opção estratégica e servem, igualmente, de diretrizes para definir a rentabilidade da estratégia. A Figura 9 resume um conjunto de métricas genéricas, escolhidas segundo processos adaptativos e opções estratégicas. As métricas sob medida específica poderiam ou, de fato, deveriam ser introduzidas em cada situação de negócio. Não se incorporam métricas financeiras, normalmente associadas com o rendimento geral do negócio devido ao fato de que têm um caráter mais padronizado.

É importante notar que os diferentes processos avançam com seu impulso normal: a Eficiência Operacional é o repositório dos impulsionadores de custo; o "Targeting" de clientes dos impulsionadores de rentabilidade; e, A Inovação dos impulsores de Renovação. Também se deve anotar que a opção BP é orientada para o produto; a TCS é orientada para o cliente; e a SLI é orientada para o sistema.

A lógica é evidente e, sem embargo, ainda se observa que a maioria das empresas só se concentra em oportunidades relacionadas com o produto. Isso é outra amostra dessa penetrante mentalidade centrada no produto. A métrica agregada é essencial para reproduzir a imagem completa do rendimento geral. E, sem embargo, não basta. Deve ser complementada com a métrica pontual, individual, com a finalidade de entender a inerente variabilidade do comportamento de alguns parâmetros críticos, como custos do produto, rentabilidade do cliente, produtividade dos empregados etc.

Indubitavelmente, o comportamento desses parâmetros é não linear. Essa regra, denominada 80/20, é universal, no sentido de que uma pequena porcentagem de itens (por exemplo, 20\% de clientes) é responsável por uma quantidade desproporcional do resultado ( $80 \%$ das utilidades). Deve-se medir essa variabilidade para determinar a raiz de suas causas. Com esse conhecimento, pode-se começar a aprender a como melhorar a rentabilidade, empreendendo ações corretivas e soluções inovadoras. 


\begin{tabular}{|c|c|c|c|}
\hline & MELHOR PRODUTO & $\begin{array}{c}\text { SOLUÇÕES TOTAIS } \\
\text { AO } \\
\text { CLIENTE } \\
\end{array}$ & LOCK-IN DO SISTEMA \\
\hline $\begin{array}{l}\text { Eficiência } \\
\text { Operacional } \\
\text { (Impulsores de } \\
\text { Custo) }\end{array}$ & $\begin{array}{l}\text { - Rendimento de custos } \\
\text { - Custo unitário } \\
\text { - Custo de vida útil } \\
\text { - Custo variável e total } \\
\text { - Impulsionadores do custo } \\
\cdot \quad \text { Rentabilidade da } \\
\text { qualidade } \\
\cdot \text { Nível de diferenciação } \\
0\end{array}$ & $\begin{array}{l}\text { - Cadeia de valor ao cliente } \\
\text { - Custo total } \\
\text { - Receita e rentabilidade } \\
\text { total } \\
\text { Impulsionadores da } \\
\text { economia do cliente } \\
\quad \text { Impacto sobre a } \\
\text { rentabilidade do cliente do } \\
\text { serviço vs. a } \\
\text { da concorrência }\end{array}$ & $\begin{array}{l}\cdot \text { Descrição da Infra-estrutura } \\
\text { do Sistema } \\
\cdot \text { Custos/Receitas totais do } \\
\text { sistema } \\
\cdot \text { Investimentos e ganhos dos } \\
\text { complementadores } \\
\cdot \text { Custos do complementador } \\
\text { para aderir ao padrão } \\
\cdot \quad \text { Impulsionadores } \\
\text { rentabilidade do sistema }\end{array}$ \\
\hline $\begin{array}{l}\text { "Targeting" em } \\
\text { Clientes } \\
\text { (Impulsores de } \\
\text { Rentabilidade) }\end{array}$ & \begin{tabular}{|l} 
- Participação do produto \\
no mercado \\
$\cdot$ - Custo dos canais \\
- Rentabilidade do produto \\
- Por tipo de produto \\
- por oferta - por canal \\
- Impulsores \\
rentabilidade \\
\end{tabular} & \begin{tabular}{|l|} 
- Participação de clientes \\
- Retenção de clientes \\
- Rentabilidade por cliente \\
individual e por segmento \\
- Estabelecimento de laços \\
com clientes - custos de \\
rotatividade
\end{tabular} & $\begin{array}{l}\cdot \text { Participação do sistema no } \\
\text { mercado } \\
\text { - Participação de } \\
\text { complementadores } \\
\text {-\% de investimentos atrelados ao } \\
\text { padrão de propriedade } \\
\text { - Ganho por } \\
\text { complementador }\end{array}$ \\
\hline $\begin{array}{l}\text { Inovação } \\
\text { (Impulsores } \\
\text { Renovação) }\end{array}$ & $\begin{array}{l}\text { - Taxa de introdução do } \\
\text { produto } \\
\cdot \text { Tempo para chegar ao } \\
\text { mercado } \\
\cdot \text { Porcentagem de vendas } \\
\text { de novos produtos } \\
\cdot \quad \text { Custo de } \\
\text { desenvolvimento do } \\
\text { produto } \\
\cdot \text { P\&D como porcentagem } \\
\text { das vendas }\end{array}$ & 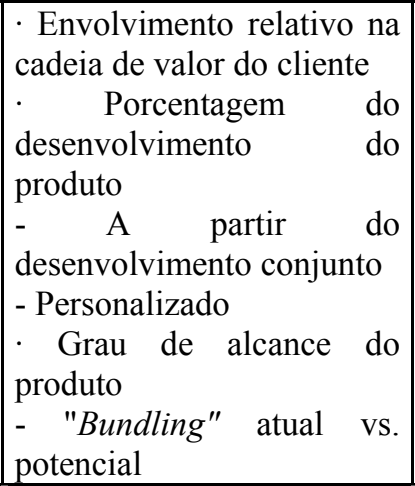 & $\begin{array}{l}\text { - Transferência de custos para } \\
\text { complementadores e para } \\
\text { clientes } \\
\cdot \text { Taxa de desenvolvimento do } \\
\text { produto } \\
\text { - Custo para os competidores de } \\
\text { imitar padrões }\end{array}$ \\
\hline
\end{tabular}

Figura 9: Métrica de rentabilidade para os Impulsionadores de Negócio do Modelo Delta

Experimentação e Feedback - os mecanismos adaptativos chaves

A última contribuição do Modelo Delta aborda os temas Experimentação e Feedback. A experimentação é a chave para levar a cabo uma transformação substancial da empresa, responsavelmente. Especificamente, quando se quer mudar de uma posição estratégica a outra, (por exemplo, de uma solução de Melhor Produto para uma de Cliente Total), a empresa se vê forçada a entrar em terreno desconhecido, sem compreensão completa do caminho preferido a ser seguido. A forma de enfrentar esse desafio é projetar um conjunto minucioso de experimentos destinados a obter melhores conhecimentos, antes de comprometer-se com um esforço organizacional em grande escala. O ponto final é o feedback.

O que se pode dizer sobre o futuro? Talvez duos coisas: não se pode predizer, e pode surpreender. Por conseguinte, o melhor é aceitá-lo e incorporar esse conceito à estratégia. Com relação a esse aspecto na Figura 2 se diz, de forma agressiva, que "os planos não são feitos para 
que serem cumpridos". Com isso, não se pode negar a importância de identificar um propósito central da empresa e do negócio. De fat, isso é o que o Triângulo supostamente deve ajudar a estabelecer. $\mathrm{O}$ processo adaptativo e a métrica relevante permitem organizar-se melhor. Sem embargo, uma vez feito tudo isso, deve-se ser consciente de que será necessário modificar os cursos de ação escolhidos e o plano estratégico resultante, para poder adaptar-se em caso de mudanças inesperadas em nas hipóteses básicas. Por esse motivo, é necessário o feedback. Medir, monitorar e fazer o follow up da rentabilidade, construindo a suficiente flexibilidade em um sistema gerencial, estruturas organizacionais e recursos, que permitam as mudanças necessárias.

\section{Reinterpretando o Modelo das Cinco Forças de Porter Mediante o Modelo Delta:_Pensando "Fora da Gaveta"}

Um dos marcos estratégicos mais influentes é o Modelo das Cinco Forças de Porter. Baseado em princípios econômico-indústriais aceitos, Porter diz que o grau de atratividade de uma indústria é definido por cinco forças que afetam os valores econômicos criados pela atividade industrial. Essas forças são: a intensidade da rivalidade entre os competidores existentes, a ameaça de novos atores potenciais (entrantes), a ameaça de possíveis substitutos, o poder de negociação dos compradores e o poder de negociação dos fornecedores. (Ver Figura 10). A interpretação convencional do modelo de Porter enfatiza a rivalidade e a concorrência como as componentes chaves da estratégia. Começa-se analisando a indústria na qual a empresa se encontra, ou seja, aquela moldada pelos competidores. Isso não somente concerne às empresas já presentes na indústria, como também aquelas que poderiam ingressar direta ou indiretamente, por meio de produtos substitutos.

Ademais, é concernente a quantidade de riqueza que pode ser apropriada pelos compradores ou fornecedores. O enfoque estratégico é interno, o clima reinante é o atrito, a forma de triunfar é derrotando e superando em inteligência aqueles que tenham pretensões sobre a riqueza da indústria. Tenha sido ou não a intenção de Porter, o legado foi uma mentalidade centrada no produto; a estratégia é a guerra.

Pretende-se reinterpretar o Modelo das Cinco Forças de Porter, segundo o Modelo Delta, em uma forma fundamentalmente nova que conduza, do posicionamento de Melhor Produto do Triângulo, às Soluções Totais ao Cliente e à opção de Sistema Fechado (System Lock-In), conforme exposto na Figura 11. Para isso, não se deve considerar a indústria como dada. Há que 
se que ver as cinco forças como uma maneira de identificar ações que conduzirão a um posicionamento muito estranho para a empresa e seus sócios mais importantes: clientes, fornecedores e complementadores. O Modelo Delta propõe o seguinte processo de transformação da empresa para reinterpretar as clássicas cinco forças:

\section{Busca da Força $10 X$}

Conceito introduzido por Andy Grove, o Presidente de Intel, em seu livro Só os Paranóicos Sobrevivem. A Força 10X não se trata simplesmente de um produto substituto em uma determinada indústria, mas uma mudança de tal ordem que definitivamente mudará as regras de concorrência e o campo de jogo em geral. O autor o chama de uma Força 10X porque é uma força cuja ordem de grandeza é maior do que a das forças existentes na indústria. Aqui se encontra esse conceito muito intrigante e, em certas ocasiões, bastante prático. Simplesmente, ele sugere que devemos refletir com uma mente totalmente aberta.

\section{Gerar barreiras ao redor dos clientes}

Não se devem considerar as barreiras de entrada como aquelas forças que evitam que alguém de fora penetre na indústria em geral. É melhor pensar em construir barreiras ao redor dos clientes chaves, para assim estabelecer uma alta rotação de custos e um lock-in do cliente. Isso não está fundamentado em um comportamento abusivo, mas, ao contrário, é construído sobre uma relação tão forte e tão mutuamente benéfica que nenhuma das duas partes se separará. A chave para conseguir essa posição é obter uma profunda compreensão do cliente e do consumidor, mediante uma cuidadosa segmentação e direcionamento (targeting). Com esse conhecimento, é possível ir mais além e desenvolver a proverbial proposta única de valor econômico ao cliente, que é a fonte das barreiras aludidas. Vale a pena notar que não é o conhecimento da própria indústria o essencial para conseguir esse estado de relações com o cliente. A indústria dos clientes é o verdadeiramente relevante. É importante ter um conhecimento profundo dos impulsionadores de utilidade e os custos dos clientes, para que as capacidades, habilidades e oferta de produtos e serviços da empresa contribuam para aumentar a rentabilidade dos clientes.

\section{Os competidores não são "benchmarks" relevantes}


Isso poderia ser visto como uma heresia. Apesar de tudo, a concorrência é o centro das Cinco Forças de Porter. Não se está sugerindo que se ignore a concorrência, mas que se deve estudá-la intensamente. É possível aprender como não fazer as coisas. Também é possível conseguir um nível de excelência tal que a empresa possa dar-se ao luxo de ignorá-la, porque, se usa os concorrentes como "benchmarks", seus padrões declinariam. É necessário desenvolver um processo de inteligência competitiva muito detalhado sobre os concorrentes, mas não com o propósito de segui-lo ou imitá-los. Imitar a concorrência só conduz à acomodação e à congruência, e isso é o oposto de liderança.

O mais relevante não é a própria indústria buscar uma estratégia TCS o SLC. As indústrias chaves que se deve compreender são as de nossas clientes, fornecedores e complementadores. $\mathrm{O}$ crítico é o sistema gerencial em geral e como se deve influenciá-lo.

\section{Desenvolver e alimentar a cadeia integrada de valor}

Os clientes e fornecedores são sócios naturais que devem ser cultivados em redor da proposta de valor ao cliente, conjuntamente estruturada. Essas relações podem ser acrescentadas mediante o uso do e-business e do e-commerce.

A cadeia de inter-relações amiúde vai além do cliente, até atingir o consumidor final. Se não se chega ao consumidor diretamente, há que se fazer um esforço para tratar de conseguir a máxima compreensão possível do consumidor. O consumidor, usuário final, o que por último paga na cadeia, é absolutamente crítico. Com a tecnologia moderna é possível individualizar cada consumidor e adaptar-se a suas necessidades de uma forma muito personalizada.

\section{Agregar um novo ator: os complementadores}

Por quê a Microsoft tem tido tanto sucesso? Porque Bill Gates conta com um exército de pessoas trabalhando para ele, as quais não estão em sua folha de pagamento.

Eles são os complementadores: produtores de software, desenvolvedores de CD ROM e um conjunto de profissionais cujo trabalho é aumentar a utilidade do sistema operacional Windows. Os fornecedores e os clientes são fundamentais para conseguir o lock-in do cliente. Os complementadores vão ainda mais longe; são os instrumentos para conseguir o lock-out da concorrência e o lock-in do sistema. 
Quem são complementadores potenciais chaves? Dever-se-ia fazer dos complementadores o sócio mais leal, oferecendo-lhes uma proposta de valor mutuamente atrativa. Dever-se-ia fazer com que invistam na empresa para que a relação seja estável e duradoura.

\section{As indústrias fragmentadas oferecem grandes oportunidades}

Se os clientes, fornecedores e complementadores são numerosos, fragmentados e, de alguma maneira "ignorados" pelos principais atores da indústria, isso poderia ser uma oportunidade de ouro para reestruturar a indústria e emergir como um líder poderoso chave.

O bom das novas tecnologias é que se pode ter acesso direto aos atores fragmentados, e criar uma entidade virtual que aproveite as economias de escala quem do contrário, estariam reservadas aos atores principais. Igualmente, se pode oferecer-lhes capacidades gerenciais de vanguarda, as quais seriam impossíveis de adquirir nas circunstâncias anteriores. (Por exemplo, a Indústria Brasileira da Saúde, ICA, Staples, Home Depot).

\section{Novos Entrantes (atores)}

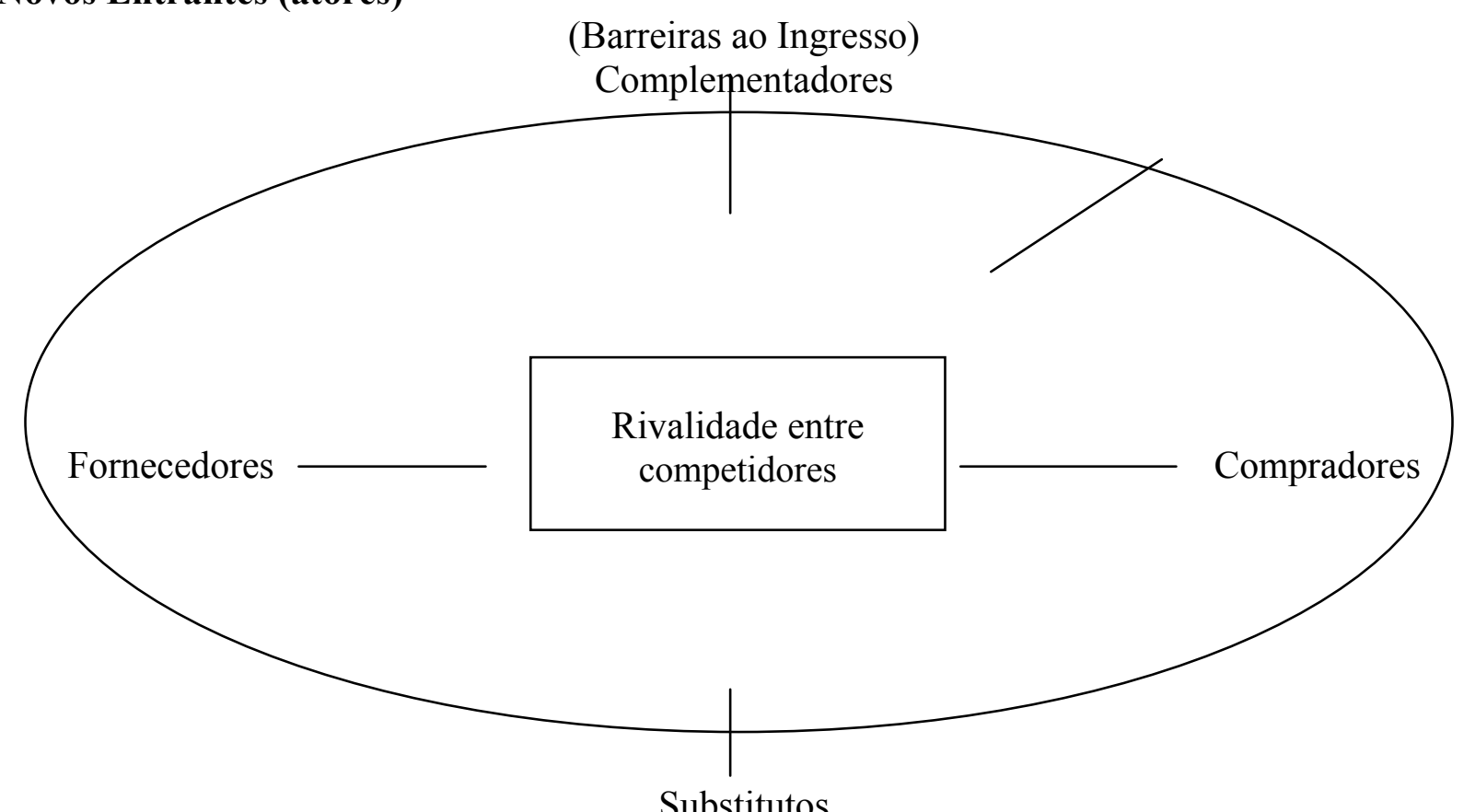

Figura 10: Reinterpretando as cinco forças de Porter mediante o Modelo Delta

1.- Criar uma poderosa Força $10 \mathrm{X}$ para mudar as regras do jogo. Rechaçar imitações da concorrência, uma mentalidade centrada no produto e uma mentalidade acomodada.

2.- Gerar barreiras significativas ao redor do cliente, mediante uma proposta de valor baseada em uma profunda segmentação de clientes e um entendimento do cliente e do consumidor.

3.- Não utilizar a concorrência como um "benchmark" central que guia as ações estratégicas. As indústrias chaves, nas quais se deve concentrar, são as dos clientes, fornecedores e 
complementadores. A estratégia não é a guerra com a concorrência, mas a aproximação aos clientes, fornecedor es, consumidores e complementadores.

4.- Desenvolver e alimentar a cadeia integrada de valor com os fornecedores é e clientes chave. Utilizar todo o poder de B2B e B2 para conseguir esse objetivo. Isso é essencial para o lock-in do cliente.

5.- Agregue um ator novo: os complementadores. Busque o apoio e a inversão dos complementadores. Convertendo-os em sócia chave na busca de Soluções Totais ao Cliente. Amplie a proposta única de valor e inclua tanto a os complementadores como aos fornecedores. Esta é a chave para obter o lock-in dos complementadores, o lock-out dos competidores e, ao final, o lock-in do sistema.

6.- Se os clientes, fornecedores, complementadores são numerosos e se encontram fragmentados, também é possível oferecer-lhes práticas gerenciais de vanguarda e uma grande riqueza de informação e inteligência, que, de outra forma, seria quase impossível obter. Dessa forma, o lock-in se veria enormemente melhorado.

\section{Os Recursos e Capacidades Requeridos pelo Modelo Delta}

Além do marco conceitual de Porter, a outra escola de pensamento influente em estratégia tem sido a visão baseada nos Recursos da Empresa, que estabelece que as empresas desfrutam de alta utilidade não pelas características intrínsecas da indústria na qual competem, mas graças aos recursos e capacidades que podem conseguir. As indagações que esta escola de pensamento tem provocado referem-se a que não se diz claramente quais devem ser esses recursos e capacidades. Após refletir sobre o potencial que oferece o Modelo Delta para a obtenção de um posicionamento estratégico sólido, pode-se sugerir uma breve lista de capacidades desejáveis que permitirão à empresa desenvolver um novo modelo de negócios mais afim com os desafios de hoje.

1. Antes de tudo, é necessário ter uma profunda compreensão do cliente e do consumidor, mediante uma segmentação detalhada e apoiada em métricas agregadas e granulares.

2. Essa compreensão deve estender-se aos fornecedores complementadores críticos. É importante a empresa não se surpreender em suas próprias tendências de identidade.

3. A implementação do novo modelo de negócios é possível, principalmente devido às possibilidades e oportunidades proporcionados pela Internet e suas tecnologias conexas: ebusiness, e-commerce, e-systems. É fundamental adquirir essas habilidades. 
4. Deve-se criar um ambiente dinâmico e empresarial que permita assumir riscos e compartilhar as recompensas, como resultado dos desafios profissionais associados a estas "novas tecnologias".

5. O produto mais significativo será o desenvolvimento e implementação de propostas de valor, singulares e vibrantes, para todos os atores chaves: clientes, consumidores, fornecedores e complementadores. A vantagem proporcionada pela postura de "pegar primeiro" é desafiadora. Há que se mover rápido.

Obviamente, devem-se complementar essas capacidades com todas as habilidades tradicionais e convencionais associadas à gerência eficaz. Têm-se enfatizado somente aquelas requeridas por esse modelo de negócios. Pensando-se detidamente, são as necessárias para o cumprimento dos três postulados abordados no início do capítulo. Assim, o ciclo se fecha.

\section{Empresas com enfoque estratégico de Melhor Produto.}

A estratégia de Melhor Produto se constrói sobre clássica forma de concorrência por meio de baixo custo ou de diferenciação. Nesse caso, os elementos relevantes estão centrados na cadeia de valor do produto o serviço. Os produtos tendem a ser padronizado.

As empresas que seguem essa estratégia têm por objetivo melhorar sempre a cadeia de matérias primas. Os consumidores são considerados em massa, da mesma forma que os canais de distribuição. A inovação é considerada a melhora da linha de produção. No melhor dos casos, a empresa tem uma área de produção em linha, onde se inova e se desenvolvem novas linhas de produtos.

O modelo de Melhor Produto surge, assim, como uma estratégia de posicionamento da área industrial. Esse tipo de estratégia atrai os clientes unicamente pelas melhores características intrínsecas do produto. Essa posição, onde a empresa não tem nada a ver com o cliente, a torna mais vulnerável ante a possível entrada de outras companhias, já que cabe a possibilidade de que o cliente se sinta atraído pela superioridade do produto de outra empresa.

Há duas principais maneiras de conseguir esse tipo de estratégia: uma, é por meio de baixos custes, que provém de vantagens de baixo preço ao cliente, ou por meio da diferenciação, que, em contrapartida à primeira, oferece um conjunto de características únicas do produto ou serviço, que são valorizadas mais do que o preço, pelo cliente.

A posição de melhor produto se baseia em atrair o cliente, por meio de uma ou de várias características do produto. Diferenciar-se é oferecer algo além do preço, algo que seja realmente distintivo. Esse modelo estratégico é muito usado atualmente. Apesar disso, é comum encontrarem-se no mercado os que consideram que certos produtos não podem basear-se em uma 
estratégia de diferenciação; sua única forma de competir é por meio de baixo custo. Desta maneira, o preço converte-se no fator determinante de atração ao cliente. Essa forma de competir se transforma normalmente em uma batalha entre as diferentes empresas, terminando em um círculo vicioso, onde todos acabam afetados.

\section{Empresas com enfoque estratégico centrado no Cliente}

O enfoque estratégico centrado no cliente difere muito do enfoque estratégico de melhor produto. Seu objetivo é conseguir uma estreita relação com o cliente. Pretende-se aprender o mais possível acerca de cada um dos clientes para proporcionar-lhe de um serviço especializado. Evitam-se a produção e distribuição em massa. Em vez de oferecer um produto apenas, é oferecido um conjunto de vários produtos e serviços que satisfaçam a necessidade do cliente.

Também aqui é completamente diferente a forma de organização interna das empresas. Não se concentram em encontrar fornecedores de baixo custo, mas, principalmente, aqueles que ajudem a satisfazer as necessidades dos clientes e sejam criativos na hora de redesenhar e inovar seus processos internos. É claro que sua estratégia se baseia na segmentação de mercado. Além do mais, para que realmente se consiga um enfoque centrado no cliente, é necessário entender como os clientes interagem com o produto ou serviço, e como é sua experiência com os mesmos.

\section{Empresas com enfoque estratégico centrado no sistema.}

O enfoque estratégico centrado no sistema é o que maior visão de conjunto do sistema tem em relação às outras estratégias. Em vez de enfocar-se unicamente no produto ou no cliente, a preocupação é sobre todos os elementos do sistema que contribuem para criar valor para um cliente.

Mais além dos elementos normais que compreendem as forças da indústria - clientes, fornecedores, canais de distribuição e novos entrantes potenciais - a preocupação reside em alimentar, atrair e reter os complementadores. Um complementador não é um competidor, ou necessariamente um fornecedor. É um fornecedor de produtos e serviços que realça, direta ou indiretamente, a oferta da empresa.

Há três formas de alcançar um enfoque estratégico centrado no sistema: por meio de padrões de propriedade, intercâmbio dominante e aceso restrito.

Um negócio bem posicionado como padrão de propriedade chega a seus clientes por meio de uma extensa rede de complementadores, que são projetados para trabalhar com o mesmo produto. 
Um negócio posicionado como de intercâmbio dominante fornece uma interface entre compradores e vendedores, ou entre partes que desejem intercambiar informações ou bens.

Em caso de acesso restrito, os competidores estão privados de aceso ao cliente, porque os canais de distribuição têm uma limitada capacidade para absorver múltiplos vendedores.

\section{Modelo de pensamento estratégico no setor de turismo.}

A partir do estudo de PORTER (1993), que definiu os quatro atributos que promovem (ou impedem) a criação da vantagem competitiva nacional, apresenta-se neste estudo o modelo teórico referencial que orientará metodologicamente as análises e estudos sobre a integração dos elementos do sistema turístico, e suas inter-relações em um destino. $\mathrm{O}$ modelo da competitividade em destinos turísticos é formado por cinco elementos: os dois primeiros (massa crítica e natureza da demanda) têm a característica de criar as condições básicas para o desenvolvimento do cluster. Esses oferecem o arranjo de partida para a configuração estratégica do mesmo. Os três elementos restantes do modelo são os que aprimoram a vantagem competitiva do cluster sendo: as estratégias competitivas, cooperativas e de relacionamento com os clientes. Esses elementos oferecem as inter-relações, conforme apresenta a Figura 11.

Figura 11: Modelo do sistema interfuncional da competitividade em destinos turísticos.

MODELO DO SISTEMA INTERFUNCIONAL DA COMPETITIVIDADE EMDESTINOS TURÍSTICOS. (SПC)

Marketing de Relacionamento

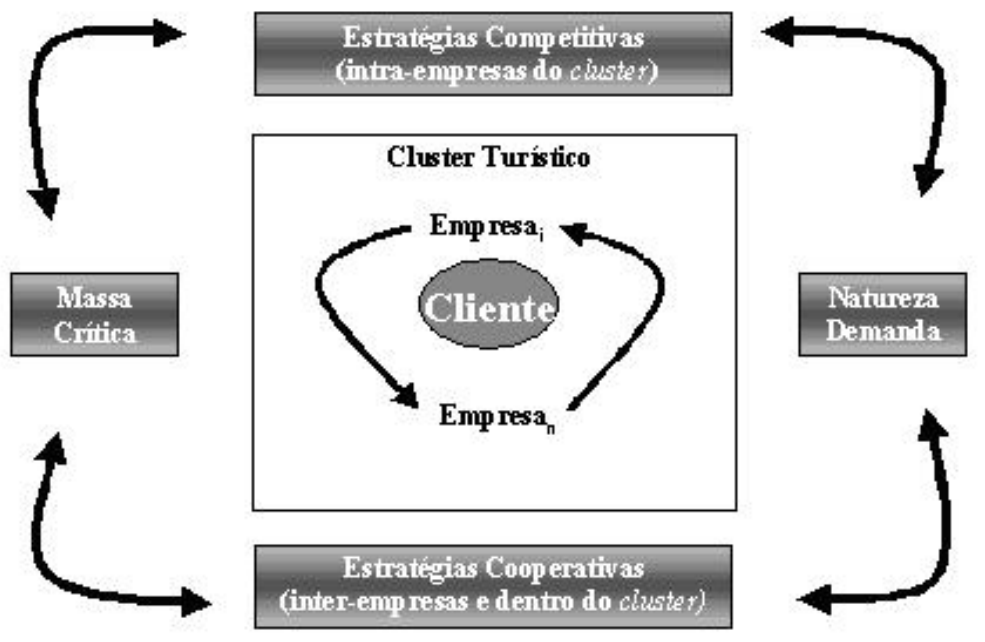

Fonte: Álvarez, Castroman (2000)

Massa crítica: é o conjunto dos fatores básicos necessários para o desenvolvimento do destino turístico. Abrange a integração dos recursos: turísticos (terra, água, geografia, clima, localização); humanos (qualidade, quantidade, custo, línguas); de capital (para o financiamento 
das empresas, de risco, de investimento); infra-estrutura (sistema de transporte, telecomunicações, reservas); de conhecimentos (técnico-científicos, universidades, P\&D, associações comerciais, associações de classe, ONGs, órgãos fiscalizadores); superestrutura (organização institucional do cluster, relações públicas-privadas, entidades de classe, relações com as regiões de origem dos turistas); segurança (sistema de apoio ao turista, garantia de livre desfrute da estada e dos atrativos).

Natureza da demanda: destacam-se, principalmente, três fatores que determinam a demanda: natureza das necessidades e desejos do consumidor turístico, tamanho da demanda e padrões de qualidade. É muito importante ter uma demanda exigente e qualificada, e gerir a demanda interna e externa (aproveitamento sinérgico da demanda turística nacional e internacional).

Estratégia competitiva: segundo PORTER (1993), uma rivalidade interna vigorosa, sem restrições e com condições iguais para competir, cria um ambiente fértil no qual as empresas do cluster podem competir e crescer saudavelmente. Esse tipo de competição exige estratégias atualizadas e a constante introdução de inovações para satisfazer as necessidades dos clientes. Um grupo de rivais internos fortes no cluster constitui um ingrediente essencial para o sucesso nesse tipo de arranjo competitivo. O sucesso internacional do cluster exige um ambiente local que coloque as empresas em padrões de competição internacional e facilite, em lugar de inibir, alcançar estes padrões de competitividade. A maneira de competir dentro do cluster deve ser acirrada, para melhor satisfazer o cliente com base na qualidade, e melhorar a identidade do cluster e sua competitividade referente a outros clusters internacionais.

Estratégia cooperativa: o processo de agrupamento geográfico em turismo é intrínseco do setor. Essa concentração em pólos com atrativos turísticos nem sempre é acompanhada pelo fomento das inter-relações entre os agentes do sistema. Utiliza-se o nome genérico de cluster turístico, ao destino, embora esse não opere com as características dos clusters de outros setores econômicos, na atual fase da globalização. Confunde-se, assim, pólo com cluster. O cluster tem como propriedade marcante o estreitamento das relações entre organizações, para criar uma rede de sinérgica, cujo objetivo é o desenvolvimento de estratégias competitivas conjuntas, criando e entregando maior valor ao mercado, por meio de relacionamentos cooperativos entre empresas independentes.

Estratégia de relacionamento com o cliente: nos modelos de gestão atuais, os relacionamentos com os clientes são altamente hierarquizados. Os clientes com seus inputs (necessidades, desejos e expectativas) otimizam a configuração do sistema, e o retro-alimentam com o processo simultâneo de produção-consumo-avaliação. 
O modelo proposto sugere que a diferença real entre o cluster turístico e o pólo tradicional é que, além de considerar os elementos de partida (massa crítica e natureza da demanda), imprescindíveis para desenvolver um pólo turístico, um cluster turístico busca sua posição competitiva em escala global, por meio de um espaço tri-dimensional (que combina estratégia competitiva, estratégia cooperativa e estratégia de relacionamento com o cliente), no qual a vantagem competitiva é alcançada pela otimização dessas três estratégias, (ver Figura 12). As empresas organizadas em cluster atingem um objetivo comum de desenvolvimento competitivo, que é definido necessariamente pela capacidade das uniões e outras complementaridades, a favor da concorrência nos mercados de atuação. Representa uma nova forma de arranjo espacial, em três direções: a primeira, estabelecida dentro da integração vertical na busca de vantagens competitivas; a segunda, na integração horizontal na busca da cooperação entre empresas concorrentes, a fim de obter um desempenho superior coletivo e; a terceira, na profundidade da agregação de valor ao cliente para o satisfazer mediante um efetivo relacionamento.

\section{Figura 12: Busca de competitividade da empresa de um cluster. BUSCA DA COMPETITIVDADE DA EMPRESA DE UM CLUSTER}

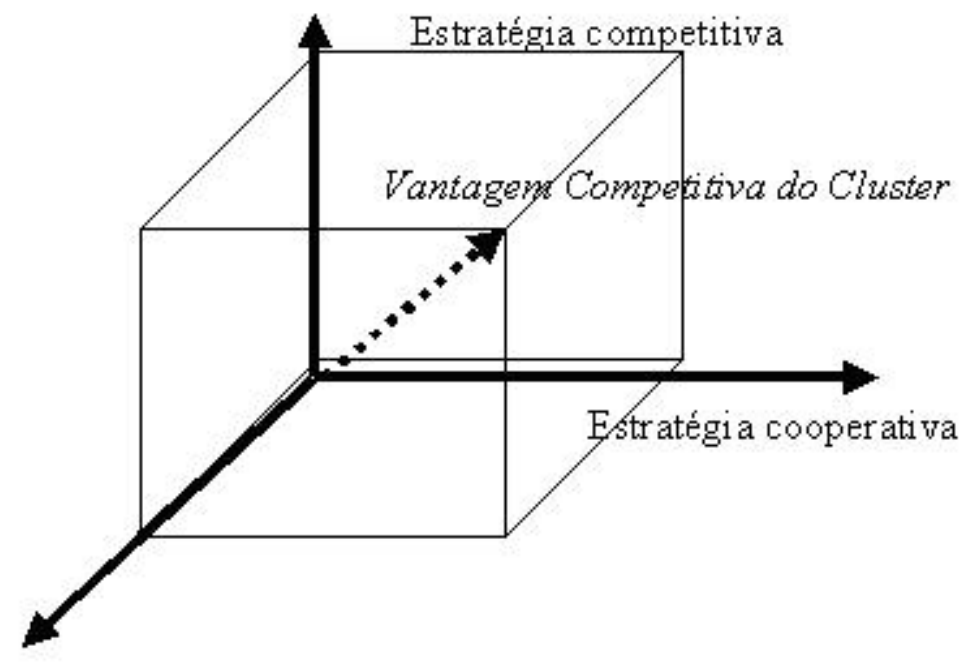

Fonte: Toledo, Álvarez e Castroman (2000)

Ao estudar a viabilidade da estratégia competitiva das empresas, no arranjo em cluster turístico, reuniram-se os seguintes conceitos de PORTER (1998), ACHROL (1991), WEBSTER (1992), MCKENNA (1993), WEHLI e JUNTER (1994), HUNT e MORGAN (1995), conforme apresentado no Quadro 2 


\section{Quadro 1: Características das estratégias das empresas para a vantagem competitiva de um cluster.}

\section{Estratégia competitiva}

Um grupo de rivais internos competitivos constitui um ingrediente essencial ao sucesso nesse tipo de ambiente empresarial.

Identificar os atores com as competências necessárias para a criação e entrega de valor no produto final superior.

Exige um ambiente local que coloque as empresas em competição internacional.

Considerar que a diversificação tem mais probabilidade de sucesso quando segue grupos nos quais a empresa já compete.

Selecionar segmentos nos quais a sua base no cluster oferece vantagens competitivas.

A empresa deve começar identificando os mercados, onde os compradores sofisticados se encontram.

Determinadas atividades na cadeia de valor devem estar dispersas pelos países que oferecem maior vantagens (sourcing global), ao mesmo tempo em que se procura aprimorar os fornecedores locais. A melhor forma de fidelidade, aos fornecedores locais, é manifestar-lhes, em termos claros, a necessidade de se equiparar aos concorrentes estrangeiros, em qualidade e produtividade, a fim de manter o negócio.

Uma empresa deve estar informada e ter acesso a toda inovação e a todo o trabalho científico que está sendo realizado não mundo e que se relacione com esta indústria. Para obter os benefícios do uso do desenvolvimento da tecnologia estrangeira, a qualidade de seu RH deve ser suficiente apta para compreender e interpretar as direções dessas tendências.

Alianças estratégicas servem para obter economias de escala, obter acesso à tecnologia ou mercados e conseguir outras vantagens, sem abrir mão da independência empresarial.

\section{Estratégia cooperativa}

Identificar mercados internacionais em que o cluster pode oferecer um valor superior.

Definir e promover os objetivos do cluster entre os elementos e atores. A coordenação das condições para poder atuar deve ser definida pelos objetivos do cluster.

Desenvolver e compartilhar os valores e a imagem do cluster entre os atores e aplicá-los aos seus produtos.

Estimular um clima de confiança, comprometimento e cooperação entre os atores.

Desenvolver a função integrando externa e interna, trazendo as necessidades do mercado para dentro do cluster integrando seus membros e recursos no atendimento dessas necessidades.

Criar uma rede de relações cujo objetivo é a aplicação da competitividade ao longo desta cadeia. Entregar valor ao mercado por meio de relacionamentos cooperativos entre empresas independentes.

Planejar, executar e disponibilizar um banco de informações para os atores. Projeção compartilhada da estratégia de marketing.

\section{Estratégia de relacionamento com o cliente}

Criar, entregar e manter os benefícios tangíveis para a manutenção do relacionamento com o cliente.

Enfatizar principalmente a necessidade de relacionamento a longo prazo com o mercado, em detrimento das práticas de transações com objetivo de curto prazo.

Devem-se alinhar políticas de recursos humanos e materiais, com a visão de alcançar a competitividade decorrente da habilidade superior para relacionar-se com o mercado.

Bancos de dados: a economia de relacionamento trata de um corpo teórico em que se mensura o valor do cliente ao longo de seu ciclo de vida como cliente de empresa. Database Marketing é a ferramenta que viabiliza tais controles.

Solidificar relacionamentos, transformar clientes indiferentes em leais e servi-los é o que deve inspirar as atividades de marketing (importante é a lealdade do cliente; a conquista de novos clientes é um processo intermediário, não processo de marketing).

O marketing de relacionamento deve ser aplicado em toda a cadeia de valor da empresa abrangendo todos os relacionamentos durante o ciclo de elaboração integral do produto turístico. 


\section{Marketing de relacionamento como dinamizador da estratégia competitiva do cluster turístico.}

A cooperação entre empresas concorrentes desenvolve-se, especialmente, no setor de turismo, segundo as atuais estratégias do marketing de relacionamento. HUNT e MORGAN (1995) as definiram como sendo as atividades voltadas para estabelecer, desenvolver e manter as trocas de sucesso, por meio de parcerias com fornecedores e canais de distribuição, parcerias horizontais (alianças estratégicas com concorrentes e com o governo) e parcerias internas (departamentos funcionais, empregados e unidades de negócio). A fidelidade aos turistas que visitam o cluster turístico é alcançada, aplicando-se as técnicas do marketing de relacionamento. Em uma abordagem centrada no consumidor EVANS e LASKIN (1994), definiram marketing de relacionamento, como sendo o processo pelo qual uma empresa constrói alianças de longo prazo com seus clientes atuais e potenciais, de forma tal que comprador e vendedor trabalhem um conjunto comum de objetivos específicos. A interface que permite a integração desses tipos de estratégias é o marketing de relacionamento, a partir dos princípios conceituais que se resumem abaixo:

1. Reconfiguração da estrutura da organização para ganhar flexibilidade, eficiência e efetividade, como em CRAVENS e PIERCY (1994), SLATER e NARVER (1995), HUNT e MORGAN (1995).

2. Configuração da estrutura setorial, procurando a coexistência competitiva e cooperativa de todos os concorrentes no mercado, como em DULL, MOHN e NOREN (1995).

3. Melhoria da perspectiva do mercado e do aprendizado, pela cooperação e compartilhamento dos dados, informações, conhecimentos e aprendizado entre os atores, como em CRAVENS e PIERCY (1994), SLATER e NARVER (1995), HUNT e MORGAN (1995).

4. Utilização de bancos de dados e data meaning para melhorar, conjuntamente, a tecnologia de mensuração e predição, conhecimento, relacionamento com o cliente, grau de satisfação, eficiência dos sistemas administrativos estratégicos/operacionais, como em CRAVENS e PIERCY (1994), ANDERSON e NAURUS (1995).

5. Alavancar e concretizar oportunidades que não são possíveis individualmente, como em CRAVENS e PIERCY (1994), SLATER e NARVER (1995), ANDERSON e NAURUS (1995).

6. Redução de custos e de preços, como em HUNT e MORGAN (1995), VARADARAJAN e RAJARATNAM (1986), DULL, MOHN e NOREN (1995). 
7. Maior valor entregue aos clientes (melhores atividades conjuntas de apoio e básicas), como em CRAVENS e PIERCY (1994), HUNT e MORGAN (1995), VARADARAJAN e RAJARATNAM (1986), ANDERSON e NAURUS (1995).

8. Diminuir e/ou compartilhar os riscos no desenvolvimento de novas estratégias de produto, distribuição, promoção e mercados, como em SLATER e NAVER (1995), HUNT e MORGAN (1995), VARADARAJAN e RAJARATNAM (1986), ANDERSON e NAURUS (1995).

9. Atendimento e relacionamento com o cliente de maneira inter-relacionada e integrada, como em DULL, MOHN e NOREN (1995), HUNT e MORGAN (1995), CRAVENS e PIERCY (1994).

10. Maior competitividade e aumento da receita ao se integrar com as competências individuais e as de cooperação e competitividade, como em CRAVENS e PIERCY (1994), HUNT e MORGAN (1995).

\section{Impacto do Modelo Delta no setor de turismo.}

Com esse epigrafo se completa a parte conceitual da tese. Durante os estudos de Doutorado e o autor procurou aplicar os mais avançados conhecimentos em matéria de estratégias e competitividade no setor de turismo.

Adentrar o setor turístico significou um desafio para o autor, apesar de já haver incursionado no setor em seu país de origem. Foi decisiva a orientação de diversos professores da USP. O modelo de Sistema de Turismo, de Beni (2001), reproduzido de forma integral nesta tese, significou o ponto de partida para reunir dois temas aparentemente divorciados: estratégias competitivas das empresas turísticas e estratégias competitivas do setor.

A partir desse raciocínio, com a orientação dos Professores Toledo e Beni, e com a ativa participação do Doutorando pela Universidade de São Paulo, Álvaro Castroman Pollero, iniciouse uma intensa etapa de pesquisa e de produção científica, na forma de artigos publicados e apresentações em diversos congressos, devotados a entender a sustentabilidade do setor de turismo como um todo: sustentabilidade da estratégia competitiva das empresas e desenvolvimento sustentável do setor na região em questão. Nessa busca, a equipe de pesquisa conheceu o notável desenvolvimento que estavam tendo os clusters em outros setores da economia, o incipiente desenvolvimento bem sucedido de clusters em pólos turísticos, na Austrália, em Alberta, no Canadá, e Costa Rica, entre outros. 
Surgiu, assim, o Modelo Interfuncional Integral de competitividade nos destinos turísticos percorrido neste capítulo, que mostra as novas formas de concorrência e cooperação como vias para alcançar a competitividade dos destinos turísticos.

Finalmente, o ciclo se fecha, com um estágio de pesquisa realizado pelo autor no Instituto de Empresas de Madrid, Espanha, durante o ano de 2002. Durante sua estada na instituição, que ocupa o segundo lugar internacional no ranking das escolas de negócio, e sob a orientação dos Professores Dr. Guillermo Cardoza Bulla, Diretor do Centro Euro latino-americano do referido Instituto, Dr. Ramón Díaz Bernardo e Professor Joaquín Garralda, o autor pesquisou a cadeia Sol Meliá, aplicando a metodologia do estudo de casos e pode conhecer o Modelo de pensamento estratégico Delta, de Hax e Wilde (2001).

Concretamente, o Modelo de Beni (2001), sugere o tratamento sistêmico que devem receber os diferentes fenômenos que ocorrem no setor de turismo, como mostra e Figura a seguir:

Sistema de Turismo (SISTUR).

SISTUR - SISTEMA DE TURISMO

Modelo Teórico Referencial - Diagrama de Contexto

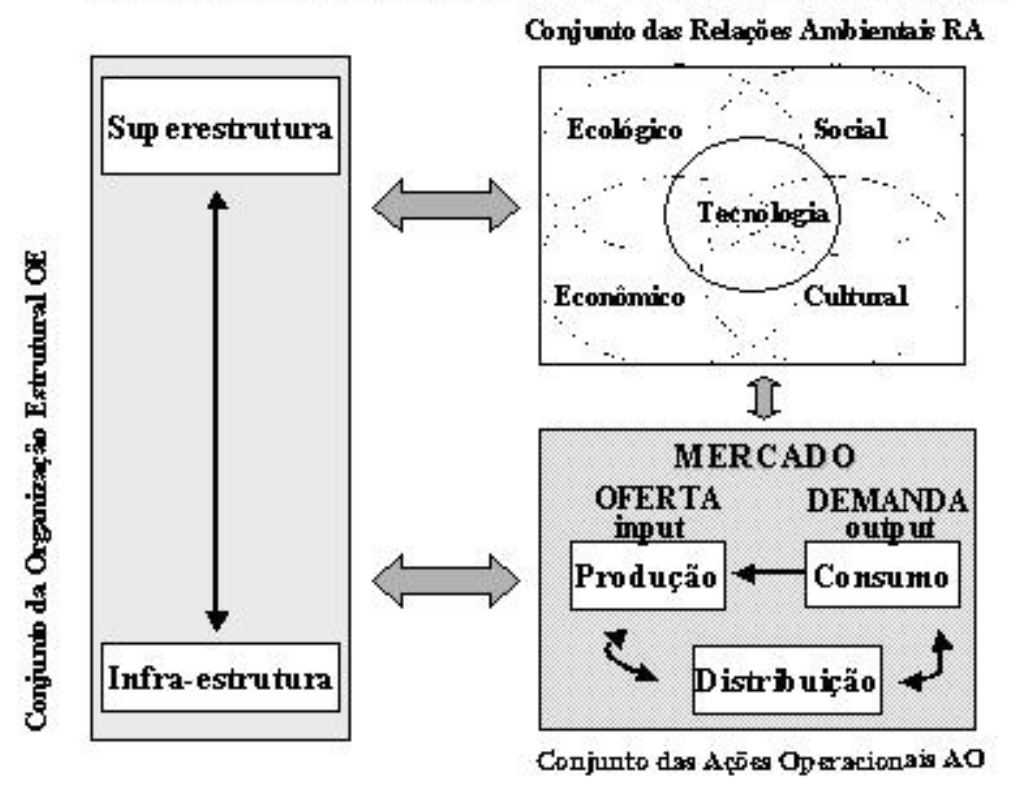

Figura 13: Sistur de Sistema de Turismo: Modelo Referencial - Diagrama de Contexto

O Modelo de Toledo, Alvarez e Castroman (2001), da competitividade nos destinos turísticos, indica o conjunto de relações que deve levar a um desempenho competitivo do destino turístico, por meio das melhores práticas de seus agentes e facilitadores, como resultante dos vetores de suas estratégias competitivas e de relacionamento com os clientes e demais atores, como apresentado nas figuras seguintes: 


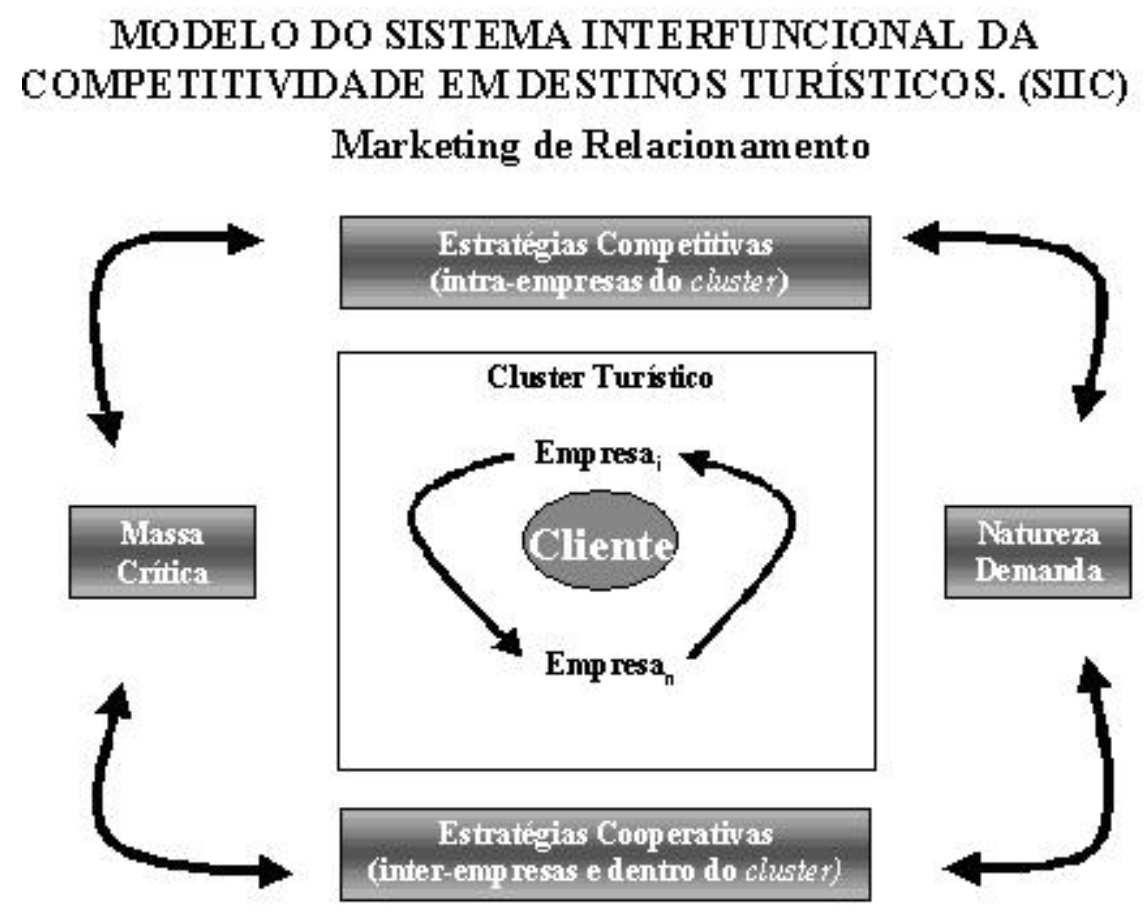

Figura 14: Modelo do Sistema Interfuncional da Competitividade em Destinos Turísticos
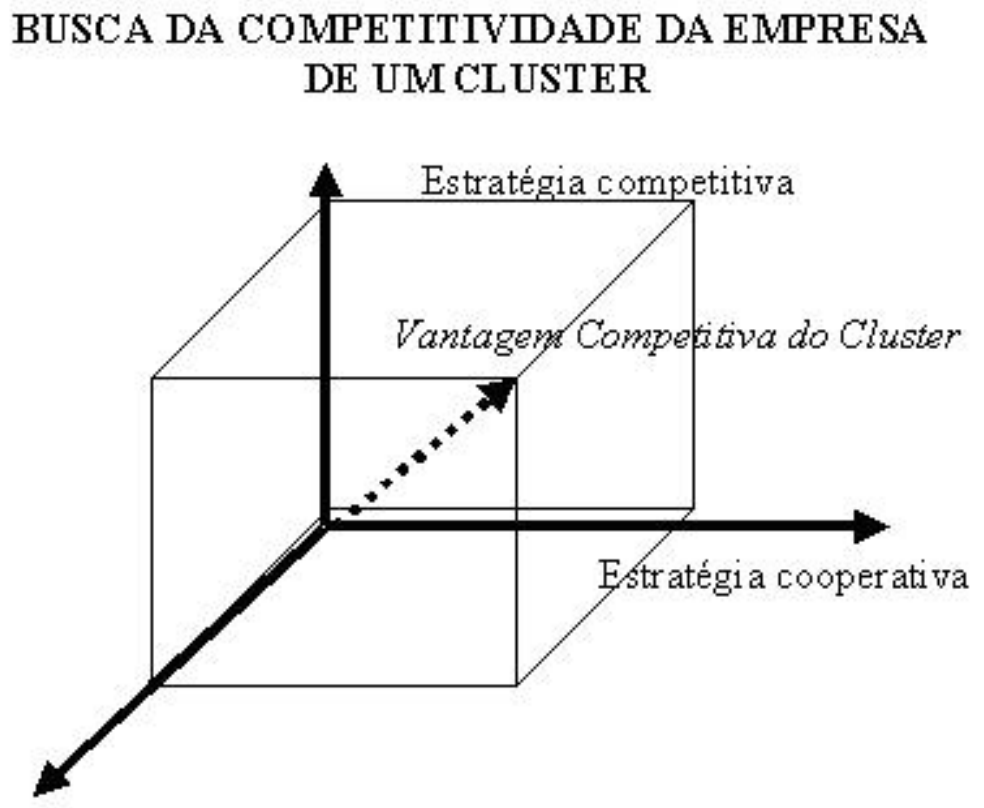

Figura 15: Busca da Competitividade da Empresa de um Cluster

Finalmente, o Modelo Delta, seguindo a mesma linha de pensamento, que impõe um desempenho competitivo de sucesso na nova economia, oferece o "o quê" e o "como" da 
estratégia, oferecendo, com seu Modelo, uma forma de localizar a posição competitiva da empresa, segundo o Triângulo observado na figura abaixo:

\section{Concorrência baseada na Economia de Sistemas}

Complementador dentro, competidor não entra, padrão proprietário.

Sistema Fechado (lock-in)

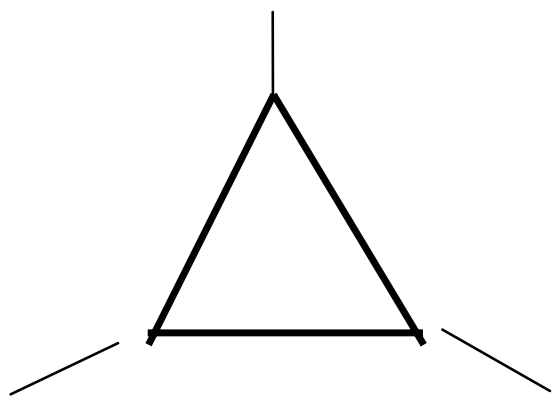

\section{Soluções Totais ao cliente}

Concorrência baseada em Economia do Cliente:

Reduzir custos ao cliente ou aumentar suas utilidades

\section{Melhor Produto}

Concorrência baseada na economia do produto: baixo custo ou um produto de posição diferenciada.

Figura 16: O Triângulo da Competitividade - Modelo Delta

Para posteriormente sugerir como devem ser reinterpretados os processos da empresa para alinhá-los com a estratégia proposta, e que apontam ao "como" no setor de turismo, embora existam empresas nos diferentes estágios de desenvolvimento, como apontou o autor na introdução do trabalho, o objetivo de tornar um destino sustentável, e o cluster como um todo competitivamente sustentável, se alcança quando todos sus agentes, públicos e privados adotam uma estratégia de Sistema Fechado, -lock in- do sistema, como estabelece Hax, entendido como a via para melhor satisfazer e fidelizar clientes.

Os três modelos que constituem o suporte teórico da tese, e que foram aplicados no estudo da cadeia hoteleira Sol Meliá, décima no ranking mundial de cadeias hoteleiras, com uma forte atuação na América Latina, permitiram um aprofundamento no estudo das estratégias de internacionalização seguidas hoje pelas empresas do setor e de como elas se materializam a partir da ótica da matriz de uma empresa transnacional.

Finalmente, destaque-se que o esforço para tornar competitivamente sustentáveis as estratégias dos agentes (públicos - privados) e destinos só será possível com a sustentabilidade do desenvolvimento local, entendido como a preservação do ecossistema, incluído como protagonista o homem, em um esforço conjunto e articulado de atuação, segundo o modelo apresentado. 
Figura 17: The Driving force-Pressure-State-Impact-Response model

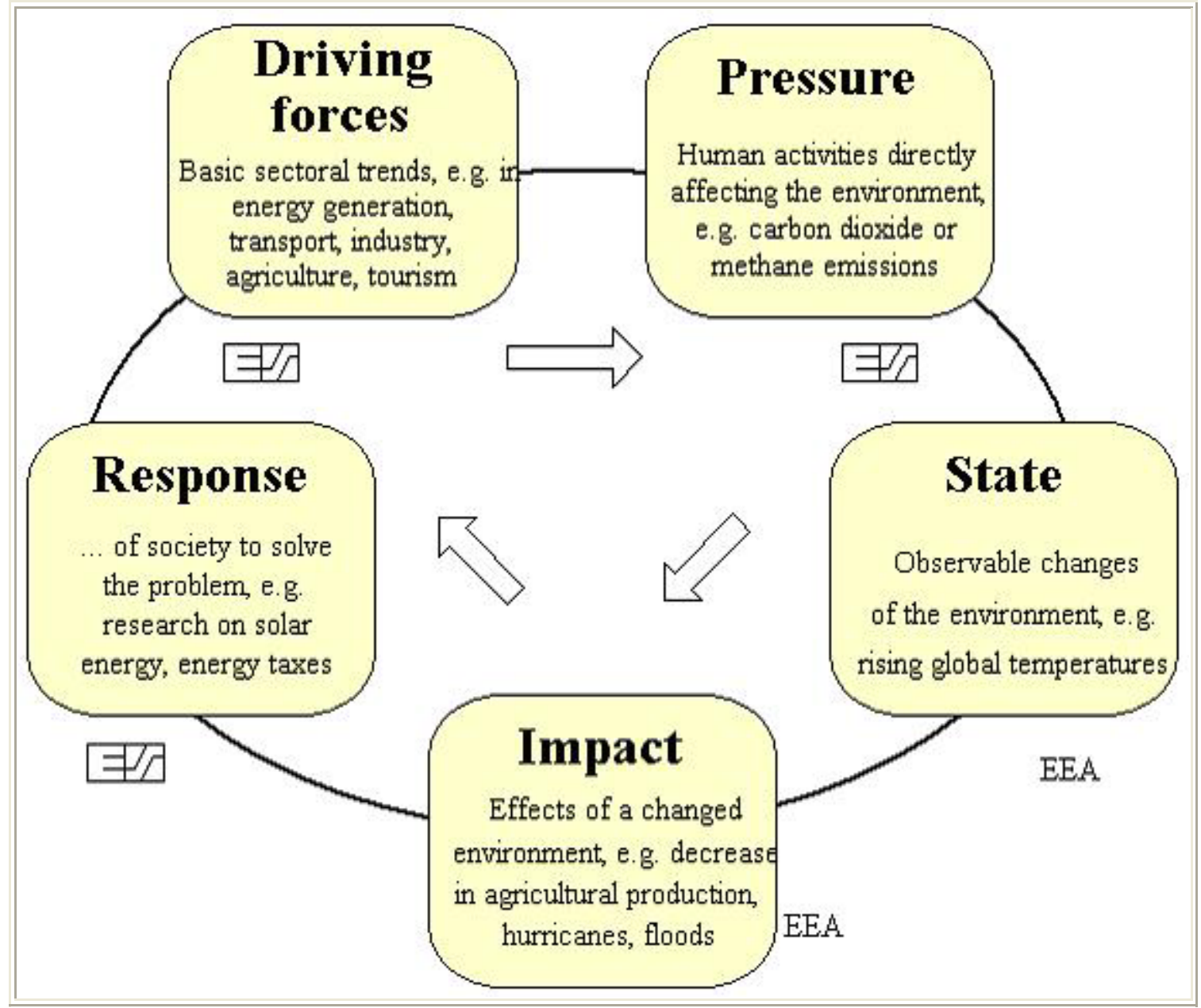

"For practical purposes, and in particular for the goals described in the Green Accounting Communication, the PSR model is sufficient. However, for compatibility reasons (e.g. to the DSR model), and for a better description of underlying economic trends, the indicator community has formulated the Driving force-Pressure-State-Impact-Response model, which includes P-S-R as special cases. Please note that, as explained before, the um CSD indicator process uses the DSR model, where the term "Driving Forces" is used synonimous for "Pressure" 
Capítulo V.

METODOLOGIA DA PESQUISA EMPÍRICA 


\section{CAPÍTULO V \\ METODOLOGIA DA PESQUISA EMPÍRICA}

1. Determinação do tipo de pesquisa

2. O projeto de pesquisa.

3. Definição das questões de estudo

4. Objetivos da pesquisa

5. Modelo operacional

6. Desenho da pesquisa

7. Tipos e fontes de informação

8. Métodos de acesso aos dados

9. Desenho de entrevistas

10. Coleta, análise e processamento da informação

11. Critérios seguidos para julgar a qualidade da pesquisa desenvolvida

12. Limitações da pesquisa de campo.

\section{Utilidade prática.}

\section{Determinação do tipo de pesquisa.}

SELLTIZ et al. (1974) destacaram que, "uma vez que o problema de pesquisa tenha sido formulado de maneira suficientemente clara, para poder especificar os tipos de informações necessárias, o pesquisador precisa criar seu planejamento de pesquisa. Um planejamento de pesquisa é a organização das condições para a coleta e análise dos dados, de maneira que procure combinar o significado para o objeto de pesquisa, com a eficiência e economia do processo. Disto decorre que os planejamentos de pesquisa variam de acordo com o objetivo da pesquisa". Caracteriza-se a pesquisa científica como um esforço cuidadoso para descobrir novas informações ou relações. Com a vista lançada na verificação e ampliação do conhecimento existente. Esta pesquisa buscou aprofundar os conhecimentos acumulados pela prática e a teoria, mediante a investigação sobre o desempenho empresarial atual do setor de turismo. Por isso, a primeira etapa da abordagem metodológica esteve vinculada à atualização e aprofundamento das bases conceituais acumuladas na administração geral, sistema estratégico, marketing estratégico e marketing turístico, segundo um enfoque sistêmico.

Nesse contexto, GREEN et al. (1988) apresentaram a seguinte definição: "um projeto de pesquisa é a especificação dos métodos e procedimentos para a aquisição dos conhecimentos 
necessários para a estruturação ou solução de problemas. O padrão operacional geral da estrutura do projeto é que estipula quais informações serão coletadas, de quais fontes, e com quais procedimentos. Um projeto eficaz deverá garantir que a informação obtida é relevante para o problema de pesquisa, que foi coletada por meio de procedimentos objetivos e eficientes".

Adotou-se, então, como referência, as considerações e definições apresentadas anteriormente. Para a elaboração do projeto de pesquisa empírica foram desenvolvidas as seguintes etapas:

— Determinação do tipo de pesquisa;

— Escolha do método;

- Escolha do setor a ser analisado;

- Escolha das unidades referenciais a pesquisar na fase exploratória do projeto;

- Definição dos profissionais a serem entrevistados;

- Elaboração dos instrumentos de coleta de dados;

— Aplicação dos instrumentos de coleta de dados;

— Processamento dos dados;

— Análise dos resultados;

— Discussão teórica e de evidências.

Para determinar o tipo de pesquisa, consideraram-se diferentes classificações. Segundo MATTAR (1994), o tipo de pesquisa é um conceito complexo que, em geral, não é descrito de maneira única. Muitas das classificações feitas por diferentes autores utilizam variáveis de classificação, que não podem ser utilizadas simultaneamente. GREEN et al. (1974) classificaram as pesquisas em três tipos: exploratórias, descritivas e causais.

Os principais objetivos dos estudos exploratórios, segundo estes autores, são a identificação de problemas, a formulação mais precisa de problemas (incluindo a identificação das variáveis relevantes) e de novas alternativas de cursos de ação. Um estudo exploratório freqüentemente é o primeiro numa série de procedimentos, que preparam para a busca de inferências entre as inúmeras variáveis envolvidas.

Os estudos descritivos voltam-se para a descrição de características ou funções. Estes estudos freqüentemente envolvem a descrição do grau de associação entre duas ou mais variáveis e podem ser utilizados para fazer inferências entre as variáveis envolvidas.

Os estudos causais procuram estabelecer e entender as relações causa-efeito, buscando determinar as causas dos eventos investigados por meio do controle das variáveis envolvidas. 
Em correspondência às características apresentadas para cada um dos tipos de pesquisa e os objetivos deste trabalho, adotou-se a pesquisa do tipo exploratório-descritivo, atendendo aos seguintes aspectos:

○ A utilização dos elementos de análise e decisão do marketing estratégico pelas empresas turísticas parece constituir um assunto relativamente novo e ainda pouco estudado no contexto dos países latino-americanos (caráter exploratório);

- Esta pesquisa busca ampliar o conhecimento existente sobre o tema, ou seja, estudar, a partir do referencial teórico, como as empresas turísticas utilizam os conceitos abordados em seus modelos de gestão e sistemas estratégicos, em sua atuação, com o objetivo de determinar como estão sendo aplicados para melhorarem seus desempenhos, caracterizando-os por sua eficiência, eficácia e efetividade (caráter descritivo).

A pesquisa apresenta abordagem positivista que, segundo MARTINS (1997), "as pesquisas consideradas positivistas utilizam fundamentalmente como técnicas de investigação os estudos descritivos, isto é, buscam a descrição das características de determinada população ou fenômeno, bem como o estabelecimento de relações entre variáveis e fatos".

Também pode ser definida como sistêmica, pois utiliza o método hipotético-dedutivo e técnicas descritivas para avaliar programas, métodos e afins. A causalidade é entendida pela lógica do inter-relacionamento integrado dos subsistemas com suas variáveis de entrada, de processo, de controle, de saída e retro-alimentação (feedback), segundo a Teoria Geral dos Sistemas.

A pesquisa utilizou os métodos qualitativos de análise para sustentar suas questões de estudo, seguindo o método de Estudo de Casos.

Segundo Yin (2001), a estratégia e o método de pesquisa estão em correspondência com o tipo de perguntas de pesquisa, resultantes da situação-problema, como se mostra na seguinte tabela:

\begin{tabular}{|c|l|c|c|}
\hline Estratégia & \multicolumn{1}{|c|}{$\begin{array}{c}\text { Forma da questão de } \\
\text { pesquisa }\end{array}$} & $\begin{array}{c}\text { Exige controle sobre } \\
\text { eventos } \\
\text { comportamentais }\end{array}$ & $\begin{array}{c}\text { Focaliza } \\
\text { acontecimentos } \\
\text { contemporâneos }\end{array}$ \\
\hline Experimento & Como, por quê & Sim & Sim \\
\hline Levantamento & $\begin{array}{l}\text { Quem, o quê, onde, } \\
\text { quantos, quanto }\end{array}$ & Não & Sim \\
\hline Análise de arquivos & $\begin{array}{l}\text { Quem, o quê, onde, } \\
\text { quantos, quanto }\end{array}$ & Não & Simão \\
\hline Pesquisa histórica & Como, por quê & Não & Não \\
\hline Estudo de caso & Como, por quê & Não & Sim \\
\hline
\end{tabular}

De acordo com o tipo de questões do estudo, a pesquisa efetuada responde a perguntas do tipo Como e Por quê, sendo conveniente o Estudo de Casos. 
Segundo Yin (2001), "em geral os estudos de caso representam a estratégia preferida quando se colocam questões do tipo "como" e "por quê", quando o pesquisador tem pouco controle sobre os eventos e quando o foco se encontra em fenômenos contemporâneos inseridos em algum contexto da vida real. Pode-se complementar esses estudos de casos "exploratórios" com dois outros tipos - estudos "exploratórios" e "descritivos". Independentemente do tipo de estudo de caso, os pesquisadores devem ter muito cuidado ao projetar e realizar estudos de casos, a fim de superar as tradicionais críticas que se faz ao método".

Fundamenta-se a adoção deste método pelas seguintes considerações:

O estudo de caso é uma pesquisa empírica que:

- Investiga um fenômeno contemporâneo dentro de seu contexto da vida real,

- especialmente quando os limites entre o fenômeno e o contexto não estão claramente definidos (há muitas variáveis exógenas).

A pesquisa de estudo de caso:

- Enfrenta uma situação tecnicamente única em que haverá muito mais variáveis de interesse do que pontos de dados, e, como resultado,

- Baseia-se em várias fontes de evidências, com os dados precisando convergir em um formato de triângulo, e, como outro resultado,

- Beneficia-se do desenvolvimento prévio de proposições teóricas para conduzir a coleta e a análise de dados.

Segundo Schramm (1971) "a essência de um estudo de caso, a principal tendência em todos os tipos de estudo de caso, é que ela tenta esclarecer uma decisão ou um conjunto de decisões: o motivo pelo qual foram tomadas, como foram implementadas e com quais resultados".

Esta pesquisa, que buscou aprofundar-se nas estratégias de marketing que utilizam as empresas turísticas na atual etapa da globalização, buscou analisar os tipos de decisões que foram adotadas por uma empresa turística internacional, em seu processo de internacionalização na América Latina, especificamente no Brasil e Cuba. A cadeia espanhola Sol Meliá, décima no ranking internacional decidiu apostar no mercado brasileiro e cubano como principais destinos na América Latina. O como e o por quê destas decisões são abordados aqui mediante o estudo de casos.

Mais ainda, a pesquisa teve como marco teórico referencial o Modelo Delta de Hax (2001), novíssimo sistema teórico que aborda os principais modelos de estratégias que adotam as 
organizações em um ambiente globalizado, onde a nova economia é um fato. Analisa-se o tema em um setor pouco explorado: o setor turístico, onde as relações que o Modelo descreve são de muita importância para a total satisfação do cliente.

Dessa forma, analisa-se um caso da vida real, em um contexto atual, em um setor de máxima importância, e se aplica um novo marco teórico referencial de análise, fatos todos que fundamentam a necessidade de aplicar um estudo de caso como pesquisa qualitativa, com a pretensão de entender o tipo de decisão, em um esforço exploratório, e descrever o tipo de resultados alcançados, interpretados dentro de um marco teórico específico e um contexto determinado de ambiente.

\section{O projeto de pesquisa.}

Segundo Nachmias e Nachmias (1992, referido por Yin: 2001), o projeto de pesquisa conduz o pesquisador através do processo de coletar, analisar e interpretar observações. É um modelo lógico de evidências que lhe permite fazer inferências relativas às relações causais entre as variáveis sob investigação. O projeto de pesquisa também define o domínio da generalização, isto é, se as interpretações obtidas podem ser generalizadas a uma população maior ou a situações diferentes. Outra maneira de se pensar em um projeto de pesquisa é como um "esquema" de pesquisa, que trata de, pelo menos, quatro problemas: quais questões estudar, quais dados são relevantes, quais dados coletar e como analisar os resultados.

Para a organização eficaz da pesquisa, seguiu-se a metodologia desenvolvida por MAZZON (1978) na elaboração de modelos em marketing. Ela consta de um roteiro que abrange: Modelo Teórico Referencial, Modelo Operacional, Sistema Estratégico em Turismo (na análise) e sua solução. Segundo APOSTEL, apud MAZZON (1978), o processo de modelagem na pesquisa permite construir uma ponte entre os níveis teóricos e práticos, proporcionando simplificação, redução, concretização, experimentação, ação, ampliação, globalização, a partir da formação de teorias e explicação, de fatos, fenômenos ou sistemas do mundo real. Para isto, seguiu-se o fluxo da figura mostrada a seguir. 


\section{Figura : Ciclo de construção e avaliação de um modelo teórico preferencial. CICLO DE CONSTRUÇÃO E AVALIAÇÃO DE UMMODELO TEÓRICO REFERENCIAL}

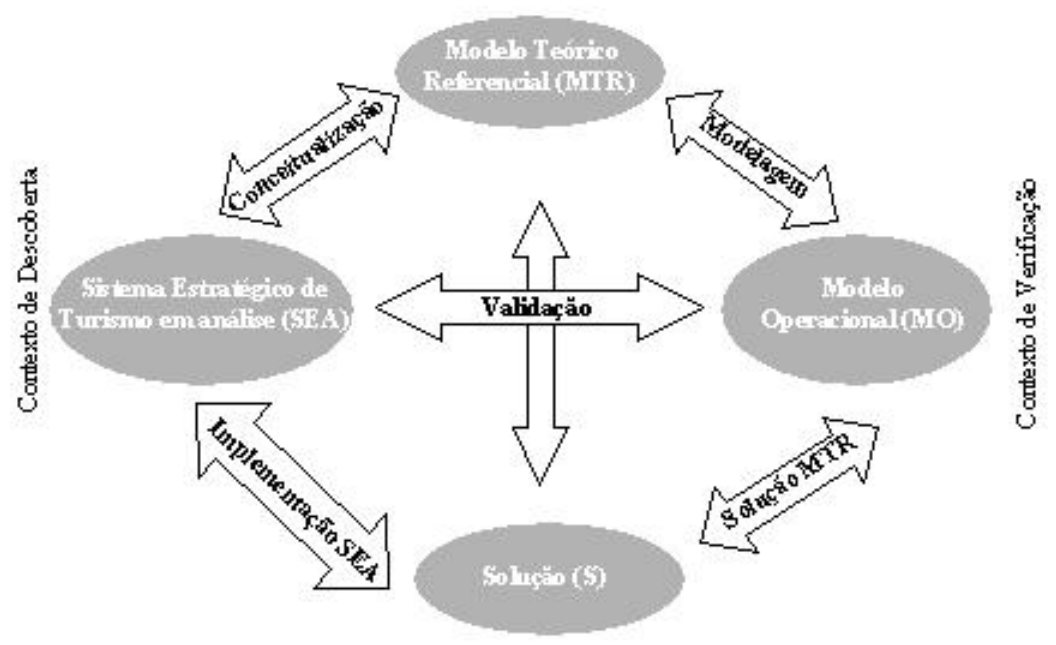

Fonte: Adaptado de MAZZON: 1978.

Este estudo constou de fases principais:

1. Conceitualização do Modelo Teórico Referencial. Processo de formação de conceitos básicos relativos ao problema. A partir da revisão da literatura técnica e científica atualizada dos temas Planejamento Estratégico, Marketing Estratégico, Marketing de Serviços, Teoria dos Sistemas em Turismo e Marketing Turístico, chegou-se à construção de um modelo que sustentou as necessidades de caráter teórico para este estudo. Neste caso, como parte do processo de pesquisa, no estágio na Espanha, o pesquisador pôde estudar o modelo teórico de pensamento estratégico, Modelo Delta de Hax (2001), do MIT dos Estados Unidos. Este modelo, de recente aparição e ainda não aplicado ao setor de turismo, constituiu um bom ponto de análise para o caso objeto de estudo. O pesquisador, junto com a equipe de pesquisa integrada pelo Orientador desta tese, Prof. Dr. Geraldo Luciano Toledo, da Universidade de São Paulo, o Doutorando Álvaro Castroman Pollero, veio investigando e produzindo artigos relacionados às novas relações entre as empresas, na era da globalização, no setor de turismo, especificamente sobre o relacionado com os clusters de empresas nos destinos turísticos, ou seja, os clusters turísticos. Como se fundamenta na teoria que sustenta esta tese, é talvez no setor turístico onde mais se fundamenta este tipo de relações, pela necessidade de explorar recursos naturais que os tornarão sustentáveis, base da competitividade das próprias empresas. Precisamente o Modelo Delta, de Hax, fundamenta esse estágio em que as empresas substituem a concorrência tradicional por novas formas de competir; no caso do turismo, competir entre clusters turísticos na forma de 
melhor servir os clientes. Daí a necessidade de aplicar estratégias como as propostas pelo modelo Delta, onde o que se busca é uma série de complementaridades entre as empresas que encerram o cliente em um sistema que o deixe totalmente satisfeito.

Caracterização do setor de Turismo no Brasil e em Cuba. Levantaram-se informações que permitiram ter uma visão ampla e atualizada do sistema empresarial no setor turístico no Brasil e Cuba. Concentrou-se, especialmente, nos aspectos referentes aos objetivos propostos neste estudo. Analisaram-se as principais estratégias dos distintos modelos de gestão aplicados e sua inserção competitiva no contexto latino-americano e mundial.

Complementou-se a revisão de literatura e levantamento, junto a cadeias hoteleiras espanholas, dos subsídios para desenvolver o estudo de caso. Essa etapa consistiu num estágio no Instituto de Empresas de Madrid, Espanha, planejado para uma duração de três meses, que se prolongou por mais de oito, por exigências próprias da pesquisa, em uma instituição patrocinadora que facilitou a orientação metodológica e contatos com empresas turísticas espanholas, com filiais no Brasil e Cuba. Este estágio foi de muita importância porque permitiu:

- Complementar a revisão da bibliografia e colher contribuições que ajudaram a desenvolver a fase qualitativa, no Brasil e Cuba.

- Visitar a várias cadeias hoteleiras, incluída a Sol-Meliá, sob os auspícios do Instituto de Empresas, a fim de:

a) colher subsídios que ajudaram no delineamento do instrumento de coleta de dados;

b) auxiliar no entendimento do processo gerencial estratégico de cadeias hoteleiras de sucesso, especialmente a questão do posicionamento estratégico das mesmas.

As visitas e os levantamentos efetuados tiveram um caráter exploratório, não havendo, portanto, compromisso do autor em incorporar os dados colhidos nos objetivos do trabalho. Esses dados foram considerados apenas parte do processo metodológico necessário para elaborar as várias etapas da tese.

Definição das proposições do estudo: Concomitantemente com a definição conceitual e operativa das variáveis, foi necessária a formulação das proposições do estudo que correlacionassem as unidades de análise escolhidas com o objeto de pesquisa. As proposições de pesquisa cumpriram a função de descrição e explicação provisória, que orientaram na aplicação das técnicas de pesquisa.

2, Construção do modelo operacional. Forma de instrumentalização do modelo teórico, face às evidências do mundo real. Adotou-se o estudo de caso como técnica de pesquisa, pelas razões já fundamentadas. 
3. Elaboração dos instrumentos da pesquisa. Foram elaborados roteiros para as entrevistas semi- estruturadas, agrupando-se as questões segundo o resultado da fase anterior, para facilitar a confecção de um instrumento enxuto e que apresentasse uma seqüência lógica e compreensível para os entrevistados, e que facilitasse a obtenção de dados acurados para a pesquisa.

4. Pré-teste dos roteiros das entrevistas. Foram desenvolvidos duas etapas das entrevistas; na primeira se ajustaram os roteiros das entrevistas de acordo com os resultados.

5. Desenvolvimento das entrevistas. Em todos os casos foram desenvolvidas as entrevistas com a participação do pesquisador.

6. Processamento da informação levantada. Foram processadas as informações primárias, resultado das entrevistas, assim como os dados secundários de toda a documentação, os quais facilitaram os entrevistados e a direção da empresa.

7. Validação e interpretação do modelo teórico referencial proposto. O capítulo VII analisa a validade dos resultados da pesquisa segundo o modelo teórico de referência adotado.

8. Discussão teórica e de evidências. Foi elaborada uma representação explicativa do sistema de planejamento estratégico de marketing, em termos de suas características e comportamentos, para contribuir, tanto na linha de pesquisa acadêmica como para o meio empresarial. As evidências e os resultados alcançados foram levados em consideração pelos especialistas do setor, em ambos os países, buscando aprimorar seus resultados com a experiência pessoal destes, para procurar a máxima adequação dos mesmos às condições do contexto do setor.

9. Elaboração da Tese. Incluem-se as conclusões, recomendações, extensões e limitações do estudo.

\section{Defesa da Tese e publicação de seus resultados.}

\section{Definição das questões do estudo}

A indagação central que motivou este trabalho correspondeu com a verificação de como é que estão sendo adotadas, pelas empresas turísticas, as estratégias de marketing, em função da crescente competitividade que gera a saturação dos mercados, em um ambiente fortemente globalizado. Em síntese, o problema de pesquisa pode ser expresso por meio das seguintes perguntas-problemas:

1. Quais são os instrumentos do marketing estratégico que estão sendo utilizados pelas empresas turísticas, para gerar vantagens competitivas em seus modelos de gestão? 
2. Como as empresas turísticas estão utilizando os elementos de análise e decisão de Marketing Estratégico, para competir no mercado internacional do turismo?

3. Que influência têm as técnicas do marketing estratégico, aplicadas nas empresas turísticas pesquisadas, em seus posicionamentos de mercado?

Para isso, pretende-se responder às seguintes questões de estudo:

1. Quais são as tendências do mercado turístico global em que operam estas empresas?

2. Qual é a estrutura competitiva do setor em que operam?

3. Qual o impacto, sobre as empresas turísticas, das forças e entidades dos ambientes econômico, tecnológico, ecológico, político e social em que operam?

4. Como administram suas carteiras de produtos?

5. Que políticas de preços empregam?

6. Quais são as estruturas e motivações dos canais de distribuição que utilizam?

7. Que força e qualidade têm os meios de comunicação que empregam?

8. Que tipos de capacidades internas, estruturas e cultura organizacional adotam?

9. Qual é o grau de criatividade e inovação de suas ofertas?

10. Quais são os desempenhos de sucesso?

11. Que tipo de estratégias competitivas elas têm adotado?

12. Estão estas organizações em condições de gerar vantagens competitivas sustentáveis?

\section{Objetivos da pesquisa}

Uma vez formuladas as perguntas-problemas, o objetivo geral perseguido foi: "estudar a utilização dos elementos de análise e decisão de Marketing Estratégico pelas empresas turísticas nos países receptivos, particularmente no Brasil e em Cuba, para alcançar um posicionamento de mercado compatível com o desenvolvimento do Turismo em suas regiões”.

A partir deste objetivo geral derivaram-se os seguintes objetivos específicos:

1. Identificar a utilização dos conceitos, modelos e técnicas de análise associadas ao marketing estratégico e sua contribuição para alcançar a competitividade das empresas pesquisadas no Brasil e Cuba; 
2. Avaliar, do ponto de vista do marketing estratégico, como as empresas que operam o turismo nos países receptivos, como Brasil e Cuba, desenvolvem suas potencialidades para serem competitivas;

3. Contribuir com o desenvolvimento de metodologias para o delineamento de estratégias competitivas no setor turístico em países como Brasil e Cuba;

4. Sugerir recomendações sobre as direções principais de mudança no enfoque gerencial das organizações turísticas que operam o turismo no Brasil e Cuba.

5. Modelo operacional. Como modelo operacional foi selecionado o método do estudo de casos na empresa Sol Meliá. Como unidades de análise, foram tomadas a Matriz da Cadeia Sol Meliá, com sede em Palmas de Mallorca, Espanha, e suas filiais em Cuba e no Brasil. A idéia, ao definir o estudo de casos como um estudo multicasos, foi a de entender as particularidades da aplicação de marketing estratégico em cada uma das filiais estudadas e contrastá-la com as definições gerais surgidas da casa-matriz.

Yin (2001) fundamenta as características dos projetos de caso único versus casos múltiplos. "Em algumas áreas, os estudos de casos múltiplos foram considerados uma "metodologia" diferente dos estudos de caso único. Por exemplo, a antropologia e a ciência política desenvolveram um conjunto de fundamentos lógicos para se realizarem estudos de caso único, e um segundo conjunto para se realizar o que se está chamando de estudos "comparativos" (ou de casos múltiplos) (veja Eckstein, 1975; George, 1979).

Projetos de casos múltiplos possuem vantagens e desvantagens distintas, em comparação com os projetos de caso único. As provas resultantes de casos múltiplos são consideradas mais convincentes, e o estudo global é visto, por conseguinte, como sendo mais robusto (Herdou \& Firestone, 1983). Ao mesmo tempo, o fundamento lógico para projetos de caso único, em geral, não pode ser satisfeito por casos múltiplos. E provável que o caso raro ou incomum, o caso crítico e o caso revelador impliquem apenas em casos únicos, por definição. A condução de um estudo de casos múltiplos pode exigir também tempo e amplos recursos, além daqueles que um estudante ou um pesquisador de pesquisa independente possuem.

Dessa forma, a decisão de se comprometer com estudos de casos múltiplos não foi tomada facilmente. Cada caso deve servir a um propósito específico dentro do escopo global da pesquisa. Aqui, uma percepção importante que se teve, foi considerar casos múltiplos como se considerariam experimentos múltiplos - isto é, seguir a lógica da replicação. As diferenças metodológicas entre essas duas visões são reveladas pelos diferentes fundamentos lógicos que subjazem a replicação, em oposição à lógica da amostragem. 
A lógica da replicação, e não da amostragem, para estudos de casos múltiplos é análoga àquela utilizada em experimentos múltiplos (veja Hersen \& Barlow, 1976). A lógica subjacente ao uso de estudos de casos múltiplos é igual. Cada caso deve ser cuidadosamente selecionado de forma a) prever resultados semelhantes (uma replicação literal); ou

b) produzir resultados contrastantes apenas por razões previsíveis (uma replicação teórica).

A capacidade de se conduzirem seis ou dez estudos de caso, efetivamente organizados dentro de um projeto de casos múltiplos, é análoga à capacidade de se conduzirem seis ou dez experimentos sobre tópicos relacionados; poucos casos (dois ou três) seriam replicações literais, ao passo que outros poucos casos (de quatro a seis) podem ser projetados para buscar padrões diferentes de replicações teóricas. Se todos os casos vierem a ser previsíveis, esses seis a dez casos, no conjunto, fornecerão uma base convincente para o conjunto inicial de proposições. Se os casos forem de alguma forma contraditórios, as proposições iniciais deverão ser revisadas e testadas novamente com outro conjunto de casos. Novamente, essa lógica é semelhante à maneira como os cientistas lidam com descobertas experimentais contraditórias.

Um passo importante em todos esses procedimentos de replicação é o desenvolvimento de uma rica estrutura teórica. A estrutura precisa expor as condições sob as quais é provável que se encontre um fenômeno em particular (uma replicação literal), assim como as condições em que não é provável que se encontre (uma replicação teórica). A estrutura teórica torna-se mais tarde o instrumento para se generalizar a casos novos, novamente semelhantes ao papel desempenhado de projetos de experimentos cruzados. Ademais, da mesma forma que na ciência experimental, se alguns dos casos empíricos não funcionarem como casos previsíveis, deve-se fazer alguma modificação na teoria.

Atendendo a estas considerações, e às questões de estudo que embasarão a pesquisa, considerouse prudente realizar um estudo de casos múltiplos, considerando a Matriz da Sol Meliá, a filial no Brasil (correspondente a toda América do Sul) e a filial na Havana, como casos independentes. Uma vez bem esmiuçado o objeto de estudo, a análise das ferramentas do marketing estratégico poderia ser efetuada para verificar se tais ferramentas poderiam ser aplicadas de forma diferente em cada contexto. Desta forma, foram tomados os casos das filiais para se realizar uma primeira rodada de entrevistas na Espanha, tanto em Madrid, como em Mallorca, para depois realizar as entrevistas específicas com os dirigentes da Sol Meliá no Brasil e em Cuba. Uma segunda rodada de entrevistas foi realizada posteriormente, tanto na matriz como nas próprias filiais, uma vez processada a informação primária inicial e as diferentes fontes de informação secundária proporcionada pela própria cadeia e as coletadas na Internet e outros 
meios. Anexa-se relação de todas as pessoas entrevistadas, assim como a relação de documentos com informação secundária revisados.

\section{Desenho da pesquisa}

A pesquisa foi desenhada segundo os seguintes critérios.

- Uma etapa de desenvolvimento das qualidades do pesquisador, segundo o programa de cursos e créditos da Universidade de São Paulo, vencida pelo exame de qualificação.

- Um estágio de atualização e preparação da pesquisa, na Espanha, no Instituto de Empresa de Madrid.

- A primeira rodada de entrevistas com os dirigentes da Sol Meliá, representantes da OMT, representantes do turismo do Brasil e Cuba na Espanha. Participação em diversos seminários na Espanha, sobre a atualidade do sistema de turismo.

- Vistas a hotéis da Sol Meliá, na Espanha, e entrevista com seus diretores.

- Como parte desta fase, foram escritos dois casos de aplicação docente, no Instituto de Empresas de Madrid.

- Trabalho de campo no Brasil. Entrevista com os dirigentes da Sol Meliá em São Paulo, representantes da Sol Meliá para toda América do Sul. Visita a hotéis. Entrevistas com funcionários da EMBRATUR, e com diversos professores e profissionais do turismo nesse país.

- Trabalho de campo em Cuba. Reuniões com os principais dirigentes responsáveis pelo desenvolvimento turístico de Cuba. Entrevistas com os dirigentes da Sol Meliá em Cuba. Percurso pelos hotéis da Sol Meliá na Ilha.

- Processamento de toda a informação coletada, tanto os resultados das entrevistas, que se encontram gravados em suporte eletrônico, como da informação secundária coletada, tanto em suporte eletrônico como em papel e outras formas.

- Análise dos resultados e redação da tese.

- Destacar que durante todo o período de pesquisa, o pesquisador apresentou diversos artigos e exposições para eventos científicos no Brasil, México, Espanha, tendo publicado vários destes artigos.

\section{Tipos e fontes de informação}

A principal fonte de informação para o estudo de casos foram as entrevistas. Para o desenvolvimento das entrevistas, houve uma etapa inicial de preparação, a partir de informação secundária sobre a própria cadeia e sobre o setor turístico em geral. 
Participou-se de um seminário de trabalho, desenvolvido pela Associação de Diretores de Hotéis da Espanha, sobre estratégia empresarial, coordenado por professores da Universidade politécnica de Madrid.

Como fontes secundárias de informação se revisaram todos os informes anuais da companhia, os distintos documentos fornecidos pelos entrevistados, assim como toda a informação coletada na Internet. Durante o período da pesquisa foi feito acompanhamento particular do processo, junto à empresa e ao setor em seu conjunto bem à imprensa especializada Da mesma forma, foram ouvidas as opiniões de expertos,.

Para realizar as entrevistas com pessoas-chave, trabalhou-se em conformidade com o horário e a disponibilidade do entrevistado. A natureza da entrevista foi muito mais aberta, e o entrevistador tinha em conta que o entrevistado podia não querer cooperar integralmente em termos de responder às questões. Esse processo, ao se realizar a coleta de dados, leva à necessidade de se terem procedimentos de campo explícitos e bem-planejados ao se "enfrentarem" comportamentos e diretrizes. Com essa orientação em mente, os procedimentos de campo do protocolo enfatizaram as principais tarefas ao se coletarem os dados, incluindo:

- Obter acesso a organizações ou a entrevistados-chave.

- Possuir materiais suficientes enquanto estiver no campo - incluindo um computador pessoal, material para escrever, papel, clipes e um local calmo e preestabelecido para tomar notas.

- Desenvolver um procedimento para pedir ajuda e orientação, se necessário for, de pesquisadores ou colegas de outros estudos de caso.

- Estabelecer uma agenda clara das atividades de coleta de dados que se espera que sejam concluídas em períodos especificados de tempo.

- Preparar-se para acontecimentos inesperados, incluindo mudanças na disponibilidade dos entrevistados, assim como alterações no humor e na motivação do pesquisador do estudo de caso.

São esses os tópicos que foram incluídos na seção de procedimentos de campo do protocolo.

\section{Métodos de acesso aos dados}

Para ter acesso à informação primária, foi necessário estabelecer as coordenadas pertinentes à alta direção da cadeia hoteleira. Há que considerar que a Sol Meliá é uma empresa que tem ações participação das na bolsa de valores de Madrid, e que, portanto, tem uma informação oficial pública e disponível em sua página Web na Internet. Mas, logicamente, este tipo de informação, 
embora sendo pertinente para a pesquisa, não redundava completa para compreender a natureza dos aspectos que se estavam investigando. Foi necessário recorrer à representante da Direção de Turismo de Cuba, na Espanha, Sra. Marité López, Representante de Cuba perante a OMT, à Presidência da Associação de Diretores de Hotéis da Espanha, D. Jesús Felipe Gallego, ao Sr. Miguel Rivas, Diretor da Consultora M Rivas Group, com amplas relações no setor, e a outras personalidades responsáveis pelo turismo no Brasil e Cuba. Para obter a autorização necessária para realizar as entrevistas, assim mesmo foi decisiva a participação dos Professores Guillermo Cardoza Bulla, Diretor do Centro Euro-Latinoamericano do Instituto de Empresas e Ramón Díaz Bernardo do próprio Instituto, os quais deram o respaldo institucional, metodológico e material para as entrevistas. Finalmente o Sr. Sebastián Escarrer, Vice-presidente da Sol Meliá e fillho de seu fundador, deu a autorização correspondente. Todo o processo culminou com uma reunião final de apresentação dos resultados da pesquisa na sede da matriz da Sol Meliá.

\section{Desenho de entrevistas}

No desenho das entrevistas se considerou que, além da pesquisa, pretendia-se elaborar diversos estudos de casos para sua utilização como material docente na formação de dirigentes no Instituto de empresa de Madrid.

O Centro Euro-Latinoamericano do Instituto de Empresas de Madrid, Espanha, dentro de seus objetivos de trabalho, fomentou o estudo daquelas empresas espanholas com práticas de gestão bem sucedidas e com atuação na América Latina.

Mediante esta pesquisa não só se enriquece o acervo do próprio Instituto que utiliza seus resultados na melhor formação de dirigentes, nos cursos de pós-graduação, de MBA, etc., como ainda facilita o acesso de candidatos dos países latino-americanos para realizar as mesmas, o que eleva o potencial de recursos humanos da região e facilita o processo de ampliação dos investimentos destas empresas, naqueles países.

Nesta ocasião, foi selecionada a Cadeia Hoteleira Sol Meliá, companhia Hoteleira líder na Espanha, América Latina e o Caribe, a segunda da Europa e a décima em nível mundial, que traz a integração da cadeia Hoteleira TRYP e dispõe de mais de 330 hotéis, em 30 países. As entrevistas foram realizadas pelo próprio autor.

A Metodologia de pesquisa que se seguiu consistiu na coleta de informação, mediante entrevistas com perguntas estruturadas e abertas aos principais dirigentes da cadeia, segundo o tema escolhido e mediante obtenção de informação documental complementar.

No desenho das entrevistas se perseguiram os seguintes objetivos: 
- Determinar as causas e condições que motivaram o processo de reposicionamento de marcas, seguido pela Cadeia Sol Meliá, recentemente.

- Conhecer como foram estruturadas as principais ações do plano de marketing da matriz e seus filiais, segundo as novas marcas adotadas.

- Precisar a influência que a nova definição de marcas teve na política de preços da Companhia.

- Conhecer o impacto do reposicionamento de marcas nos canais de distribuição que utiliza a Empresa.

- Conhecer os aspectos mais importantes do processo de comunicação desenvolvido para o reposicionamento das marcas adotadas.

- Avaliar a influência do reposicionamento de marcas no processo de internacionalização e expansão da Empresa especialmente na América Latina.

\section{Dirigentes programados para as entrevistas - (Primeira etapa)}

- Sebastián Escarrer Jaume, Vice-presidente.

- Luis do Olmo, Diretor de Marketing.

- Evagrio Sánchez, Diretor de Expansão para América Latina

- Gabriel Cánaves, Divisão Cuba

\section{Dirigentes programados para as entrevistas - (Segunda Etapa)}

- Marité López, Diretora da Oficina de Turismo de Cuba na Espanha e representante ante a OMT

- Elizabeth Kyoko Wada, Diretora de Marketing da Sol Meliá para o Brasil

- Juan Oscar González, Diretor de Marketing da Sol Meliá em Cuba

- Um Diretor de Hotel da Cadeia Sol Meliá em Madrid, em Havana e em São Paulo.

\section{Participantes nas entrevistas:}

- Prof. Guillermo Cardoza, Diretor do Centro Euro-Latinoamericano do Instituto de Empresas.

- Marité López, Diretora do Escritório de Turismo de Cuba na Espanha, e representante perante a OMT

- Prof. Ramón Díaz Bernardo, Professor de marketing do Instituto de Empresas.

- Miguel Rivas, Diretor de Training Outsourcing

- Jesús Alvarez Valdés, pesquisador 
As entrevistas foram do tipo semi-estruturadas a fim de permitir ao entrevistado ampliar, a seu critério, aqueles aspectos que considerados de maior interesse.

Em uma segunda etapa, direcionou-se a objetivos mais específicos nas entrevistas:

\section{Área: Expansão.}

1. Determinar as características do processo de expansão da empresa Sol Meliá

2. Identificar as fontes de vantagens competitivas da empresa e o posicionamento alcançado nos principais produtos-mercados

3. Conhecer as características dos processos de implementação da estratégia de expansão da empresa

\section{Área: Inovação e desenvolvimento.}

1. Conhecer as características da estratégia de P\&D da empresa.

2. Determinar como são incorporadas as necessidades e motivações dos clientes no processo de inovação de produtos da empresa.

3. Conhecer os programas de sustentabilidade do meio ambiental nos diferentes destinos turísticos em que opera a empresa.

\section{Área: $e$-transformação}

1. Conhecer o processo de introdução e aplicação das tecnologias da informação na empresa.

2. Determinar os benefícios da e-transformação da empresa para todos os tipos de clientes.

\section{Área Recursos Humanos}

1.Conhecer as características principais dos processos de formação dos recursos humanos da empresa.

2. Conhecer os resultados do programa GSA desenvolvido pela empresa.

\section{Área Marketing}

1. Conhecer as principais características da segmentação de mercado que realiza a empresa.

2. Determinar a adequação da política de produto da empresa segundo os diferentes segmentos objetivos.

3. Conhecer as características da comercialização e vendas dos produtos da empresa

4. Identificar as características da estratégia de comunicação e marcas que desenvolve a empresa 
5. Determinar como se concretiza a estratégia de orientação ao cliente que segue a empresa

\section{Área Marketing}

\section{Política de produto - Questões}

- Como a empresa se integra oferta (produto, preço, comunicação e distribuição) em um conjunto de atributos únicos, segundo as necessidades de cada segmento objetivo?

- Como a empresa Sol Meliá combina a política de elaboração de manuais detalhados para especificar as características de parâmetros físicos e de serviços de cada um de seus estabelecimentos, com a necessidade de alcançar uma composição personalizada de produtos e serviços ajustada a cada segmento de clientes?

- Em que medida a oferta é complementada por outros serviços, não propriamente hoteleiros (seguros turísticos, transportes, serviços médicos, ofertas de opções de lazer, de saúde, etc), para satisfazer integralmente aos clientes da empresa?

\section{Critérios de comercialização - Questões}

- Quais são os canais de distribuição que de se utiliza a empresa para a comercialização de seus hotéis?

- Que peso têm os tour-operators na comercialização dos estabelecimentos da empresa?

- Existem canais diretos de comercialização que a empresa utiliza para seus segmentos alvo?

- A empresa possui seus próprios canais de comercialização: tour-operators, agências de viagens?

- Que peso têm as vendas on line, pela Meliá-Viagens, sobre o total vendas?

- Qual é o peso da Central de Reservas SolRes?

- Como se integra a oferta da Sol Melía aos GDS?

\section{Critérios de branding - Questões}

\section{Sobre a reestruturação de marcas que a empresa desenvolveu:}

- A empresa é direcionada para a política de destacar os atributos de seus produtos?

- Em que medida as novas marcas estão em harmonia com os segmentos de clientes da empresa?

- Existe relação entre a estrutura de marcas da empresa e a de empresas de serviços complementares aos clientes (seguros turísticos, transportes, serviços médicos, ofertas 
de opões de lazer, de saúde, etc)?

\section{Critérios de orientação para o cliente - Questões}

- Como se estrutura a política de orientação para o cliente da empresa?

- Em que medida é possível personalizar os serviços segundo os segmentos alvo?

- Como a empresa organiza o processo de feedback (retro-alimentação) e aprendizagem, a partir das experiências dos clientes?

- Como mede a empresa mede o retorno dos clientes (uso repetido de seus serviços)?

- Quais são as bases do programa MAIS de fidelização da empresa? Que peso tem o programa?

- Como são aplicadas as tecnologias da informação para elevar o grau de vinculação com os clientes?

- Integram-se as informações relevantes sobre os clientes, com outras empresas complementadoras de serviços aos clientes (seguros turísticos, transportes, serviços médicos, ofertas de ócio, de saúde, etc)?

- Quais são os critérios de segmentação de mercado a empresa que aplica?:

_ Pelas características sociodemográficas dos consumidores

_ Pelas vantagens buscadas no produto

_ Pelas características do comportamento de compra (segmentação comportamental)

_ Pelos estilos de vida, descritos em termos de atividades, interesses e opiniões (segmentação sociocultural e/ou psicográfica).

- A segmentação poderia ser caracterizada, em termos quantitativos, segundo estes critérios?

- Qual é o comportamento da freqüência dos fluxos de turistas (freqüência de uso)? Causas.

- A que fatores de marketing são mais sensíveis os turistas atuais e potenciais?

- A empresa tem implementado o procedimento de feedback sobre mudanças de comportamento dos consumidores?

\section{Fornecedores - Questões}

- Quais são as principais políticas da Sol Meliá relativo a seus fornecedores?

- Desenvolve a empresa cadeias próprias fornecimento?

- Existem alianças ou integração vertical com sub-fornecedores-chave?

- Como é integrada a cadeia de suprimentos para satisfazer as necessidades de clientes, segundo os diferentes segmentos? 
- Existem acordos de integração com fornecedores comuns a empresas complementadoras dos serviços da empresa?

\section{Pesquisa e Desenvolvimento}

- Como é desenvolvida a estratégia de inovação na empresa?

- O enfoque da inovação na empresa está dirigido ao desenvolvimento interno de seus produtos?

- Que participação têm os clientes no processo de inovação da empresa?

- Existem programas em conjunto com outras empresas complementadoras dos serviços que a empresa oferece a seus clientes?

- Quais são os principais programas de sustentabilidade do meio ambiente que a empresa realiza?

\section{Papel das tecnologias da informação.}

- Qual é a estratégia de introdução e aplicação das novas tecnologias da informação na empresa (e-business, e-commerce, e-system)?

- Em que consiste a $e$-transformação da empresa?

- Como as tecnologias da informação oferecem um suporte interno à gestão da empresa?

- Como a aplicação das tecnologias da informação da empresa se entrelaça com os fornecedores?

- Como as TI oferecem um suporte para os clientes (pré-consumo-pós)?

- A empresa integra seus programas de desenvolvimento das TI às empresas complementadoras de serviços aos clientes?

\section{Área: Expansão - Questões}

\section{Adequação da estratégia da empresa às características da região latino-americana.}

- Como é avaliado o contexto macro-econômico em que a empresa desenvolve empresa sua expansão na América Latina, especialmente no Brasil e Cuba?

- Como foram considerados os marcos econômicos desta operação?

- Como foram consideradas as condições do meio ambiente natural em que se desenvolve a atividade, segundo a região?

- Que grau de desenvolvimento têm os recursos artificiais e as infra-estruturas existentes para lograr a sustentabilidade da exploração turística na região? 
- Que organizações jurídicas e estruturais estão sendo criadas pelos órgãos públicos e privados, para assegurar o cumprimento das políticas e diretrizes por todos os agentes atuantes?

- Como foram considerados os marcos legais em cada região?

- Que políticas de inovação tecnológica e de assimilação de novas tecnologias estão sendo adotadas?

- Em que medida a sociedade local está consciente da importância e natureza do desenvolvimento turístico na região? Como está preparada a população para acolher com hospitalidade os turistas nacionais e estrangeiros?

- Como foram considerados os marcos operacionais para a expansão em cada região?

- Quais são as características do mercado no qual o pólo desenvolve sua atividade?

- Como estão delimitadas as condições da oferta quanto à diversidade de produto, preço, distribuição e comunicação, na região?

- Como são ajustadas as campanhas de comunicação da empresa à projeção da imagem de cada pólo?

- Que estudos de mercado são realizados que contemplem uma caracterização das motivações e necessidades dos vários tipos de clientes que se pretende atrair para os estabelecimentos da empresa segundo o pólo?

- Que estratégias de fidelização dos clientes estão sendo adotadas pelos agentes da região?

- Que estruturas para a segurança (sanitária e física) do turista estão sendo aplicadas?

\section{Fontes de vantagens competitivas.}

- Quais fontes de vantagens competitivas da empresa são consideradas?

- Quais são as vantagens competitivas da empresa em cada produto-mercado e segmentos? Baseiam-se as vantagens em estratégias de custos, de diferenciação ou de especialistas?

- São defensáveis e sustentáveis as vantagens competitivas da empresa?

- Qual é o posicionamento adotado em cada produto-mercado?

- Os pontos de referência da empresa, em sua monitoria do mercado (benchmarking), estão direcionados até as empresas competidoras, os clientes ou as empresas complementadoras?

- Qual é o grau de atratividade de cada um dos produtos-mercados e segmentos para os quais se dirige a empresa? 
- Como podem ser definidas as estratégias de crescimento da empresa? (nota de 1 a 10)

○ Crescimento intensivo, que pode ser: por penetração de mercado, ou por desenvolvimento de produtos;

○Crescimento integrado, ou crescimento no seio do setor, por meio de uma extensão vertical ou horizontal.

○Crescimento por diversificação, que se apóia nas oportunidades da empresa, situadas fora de seu campo habitual.

○ Estratégia de líder - por desenvolvimento da demanda primária, por uma estratégia defensiva ou por uma estratégia ofensiva; de desafiador - por ataque frontal ou por ataques laterais; de seguidor - por comportamento adaptativo, alinhando as decisões com as adotadas pela concorrência; de especialista - de especialização em um nicho.

- Qual é o número de competidores diretos?

- Que participação de mercado possuem os maiores competidores?

- Qual é a força da imagem de marca dos competidores atuais?

- Qual é a fonte de vantagem competitiva dos competidores mais importantes?

- Qual é o grau de concentração dos tour-operators turísticos e que poder de negociação têm graças a este?

Critérios sobre as características dos processos de implementação da estratégia da empresa.

Os processos de implementação da estratégia estão dirigidos a: (classificar de 1 a 10)

- Estabelecer uma infra-estrutura de custos internamente eficiente

- Buscar a cobertura do target de clientes por intermédio da comercialização em massa via tour-operators e agências de viagens

- Perseguir, mediante a inovação e desenvolvimento dos melhores produtos da empresa, com a ajuda das plataformas apropriadas à expectativa de ser "os primeiros no mercado"

- Melhorar a economia do cliente e os vínculos horizontais nos componentes que trazem soluções totais para os mesmos.

- Identificar "pacotes de soluções integrais" para os clientes, explorando oportunidades que agreguem valor a clientes-chave e examinando opções de propriedade de canais.

- Buscar, mediante a inovação, identificar e explorar o desenvolvimento associado com a cadeia de valor do cliente e integrar e inovar funções de atenção ao cliente. 
- Aumentar a fidelização de clientes pela personalização e a aprendizagem de suas necessidades.

- Melhorar os geradores de rendimento do sistema, integrando os complementadores para melhorar o rendimento do sistema.

- Identificar a arquitetura do sistema e seus principais complementadores para consolidar uma posição de fechamento do sistema com os complementadores.

- Aumentar o número e variedade de complementadores e se possível conquistar a propriedade de canais de distribuição direta.

\section{Critérios sobre a efetividade e eficiência dos processos de expansão (métrica dos processos).}

- Quais são os critérios de qualidade e dos produtos?

- Quais são os indicadores que a empresa utiliza para medir a efetividade de suas operações?

- Quais são os indicadores que a empresa utiliza para medir a efetividade de seus processos de orientação ao cliente?

- Quais são os indicadores que medem a efetividade dos processos de inovação que a empresa desenvolve?

\section{Recursos Humanos}

- Qual é a estratégia de formação dos recursos humanos que a empresa desenvolve

- Como se instrumentou o programa GSA?

\section{Coleta, análise e processamento da informação}

A dificuldade para fixar as entrevistas e obter as autorizações correspondentes atrasou o cronograma da pesquisa proposto originalmente. Finalmente o pesquisador obteve toda a informação necessária para a elaboração da análise e das conclusões. Há que destacar que uma aplicação prática da pesquisa foi a publicação de dois estudos de caso sobre a cadeia Sol Meliá, em duas versões, em papel e virtual (on line).

Seguindo as recomendações de Yin (2001), para a realização das entrevistas foi desenvolvido um protocolo que refletiu duas características:

○ Primeiro: as questões foram feitas ao pesquisador e não ao entrevistado? Foram, em essência, os lembretes que foram utilizados para recordas as informações que precisariam ser coletadas e o motivo para coletá-las. Em alguns exemplos, as perguntas específicas também poderiam servir de aviso ao se formularem as questões durante a entrevista; o objetivo principal dessas questões, no entanto, foi manter o pesquisador na pista certa à 
medida que a coleta avançava.

- Segundo: cada questão deveria vir acompanhada de uma lista de fontes prováveis de evidências. Tais fontes poderiam incluir os nomes de cada entrevistador, os documentos ou as observações. Esse caminho, entre as questões de interesse e as prováveis fontes de evidências, foi extremamente útil ao se coletarem os dados. Antes de iniciar uma determinada entrevista, por exemplo, o pesquisador pôde rapidamente rever as principais questões que a entrevista deveria abranger. Ressalte-se que essas questões formaram a estrutura da pesquisa e não foram feitas literalmente ao entrevistado.

\section{Critérios seguidos para julgar a qualidade da pesquisa desenvolvida}

Um projeto de pesquisa deve representar um conjunto lógico de proposições. Por isso, é necessário julgar a qualidade do projeto, de acordo com certos testes lógicos. Segundo Yin (2001), quatro testes tem sido comumente utilizados para se determinar a qualidade de qualquer pesquisa social empírica. Una vez que os estudos de caso representam uma espécie desses estudos empíricos, os quatro testes também são importantes para a pesquisa de estudo de caso. A Tabela abaixo apresenta os quatro testes amplamente utilizados, as táticas recomendadas de estudo de caso, assim como uma referência à fase da pesquisa em que a tática foi empregada. 
Táticas do estudo de caso para quatro testes de projeto

\begin{tabular}{|c|c|c|}
\hline Testes & Tática do estudo de caso & Fase da pesquisa onde a tática foi aplicada \\
\hline Validade do construto & $\begin{array}{l}\text { Utiliza fontes múltiplas de evidências } \\
\text { Estabelece encadeamento de evidências } \\
\text { O rascunho do relatório } \\
\begin{array}{l}\text { Estudo de caso é revisado por informantes } \\
\text { chaves }\end{array}\end{array}$ & $\begin{array}{l}\text { coleta de dados } \\
\text { coleta de dados } \\
\text { composição }\end{array}$ \\
\hline 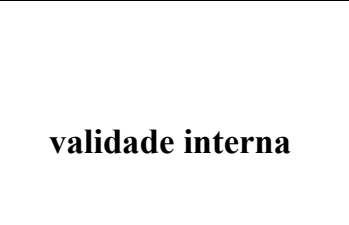 & $\begin{array}{l}\text { Faz adequação ao padrão } \\
\text { Faz construção da explanação } \\
\text { Faz análise de séries temporais }\end{array}$ & $\begin{array}{l}\text { análise de dados } \\
\text { análise de dados } \\
\text { análise de dados }\end{array}$ \\
\hline validade externa & $\begin{array}{l}\text { Utiliza lógica de replicação em estudos de casos } \\
\text { múltiplos }\end{array}$ & projeto de pesquisa \\
\hline confiabilidade & $\begin{array}{l}\text { Utiliza protocolo de estudo de caso } \\
\text { Desenvolve banco de dados para o estudo de } \\
\text { caso }\end{array}$ & $\begin{array}{l}\text { coleta de dados } \\
\text { coleta de dados }\end{array}$ \\
\hline
\end{tabular}

Fonte. Estudo de Caso. Planejamento e Métodos. Robert Yin (2001)

Validade do construto: estabelecer medidas operacionais corretas para os conceitos que estão sob estudo. Este teste é considerado como válido para a pesquisa desenvolvida toda vez que o método do estudo de caso escolhido é o que mais se adapta às características específicas do modelo teórico, marco conceitual para a pesquisa

Validade interna: Não é aplicável a essa pesquisa, de caráter exploratório-descritivo, mas apenas para estudos exploratórios ou causais, e não para estudos descritivos ou exploratórios. Estabelecer uma relação causal, por meio da qual são mostradas certas condições que levam a outras condições, como diferenciadas de relações espúrias.

Validade externa: estabelecer o domínio para o qual as descobertas de um estudo podem ser generalizadas. Os estudo de casos não são generalizáveis, mas os resultados alcançados, nas distintas unidades de análise, (Matriz, Brasil e Cuba) demonstram certas regularidades dos processos decisórios do marketing estratégico que permitem confirmar os aspectos teóricos que foram desenvolvidos sobre o tema. 
Validade externa: estabelecer o domínio para o qual as descobertas de um estudo podem ser generalizadas. Os estudo de casos não são generalizáveis, mas os resultados alcançados, nas distintas unidades de análise, (Matriz, Brasil e Cuba) demonstram certas regularidades dos processos decisórios do marketing estratégico que permitem confirmar os aspectos teóricos que foram desenvolvidos sobre o tema.

Confiabilidade: demonstrar que as operações de um estudo - como os procedimentos de coleta de dados - podem ser repetidas, apresentando os mesmos resultados. Foram mostradas evidências sobre todo o processo de pesquisa seguido, ainda de toda a documentação coletada, o que reafirma a confiabilidade da pesquisa.

\section{Limitações da pesquisa de campo.}

AAKER e DAY (1986) afirmaram que as entrevistas pessoais consumem grande quantidade de tempo, sendo administrativamente difíceis e caras. Conforme esses autores, e estendendo-se para esta pesquisa, são esperados alguns tipos de limitações. Com relação à parte exploratória, os resultados levantados podem não ser necessariamente representativos da população. Esta situação procurou ser resolvida com a aplicação de um questionário a uma amostra selecionada da população. Para evitar erros na aplicação dos questionários, o pesquisador procurou estabelecer o mais amplo intercâmbio com os respondentes, além de, inicialmente, pré-testar os questionários junto a um grupo reduzido de empresas.

\section{Utilidade prática.}

Podem-se destacar as seguintes contribuições:

\section{No âmbito acadêmico:}

- Aprofundamento específico do tema da competitividade das empresas de turismo na fase atual da globalização. Reunião de conceitos relativos ao tema abordado, principalmente, no contexto do sistema e a relação entre aspectos de estratégia, globalização e competitividade de empresas de turismo.

- Avaliação, discussão teórica dos conceitos e reunião de evidências de situações empíricas, para verificar a intensidade de aplicação daqueles, em situações da vida real das empresas estudadas, Isso permitirá ter uma base para um questionamento e aprofundamento, em estudos posteriores.

- Apresentação dos resultados práticos do uso do Modelo Teórico Referencial desenvolvido.

\section{Para o sistema empresarial latino-americano:}

- Contribuição para os profissionais que lidam com a América Latina e a globalização, no sentido de acrescentar dados para uma compreensão da dinâmica que envolve aspectos do 
Sistema Estratégico, relacionados à competitividade nas relações de globalização do Sistema de Turismo.

- Considera-se como uma contribuição original da pesquisa o estudo de um setor importante para a sociedade latino-americana atual no novo contexto empresarial de seus países. Estas empresas possuem sistemas reais de estratégias competitivas e, como esses sistemas são pouco estudados, pode-se considerar que, provavelmente, essa é uma pesquisa pioneira nesses países.

- Descrição das possíveis mudanças a introduzir, em nível nacional, no sistema turístico, tanto especificamente nas próprias empresas como em outros componentes do sistema. Servirão de base aos usuários para o planejamento e implementação de estratégias competitivas em suas respectivas organizações.

- Proporcionar um perfil das empresas turísticas nos países latino-americanos, que favoreçam a eficiência da recepção de turistas, como via para o fomento de suas economias regionais, o que contribuirá para a conformação e implantação de estratégias de desenvolvimento do setor turístico.

- Contribuir para aprofundar as teorias e pesquisas empresariais sobre Sistema Estratégico, Planejamento Estratégico, Marketing Estratégico, Marketing Turístico e de Serviços e sua aplicação concreta nas organizações turísticas de países latino-americanos.

\section{Modelo de pesquisa.}

As figuras a seguir dão uma visão panorâmica do modelo de pesquisa adotado 


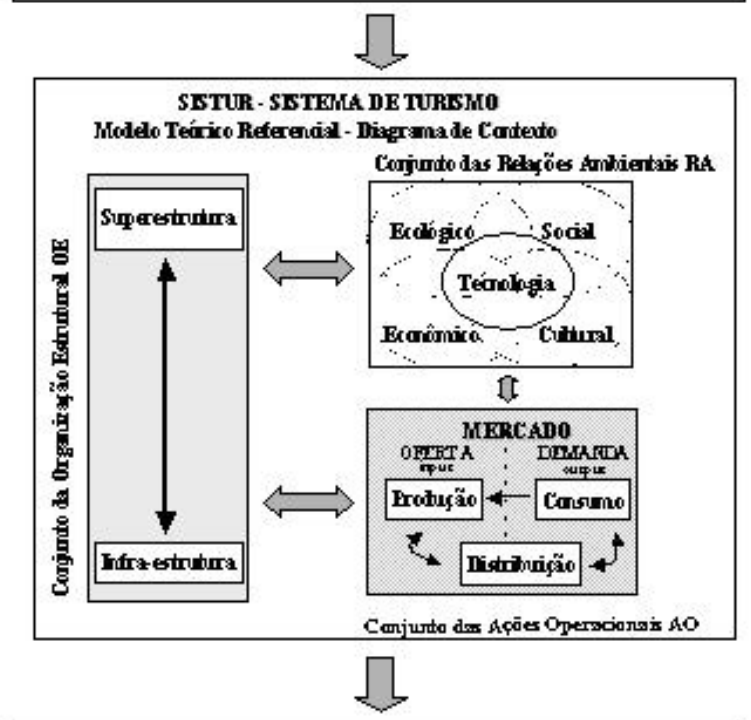

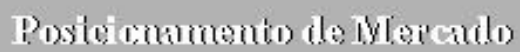

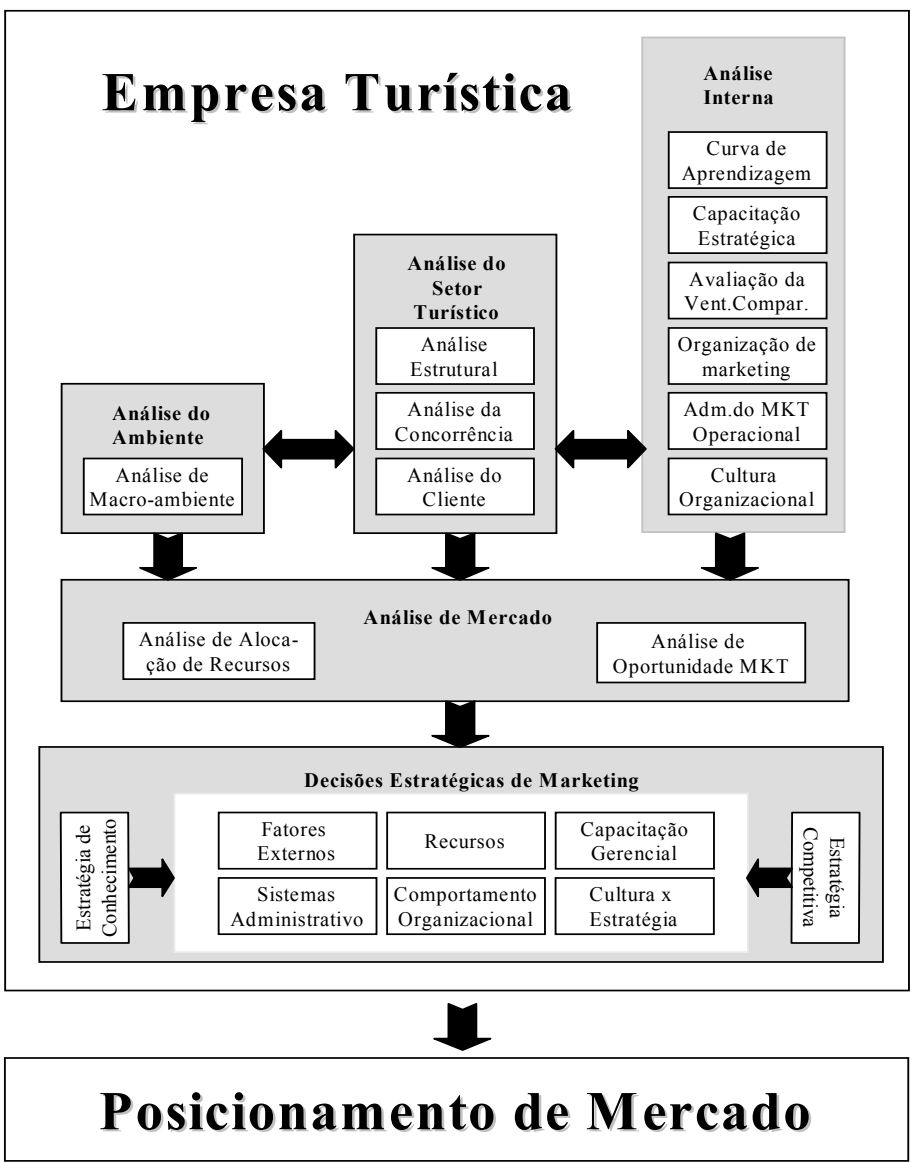


Capítulo VI

\section{ESTUDO DE CASO: SOL MELIÁ}




\section{CAPÍTULO VI \\ ESTUDO DE CASO: SOL MELIÁ}

I Introdução: Sol Meliá - décima empresa hoteleira no ranking internacional de cadeias hoteleiras

10. Breve história da empresa: a expansão nacional e a internacionalização

11. A saída para a bolsa

12. Estratégia de marketing. Orientação para o cliente

13. Estratégia de marcas.

14. Cultura organizacional. Gestão de recursos humanos

15. A gestão da qualidade

16. A introdução e o desenvolvimento de novas tecnologias da informação: a $e$ transformação da empresa

17. Análise econômico-financeira

18. Alianças, fusões e aquisições. Problemas estratégicos

II. Sol Meliá Cuba: o desafio

2. Particularidades do crescimento em Cuba

III. Sol Meliá na América do Sul.

IV. Análise da concorrência

\section{Introdução. Sol Meliá: décima empresa hoteleira no ranking internacional de cadeias hoteleiras.}

Sol Meliá, sociedade anônima cotada na Bolsa de Madrid e que forma parte do seletivo índice IBEX 35, pertence a família Escarrer, que detém em $52 \%$ de seu capital. O presidente da Sol Meliá é Gabriel Escarrer, fundador da companhia. Seu filho, Sebastião Escarrer, é seu vicepresidente. O escritório central do grupo está situado em Palma de Mallorca.

Em 2001, a cadeia maiorquina era a décima do mundo em número de suítes e a segunda em nível europeu, apenas atrás da francesa Accor. A Sol Meliá está estruturada em cinco divisões: Europa Urbana, Europa Turística, América, Cuba e Ásia-Pacífico.

\section{Breve historia da empresa: a expansão nacional e a internacionalização}

A entidade que deu origem à Sol Meliá S. A. foi fundada em 1956 por Gabriel Escarrer Juliá, quando começou a questionar um hotel de 60 quartos em Palma de Mallorca.

O forte desenvolvimento turístico espanhol nos anos 60 e o reinvestimento dos lucros obtidos 
favoreceram a consolidação e expansão do negócio e a criação da Hotéis Mallorquines Associados, uma pequena cadeia hoteleira que operava exclusivamente nas Ilhas Baleares, e com a maioria dos hotéis operados no regime de propriedade.

No ano 1976, o grupo começou a se estabelecer na península (Costa do Sol) e nas Ilhas Canárias. Essa primeira expansão provocou a necessidade de mudança do nome da companhia, para Hotéis Sol. Em 1984, o grupo adquiriu a cadeia hoteleira espanhola Hotasa, pertencente ao Grupo Rumasa, integrada por 34 hotéis urbanos (de negócios), conseguindo, assim, uma presença nas principais cidades espanholas. Graças a essa aquisição, o grupo tornou-se o líder indiscutível do setor hoteleiro na Espanha, tanto em oferta de hotéis urbanos como de hotéis turísticos.

O boom turístico da década dos 60 foi um fator decisivo para a consolidação da estrutura da empresa nascente. Reinvestindo os lucros obtidos, e em crescente colaboração com os tour operators (operadoras de turismo) e com os créditos bancários obtidos, a companhia tomou forma.

Foi durante a década dos anos 70, quando ocorreu o período de implantação nas Ilhas Balneárias, nas principais áreas costeiras da Península e no arquipélago canário. Adquiriu-se, então, os primeiros hotéis turísticos.

Durante esses 20 anos, até 1976, coincidindo com o auge da Espanha como destino turístico, Escarrer foi construindo uma pequena cadeia, com um forte crescimento em Balneárias e com a denominação de Hotéis Mallorquines. Já nesta época fundiram-se as bases da filosofia da companhia: Reinvestir os lucros em novas aquisições, crescer por meio de operações de compra de cadeias e remodelar a planta hoteleira existente.

Nos finais dos anos 70, a Sol Meliá consolidou seu plano de expansão nacional, implantando-se nos principais destinos turísticos da Península e de Canárias, e trocando seu nome no registro social pelo de Hotéis Sol.

Em uma operação conjunta com o Aresbank (representante financeiro do grupo KIO na Espanha), em 1984 adquiriu os 32 hotéis da cadeia HOTASA de Espanha. Após a compra, a sociedade iniciou sua atividade no segmento dos hotéis urbanos, e cresceu até o posto $\mathrm{n}^{\mathrm{o}} 37$ no ranking mundial. Assim mesmo, a nova companhia se ergueu como a primeira grande cadeia hoteleira espanhola, uma posição de liderança que, desde então, não abandonou.

Em 1985, a companhia iniciou sua expansão internacional, com a incorporação de seu primeiro hotel fora das fronteiras espanholas, o Bali Sol, que constituiu um êxito comercial, após ter 
convertido a Sol Meliá na primeira cadeia internacional em construir um complexo hoteleiro na área mais virgem da então desconhecida ilha de Bali.

Seguindo com essa filosofia de crescimento, por meio de grandes aquisições, em 1986, os Hotéis Sol absorveram a Companhia Hoteleira do Mediterrâneo, formada por 11 hotéis, contando com o grupo aéreo britânico British Caledonian.

O dia 27 de junho de 1987 constituiu um novo marco na história da companhia, ao se adquirirem os hotéis Meliá. Esta cadeia de 22 hotéis, em mãos do Grupo luxemburguês Interport, era objeto de desejo por parte das grandes cadeias internacionais como Sheraton, Wagon-Lits e Hilton; após uma árdua negociação, Gabriel Escarrer conseguiu tornar-se também o Presidente da empresa. A aquisição da Meliá contribuiu muito para a empresa, por várias razões: quadro de dirigentes preparados, nos diferentes níveis administrativos; hotéis com prestígio e imagem de qualidade de serviços, no âmbito nacional; reconhecimento de marca internacional pelas agências de viagens Meliá, com presença na Europa e na América Latina.

Durante esses anos continuou-se a expansão na Europa, América, Caribe, Sudeste Asiático e Bacia do Mediterrâneo. Em outras palavras, a cadeia internacionalizou-se e diversificou-se.

A vinda, em 1993, de Sebastião Escarrer trouxe ares novos à companhia. Sua entrada provocou uma revolução na estratégia empresarial da Sol Meliá, que sofreria uma mudança na estrutura organizacional, que adotou o modelo matricial, ainda hoje vigente.

Para fazer frente à nova política de crescimento, novos membros incorporaram-se à equipe dirigente, sendo introduzidas mudanças nos sistemas de gestão da empresa (informações contáveis, controle de qualidade, introdução de remuneração variável, gestão financeira, criação de valor ao cliente, etc). Assim mesmo, e sempre se mantendo fiel à sua filosofia e aos valores culturais, a companhia adotou um estilo mais empreendedor e de equipe, mediante um esquema de comunicação mais fluido e uma maior e melhor orientação para o mercado e para o cliente.

Neste mesmo ano a empresa recebeu o prêmio Príncipe Felipe de excelência turística, em reconhecimento à política de gestão e ao crescimento.

Uma vez consolidado o novo projeto de empresa, a Sol Meliá se converteu, em 2 de junho de 1996, na primeira empresa de gestão hoteleira da Europa a ter ações cotadas no mercado de capitais. Para isso, previamente se havia procedido à divisão da companhia em duas novas sociedades: Inmotel. SA., proprietária de estabelecimentos hoteleiros e a nova Sol Meliá S.A, companhia de gestão hoteleira.

Ao final de um ano, o valor das ações da companhia aumentou 72,2\%, incorporando-se ao IBEX 35, o índice que aglutina as empresas de maior liquidez das Bolsas espanholas. Meio ano depois, 
a agência norte-americana Standard \& Poor's a outorgou-lhe a classificação $B B B+$, transformando-a na companhia hoteleira européia mais solvente e com maior capacidade de captação de recursos no mercado de capitais.

Entre 1998 e 1999, adotou-se a decisão estratégica de juntar os negócios de gestão e de propriedade de hotéis. Começou, então, a expansão e a transformação tecnológica da companhia. Esta integração culminou, em 1999, com a Oferta Pública de aquisição de ações (OPA) da Meliá Investimentos Americana (MIA) e a fusão, por absorção, do Inmotel Investimentos. A nova Sol Meliá se converteu, assim, no $12^{\circ}$ grupo hoteleiro mundial, com mais de 260 hotéis, em 27 países. A nova companhia somou uma capitalização em bolsa de cerca de 2.300 milhões de $€$, correspondentes a 382.646 milhões de pesetas.

Após a criação da nova Sol Meliá, os outros dois filhos do presidente incorporaram-se à empresa, na qualidade de Conselheiros Delegados. A partir de então, o Conselho Delegado da Inmotel Investimentos conseguiu levar ao extremo um importante processo de modernização e adaptação da companhia, para sua posterior fusão com Sol Meliá; a par disso lançou-se, com total êxito, um ambicioso plano de remodelação dos ativos hoteleiros.

Durante o ano de 1999, a companhia incorporou 34 hotéis, desenvolvendo ou reforçando, de maneira progressiva, sua presença nos três enclaves que constituem seus mercados naturais: América Latina, a Bacia Mediterrânea e as principais capitais européias. O investimento realizado para desenvolver o projeto de aquisições aumentou em 604.75 milhões de $€$, ou seja, 100.623 milhões de pesetas.

Graças a essa estratégia, a companhia ingressou nas três capitais por excelência de turismo e de negócios: Roma, Paris e Londres.

A evolução natural do mercado levou a Sol Meliá à criação de uma nova Divisão, de e-Business, à frente da qual está Luis do Olmo, Diretor Geral de Marketing e Vendas da Sol Meliá. Com esa iniciativa, se pretendeu adaptar todas as operações de compra e venda do grupo, assim como sua própria gestão interna, ao novo ambiente de Internet, transformando o grupo em uma "solmelia.com".

Ao final do ano 2000, a companhia experimentou resultados econômicos recordes, principalmente pelo bom comportamento das Divisões Europa Urbana e Europa Turística, e pela recuperação dos mercados asiático e americano. Mas, mais do em função de qualquer outro fator, na consecução dos surpreendentes resultados apontados acima, desempenhou um papel essencial aquela que foi a operação mais importante do ano: a integração dos 75 hotéis da Cadeia Tryp Hotéis, com 60 estabelecimentos já em operação e 15 em fase de projeto. 
Após reafirmar sua posição de liderança na Espanha, América Latina e Caribe, e a segunda posição no ranking europeu, tal aquisição permitiu à Sol Meliá a entrada no disputado clube Top Tem, que integra as maiores cadeias hoteleiras em escala mundial, fato que constituiu um novo passo em sua política de crescimento e diversificação. Além do mais, durante o ano de 2000 foram incorporados 81 hotéis em 11 países, e firmados acordos para a abertura de mais de 70 novos projetos nos dois anos seguintes.

Atualmente, a Sol Meliá administra mais de 330 hotéis, em 30 países de quatro continentes, e dispõe de um quadro de funcionários de mais de 33.000 trabalhadores:

- Maior companhia hoteleira turística do mundo.

- Líder absoluta do mercado espanhol tanto no segmento urbano como no turístico.

- Primeira companhia hoteleira da América Latina e Caribe.

- Segunda cadeia hoteleira da Europa.

- Sétima por capitalização na Bolsa de Valores.

- Décima no mundo por número de suítes .

- Presente em 30 países.

- Mais de 33.000 empregados.

- Primeira Companhia européia certificada com ISO 9002

- Membro fundador do Clube Gestão de Qualidade

- Prêmio Príncipe Felipe de Excelência Empresarial

- Certificado "Q" de Qualidade do Instituto de Qualidade Turística de Espanha (ICTE) a 13 de seus hotéis

- ISO 14001 em cinco de seus hotéis

\section{A saída para a Bolsa}

Ao final de 1995, depois de três anos de minuciosa preparação, o Grupo Sol Meliá decidiu sair da Bolsa. O objetivo da companhia, com esta operação, foi posicionar-se ante os desafios que um ambiente de mudança exigia: a crescente concorrência existente no setor, as grandes oportunidades de expansão, motivadas por um processo de concentração hoteleira em nível mundial, e a aparição de novos destinos turísticos.

A estratégia de saída do mercado de capitais do Grupo Sol Meliá foi conduzida em três etapas, de forma similar à realizada por grandes cadeias hoteleiras, como Marriott Internacional, Hospitality Franchise Systems e Renaissance. Primeiramente, a companhia enfrentou uma reestruturação, mediante a qual, o grupo se dividiu em duas companhias: Sol Meliá S. A. e Hotéis Meliá S. A.

A Sol Meliá, companhia que começou a ser cotada em bolsa, dedicou-se à gestão e ao franqueamento de estabelecimentos hoteleiros, convertendo-se, assim, na primeira empresa hoteleira européia, dedicada unicamente à gestão hoteleira, que com cotação em bolsa de valores. Essa empresa é a proprietária das marcas de todos os hotéis da Hotéis Meliá e mantém 
contratos de gestão com os estabelecimentos de outros proprietários, o que a converteu em uma sociedade com endividamento zero e uma altíssima rentabilidade.

A Hotéis Meliá, empresa proprietária, manteve a propriedade dos imóveis hoteleiros, dos centros de serviço e de outros negócios e, diferentemente da situação anterior, não possui ações na Bolsa, permanecendo 80\% de seu capital em mãos da família Escarrer.

A segunda etapa iniciou-se em julho de 1996, com a saída da Sol Meliá da Bolsa. Para isso, foi realizado um aumento de capital, mediante uma Oferta Pública de Vendas de Ações até um máximo de 45,45\% de seu capital, o que supôs a emissão de 13 milhões de ações. Na operação, a maior parte do capital continuou sendo propriedade da família Escarrer. Os coordemadores globais da operação foram Argentaria S.V.B., Central Hispano Bolsa S.V.B. e União de Bancos Suíços.

A operação culminou com uma terceira etapa, em que a Sol Meliá promoveu uma ampliação de capital de 19,81\% da Hotéis Meliá, por meio de um aporte de mais de 100 milhões de $€$, equivalentes a 16.643 milhões de pesetas. Assim mesmo, destinaram-se outros 80 milhões de $€$, ou 13.663 milhões de pesetas, para comprar a Hotéis Meliá e participações minoritárias de sociedades de gestão de estabelecimentos hoteleiros.

A saída da Bolsa e a conseqüente reestruturação do Grupo Sol Meliá trouxe vantagens tanto para a Sol Meliá como para a Hotéis Meliá.

Para Sol Meliá, as principais vantagens foram, de lado, a concentração de sua direção na gestão puramente hoteleira, e por outro, a obtenção de recursos financeiros para dar suporte à sua expansão, à exportação de tecnologia hoteleira e ao fortalecimento das marcas e dos serviços corporativos.

A Hotéis Meliá se beneficiou dessa operação por meio da atenção prioritária de sua direção na gestão de imóveis para exploração hoteleira, possibilitando a melhora dos estabelecimentos, a aquisição de outros novos, assim como a liquidação da dívida em razão dos recursos financeiros obtidos com a operação.

A operação de ida à Bolsa foi um êxito: a demanda de títulos superou a oferta, e a cotação das ações se viu favorecida por uma situação de alta generalizada da Bolsa. O preço de saída das ações foi de 2.700 pesetas ( 2 de julho de 1996); um ano depois, com um aumento do $125 \%$, a cotação alcança 6.080 pesetas (1 de julho de 1997).

Durante o ano de 1996, a Sol Meliá começou a fazer parte do índice IBEX-35, o que propiciou uma garantia de liquidez para seus acionistas. 
Em novembro de 2000, a Standard \& Poor's concedeu-lhe o rating BBB, com projeção estável, outorgando-lhe, dessa maneira, o segundo melhor rating de companhias hoteleiras do mundo, no que diz respeito ao risco de crédito, convertendo-a no único grupo hoteleiro espanhol a obter esse reconhecimento na época.

Esse fato assegurou a capacidade da Sol Meliá de captar mais recursos no mercado de capitais, política que a companhia segue potencializando, para diversificar suas fontes de financiamento.

Assim, a obtenção do rating da Standard \& Poor's permitiu à Sol Meliá aplicar uma filosofia de diversificação de suas fontes de financiamento, mediante o estabelecimento de um programa de Emissão de Euronotas de médio prazo (EMTN), por um valor total de 1500 milhões de $€$, correspondentes a 249.900 milhões de pesetas. No esteira do mesmo realizou-se uma primeira emissão de 340 milhões de $€$, ou 56.644 milhões de pesetas, com vencimento previsto para cinco anos. O Deutsche Bank foi o Coordemador Global dessa fase.

Os fundos obtidos por essa emissão foram aplicados na aquisição da Tryp ( $€ 162$ milhões), ou 26.990 milhões de pesetas) e no refinanciamento da dívida existente ((€138 milhões), ou 22.990 milhões de pesetas).

Durante o segundo trimestre de 2001, a agência de crédito FITCH anunciou o rating de BBB+ para a Sol Meliá, o segundo melhor rating de crédito entre as companhias hoteleiras mundiais.

A Meliá Investimentos Americanas (M.I.A.) aparece nas bolsas espanholas com uma oferta pública, lançada em 11 de junho de 2001. O nível de aceitação de tal oferta foi de 63,9\%, deixando a Sol Meliá com 99,35\% da M.I.A..

Entretanto, são apontadas características da Sol Meliá que fazem com que os analistas das Bolsas se mostrem cautelosos em suas recomendações de compra das ações do grupo. Alegou-se, principalmente, a alta dependência da empresa do mercado latino-americano, representada por $27 \%$ do Ebitda, no ano 2000, o que significa um risco analítico, pela instabilidade econômica e política dos países da região. De igual forma, foram feitas ressalvas ao da empresa, além a existência de um acionista majoritário, que poderia limitar a participação da empresa em movimentos corporativos mais amplos, influindo negativamente no valor das ações.

Outro ponto levantado pelos analistas da Bolsa, em suas considerações sobre a Sol Meliá, foi que o grupo não tinha exposição direta alguma nos EUA, o que o obriga a depender do turismo de grande jornada, principalmente europeu, para ocupar suas suítes na América Latina. Esse elemento estabelece uma forte dependência aos tour operadores e às linhas aéreas. Naturalmente, a não existência de instalações da Sol Meliá nos EUA limita o acesso ao mercado emissor norteamericano. 
Os analistas mais otimistas assinalam, a favor da estabilidade do valor das ações e sua recomendação de compra, o fato que a Sol Meliá obtém $60 \%$ de seus lucros, cerca $60 \%$ do Ebitda do grupo, na Espanha, um destino considerado como seguro, onde os grandes complexos hoteleiros se beneficiam do turismo europeu, que busca antes de tudo o clima da Espanha e sua segurança, constituindo-se, portanto, um mercado estável.

O gráfico a seguir mostra a evolução do valor da ação da Sol Meliá no mercado:

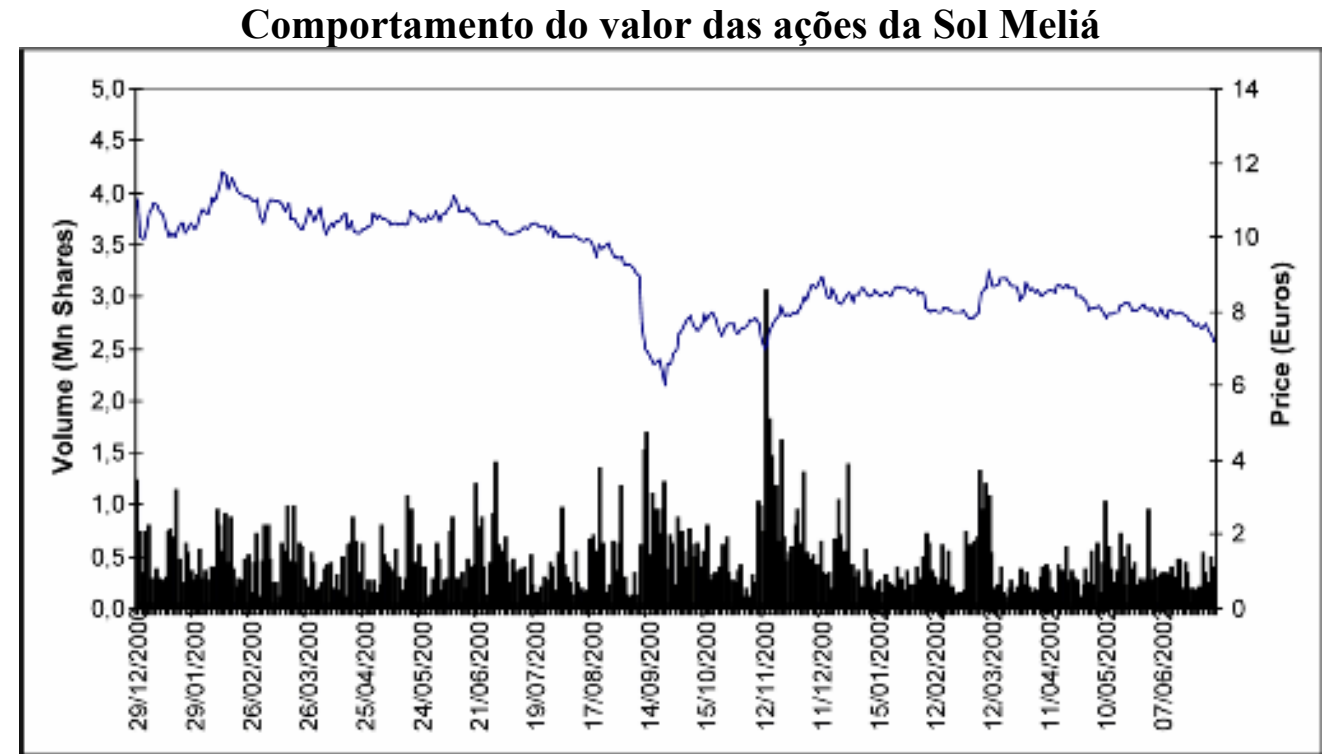

Fonte: Memórias da Sol Meliá 2001

Um retrato financeiro da empresa, no ano de 2001, pode ser apreciado no quadro seguinte:

\section{Perfil Financiero}

Perfil financeiro da Sol Meliá 2001

\begin{tabular}{l} 
- Fecha de Constitución de la Compañía: 1956 \\
\hline - Fecha de Salida a Bolsa: 2 de julio de 1996 \\
\hline - Precio salida acción (antes de split): 900 ptas. (5.41 Euros) \\
\hline - Ticker Symbol: Sol \\
\hline - Plaza en la que cotiza: Mercado Continuo (España) \\
\hline - Forma parte del IBEX 35 \\
\hline - $N^{\circ}$ acciones: 184.776 .777 \\
\hline - Cotización bursátil a 31/12/01: 8,54 Euros por acción \\
\hline - Rating BBB Estable de Standard \& Poor's y BBB+ Estable de Fitch \\
\hline Revalorización desde la fecha de salida hasta 31/12/01: 57,9\%
\end{tabular}

Fonte: Memórias da Sol Meliá 2001

Como mencionado anteriormente, a Sol Meliá tem ações da NH Hotéis cotadas na bolsa espanhola. Os analistas indicam que a NH Hotéis e a Sol Meliá contam com perfis de negócio muito diferentes, que poderiam determinar a evolução futura de cada companhia. 
NH nutre-se fundamentalmente da atividade de viagens de negócio, com seus estabelecimentos localizados nos centros urbanos. Esse turismo se apresenta como menos estável e mais vulnerável a conflitos internacionais, depressão econômica e outros fatores ambientais. A Sol Meliá, que também compete nesse segmento, tem muito mais peso no turismo de lazer, oferecendo ao consumidor predominantemente a idéia de lugares de refúgio, longe dos conflitos e do terrorismo, posicionamento que sempre é muito bem aceito.

Os analistas destacam, a favor da NH, sua excelente posição na Espanha e na Holanda, uma alta qualidade de sua equipe gestora, o que a faz candidata a possíveis movimentos corporativos na Europa, já que sua ampla cadeia na Espanha poderia suscitar interesse de algumas companhias internacionais.

\section{Estratégia de marketing. Orientação para o cliente.}

A internacionalização da Sol Meliá tem-se baseado em uma cuidadosa estratégia de marketing. Durante as primeiras décadas, como era habitual, confundiram-se as atividades de venda e as de marketing. Por outra parte, os produtos oferecidos pela cadeia eram exclusivamente turísticos, muito padronizados e comercializados pelos tour operadores. Tratava-se de um produto que se vendia facilmente, sem a necessidade de um suporte de marketing.

$\mathrm{O}$ mercado turístico atual é diferente. As novas tecnologias da informação revolucionaram o setor. Surgem clientes mais exigentes e sofisticados, por seu nível de informação, e uma maior concentração de tour operadores, com mais poder de negociação. Esses fatores motivaram a Sol Meliá a elaborar uma cuidadosa estratégia comercial. Seus elementos fundamentais compreendem: a) um mix de produto, que combina os segmentos de lazer e de negócios, buscando alcançar nessas duas categorias nichos com poder aquisitivo, desde os níveis mais altos até os mais populares, com políticas de preços respaldadas por padronização de serviços, garantindo uma boa relação qualidade-preço em cada segmento; b) uma rede de distribuição ampla, que engloba todos os tour operadores, respaldada por sua própria central de reservas e força de vendas; c) uma cuidadosa estratégia de comunicação que reforça o posicionamento alcançado por cada uma de suas marcas, com o objetivo de fidelização de seus clientes.

Nos últimos anos, a companhia realizou um grande esforço para inovar os sistemas tradicionais de distribuição existentes no setor. Para isso, foram criados novos produtos como: pacotes promocionais e ofertas especiais dos serviços já existentes.

O Programa MaS: programa de fidelização da companhia, foi lançado em 1994, com o objetivo de premiar os clientes por sua lealdade à cadeia. Por meio do cartão MaS, os clientes podiam acumular pontos, que podiam ser trocados por hospedagem gratuitas em qualquer hotel. Além do 
mais, seus membros gozavam de outros benefícios adicionais, tais como: hospedagem gratuita para uma segunda pessoa, jornal diário gratuito, possibilidade de empréstimo ao cliente, express check in, late check out (podendo, ainda, fazer o check-out do quarto às 16 horas, e não às 12 horas), etc.

Programa estrelas, dirigido ao pessoal interno da companhia, com ofertas muito vantajosas de preços, nos estabelecimentos administrados pela Sol Meliá. O programa MaS, ao final de 2001, estava integrado por mais de 360 mil titulares. A Sol Meliá criou, por sua vez, o Clube de Amigos, para agentes de viagens e operadoras de turismo, o qual conta com mais de 60 mil titulares, na Espanha, Alemanha, Suíça, Portugal, Estados Unidos, México e Canadá.

A empresa participa de outros programas de fidelização, que integram sua oferta hoteleira, juntamente com companhias aéreas, como: Iberia, Spanair, Sky Club de Portugal Airline, Millage de United Airline, American Adventage de American Airline, Travel Club de Espanha, entre outras.

\section{Programas de lazer, para incentivar a venda de suítes em momentos especiais.}

Para incentivar a venda de suítes em momentos especiais há vários programas

- Talonários cinco noites: trata-se de um sistema de comercialização criado pela Sol Meliá há anos. Seu funcionamento consiste na compra de um talonário e a possibilidade de pagar posteriormente a hospedagem nos hotéis com os talões.

- Pontes e fins de semana. De forma alternativa, os hotéis administrados pela Sol Meliá oferecem hospedagem durante fins de semana, e pontes, a um preço muito competitivo.

- Escapadas. Ofertas especiais de hospedagem em hotéis situados em zonas privilegiadas com o lema descanso.

- Presentes inesquecíveis. Ao celebrar o banquete de bodas em um hotel Sol Meliá, os cônjuges são presenteados com dias de hospedagem gratuitos em qualquer estabelecimento da companhia.

- Programas de negócios, tal como indica o nome, são programas dirigidos ao segmento de empresas.

A rede comercial em Sol Meliá se estrutura em três níveis:

- Direção comercial de cada divisão, cuja missão principal é a de delinear as políticas, metas e diretrizes de sua área de negócio. As equipes que as compõem se especializam por segmentos ou por zonas geográficas.

- Delegações comerciais, cujo trabalho é a promoção de todos os estabelecimentos da companhia em agências de viagens e empresas da área. 
- Equipe de vendas de cada hotel, cuja missão equipe é complementar, de forma coordenada, as ações comerciais empreendidas tanto no nível central como no regional, dando especial ênfase à promoção e venda de seu próprio hotel.

\section{Fontes de Informação utilizadas pelo Departamento de Marketing da Sol Meliá.}

As informações de Marketing utilizadas pela Sol Meliá provêm das seguintes fontes:

- Subcontratação de agências especializadas em pesquisa de mercados, que proporcionam uma vasta gama de informações sobre fatores e agentes do micro e do macroambiente ambiente de marketing, assim como estudos de opinião / satisfação do cliente.

- Questionários para medir o grau de satisfação dos clientes, aplicados nos próprios estabelecimentos da companhia. Desses questionários se extrai informação acerca de expectativas, gostos e opiniões.

- O Business Plan, documento elaborado pela Direção do hotel, onde se encontra informação abundante sobre a concorrência e o ambiente.

- Os intermediários, agências e operadores de turismo, proporcionando informação sobre a parte do processo de comercialização de que eles participam.

- A agência virtual SolRes, a central de reservas e as visitas ao site SolMeliá.com

- Os membros do programa MaS de fidelização.

A ampla rede descrita proporciona um fluxo essencial de informações para que a Sol Meliá possa adaptar-se às demandas do mercado. Essa estratégia de marketing tem resultado em uma ampla diversificação da carteira de produtos da empresa, como pode ser observado nos gráficos abaixo: 
Composição da oferta hoteleira da Sol Meliá em 2001

Urbanas-Férias - Por regime de exploração - Por área geográfica

Diversificação da oferta mercado negócio e turístico por número de hotéis)

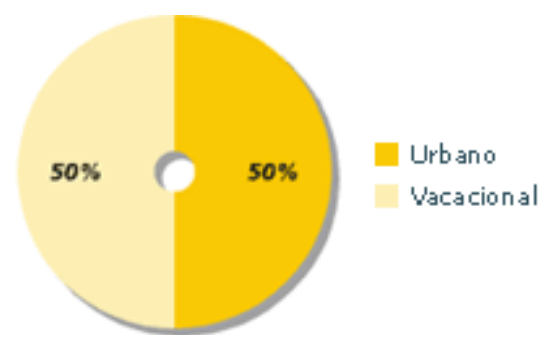

Diversificação da carteira de hotéis por regime de exploração

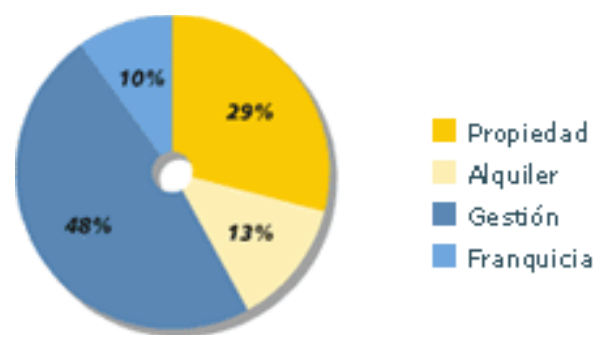

Diversificação do número de suítes por área geográfica

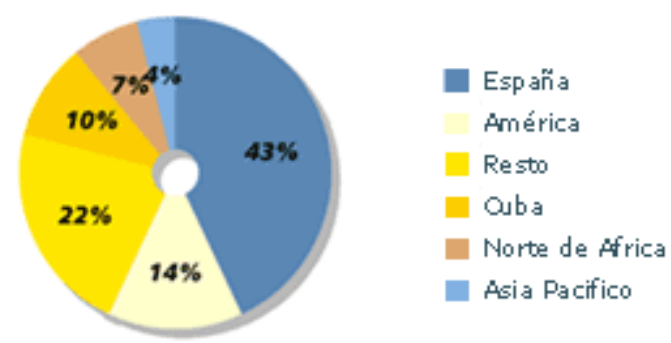

A Sol Meliá conta com uma rede de comercialização com 28 escritórios de venda, em 17 países, e conta com Departamentos comerciais especializados em TTOO, Empresas de Convenções, Congressos e Promoções, Agências de Viagem, Grupos e Associações. Além do mais, possui seu prórpio sistema de reservas, Sol Res, que, no ano de 2001, recebeu mais de um milhão de chamadas. Possui, também, um sistema de conexão, em tempo real, com os principais GDS (Global Distribution Systems), como Amadeus, Galileo, Sabre e Worlspan. 


\section{Estratégia de marcas - A marca Sol}

A história do grupo Sol Meliá pode resumir-se na história de suas marcas. Quando, em 1956, Gabriel Escarrer, fundador e presidente da Sol Meliá, iniciou a exploração do primeiro hotel - O Altair, de Palma de Mallorca- provavelmente não antecipava a importância que poderia chegar a ter a gestão das marcas. Praticamente desde o princípio da história da Sol Meliá, na década dos 60, Escarrer e seu pequeno grupo, aprenderam que um fator decisivo para a consolidação da então nascente empresa, era o reinvestimento dos lucros obtidos, a obtenção de créditos bancários e a colaboração com as operadoras para comercializar seus hotéis; e, para tudo isso, era necessário possuir uma marca forte e conhecida no mercado. Até 1976, Hotéis Mallorquines foi o nome da cadeia, sem que se adotasse esse nome como uma marca de seus hotéis. A partir daí, constatou-se um grande crescimento, devido, principalmente, à aquisição dos primeiros hotéis turísticos, nas ilhas Balneárias e Canárias, assim como nas principais áreas costeiras da Península, conforme já mencionado. Para respaldar esse crescimento, houve a necessidade de um nome mais forte no mercado. Nasceu, assim, a Hotéis Sol. A força da palavra "Sol” consolidou o posicionamento da empresa no mercado de turismo de férias massivo, o mais importante na Espanha daquela época. Esses elementos favoreceram o rápido crescimento da empresa na década, sabendo aproveitar o boom turístico em que se encontrava a Espanha. Em 1984, continuando com a expansão na Península, a empresa iniciou suas atividades no segmento de negócios, com a aquisição da cadeia HOTASA, a qual não possuía uma marca específica para seus hotéis. Em 1985, a Hotéis Sol iniciou sua expansão internacional, com a abertura do hotel Bali Sol, na Indonésia. Continuando a expansão, em 1986 adquiriu a Companhia Hoteleira do Mediterrâneo, formada por 11 hotéis pertencentes ao grupo aéreo britânico British Caledonian, hotéis que se incorporam à marca Sol. Nesse período, ocupavam o posto $\mathrm{n}^{\mathrm{o}} 37$ do ranking mundial, convertendo-se na primeira cadeia hoteleira espanhola.

A compra de Hotéis Meliá, em junho de 1987, constituiu um novo marco na historia da companhia. Esta cadeia de 22 hotéis trouxe à empresa um staff e dirigentes qualificados, hotéis com prestígio de qualidade, no âmbito nacional, e o reconhecimento de uma marca já conhecida internacionalmente pela rede de Agências de Viagens Meliá, que tinha uma notável presença na Europa e América Latina. Nasceu, assim, a Sol Meliá, como empresa que continuou sua expansão na Europa, América, Caribe, Sudeste Asiático e Mediterrâneo.

O dia 2 de junho de 1996 constituiu um momento chave no desenvolvimento do Grupo Sol Meliá, ocasião em que se tornou a primeira empresa de gestão hoteleira da Europa a ser cotada em Bolsa, fato que contribuiu para consolidar o reconhecimento internacional da companhia. 
Previamente, dividiu-se a companhia em duas novas sociedades: Inmotel SA. - proprietária de estabelecimentos hoteleiros - e a nova Sol Meliá S.A. - companhia de administração de hotéis.

Os anos 1997 e 1998 foram de intenso crescimento e de reestruturação interna. Essa etapa marcou também um momento importante para o portfolio de marcas do grupo.

O vertiginoso crescimento do grupo provocou a incorporação de hotéis que não se adequavam exatamente aos parâmetros físicos e de serviços dos estabelecimentos até então existentes. Por isso, se procedeu a criação de submarcas, que permitiram incorporar os novos hotéis ao grupo, e oferecer um produto específico para cada segmento de mercado. Em abril de 1996, a marca Meliá, com 79 hotéis, subdividiu-se em Gran Meliá, Meliá e Meliá Confort, e a marca Sol, com 96 hotéis, em Sol Elite, Sol Club, Sol, e Sol Inn. Criou-se, além disso, a nova marca Paradisus com dois hotéis.

Em 1998, a companhia gestora de hotéis Sol Meliá apresentou seus planos para converter-se em uma das cadeias hoteleiras mais importantes do mundo, com a criação de MIA (Meliá Investimentos Americanas) ${ }^{33}$, proprietária de hotéis na América do Sul e Caribe, e a posterior fusão com a Inmotel, proprietária de hotéis na Europa. Após a Oferta Pública de aquisição de ações da MIA, passou a controlar 97,12\% da empresa. Dessa forma, o grupo pôde desenvolver mais intensamente seu plano de crescimento nas principais capitais da Europa, no continente americano e em outros destinos do mundo, no esquema de gestão ou franquia de estabelecimentos independentes, afiliados à organização, e de aquisição de propriedades. Ao final do ano de 1998, a empresa tinha uma carteira composta por 246 estabelecimentos em 24 países, com um índice de alavancagem financeira da ordem de $10 \%{ }^{34}$, o que refletia sua excelente capacidade de financiamento.

Em 1999, a companhia incorporou 27 estabelecimentos e adquiriu 34 hotéis, reforçando de maneira progressiva sua presença nos três enclaves que constituem seus mercados alvo: América Latina, a Bacia Mediterrânea e as principais capitais européias, entre elas, Roma, Paris e Londres, onde começou a desenvolver uma nova categoria: os hotéis Boutique ${ }^{35}$. O investimento realizado para levar a cabo esse projeto de aquisições aumentou em 605 milhões de $€$. Ao final de 99 a empresa alcançou a cifra de 262 hotéis em 27 países.

\section{Incorporação da Tryp.}

\footnotetext{
${ }^{33}$ Empresa do grupo Meliá com propriedade de hotéis e investimentos na América Latinas.

${ }^{34}$ a indústria se situa próximo a $85 \%$

${ }^{35}$ Hotéis Boutique. Hotéis de grande luxo, em edifícios antigos de alto valor arquitetônico.
} 
A aquisição da Tryp Hotéis permitiu a incorporação de 60 hotéis com mais de 9.700 suítes . Naquele momento, a Tryp estava amplamente consolidada na Espanha (50 hotéis) e tinha presença internacional em Cuba (3 hotéis), Andorra (1) e Túnez (7).

Ao final de 1999, a carteira do grupo se consolidava com três marcas e sete submarcas, cada uma delas dirigida a públicos diferentes:

- Meliá Hotéis representava o padrão mais alto de estabelecimentos do grupo, sendo integrada pelas seguintes submarcas:

- Gran Meliá: ocupava o patamar superior da Meliá. Ela agrupa os estabelecimentos de alto padrão que, por sua concepção, desenho e conforto são dirigidos ao público mais exigente. Oferece serviços de grande luxo e se localiza nos centros urbanos, assim como nos destinos turísticos de primeira linha. Os hotéis são singulares, por suas características arquitetônicas não habituais.

- Meliá: reunia os estabelecimentos de quatro estrelas, propondo uma concepção de oferta destinada a homens de negócios, em hotéis urbanos, ou para turistas com alto poder aquisitivo, em hotéis turísticos. Costumavam possuir uma ampla oferta de instalações para congresso, convenções e reuniões.

- Meliá Confort: linha especialmente concebida para homens de negócios. Seus hotéis estão situados nos centros comerciais e de negócios das mais importantes cidades.

- Sol Hotéis: marca que deu nome à cadeia, integrando as seguintes submarcas:

- Sol Elite: englobava hotéis de praia de quatro estrelas, localizados nas zonas de férias mais importantes do mundo; oferece uma ampla oferta de instalações de lazer.

- Sol: marca original da cadeia, operando nos segmentos de férias (lazer) e urbano (negócios); representativa do padrão intermediário dos hotéis da empresa.

Entre ambas as submarcas, Sol Elite e Sol, ofereciam-se produtos especializados: Sol Club e Sol Família. Esses tipos de estabelecimento foram concebidos especialmente para famílias e grupos que proocuram uma ampla oferta de lazer. Possuem amplas instalações assim como uma oferta gastronômica e de diversão muito importante. Destacam-se os Clubs, fórmula inventada pelo grupo para satisfazer às necessidades dos clientes mais jovems. Pora isso, forma constituídos os Club 3-6, Club 7-13 e o Club teenager.

- Sol lnn: integrada por estabelecimentos acessíveis e funcionais, para homens de negócios e turistas, Localizando-se principalmente em áreas urbanas ou em estradas, oferecendo uma excelente relação qualidade-preço. 
- Paradisus: integrando os hotéis de alto nível, em destinos turísticos singulares, que operam sob o sistema all inclusive.

No ano 2000, com a aquisição da cadeia de hotéis Tryp, a empresa avaliou a necessidade de uma revisão de seu portfolio de marcas. Para tanto, encarregou um estudo à empresa Infratest Burke, líder mundial em pesquisa de mercados e posicionamento estratégico de marcas. Os resultados indicaram que existia no mercado um alto índice de reconhecimento da marca Sol Meliá, que é a marca institucional da empresa. A pesquisa refletiu uma confusão entre as submarcas Meliá e Sol. A marca Paradisus foi pouco reconhecida, talvez por ser um produto ainda em expansão. No mercado, a marca Tryp era relativamente conhecida, sobretudo na Espanha, por ser um produto de cidade, bem localizado, e com uma correta relação qualidade-preço.

Por outra parte, o estudo refletia que, no mercado turístico internacional, existe uma alta concentração de hotéis, com um número reduzido de marcas, e que só se utilizava o conceito de submarcas para os segmentos especializados, como o de saúde, golfe e congressos, entre outros. $\mathrm{O}$ estudo da Infratest Burke acrescenta os seguintes dados sobre alguns dos principais competidores:

“As principais competidoras da Sol Meliá no mercado internacional são as empresas situadas acima da mesma no ranking internacional de cadeias hoteleiras ${ }^{36}$, principalmente as norte-americanas e a francesa Accor. Cada uma destas empresas tem seu modo específico de administrar suas marcas:

A Six Continents (Bass), com 2886 hotéis, possui quatro marcas e uma submarca: Intercontinental, Crow Plaza, Holiday Inn, Express of Holiday Inn e Staybridge SuiteInn.

A Marriot, com 1880 hotéis, administra cinco marcas e quatro submarcas: Marriot, Marriot Conference \& Centers, Marriot Executive Apartments, Marriot Vacation Club, Marriot Resort \& Suites, Renaissance, Fairfield Inn, Towne Place \& Suites e Ritz-Carlton.

A Cendant, em seus negócios de hotelaria agrupa 6315 hotéis, utiliza oito marcas, que administra como cadeias independentes: Days Inn, Howard Johnson, Ramada, Knights, Amerlfost Inn \& Suites e Super 8 Hotel.

O grupo francês Accor, com 3234 hotéis, segue o critério de criar marcas com nomes diferentes para cada tipo de hotel, segundo o segmento de mercado que deseja atender, desde os hotéis funcionais e econômicos, como os Formule 1, até os mais sofisticados, como os Mercure. Lida com um total de oito marcas e nenhuma das quais utiliza o nome corporativo: Sofitel, Novotel, Mercure, Ibis, Suite Hotels, Etap Hotel, Formule 1 e Motel 6. 
A Choice Hotels International, com 4248 hotéis, utiliza sete marcas: Slep Inn \& Slep Inn \& Suites, Confort Inn \& Confort Suites, Quality Inn, Hotels \& Suites, Clarion Hotels, Rodeway Inn, Econolodge e Maintay Suites

A Hilton, com 1700 hotéis administra sete marcas e quatro submarcas: Hilton, Hilton Garden Inn, Hilton Gran Vacation Company, Douveltre Guest Suites, Duveltre Club Hotel, Hampton Inn, Hampton Inn \& Suites, Embassy Suites, Homewood Suites, rede Lion Hotels \& Inn, Conrad International e hotéis sem marca.

Os competidores mais desafiadores na Espanha, onde a Sol Meliá realiza 60\% de suas operações, são NH Hotéis (no segmento de viagens de negócios) e Riu Hotéis \& Resorts (no segmento de turismo de férias).

A NH Hotéis segue o critério de desenvolver uma única categoria de hotéis com uma marca: NH. Explora hotéis de cidade, com serviços funcionais para homens e mulheres de negócio.

A Riu Hotéis \& Resorts, dedicada ao turismo de férias, utiliza a marca corporativa Riu para denominar as seguintes submarcas ou categorias: Club Hotel Riu (resorts de 3,4 5 estrelas "all inclusive"), Hotel Riu Palace (Hotéis quatro estrelas) e Hotel Riu Grand Palace (Hotéis cinco estrelas)".

A consultoria, tomando como amostra usuários de serviços hoteleiros e agências de viagens, mediante o método de entrevistas pessoais e por telefone, emitiu as seguintes considerações sobre as marcas do Grupo Sol Meliá:

- Sol Meliá, como marca institucional da empresa é identificada principalmente como Meliá no mercado;

- A marca Meliá tem o mais alto nível de reconhecimento dentro do portfolio da Sol Meliá;

- Segundo a percepção dos consumidores, Paradores e NH são os principais competidores da Sol Meliá na Espanha;

- A marca Tryp possui um considerável reconhecimento na Espanha, atrás da NH Hotéis;

- A Sol Hotéis tem importância nos principais mercados emissores turísticos do segmento de férias, sendo a marca com maior reconhecimento no mercado britânico; mas a Riu Hotéis tem maior reconhecimento no mercado alemão no mesmo segmento;

- A Meliá Confort, por sua vinculação com a Meliá, alcança uma parcela semelhante de reconhecimento, mas não apresenta elementos de diferenciação;

- A Tryp Hotéis alcança o índice médio de reconhecimento de mercado no segmento urbano, destacado por uma boa relação qualidade-preço e pela funcionalidade de seus estabelecimentos;

- A Sol Inn Hotéis se situa abaixo da média em termos de reconhecimento de marca.

- A Gran Meliá possui o mais alto índice de reconhecimento dentre as submarcas da Meliá; 
- A Meliá Confort é associada à Meliá, mas existe um elevado nível de confusão com respeito à categoria e ao nível de serviços esperados prestados;

- Entre Sol e Sol Elite não existe uma diferenciação quanto à categoria de ambas as submarcas, pois se posicionan no mesmo segmento de mercado (férias);

- A Sol Inn não possui um reconhecimento de marca destacável. Há confusão a respeito do segmento em que se encaixa.

- Paradisus tem níveis de reconhecimento muito baixos, assim como a Hotéis Boutique.

Outra conclusão do levantamento da Infratest foi:

"A estratégia de comunicação seguida pelas principais cadeias internacionais está direcionada para alcançar o posicionamento de cada marca individualmente, sem que, necessariamente, se destaque o nome do grupo a que pertencem, como é o caso da francesa Accor".

A decisão de reestruturar a carteira de marcas da empresa não foi fácil. Como expressou, em entrevista ao autor, o Diretor de Marketing e Vendas da Sol Meliá, José María Dalmau:

"Na decisão das marcas não estamos sós. Uma das razões da proliferação de submarcas é o rápido crescimento do grupo, e isso tem significado incorporar hotéis com diferentes parâmetros físicos e de estado de conservação das instalações. O rebranding de um hotel muitas vezes implica fazer fortes investimentos em suas instalações, para adaptá-las a um certo padrão. Todavia, a Sol Meliá não é proprietária de muitos desses estabelecimentos, o que implicaria convencer seus donos sobre a necessidade de se fazerem as reformas necessárias, se realmente se deseja mudar a marca do hotel."

Finalmente, a decisão foi adotada, e uma reestruturação geral do portfolio de marcas foi feita. Como resultado da análise das recomendações da consultoria Infratest Burke e da equipe de Marketing e Vendas da própria companhia Sol Meliá, ocorreu, durante o ano 2001, um processo de redução de seu portfolio de marcas, buscando-se simplificar e tornar mais nítidas as mesmas, de acordo com os segmentos de mercado a atender:

\section{Concentrar-se em quatro marcas da Sol Meliá}

- Meliá, Hotels \& Resorts: estabelecimentos de alto prestígio e luxo, quatro estrelas superior e cinco estrelas, idealizados especialmente para reuniões e convenções tanto nas grandes cidades como nos principais pólos de férias;

- Tryp Hotéis: hotéis em Cidade, localizados nas principais áreas urbanas, com uma excelente relação qualidade e preço, e ideais para viagens de negócios.

- Paradisus Resorts, "all inclusive Resorts": hotéis excepcionais com "tudo incluso", localizados em zonas exóticas e de tom singular. 
- Sol Hotéis, Hotéis \& Resorts: excelente relação qualidade e preço, destacam-se pela organização de atividades desportivas e de divertimento, destinada a viagens em família.

\section{Reforçar a marca Meliá}

Procurar um posicionamento como Hotéis cinco estrelas ou quatro estrelas superior, especialmente idealizados para o estabelecimento de reuniões e convenções de importância internacional; localizados em cidades e em destinos de férias de primeira linha; serviços de alto padrão, personalizados e de qualidade. Essa marca teria duas categorias: os Hotéis Gran Meliá e as Boutique Hotéis.

Essa categoria de hotéis teria como seus principais competidores no mundo os estabelecimentos com as bandeiras Hilton, Marriot, Hyatt, Le Meridien, Westin e Intercontinental.

\section{Incorporar a marca Tryp como uma marca do grupo}

Isso se faria, potencializando seu reconhecimento como marca. O posicionamento deveria ser no segmento Hotéis de quatro estrelas e três estrelas superior; urbanos, funcionais e confortáveis; localizados em cidades e áreas urbanas com intensa atividade comercial; ideais para a celebração de reuniões e banquetes; excelentes por sua relação qualidade-preço; destinados a homensmulheres em viagens de negócios. Sus principais competidores nesta categoria seriam NH Hotéis, Scandic, Dorint e Novotel.

\section{Desenvolver o conceito da marca Sol Hotéis}

Desenvolver o conceito baseado em: Hotéis de quatro estrelas e cinco estrelas superior, para famílias em férias; localizados nos principais destinos turísticos; ampla oferta de buffets, entretenimento e diversão; serviço amável e profissional, com clima familiar; excelente relação qualidade-preço. Principais competidores, na categoria: Riu Hotéis, Iberostar, Aldiana, Club Méd.

\section{Posicionamento da marca Paradisus}

O posicionamento da marca Paradisus seria: Resorts cinco estrelas de luxo "all inclusive", no segmento de férias; excelente nível de serviços e de atendimento; localizados nas zonas turísticas de maior prestígio internacional; integrados à natureza e em destinos exóticos e privilegiados; arquitectura e ambiente singulares; representa a exclusividade do padrão mais alto dos resorts; grande variedade de propostas de descanso e de programas de entretenimento; Os principais competidores nesta categoria seriam Sandals, e Club Lido. 


\section{Novas Marcas da Sol Meliá a partir de 2000}

Composição da carteira de produtos, por tipo de marcas - 2001

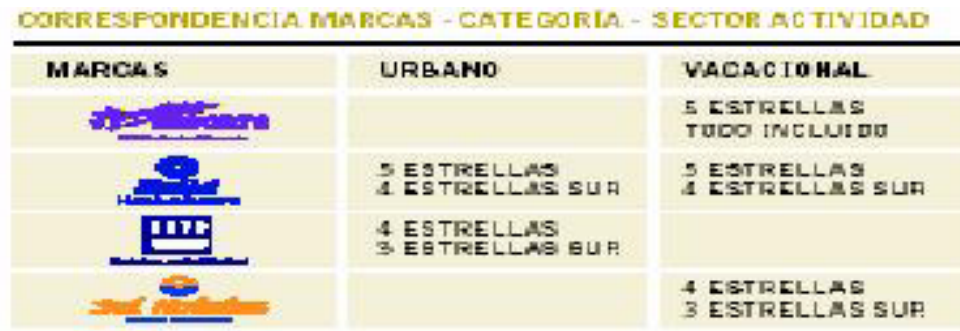

Paradisus Rescrits: hoteles escepcionales con "todo incluido". ubicados en zonas cxosticas $y$ de tone singular.

Meliá Hotels \&e Resorts: establecimientos deprestigio y lujo, de 4 estrellns ouperior y 5 estrellas, especialrnente ideadoe para reuniones y comwenciones.

Tryp HIoteles: ubicados en las principales areas urbanas, con una excelente relacion calidad y precio, e ideales pan vinjes de negrocios.

Sol Resorts: con una excelente relación cnlidad y precio, destacan por la organización de actividades deportiwas y de animación destinadas a los viajes en familia.

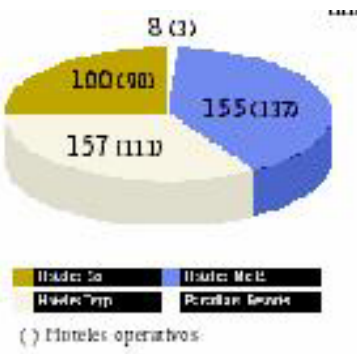

Esse processo, que requereu um importante investimento por parte da empresa, abrangeu a quantidade de hotéis mostrada na tabela abaixo:

\begin{tabular}{|l|c|c|c|}
\hline Marcas & Mudam & Não mudam & Total \\
\hline Meliá & 39 & 98 & 137 \\
\hline Sol & 8 & 82 & 100 \\
\hline Tryp & 72 & 39 & 111 \\
\hline Total & 119 & 219 & 338 \\
\hline
\end{tabular}

Juntamente com o investimento em remodelação dos hotéis e reconfiguração de sua nova imagem de marca, fortes investimentos em propaganda foram levados a efeito. Foi necessário 
considerar o investimento histórico que as principais cadeias hoteleiras faziam em investimentos promocionais, tal como visto no quadro exposto a seguir

Investimentos do setor hoteleiro na Espanha em 2001, por tipo de veículo

\section{TOTAL SECTOR / INVERSIÓN POR MEDIOS}

TOTAL SECTOR : $2.149 \mathrm{MM}$ PTAS:

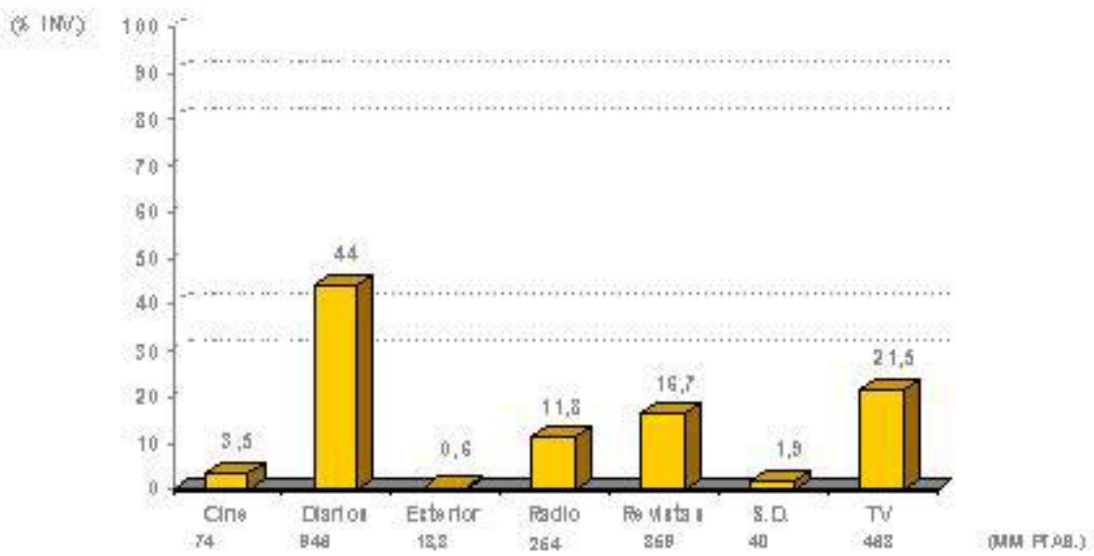

Predominantemente, são utilizados, na estratégia publicitária das diferentes cadeias hoteleiras, os jornais e a televisão. O investimento mensal é mostrado em seqüência:

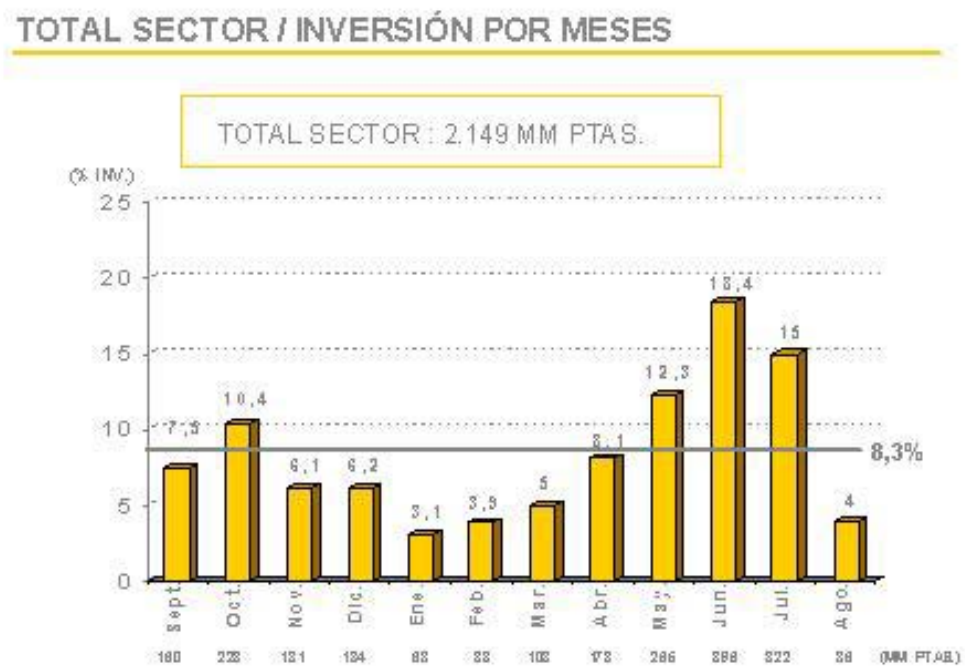

O fato de a Sol Meliá ser líder no mercado está em relação direta com o investimento em Marketing e com a estratégia de comunicação de suas marcas, como mostra a figura a seguir: 


\section{Gastos em publicidade, por marca, do setor hoteleiro na Espanha - 2001}

\section{TOTAL SECTOR / RANKING PRINCIPALES MARCAS}

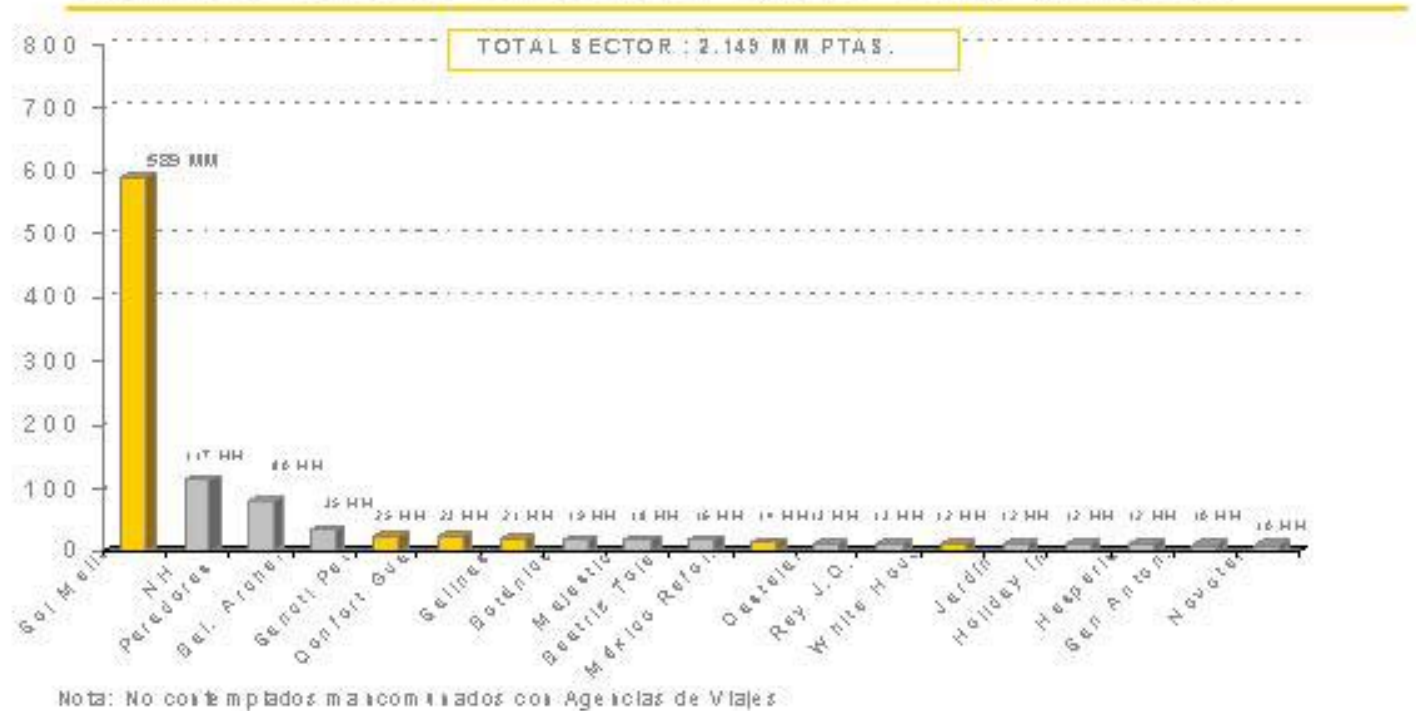

Como parte de sua estratégia de crescimento, e seguindo a evolução do setor, a Sol Meliá diversificou sua carteira de produtos, atendendo a seu modelo de gestão. Assim, em sua carteira pode observar-se a proporção de tipos de variantes de gestão entre os hotéis que levam suas marcas. Nos últimos anos, o crescimento tem sido feito por meio de contratos de gestão, mantendo-se hotéis em regime de exploração de propriedade e de franquia ${ }^{37}$. A estrutura da carteira, ao término do primeiro semestre do 2001, pode ser apreciada na s tabela seguinte:

\footnotetext{
${ }^{37}$ Contratos de gestão: a cadeia hoteleira se responsabiliza por toda a operação do hotel, nomeia o diretor, implanta seus sistemas e procedimentos internos, conduz os controles administrativos, econômicos e contábeis, comercializa o hotel em sua totalidade, incluindo-o em seus programas corporativos de marketing e em suas campanhas de publicidade, implanta suas políticas de recursos humanos e seus sistemas de qualidade. O grupo recebe como contraprestação uma basic fee, (4-6\% das receitas brutas), e uma incentive fee, (5-10\% do GOP, ou lucro operacional bruto). Além disso, o grupo cobra uma comissão ao proprietário pela utilização do Sistema Central de Reservas. A duração dos contratos costuma ser entre 5 e 20 anos.

Contratos de franquia: sistema contratual em que não se administra o hotel, cedendo ao proprietário o uso de algumas de seus marcas e incluindo-o em seu sistema de comercialização, de marketing e de controle de qualidade. Como contraprestação, a empresa franqueadora recebe uma affiliation fee, no momento da adesão do hotel ao grupo (taxa inicial de adesão) e uma annual fee como pagamento anual (2-5\% do GOP)

Contratos de aluguel: o grupo arrenda a os proprietários o imóvell, geralmente por uma quantidade fixa e se ocupa da operação e resultados.
} 
Composição da carteira de hotéis Sol Meliá, por regime de exploração

\begin{tabular}{|c|c|c|c|c|c|c|c|c|c|c|c|c|}
\hline \multirow[t]{2}{*}{ 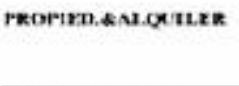 } & 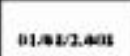 & \multicolumn{2}{|c|}{ scove. } & \multicolumn{2}{|c|}{ พื่ม } & \multicolumn{2}{|c|}{ Costanos } & 312062004 & \multicolumn{2}{|c|}{ BüLuacs } & \multicolumn{2}{|c|}{$\begin{array}{l}\text { Toru. } \\
\text { calio }\end{array}$} \\
\hline & H R & H & $\mathbf{R}$ & и & R & $\boldsymbol{\mu}$ & R & H $\quad$ R & и & $\mathbf{n}$ & н & R \\
\hline 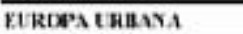 & $76 \quad 12.207$ & 1 & 68 & $\bullet$ & 2 & D & 4 & $77 \quad 12.313$ & 20 & 2.993 & 97 & 15.3196 \\
\hline Horefes en fropicidat & 6.894 & $\bar{a}$ & $\overline{0}$ & $\theta$ & 2 & $\bar{\theta}$ & $\Rightarrow$ & 366.852 & 9 & 42 & 39 & 7.954 \\
\hline Hoteles avityener & 5.3 .3 & 1 & as & 0 & $o$ & D & $\theta$ & 5.421 & 17 & 2.551 & 58 & 7.973 \\
\hline RIRDPA VACICIONAI. & $63 \quad 17.492$ & a & D & $\bullet$ & v & b & 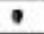 & as 17,492 & 5 & 1.722 & $6 x$ & 19.214 \\
\hline Fistefes ar fropotibat & $\$ 2 \quad 13.076$ & a & $\bar{\theta}$ & $\bar{\theta}$ & $\theta$ & 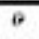 & 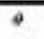 & $12 \quad 13,016$ & 2 & 1.012 & & $1+026$ \\
\hline Hoteles as thyeNor & 4.436 & a & o & 0 & $o$ & 0 & $\theta$ & $28 \quad 6.476$ & 3 & 710 & 21 & 3. 184 \\
\hline 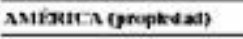 & $13 \quad 4.457$ & $a$ & $\theta$ & 0 & 0 & 0 & - & $53 \quad 4.857$ & $t$ & 500 & $t t$ & $5.55 \%$ \\
\hline TOTAL_VROVIXDAD & 9124.767 & a & & 4 & 2 & 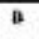 & 4 & 9124.765 & 6 & 1.954 & 97 & 26.719 \\
\hline TOTNLAMEUIXR & 9.829 & 1 & 68 & $\bullet$ & o & n & - & $62 \quad 9.597$ & 20 & 3.261 & BI & 13.158 \\
\hline Torat_angen & $158 \quad 34.596$ & 1 & 68 & $\bullet$ & 2 & 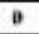 & 4 & 15334.662 & 36 & 5.215 & 179 & 39.877 \\
\hline
\end{tabular}

\begin{tabular}{|c|c|c|c|c|c|c|c|c|c|c|c|c|c|c|}
\hline \multirow{2}{*}{\multicolumn{2}{|c|}{ Eastuar.ubos }} & \multicolumn{2}{|c|}{ 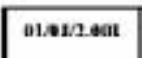 } & INCORP. & \multicolumn{2}{|c|}{ mivarbss } & \multicolumn{2}{|c|}{ colmos } & \multicolumn{2}{|c|}{ 3ex:20nt } & \multicolumn{2}{|c|}{ vikHADCs } & \multicolumn{2}{|c|}{$\begin{array}{l}\text { Toral. } \\
\text { Gataro }\end{array}$} \\
\hline & & и & $\mathbf{R}$ & H $\mathbf{R}$ & $\mathbf{H}$ & $\mathbf{R}$ & H & $\mathbf{R}$ & H & $\mathbf{R}$ & $\mathbf{H}$ & $\mathbf{R}$ & H & $\mathbf{R}$ \\
\hline \multirow[t]{2}{*}{ RURCFA EMHaY, } & 13 & 90 & 4.429 & 277 & 1 & 40 & 0 & 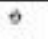 & 92 & 4.766 & 4 & 566 & 96 & 5.932 \\
\hline & 52 & 24 & 2825 & 162 & 3 & 378 & 0 & 9 & 22 & 2.509 & 1 & 215 & 23 & 2.724 \\
\hline \multirow[t]{2}{*}{ RUROAE VACACIOX.LI. } & M. 4 & 49 & 18.033 & $8 \quad 1305$ & 0 & 0 & D & 9 & 571 & 19,338 & 12 & 3.403 & 69 & 22741 \\
\hline & $\mathbf{F} 1$ & 17 & 5.702 & b $\quad 0$ & $\theta$ & 0 & 0 & 0 & 17 & 5.302 & 1 & 300 & 18 & 5.002 \\
\hline \multirow[t]{2}{*}{ ANIIAREA } & M 2 & 23 & 4.3 .44 & 3624 & a & a & 0 & 9 & & 4.968 & 25 & 4.364 & 51 & 0.332 \\
\hline & $\begin{array}{lll}\mathbf{F} & 1 \\
\end{array}$ & 10 & 1.369 & 0 & 0 & 0 & 0 & & to & 1.369 & 0 & 0 & 10 & 1.369 \\
\hline \multirow[t]{2}{*}{ AStA-PACirHeO } & \begin{tabular}{l|l}
31 & 1
\end{tabular} & 10 & 3,359 & 0 & $\theta$ & 0 & 0 & 6 & 10 & 3.539 & $\bar{D}$ & 6 & 10 & 3.539 \\
\hline & $\mathbf{F}:$ & 0 & 0 & $a$ & 0 & 0 & 0 & 9 & & 0 & D & 0 & 0 & 0 \\
\hline CLBs & 92 & 20 & 7.385 & 0 & 9 & 0 & (i) & 9 & 20 & 7.785 & 5 & 2.275 & 25 & 0.760 \\
\hline \multirow[t]{2}{*}{ st BTOTAL. } & M 13 & 132 & $37 . \mathrm{kSt}$ & 142.206 & 1 & st & D & a & 145 & 10.016 & 16 & 1a.70s & 191 & 50.724 \\
\hline & F 4 & st & 9.496 & $1 \quad 62$ & , & $37 x$ & 0 & 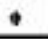 & $\infty$ & 9.180 & 2 & 514 & st & $\$ .695$ \\
\hline ToTA. & & 183 & 47.346 & 152.264 & 4 & 418 & D & a & 194 & 40,106 & 48 & 11.223 & 242 & $60+19$ \\
\hline TOTAL_CATPO & & 335 & 81.942 & 162.336 & 4 & 420 & D & 4 & $34 \%$ & 83.858 & 74 & 16.434 & 121 & 106.276 \\
\hline
\end{tabular}

Ao final de 2001, a composição da carteira, segundo o tipo de contrato de gestão, mostrava esta composição: 


\section{Estrutura organizacional da Sol Meliá em 1993}
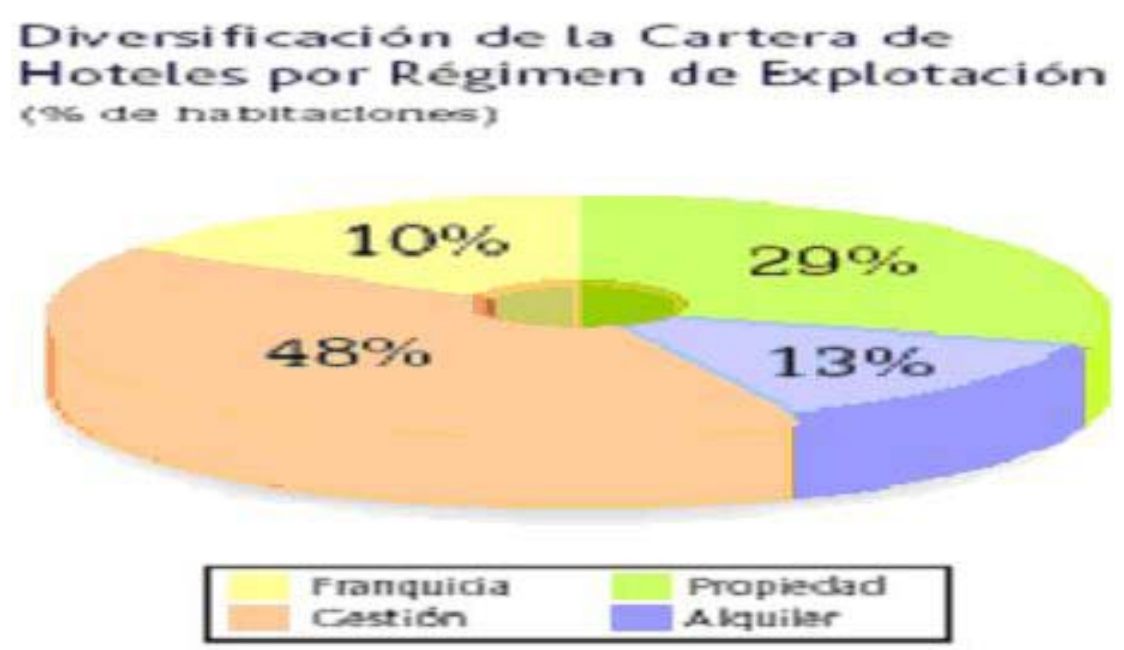

Fonte. Dirección de Recursos Humanos de Sol Meliá

\section{Cultura organizacional. Gestão de recursos humanos.}

\section{A Estrutura Organizacional}

A estrutura organizacional da Sol Meliá tem estado em constante aprimoramento. Quando, ao final de 1995, após três anos de minuciosa preparação, o Grupo Sol Meliá foi à Bolsa, demonstrou uma atitude proativa frente aos desafios que o ambiente mutável lhe impunha, como crescente concorrência existente no setor, oportunidade de expansão em decorrência do processo de concentração hoteleira em nível mundial e surgimento de novos destinos turísticos. Em 1993, a estrutura da companhia afastava os altos dirigentes de hotel dos clientes, por ter vários níveis hierárquicos, como se pode ver na figura a seguir. 
Organograma da Sol Meliá, em 1993

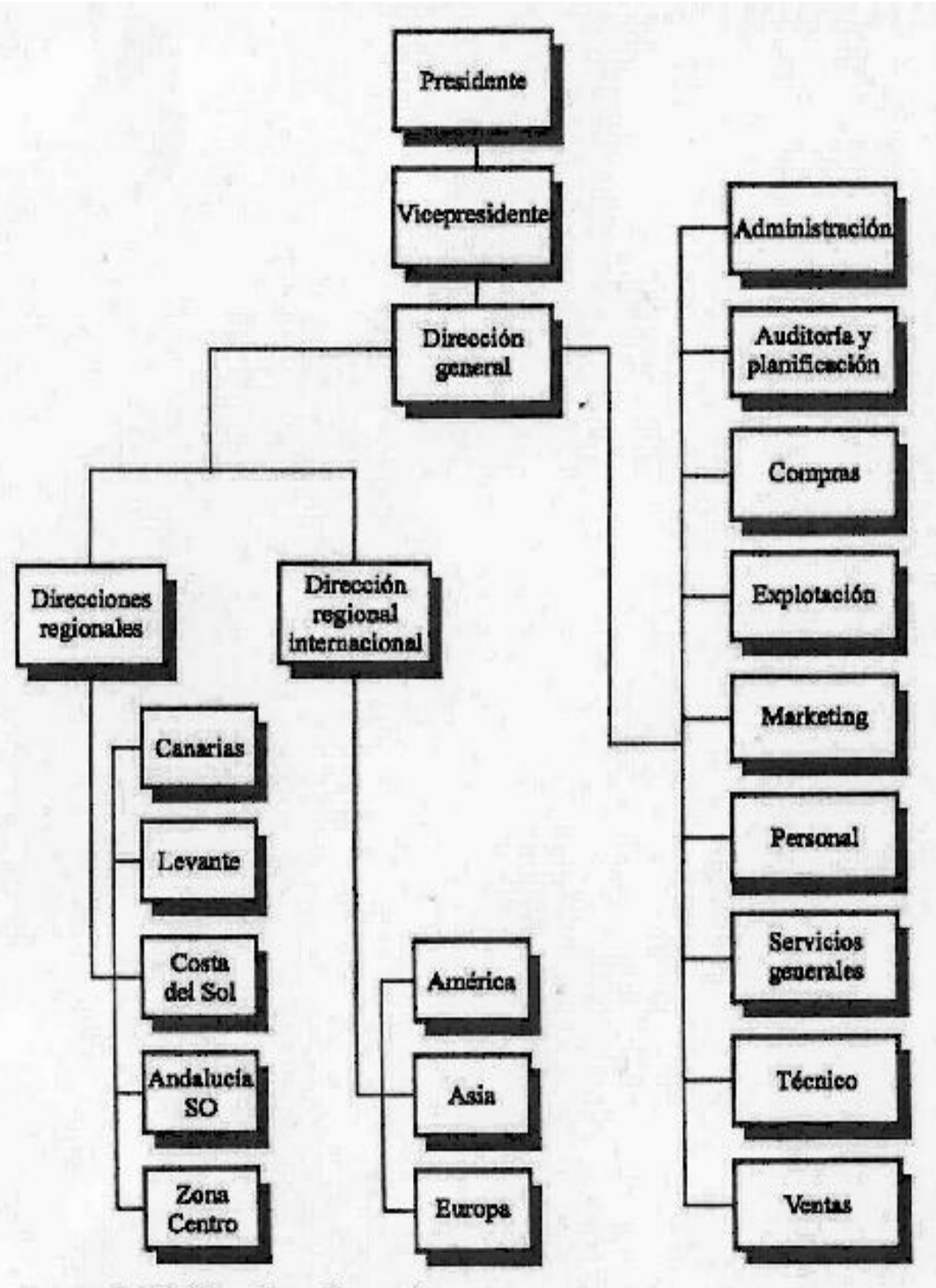

FURArE: Sol Melid y elaboración propia.

Figura 2.3.-Organigrama del Grupo Sol en 1993. 


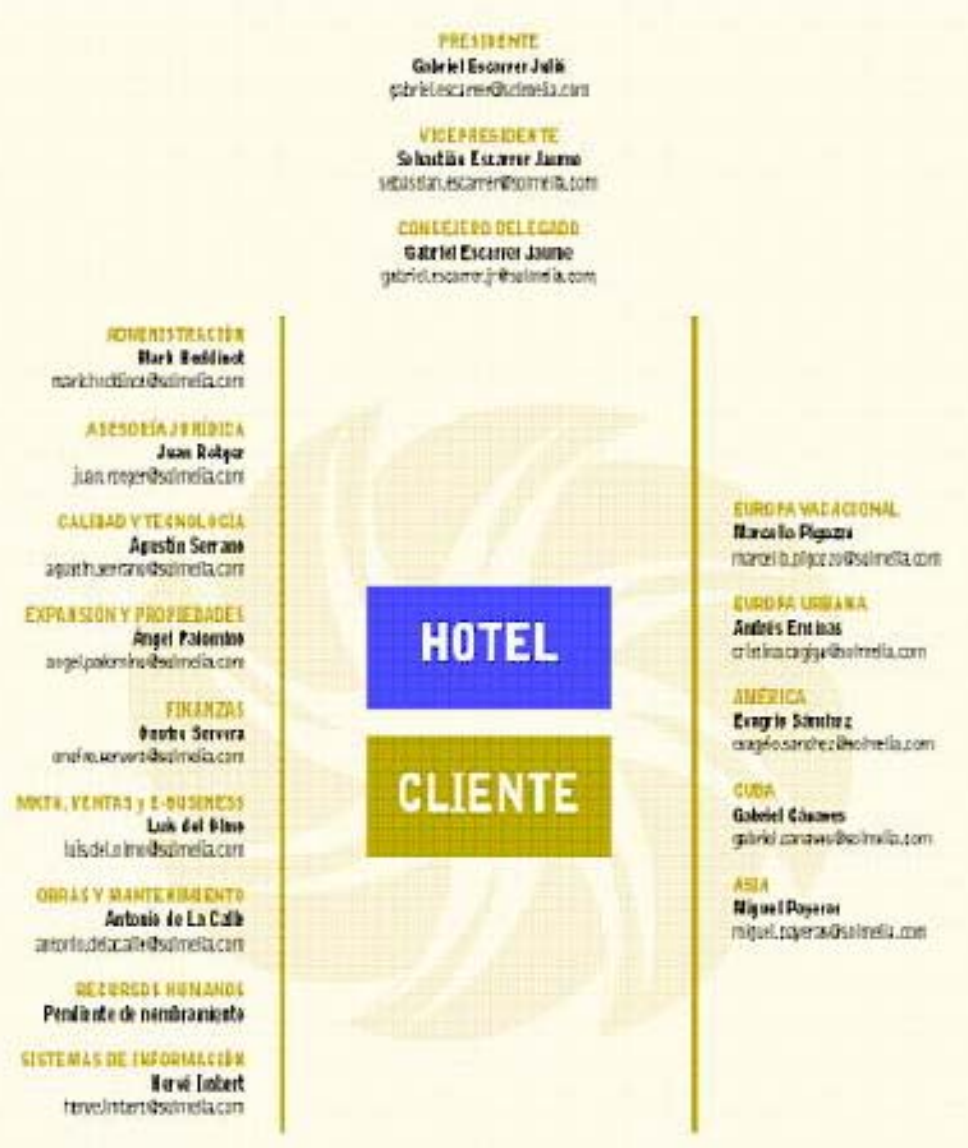

\section{Organograma da Sol Meliá - 2001}

Fonte. Memoria Anual de Sol Meliá 2001

Atualmente, a estrutura organizacional revela uma redução considerável de níveis hierárquicos, e tem como centro o hotel e seus clientes, os últimos a razão de ser da empresa, como mostra a figura acima.

Os ajustes feitos na estrutura organizacional da empresa têm-se apoiado em uma sólida cultura organizacional, a qual se sustenta nos seguintes valores compartilhados:

- Oferecer aos clientes o melhor equilíbrio qualidade-preço.

- Proporcionar serviço personalizado e com amabilidade.

- Fomentar os critérios de trabalho intenso, simplicidade, ética profissional, controle de custos e não ostentação.

- Espírito de superação contínua. 
- Reciclar o pessoal mediante programas de formação permanentes.

- Utilizar o ambiente propício de uma empresa familiar.

- Pregar com o exemplo a partir da cúpula diretiva.

- Estabelecer os controles necessários e uma adequada supervisião.

- Potencializar o sentido da responsabilidade.

- Delegação de funções.

Gestão por Competências vinculada à estratégia empresarial Sol Meliá. O modelo S.O.L. Meliá de Gestão por Competências e as Políticas de Recursos Humanos

A organização Sol Meliá é uma empresa hoteleira nacional (mais de 50\% do capital é espanhol) e multinacional, com mais de 21 milhões de estadas, distribuídas em mais de 330 hotéis, distribuídos por 30 países e quatro continentes, denotando um conceito de globalização próprio das características que fazem parte da empresa.

A companhia espanhola de gestão hoteleira Sol Meliá conta com um quadro de funcionários composto por mais de 30.000 empregados e um investimento global de mais de 900 milhões de euros.

Em nível internacional, a companhia conta com cinco grandes divisões de negócio, formados pela linha implantada na Europa: Europa Urbana e Europa De Férias, Ásia-Pacífico, América Latina e Cuba, localizando-se nesses diferentes pontos do mundo.

Os acordos de gestão e de franquia são a principal forma de crescimento da empresa, juntamente com os investimentos diretos em conquista de participação e formação de joint-ventures.

A Sol Meliá administra hotéis em regime de propriedade, aluguel, gestão e franquia; cada uma dessas fórmulas permite uma expansão rentável e sustentável da empresa.

Nesse sentido, a missão da Sol Meliá é "oferecer produtos e serviços hoteleiros em todo o mundo, onde o compromisso de nossos empregados torne possível a satisfação de nossos clientes e um crescimento rentável e sustentável". "Tudo é possível com alegria no serviço": sob esse lema a Sol Meliá aposta na qualidade de um serviço simples e cálido.

\section{Uma cultura multinacional}

$\mathrm{Na}$ Sol Meliá, a filosofia se fundamenta no estilo e na cultura de trabalho, sendo seus principais valores:

- Qualidade-Preço

- Serviço Personalizado

- Austeridade, trabalho, simplicidade e ética. Superação contínua

- Formação-Promoção 
- Empresa com ambiente familiar.

- Pregar com o exemplo

- Delegar

- Potencializar a responsabilidade

- Controle

No que diz respeito ao estilo e cultura da empresa, como valores relacionados com as pessoas que integram a organização, distinguem-se os seguintes elementos, que fazem parte do funcionamento e cumprimento das tarefas inerentes ao trabalho do dia-a-dia:

- Espírito Empreendedor

- Fortalecimento do pessoal mediante delegação

- Orientação para o Mercado

- Trabalho em Equipe

- Gestão orientada para o cliente

- Comunicação franca: aberta e honesta

- Transferência de experiências

Esses valores se refletem na gestão por competências da Sol Meliá, representando os pilares fundamentais, desde que as gestão em linha foi rompida com o novo direcionamento estratégico da companhia. Um claro exemplo dessa análise é que, para as pessoas que ingressam na companhia, é entregue um manual de boas vindas em meio eletrônico, contendo um cartão com os valores da companhia.

Sendo os valores da companhia um pilar fundamental, eles se refletem em todo o processo de gestão levado a cabo pela organização como um todo, e, como tal, há que se ter consciência das três ferramentas e adotadas pela companhia.

Por essa razão, a Sol Meliá tem apostado nas novas tecnologias como ferramentas de gestão, desenvolvendo:

- Intranet: entre as numerosas vantagens em termos de gestão empresarial, destaca-se o fato de se dispor de uma qualidade da informação, a qual parte sempre da mesma fonte e é progressivamente atualizada.

- Internet: cuja página web (http://www.solmelia.com) oferece, entre os diferentes serviços, a possibilidade de dispor de informação atualizada dos hotéis da companhia.

Além do mais, a Sol Meliá conta com intensos programas de fidelização e corporativos, produto dos seguintes objetivos da companhia: 
- Otimizar a rentabilidade.

- Padronização da qualidade.

- Dirigir seu crescimento.

- Evolução na Internet.

- Considerar cada hotel como núcleo da organização.

- Trabalho conjunto com a cadeia integrada TRYP.

Para levar a cabo a gestão da Sol Meliá, são utilizadas poderosas ferramentas de informática, como é o sistema SAP, que, para RH (SAP RH), proporciona a otimização da gestão da área na companhia, descentralizando-se, assim, a tomada de decisões e agilizando os processos, tanto em sua implantação como em seu desenvolvimento.

\section{Gestão por Competências vinculada à Estratégia Empresarial da Sol Meliá}

O modelo de gestão por competências da Sol Meliá parte da estratégia empresarial e da necessidade "de saber quem somos, onde estamos e para onde queremos ir". Assim, Javier Alonso, responsável pela gestão por competências da companhia, afirma que "a gestão por competências nasceu de uma necessidade de administrar seus recursos, quando estava experimentando uma mudança muito forte". A origem da gestão por competência se situava, portanto, no contexto da necessidade de conhecer o recente sucesso experimentado pela Sol Meliá. Além do mais, e levando em conta sua concretização prática, tratava-se de "tirar uma fotografia" das competências chaves daqueles dirigentes bem sucedidos, para saber, de um lado, de que recursos dispunha a Sol Meliá e que características faziam os dirigentes diferenciar-se do restante da companhia de outro lado, tratava-se de conhecer as carências ou aquelas características que faltavam à Sol Meliá para posicionar-se ante as mudanças futuras.

Para conhecer esses critérios e procurar novos, realizou-se um estudo quantitativo e qualitativo, contando com o apoio de uma consultoria, e, dessa forma, identificaram-se as competências chaves da companhia.

Para isso, foram utilizadas, como ferramenta básica, entrevistas estruturadas, tendo por grupo de referência os "dirigentes estrela" da companhia. O resultado obtido foi a criação de um sistema de gestão por competências que, tomando como por base os objetivos da companhia, vinculouse, inicialmente, a três políticas estratégicas e básicas para a gestão hoteleira, como: seleção, desenvolvimento e remuneração.

Dessa maneira, a Gestão de Recursos Humanos vincula-se à gestão por competências como modelo implantado e, além do mais, graças ao sistema e à tecnologia de informação, permanece integralmente na companhia. Nesse sentido, na Sol Meliá se "realiza a Gestão de Recursos 


\section{Humanos a partir do Know-How da companhia".}

Além do mais, tratou-se de fazer com que a gestão ficasse sempre vinculada à participação, posto que, em todos os níveis e em toda a organização, ocorre uma vinculação que, em maior ou menor medida, vem reforçar e desenvolver o sistema de gestão criado especificamente para a gestão e o trabalho diário da Sol Meliá.

O plano de comunicação da empresa converte-se em elemento facilitador, e, em prol do desenvolvimento da gestão por competências, "identifica e comunica as competências no dia-adia". Como caso prático, podem ser mencionados os cursos desenvolvidos pela Sol Meliá, destinados a todos os funcionários de nível intermediário, buscando a compreensão e a implantação do modelo, que, mediante ações de formação, permitem que a gestão no dia-a-dia realmente funcione de acordo com as linhas traçadas para alcançar as metas propostas.

A organização do trabalho da Sol Meliá é acentuamente marcada pela estrutura de seus hotéis, cujo valor agregado fundamental é fazer com que o cliente não distinga em que tipo de hotel se encontra; na Sol Meliá, como já dito, existem os hotéis em regime de propriedade, de franquia e de gestão, sendo que os dois últimos têm proprietários diferentes dos da Sol Meliá.

Por essa característica especial da estrutura de hotéis da Sol Meliá, a organização é cuidadosa em relação a tudo o que diga respeito às três figuras chaves sobre as quais a gestão por competências da empresa gravita: o Diretor de hotel, o Chefe de vendas e o Diretor Administrativo. Esses postos típicos são aqueles sobre os quais se aplicam as competências "S.O.L." da companhia, porque são figuras representativas e constituem o know-how da organização.

Faz-se com que os processos seja conduzidos por critérios uniformes e objetivos no sistema de gestão. Para isso, utiliza-se uma ferramenta chave na organização Sol Meliá: o Quadro de Comando, que, conforme o esquema de gestão integral da empresa, avalia o sistema dos postos típicos. Em cada direção geral, tem sido desenvolvido um máximo de três pessoas por nível, de maneira que o desenvolvimento pessoal e profissional de cada uma dessas pessoas seja estabelecido com base nas competências chaves a desenvolver e, além do mais, vinculam-se a essas competências as faixas salariais estabelecidas para cada uma delas.

É aí que se encontra uma dificuldade funcional do sistema, já que discriminar níveis de competências e definir em que grau se deve desenvolver uma competência concreta é muito complexo, apesar da simplicidade do modelo de gestão, em implantação desde 1996. Para superar essa dificuldade utiliza-se como instrumento a entrevista de incidentes críticos.

Nesse sentido, não se pode esquecer de outra das características fundamentais da empresa, ou seja, seu carácter global e multinacional. Para diminuir essa dificuldade e poder adaptar-se ao 
modelo de gestão por competências, a Sol Meliá distingue dois tipos de empregados: "Os Global Players" e os "Local Players'. Aplica, então, aos primeiros, as competências fundamentais do modelo, que enfatizam o valor global como potencialidade principal, e adaptam o modelo aos segundos. Como resultado obtém-se a aplicação da gestão por competências a toda a companhia e, em termos de adaptação daquele, desenvolve um Plano de Desenvolvimento Global e/ou um Plano de Desenvolvimento Local, dependendo do enfoque que se necessite adotar.

\section{O Modelo S.O.L. Meliá de Gestão por Competências e as Políticas de Recursos Humanos.}

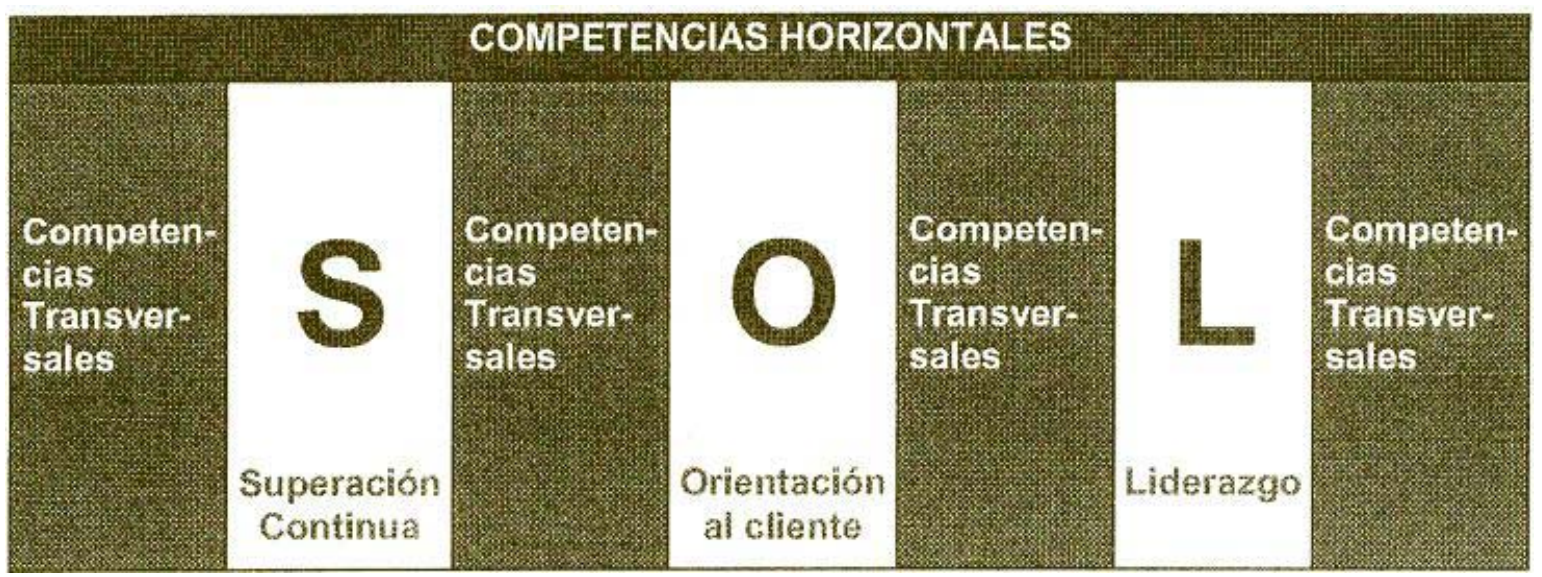

No modelo S.O.L., foram estabelecidas as Competências Horizontais, aquelas que afetam uma posição concreta dentro da organização, como Diretor Comercial ou Diretor de Hotel, e as Competências Transversais, aquelas que afetam todas as pessoas que integram o sistema interno. Por sua vez, no âmbito das competências transversais, foram estabelecidas as competências de caráter estratégico, também chamadas de competências críticas. Trata-se das competências S.O.L (Superação Contínua, Orientação para o Cliente e Liderança), as quais todas as pessoas da Sol Meliá devem possuir. Elas se caracterizam como competências críticas. Esses três conceitos devem permear todo o processo de seleção, que é baseado em competências.

Todo o conjunto de competências envolve as competências brandas ou Competências Intangíveis associadas "aos comportamentos ligados às características pessoais, as quais garantem resultados superiores".

Por outro lado, as competências duras, ou Competências Tangíveis, de caráter técnico, são "os conhecimentos e habilidades necessários, mas que não garantem por si só resultados superiores". Elas foram estabelecidas com base nas figuras-chave que analisadas no momento da criação do modelo e desenvolvidas para implantação posterior.

\section{Política de Formação e Desenvolvimento.}

Outro fator determinante do estabelecimento dos diferentes níveis de cada competência é que se 
torne perfeitamente tangível a definição da competência que está sendo determinanda para a pessoa da companhia (seja gestor ou colaborador da Sol Meliá).

É interesante, nesse sentido, mencionar um instrumento básico facilitador dessa tarefa, "O guia de recursos para o desenvolvimento das competências", cuja ênfase repousa sobre as três figuras pivôs da Sol Meliá.

O guia, cujo uso pode generalizar-se para todas as pessoas da empresa, converte-se em um instrumento de concretização do Plano de Auto Desenvolvimento Individual, e é estabelecido com base em um bloco que inclui sugestões para alcançar as fronteiras de cada competência. Essas são indicadores chaves para conhecer em que nível de competência encontra-se a pessoa. O guia representa o principal documento de consulta a respeito do conteúdo dessas competências, tornando-se um compêndio sobre os comportamentos efetivos para alcançar o nível de competência. Além disso, alguns livros de desenvolvimento das diferentes competências são colocados à disposição.

Esse instrumento é parte integrante dos Programas de Desenvolvimento Interno (os P.D.J.), que são a base para a formação e desenvolvimento a serviço dos objetivos básicos da companhia. Os P.D.J. estão orientados para identificar, formar e promover os colaboradores com maior projeção na empresa, "permitindo formar jovens profissionais com potencial naqueles postos estratégicos para a expansão da Sol Meliá".

Cada programa aplicado a cada figura estratégica da empresa é conduzido por meio de cinco fases:

1. Identifica-se o perfil de competências do Diretor de Hotel, do Diretor Administrativo e do Chefe de Vendas.

2. Projeta-se a campanha de recrutamento e de seleção, que se inicia por meio de uma campanha de comunicação dirigida aos colaboradores da companhia, mediante a Intranet da Sol Meliá, a qual reflete um dado fundamental: "que as oportunidades de promoção cheguem a todos os colaboradores da companhia".

3. Criou-se o Development Center, com base nas competências, levando em conta os dois tipos de competências, as duras e as brandas, e o nível requerido de cada uma de elas.

4. Realiza-se a seleção de hotéis e instrutores: o critério para a seleção é escolher "aqueles dos quais se pode aprender mais e melhor".

5. Define-se a metodologia de treinamento e de formação que se porá em prática, elaborando um cronograma para a composição dos grupos de empregados que participarão do projeto.

Resumindo, os programas darão o suporte à implantação, na Sol Meliá, da Gestão por 
Competências, mediante um enfoque prático e dinâmico, que, juntamente com a gestão do desempenho, melhorará a administração dos estabelecimentos hoteleiros, em qualidade e rentabilidade.

\section{Política de Remuneração}

A política de remuneração permite que "a estratégia e os objetivos da empresa sejam traduzidos em objetivos para cada pessoa", fazendo com que o pessoal conheça precisamente o que se espera dele, e possibilitando um assessoramento constante para a consecução de seus objetivos e, com isso, a obtenção de reconhecimento e de recompensa adequados.

Dessa maneira, a remuneração é variável e vinculada à qualidade e ao desempenho das tarefas e funções, levando em conta também os aspectos econômicos. Trata-se de criar e usar o modelo de remuneração variável no autodesenvolvimento e a superação contínua como bases fundamentais de aplicação de competência crítica.

Assim, os postos chaves dos hotéis saberão quais são e como desenvolver o que os melhores profissionais da Sol Meliá têm em comum, de acordo com as próprias responsabilidades, começando a por em prática o plano de desenvolvimento personalizado de cada funcionário. "Isso permite promover uma companhia centrada nas pessoas, desenvolvendo as condutas que caracterizam os profissionais, e projetar a formação e a remuneração de forma justa e eficaz",

\section{Política de Seleção e Promoção Interna:}

A Sol Meliá fundamenta o modelo em "encontrar as diferenças entre um desempenho destacado e um desempenho normal", apontando as figuras chaves de aplicação do modelo: Diretor Gerente; Diretor Administrativo; Diretor Comercial e/ou Chefe de Vendas; cargos intermediários.

Trata-se, então, de identificar quais são as competências que convertem em melhores as pessoas que integram ou irão fazer parte da organização. Por esse motivo, criou-se um sistema objetivo de seleção, que permite, não apenas selecionar, como também promover as pessoas que demonstrarem o conjunto de competências requeridas.

Para isso, identificou-se o perfil de competências duras, ou de conhecimentos, identificando-se as áreas de conhecimentos específicos para um adequado desempenho das tarefas requeridas, como, idiomas ou informática. Em seguida, foram projetadas ferramentas concretas, com o objetivo de analisar se a pessoa possuía ou podia desenvolver as competências estabelecidas no perfil de competências brandas, as comportamentais.

Isso é aplicado pelo Development Center, se se tratar de promoção interna, ou por meio de entrevista baseada em competências, se se tratar de contratação externa. No primeiro caso, cada 
participante realiza várias provas, nas quais demonstra seu nível de competências. Diferentes examinadores externos e internos avaliam os resultados. Assim, todas as competências são avaliadas por diferentes provas e por diferentes observadores.

No segundo caso, entrevista baseada em Competências, parte-se do fato de que o RH não pode fazer todas as entrevistas de entrada, e que só os dirigentes de linha são os que podem garantir a aplicação do sistema de seleção baseado em competências. Por este motivo, cria-se uma ferramenta de seleção baseada em competências e se desenvolvem cursos de formação em Seleção por Competências para Dirigentes. Isso porque há que se considerar que o Dirigente escolhido, em um primeiro momento não se considera "um grande entrevistador em competências".

A ferramenta criada funciona com base nos seguintes itens:

- Recepção por diferentes vias da solicitação de emprego.

- Aplicação de questionários de personalidade baseados em competências.

- Bateria de perguntas vinculadas às competências duras.

- Guia de entrevista baseada nas competências chaves.

Assim, o resultado é que se dispõe da definição de competências para as figuras-chave da Sol Meliá e se desenha e implementa uma Política de Promoção Interna baseada nelas, colocando-se sempre desafio de "ser capaz de criar e manter um sistema de seleção externa baseada em competências",

\section{Superar Dificuldades e Potencializar as Vantagens do Modelo de Gestão por Competências da Sol Meliá.}

Uma primeira dificuldade a ser enfrentada a cada dia pela Sol Meliá, na gestão contínua de seus Recursos a partir da Gestão por Competências, é sua característica de multinacional.

Isso faz com que, partindo de um único Modelo de Gestão por Competências da companhia, ela tenha que levar em conta as diferentes culturas às quais o modelo deve adaptar-se. Assim, por exemplo, a Sol Meliá considera que, ao definir e aplicar a competência "orientação para o cliente", não vai obter o mesmo desenvolvimento e análise na República Dominicana do que na Espanha. Por isso, é necessário adaptar progressivamente o modelo aos valores próprios de cada cultura, par manter a coerência com o cliente interno e externo da organização.

Como comenta um dos responsáveis pela gestão por competências da companhia: "romper barreiras, porque entender a promoção com base na gestão por competências é complicado e é necessário dominá-la tecnicamente para que o modelo cresça e se desenvolva",

Afora essa dificuldade, foi preciso realizar um "self assessment", comparando cada perfil dos 
dirigentes da companhia com os perfis de competências definidos pelos especialistas da Sol Meliá.

Entende-se, então, que o processo de adaptação e aplicação da gestão por competências não é linear, mas ".. um processo de ensaio-e-erro".

Superar uma última dificuldade trouxe conseqüências positivas para o modelo; é a influência que o estilo que o dirigente imprime à cultura da empresa, vinculando-a, com isso, à gestão por competências.

Por essa razão, foi necessário partir "da fotografia da organização", para saber o que é que se tem, onde se está e o que se quer conseguir no futuro. Assim, estão sendo consideradas, no desenvolvimento do modelo e, com isso, no desenvolvimento das pessoas, as competências futuras requeridas para a Sol Meliá, que lhe permitam assumir os novos desafios.

Para a Sol Meliá, administrar competências significa também incorporar a gestão de mudança como parte da gestão integral dos Recursos Humanos da companhia.

Potencializando as vantagens do modelo, a Sol Meliá obtém a primeira conquista, que consiste em "unir todas as pessoas da organização por meio de uma mesma linguagem; trata-se de obter um mesmo canal de comunicação que reúna as pessoas que integram a Direção de Recursos Humanos e a Direção Geral da companhia".

No centro da análise realizada reside o fato de que a gestão por competências se orienta para a empresa que se quer no futuro: "uma empresa de alto rendimento", centrada em:

- Rentabilidade.

- Inovação.

- Envolvimento.

- Melhora Contínua

- Preparada para crescer.

\section{A gestão da qualidade}

Um dos princípios e valores da Sol Meliá, desde sua fundação, tem sido a qualidade dos serviços. Para os dirigentes da empresa, na qualidade alcançada está a chave de sua internacionalização. Hoje, em qualquer parte do mundo em que se encontre um hotel da Sol Meliá, ele é um sinônimo de qualidade, o que confere um grande prestígio à companhia junto à TTOO, AAVV e aos clientes finais. Segundo se pôde depreender das entrevistas junto aos dirigentes da empresa, relacionados com a atividade, os primeiros planos e programas de gestão de qualidade datam do ano 1984. Esses programas continuam a ser aplicados e aperfeiçoados, mediante um processo de melhora contínua. 
A idéia da direção da empresa se materializa no modelo EFQM de melhora contínua dos processos, como fator para elevar a qualidade. Segundo Sebastián Escarrer, em entrevista concedida ao pesquisador, os dois pilares desse processo são a padronização e a formação do pessoal.

Modelo EFQM de Gestão de Excelência na Gestão Empresarial.

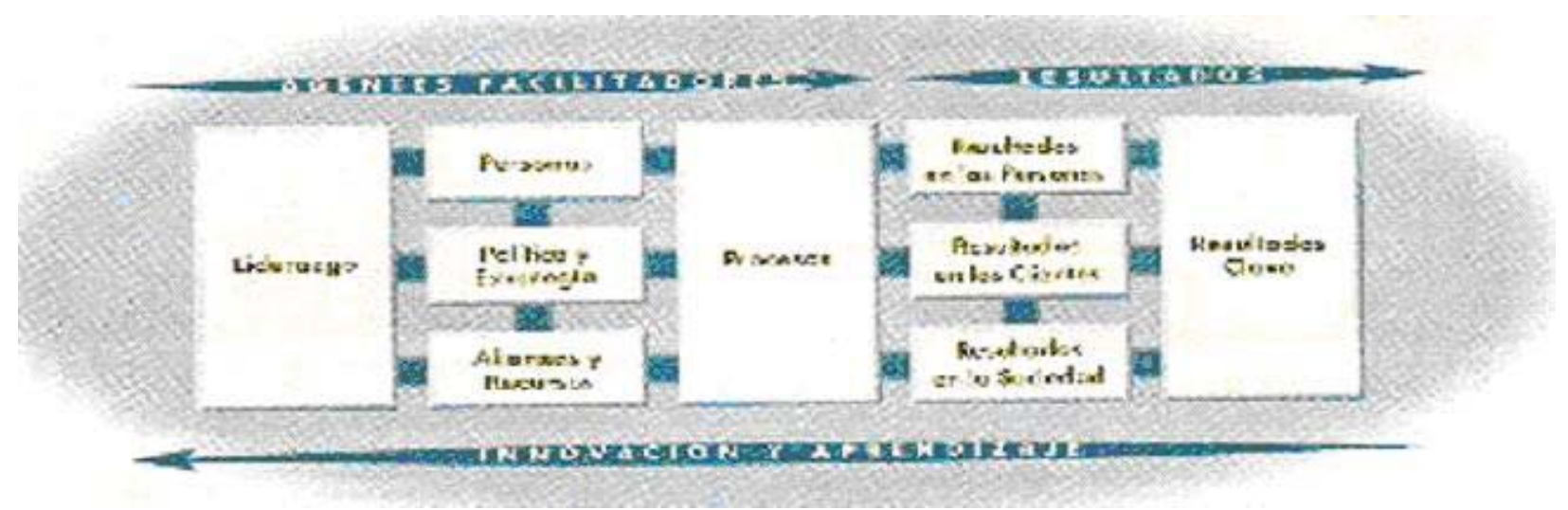

Fonte: Modelo EFQM de Excelência. Club Gestão de Qualidade.

A concepção do modelo se baseia nos seguintes conceitos:

- Orientação para resultados. A excelência depende do equilíbrio e da satisfação das necessidades de todos os grupos de interesse relevantes para a organização (as pessoas que trabalham nela, os clientes, fornecedores e a sociedade em geral, assim como todos os que têm interesses econômicos na organização - os stakerhorders e os shareholders).

- Orientação para o cliente. O cliente é o árbitro final da qualidade do produto e do serviço. O melhor modo de otimizar a fidelidade e a retenção do cliente, bem como o aumento na participação de mercado, é mediante uma orientação clara para as necessidades dos clientes atuais e potenciais.

- Liderança e constância nos objetivos. O comportamento dos líderes de uma organização provoca nela clareza e unidade nos objetivos, bem como um ambiente que permite à organização e às pessoas que a integram alcançar a excelência.

- Gestão por processos. As organizações atuam de maneira mais efetiva, quando todas as suas atividades inter-relacionadas são compreendidas e administradas de maneira sistemática, e as decisões relativas às operações em vigor e às melhoras planejadas são adotadas a partir de informação confiável, que inclui as percepções de todos os seus grupos de interesse.

- Desenvolvimento e envolvimento das pessoas. O potencial de cada uma das pessoas da organização aflora melhor porque existem valores compartilhados e uma cultura de confiançaa e assunção de responsabilidades que fomentam o envolvimento de todos. 
- Aprendizagem, Inovação e Melhora Contínua. As organizações alcançam seu rendimento máximo, quando administram e compartilham seu conhecimento no contexto de uma cultura geral de aprendizagem, inovação e melhora contínuas.

- Desenvolvimento de Alianças. A organização trabalha de um modo mais efetivo, quando estabelece, com seus partners, relações mutuamente benéficas, baseadas na confiança em dividir com eles o conhecimento e a integração.

- Responsabilidade social. A longo prazo, o melhor modo de servir aos interesses da organização, das pessoas que a integram é adotar um enfoque ético, superando as expectativas e as normas da comunidade.

Para materializar esses conceitos, a matriz da Sol Meliá implantou em todos os seus hotéis o programa Guest Satisfaction Assurance, que instrumentaliza esses princípios, mediante diferentes procedimentos. tais como mostrado a seguir. 


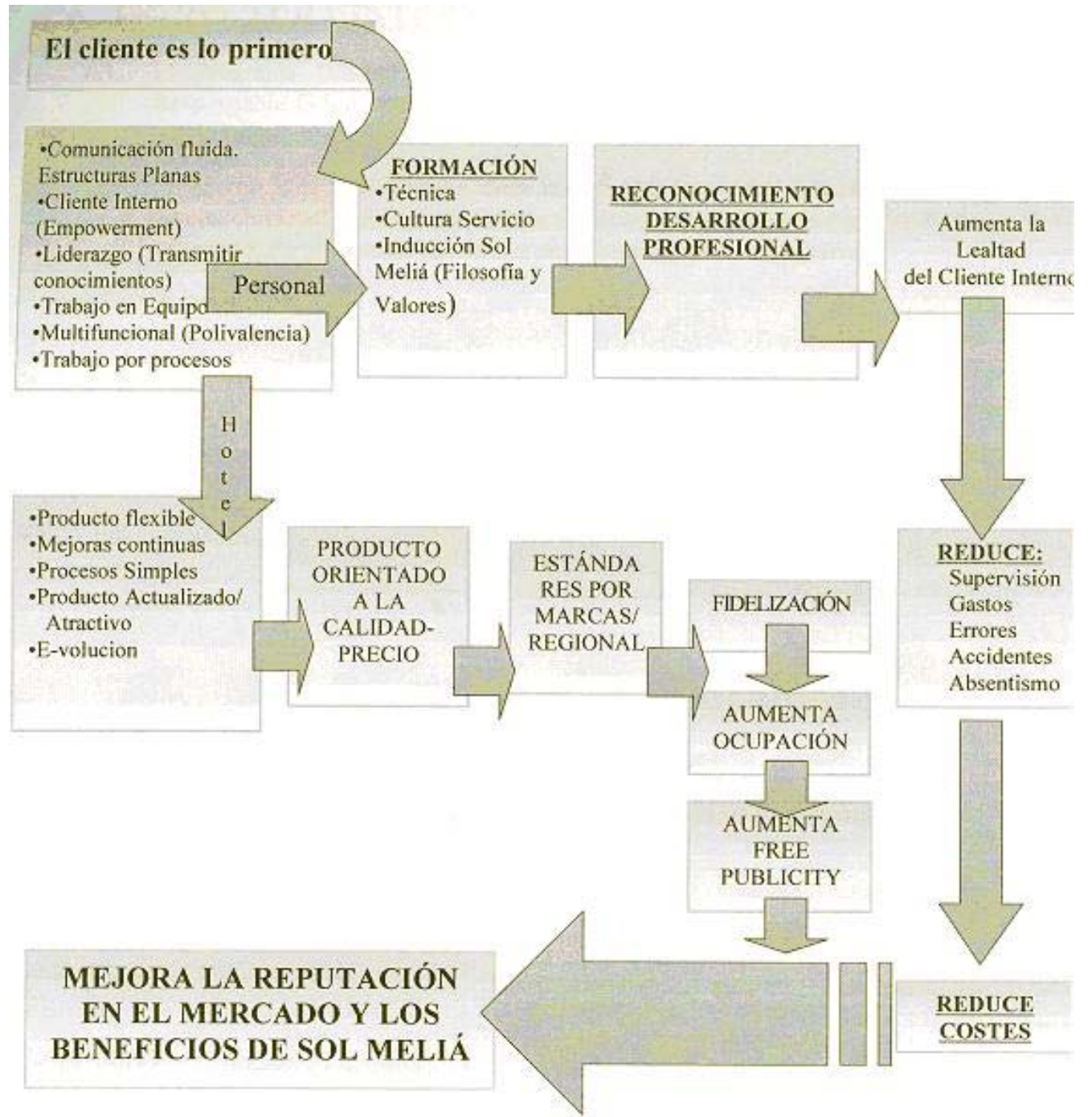

Fonte. Dirección de Calidad. Sol Meliá 2001

\section{A introdução e o desenvolvimento das novas tecnologias da informação: a $e$ -} transformação da empresa.

A Sol Meliá iniciou, durante o ano 2000, a e transformação da companhia. Ele foi considerado como um processo interno necessário para modernizar a empresa e adaptá-la à nova economia. Com um orçamento de 12 bilhões de pesetas, destinado à incorporação de nova infra-estrutura tecnológica e à participação em joint venture, para continuar sendo competitiva em um mundo empresarial dominado por novas tecnologias. $O$ investimento se distribuiu da seguinte forma: $E$ transformação, 30 milhões de euros; E-Procurement, 3 milhões de euros, Prodigios, 21 milhões de euros, MeliaViajes.com, 18 milhões de euros.

A filosofia desse processo pode ser entendida segundo o esquema da figura abaixo. 
Mediante a integração das novas tecnologias, a empresa busca incrementar, em definitivo, a eficiência e a efetividade de seus processos, que se traduzem no indicador chave de rendimento por acomodação, Rev Par, conforme mostrado no modelo aplicado pela empresa.

Integração dos elementos do sistema $e$-transformação da Sol Meliá e impacto no Rev Par

The new paradigm is a focus on customer value creation in developing, selecting, and implementing strategies

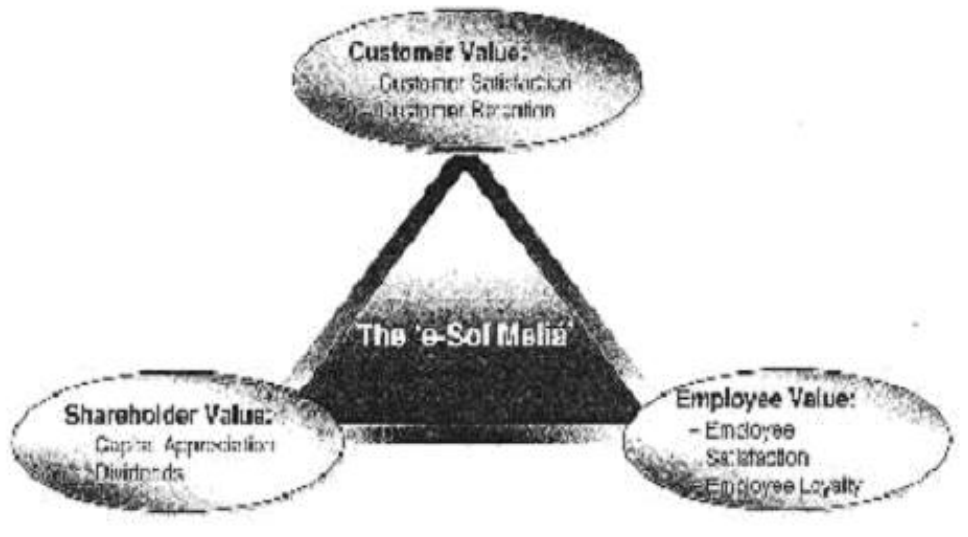

Fonte. Dirección de $e$-transformação da Sol Meliá

O modelo aponta como a criação de valor para clientes, empregados, acionistas e outros públicos interessados nos lucros da empresa, gera aumento no rendimento global da empresa. Para administrar esse processo, criou-se na empresa uma equipe especializada que deveria concretizar um programa em três áreas fundamentais:

a. Estratégias B2C.

Essa área foi organizada com a missão de produzir uma mudança definitiva na relação com os clientes, facilitar a distribuição de produtos, aumentar a captação de clientes, mediante o aperfeiçoamento dos programas de fidelização, e melhorar o serviço prestado aos hóspedes atuais e potenciais, proporcionando-lhes ampla informação sobre os produtos da empresa.

b. Estratégias Inside.

Para isso, procurou-se otimizar as funções integradas na Intranet da empresa. Assim, a incorporação da plataforma SAP (System Application Programs) permitiu armazenar um glande e detalhado volume de informações para melhorar e agilizar os processos, utilizando os novos canais oferecidos pela Internet. A nova aplicação inclui cinco áreas, as quais se concretizaram na automatização da força de vendas (CRM), recepção nos hotéis (RA 2000), instrumentos de controle financeiro, Recursos Humanos e Divisão de Compras.

c. Estratégias Business to Business. 
A incorporação dessa nova tecnologia permitiu centralizar toda a gestão de compras da companhia e administrá-la On Line, com o objetivo de aperfeiçoar a relação com os fornecedores, obter preços mais competitivos e otimizar os processos. Para implementá-la, a Sol Meliá fundou, juntamente com a Telefônica, o BBVA, a Barceló Hotéis e a Iberostar, o portal Hotelnetb2B.com, que integram 18 empresas, com o objetivo de otimizar os processos de compra em todo o setor. O portal opera na Espanha e em toda a costa do Mediterrâneo e tem um portfolio de mais de 900 hotéis em 21 países. Para sua implantação e início de operação, previu-se um investimento inicial, abrangendo os dois primeiros anos, de mais de 30 milhões de euros

Os resultados esperados pela aplicação dessas estratégias podem ser analisados na figura abaixo.

\section{Impacto da e -transformação da Sol Meliá na efetividade e eficiência da empresa}

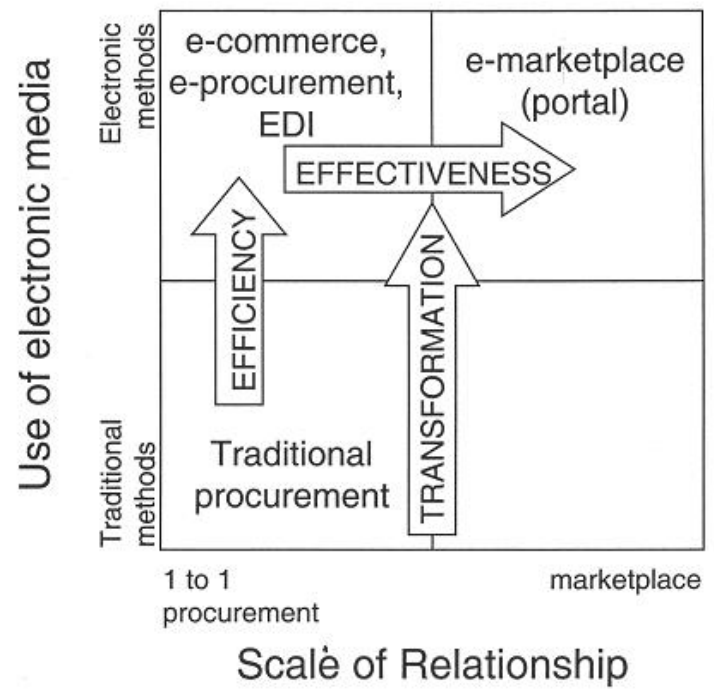

Fonte. Dirección de e -transformación Sol Meliá 2001

A empresa avaliou o impacto dessas estratégias em toda a sua cadeia de valor, na cadeia de valor de seus fornecedores e na de seus clientes, segundo pode ser apreciado no modelo apresentado a seguir. 


\section{Impacto da e -transformação na cadeia de valor da Sol Meliá}

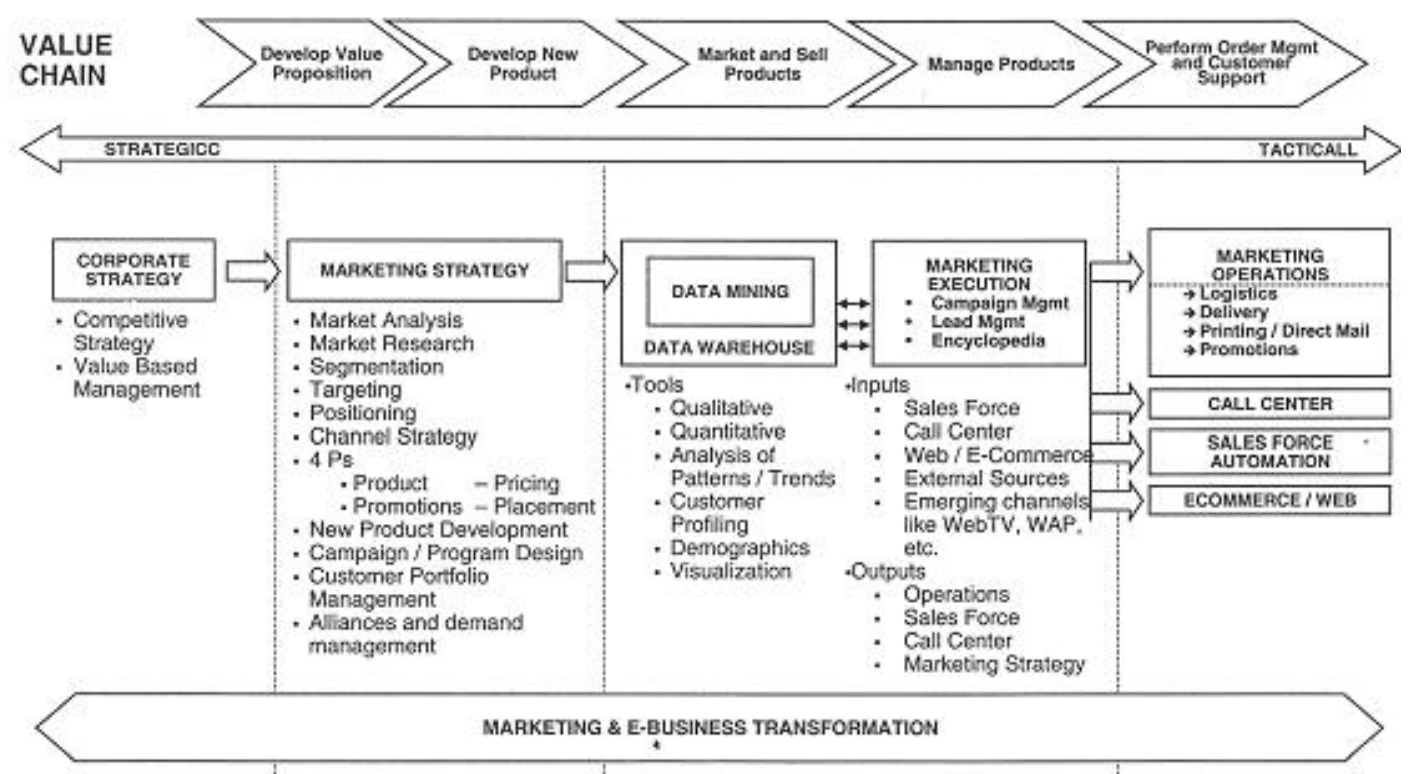

Fonte. Dirección de $e$-transformação da Sol Meliá 2001

A aplicação, pela Sol Meliá, da $e$-transformação demonstra a orientação voltada para o cliente, por parte da direção da empresa, e seu impacto direto na estratégia de marketing. Agregar valor ao cliente é algo entendido como parte do processo estratégico, cuja filosofia a empresa incorporou às políticas de marketing, como observado no diagrama que se segue.

\section{E -transformação e Marketing Estratégico em Sol Meliá}

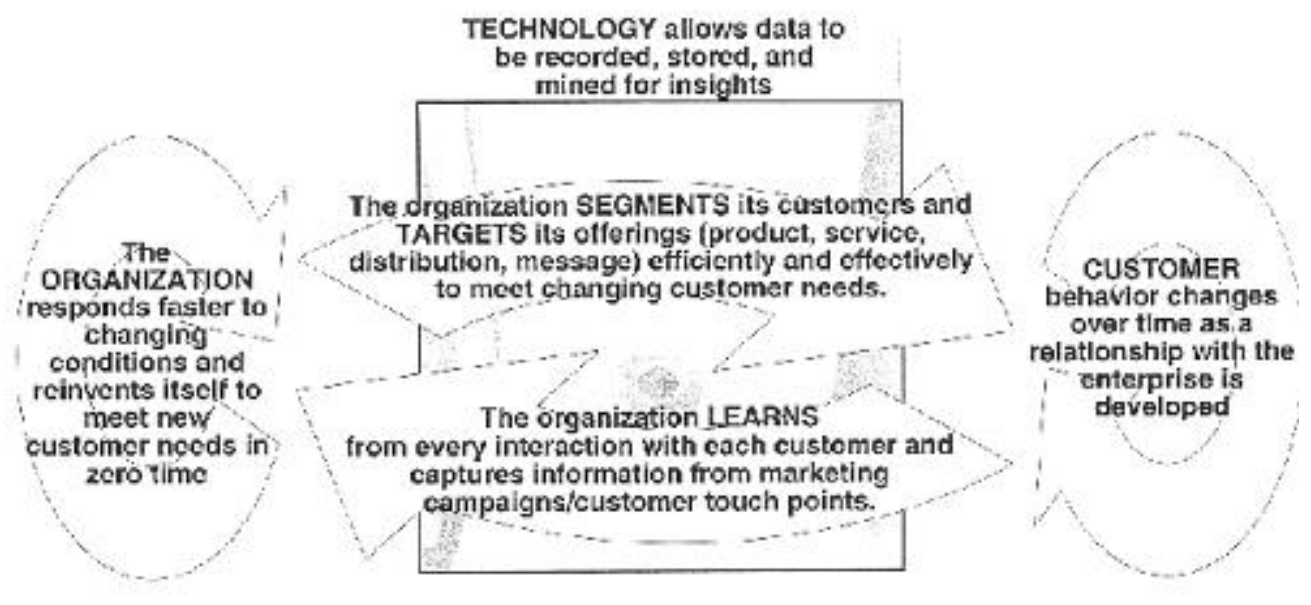

Uitimately, the results of achieving this vision will bc increascd wallet share, increased relurn on cainpaign spending, greater profitability por customer and greater shareholder value.

Fonte. Fonte: Dirección de $e$-transformação da Sol Meliá 2001

Portanto, a tecnologia permite à empresa coletar, armazenar e administrar informações sobre seus clientes, o que facilita o processo de segmentação, propiciando, conseqüentemente, oferecer produtos e serviços cada vez mais "customizados". Informações dessa natureza favorecem muito 
o aprendizado da empresa sobre a interação com seus clientes, o que redunda em respostas cada vez mais rápidas às mudanças de comportamento dos consumidores.

\section{Análise econômico-financeira.}

Os resultados econômicos e financeiros da Sol Meliá, no ano 2001, foram muito influenciados pela repercussão dos acontecimentos de 11 de Setembro, ocorridos nos Estados Unidos. Tais acontecimentos afetaram todos os setores da economia, mas em dose muito maior o setor de viagens e de turismo. A empresa, não obstante essa situação, obteve um aumento nas receitas totais de $13,9 \%$, relativamente ao ano de 2000 , segundo pode ser apreciado na tabela a seguir. O impacto da situação internacional refletiu-se, fundamentalmente, nos lucros, os quais revelam uma forte queda no ano de 2001, como mostrado nas tabelas e figuras seguintes, que comparam os resultados dos últimos anos de gestão da cadeia:

Evolución Económica

En Millones de Euros

\begin{tabular}{lrrrrrrr}
\hline & 1996 & 1997 & 1998 & 1999 & 2000 & 2001 & C.A.G.R. \\
\hline INGRESOS & 51 & 80 & 95 & 659 & 892 & 1016 & $82 \%$ \\
\hline & $\cdot$ & $58 \%$ & $18 \%$ & $596 \%$ & $35 \%$ & $14 \%$ & \\
\hline EBITCA & 27 & 43 & 50 & 199 & 261 & 241 & $55 \%$ \\
\hline & - & $56 \%$ & $17 \%$ & $301 \%$ & $31 \%$ & $-7 \%$ & \\
\hline BENEFICIONETO & 21 & 34 & 42 & 88 & 113 & 59 & $23 \%$ \\
\hline & - & $63 \%$ & $21 \%$ & $112 \%$ & $28 \%$ & $-48 \%$ & \\
\hline
\end{tabular}
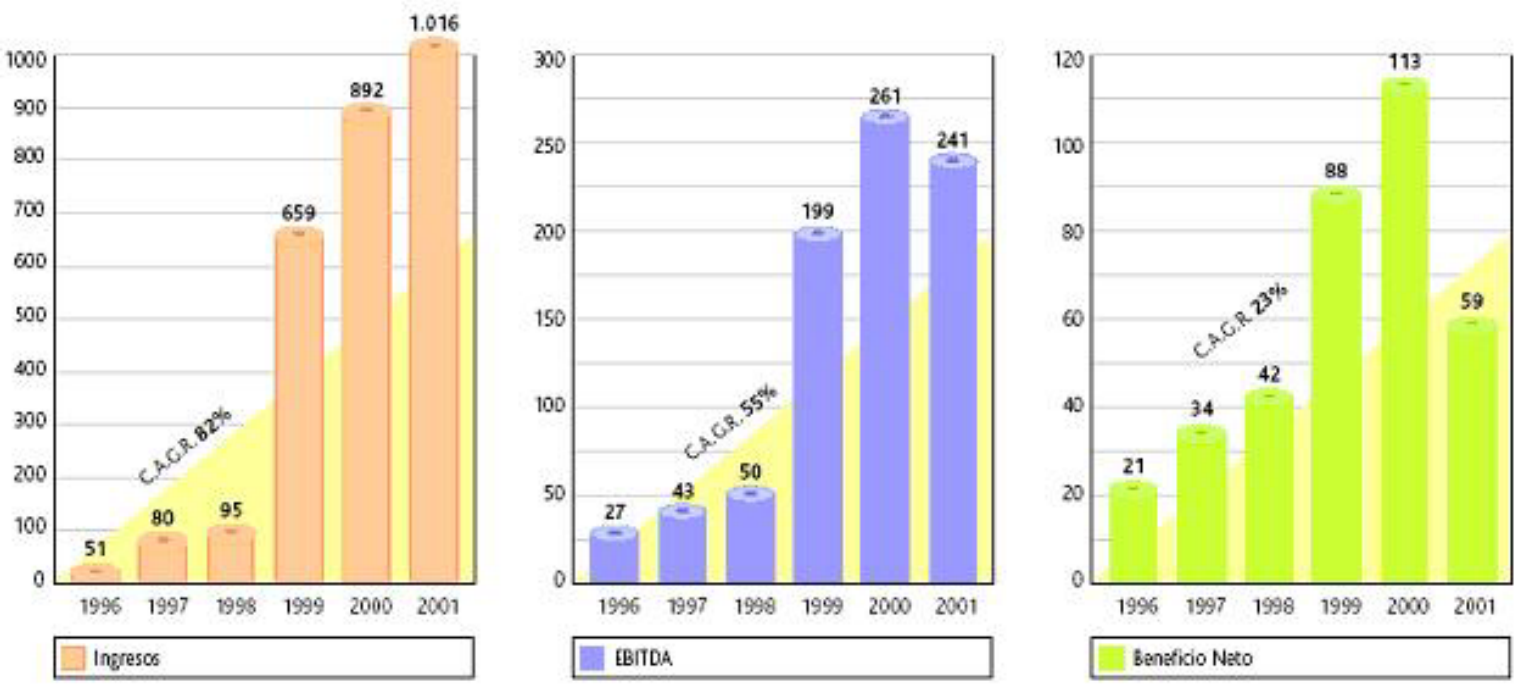

Fonte: Memoria da Sol Meliá 2001

Dessa forma, o balanço da empresa, no ano 2001, segundo os dados oficialmente publicados pela companhia, pode ser resumido na tabela seguinte: 
Balance Final 2001

\begin{tabular}{|c|c|c|c|}
\hline & Dic 2001 & Dic 2000 & Dic 1999 \\
\hline CAIA & 175,8 & 74,4 & 62.7 \\
\hline INV.FINANCIERAS TEMP. & 0,3 & 21,3 & 0.1 \\
\hline DEUDORES & 143,7 & 107,5 & 786 \\
\hline EXISTENCLAS & 39,7 & 36,0 & 25,4 \\
\hline OTROSACTNOS CRCULANTES & 123,8 & 121,0 & 112,0 \\
\hline ACTIVO CIRCULANTE & 483,3 & 360,3 & 278,8 \\
\hline ACTIVO FIJO BRUTO & $2.843,1$ & 2.903 .8 & 2020,2 \\
\hline DEPRECLACION & {$[630,0)$} & $(550,9)$ & $(426,1)$ \\
\hline ACTIVO FIIO NETO & $2.213,1$ & $2,352,9$ & $1.594,0$ \\
\hline INVERSIONES FINANCIERAS & 187,6 & 189,2 & 181,3 \\
\hline OTROSACTNOS FIJOS & 46,9 & 42.7 & 36,3 \\
\hline TOTAL ACTIVO & $2.930,8$ & $2.945,1$ & $2.090,4$ \\
\hline
\end{tabular}

\begin{tabular}{|c|c|c|c|}
\hline & Dic 2001 & Dic 2000 & Dic 1999 \\
\hline ACREEEDORES C.P. & 137,4 & 117,0 & 70,9 \\
\hline PRESTAMOS C.P. & 154,2 & 153,8 & 153.7 \\
\hline OTRAS DEUOAS C.P. & 145,9 & 60,8 & 51,7 \\
\hline TOTAL DEUDAS C.P. & 437,6 & 331,6 & 276,3 \\
\hline PRESTAMOSL.P. & $1.162,9$ & 1.020 .1 & 606,9 \\
\hline OTRAS DEUDAS L.P. & 180,9 & 182.5 & 164,7 \\
\hline TOTAL DEUDAS L.P. & $1,343,8$ & $1.202,7$ & 771,6 \\
\hline MINORITARIOS & 64,7 & 58,9 & 43.6 \\
\hline CAPITAL+RESERVAS & 1084,8 & 1.352 .0 & 9990 \\
\hline TOTAL FF.PP. & $1.149,5$ & $1.410,9$ & $1.042,6$ \\
\hline TOTAL PASIVO & $2.930,8$ & $2.945,1$ & $2.090,4$ \\
\hline
\end{tabular}

Fonte: Memoria da Sol Meliá 2001

A conta de resultados de 2001, comparada com o ano de 1999, encontra-se na tabela a seguir:

\begin{tabular}{|c|c|c|c|}
\hline & Dic 2001 & Dic 2000 & Dic 1999 \\
\hline TOTAL INCRESOS & $1.016,1$ & 891,9 & 658,6 \\
\hline TOTAL GASTOS OPERATIVOS & $(774,8)$ & $(631,2)$ & $(459,7)$ \\
\hline EBITDA & 241,3 & 260,7 & 198,9 \\
\hline EBITDAR & 299,0 & 289,6 & 209,4 \\
\hline BENEF/PÉRDIDA SOC. EQUIVALENCIA & $(2,7)$ & 1,0 & 1,0 \\
\hline INTERESES NETOS & $(65,9)$ & $(50,9)$ & $(23,6)$ \\
\hline DIFERENCIAS DE CAMBIO & 0,7 & $(0,3)$ & $(1,5)$ \\
\hline RESULTADO FINANCIERO & $(65,3)$ & $(51,1)$ & $(25,1)$ \\
\hline AMORTIZACIONES & $(94,9)$ & $(84,0)$ & $(62,4)$ \\
\hline AMORTIZACIÓN FONDO DE COMERCIO & $(2,6)$ & $(2,7)$ & $(1,8)$ \\
\hline BENEFICIO/(PÉRDIDA) DE ACTIVIDADES ORD INARIAS & 75,9 & 123,8 & 110,6 \\
\hline RESULTADO EXTRAORDINARIO & 4,8 & 20,8 & 5,3 \\
\hline RESULTADO ANTES DE IMPUESTOS Y MINORITARIOS & 80,7 & 144,6 & 115,9 \\
\hline IMPUESTOS & $(16,0)$ & $(26,0)$ & $(21,7)$ \\
\hline RESULTADO NETO & 64.7 & 118,6 & 94.2 \\
\hline MINORI TARIOS & $(5,7)$ & $(6,0)$ & $(6,2)$ \\
\hline BENEFICIO/(PERDIDA) ATRIB, SOC. DOMINANTE & 58,9 & 112,7 & 88,0 \\
\hline CASH FLOW DE LAS OPERACIONES & 176,0 & 202,7 & 159,4 \\
\hline
\end{tabular}

Fonte: Memórias Sol Meliá 2001.

Como pode ser observado, as receitas geradas pela empresa, no decorrer do ano 2001, foram de 1.016 milhões de Euros, o que representou um aumento de $14 \%$, relativamente ao ano anterior, apesar de os lucros de exploração, antes de juros, amortizações, impostos e aluguéis, terem ascendido a 299 milhões de euros, cerca de 3,2 \% superiores aos do exercício anterior. Por outro lado, o lucro líquido diminuiu $45 \%$. A empresa assinala que a redução nos lucros também se deve a fato de que, em 2001 não foram reportados lucros extraordinários refletidos em 2000, como resultado da venda de alguns hotéis. No entanto, como um indicador de eficiência, a receita média por suíte (Rev Par) foi de 47 Euros, com um aumento de $1 \%$, relativamente ao 
exercício anterior. No que diz respeito à ocupação dos hotéis, alcançou-se, em termos globais, um percentual de $69 \%$, o que pode ser considerado um indicador positivo e além da média do setor.

\section{Alianças, fusões e aquisições. Problemas estratégicos}

Segundo Oriol (2001), se o fundador da companhia se sentia sempre tentado à compra de novos hotéis e à incorporação de novos estabelecimentos à cadeia, o herdeiro e vice-presidente manifestou, desde o princípio, uma clara inclinação por alianças com outras companhias, por acordos e até mesmo fusões, como forma de crescer e de situar-se entre os primeiros grupos turísticos do mundo, ainda que isso não significasse haver renunciado à aquisição de cadeias ou hotéis na Espanha ou no estrangeiro.

Sebastián Escarrer não queria perder tempo, e após haver concretizado a ida à Bolsa de MIA, em meados de 1998, negocia uma grande aliança com a Iberia e a Air Europa, para constituir um tour operator para comercializar pacotes de viagens para o mercado interno espanhol. Esse projeto, que serviu para dar um passo a mais em seu ambicioso plano de expansão, foi tomando vulto em pouco tempo, durante o qual se incorporaram novos sócios, todos eles com capital nacional, e relacionados com o negócio turístico. A idéia era aproveitar as vantagens de cada um, especialmente os milhões de assentos vazios que a companhia aérea acumulava ao cabo do ano. Parte dessa capacidade ociosa correspondia aos vôos fora de temporada, realizados entre a Península e as Ilhas Canárias e Baleares. Isso significava que havia também um excesso de praças hoteleiras que, naquele momento, se calculava como algo em torno de 400.000 suítes ao ano. Não obstante, os sócios não queriam restringir sua atividade a esses destinos, e também juntavam a isso a possibilidade de realizar pacotes turísticos para a América Latina e, de modo especial, ao Caribe, onde a Sol Meliá apresentava uma infra-estrutura hoteleira potente e em crescimento.

Finalmente, constituiu-se o novo tour operator, sob o nome de Viva Tours, com a participação majoritária da Ibéria (51\%), ficando a Sol Meliá como segundo acionista, com o $22 \%$ das ações. Também entram no projeto outras duas empresas fortemente estabelecidas no setor turístico: Grupo Viajes Iberia (GVI), cujo presidente, Miguel Fluxá, tinha uma estreita relação com Escarrer, e o grupo Air Europa, que acabava de mudar sua denominação para Globalia, à frente do qual estava o empresário Juan José Hidalgo. O GVI detinha 15\% do capital, a Globalia 7\%, e o ex-dirigente da Air Europa, Herminio Gil, ficava com os 5\% restante. Havia, assim, nascido um tour operator que competiria com os demais, que já existiam no mercado, incluindo Tempo Libre Mundicolor, no qual a companhia aérea de bandeira também participava. 
Mas essa não era a primeira aliança conduzida por Sebastián Escarrer. Anteriormente, ele havia experimentado outras de menor intensidade, para as quais vislumbrava a estratégia de crescimento que ele queria levar a cabo. Dois anos antes, precisamente, enquanto se ultimavam os preparativos para a ida à Bolsa, em maio de 1996, a cadeia hoteleira firmava um acordo com a Transmediterrânea para desenvolver o negócio dos cruzeiros, por meio da Schembri, filial da empresa navegadora de controle estatal. Segundo o projeto que se colocou em marcha, a Sol Meliá alugava, por meio de Cubacán, sua filial no Caribe, o Don Juan, um barco com capacidade para 400 passageiros, o qual não havia conseguido o resultado esperado na temporada de inverno do arquipélago das Ilhas Canárias. O objetivo era organizar cruzeiros pelos países caribenhos, em especial Cuba, e fazer com que o barco desse lucro.

Sem embargo, um ano mais tarde, em maio de 1997, a Sol Meliá rompe sua aliança dois meses antes do previsto, argumentando que a Transmediterrânea não tinha intenção de renovar o acordo, e que só tentava aproveitar-se da estrutura comercial do grupo hoteleiro. Não obstante, a companhia, que já tinha ações cotadas na Bolsa, havia intensificado seus contatos com outras empresas turísticas que complementavam sua atividade, e podiam contribuir para se alcançar um crescimento mútuo.

A queda de ocupação, devido a uma diminuição das reservas por parte do turismo britânico, foi atenuada por meio de uma aliança comercial com agências de viagens espanholas para lançar ofertas conjuntas dirigidas ao mercado interno. No início do mês de julho de 1996, com a estréia do ingresso na Bolsa ainda ressoando, foi firmado um acordo com a Halcón Viajes e a Air Europa para comercializar pacotes turísticos conjuntos. Um mês mais tarde, em pleno agosto, sela-se outra aliança, dessa vez com a Viajes Marsans, Viajes Internacional Expreso (VIE) e a Spanair. O objetivo era o mesmo: atrair o turismo nacional, mediante um desconto no preço, neste caso entre $10 \%$ e $20 \%$.

Após essas iniciativas, outros grupos hoteleiros seguiram o exemplo, e começaram a empreender, junto às agências de viagem, pacotes destinados a completar sua ocupação. Essa dinâmica de abordagem entre os diversos setores implicados no negócio turístico foi um pouco mais além, quando a Ibéria firma uma série de acordos com os principais grupos hoteleiros, entre os quais o Sol Meliá, para estabelecer vôos diretos às cidades e zonas turísticas onde previam instalar-se, especialmente na América Latina. Era o momento em que esses países revelavam-se economias emergentes, e numerosas empresas espanholas começavam a considerar a posibilidade de "fazer as Américas".

Entretanto, Sebastián Escarrer não se conformava, e seguia empenhado em buscar um sócio que 
o ajudasse a crescer. No primeiro trimestre de 1997, a Sol Meliá se alia à Barceló, para negociar, de forma conjunta, a entrada no capital da Air Europa. Com isso, a Sol Meliá e a Barceló obteriam o apoio da companhia aérea no mercado turístico e o aceso às agências de viagens Halcón, enquanto que, para a Air Europa, haveria um reforço em sua estrutura financeira, e a possibilidade de contar com uma ampla rede hoteleira. Sem embargo, o acordo entre as três empresas maiorquinas não chegou a materializar-se, porque a Sol Meliá se desligou da negociação. O motivo era querer concentrar os esforços em seu objeto social, ou seja, o setor hoteleiro, conforme afirmou o presidente Gabriel Escarrer à imprensa balear.

Mas, ao mesmo tempo em que se descortinava o horizonte turístico e se negociavam diversas alternativas para o crescimento ansiado pela nova equipe dirigente, o grupo hoteleiro também realizava uma série de importantes reformas em seus estabelecimentos próprios. O encarregado de dirigir os trabalhos foi Gabriel Escarrer Filho, que se havia incorporado à companhia em julho de 1996, em plena movimentação do ingresso na Bolsa de Valores. O mais jovem dos Escarrer havia entrado na Inmotel (então a companhia detentora dos imóveis) como adjunto ao vicepresidente Juan Vives, para ocupar o posto de conselheiro delegado ao cabo de um ano. Ali permaneceu até finais de 1998 (quando se produz a integração de todas as companhias do grupo), antes de converter-se em conselheiro delegado da nova Sol Meliá.

Durante sua permanência na Inmotel levou a cabo um ambicioso programa de remodelação de hotéis, com investimentos que rondaram as 20.000 milhões de pesetas anuais, e durante um período de três anos. No total, modernizaram-se 93 estabelecimentos na Espanha e cinco na América Latina, sempre com um esquema de planejamento que tentava reduzir ao máximo o impacto no cliente. Assim, as obras eram realizadas durante a baixa temporada, para que o lucro cesante fosse mínimo. Tratava-se de um projeto de crescimento interno, que complementava a expansão externa que a cadeia estava procurando.

Uma das prioridades foi a otimização da área dos hotéis, sobretudo naqueles do centro da cidade, onde o preço por metro quadrado é mais elevado. No caso do hotel madrileno Os Galgos, por exemplo, ganhou-se o espaço pertencente a terraças. Talvez, uma das ações que maior repercussão provocou foi a remodelação das cozinhas, porque isso supunha uma grande economia de tempo e de recursos humanos. Instalaram-se modernas instalações hidráulicas, otimizaram-se os processos e modernizararam-se as equipes, o que contribuiu para reduzir os gastos. No outro lado da moeda, entretanto, aparecia um novo problema: havia uma parte do pessoal que havia sido dispensada, e que, agora, teria que ser reposta. Para isso, foi posta em prática uma série de programas de formação, os quais permitiram recuperar a maior parte dos 
empregados, e se investiram cerca de 1.500 milhões de pesetas, durante um período de três anos. Também foram incorporados restaurantes temáticos, ginásios e uma série de serviços capazes de atrair um novo tipo de cliente, que, em alguns casos, nem sequer chega a alojar-se no estabelecimento.

\section{Outras operações estratégicas}

Várias outras ações estratégicas foram empreendidas, como, por exemplo, a criação da Meliaviagens.com, que coincidiu com a entrada da «America Online» (AOL) na Espanha. Por meio do portal da Internet Prodigios, a Sol Meliá, fundadora desse ambicioso projeto de $e$ business, criou uma agência de viagens virtual independente, a qual, sob a denominação meliaviagens.com, seria a responsável pelo fornecimento, com exclusividade, dos produtos de lazer e viagens que comercializasse esse portal. A entrada da Sol Meliá no portal «AOL Avant», como fornecedor exclusivo de produtos de lazer e viagens, garantia à nova agência o aceso a mais de um milhão de usuários espanhóis. O investimento previsto para o desenvolvimento do meliaviagens.com ascende a 18,030 milhões de euros.

Segundo o vice-presidente da Sol Meliá, Sebastián Escarrer, o meliaviagens.com nasce com a intenção de atingir 20\% de participação de mercado de viagens on-line e converter-se na agência de viagens virtual líder no mundo de língua espanhola e portuguesa».

Recentemente, a Sol Meliá e o portal britânico lastminute.com fizeram um acordo, cuja principal conseqüência prevê a integração da versão espanhola lastminute.com na meliaviagens.com. A Sol Meliá fica com $70 \%$ da web espanhola lastminute, enquanto que a empresa britânica mantém o controle de $30 \%$ de seu portal espanhol, em uma significativa operação que põe em destaque os momentos de mudança que o setor das agências on-line vivem. Há que relacionar esses movimentos com outros semelhantes ocorridos recentemente no mercado internacional, episódios tão destacados como a aquisição da Expedia por parte da USA Networks.

A Sol Meliá manifesta que o principal objetivo dessa iniciativa é aproveitar as sinergias que podem ocorrer entre ambas as agências multicanal, assim como melhorar a promoção e venda dos hotéis do grupo por meio da rede. Além do mais, a operação é defendida também como uma forma de reduzir custos de ambas as empresas, ao mesmo tempo que pode facilitar o desenvolvimento conjunto de ações comerciais.

A Sol Meliá, durante os últimos anos, realizou operações de integração vertical e, evidentemente, por ser membro das TOP TEN mundiais, realizou a integração horizontal com muita mais força. A empresa aposta, fundamentalmente, na integração horizontal. Como prova disso, destaca-se a recente aquisição da cadeia de hotéis urbanos Tryp. Com a integração, a Sol Meliá se situou 
entre as dez primeiras cadeias hoteleiras do mundo.

Com a integração da totalidade dos hotéis da Tryp, por um montante de 336,567 milhões de euros, a Sol Meliá consolida sua posição de liderança no setor hoteleiro espanhol, com 180 hotéis nesse país. A empresa emitiu 340 milhões de euros em bônus não conversíveis, usados para liquidar o crédito-ponte que lhe foi concedido pelo Deutsche Bank, para a compra da cadeia Tryp, no mês de julho do ano 2000, assim como para refinanciar a dívida existente a curto prazo e passá-la a médio prazo. Estima-se que a economia de custos e as importantes sinergias provocadas pela fusão das duas organizações superarão 6,010 milhões de euros anuais. A integração supõe a incorporação de 60 hotéis, com mais de 9.700 suítes e outros 15 estabelecimentos já firmados pela Tryp.

Dessa forma, a companhia reforça sua estratégia de diversificação em escala global, ao situar em $48 \%$ sua oferta de férias, e em $52 \%$ a oferta de hotéis urbanos nas principais cidades do mundo. Como fruto da aquisição, a Sol Meliá reforça sua liderança indiscutível no segmento urbano do país, com 97 hotéis e uma oferta de 15.000 suítes. No que respeita à oferta de hotéis de férias na Espanha, a Sol Meliá incorporará 11 hotéis da Tryp, entre os quais se destacam o Mondariz, em Pontevedra, e o Tryp Tanau, no Valle de Arán, com o quê a cadeia também garante sua posição de liderança nesse importante segmento de negócios. Destaca-se, também. a aquisição de 21 estabelecimentos turísticos, que somam 16.000 praças de camping, na Croácia. A operação foi realizada mediante a compra de $100 \%$ do capital da empresa Croatian Hotels \& Resorts Management, por três milhões de dólares. Todos os alojamentos se encontram na península de Istria, onde a Sol Meliá terá 50\% das praças, convertendo-se na cadeia hoteleira mais importante de Croácia.

A Sol Meliá firmou, ainda, uma aliança estratégica com a Telefônica e a Barceló, a lberostar e o BBVA, com a finalidade de constituir um portal de Internet, hotelnetb2b.com. Mediante a aliança, a Sol Meliá lidera, junto com a companhia de telecomunicações, a criação de um portal de comércio eletrônico entre as empresas do setor hoteleiro.

A compra da Tryp situa a Sol Meliá entre os dez primeiros grupos hoteleiros do mundo, com mais de 400 estabelecimentos e cerca de 100.000 suítes, distribuídas em 33 países, e um quadro de funcionários superior a 33.000 empregados. Sem embargo, em um primeiro momento, o mercado mostrou-se um pouco surpreendido e, em alguns casos, até desiludido. Sebastián Escarrer havia dito, uma vez ou outra, que o objetivo da companhia era crescer mediante a integração de um grande grupo internacional, fosse ele tour operator ou hoteleiro.

Nos anos anteriores, a Sol Meliá havia tornado pública sua intenção de entabular contatos com 
companhias multinacionais e, nesse aspecto, esteve em dúvida entre promover uma integração vertical (com um tour operator que complementasse seu negócio), ou horizontal (com outra cadeia hoteleira). Após alguns flertes com várias empresas, em outubro de 1999, decidiu-se que o coração do negócio é o hotel, e que as novas tecnologias, e a possibilidade de realizar reservas diretas de qualquer parte do mundo por meio da Internet tornava atrativo um acordo com um tour operator.

Em todo o caso, as contínuas alusões de Sebastián Escarrer a essa “inevitável” aliança, sobre a qual nunca se especificava nada, haviam causado irritação a algum acionista. De fato, na reunião geral celebrada em Mallorca, em maio de 2000, o fundo de investimento alemão Union Investiment questionou a atuação da família Escarrer à frente da companhia, e votou contra a administração. O advogado Álvaro Gasull, que atuava como representante do grupo alemão, pediu ao conselho que concretizasse sua estratégia de alianças com os grandes grupos alemães. Escarrer descartou uma fusão com um tour operator, mas mantinha as portas abertas a uma possível aliança estratégica que lhe servisse para aumentar seu volume de negócios.

O grupo maiorquino havia negociado diversas alianças. Starwood, Marriot, TUI e Hilton foram algumas das multinacionais com as quais foram entabuladas conversações. Nesses contatos, houve momentos difíceis, sobretudo relacionados à origem de alguns filtros aos meios de comunicação, em julho de 2000, sobre as negociações que haviam sido abertas com o grupo britânico Hilton Group, proprietário da Ladbroke (especializada em cassinos e jogos) e dos hotéis Hilton fora dos Estados Unidos, exatamente quando estava sendo fechada a operação com a Tryp.

Um ano antes, em novembro de 1999, havia também vazado à imprensa, a aproximação entre a TUI (o maior grupo turístico europeu) e a Sol Meliá, para analisar algum tipo de acordo. A diretora da TUI para a Espanha, Gudrun Bogards, reconheceu em Chiang Rai (Tailândia), durante a apresentação dos resultados do grupo majoritário alemão, a existência de "conversações para alcançar uma estreita colaboração", e assegurava que as negociaões estavam sendo conduzidos no mais alto nível. A imprensa espanhola fez eco desses comentários e se chegou até mesmo a falar de uma possível OPA (oferta pública de aquisição de ações).

Tudo isso fez com que a cotação reagisse de forma positiva, e que as ações subissem, quando parecia que, por fim, haviam sido plantadas as bases de uma possível aliança.

\section{Sol Meliá Cuba: o desafio}

\section{Particularidades do crescimento em Cuba}


A entrada da Sol Meliá em Cuba começou em 1988, quando o Sr. Martinón, investidor espanhol, pediu a Escarrer a participação do grupo em um projeto de desenvolvimento turístico nesse destino, com apoio do governo cubano. Naquele momento, o Sr. Martinón, que havia reunido um grupo de interessados nessa empreitada, considerou que, à luz dos fatos, este objetivo estava de acordo suas possibilidades e pediu a participação na Sol Meliá.

A experiência na gestão de recursos humanos de Cánaves havia sido um fator fundamental para que Escarrer o incluísse no grupo que visitaria o país pela primeira vez. Condições naturais, recursos turísticos virgens, cultura, história, um povo culto, de uma simpatia e hospitalidade cativantes, eram alguns dos atributos do destino. Mas, em um país de economia centralizada, com total controle, por parte do governo, de todas as decisões, as negociações podiam ser muito difíceis. E daí surgia a experiência de Cánaves.

Sem embargo, naquelas reuniões para decidir se se entrava em Cuba e como isso seria feito, um elemento fundamental havia sido a colaboração e firme determinação, da parte cubana, para adequar-se à legislação vigente. Existia vontade para proporcionar facilidades e garantias aos investimentos estrangeiros no país, e em adequar as leis trabalhistas para favorecer tais investimentos. Esses fatores foram decisivos para que a Sol Meliá entrasse em Cuba.

Hoje, o sucesso da Sol Meliá em Cuba é indiscutível, alavancando o posicionamento da empresa no âmbito internacional. O reconhecimento desse sucesso se deveu, em seu julgamento, à qualidade das instalações que operam na ilha, ao excelente trabalho com os canais, tour operators e agentes de viagens, além do cuidadoso lançamento de suas novas instalações, as quais diminuem os tradicionais problemas de comunicação que existem com esse país. Especialmente no mercado espanhol, a marca e a imagem corporativa, é posicionada em função da força da cadeia, com um serviço de qualidade superior. Esse importante desenvolvimento, em um tempo que pode considerar-se como recorde, não somente permitiu a Cuba contar com os serviços de uma empresa espanhola, que garantisse níveis de qualidade nunca antes vistos, como também facilitou a transmissão, aos cubanos, de know-how, o que elevou o nível geral dos serviços no destino.

Desta forma, a Sol Meliá contribuiu para alcançar, também em tempo recorde, a visita de quase dois milhões de turistas a um país praticamente fechado ao turismo internacional até inícios da década dos anos 90. A isso se acrescenta que outros investidores, espanhóis ou não, ganharam confiança para investir na ilha, ao ver a seriedade e as garantias que o governo cubano outorgou aos investimentos do grupo. Também para a Sol Meliá havia significado uma importante e benéfica decisão. Cuba se converteu no destino de maior presença para o grupo, fora da Espanha, 
o que trouxe importantes experiências de como tentar a expansão na América latina.

Depois surgiu o problema com as autoridades dos Estados Unidos, onde a empresa ficou ameaçada pelas leis de embargo à ilha, e, onde - graças ao pleno respaldo recebido do governo espanhol à companhia - prevaleceu a cultura, uma atuação sempre com responsabilidade e ética com todos os sócios. Frente às pressões, manteve-se a posição assumida desde que se inaugurou o primeiro hotel do grupo em Cuba: “A Sol Meliá não mistura política com seus negócios”..., “a responsabilidade e a ética perante os compromissos contraídos com nossos sócios são de estrito cumprimento como norma na empresa"..., foram as palavras de Escarrer, Presidente e fundador da empresa.

Os Estados Unidos não levaram a Sol Meliá perante a corte da Haya por suas operações em Cuba, nem aplicaram, as mencionadas sanções previstas na Lei Helms-Burton, mas as enormes pressões continuaram, e, ao final, a Sol Meliá teve que liquidar seus hotéis nos EUA. Como resultado, a empresa teve que sair desse país e perder, assim, a presença no primeiro mercado emissor e receptor de turismo do mundo. Veja-se, na página seguinte, alguns destaques da imprensa sobre o tema das pressões dos Estados Unidos sobre a Sol Meliá.

Os dirigentes da empresa estão conscientes de que o crescimento do mercado, em Cuba, é limitado pelo próprio embargo norte-americano, dependendo o destino, fundamentalmente, dos turistas europeus.

O país revelava, também, uma forte carência de aviões, que a maioria das grandes empresas de aviação não se dispunham a arrendar, limitações na oferta extra-hoteleira interna, e os desajustes econômicos de um país bloqueado.

A pressão dos acionistas para obter maior rentabilidade de suas ações, a evolução que estava ocorrendo no mercado, com a crescente concentração das cadeias hoteleiras, produzindo fusões e aquisições que reduziam cada vez mais a lista das grandes cadeias hoteleiras e as limitações já existentes no mercado cubano, constituem um problema estratégico para a Sol Meliá.

Cuba é o maior arquipélago do Caribe insular. Possui uma beleza, caracterizada pela exuberância de sua vegetação e pela harmoniosa combinação de clima, natureza, e identidade cultural. São 255 quilômetros de praias, entre as quais está a mais conhecida internacionalmente, Varadero, com mais de 20 quilômetros. Suas áreas montanhosas são pouco abundantes, mas existem três sistemas, com especial atrativo turístico: Ocidente, Centro e Oeste do país. 
"Impact of the Helms-Burton Law (The Cuban liberty act) on Cuban Tourism". Cuba in transition. ASCE 1997

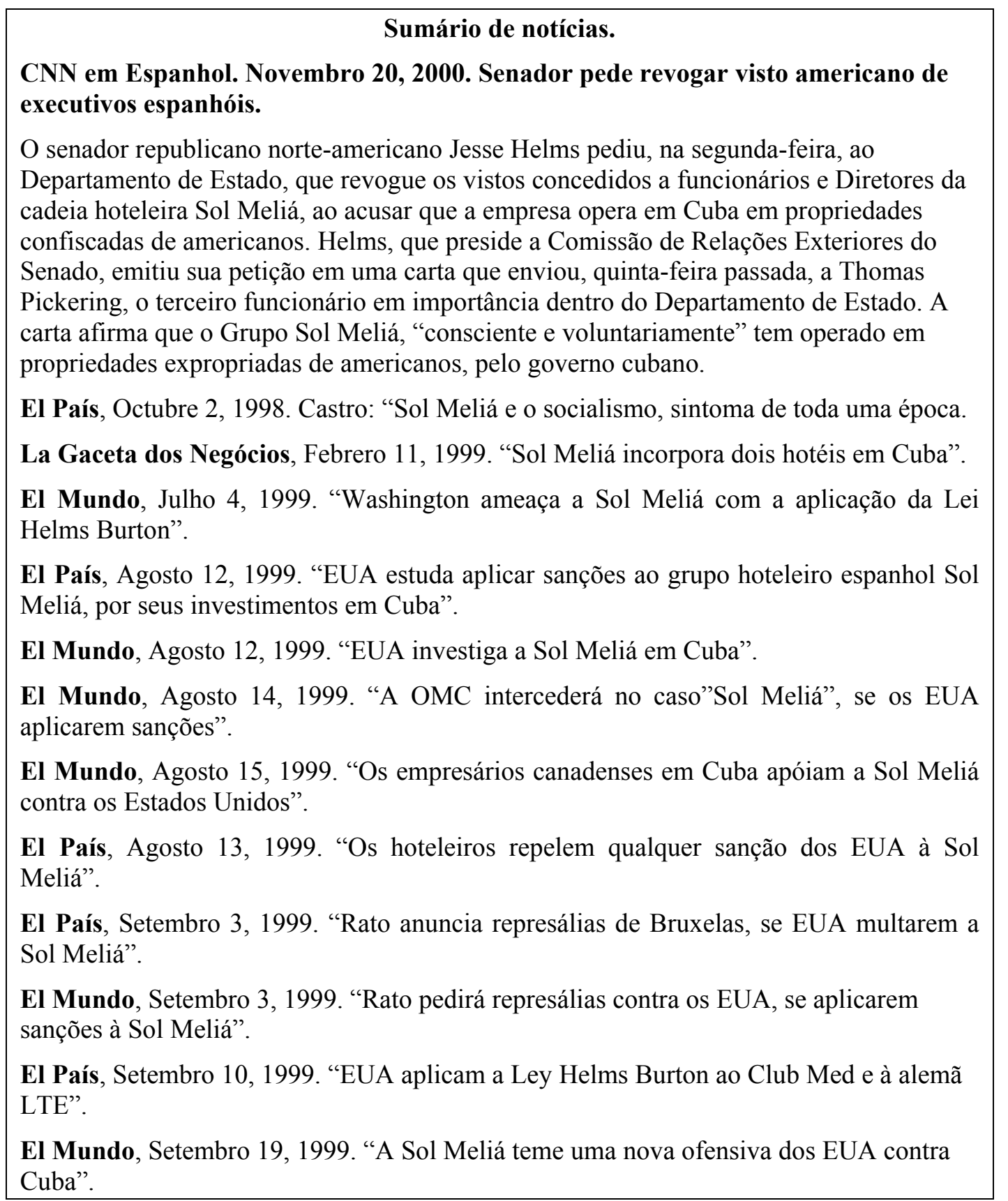

Em Cuba se localizam três cidades com regiões revelando forte arquitetura colonial: Trindade, Santiago de Cuba e a Cidade da Havana, declarada, faz alguns anos, pela UNESCO, como "Patrimônio da Humanidade".

Cuba é um destino novo que estimula a entrada dos turistas, pelo interesse em conhecer suas cidades, sua natureza e identidade, e especialmente o povo, cuja hospitalidade, capacidade de comunicação e forma de ser se converte em um dos maiores motivos de visita e de retorno dos turistas. 
O governo cubano, desde finais da década dos anos 80, decidiu priorizar o fomento do turismo no país, como uma forma de sair da crise econômica em que se encontrava, depois da queda do muro de Berlim e pelo embargo norte-americano.

Em dez anos triplicou o número de suítes, quintuplicaram-se as chegadas de visitantes e a receita multiplicou-se por oito; somente duplicando a força de trabalho, simultaneamente se quintuplicou a participação da indústria nacional nos insumos do turismo. Nesse importante crescimento, a Sol Meliá se converteu na líder indiscutível das diferentes cadeias hoteleiras européias que ali se instalaram. Na maior ilha do Caribe, existem várias cadeias hoteleiras espanholas, como Hotéis Barceló, Riu, Hotéis $\mathrm{C}$ e NH, além das francesas Accor e Clube Mediterranée, entre outras.

A vinda de 1.774 mil visitantes à Ilha, no ano 2000, mais que quintuplicou os 340 mil recebidos no ano 1990. Nesse intervalo de tempo, as chegadas de visitantes estrangeiros revelaram uma taxa de crescimento médio anual de 18,0\%, enquanto que, no período, o Caribe cresceu a uma taxa média de 4,3\%, e o mundo de 4,7\%. Em 1990, Cuba recebeu 3\% dos turistas que chegaram ao Caribe; em 2000, a dita recepção se elevou a 9\%.

Desde 1996, Cuba se incorporou ao reduzido grupo de cinco países do Caribe Insular (Porto Rico, República Dominicana, Cuba, Bahamas e Jamaica), os quais recebem mais de um milhão de visitantes estrangeiros por ano. Para 2005, estima-se uma chegada de aproximadamente três milhões de visitantes, com uma taxa de crescimento anual de $11 \%$, para o período de 2001 a 2005. E isso sem ter muitas possibilidades, pela proibição de receber, diretamente, turistas dos EUA; destaque-se que esse crescimento seria muito superior, se não existisse o embargo norteamericano. Cuba privou-se, em razão dessa lei, de 8,9 milhões de norte-americanos que visitaram o Caribe no ano 2000.

Quanto à oferta da Sol Meliá, seus 20 hotéis a posicionam como cadeia líder na oferta do país caribenho. Nesse sentido, as seis incorporações que tiveram lugar em 2001, são só um passo a mais na firme aposta da companhia nesse destino de primeira ordem e, em especial, por estar destinado a converter-se no segundo pólo turístico do país, a zona das restingas (cayos). Atualmente, a Sol Meliá dispõe de dois hotéis em Cayo Coco, dois em Cayo Guillermo e um em Cayo Largo, e, entre seus projetos imediatos, está contemplada a abertura de um estabelecimento em Cayo Santa Maria, todos novos destinos que se desenvolvem em Cuba.

Outro dos aspectos singulares da administração da Sol Meliá em Cuba, foi sua capacidade de adaptar-se às características políticas e de gestão que ali existem. Por decisão do governo cubano, os hotéis têm uma dupla estrutura em sua administração, de nacionais e de estrangeiros. 
O objetivo é adquirir o know-how dessas cadeias hoteleiras, e a Sol Meliá acolheu essa decisão, desenvolvendo um amplo programa de capacitação dos recursos humanos do país.

Para a cadeia, a decisão de permanecer em Cuba significou a saída dos Estados Unidos. Hoje, a empresa seguramente teria, nos Estados Unidos, muitos hotéis, de acordo com o crescimento verificado nos últimos anos. Além do mais, ela se viu privada dos fundos de investimento, em decorrência de pressões da Espanha e de outros países, o que limitou a construção de novos hotéis em Cuba.

Os Estados Unidos não somente são um destino turístico importante, como também são um grande país emissor, e, por meio da presença ali da Sol Meliá, seria facilitada a comercialização de seus hotéis na América Latina e na Europa. Foi perdido, fundamentalmente, o mercado americano, com 200 milhões de pessoas.

Em contraposição a esses fatos, e a expectativa de mudança no futuro, essa decisão dará à Sol Meliá uma vantagem, por estar presente na Ilha, onde o turismo está por ser desenvolvido, e onde o grupo está tendo e terá uma participação importante, quando finalmente tiver sido eliminado o embargo americano.

\section{A Sol Meliá na América do Sul.}

Uma vez consolidada sua posição entre as TOP TEN das principais cadeias hoteleiras do mundo, a Sol Meliá segue adiante com seu ambicioso plano de expansão, baseado em um crescimento sustentável em seus principais mercados, e que a leva a ser uma empresa cada vez mais global. Esta estratégia é sua ponta de lança para garantir sua liderança e o reconhecimento em escala mundial.

A estratégia de crescimento da Sol Meliá, na América Latina e no Caribe, tem seu foco no mercado emissor europeu. Aproveitando a imagem da marca na Espanha, um país que recebe quase 50 milhões de turistas do velho continente, fundamentalmente, faz uso dessa sinergia para promover esses destinos, com a garantia da qualidade de seus serviços.

Desta forma, os países da América Latina pertencem aos mercados naturais da Sol Meliá, e neles a companhia ampliou, melhorou e complementou a oferta, tanto de turismo de negócios - com presença nas principais capitais do novo continente, inaugurando modernos Centros de Convenções em três de seus melhores hotéis de férias: Meliá Cancun, Meliá Cabo (México) e Meliá Caribe (Ponta Cana, República Dominicana) - como de férias.

Ao final do exercício de 2001, a Sol Meliá obteve, mais uma vez, a categoria de líder do mercado hoteleiro da América Latina e do Caribe. A abertura de 13 hotéis nessas duas áreas chaves de férias teve muito a ver com isso. Assim, em 2000, foram incorporados sete novos 
estabelecimentos (1.430 suítes), em três países da América: Brasil (5), Panamá (1) e Peru (1) e outros seis (2.593 suítes) em Cuba. A Sol Meliá, ao final de 2001, possuía 76 hotéis na América Ibérica, com 21.506 suítes, na Argentina, Brasil, Colômbia, Costa Rica, Cuba, Guatemala, México, Panamá, Peru, República Dominicana, Uruguai e Venezuela.

Para entender as particularidades do processo de internacionalização na América Latina, o grupo Sol Meliá contratou, há mais de dez anos Rui Manuel Oliveira, um português residente no Brasil há mais de trinta anos, e com ampla experiência no setor da hotelaria nesse país.

As observações de Rui sobre as peculiaridades do crescimento do setor no Brasil e em outros países do continente são reveladoras da capacidade da empresa de adaptar-se às condições do ambiente em que atua.

O Brasil tem muitas diferenças relativamente a outros países da América do Sul, destacou Oliveira:

"É preciso entender bem as características do mercado brasileiro. Quanto aos Estados Unidos, as coisas são mais claras, do ponto de vista dos resultados que se esperam, quer se queira ou não. Eu diria que somos mais latinos, há mais influência dos aspectos pessoais nos negócios. Não é só um papelzinho com um estudo de viabilidade que garante um futuro investimento; isso é o que ocorre em todos os países latinos, mas em especial no Brasil. Há que se transmitir confiança. A Sol Meliá entrou no Brasil faz 10 anos, continua Oliveira, e veio para cá como havia feito nos demais países da América Latina. Pela potencialidade do Brasil, esperava-se muito na área hoteleira, e o que aconteceu? O Brasil trouxe muitas novas oportunidades nessa época, para as pessoas e para empresas estrangeiras que queriam investir.

Por quê? Porque havia um grande mercado que queria consumir, e se poderia dizer que estava adormecido, e que, ao despertar, ia ser importante.

Sabíamos também a respeito da estrutura social e econômica do povo brasileiro, da pirâmide de grande base de não-consumidores, na qual só $20 \%$ consumiam, e que a base, ao ser despertada, permitiria uma grande possibilidade para o desenvolvimento dos negócios no país. Potencial há.

Também há poucos investimentos em educação. Não é suficiente, não há pessoas preparadas para o futuro. Há coisas que são típicas de um país em desenvolvimento e outras nem tanto. Com o Presidente Fernando Henrique Cardoso, o país mudou muito; o processo, entretanto, começou com o Presidente Collor e sua abertura para produtos 
estrangeiros, cortando o ciclo vicioso das indústrias nacionais e seu baixíssimo índice de re-investimento. Pode ser que o tenha aberto mal, mas foi o começo. Com FHC houve um importante volume de investimentos de empresas estrangeiras no Brasil. O país teve uma importante época de crescimento. Isso cria um movimento muito importante de conhecimento, de técnicos, de diretores e de equipes, e cria também a necessidade de novos hotéis, principalmente na cidade.

Creio que o Brasil deu um salto muito importante. Antes desse salto, por exemplo, em São Paulo havia uma alta concentração de hotéis cinco estrelas, sendo quase os únicos que tinham condições de cobrir essa necessidade.

Se uma empresa não queria um cinco estrelas para seus executivos, pois cobrava caro, não havia nenhum outro hotel que lhe oferecesse o mínimo necessário, sem mencionar que quase não existem nem mesmo estabelecimentos de quatro estrelas.

O mercado hoteleiro, nos anos 70 e começos dos 80, estava muito desbalanceado. Só existiam cinco estrelas e não havia coerência na classificação. Existia, assim, uma demanda crescente de novos produtos posicionados no segmento qualidade e preço, afora os cinco estrelas.

Outro forte fator foi o desenvolvimento imobiliário. Com o crescimento imobiliário, relacionado com as novas leis de aluguel, explosão demográfica e de empresas em nível nacional, cria-se, assim, o apart-hotel ou hotel-condomínio (flat). Dividem-se custos e se ganha economia de escala".

Desta forma nasce uma forte demanda por uma oferta hoteleira que não a de luxo, para hospedar funcionários e homens de negócio, em geral, que vêm a São Paulo para trabalhar. As empresas, ao faltarem produtos que não fossem cinco estrelas, começaram a colocar seus empresários nos apart-hotéis. Isso, nos inícios dos anos 80, caracterizou um boom. Embora as pessoas objetivassem, ao servirem-se desse produto, viver e dividir custos, eles se transformam praticamente em hotéis, pois ofereciam serviços como tal.

Foi quando apareceu, segundo Oliveira, a figura do developer. Os developers conectam fontes de investimento, empresas construtoras e clientes para adquirir os imóveis construídos. O apart-hotel cresceu tanto, por ter uma estrutura mais flexível de imposto de renda que os hotéis, e oferecer maior flexibilidade também em seus serviços. A concepção do apart-hotel foi se modificando. Em uma etapa inicial, a idéia era, uma vez construído, ser vendido como apartamento, ou ser alugado visando a longa permanência, como moradia. Mas, ao não existir em São Paulo estrutura de hotéis de três ou quatro estrelas, as empresas 
começaram a alugar apartamentos nos flats para seus executivos, para curta permanência. Surgiu a necessidade de oferecer-lhes serviços hoteleiros. O fenômeno cresceu e, hoje, há dois tipos de produtos nos apart-hotéis: residencial, para famílias, e o hoteleiro.

Os developers começaram a buscar empresas que administram esses serviços, e recorreram a empresas como a Sol Meliá, com uma ampla experiência na gestão de hotéis de terceiros, o que proporcionava maiores garantias aos investidores. Assim multiplicou-se o crescimento hoteleiro, pois as construtoras, os investidores e os developers desenvolviam seus produtos imobiliários e os vendiam já com uma empresa encarregada de administrá-los.

O crescimento da Sol Meliá no Brasil começou em Maceió, com um produto de férias, e com a aquisição do Savoy, em São Paulo, no setor de negócios; logo surgiram outros quatro, que proporcionaram à Sol Meliá uma imagem muito forte. No Brasil, conhecia-se a Meliá Viagens, que eram agências de viagem do mesmo grupo.

Continua Oliveira: “agora todos me perguntam: Por que a Sol Meliá cresceu tanto? Por que outras companhias, como Hilton, Holiday Inn, Sheraton, que estão no Brasil há mais de 50 anos, não se desenvolveram tanto, se tiveram as mesmas oportunidades no Brasil?.

Uma razão está na comunicação, pois, embora a Sol Meliá seja espanhola, por sua origem latina, comunica-se com os homens de negócio do Brasil com mais facilidade do que os americanos. Há outro tema que talvez os americanos não souberam aproveitar:

- Um nome internacional que os brasileiros com poder aquisitivo reconhecem, quando viajam ao exterior;

- Sua posição na bolsa, criando uma imagem institucional perante as pessoas desejosas de investir e que vejam na Sol Meliá uma boa oportunidade para rentabilizar seus negócios;

- Localização de seus hotéis localizados em lugares estratégicos, de explosão demográfica, centros financeiros, fácil acesso, trânsito, em regiões seguras.

Também, segundo Oliveira, a Sol Meliá soube atender melhor as novas necessidades dos consumidores no Brasil. Ela avaliou como mudaram as necessidades dos clientes e sua percepção do serviço de qualidade; isso motivou uma descentralização no setor hoteleiro, com o surgimento de micro-regiões em São Paulo, cada uma com características próprias, como é o caso de Tatuapé, um bairro dormitório, que agora tem quatro grandes centros comerciais. Outra região é a Berrini, um novo centro financeiro e de negócios.

A Meliá Brasil considerou tudo isto, ao contrário de outras empresas hoteleiras, que se deixaram levar mais pela tradição do que pelas mudanças das cidades brasileiras. As pessoas 
se afastam dos hotéis da Avenida Paulista, justamente por seu preço, trânsito, e pouca segurança, e se dirigem a outras regiões, que logo precisam de infra-estrutura, restaurantes, shopping centers, discotecas, bares e, logicamente, hotéis; e assim se acelera o desenvolvimento. Os novos consumidores já não querem ficar o tempo todo na Avenida Paulista e perder o dia indo a um centro empresarial para logo voltar ao hotel, perdendo duas horas, e à noite, novamente sair para um bar e perder outras três horas no trânsito. Agora, busca-se tudo perto do objetivo do trabalho ou dos negócios, e com o máximo de conforto e qualidade. Por essa razão, a Sol Meliá avaliou o potencial dessas micro-regiões e o seu crescimento potencial. Para isso, foram mapeadas as mais importantes zonas de São Paulo e as outras regiões brasileiras, em coordenação com os developers. Deste modo, aos investidores não só se lhes mostra o potencial da zona em que poderá investir, como também lhes explicam todos os demais estudos, fatos e a avaliação do porquê o projeto tem que ser realizado em uma determinada região, e não em outra região. Este foi um fator de sucesso: "management da localização, algo essencial nos serviços", enfatiza Oliveira.

$\mathrm{O}$ americano em mudança não se adapta a essa peculiaridade do investidor brasileiro. É tudo igual, padronizado (está tudo escrito em um manual); o brasileiro é muito especial nesse tipo de relação para se sentir seguro em investir. A Sol Meliá soube dar segurança ao investidor brasileiro, oferecendo-lhes a melhor solução e agregando-lhe o calor humano espanhol e atenção, algo que constitui a característica latina da Sol Meliá e que se ajusta muito bem ao mercado brasileiro.

Foram adaptados os padrões Meliá da Europa para as necessidades e exigências brasileiras. Em nível de serviços acabados, estruturas, esses padrões estão sendo pensados com muita consciência.

As características descritas foram a chave do sucesso da Sol Meliá no Brasil. Logicamente, há que se estar muito atento às variações do mercado e às suas novas exigências, assinala Oliveira. Por exemplo, o programa de qualidade, que é importante para a companhia, que se baseia fortemente em um questionário preenchido pelo cliente. Com as informações obtidas por esse instrumento têm-se elementos para se fazerem mudanças, melhoras, inovações, orientando a empresa para proporcionar a maior satisfação do cliente, antes que outros o façam. Tudo isso reverte em uma imagem de companhia proativa, no mercado, sempre buscando inovações para atender melhor o cliente. Se o cliente se dá conta desse esforço, tem-se um ponto a favor em relação à concorrência, e o grau de fidelização será alto. $\mathrm{O}$ cliente pensa: "esta cadeia é séria", e busca a empresa efetivamente. 
Desta maneira, a companhia consolidou posições no Brasil, onde já possui 21 hotéis, e espera chegar a 50, contando os que estão em projeto.

Além disso, ampliou sua presença em países em que até agora não estava presente, como é o caso do Peru e do Panamá. Nas imediações do aeroporto, do centro histórico e do Recinto Ferial e de congressos, o Meliá Lima constitui uma excelente combinação de lazer e negócio. Por seu lado, o Meliá Panamá Canal, localizado em um ambiente natural de luxo, dispõe de uma ampla oferta, de caráter recreativo, profissional e ecológico, que é adequada para satisfazer às necessidades de todo tipo de cliente.

Outro fator de sucesso reside na qualidade da oferta, reconhecida em primeiro lugar pelos turistas que visitam os hotéis do grupo, sobre o que os tour operators fazem alarde. Assim, os mexicanos Meliá Azul Ixtapa e Meliá Cabo Real receberam o Golden Award, outorgado anualmente pelo tour-operator Apple Vacation, embora o Jet Tours haja premiado o Paradisus Ponta Cana (República Dominicana) com o Troféu, pela qualidade de prestação de serviço.

O México é outro destino importante para a Sol Meliá, com cerca de doze hotéis; recentemente foi aberto um hotel Paradysus em Cancún, onde já existem outros três.

Em outros países da América do Sul, o crescimento é ainda limitado. Como menciona Oliveira, "não se dá o mesmo tipo de desenvolvimento que o observado no Brasil; na Argentina, por exemplo, não existimos. Não há quem se concentre no pequeno investidor. No restante da América do Sul, eles não existem tampouco. Na Venezuela temos um hotel fantástico, em Caracas, mas fomos nós o investidor".

\section{Análise da concorrência.}

$\mathrm{Na}$ Espanha, a Sol Meliá ostenta a condição de líder absoluto em sentido geral, tanto em hotéis de férias como urbanos. No ano 2000, a composição do ranking espanhol de cadeias hoteleiras é mostrada na tabela a seguir: 


\begin{tabular}{|c|c|c|}
\hline \multicolumn{3}{|c|}{ RANKING HOTELERAS EN ESPARA* } \\
\hline COMPAÑIA & HOTELES & HABIT. \\
\hline SOL MELIA & 203 & 42.281 \\
\hline RIU HDTELS & 59 & 14.377 \\
\hline NH HOTELES & 86 & 10.101 \\
\hline FJESTA HOTELS & 34 & 8.369 \\
\hline IBERDSTAR & 25 & B.173 \\
\hline BARCELO HOTELS & 28 & 7.743 \\
\hline H10 HOTELS & 21 & 6.647 \\
\hline HOTELES GLOBALES & 31 & 6.376 \\
\hline PRINCESS HOTELS & 15 & 5.910 \\
\hline GRUPOTEL & 38 & 5.470 \\
\hline
\end{tabular}

Especialmente importante, para a Sol Meliá é o prosseguimento da evolução da NH Hotéis, por ser a única cadeia hoteleira que - juntamente com a Sol Meliá - tem ações cotadas na Bolsa de Valores de Madrid. A NH Hotéis está presente no principal parque espanhol, desde 1992, fazendo parte do Ibex 35, e também tem ações cotadas na Bolsa de Amsterdã (Euronext), desde setembro de 2000. Por outro lado, a NH Hotéis é membro do EuroStock 600, que inclui as 600 melhores empresas européias cotadas em Bolsa. E, na Bolsa de Nova York, as ações estão sob um programa ADR nível 1. Após a aquisição, em julho de 2001, da cadeia holandesa Krasnapolsky, a NH Hotéis se converteu em uma das companhias líderes do mercado urbano europeu de hotéis. Com um total de 195 hotéis em operação (em propriedade, arrendamento ou gestão a longo prazo), e mais de 22.400 leitos, está presente em 16 países e é a proprietária de 94\% da Sotogrande, S.A., sociedade que explora o complexo turístico mais prestigioso da Costa do Sol, e que conta, entre seus ativos, com um hotel (Almenara Golfe Hotel), um campo de golfe e terrenos edificáveis.

A NH Hotéis e a Sol Meliá contam com perfis de negócio muito diferentes. A primeira se concentra no segmento de viagens de negócio, e seus estabelecimentos se localizam nos centros urbanos. Esse turismo se apresenta como menos estável e mais vulnerável a conflitos internacionais, depressões econômicas etc.. Os analistas destacam, a favor da NH, sua excelente posição na Espanha e na Holanda, e uma alta qualidade de sua equipe gestora, o que faz com que ela possa suscitar interesse em algumas companhias internacionais. A Sol Meliá, que também compete nesse segmento, tem muito mais peso no turismo de lazer.

No ano 2000, a RIU Hotels \& Resorts foi a segunda cadeia hoteleira da Espanha (com 45.000 leitos, em 93 hotéis localizados em 10 países distintos, 11.500 empregados e 1,2 milhões de 
clientes por o ano). A cadeia, que goza de prestígio internacional, está presente na Espanha, Portugal, República Dominicana, Cuba, Florida, México, Tunísia, Bulgária e Chipre. A qualidade do produto RIU se traduz em uma média de ocupação anual de $87 \%$ e em um índice de fidelização de $35 \%$. Contribuem também para a comercialização do produto RIU os acordos da cadeia com os principais tour operators do mundo, especialmente com o alemão TUI, que é o número um da Europa e sócio-acionista da Sol Meliá, desde 1976.

Internacionalmente, as principais cadeias hoteleiras com as quais a Sol Meliá compete são as apontadas a seguir.

Cendant Corporation, com sede em New Jersey, Estados Unidos, é o resultado da fusão, em outubro de 1997, de CUC International e Hospitality Franchise Systems Corporated (HFS). Seu presidente e Diretor Geral, Henry Silverman, é também o fundador e principal acionista da companhia.

O grupo não se dedica exclusivamente à atividade hoteleira; possui três divisões diferenciadas, dirigidas a três negócios: viagens e hotelaria, imobiliárias e alianças de marketing.

A divisão hoteleira de Cendant Corporation conta com nove marcas, que se posicionam nos segmentos econômico e médio do mercado. No segmento econômico opera com cinco marcas: Super 8 Motels, Villager Lodges, Days Inn, Travelodge Hotels e Knights lnns Franchise Systems. Por último, no segmento médio de mercado está posicionada com as Ramada Franchise Systems, Howard Johnson, AmeriHost lnn e Wingate lnns.

A principal estratégia competitiva seguida pela Cendant Corporation é a de ser líder em preços, competindo com preços muito agressivos, a fim de conseguir vantagens por suas economias de escala, e reduzir, por intermédio das sinergias com seus outros negócios, tanto os custos operacionais de seus franqueados como os seus próprios, aumentando, desta forma, seus lucros.

A Cendant Corporation é uma companhia franqueadora pura, isto é, 100\% de sua carteira são contratos de franquia. Sua estratégia futura, nesse sentido, é continuar com a expansão por meio de contratos de franquia, assim como ampliar o número de franquias-master, já que elas permitiriam iniciar e, posteriormente, consolidar a pretendida expansão internacional da companhia. .

Atualmente, os 6.624 hotéis e mais de 553.000 suítes convertem a Cendant Corporation na maior cadeia hoteleira do mundo. Ela cresceu em um ritmo de 46 estabelecimentos mensais e 110 unidades de alojamento diárias, desde 1991 até janeiro do ano 2002. A capacidade média dos hotéis da Cendant Corporation é de aproximadamente 84 suítes por hotel.

Em número de suítes, $75 \%$ da oferta hoteleira da Cendant Corporation pertencem unicamente a 
três marcas: Days In, Ramada e Super 8 Motels.

O grau de internacionalização de Cendant Corporation é de 8\%, com 435 hotéis e 41.757 suítes localizadas nos mercados internacionais. Sua maior expansão foi no Canadá e México, totalizando 361 e 27 estabelecimentos, respectivamente.

Os maiores hotéis de Cendant Corporation se encontram na China, com 146 suítes por estabelecimento, e os menores se encontrem na Venezuela, com uma capacidade média que não alcança as 70 suítes por estabelecimento.

Howard Johnson e Travelodge são as marcas mais internacionalizadas da Cendant Corporatíon; a primeira o é em cobertura de países, com presença em 17 países, e a segunda, em termos de carteira, com 9.800 suítes fora dos Estados Unidos, embora toda ela esteja situada na América do Norte.

A área de marketing da Cendant Corporation oferece mais de vinte programas de serviço ao consumidor, por meio de sua divisão de marketing integrado. Os afiliados podem beneficiar-se da disponibilidade de marcas de reconhecido prestígio dentro dos próprios negócios da Cendant Corporation, sobretudo entre as imobiliárias e as relacionadas com o turismo.

A marca hoteleira Howard Johnson foi a primeira a aproveitar as vantagens que se podem alcançar simplesmente por dirigir-se aos clientes em sua língua materna, tais como fidelização e aumento do número de reservas. Por esse motivo, sua página Web é bilíngüe, convertendo-se, desta maneira, em uma das primeiras cadeias hoteleiras norte-americanas a utilizar a língua espanhola na rede.

O programa de fidelização VIP Clube, da marca Super 8 Motels, com mais de 5 milhões de membros, é o maior programa de fidelização de Cendant Corporation.

O faturamento hoteleiro da Cendant Corporation, em 2001, ascendeu a 497,2 milhões de dólares. Seu G.O.P foi de $45 \%$ do faturamento, enquanto que seu B.D.I.T se situou em $27 \%$. O R.O.I. da companhia foi $206 \%$ e seu R.O.E. ascendeu a $665 \%$.

Six Continents PLC, companhia britânica com ações cotadas nas Bolsas de Londres e de Nova York, procede, desde 30 de julho de 2001, do nome da antiga companhia Bass PLC. Isto se deve a que, no ano 2000, a Bass PLC vendeu a totalidade de seu negócio de cervejas, com a finalidade de concentrar-se mais em sua divisão hoteleira.

A companhia não se dedica exclusivamente à atividade hoteleira, mas possui três áreas de operações, tais como o negócio hoteleiro (Six Continents Hotels), o negócio complementar de lazer (Six Continents Retail), e o negócio de refrescos (Britivic Soft Drinks). A divisão hoteleira da Six Continents opera com suas nove marcas em três dos quatro segmentos de mercado, não 
tendo representação no segmento de grande luxo. No segmento econômico, está posicionada com a marca Express by Holiday Inn. No segmento médio de mercado, está posicionada com cinco marcas: Forum Hotels, Holiday Inn, Holiday Inn Select, Holiday Inn Family Suites Resorts, Holiday e Holiday Inn SunSpre Resorts. Por último, no segmento alto $1 \mathrm{~S}$, possui as marcas Crowne Plaza e Inter-Continental.

Os objetivos estratégicos da Six Continents PLC consistem em aumentar a companhia e ampliar a representação global de suas marcas hoteleira. A empresa se expandiu, principalmente por meio de contrato de franquia (76\%). De qualquer forma, parece que, no futuro, vai reforçar o management contract (19\%). Por último, cabe ressaltar que a Six Continents se expande, embora de maneira minoritária, por meio de contratos de propriedade e de aluguel (5\%).

Atualmente, os 3.244 hotéis e mais de 514.000 suítes convertem a Six na segunda maior cadeia hoteleira do mundo.

A Marriott International é uma cadeia hoteleira com ações nas Bolsas de Nova York, Chicago, Filadélfia e Pacífico. A companhia, formada em 1927, demorou 30 anos para ingressar no negócio hoteleiro, abrindo seu primeiro hotel em 1957. Em 1980, a companhia tinha em carteira 100 hotéis, a maioria nos Estados Unidos; sua primeira propriedade internacional foi o «Sam Lords Castle», em Barbados, inaugurada em 1972.

A companhia não se dedica exclusivamente à atividade hoteleira; possui, porém, cinco áreas de operações bem definidas, tais como o mencionado negócio hoteleiro (Marriott Lodging), o negócio timesharing (Marriott Vacation Club lnternational), o negócio catering (Marriott Distribution Services), o negócio residências para idosos (Marriott Senior Living Services) e o negócio de serviços diversos.

A divisão hoteleira da Marriott International opera com suas 11 marcas em todos os segmentos do mercado. No segmento econômico, está posicionada com as marcas Fairfield, SpringHill Suites e TownePlace Sude; no segmento médio, está posicionada com três marcas:. Courtyard, Residene Inn e Ramada International; No segmento superior, está posicionada com duas marcas: Marriott Hotels \& Resorts e Renaissane. Por último, no segmento de grande luxo, está posicionada com a marca Ritz Carlton. As marcas Marriott Exeutive Apartments e ExeuStay by Marriott pertencem ao negócio timesharing.

Os objetivos estratégicos da Marriott Intemational se concentram no desenvolvimento de suas operações hoteleiras, com a finalidade de ampliar a representação global de suas marcas hoteleiras. Para isso, além de racionalizar as marcas novas, a companhia pretende melhorar sua carteira, com a realização de várias aquisições hoteleiras, entre as quais se destaca a possível 
incorporação da companhia hoteleira Swissotel.

A Marriott Intemational se expandiu, principalmente por meio do management contract (59\%), se bem que, nos últimos anos, tenha aumentado o número de contratos realizados por intermédio de lla franquia (41\%).

Atualmente, os 2.400 hotéis e 436.000 suítes colocam a Marriott International como a terceira maior cadeia hoteleira do mundo. A Marriott Intemational cresceu a um ritmo de quase 20 estabelecimentos por mês e mais de 106 unidades de alojamento diário, no período de 1995 até janeiro do ano 2002. A capacidade média dos hotéis da Marriott Intemational é aproximadamente de 182 suítes por estabelecimento.

Cabe ressaltar que mais de $81 \%$ da oferta hoteleira da Marriott Intemational, em número de suítes, pertence unicamente a quatro marcas: Marriott Hotels, Resorts \& Suites, Ritz-Carlton, Courtyard by Marriott e Faiifield Inn.

Cerca de $85 \%$ da carteira da Marriott Intemational se acham nos Estados Unidos, pelo que o grau de internacionalização da cadeia ascende a 15\% dos hotéis, ou 332 estabelecimentos. Em importância, os países seguintes são Alemanha e o Reino Unido, ambos situados a uma enorme distância, já que contam unicamente com 69 e 59 estabelecimentos, respectivamente.

Embora o grau de internacionalização da cadeia hoteleira não seja muito elevado, deve-se mencionar que a Marriott Intemational ocupa a sexta posição do mundo quanto à cobertura por número de países, estando presente em 50 deles.

Os maiores hotéis de Marriott Intemational se acham na Turquia, com 721 suítes por estabelecimento, enquanto que os menores situam-se na Suíça, com uma capacidade média de 118 suítes por estabelecimento.

A Marriott Hotels \& Resorts é a marca mais internacionalizada da Marriott International, tanto em cobertura de países, com presença em 50 países, como em carteira, com mais de 35.500 suítes nos mercados internacionais.

O Marriott Rewards é o maior programa de fidelização do mundo, contabilizando 12 milhões de membros.

O faturamento hoteleiro da Marriott International ascendeu a 1.101 milhões de dólares. Seu G.O.P. corresponde a $85 \%$ do faturamento, enquanto que seu B.D.I.T se situa em 52\%. O R.O.I. da companhia é $714 \%$ e seu R.O.E. ascende a $1.105 \%$

Accor, companhia francesa cotada na Bolsa de Paris, procede da abertura de seu primeiro hotel Novotel, em Lille, França, em 1967. Em 1983, a companhia passou a chamar-se Accor, depois de fundir-se com Jacques Borel International. Atualmente, o grupo hoteleiro Accor contabiliza o 
maior patrimônio hoteleiro do mundo.

A companhia não se dedica exclusivamente à atividade hoteleira; possui, porém, três áreas de operações bem definidas, como os negócios hoteleiros, de lazer e de serviços.

A divisão hoteleira da Accor opera com suas marcas em três dos quatro segmentos do mercado, não tendo representação no segmento de grande luxo. No segmento econômico está posicionada com cinco marcas: Ibis, Motel 6, rede Roof Inns, Formule 1 e Etap. No segmento médio de mercado está posicionada com duas marcas: Novotel e Mercure. No segmento alto está posicionada com a marca Sofitel.

Os principais objetivos estratégicos do Accor se concentram no crescimento de suas operações hoteleiras, com a finalidade de ampliar a representação global de suas marcas hoteleiras, o desenvolvimento das operações de Internet, o fortalecimento das alianças estratégicas e a implantação da segunda etapa do programa Accor 2000.

A companhia francesa se expandiu, principalmente, por meio dos contratos de leasing, com $38 \%$ das suítes, e de propriedade, com $32 \%$, se bem que também utiliza os management contracts, em $17 \%$, e a franquia, em $13 \%$ de sua carteira de suítes.

Atualmente, os 3.650 hotéis e mais de 413.000 suítes convertem a Accor na quarta maior cadeia hoteleira do mundo. A Accor cresceu a um ritmo de mais de 16 estabelecimentos mensais e 61 unidades de alojamento diárias, desde 1994 até janeiro do ano 2002. A capacidade média dos hotéis da companhia é aproximadamente de 113 suítes por hotel.

O grau de internacionalização da Accor é de $72 \%$ de sua oferta hoteleira, com 2.261 hotéis e quase 284.000 suítes situadas nos mercados internacionais. A França é o país com o maior número de hotéis, com 1.203 estabelecimentos. O segundo país em importância são os Estados Unidos, com 1.195 estabelecimentos. Os demais países estão muito distanciados, como o terceiro lugar ostentado pela Alemanha, país que conta com 248 estabelecimentos.

Os hotéis de maior capacidade média da cadeia francesa se acham na Bulgária, com 458 suítes por estabelecimento, enquanto que os menores são encontrados em St. Barthélémy, com uma capacidade média de 41 suítes por hotel.

Além de ter uma grande presença internacional em termos de carteira, a Accor ocupa a segunda posição do mundo quanto à cobertura em termos de número de países, já que está presente em 89 países, unicamente atrás de Six Continents PLC.

Novotel e Mercure são as marcas mais internacionalizadas da Accor; a primeira o é em cobertura de países, com presença em 55 deles, e a segunda em termos de carteira, com 254 estabelecimentos fora de França. 
O faturamento hoteleiro da Accor ascendeu a 4.345 milhões de euros em 2001. Seu G.O.P. é de $26 \%$ do faturamento, enquanto que o B.D.I.T. se situou em $10 \%$. O R.O.I. da companhia é de $9 \%$, e seu R.O.E. ascende a $13 \%$.

Choice Hotels Intemational, companhia estadunidense com sede em Maryland, cotada na Bolsa de Nova York. A companhia procede da antiga cadeia hoteleira Quality Inn, adquirida em 1980 por Manor Careo. Em 1996, e 15 anos depois de figurar como subsidiária da Manor Careo, a companhia se desligou para ser cotada independentemente no mercado de capitais. Atualmente, a Choice Hotels International é a segunda maior franqueadora hoteleira do mundo, depois da Cendant Corporation. Diferentemente das demais cadeias hoteleiras estudadas até o momento, a Choice Hotels International se dedica exclusivamente à atividade hoteleira.

A Choice Hotels International conta com oito marcas, que se posicionam em três dos quatro segmentos de mercado, não tendo presença no segmento de grande luxo. No segmento econômico opera com três marcas: Slep Inn, Rodeway e Econo Lodges. No segmento médio de mercado está posicionada com quatro marcas: Quality, Comfort, MainStay Suites e Flag Choice. Por último, no segmento alto de mercado está posicionada com a marca Clarion.

A estratégia prioritária da Choice Hotels International consiste na "potencialização" de seu sistema de franquias em mercados estratégicos. No processo de crescimento internacional, a companhia se expande mediante a tática denominada hub-and-spoke.

A Choice Hotels International é uma companhia franqueadora «pura», isto é, a totalidade de sua carteira está em regime de franquia. Sua estratégia futura consiste em incrementar tanto os contratos de franquia como os de franquia master.

Atualmente, os 4.545 hotéis e mais de 362.000 suítes convertem a Choice Hotels International na quinta maior companhia hoteleira do mundo. Ela cresceu a um ritmo de mais de 15 estabelecimentos mensais e mais de 30 unidades de alojamento diárias, desde 1995 até janeiro do ano 2002. A capacidade média dos hotéis da Choice Hotels International é de aproximadamente 80 suítes por hotel.

Ressalte-se que $78 \%$ da oferta hoteleira da companhia, em número de suítes, pertencem unicamente a três marcas: Comfort, Quality e Econo Lodge.

O grau de internacionalização da Choice Hotels International é de $26 \%$, com 1.166 hotéis e mais de 91.000 suítes situadas nos mercados internacionais. Sua maior expansão foi na Austrália e Canadá, com 339 e 248 estabelecimentos, respectivamente.

Os hotéis de maior tamanho da Choice Hotels International se acham na Malásia, com 251 suítes por estabelecimento, enquanto que os menores se encontram na Suíça, com uma capacidade 
média que não alcança 50 suítes por hotel.

Comfort e Quality são as marcas mais internacionalizadas da Choice Hotels International; a primeira o é em cobertura de países, com presença em 25 países, e a segunda em termos de carteira, com mais de 35.000 suítes fora dos Estados Unidos. .

O programa de fidelização da companhia é o «Guest Privileges», o qual se aplica às marcas Comfort, Quality, Clarion e Slep Inn. As reservas pela Internet experimentaram um crescimento do $186 \%$ relativamente às realizadas em 1999, gerando uma receita anual, durante o ano 2000 , de 43,6 milhões de dólares. .

O faturamento hoteleiro da Choice Hotels International ascendeu a 167,5 milhões de dólares. Seu G.O.P. foi de 55\% do faturamento, enquanto que seu B.D.I.T se situa em 33\%. O R.O.I. da companhia é de $147 \%$ e sua R.O.E. ascende a $466 \%$.

Hilton Hotels Corporation, companhia estadunidense com sede na Califórnia, cotada na Bolsa de Nova York desde 1946, é a cadeia hoteleira que apresenta o maior valor de marca hoteleira do mundo. A Hilton Hotels Corporation é uma companhia hoteleira genuína, já que a divisão de jogos se separou dela, no ano 1998.

A Hilton Hotels Corporation conta com seis marcas principais, que se posicionam em três dos quatro segmentos de mercado, não tendo presença no segmento de grande luxo. No segmento econômico opera com a marca Hampton In; no segmento médio está posicionada com a marca Hilton Garden Inn. Por último, no segmento alto, está posicionada com as seguintes marcas: Hilton Hotels, Conrad International, Homewood Suites e Doubletree.

A estratégia futura da empresa depende da aliança com a Hilton Internacional e da aquisição da cadeia hoteleira Promus. A Hilton Hotels Corporation espera alcançar as sinergias esperadas com ambos os movimentos.

A Hilton Hotels Corporation, para cada 100 suítes, tem 63 sob o sistema de franquia, 16 em management contract, 11 em regime de propriedade, seis em joint venture e quatro em aluguel.

Atualmente, os 1.986 hotéis e quase 328.000 suítes convertem a Hilton Hotels Corporation na sexta maior companhia hoteleira do mundo. Ela cresceu a um ritmo de 24 estabelecimentos mensais e 107 unidades de alojamento diárias, desde 1995, até janeiro do ano 2002. A capacidade média dos hotéis da Hilton Hotels Corporation é de 165 suítes por estabelecimento.

Cabe ressaltar que mais de $69 \%$ da oferta hoteleira da companhia, em número de hotéis, e $62 \%$ em termos de suítes são representadas somente por duas marcas: Hilton Hotels e Hampton Inn.

O grau de internacionalização da Hilton Hotels Corporation é de 8\%, com 79 hotéis e cerca de 25.000 suítes situadas nos mercados internacionais. Sua maior expansão também se verifica na 
América do Norte, concretamente no Canadá e México, países em que totaliza 30 e 12 estabelecimentos, respectivamente.

Os hotéis de maior tamanho da Hilton Hotels Corporation se acham em Hong Kong, com 632 suítes por estabelecimento, enquanto que os menores são encontrados na Colômbia, com uma capacidade média que não alcança as 100 suíte por estabelecimento.

A Hilton Hotels é a marca mais internacionalizada da companhia, tanto em cobertura de países como em carteira, com presença em 13 países; ela possui 17.000 suítes fora de Estados Unidos.

Desde a aliança das duas companhias, a Hilton conseguiu um grande número de conquistas com respeito ao marketing da cadeia hoteleira. O programa de fidelização da companhia é o «Hilton Honoré», o qual conta com mais de seis milhões de membros e se aplica às marcas Hilton International, Doubletree, Embassy Suites, Hampton, Homewood Suites e Conrad International. O faturamento hoteleiro da Hilton Hotels Corporation ascendeu a 1.769 milhões de dólares. Seu G.O.P. é $26 \%$ do faturamento, enquanto que seu B.D.I.T se situa em 12\%. O R.O.I. da companhia foi de $15 \%$ e seu R.O.E. ascendeu ao $56 \%$.

Best Western International é uma associação de hotéis independentes. A companhia é propriedade dos hoteleiros associados, que, simultaneamente, são proprietários e gestores de seus estabelecimentos. É, com efeito, um consórcio de marketing que possui sua própria marca. A companhia, com sede nos Estados Unidos, mais concretamente em Phoenix, Arizona, opera como uma organização sem finalidade lucrativa.

A Best Western International é a maior marca hoteleira do mundo, com 4.052 estabelecimentos e mais de 306.000 suítes. Todos os hotéis trabalham sob a marca Best Western International; não existem outras marcas.

O estabelecimento médio da Best Western International é um hotel de três estrelas, mas dentro da carteira há muita variedade. A estratégia de Best Western International consiste em expandirse no segmento médio e na faixa mais alta do segmento econômico.

A afiliação à Best Western International é renovável anualmente, diferentemente dos contratos de franquia e management. Não obstante, a taxa média de renovação anual dos membros da Best Western International foi de $99 \%$ durante o último qüinqüênio.

Atualmente, os 4.052 hotéis e mais de 306.000 suítes convertem a companhia na sétima maior organização hoteleira do mundo. Ela cresceu a um ritmo de mais de seis estabelecimentos mensais e 12 unidades de alojamento diárias, desde 1991 até janeiro do ano 2002. A capacidade média dos hotéis da Best Westem International é de aproximadamente 76 suítes por hotel.

O grau de internacionalização da Best Western International é 52 \%, com 1.937 hotéis e 120.000 
suítes situadas nos mercados internacionais. Sua maior expansão se realizou no Reino Unido $e$ Austrália, totalizando 344 e 276 estabelecimentos, respectivamente.

O hotel de maior tamanho da Best Western International se acha em Orlando, com 672 suítes por estabelecimento, enquanto que o menor é encontrado na Nova Zelândia, com tão somente cinco suítes.

A capacidade do consórcio para fazer um bom marketing, incluindo o reconhecimento da marca e o sistema gratuito de reservas, é o principal atrativo para os novos membros da Best Western International.

O programa de fidelização da companhia, com aproximadamente um milhão de membros, e que gera $1,5 \%$ da receita total da companhia, é o Gold Crown Club lnternational, o qual oferece a seus membros um ponto por cada dólar faturado em qualquer estabelecimento Best Western International do mundo. Em 1998, a Best Westem Intemational obteve um lucro de 518.000 dólares, para um faturamento de 141,5 milhões de dólares.

As taxas e cotas da Best Westem Intemational estão baseadas no número de suítes do hotel e não em sua receita por alojamento. Além do mais, os hotéis Best Westem Intemational não fornecem à central os resultados de suas operações, pelo que se desconhece o faturamento total de seus membros. O lucro do consórcio, por não ter finalidade lucrativa, é praticamente nulo.

Carlson Companies, sociedade não cotada em Bolsa, pertence a um grupo familiar, a família Carlson. O grupo não se dedica exclusivamente à atividade hoteleira, mas, opera com seis divisões principais, tais como o negócio hoteleiro (Carlson Hospitality Worldwide), o negócio de restauração (Carlson Catering group), o negócio de cruzeiros (Carlson Cruises Worldwide), o negócio complementar de lazer (Carlson Leisure Group), o negócio de agências de viagens (Carlson Wagonlit Travel) e o negócio de construção (Carlson LeaSemg e Carlson Real Estate Company Group).

A Carlson Hospitality Worldwide opera com suas três marcas principais, em três dos quatro segmentos de mercado, mas não tem representação no setor econômico do mesmo. No segmento médio está posicionada com a marca Country Inns \& Suites; no segmento alto o está com a marca Radisson Hotels, e, por último, no segmento de grande luxo se posiciona com a marca Regent.

Os principais objetivos estratégicos da Carlson Hospitality Worldwide passam por expandir-se na Alemanha, Reino Unido, Benelux, França e Itália e por aumentar sua presença nas principais gateway cities, assim como incrementar os centros de férias e o número de hotéis de aeroporto.

A Carlson Hospitality Worldwide tem $96 \%$ de sua carteira em franquia, estando os $4 \%$ restantes 
em management contract.

Atualmente, os 778 hotéis e 135.000 suítes convertem-na na nona maior companhia hoteleira do mundo. Ela cresceu a um ritmo de mais de seis estabelecimentos mensais e mais de 24 unidades de alojamento diárias, desde 1995 até janeiro do ano 2002. A capacidade média dos hotéis da companhia ascende a 172 suítes.

Cabe ressaltar que mais de $94 \%$ de sua carteira em número de hotéis, e 92\%, em termos de suítes, são representadas somente pelas marcas Radisson e Country, enquanto que a marca Radisson, por si só, representa mais de $57 \%$ do número dos hotéis e mais de $75 \%$ do número de suítes da companhia.

O grau de internacionalização da empresa é de 40\% das suítes, com 53.500 suítes situadas nos mercados internacionais. Sua maior expansão foi no Canadá e na Noruega, totalizando 36 e 22 estabelecimentos, respectivamente.

Os hotéis com maior capacidade média da Carlson Hospitality Worldwide são os pertencentes à marca situada no segmento mais alto do mercado, isto é, a marca Regent, com uma capacidade média de quase 347 suítes por hotel. Em contrapartida, a marca com menor capacidade média é a Country, com 77 suítes por estabelecimento, marca situada no segmento médio. A Radisson é a marca mais internacionalizada da Carlson Hospitality Worldwide, estando presente em 57 países. A Carlson Hospitality Worldwide é titular do programa «Look to Book», definido pela imprensa americana como "provavelmente o programa de incentivo de viagens mais agressivo da indústria». 
Capítulo VII

\section{CONCLUSÕES, LIMITAÇÕES E RECOMENDAÇÕES}




\section{CAPÍTULO VII \\ CONCLUSÕES, LIMITAÇÕES E RECOMENDACÕES}

\section{Conclusões}

1. O setor de turismo tem demonstrado um peso e uma influência notáveis na economia mundial. Desde 1950, segundo dados da OMT (2001), quando o turismo internacional começou a ser acessível ao público em geral, as atividades turísticas têm crescido a uma taxa média de 7,1\%, passando de 25 milhões para 565 milhões, em 1995, e de 12,4\% em relação às receitas turísticas internacionais (a preços correntes, excluindo o gasto com transporte internacional), passando de 2,1 para 406 bilhões de dólares. O contínuo e vigoroso crescimento das chegadas de turistas internacionais, na primeira metade dos anos noventa (taxa média anual de 4,3\%, somente meio ponto percentual abaixo da taxa de crescimento alcançada na década de oitenta), indica a força do turismo frente à desaceleração econômica experimentada no início dos anos noventa. As regiões que se destacaram como as de maior crescimento, entre 1990 e 1995, foram o Oriente Médio (6,6\% de crescimento anual em chegadas), Ásia Oriental e o Pacífico (8,3\% anuais), Ásia Meridional (5,9\% anuais) e África (6,1\% anuais), com resultados abaixo da média somente no caso da Europa (3,7\% anuais) e das Américas (3,3\% anuais).

As participações de mercado de chegada de turistas internacionais de longa distância ou interregionais têm permanecido constantes, entre 1990 e 1995, com uma relação de 82\% para 18\%. Existem marcadas diferenças entre as regiões, com as chegadas inter-regionais dominando,: em 1995, na Europa (88\%), Ásia Oriental e o Pacífico (79\%), as Américas (77\%) e África (58\%), enquanto que as chegadas de longa distância constituem a categoria principal para Ásia Meridional (76\%) e Oriente Médio (58\%).

2. Com a globalização e a era pós-industrial os serviços em geral, o lazer e as viagens, em particular, ocuparam cada vez mais uma maior importância, favorecendo a balança comercial dos países receptivos. Esse setor já havia sido reconhecido por muitos outros países, com economias emergentes, como uma via para o desenvolvimento das economias dos mesmos, colocando, assim, à disposição da demanda, novos destinos, em muitos casos virgens e capazes de atrair as novas levas de turistas provenientes dos países mais desenvolvidos. Os fatores principais que favorecem este fato são:

Econômicos. A recuperação econômica do pós-guerra nos países industrializados deu como resultado o crescimento das receitas pessoais e da disponibilidade de tempo livre - fatores fundamentais para participar do turismo, ou melhor, tempo e dinheiro -. Visando ao futuro, as 
principais instituições econômicas e financeiras mundiais previram, no longo prazo, taxas persistentes de crescimento da economia mundial, entre moderadas e boas. Os antigos "tigres" econômicos se recuperaram e surgiram novos "tigres" (China, Índia, Brasil, Federação Russa). Os fatores econômicos se mantiveram positivos para o turismo.

Tecnológicos. O desenvolvimento chave reside na tecnologia da informação e da comunicação. Novas possibilidades, disponíveis em parte por tecnologias novas ou pelas já existentes, estão transformando substancialmente tanto a oferta (reservas, gestão, marketing, comunicação de empresa a empresa e de empresa a cliente, etc.) como a demanda. A sucessiva geração de sistemas cada vez mais complexos, que está proporcionando acesso imediato e interativo às ofertas de produtos turísticos, está conferindo aos turistas um controle sem precedentes sobre como dedicar seu tempo e seu dinheiro. Ao mesmo tempo, o resultado é uma mudança de enfoque na opção da maioria das viagens, em resposta às ameaças e oportunidades, dependendo de como se enxergue, representado pela compra eletrônica ou a domicilio.

Também se espera que os avanços nessa área continuem afetando o terreno tecnológico dos transportes. A aplicação da tecnologia de reatores comerciais torna tecnicamente possível uma crescente proporção da população viajando para destinos no exterior. Aviões com menor consumo de combustível reduzem os custos reais das viagens nacionais. Os desenvolvimentos futuros garantem aviões com capacidade cada vez maior, disponibilidade de aviões mais adequados, ou seja, assentos, outras facilidades e prestação de serviço aplicado a uma variedade de tipos de rotas, permitindo uma melhor "adaptação".

Facilitação. São de suma importância para o turismo, os esforços destinados a suprimir as barreiras das viagens internacionais, mediante a liberalização de transporte e de outras formas de “desrregulação" em curso. No passado, isso representou um papel fundamental, quando foram progressivamente se reduzindo os controles nacionais das viagens, ao ser reconhecido o turismo como um setor econômico que se devia encorajar. Esse processo continuou nos anos noventa, ao facilitarem-se as viagens aos países do antigo bloco soviético e continuarão no século XXI. As implicações são: em primeiro lugar, menos países requerendo vistos e, em segundo lugar, os passaportes podem, finalmente, ser substituídos por sistemas de nova tecnologia de comprovação pessoal, tais como a inspeção da geometria da mão ou da retina. Um passo à frente constitui as iniciativas, como o acordo Schengen, com o objetivo de abolir os controles alfandegários entre cerca de quinze países europeus, atualmente, permitindo às pessoas viajar sem passaportes ou controles alfandegários.

Segurança. Visto que o turismo não prosperará em destinos com perturbações sociais, em 
guerra, ou onde se perceba que a saúde ou a segurança do turista esteja ameaçada, a segurança nas viagens deve-se incluir como um fator fundamental ou básico. Os conflitos, desastres e incidentes podem influir fortemente na saúde e no crescimento do turismo. Tudo depende, sem embargo, em como são tratados esses eventos negativos. A parte boa é que a experiência em diferentes partes de mundo tem demonstrado, repetidamente, que o turismo, quase sem exceção, resulta ser muito resistente e mostra uma forte capacidade de recuperação. Os destinos que tratam mais eficazmente os acontecimentos negativos são os que limitam melhor seu impacto. Em geral, as conseqüências negativas podem ser reduzidas consideravelmente, mediante uma abordagem aberta e sensível, que considere os problemas com clareza e profissionalmente, em lugar de tentar negá-los. Em primeiro lugar, é indispensável estabelecer uma proteção eficaz aos turistas que se deslocam, ao considerarem os incidentes ocorridos como acontecimentos isolados, que não representam um perigo para os visitantes.

Demográficos. Continuará a tendência de envelhecimento da população nos países industrializados. Associada a isso está a contratação de trabalhadores nesses países. Há menos gente jovem integrando o sistema; por conseguinte, existirá uma maior emigração do sul para o norte. As implicações desse cenário são: crescimento contínuo do turismo nos segmentos de mercado mais antigos, aumento dos visitantes a parentes e amigos (VPA), no eixo norte - sul, decorrente do grande volume de imigrantes nos países industrializados. Outra tendência demográfica é a erosão posterior da tradicional família ocidental, em razão do crescente número de divórcios e de matrimônios tardios e a formação tardia das famílias. A implicação para o turismo é que existe um maior número de tipos diferentes de famílias ou de segmentos do que se tem presenciado na atualidade.

Globalização. O turismo, como a política e a economia em geral, terá que enfrentar a tendência geral de globalização, ou seja, o poder crescente das forças econômicas e de mercado internacionais e a diminuição da capacidade de cada estado de controlar sua própria economia, e a das corporações privadas de dominar os mercados internos, no contexto de seus limites geográficos. O impacto sobre o turismo é que um número menor de redes mundiais de viagens e de turismo obterá mais poder, desde que elas consigam globalizar-se mediante integração vertical e horizontal, ou mediante integração diagonal, economias de escala e grandes investimentos em bases de dados e em marketing.

Localização. No outro extremo da escala em direção à globalização está a localização. Em particular, nos países em desenvolvimento, é provável que se intensifique o conflito entre identidade e modernidade. Assim, por exemplo, grupos definidos por sua etnia, religião, ou 
estrutura social, exigirão seu reconhecimento como tal, devendo lutar pelos seus direitos. Nesse contexto, o turismo é uma peça chave, o que provoca o questionamento crescente sobre a forma e a escala do marketing de turismo em tais sociedades. Parece provável que exista uma oportunidade enorme para o desenvolvimento de experiências turísticas relacionadas com a exploração dos recursos culturais e naturais destes subconjuntos da sociedade.

Conscientização sócio-ambiental. Prevê-se que a conscientização pública dos problemas socioculturais e do meio ambiente cresça nos próximos anos. Após os resultados conseguidos nos anos oitenta e noventa com a Cúpula do Rio de Janeiro, em 1992, os temas relacionados ao meio ambiente deverão ser levados em consideração com muito mais intensidade nesse novo milênio.

Ambientes de vida e de trabalho. A crescente congestão urbana que vem ocorrendo e que, provavelmente, continuará a ter lugar, tanto nos países industrializados como nos em desenvolvimento, conduz a um crescente sentimento de necessidade de empreender turismo direcionado para escapar e desfrutar. A mudança no sistema e nas práticas trabalhistas (menos emprego integral, mais trabalho terceirizado) implica mais férias, porém mais curtas, e uma distinção menos clara entre tempo de trabalho e tempo de lazer (que se manifesta por um aumento nas viagens combinadas, de trabalho e de prazer). Pressões mais intensas sobre o tempo e níveis crescentes de "estresse" dão lugar a uma maior importância em relação às maneiras de "escapar", recorrendo-se a férias, em particular para destinos distantes e exóticos.

Mudança da economia de "serviço" para a de "experiência". O mundo industrializado está em fase de transição, de uma economia de serviço para uma de experiência, uma vez que, em determinados países, a economia de serviço já atingiu o máximo. O objetivo está mudando em direção à entrega de experiências únicas, envolvendo pessoalmente o cliente, o que implica claramente, para o turismo, a necessidade de diferenciar o desenvolvimento e o marketing do produto turístico tanto por parte dos destinos como das operadoras.

Marketing. O grande desafio em marketing consistirá no tratamento eficaz, por um lado, do conjunto sempre crescente e diversificado de desejos, interesses e gostos dos consumidores, e, por outro, dos produtos turísticos oferecidos. A utilização de tecnologia da informação permitirá a identificação mais rápida e precisa dos segmentos e nichos de mercado, e permitirá comunicarse com eles com maior eficácia. Isso facilitará o micromarketing, tanto de destinos turísticos como de fornecedores de serviço.

A maioria dos fatores apresentados exerce influência de forma combinada e vai produzir uma polarização dos gostos e da demanda turística. O resultado será uma evolução para um turismo 
"principal", em grande escala, que acarreta, de um lado, o movimento de grandes volumes para destinos amplamente desenvolvidos, e, de outro lado, em uma escala menor, um turismo "individualizado", novo, alternativo.

2. Evolução de turismo na globalização. Turismo postfordista ou de terceira geração. $\mathrm{O}$ consumo turístico não será nunca mais do tipo fordista, entendendo-se por fordismo o consumo em massa de produtos não diferenciados. A hiper-realidade e o hiper-vínculo dominaram os gostos do novo consumidor turístico. Os novos destinos terão que escapar da tendência de repetir a oferta massificada de mediterrâneo e Espanha. Na América Ibérica deve-se evitar a repetição de destinos como Cancún e Sauípe, que repetem o modelo fordista de consumo. O turista postfordista terá uma sensibilidade maior em relação ao meio ambiente; ele saberá o que é qualidade e a exigirá, e não pagará se o que for consumido não corresponder a suas expectativas. Esse novo turista procurará programas específicos, ajustados a seus desejos, gostos e necessidades. As empresas turísticas deverão conhecer essas mudanças e adaptar sua oferta ao novo perfil da demanda.

3. Segundo as previsões da OMT, as Américas continuarão sendo um destino preferido internacionalmente. Especialmente o Brasil será um dos grandes destinos da próxima década juntamente com a China. O Caribe continuará sendo o paraíso de sol e praia. Para Cuba, haverá um forte desenvolvimento quando o país se abrir para o turismo norte-americano. A presença das empresas espanholas terá muita importância para esse desenvolvimento. A identidade cultural e a latinidade das formas de atuação e de gestão serão pontos básicos para favorecer a aquisição do necessário know how das empresas espanholas por parte das empresas receptivas da América Ibérica.

4. O marco teórico que deu suporte à pesquisa empírica realizada foi enriquecido e atualizado pelas tendências gerais que se apresentam, no contexto da globalização, em matéria de gestão estratégica e estratégias competitivas. Foi possível avaliar a evolução das estratégias nesse contexto e estudar os novos enfoques que sustentam as estratégias da empresas na nova economia. Empresas organizadas em redes internacionalizadas, que alcançam vantagens competitivas mediante concorrência predatória, e não pela cooperação, são uma nova forma de ganhar, ou seja, ganhar na globalização. Os clusters de empresas que atuam com sucesso nos diferentes setores da economia demonstram que uma nova forma de marketing consiste em interpretar e atuar nessas condições. Especial atenção foi dada, nesse estudo, às estratégias de internacionalização, pois seu entendimento é de suma importância para os países de economias emergentes como os da América Ibérica. 
5. O sistema de turismo apresenta especial complexidade nesse contexto. Por um lado, se for adequadamente administrado converte-se em um elemento dinamizador da economia dos países; por outro, sem um adequado plano estratégico pode ocasionar danos irreversíveis aos recursos que explora. Na indústria de turismo, como em nenhum outra, a combinação de esforços dos setores públicos e privados deverá prevalecer como conceito. Os clusters turísticos estudados têm demonstrado sua eficácia. Esse estudo procurou mostrar que cada vez mais se compete entre clusters ou destinos e não entre empresas turísticas de uma mesma região. Entender essa idéia pelos empresários e tomadores de decisão dos governos locais é essencial para desenvolver os novos destinos.

6. Na atual conjuntura globalizada, no setor turístico, da mesma forma que nos demais setores, tem-se presenciado uma forte concentração de empresas. A tese procura avaliar as mais importantes cadeias hoteleiras internacionais, destacando o papel que o marketing estratégico tem em seus respectivos desempenhos competitivos e posicionamentos. Aborda, ainda, uma nova teoria, o Modelo Delta, que se caracteriza pelos diferentes estágios de competitividade segundo as estratégias adotadas pelas empresas. Muda-se, assim, de um enfoque totalmente centrado no produto e em sua venda, para uma etapa superior, em que os clientes concentram toda a atenção da empresa. Chega-se a uma posição em que se busca a satisfação total das necessidades dos clientes, estabelecendo-se redes de empresas para agregar valor a uma oferta sistêmica. Procura-se a total fidelização dos clientes de modo a atingir o lock in do sistema.

7. Foi adotado como caso de estudo a empresa espanhola Sol Meliá. A empresa ocupa o décimo lugar no mundo em número de quartos e hotéis, sendo líder mundial no segmento de turismo de férias, líder absoluto na Espanha, na América Latina e terceira na Europa. O estudo da rede hoteleira Sol Meliá deveu-se ao importante papel que essa empresa está ocupando no desenvolvimento turístico dos países ibero-americanos. Foram entrevistados os principais diretores da empresa, desde seu Presidente e Vice-presidente, os Diretores da matriz central, e os dirigentes das divisões ibero-americanas do Brasil (que engloba toda América de Sul) e de Cuba. Foram visitados 23 hotéis, e entrevistados seus diretores, como forma de verificar como a estratégia empresarial desenhada no nível corporativo era posta em prática pelas filiais e aplicada nos hotéis.

8. Uma análise da empresa Sol Meliá, tendo por referência conceitual o Modelo Delta, reflete uma preocupação da cadeia e uma tendência de adotar um rumo estratégico que a conduza a um estágio superior em termos de satisfazer integralmente seus clientes em cada um dos destinos em que atua. Prova disso são as alianças que estão sendo realizadas pela empresa com diferentes 
empresas complementadoras. A utilização da chamada nova tecnologia, ou tecnologia da informação, tem sido feita, pela empresa, de forma intensiva, como forma de atender aos seus clientes e a suas necessidades de forma cada vez melhor. Uma nova estratégia de marcas foi adotada pela empresa recentemente, dando solidez à sua definição de produtos - mercados. A empresa, por ser muito internacionalizada, ainda não conseguiu a necessária integração com as demais em alguns dos novos destinos em que, mas o rumo estratégico está traçado para alcançálo. A empresa aplica criativamente os instrumentos de marketing estratégico em sua atuação, o que o permite um processo de internacionalização mais coerente com as características específicas dos países onde está presente. Como parte dessa pesquisa, foi possível mostrar a efetividade dos instrumentos de marketing estratégico, os quais se aplicam a situações tão distintas como a de operar em Cuba e no Brasil, nos dois casos com êxito. Dois países totalmente diferentes em condições políticas e de desenvolvimento.

9. A pesquisa foi conduzida metodologicamente mediante o estudo de casos, que demonstrou sua eficácia como estratégia de pesquisa. Foi possível aplicar, criativamente, a metodologia desenvolvida por Yin (2001) e cumprir os objetivos da tese.

Verificou-se como é que estão sendo aplicadas pela empresa de turismo as estratégias de marketing, em função da crescente competitividade em um ambiente globalizado.

Foram respondidas, no desenvolvimento da pesquisa e neste relatório final, as seguintes questões:

1. Quais são os instrumentos do marketing estratégico que estão sendo utilizados pelas empresas turísticas, para gerar vantagens competitivas em seus modelos de gestão?

2. Como as empresas turísticas estão utilizando os elementos de análise e decisão de Marketing Estratégico, para competir no mercado internacional do turismo?

3. Que influência têm as técnicas do marketing estratégico, aplicadas nas empresas turísticas pesquisadas, em seus posicionamentos de mercado?

Para a compreensão desses fenômenos foi necessário indagar:

1. Quais são as tendências do mercado turístico global em que operam as empresas?

2. Qual é a estrutura competitiva do setor em que operam?

3. Qual o impacto sobre as empresas turísticas dos ambientes econômico, tecnológico, ecológico, político e social em que operam?

4. Como administram suas carteiras de produtos? 
5. Que políticas de preços empregam?

6. Quais são as estruturas e motivações dos canais de distribuição que utilizam?

7. Que força e qualidade têm os meios de comunicação que empregam?

8. Que tipos de capacidades internas, estruturas e cultura organizacional adotam?

9. Qual é ou grau de criatividade e inovação de suas ofertas?

10. Quais são os desempenhos de sucesso?

11. Que tipos de estratégias competitivas têm adotado?

12. Estão estas organizações em condições de gerar vantagens competitivas sustentáveis?

Considera-se, que o objetivo geral da pesquisa foi atingido, com o aprofundamento do estudo da utilização dos elementos de análise e decisão do Marketing Estratégico pelas empresas turísticas nos países receptivos, particularmente no Brasil e em Cuba, para alcançar um posicionamento de mercado compativel com o desenvolvimento do turismo em suas regiões.

Para atingir esse objetivo geral foi necessário:

1. Identificar a utilização dos conceitos, modelos e técnicas de análise associada ao marketing estratégico e sua contribuição para alcançar a competitividade das empresas pesquisadas no Brasil e em Cuba;

2. Avaliar, do ponto de vista do marketing estratégico, como as empresas que operam o turismo nos países receptivos, como Brasil e Cuba, desenvolvem suas potencialidades para serem competitivas;

3. Contribuir para o desenvolvimento de metodologias voltadas para o delineamento de estratégias competitivas no setor turístico, em países como Brasil e Cuba;

4. Sugerir recomendações sobre as direções principais de mudança no enfoque gerencial das organizações turísticas que operam o turismo no Brasil e Cuba.

\section{Limitações:}

As limitações da pesquisa, em especial a pesquisa de campo, dizem respeito principalmente aos aspectos metodológicos, conforme salientado no Capítulo V. A pesquisa, de caráter exploratório, e envolvendo um estudo de caso, implica que os resultados apurados não podem ser necessariamente generalizados para a população de cadeias hoteleiras, usando-se os recursos da inferência estatística. Por outro lado, a escolha da amostra (caso), além de limitada numericamente, foi intencional. 
Outra questão está relacionada ao instrumento de coleta de dados e, principalmente à sua aplicação. Por ser tratar de pesquisa exploratório, a coleta de dados apresenta um caráter mais elástico quanto a aspectos relativos à formulação das questões e a forma de aplicação do instrumento. Além disso, a interpretação dos depoimentos e das respostas dos entrevistados pode conter vícios no tocante à percepção do entrevistado quanto ao conteúdo das questões propostas, ou ao entendimento do conceito teórico sobre o qual a situação investigada está embasada e a outros problemas associados. Para diminuir a possibilidade de ocorrência de erros na aplicação do instrumento, o pesquisador procurou estabelecer o mais amplo diálogo com os respondentes, além de, inicialmente, pré-testar o instrumento de coleta junto a um grupo de empresas.

\section{Recomendações:}

Pela importância do setor de turismo para países emergentes como Brasil e Cuba, a pesquisa não pode considerar-se fechada. $\mathrm{O}$ estudo das melhores práticas de empresas internacionais, como a Sol Meliá, merece um prosseguimento por parte das instituições acadêmicas e de pesquisa. No desenvolvimento da tese foram resumidos os conceitos mais recentes sobre a competitividade das empresas e dos destinos turísticos. Uma preocupação pela sustentabilidade dessas estratégias competitivas deverá estar presente no desenvolvimento de novos trabalhos. $\mathrm{O}$ autor considera que a pesquisa deveria prosseguir abrangendo a questão da sustentabilidade competitiva de empresas e organizações, representadas pelos agentes, na competitividade dos destinos, ampliando a sustentabilidade de desenvolvimento local. Somente assim o turismo se converterá em um ente dinamizador de desenvolvimento humano. Unindo esses elementos, as estratégias de destinos e de empresas serão efetivamente sustentáveis. 


\section{BIBLIOGRAFIA}




\section{BIBLIOGRAFIA}

ACERENZA, M. A Agencias de viajes: organización y operación. Trillas, México, 1992.

ACERENZA, M. A Promoção turística: um enfoque metodológico. $5^{\mathrm{a}}$ ed., Pioneira, São Paulo, 1991.

ACEREnZA, M. A. Administración del Turismo. $2^{\text {a }}$ ed., Trillas, México, 1986.

ADLER, N. International Dimensions of Organizational Behavior. Kent Publishing Company, Nova York, 1986.

AGUILÓ, E; "Evolución y expectativas de la actividad turística", in Pedreño, A. y Monfort, V.M., 1996

ALPERT, M. Identification of Determinant Attributes: a Comparison of Methods. Journal of Marketing Research, V.8, Nova York, 1971.

ALVAREZ, J.; VALDÉS, L. Diseño de una estrategia corporativa del Hotel Horizontes Capri desde un enfoque de oferta. Dissertação de Mestrado, Universidade de Havana, Havana, 1996.

ALVAREZ, V. JESÚS, CARDOZA, B. G, DÍAZ, B. R. Caso de estudio: Sol Meliá: Estrategias de Internacionalización. Instituto de Empresa, Medrid, 2002

ALVAREZ, V. JESÚS, CARDOZA, B. G, DÍAZ, B. R. Caso de estudio: Sol Meliá: Estrategias de Branding. Instituto de Empresa, Madrid, 2002.

ALVARO C. C. Estructura de propiedad y comportamiento de la empresa: Objetivos alternativos de los accionistas en España, 1997

ANDRADE, J.V. Turismo: fundamentos e dimensões. Ática, São Paulo, 1992.

ANSOFF, H.I. Business Strategy. Penguin Books, Boston,1977.

ANTON, S "El parque temático Port Aventura. Estrategias de producto para la reestructuración de núcleos consolidados en Cataluña”, Estudios Turísticos, . 1996

ANTON, S.; Diferenciació i reestructuració de l'espai turístic. Processos i tendències al litoral de Tarragona, Tarragona, E1 Mèdol, 1997

ARAGAY, J.J.; GRANDE, J. Marketing Turístico. Servicios Editoriales y de Empresas, Madrid, 1978.

ARELlANO, R. Comportamiento del consumidor y Marketing. Harla, México, 1993.

ARRILlaGA, J. I. Sistema de Política turística. Aguilar, Madrid, 1955.

ASHWORTH, G. J.; GOODALL, B. Marketing tourism places. Routledge, Nova York, 1990.

ASSIS, K. M. B. Turismo interno no Brasil. S.N., Porto Alegre, 1976.

BALTAZAR, D. D. Turismo: dinâmica social e econômica. Instituto de Cultura e Ensino Pe. Manoel da Nóbrega, São Paulo, 1982. 
BARETJE, R. Désequilibres Économiques de Tourisme. Berger-Levrault, Paris, 1972.

BARETJE, R.; DEFERT, P. Aspectes économiques de tourisme. Berger-Levrault, Paris, 1972.

BARRETO, M. Planejamento e organização em Turismo. Papirus, Campinas, 1991.

BARRIO, R. M. Interdependencia Social en torno el Fenómeno Turístico. Instituto de Estudios Turísticos, Madrid, 1971.

BECKWITH., N. E.; FITZGERALD, T. J. Marketing of Services: Meeting of Different Needs. In: DONNELLY JR- James H.; GEORGE. William R. Marketing of Services, American Marketing, Chicago,1981.

BENI, M. C. Caracterização da natureza dos fluxos para classificação da demanda por turismo. Dissertação de Mestrado, ECA/USP, São Paulo, 1981.

BENI, M. C. Análise Estrutural do Turismo. Ed. SENAC, São Paulo, 2000.

BENI, M. C. Sistema de Turismo - Construção de um modelo teórico referencial para aplicação na pesquisa em Turismo. São Paulo, Tese de Doutorado, ECA/USP, 1988.

BERRY, L. The Employ as Costumer. Journal of Retail Banking, V.3, Nova York, 1981.

BERRY, L. Service Marketing is Different. Business Magazine, V.30, Nova York, 1980.

BERRY, L.; PARASURAMAN, A. Serviços de Marketing. Norma, São Paulo,1992.

BLASS NOGUEIRA, M. Estacionalidad en el turismo y sus posibles correctivos. IET, Madrid, 1968.

BLOEMER, J. M.; POLESZ, T. B. The Ilusion of Consumer Satisfaction. Journal of Consumer Satisfaction. Dissatisfaction and Complaining Behavior, V.2, Chicago, 1989.

BOOMS, B. H.; BITNER, M. J. Marketing Strategies and Organization Structures for Services Firms. In: Marketing of Services. DONNELY; GEORGE, AMA Chicago, 1981.

BOOMS, B. H.; NYQUIST, J. Analyzing the Customer Firm Communication Component of the Service Marketing Mix. In: George. ed. Marketing of Services, AMA, Chicago,1981.

BOULlÓN, R. C. Los municípios turísticos. Trillas, México, 1995.

BOUlLÓN, R. C. Planificación del espacio turístico. 2a ed., Trillas, México, 1994.

BOULlÓN, R. C. Planificación del espacio turístico. Trillas, México, 1991.

BOYD, H.; WESTFALL, R. Pesquisa Mercadológica. Fundação Getúlio Vargas, Rio de Janeiro, 1979.

BURKART, A. J. Tourism: past, present and future. 2a ed., Butterworth-Heinemann, Oxford, 1992.

BURKART, A. J.; MEDLIK, S. The Management of Tourism. Heinemann, London, 1975. 
BUTLER, R.W.; “Alternative tourism: pious hope or trojan horse?”, Journal of Travel Research, 390-407, 1990.

BUTLER, R.W.; "The concept of a tourist area cycle of evolution: implications for management of resources", Canadian Geographer, 24, 5-12, 1980

CADOTTE, E. R.; WOODRUF, R. B.; JENKINS, R. Expectation and Norms in Models of Consumer Satisfaction. Journal of Marketing, V.24, Nova York, 1987.

CALZADILLA, I. Turismo en el camino del liderazgo. Jornal Granma, Havana, 1997.

CAMPOMAR, M. C. Do uso de "estudo de casos" em pesquisas para dissertações e teses em administração. Revista de Administração, São Paulo, 1991.

CARCENAS, F. Producto Turístico. Trillas, Barcelona, 1986.

CARDENAS, T. F. La segmentación del mercado turístico: comercialización y venta. Trillas, México, 1991.

CARDENAS, T. F. Proyectos turísticos: localización e inversión. Trillas, México, 1991.

CARDENAS, T. F. Comercialización del turismo: determinación y análisis de mercados. $3^{\mathrm{a}}$ ed., Trillas, México, 1990.

CARMAN, J. M.; LANGEARD, E. Growth Strategies of Services Firms. Strategic Management Journal, EUA, 1980.

CASTELLI, G. O hotel como empresa. Sulina, Porto Alegre, 1982.

CASTELli, G. Turismo e Marketing. Livraria Sulina Editora, Porto Alegre, 1984.

CASTELLI, G. Turismo, análise e organização. Livraria Sulina Editora, Porto Alegre, 1975.

CASTELli, G. urismo, análise e organização. Sulina, Porto Alegre, 1975.

CASTRO, C. M. A Prática da Pesquisa. Mc Graw Hill, São Paulo, 1977.

CENTENO, R. R. Metodología de la investigación aplicada al turismo: casos prácticos. Trillas, México, 1992.

CHANG, T.C. et al. "Urban Heritage Tourism. The Global-Local Nexus", Annals of Tourism Research, 1996.

CHASE, R. The 10 Commandments of Service System Management. Interfaces, V15, EUA, 1985.

CLAVER, E. C. y QUER, D. R. ; Estrategias de internacionalización de la empresa. Editorial Club Universitario Universidad de Alicante, 2001

CLUB DE GESTIÓN DE CALIDAD EUROPEO. Modeo EFQM de Excelencia, Bruselas, 2001.

COBRA, M. Marketing de Turismo. Cobra Editora \& Marketing, São Paulo, 2001

CODINA, A. ¿Cómo Negociar con Cuba? Editorial F. Varela, Havana, 1994. 
COLTMAN, M.M. Tourism marketing. Van Nostrand Reinhold, Nova York, 1989.

CRISTOPHER M. P. A.; BALLANTYNE, B. Relationship Marketing Bringing Quality. Costumer Services and Marketing Together. Center for Services Management Butter Worth Heinemann, Oxford, 1991.

CRISTOPHER, H. L. Services Marketing. Prentice Hall International Edition. Second Edition, EUA, 1991.

DAVIDOW, W.; UTTAL B. Services Companies: Focus Falter. Harvard Business Review, Harvard, 1989.

DAY, G. S. Estratégia Voltada para o Cliente. Nova York, 1990.

DIMINGO, E. The Fine Art of Positioning. The Journal of Business Strategy, March/april, EUA, 1988.

DONAIRE, J.A., FRAGUELL, R.M. Y MUNDET, LL.; "La Costa Brava ante los nuevos retos del turismo", Estudios Turísticos, 1977

DONAIRE, J.A.; El turismo a los ojos del postmodernismo. Una lectura desde la dialéctica socioespacial, Tesis Doctoral, Universitat Autònoma de Barcelona, no Publicada. 1996

DRUCKER, P. F. Prática da administração de empresas. Livraria Pioneira Editora, São Paulo, 1981.

DUNNIG, J. H. Multinacional Enterprises and Global Economy. Adisson Wesley Publishing Company, Esdos Unidos, 1994.

Eco, U. La guerre du faux, París, Grasset, 1982

ECONOMICS PRESS SERVICE. La Economía Cubana 1989-95. Año 9, Nº16, Havana, 1996.

EMBRATUR. Perfil comercial da hotelaria brasileira 2001.

EMBRATUR. Roteiro para projeto definitivo de hotéis de turismo: roteiro. $h$ 4-A EMBRATUR, 1972.

EMBRATUR. Turismo, legislação básica. 2a ed., EMBRATUR, Rio de Janeiro, 2000.

Empresa Brasileira de Turismo, Rio de Janeiro, 2001. http://www.embratur.gov.br/economia/cenprospectivos.asp

ENDERS, W. T.; MENDES, N.; HESKEETH. J. A. Pesquisa da Percepção Individual Aplicada às Áreas de Administração e Planejamento: Conceitos, Teoria e Metodologia. Revista de Administração, vol.18, São Paulo, 1983.

ENGEL, J.; BLACKWELL, R. D.; MINIARD, P. W. Consumer Behavior. The Dryden Press, Orlando, 1993. 
ESCUELA DE ALTOS ESTUDIOS DE HOTELERIA Y TURÍSMO. Evolución de la Planta Hotelera de la Región del Caribe: Tendencias de Desarrollo. Evolución y Tendencias de la Industria Turística, Ano 1, № 3, Havana1997.

EVERLENY, O et. al. Cuba Ventajas para la inversión. ADAR Communications, Havana, 1997. FALKENSTEIN, H.; "Nuevos medios y tecnologías de distribución en el sector turístico", Estudios Turísticos, 134, 1977

Federación Española de Hostelería. Madrid, España, 2002

FERNÁNDEZ FUSTER, L. Comercialización del Turismo. Anthropos. Barcelona, 1987.

FERNÁNDEZ FUSTER, L. Teoría y técnica del Turismo. $2^{\mathrm{a}}$ ed., Editora Nacional. Madrid, 1971.

FERNÁNDEZ FUSTER, L. Teoría y Técnica del Turismo. Editora Nacional, Madrid, 1978.

FERNÁNDEZ S. E. Y VÁZQUEZ O. C. La internacionalización de la empresa. Universidad de Oviedo, España. 2001

FIGUEROLA, P. M. 2010, Hacia un nuevo turismo español (una reflexión sobre el futuro), FEHR

GALLEGO, J. F Dirección Estratégica en los Hoteles del siglo XXI. McGraw-Hill, Madrid, 1996.

GARCELL, H. ¿Puede el turismo ayudar al desarrollo económico de Cuba? Boletim Econômico do ICE, Havana 1994.

GETINO, O. Turismo y desarrollo en América Latina. Noriega, México, 1987.

GODOY, A. S. Introdução à Pesquisa Qualitativa e suas Possibilidades. Revista de Administração de Empresas, São Paulo, 1995.

GOMEZ, V. B. Planificación económica del turismo: de una estrategia masiva a una artesanal. Trillas, México, 1990.

GONZALEZ, S. J. La Motivación. Psicología, La Habana, 1982.

GRASSIELLI, P. Economía del Turismo. São Paulo, 1989.

GREEN, P. E.; CARMONE, F. J., Multidimensional Scaling and Related Techniques in Marketing Analysis. Boston, Mass. Allyn, 1988.

GUNN, C. A. Tourism planning. $2^{\mathrm{a}}$ ed., Taylor \& Francis, Nova York, 1988.

GUTIÉRREZ, E.C.; BORDAS, E. La competitividad de los destinos turísticos en mercados lejanos. AIEST, St. Gallen, Suíça, 1993.

HAMEL, G.; PRAHALAD, C. K. The core competence of the Corporation. Harvard Business Review, Harvard, 1990. 
HARVEY, D. The condition of postmmodernity, Nueva York, Blackwell, 1989

HARVEY, D. ; Justice, Nature and the Geography of Difference, Nueva York, Blackwell, 1996

HAX E WILDE, The Delta Project. Discovering New Sources of Profitability in a Network Economy, Palgrave, England, 2001

HEARTH, E. Marketing tourism destinations: a strategic planning approach. Wiley, Nova York, 1992.

HERNANDEZ DÍAS, E. A. Planificación turística. Trillas, México, 1992.

Hewison, R. ; The heritage industry: Britain in a climate of decline, Londres, Methuen, 1987

HOLLOWAY, J.C. The business of tourism. Pitman. $3^{\text {a }}$ ed., London, 1992.

HOWARD, J.; SHET, J. A Theory of Buyer Behavior. Wiley, Nova York,1969.

Hughes, G. ; “Authenticity in tourism”, Annals of Tourism Research, 1996

HUNZIKER, W. L'organization de l'entreprise touristique. Revue de Tourisme, n.2, Zurique, 1949. In: Brookes R., ed., Customer Satisfaction Research: Esomar, Amsterdam, 1995.

HUNZIKER, W.; KRAPF, K. Algemeine Frendenverkehrslehre. Zurique, 1942.

Indovina, F.; "Turisti, pendolari, residenti”, Co.S.E.S. Informazioni, Turismo a Venzia, 32-33, $37-42,1988$

INSTITUTO DE EMPRESA. Notas Técnicas. Estrategias de Internacionalización. Madrid, España, 1999.

INTERNATIONAL BANK FOR RECONSTRUCTION AND DEVELOPMENT. Report on Cuba Findings and Recommendations of an Economic and Technical Mission. Organized, Havana, 1950.

INTERNATIONAL CONGRESS LATIN AMERICAN SEMINAR, Capacitación turística: su aporte a los sectores público y privado. Asociación Mundial para la Formación Profesional Turística: [1989] Centro de Investigaciones y Estudios Turísticos, Buenos Aires, 1989.

JAFARI, J. Palestra Magistral. Congresso Internacional AMFORT, Havana, 1990.

KLUCKHOHN, C.; MURRAY. H. A personalidade na natureza, na sociedade e na Cultura. Livraria Itatiaia, Belo Horizonte, 1965.

KOTLER, P. Administração de Marketing. PHB, São Paulo, 1995.

KRIPPENDORF, J Marketing et tourisme. Herbert Lang et Cie, Berne, 1971.

KRIPPENDORF, J The holiday makers: understanding the impact of leisure and travel. Translated by Vera Andrassy, Heinemann, Londres, 1987.

KRIPPENDORF, J. Les Devoreus des paysages, Ed. 24 heurs, Lausanne, 1977.

LAGE, B. H. G. Economia do turismo. Papirus, Campinas, 1991. 
LAMBIN, J. J. Marketing Estratégico. MacGraw-Hill, Madrid, 1989.

LARREA, P. Calidad de Servicios. Díaz de Santos, Madrid, 1991.

LEA, J. P. Tourism and development in the Third World. Routledge, Nova York, 1988.

LEMOS, A. G. (org.) Turismo impactos sócio-ambientais. Hucitec, São Paulo, 1996.

LEVITT, T. Diferenciação de Qualquer coisa. São Paulo, 1972.

LLURDÉS, J.-C.; “Les activitats turístiques de nova creació: una estratégia de reconversió econòmica i ambiental per a zones en decadència. L'exemple del turisme de patrimoni miner a Cardona (Bages)", Documents d'Anàlisi Geogràfica, 1995

MACHIN, C. A. Marketing y turismo: introducción al marketing de empresas y destinos turísticos. Síntesis, Madrid, 1993.

MARCHENA, M. “A propósito de Sevilla (Expo)'92: el turismo una experiencia de descubrimientos", Estudios Turísticos, 113, 9-25, 1992

MARCHENA, M. "Un ejercicio prospectivo: de la industria del turismo "fordista" al ocio de producción flexible", Papers de Turisme, 14-15, 77:94, 1994

MARTÍNEZ, B. A. Internacionalización de la empresa y elección del modo de entrada en los mercados exteriores. Un enfoque institucional. Editora Septem Universitas, Universidad de Oviedo, 2001

MARTINS, A.G. Abordagens Metodológicas em Pesquisas na área de Administração. Revista de Administração, V.32, São Paulo, 1977.

MARTORELL, C. D. El top ten de cadenas Hoteleras Internacionales, Univesidad de Islas baleares, 2002.

MATHIESON, A.; GEOFFREY, W. Tourism: economic, physical and social impacts. Harlow: Longman, Nova York, 1990.

MATSUMOTO, H. Desenvolvimento de um sistema de planejamento regional de turismo. S.N., Florianópolis, 1978.

MAZZON, J. Formulação de um modelo de avaliação e comparação de modelos em marketing. Dissertação de Mestrado, FEA-USP, São Paulo, 1978.

McCARTHY, B. B. Cultural tourism: how the arts can help market tourism products, how tourism can help provide markets for the arts. B.B. McCarthy, Portland, 1992.

McINTOSH, R. W. Tourism principles, practices, philosophies. Grid, Ohio, 1977.

McINTOSH, R. W. Turismo: planeación, administración y perspectivas. Noriega, México, 1993.

MEDLIK, S. Managing tourism. Butterworth-Heinemann, Oxford, 1991. 
Meethan, K. ; “Consuming (in) the civilized city”, Annals of Tourism Research, 23 (2), 322-340, 1996

MIDLETON, V. T. C. Marketing in travel and tourism. Butterworth-Heinemann, Oxford, 1993.

MILL, R. C. Tourism: the international business. Prentice Hall, Nova Jersey, 1990.

MINTUR Cuba, 2001. Balance Anual de Trabajo del Año 2000, La Habana Cuba, 2001

MINTZBERG, H.; QUINN, J. O processo da Estrátegia. 3a. Edição, Bookman, Porto Alegre, 1998.

MOLINA E., S. Planificación integral del turismo: un enfoque para Latinoamérica. Trillas, México,1991.

MORRISON, A. M. Hospitality and travel marketing. Albany, Nova York, Delmar, 1989.

MUÑOZ, F.E. Crítica de la Economía Turística. CSIC, Madrid, 1993.

MUÑOZ, F.E. Turoperadores y Producción del Turismo. Revista Estudos Turísticos, Madrid, 1990.

NACIONES UNIDAS, Directrices para la Compilación de Estadísticas de Turismo. UNCTAD, Nova York, 1971.

NASSER, T. Desenvolvimento turístico do litoral norte de São Paulo. FAU, São Paulo, 1976.

NURYANTI, W. ; “Heritage and Postmodern Tourism”, Annals of Tourism Research, 23, 249260,1996

OHMAE, K. O Estrategista em Ação: a arte japonesa de negociar. Pionera, São Paulo, 1985.

OLIVEIRA, A. U. Turismo: a grande indústria. Kosmos, São Paulo, 1981.

OLIVER, R. L.; SWAN, J. E. Equit and Disconformation Perceptions as Influences on Merchant and Product Satisfaction. Journal of Consumer, v.16, EUA, 1989.

OPUP, S. Cuba un destino para cada deseo. Revista Business Tips on Cuba, V.2, Havana, 1995.

ORGANISATION DE COOPERATION ET DE DEVELOPMENT ECONOMIQUES, Tourisme international et politique du tourism dans les pays de l'ocde: evolution du tourisme dans les pays member. OCDE, Paris, 1971.

ORGANIZACIÓN MUNDIAL DEL TURISMO. Informe Anual. Madrid, 2001.

ORGANIZACIÓN MUNDIAL DEL TURISMO. Compendio de Estadística 1992-1996. Madrid, 1998.

ORGANIZACIÓN MUNDIAL DEL TURISMO. Tendencias del mercado turístico. Las Américas. Madrid, Edición 2001.

OSEKI, J. H.; SHIBUKAWA, M. S. Turismo. FAU, São Paulo, 1969.

PARASURAMAN, A.; ZEITHAMLII., V.; BERRY, L. A. Servqual: a Multiple Item Scale for 
Measuring Consumer Perception of Services Quality, Journal of Retailing, v.64, EUA, 1988.

PARDO, J.; "El turisme. Una visió des de la gestió del patrimoni cultural”, in Turisme, territori i estratègies de desenvolupament, Actas de las Jornadas sobre el turismo en los espacios litorales, Girona, 29 marzo - 1 abril de 1995, 101-108., 1996

PEARCE, D. G. Tourist development. 2a ed., Wiley, Nova York, 1989.

Pedreño, A. y Monfort, V.M.; Introducción a la economía del turismo en España, Madrid: Civitas, 1996

PELIZZER, H. A. Uma introdução à técnica do turismo: transportes. Pioneira, São Paulo, 1978.

PLOG, S. C. Why destination areas rise and fall in popularity. In: Tourism destination, EUA, 1974.

PONTEIRO VITALE, S. Metodologia en el turismo. Trillas, México,1991.

Poon ; "Competitive strategies for a "new tourism"” in Cooper, C. (ed.); Progress in tourism, Recreation and Hospitality Management, Bellhaven, Londres, vol. 1, 91-102, 1989

POON, A. Tourism, technology and competitive strategies. Cab International, Wallingford, 1994.

PORTER, M Vantagem Competitiva, Editora Campus, Rio de Janeiro, 1989.

PORTER, M. El Poder de decir no. Revista Banking Strategy. http://www.crie.coope.ufrj.br/kmtools/knowledge/kr-glossarios/ 1998.

PORTER, M. La Ventaja Competitiva de la Naciones. Editorial Plaza Janes, Espanha, 1991.

Pretes, M.; "Postmodern Tourism. The Santa Claus Industry", Annals of Tourism Research, 23, 1-15, 1995

PUDDU, G. L. Lo que se espera del turismo para la década de los 90. AMFORT/ECA-USP, São Paulo, 1991.

RABAHY, W. A. Planejamento do turismo: estudos econômicos e fundamentos econômicos. Loyola, São Paulo, 1990.

RAMÍREZ, C. Gestión administrativa para empresas turísticas. Trillas, México, 1993.

RAMÍREZ, C. Hoteles: gerencia, seguridad y mantenimiento. Trillas, México, 1990.

RAMÍREZ, M. Teoria general de turismo. $2^{\mathrm{a}}$ ed., Diana, México, 1992.

RIBEIRO, M.; CHAHAD, M.; FILARDO, M. Turismo brasileiro: textos selecionados. Instituto de Pesquisas Econômicas, São Paulo, 1983.

Richards, Greg; "Production and Consumption of European Cultural Tourism", Annals of Tourism Research, 23, 261-283, 1996

RIES, A.; TROUT, J. Positioning the Battle for your Mind. Warner Books, New York, 1981. 
ROBBINS, S. Comportamiento Organizaciona., Prentice-Hall, México,1994.

ROMÁN, J. A. Gestão de Marketing e Vantagens Competitivas em Mercados Industriais. Dissertação de Mestrado, FEA/USP, São Paulo, 1996.

RONQUILLO, R. Isla Azul por encima del millón de turistas nacionales Journal Juventud Rebelde, Havana, 1997.

ROTERMUND, M. L. G. Percepção da Qualidade de Serviço. Dissertação de Mestrado, PPGA, Porto Alegre, 1993.

RUGMAN, A.M. How to operationalize Porter's diamond of international competitiveness. The International Executive, Vol. 35, Havana, 1993.

RUSCHMANN, D. M. Marketing Turístico. Um enfoque promocional. $2{ }^{\text {a }}$ Edição. Papirus Campinas, 1995

RUSCHMANN, D. M. Turismo e planejamento sustentável: a proteção do meio ambiente. Papirus, Campinas, 1997.

Sack, R.D.; Place, modernity and the consumer's wolrd, Baltimore, Jonhs Hopkins University Press, 1992

SAUNDERS, J.; HOOLEY, G. J. Posicionamento Competitivo. Makrom Books, EUA, 1996.

SCHARAMAMM, V. Notes em case studies of instructorial media projects. Working Paper for Academy, for Educational Development, Washington, 1971.

SCHULZ, M. R. Travel \& tourism. F. Watts, Nova York, 1990.

SCHWARZ, J. J. Dynamique du tourisme \& marketing. Université de Droit, d'Economie et des Sciences D'Aix-Marseille, Marselha, 1976.

SECRETARIA DE TURISMO de MÉXICO. Operación de turismo receptivo y nacional. Noriega, México, 2001.

SECRETARIA DE TURISMO de MÉXICO.. Promoción y comercialización de turismo receptivo y nacional. Noriega, México, 2001.

SELLTIZ, C. et al. Métodos de pesquisa nas relações sociais. $8^{a}$ reimp. São Paulo, EPU, 1997.

SEMINÁRIO LATINO-AMERICANO SÃO PAULO 1990. Turismo: grande desafio dos anos 90. ECA/USP, São Paulo, 1991.

SESSA, A Il turismo nei rapporti internazionale. Ed. Sarda Fossataro, Cagliari, 1968.

SESSA, A Turismo e politica di sviluppo. Ed. Univ., Veneza, 1976.

SESSA, A. Turismo e politica de desenvolvimento. Uniontur, Porto Alegre, 1983.

SESSA, A. Turismo i terzo mondo. Ed. Sarda Fossataro, Cagliari, 1972. 
Shaw, G. y Williams, A.M.; Critical issues in tourism. A geographical perspective, Blackwell, Oxford, 1994

Shields, R. ; Places on the margin. Alternative geographies of postmodernity, Londres, Routledge, 1991

SHING, J. Consumer Complaint Intentions and Behavior: Definitional and Taxonomical Issues. Journal of Marketing, V.52, EUA, 1988.

SIMON, F. L. Tourism Development in Transition Economies. The Cuba Case. The Columbia Journal of World Business, 1995.

SINCLAIR, T. Y STABLER -eds.-; The tourism industry: an international study, Wallingford, C.A.B., 1991

Sol Meliá, Memoria Anual 2001, Informe Financiero 2001. Palmas de mallorca, España, Marzo del 2002.

SORKIN, M. -ed.- Variations on a theme park. The new american city and the end of public space, Nueva York, Noonday, 1992

SOUZA, A. A. El ocio turístico en las sociedades industriales avanzadas, Bosch, Barcelona, 1994.

SPRENG, R.; MACKENZIE, S.; OLSHAVSKY, R. A Reexamination of the Determinants of Consumer Satisfaction, Journal of Marketing, V.60, EUA, 1996.

STAlK, G.; EVANS, P.; SHULMAN, L. E. Competing on Capability: The New rules of Corporate Strategy. Harvard Business Review, Harvard, 1992.

STEPHEN, F.; WITT, L.M. Tourism marketing and management handbook. Prentice Hall, Nova York, 1989.

TAGLIACARnE, G. Técnica y Práctica de las Investigaciones de Mercado. Segunda Edición en Castellano, Ediciones Ariel, Barcelona, 1962.

TEIXEIRA, G. J. W. Classificação de variáveis nas pesquisas de recreação e turismo. FEA, São Paulo, 1974.

THE FINANCIAL RESEARCH INSTITUTE. Cuba's Economic Reforms: Results and Future Prospects. Havana, 1997.

THOMAS, D. Strategy is Different in Services Business. Harvard Business Review, Harvard, 1978.

TINARD, Y. Turismo: economía y gestión. Tradução e adaptação para o setor Turístico espanhol de Antonio Álvarez Sousa. Bosch, Barcelona, 1996.

TOLEDO, G. Marketing Estratégico e Varejo: o Caso Europeu. ANPAD, São Paulo, 1997. 
TOLEDO, G. L. Segmentação de Mercado e Estratégia de Marketing. ANPAD, São Paulo,1972. TOLEDO, G; HEMZO, M. A. O processo de posicionamento e o Marketing Estratégico. ANPAD, São Paulo, 1992.

TOLEDO, G .L; VALDÉS, J. A. POLLERO, A. C., Marketing y Competitividad de empresas turísticas en ambiente globalizado. Estudio de casos de clusters turísticos. Anais (em meio eletrônico) da $36^{\mathrm{a}}$ Assembléia Anual do Cladea, Conselho Latino-Americano de Escolas de Administração. Cidade do México, México. Setembro. 2001

TOledo, G L, SZTUTMAN, L., RUBAL, J. M., Comércio Eletrônico em Agências de Viagem - Estratégias Competitivas e de Marketing. Revista Turismo em Análise, vol. 12, n ${ }^{\circ} 2$, novembro de 2001, p. 90-116. Escola de Comunicações e Artes da USP. SP, Brasil.

TOlEDO, G .L; VAldÉS, J. A. POLlERO, A. C., Configuración del turismo en el ambiente globalizado. Estudio de casos de Clusters turísticos. Revista Turismo em Análise, vol. 13, n ${ }^{\circ}$ 1, maio de 2002, p. 90-104. Escola de Comunicações e Artes da USP. SP, Brasil.

TOLEDO, G .L; VALDÉS, J. A. POLLERO, A. C., Turismo en el Ambiente Globalizado y su Reconfiguración Espacial para y Desarrollo Regional - Estudio de Casos de Clusters Turísticos, Revista de Desenvolvimento Econômico, ano IV, $\mathrm{n}^{\circ}$ 6, julho de 2002, p. 81-88, Salvador, BA.

TOlEDO, G .L; VAldÉS, J. A. POLlERO, A. C., Planificación Estratégica de Empresas de Turismo y Desarrollo Sustentable del Sector. .Estudios y Perspectivas en Turismo, Vol. 11, $\mathrm{n}^{\circ} 3$ e 4, julho-outubro p. 197-225, 2002, Centro de Investigaciones y Estudios Turísticos, Buenos Aires, Argentina.

TOlEDO, G .L; VAldÉS, J. A. POLlERO, A. C., Estratégias Competitivas en América Latina. Estudio de Caso: Costa Rica, México, Brasil, Revista Econômica do Nordeste, vol. 33, n ${ }^{\circ}$ 4, out-dez. 2002, p. 817-830, Fortaleza, CE.

TORRUCO, M.; RAMÍREZ, M. Servicios turísticos: la oferta turística y sus principales componentes. Diana, México,1991.

TRIGO, L. Turismo e qualidade: tendências contemporâneas. Papirus, Campinas, 1993.

URIEL, E. , Sol Meliá, El viajero Universal. Editorial Pirámide, Madrid, España, 2001

Urry, J.; The tourist gaze. Leisure and travel in contemporary societies, Londres: Sage, 1990

VERA, F. -ed.-; Análisis territorial del turismo, Barcelona, Ariel, 1997

VERA, F. Y MARCHENA, M., "El modelo turístico español: perspectiva económica y territorial", in Pedreño, A. y Monfort, V.M., op. cit, 327-364, 1996

VERA, F. Y MARCHENA, M.; "Turismo y desarrollo regional: un planteamiento actual", Papers de Turisme, 4, 59-84, 1990 
VERA, F. Y MONFORT, V.M.; “Agotamiento de modelos turísticos clásicos. Una estrategia territorial para la cualifiación. La experiencia de la comunidad valenciana”, Estudios Turísticos, 171,1995

VICENTE, J.; "Per què fa, com a mínim vint anys que es parla de crisi del turisme a la Costa Brava?. Vuit fragments de resposta $\mathrm{i}$ reflexió in Turisme, territori i estratègies de desenvolupament, Actas de las Jornadas sobre el turismo en los espacios litorales, Girona, 29 marzo - 1 abril de 1995, 169 - 171., 1996

VILAFRADERA, J. Elementos Constitutivos del Marketing Turístico, Recepção.

VINSON, D.; LAMONT L. The Role of Personal Values in Marketing and Consumer Behavior. Journal of Marketing, V.46, EUA, 1977.

VLADIMIR, A. The complete travel Marketing handbook: 37 industry experts share their secrets. Ntc Business, Lincolnwood, 1990.

WAHAB, S. Introdução à administração do turismo. Pioneira, São Paulo, 1977.

WALTERS, C.; BERGIEL H. Marketing Channels. Willey, NovaYork, 1982.

WATSON, G.L. Y KOPACHEVSKY, J.P.; “Interpretations of Tourism as Commodity”, Annals of Tourism Research, 21, 643-660, 1994

WESTBOOK, P. Sources of Consumer Satisfaction with Retail Outlets. Journal of Retailing, V.57, EUA, 1980.

WILLIAMS, A.; SHAW, G. Tourism and economic development: Western European experiences. $2^{\mathrm{a}}$ ed., Belhaven, Londres, 1991.

WILSON, A. The Marketing of Professional Services. Mc Graw Hill, Londres, 1972.

WIND, Y. Product Policy Concepts, Methods and Estrategy Aplication. Wesley Publishing Company, Massachussets, 1982.

YIN, R. Case Study Research. Sage Publications, California, EUA, 1990.

ZEITHAML, V.; BERRY. L.; PARASURAMAN, A. Calidad Total en la Gestión de Servicios.

Diaz de Santos, Madrid, 1993.

ZEITHAML, V.; BERRY. L.; PARASURAMAN, A. Reassessment of Expectations as a Comparison Standard in Measuring Service Quality Implications for Future Research. Journal of Marketing, V.58, EUA, 1995.

ZEITHAML, V.; BERRY. L.; PARASURAMAN, A. The Behavioral Consequences of Services Quality. Journal of Marketing. V.60, EUA, 1993. 